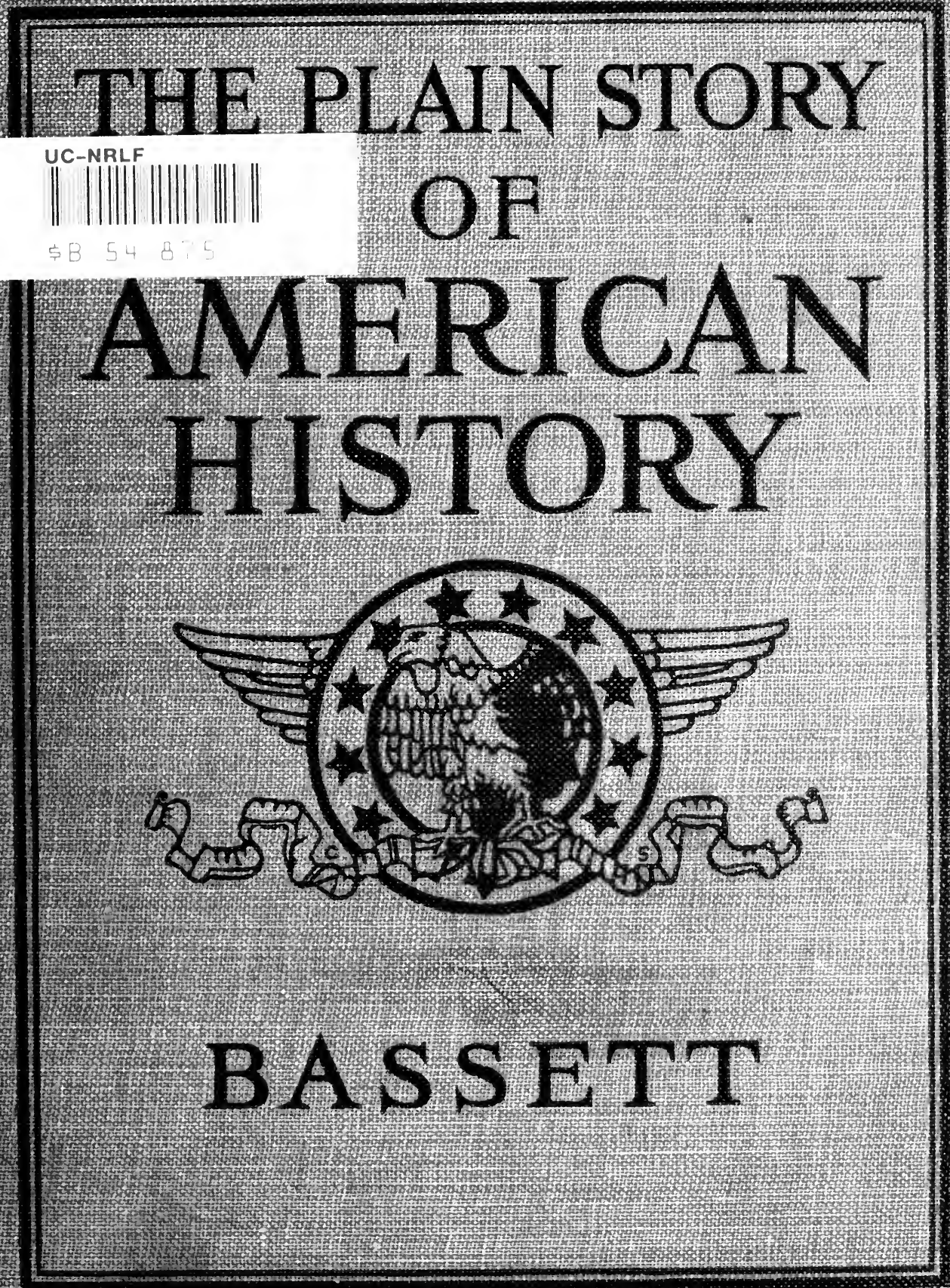



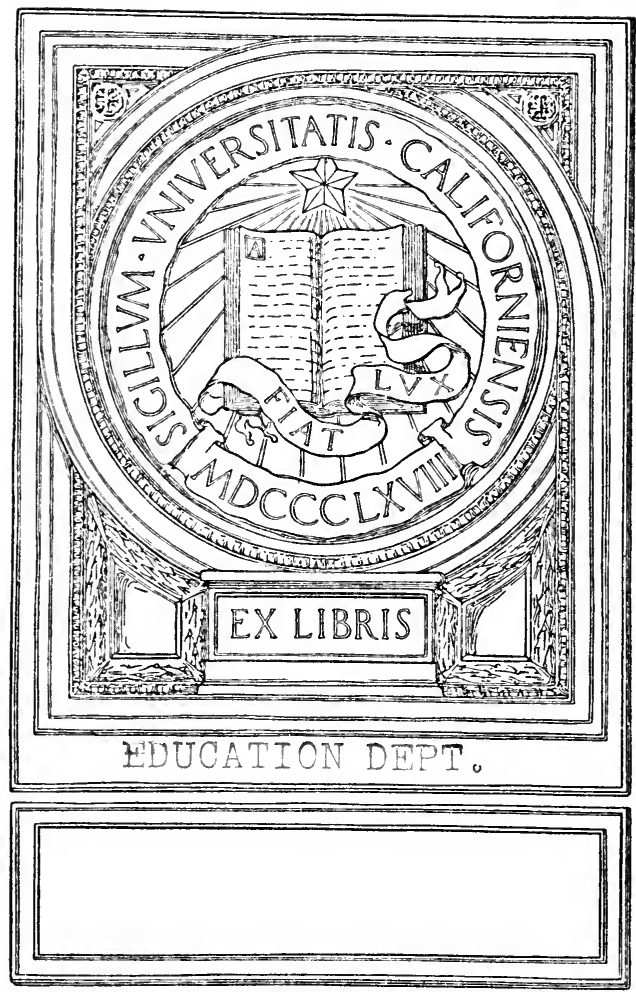


\section{$4 \times 5$}

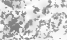

towth

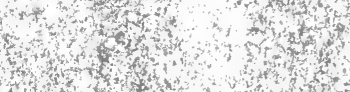

$x_{x \rightarrow \infty}=0$

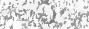

ind

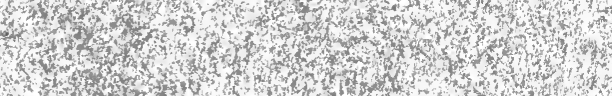

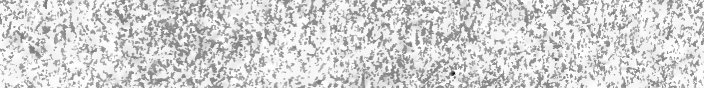

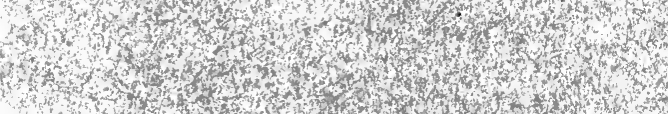

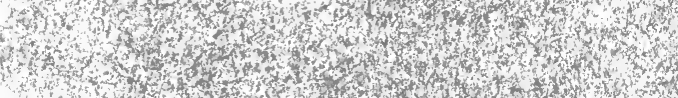

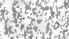

the

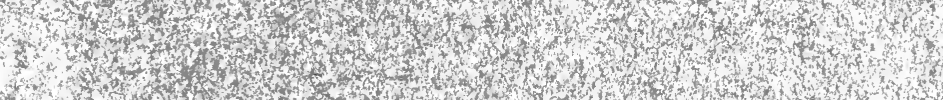

1 .

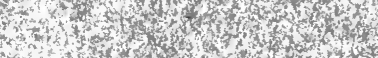

3
3

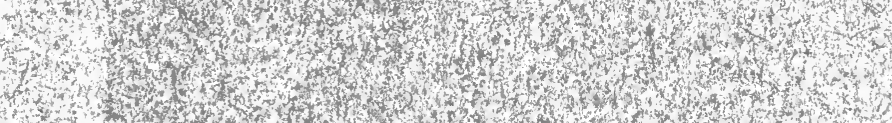

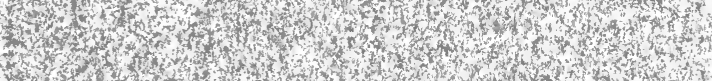

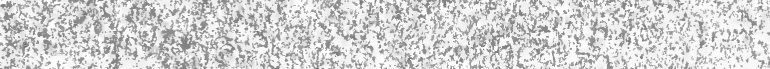

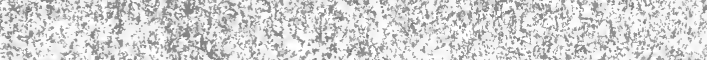

7
4

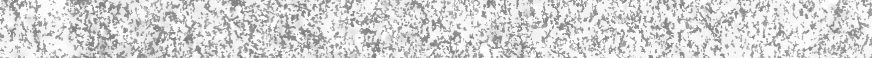

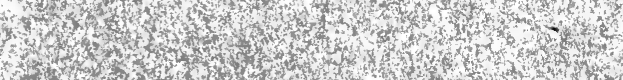

1
1

7
6

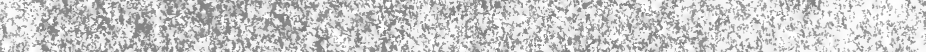

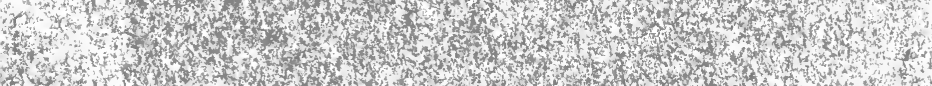

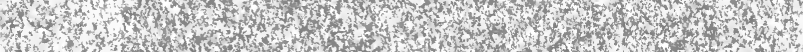

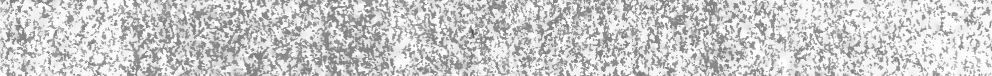

5.

6.

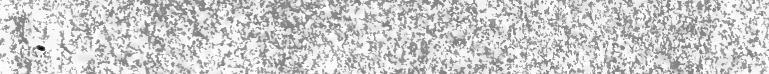

1. H.

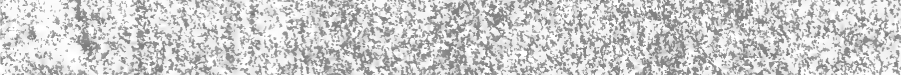

4.

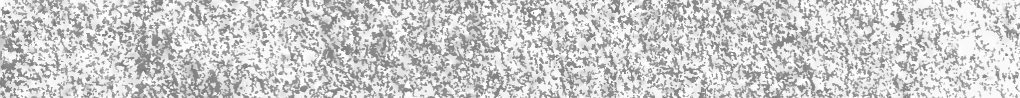

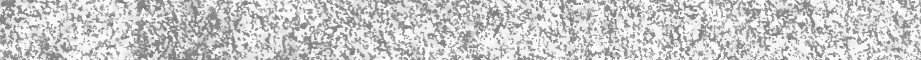

1.7.

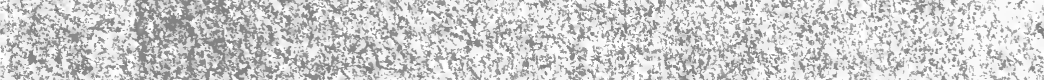

f 


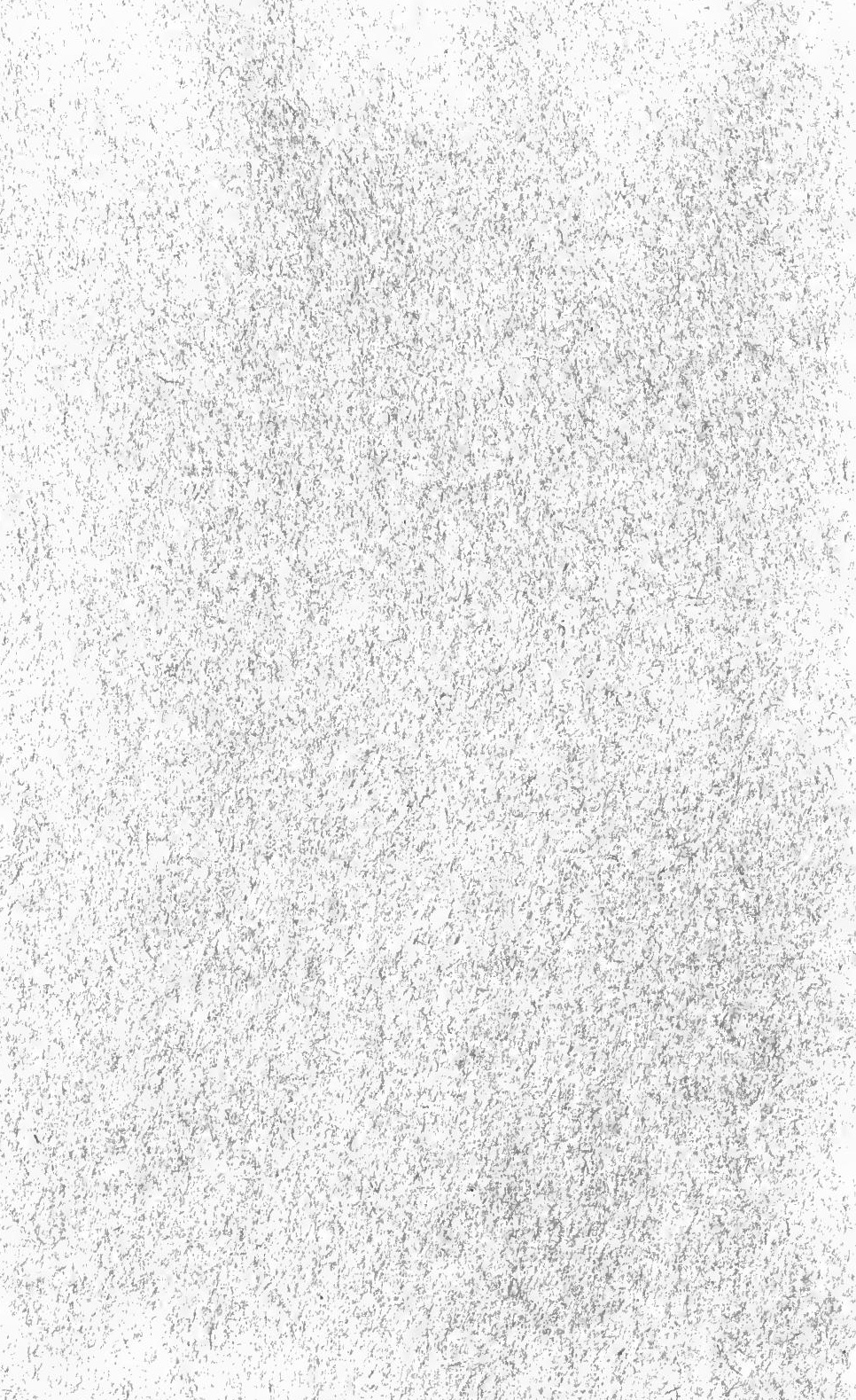


THE PLAIN STORY OF AMERICAN HISTORY 


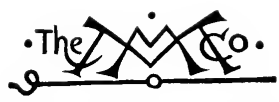

THE MACMILLAN COMPANY

NEW YORK - BOSTON - CHICAGO - DALLAS

ATLANTA - SAN FRANCISCO

MACMILLAN \& CO., LiMiTED

LONDON - BOMBAY - CALCUTTA

MELBOURNE

THE MACMILLAN CO. OF CANADA, Ltd.

TORONTO 


\title{
THE PLAIN STORY \\ OF AMERICAN HISTORY
}

BY

\begin{abstract}
JOHN SPENCER BASSET'T, Ph.D.
SYDENHAM CLARK PARSONS PROFESSOR OF AMERICAN HISTORY

IN SMITH COLLEGE
\end{abstract}

New Tork

THE MACMILLAN COMPANY

1916 


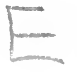

1

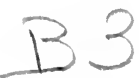

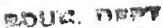

\section{EDUCATION DEPT.}

Copyright, 1916,

\section{BY THE MACMILLAN COMPANY.}

Set up and electrotyped. Publisted, February, rgr6. 
To

R. H. B. AND II B. B.

THIS BOOK

IS AFFECTIONATELY

IDEIII A'TEI 



\section{PREFACE}

Mr purpose in writing this book is expressed in the title. I wish that it may be a plain story of the achievement of human beings in that part of the Western Hemisphere which is now the United States of America. To relate the main facts clearly and broadly, rather than to describe many detailed occurrences, has been constantly in my mind. The story here presented may be taken as an introduction for a wider study of our history. It has been my aim to use simple but strong language, and to place the emphasis of the book on human actions. But much attention has been given to social history, and in two chapters the outlines of American government have been presented. I hope the book will prove neither hard nor easy for pupils. If it is received as a straightforward story, drawing forth the earnest efforts of capable pupils and making for the success of faithful teachers, it will be a source of pleasure for the author, repaying him for many days and nights of careful study of our national history. More especially, I wish that the book may serve, along with many other excellent works of similar scope, to give to the American youth a better appreciation of the glorious history of their native land, and to create in them a warmer purpose to serve their country and promote its progress.

With the hope of making the task of the teacher lighter, the chapters have been made short and an abundance of marginal headings has been introduced. On the basis of these headings complete outlines can be made by the pupils, which, when studied under the chapter headings, will give the pupil good topical grasp of the subject. The questions at the ends of the chapters are intended for 
the use of pupils in the preparation of their work. They are so arranged as to call forth efforts to define the facts in the text from more than one point of view. Although this practice may suggest partial repetition, it will, if persistently followed, make for accurate knowledge. One of the traits most generally lacking in advanced students of history is the ability to make careful and discriminating statements. No effort will be spared by the good teacher to remedy this deficiency. The full questioning on details, here offered so that the pupil may test himself while preparing his lesson, should aid in developing accuracy. The topies at the ends of chapters are suggestions for the teachers who wish to prepare lectures on supplementary subjects, or who wish to have students write short reports on topies not fully treated in so brief a text as this must necessarily be. The resourceful teacher will reject them as freely as he desires, or add to them from his knowledge.

JOHN SPENCER BASSET'T.

Northampton, Massachusetts, July $12,1915$. 


\section{CONTENTS}

CHA PTER

PAGE

I. America before the Arrival of Columbus . . . . 1

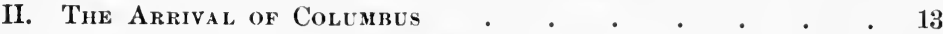

III. The Spaxish Colonies in America . . . . . . 27

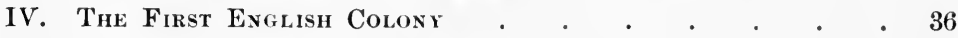

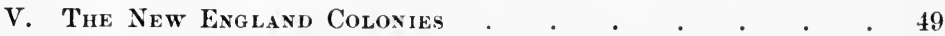

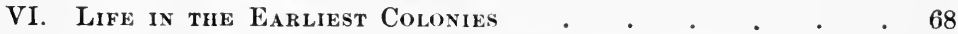

VII. The Later Group of Colonies . . . . . . . . 45

VIII. The Earliest Signs of Union among the Colonies • . 100

IX. The Wars against the Indias axd the French • • . 110

X. The Governiext of the Colonies . . . . . . 128

XI. The Causes of the American Revolution . . 140

XII. The Revolutionary War . . . . . . . . 156

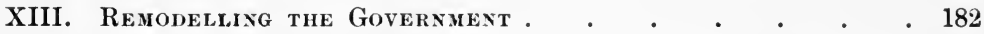

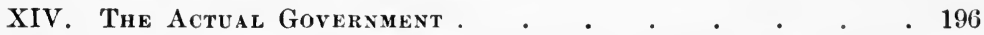

XV. The National Governuent under the Federalist Party . 208

XVI. The Government under the Early Republicans, 1801-1811 222

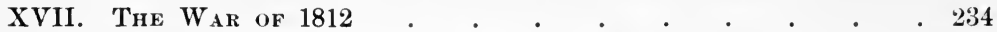

XVIII. The Settlement of the West, 1783-1820 • • • • 245

XIX. The Government under the Later Republcans, 1811-1820 261

XX. The Governient under Jackson and Van Buren • . 276

XXI. How Slavery Divided the North and the South • . 290

XXII. The Early History of Texas and the Southwest • 299

XXIII. The Controversy over Slavery in the Territories • 313

XXIV. The Steps Leading to IVar . . . . . . . . . . . 324

XXV. The War IN The West . . . . . . . . . . 335

XXVI. The War in The East . . . . . . . . 357 
CHAPTER PAGE

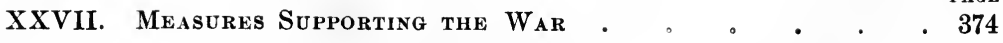

XXVIII. The Reconstruction of the South 。 . . . . 384

XXIX. The Political History under Johnson and Grant • . 396

XXX. The Growth of the Nation after the War . . . 408

XXXi. The Settlement of the Far West . . . . . . . 419

XXXII. The Political History from 1877 to 1897 . . , . 432

XXXiII. A New Attitude toward Foreign Nations . • . . 446

XXXIV. Tile Wars with Spain and the Filipinos . . . . . 457

XXXV. The Political Life since the Spanish War • . 472

XXXVI. The Progress of the People, 1865-1915 • • • • 489

Appendix :

The Declaration of Independence • • • • . 505

The Constitution of the United States . . . . 510 


\section{COLOR MAPS}

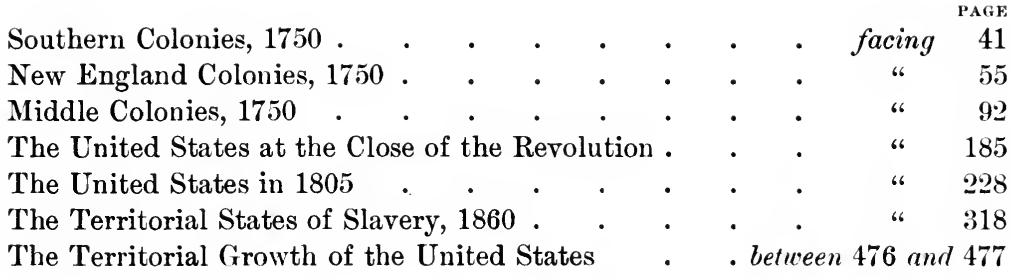




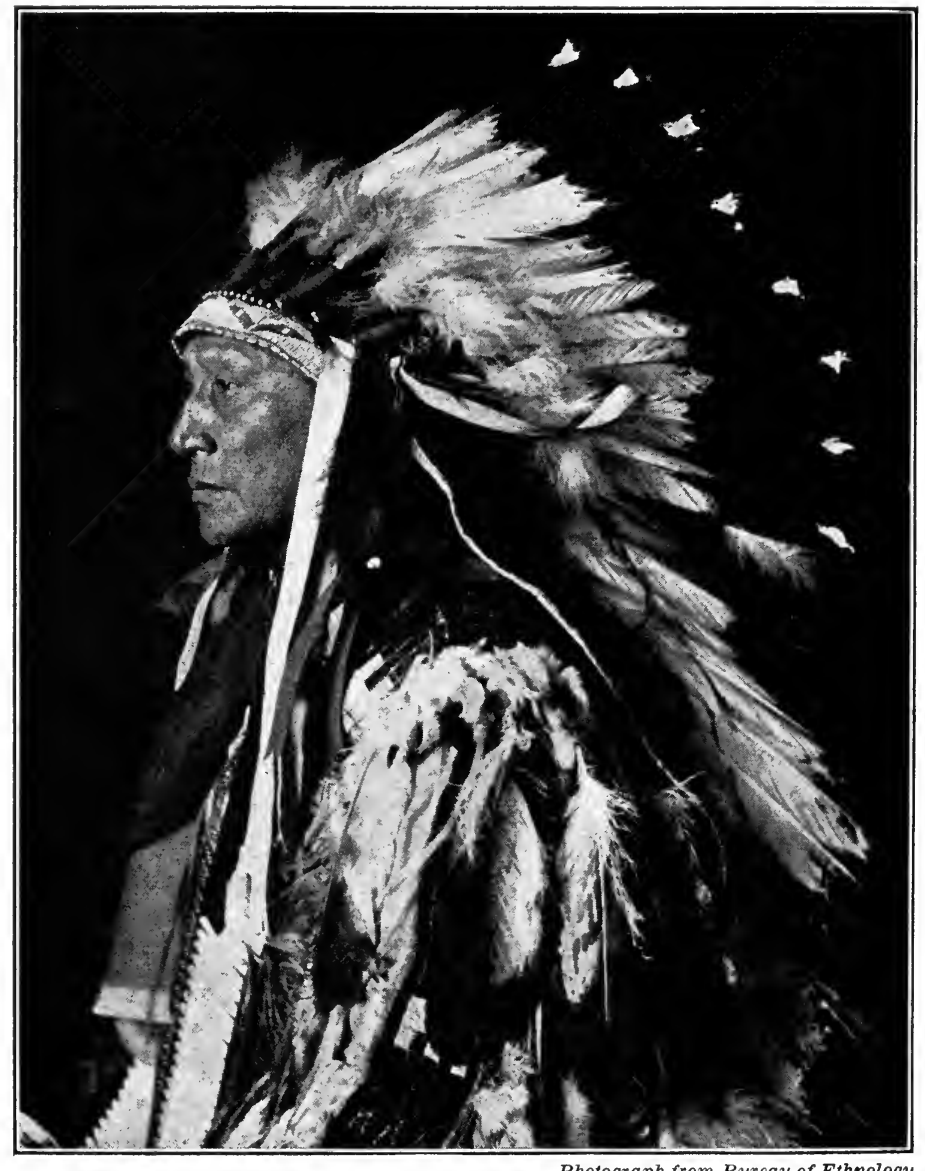

Photograph from Bureau of Ethnology

A North American Indian 


\section{THE PLAIN STORY OF AMERI- CAN HISTORY}

- CHAPTER I.

\section{AMERICA BEFORE THE ARRIVAL OF COOLUMBUS}

We must not think that the history of our country began with the arrival of men from Europe. Many hundreds of years earlier than that time Indians lived here in their own way. The early They knew nothing of Europe nor of the cities, states, Americans and fine manners of the great nations which made history on the eastern side of the Atlantic. To them America was the only world in existence and the Indian life the only life a people could possibly lead. They considered an Indian canoe the only possible kind of boat, an Indian house the only kind of house, and an Indian village the only kind of town. Before we read about America in the hands of the whites, we must know something of the Indians and see how they were in the habit of governing themselves. We must also see how they lived in their daily lives. So far as we can learn, they were the earliest Americans.

We do not know for certain where the Indians came from, but there is reason to suppose that they are of the same stock as the inhabitants of the northeastern corner of Asia. Both Origin of the peoples have the same kind of coarse black hair, the Indians same copper-colored skin, and the same high cheek bones. To this day the natives cross the Bering Straits in their rude boats, and it is possible that our earliest inhabitants came from Asia in this way. It is also possible that the people of northeastern Asia arrived there from Alaska. 
All the earliest Americans were probably Indians; but great differences grew up among them because the various branches of Eskimos the race dwelt far apart. Some of them inhabited warm countries and had to live very unlike people who dwelt in cold regions. The Eskimos are Indians, but they are forced to dress in furs. They cannot have farms or gardens and must live on fish and other wild animals of the frozen North. The people:-who lived in Mexico and Peru before the arrival of the whites were, alsø of pure-Indian blood, but they lived in a warm eimate, where fruts and vegetables grew abundantly and were raised with little effort. The people found it easier to live by their gardens and fields than to hunt for their food; and they thus grew into an agricultural people. In Mexico it was not advisable to move from one place to another, for in doing so it would be necessary to give up the fields. The people, therefore, Mexicans came to build permanent houses out of adobe, which
is a kind of sun-dried brick. These people became numerous, powerful, and prosperous. They also had time to improve their habits of life. They discovered how to make cloth, and they made pots for their household service. After a time they discovered the way to beautify pottery and cloth. This was their beginning of art. When the Spaniards conquered Mexico, they found cities, temples, and many people living in great comfort. But the Mexicans were Indians for all that, Indians in a high state of development.

The Indians living in what is now the United States were less rude than the Eskimos and less advanced than the Mexicans. Our Game was abundant in this region, where the climate Indians was neither very hot nor very cold. Although the inhabitants had small fields in which they raised corn and pumpkins, most of their food came from forest and stream. When the game became scarce in one place, they moved to another where it was more plentiful. Thus they had to abandon their houses after a few years of use and did not take the trouble to make them of 


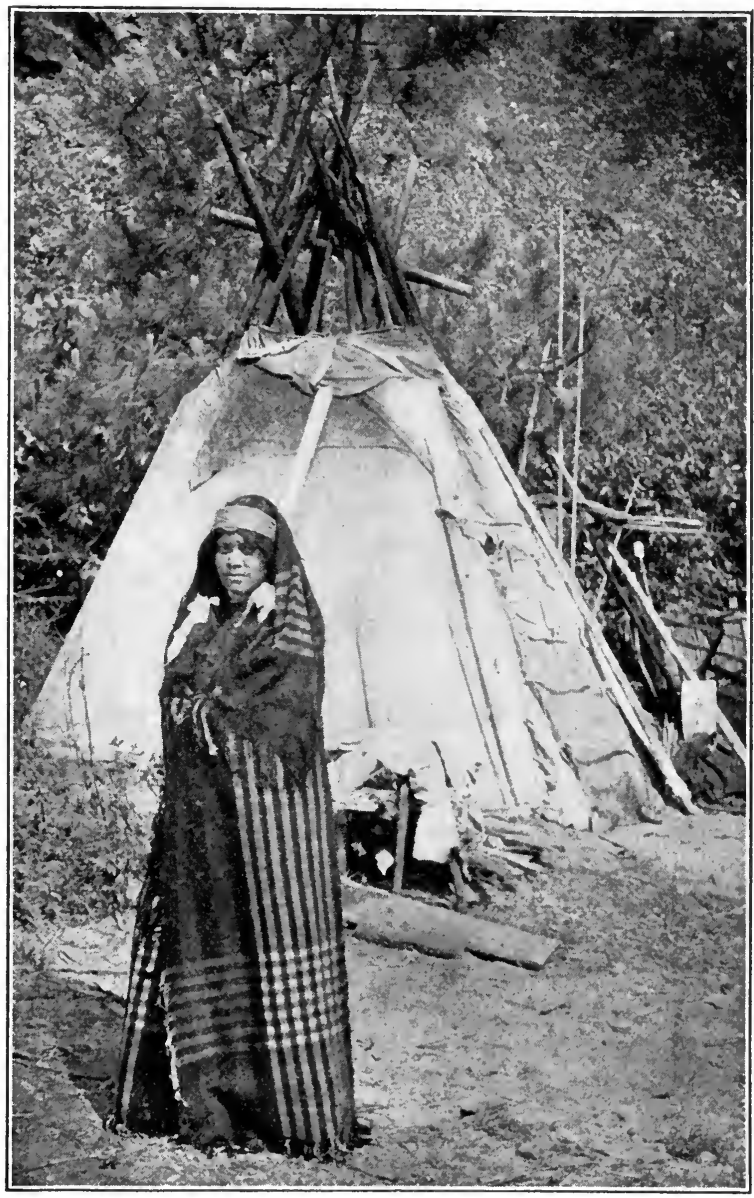

An Indian wigwam

stone or brick. Wigwams covered with skins, bark, or grass gave sufficient shelter from the storms and could easily be rebuilt when the tribe changed its abode. 
How long had the Indians lived in America when the whites first saw them? That is a question about which there is much Age of dispute. The Indians had no books and the stories the Indian they told were too vague to throw any light on the race subject. Learned men have thought that an answer to the question may be found in the stone arrows, axes, and knives that are sometimes dug up at the bottoms of wells or other excavations. It is said that these things must have been made by hand, that they must have been dropped and covered up by sand and clay as it was brought forward by some river which once flowed over the site of the digging, and that it took a very long time to cover the implements and for the river then to dry up or change its course. Stone implements have been found near the Delaware River many feet below the present surface of the earth. No one will say how long it has been since they were dropped at what must once have been the bottom of the river.

The boldest claim of this kind was made for the "Calaveras skull." In 1866 a skull was produced in California, which, it was The Cala- claimed, had been found by workmen digging a mine veras skull shaft as much as 130 feet below the surface. If what was claimed was true, this human skull must have lain where found through more than 100,000 years; for the region was volcanic, and above the spot in which it was said to have been found were layers of gravel on the top of thick layers of lava. The skull is now in a museum at Harvard University; but there are many men who do not think it was found where the miners claim.

At Lansing, Kansas, in 1902, two skulls were found 20 feet below the surface near the banks of the Missouri River. It was The Lansing evident that the spot at which they were found was skulls once river bottom and is now exposed and dry because the current has shifted. We do not know how long the Lansing skulls lay in the ground before discovery. It is supposed by some that the time was not more than one thousand years, and by 
others the period is estimated at thirty thousand years. The skulls of Indians are unlike those of other races, and when we see that the Lansing skulls are very much like those of the present race of Indians, we conclude that Indians lived on the banks of the Missouri from one to thirty thousand years ago. Other evidence points to the same conclusion. This is about all we can say in answer to the question: How long has man lived in America?

Some Indians buried their dead in mounds, either round or long and irregular in shape. When one of these mounds is opened we find skeletons and many implements. It was The mound thought that a dead Indian would need his bow, arrows, builders hatchets, and jars of food, as well as his beads and other ornaments, on his journey to the happy hunting grounds beyond the grave. The burial mounds in the Ohio valley are so large that it was once thought that they were constructed by a race superior to the Indians. But when we dig into them we find they were burial places, like other mounds. The skeletons they contain are Indian skeletons. The old view that the mound builders were a separate race has been given up.

The Indians lived in small numbers scattered over large areas. They dwelt in this way because a numerous population in one place would destroy the game. They were in tribes, Linguistic or "nations," as they were sometimes called. A families tribe would wander forth in search of better game or in an attempt to shun some strong hostile Indians. Thus some tribes which once lived side by side became widely divided. The best way of telling which tribes are related to one another is to observe their language. For example, the Cheyennes who once lived in Wyoming and Colorado speak a language like that of the Algonquins in New England, and we conclude that the two tribes once lived together. A group of tribes speaking the same language is called a linguistic family.

Three great families occupied the eastern part of North America from Florida to Newfoundland. The first was the Algonquian 
Family. It takes its name from the Algonquins, one of its tribes, who lived on the St. Lawrence River. Other tribes were the The great Mohegans on the Hudson; the Pequots and Narraganfamilies setts in New England; the Delawares in Pennsylvania; the Powhatans in Virginia; the Pamlicos in North Carolina; the Shawnees of Tennessee; the Miamis, Illinois, Kickapoos, and Foxes in the region between the Ohio River and the Lakes; and the Cheyennes and Arapahoes in the upper Missouri valley. All these tribes played important parts in opposing the attempts of the whites to settle the country. The Iroquoian Family was also very important. It contained the Iroqouis, or Five Nations, in New York; the Hurons, on the shores of Lake Huron; the Cherokees, in the southern Appalachian Mountains; and the Tuscaroras, in eastern North Carolina. The third great family was the Muskhogean. It contained the Creeks, living in Georgia and Alabama; the Chickasaws, living west of the Creeks; the Choctaws on the lower Mississippi; and the Seminoles in Florida. West of the Mississippi River were many families, some of them quite small. The greatest was the Siouan Family, living chiefly in the Dakotas. It contained the Sioux tribes, the Crows, Caws, Omahas, and Winnebagos. One tribe of this family, the Catawbas, lived far eastward in South Carolina. The student should remember the location of the leading Indian tribes. $\mathrm{He}$ should also remember that there were tribes that did not belong to either of these families.

The Indian knew nothing about a linguistic family, and fierce wars were sometimes waged between tribes speaking the same Confed- language. To him it was sufficient to stand by the eracies members of his tribe. He knew nothing of exact boundaries between tribes. Some small valley, peninsula, or the shores of a bay might mark the limits in which a tribe lived. We sometimes come across confederacies made up of several small tribes. They were usually formed through conquest and grew up because in one of the tribes was a powerful chief who could 
make men obey him. Such a chief was Powhatan, whose rule extended over most of the Virginia tribes when the whites arrived in that colony. He surrounded himself with a guard of fifty men who acted as a kind of police, protecting him from attack and seeing that the warriors obeyed his will.

A still greater confederacy was that of the Iroquois, in middle and western New York, composed of five tribes, or nations; the Mohawks, Oneidas, Senecas, Onondagas, and Iroquois Cayugas. After the Tuscaroras, of North Carolina, Confederacy were conquered by the whites in 1713, they removed to New York and became the sixth of the Iroquois nations. The confederacy had a great council in which each tribe had representatives. The council decided upon matters concerning all the tribes, such as war and peace; and its decisions were treated with great respect. The Iroquois confederacy was more like modern government than anything else among the Indians.

Indians of the same kindred were said to belong to a common clan, and there were several clans in each tribe. The clan had the name of an animal by which it was known, as the "Wolf," or the "Bear" clans. When an animal The clan was thus taken as the name of a clan, it was called a totem. It is plain that the totem was supposed to have some power of protecting or helping the members of the clan; and an Indian treated his totem with great respect. A man might be adopted in a clan; and sometimes prisoners of war, who were about to be killed, were rescued and adopted. If an Indian was captured, he thought it great shame to show that he feared death; and no other Indian was likely to claim him for adoption if he seemed afraid to die.

Most of the government of Indians was done within the clan, at the head of which was a man of great dignity, called a sachem. He was supposed to know all about the old customs of Sachem the clan. If a man or woman had violated these cus- and council toms, the sachem tried the case and decided what the penalty 
should be. When the sachem died all the men and women met in a council of the clan and elected his successor, and the votes of the women were equal in weight to those of the men.

There was also a war chief, a man selected by the council for his bravery and skill in war. The warriors were called braves, and they gloried in their deeds of valor. When they went on the warpath they painted their faces in red and black, and they wore Chiefs and feathers, the heads of animals, and other awe-inspirbraves ing objects. They believed that by making themselves terrible to look at they would frighten their opponents from the field of battle. As each side knew that behind each hideous mask was only an Indian, it is likely that most of their care to decorate themselves was wasted.

The Indian law forbade a man to marry within his own clan, and a wife was never considered a member of her husband's clan. Marriage, If she became a widow, she returned to her own people kinship, and her children went with her. They were not kin property to her husband's people, but only to their mother's kindred. One of the effects was that children did not inherit the property of their father; for it must go to his own kindred, who were members of his own clan, that is, to his mother's children. As the Indians had no such thing as private property in land this was not a very important matter. Land belonged to the tribe; and about the only thing a man possessed was his hunting implements and his clothing. After the arrival of the whites, however, the Indians began to own private property, but it was a long time before they showed a desire to become landowners.

The Indians drew a distinct line between the work a man should do and that which a woman should do. Fighting against Work of the tribal enemies and hunting was the man's work. It men and was the work in which there was danger, and facing women danger boldly was a great virtue in the eyes of these people. This work also demanded the power to endure hunger, 
to march cautiously through the forest, and to be ready to die without flinching. The Indian women admired the courage of the men. They willingly worked the fields of corn and dressed the game their husbands killed. They lived happily in their own employment and did not think they were treated badly. White people are brought up to feel that farm labor should be done by men, and it seemed to the colonists that the Indians were very unfair to their women. We should be able to look at the matter from the Indian's point of view, but this does not mean that we should adopt his customs.

When the whites make war they fight for some special object. Sometimes it is for territory, and sometimes for tribute. At the end of the war they make a treaty. But the Indians usually fought because they felt themselves the herediMaking war tary foes of their enemies. They did not make treaties after fighting one another. The defeated side only waited until it recovered from the blow it had received, which might be several years, and then fell suddenly on its former conqueror, trying to wipe out the disgrace of the old defeat. When the warriors were ready to go on the warpath they assembled for a war dance, and then they set out in war paint. Each man carried a leather pouch of roasted corn meal, called rockahominy, tied around his waist. When they arrived in the enemy's country, they could not cook food lest the smoke of their fires show they were coming. Then the rockahominy was used. A spoonful in the palm of the hand moistened with water would restore the strength of a famishing man for several hours. The Indian was trained to endure extreme hunger. When a war party had struck their blow at an enemy they returned to their own country. It might be several years before the other side was able to try to take its revenge, but they were sure to make the attempt. A great many Indians were killed in these unending wars, and the result was that the population did not increase. Another thing that kept down the number of the Indians was smallpox. They did not know how 


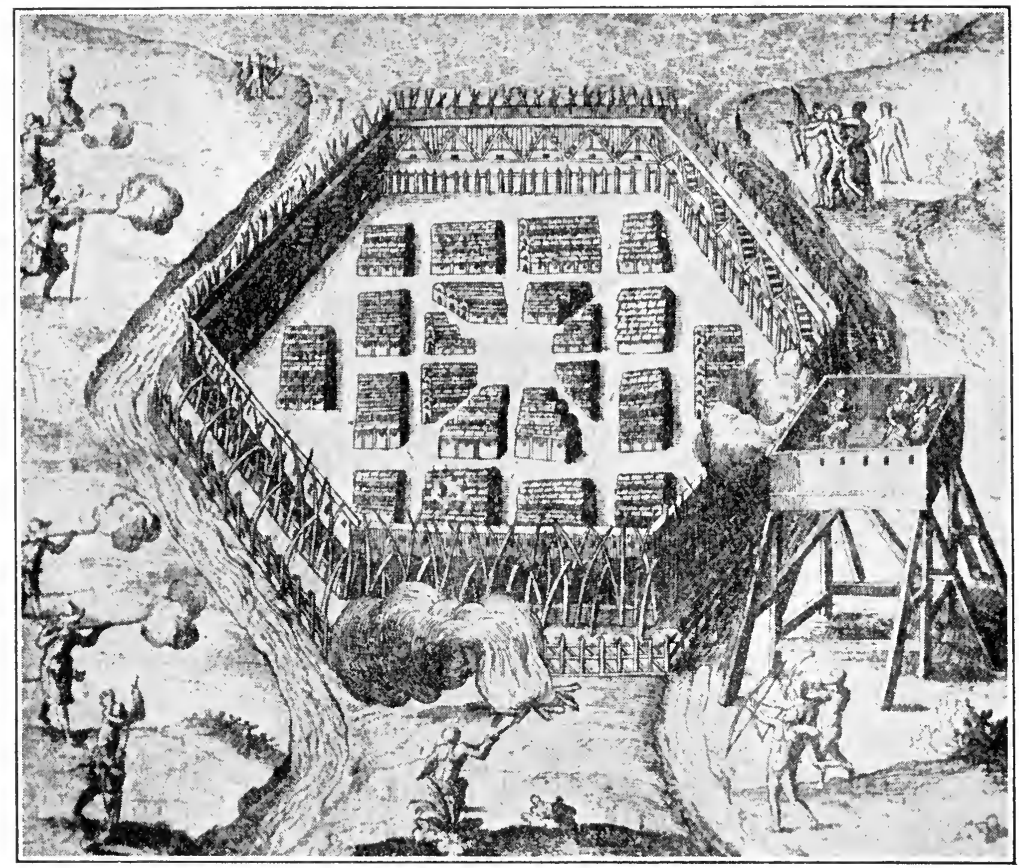

This picture was designed to show Champlain's attack on the Iroquois fort Inside the fort are the long houses of these Indians.

to treat the disease, and when it broke out in a village it destroyed many people.

Most of the life of the Indians was spent out of doors. They used a house as a sleeping place and for protection against rain and cold. The building was either round or long. The round Houses house was brought to a point at the top and covered with bark, skins, or grass. At the tip of the roof was a hole through which came the smoke that arose from the hearth just beneath it. Inside were several rooms which got narrower around the hearth, like the points in the slices of a pie. Each room could thus have the benefit of the fire. The long houses 
also were divided into rooms, and between the rooms were fire pits with holes above them. The smoke was supposed to go out of the roofs, but it usually went all through the house before it escaped. It proved very trying to the whites who had to visit the Indians, but the savages were used to the smoke and did not suffer.

The great ships of the first white men who came to America, the guns that roared out death to men at a distance, and steel axes that would cut more in an hour than a stone ax Indians and would cut in a week, - all these possessions of the stran- the whites gers seemed to the natives to show that the white men were aided by powerful gods. They had great respect for the strangers, presented them with food, and wished to have them for friends. After a while they saw that the whites were only men. They stole the wonderful hatchets and guns and the whites punished them sternly. Wherever the two races came together they were soon at war. The whites captured the Indians and took them away as slaves. If the natives saw a white man's ship in a harbor or river's mouth, they lay in wait to seize and murder any of the crew who came ashore. This happened when ships came to explore the country or to trade for furs. After a long time the whites began to arrive as settlers, clearing the forests, building houses, and planting fields.

The Indian became alarmed, lest his lands be taken away and the game be destroyed. Now came fiercer wars than before. But the Indian was no match for the white man. The Indians Walled towns, strong forts, cannon, and muskets were driven westtoo much for him. He was driven back from the ward coast, across the mountains, and then across the great plains in the middle of the continent, until at last he ceased to fight and settled down to a quiet life in the Far West. The government of the United States has spent much money in the past fifty years to educate him and to induce him to adopt the habits of white men. In spite of this generous treatment the Indians as a race progress slowly. 


\section{QUESTIONS}

I. What was the probable origin of the American Indians? How did differences grow up between the branches of the Indian race? Give the important characteristics of the Eskimos, the Mexicans, and the Indians of the United States.

II. About how long have the Indians lived in America? How do we get evidence on this point from stone implements? What was claimed for the Calaveras skull? What do the Lansing skulls indicate? How did the Indians bury their dead? Explain the great mounds in Ohio.

III. Explain the linguistic family. How does language show the kinship of tribes? Describe the location of the Algonquian, Iroquoian, Muskhogean, and Siouan families.

IV. What was an Indian confederacy? Describe the confederacy of the Iroquois. Describe the clan, the totem. What did adoption signify? What was the position of a sachem? Describe the tribal council. Explain the position of the chief. What was a brave?

V. Explain the nature of Indian kinship. What was the Indian's idea of private property? How was the work divided between men and women? How did the Indians conduct their military campaigns? What kept the Indian population from increasing? Describe the Indian house.

VI. How did the Indians first treat the whites? What caused them to change their attitude? Show how the Indian was driven westward.

\section{SUGGESTED TOPICS}

Theories of the Origin of the Indians; Controversy over the Calaveras Skull; The Serpent Mound of Ohio; A Pueblo; The Power of the Iroquois ; The Indian's Religion. 


\section{CHAPTER II}

\section{THE ARRIVAL OF COLUMBUS}

In the days of the Roman empire the Mediterranean Sea, as the name indicates, was considered the middle of the world. To the people living in Italy northern Europe seemed as Early wild as northern Canada now seems to the people of notions the United States. The Italians thought the earth a flat plain surrounded by seas in which dwelt monsters who would destroy whatever ship came in their reach. When a vessel ventured out of the Straits of Gibraltar it kept close to the shore and felt itself lucky if it reached Britain and returned safely. It did not dare go far south of the straits; for it was supposed that the great heat there would draw the bolts from the ship and allow it to fall into pieces under the crew. The mariners had no compass by which to steer when sun and stars were not visible and they had no instruments to reckon latitude and longitude. It is not surprising that the sailors were very timid and superstitious.

As time passed and civilization and commerce spread through northern Europe, men came and went more freely from the Mediterranean to the English Channel, the Baltic Sea, and Iceland and Norway and Sweden. The Norsemen, who lived for Greenland the most part in Norway, were a bold people and in the ninth century were showing the effects of their contact with the civilized south. They built long boats which they sailed very skillfully and began to visit many distant lands. Some of them turned northward along the coast of Scotland, and in 874 they planted a colony in Iceland. Shortly afterwards one of their ships was blown beyond Iceland to the west and returned with the story of 


\section{THE PLAIN STORY OF AMERICAN HISTORY}

a great country it had discovered. The adventure was long remembered, and in 983 Eric the Red, an Iceland chief, sailed west and discovered Greenland, where he founded a colony in which his family became very important.

About 1000 his son, Leif Ericsson, with a company of hardy Norsemen sailed still farther west looking for a country about Leif Erics- which vague reports had reached him. He came after son a time to a great continent and sailed southward along its rocky shores for many days. He called the country Vinland, because he found wild grapes there; and he tried to plant a colony,

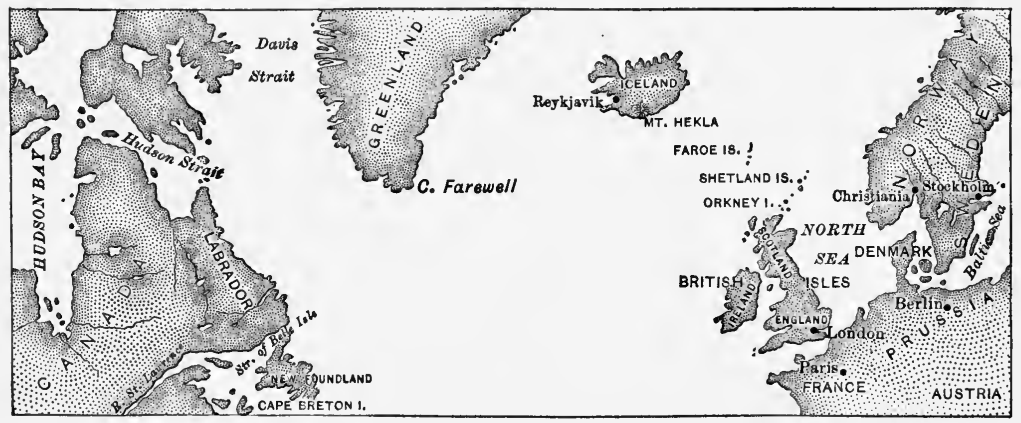

Where the Norsemen sailed

perhaps on the New England coast. Seven voyages were made to Vinland, but after a while the people of Greenland lost interest in it, and the colony was abandoned. The discovery of Vinland is described in the Norse Sagas, a collection of Scandinavian stories. There were at that time no printed books; and it is not thought that Columbus ever heard of Leif Ericsson or his discovery. From Leif to Columbus was nearly five hundred years, which is more than from Columbus to our day.

In the Middle Ages the people knew that an ocean lay west of Medieval Europe and a great sea south of it; and they had geography heard from travelers that water was on the east and south of Asia. But this theory did not answer the question, 
"What about Africa?" There it was south of the Mediterranean, a burning desert in the interior, and no one was willing to explore it. The impression prevailed that it grew hotter and hotter as one went southward. The only proper way to treat such assertions as these was to go and see if they were true.

In the fifteenth century European mariners began to use a compass to steer by and an astrolabe to tell where they were on the ocean when out of sight of land. These two little in- The navigastruments made them much bolder in sailing the seas. tors

A new race of navigators grew up. They were men who studied geography, made maps of newly discovered regions, and made voyages to learn still more than was known. To-day we know so much about the surface of the earth that there is little for navigators to explore. It was not so in the fifteenth century. The navigators were bold and learned, and we owe them much for their patient discoveries.

The most famous of these men was Prince Henry, the Navigator, brother of the king of Portugal. He established a school in which the latest discoveries were taught to hardy sea- West coast men, a trained band of courageous explorers. Their of Africa main purpose was to pass around the continent of Africa and reach the East Indies, where the valuable spices grew. Ship after ship went out, and each sailed a little farther southward. When the equator was crossed safely and the captain found he could return to Portugal there was great joy. After that the explorers went more boldly into the unknown African waters. When they turned Cape Palmas and found that the shore ran east and west they thought the continent was at last passed and they were on the road to the eastern coast of Africa. But they were on the Guinea coast, and when the land began to run southward again for many miles they were discouraged and turned back. Others came, and in 1487 their perseverance was rewarded when Bartholomew Diaz passed the Cape of Good Hope and found that he was sailing nearly northward. He would have gone on to India, but his crew 


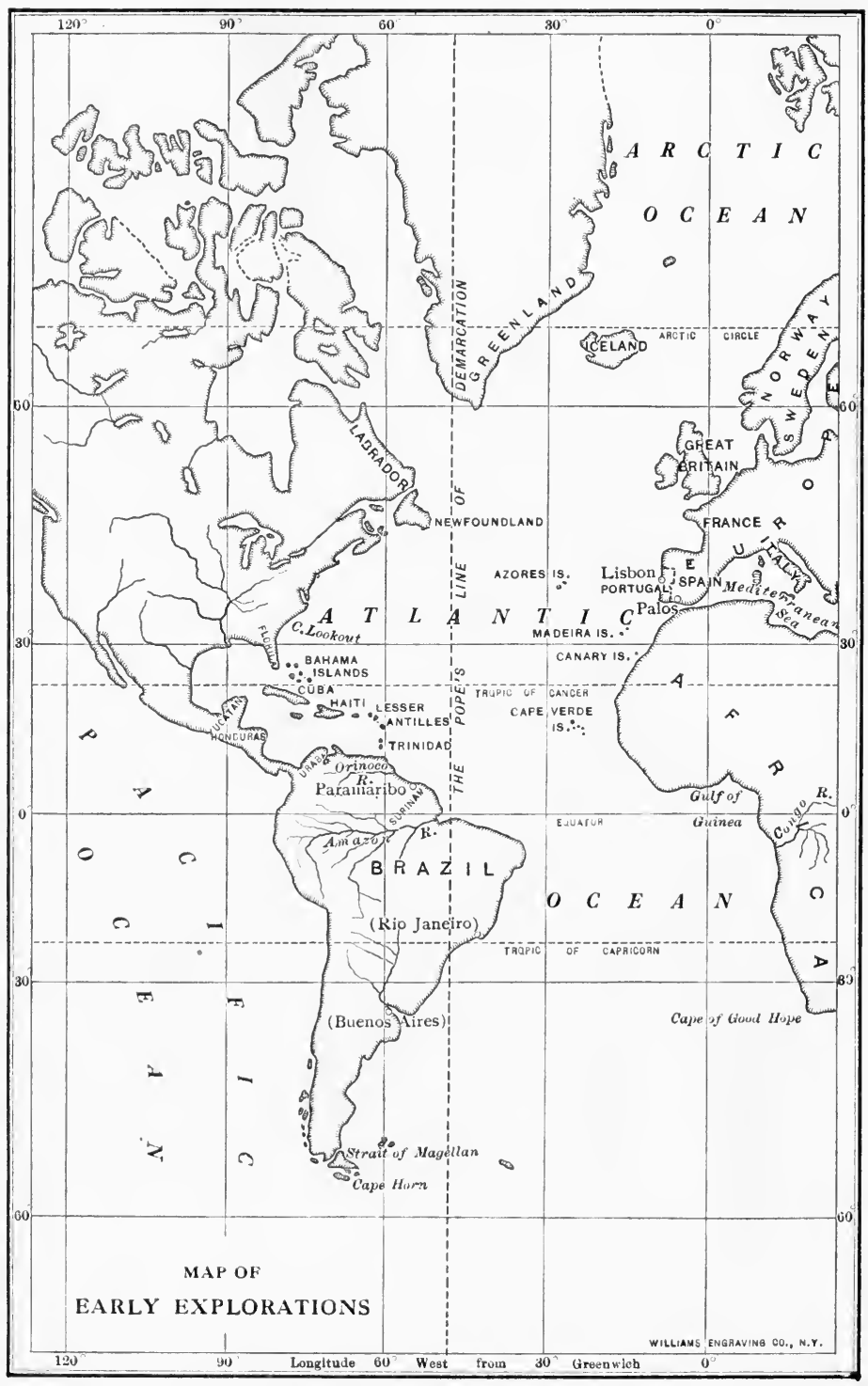


refused to proceed, and he had to return. The sailors feared that they would go so far they would never see their homes again.

The next step was taken by Christopher Columbus. He was a skillful navigator and a man who dared to try to carry out what reason told him could be accomplished. He believed Columbus's that by sailing westward he could cross the Atlantic idea and find whatever land lay beyond it. He seems to have thought that the first land he might reach would be India or Japan, from which came the rich goods of the East. Marco Polo, a Venetian, who went to the East overland in the thirteenth century, had written a book in which he described the country, its great riches, and its coast line. The book was now much talked about, and it helped to fire the imagination of those who wished to reach India by water.

Columbus was poor and money was needed to get ships and sailors for his explorations. The king of Portugal was using his ships for the discoveries by way of Africa and refused Ferdinand aid. Then Columbus applied to Ferdinand and Isa- and Isabella bella, king and queen of Spain. He made excellent arguments to show them that his plans were good, but the king and queen were ignorant of the work of the navigators and were busy trying to drive the Moors out of Spain. They referred the petition of Columbus to wise men at their court. But the wise men were not in favor of new ideas, and as they pointed to the old traditions to show that Columbus was a dreamer his request was refused. He did not give up, but for seven years urged his case so patiently that his faithfulness was at last rewarded. Perez, the confessor of the queen, and Santangel, her treasurer, were convinced by his arguments, and through their influence the queen furnished most of the money the explorer needed.

Soon all was ready, and August 3, 1492, he set sail with three vessels, so small that in our day they would hardly be considered 
safe for coastwise traffic. They were called the Santa Maria, the Pinta, and the Niña. They first went to the Canaries, where First voyage they repaired some damages they had sustained, and of Columbus September 6 they again were under way. Columbus now steered straight into the unknown ocean. He knew well

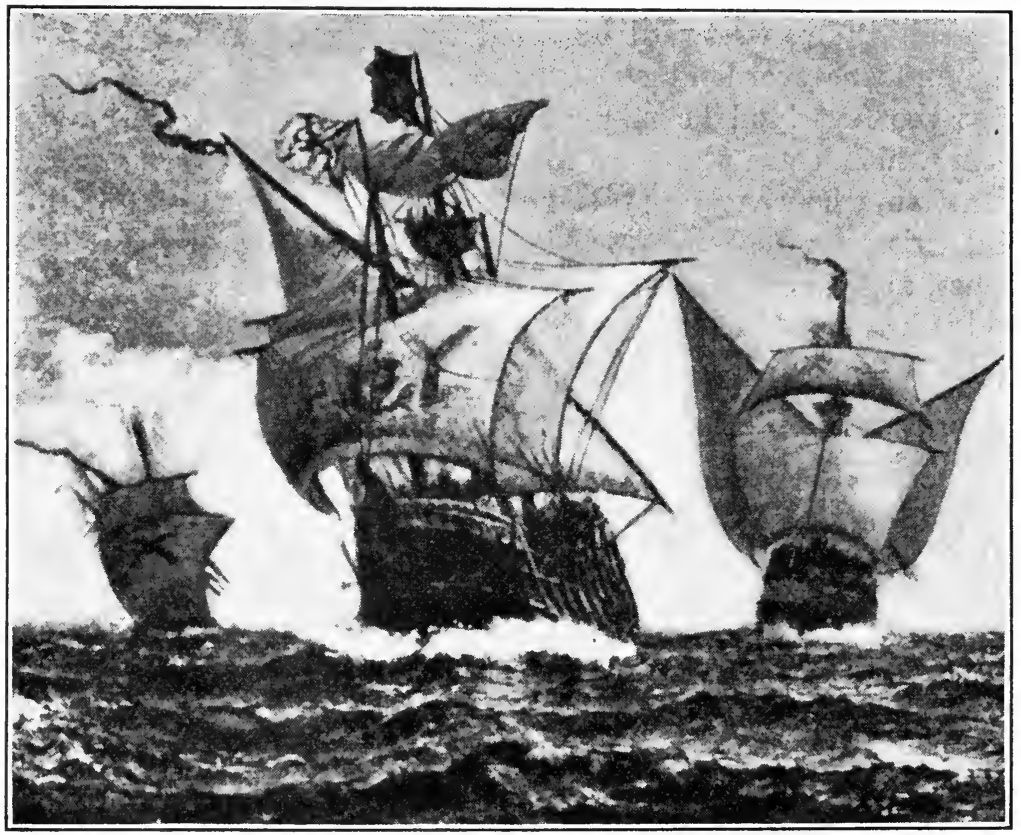

The ships of Columbus

the superstition of his sailors and to quiet their fears kept two logs: one for the sailors, in which he made the sailings shorter than they really were, and another for himself, in which he kept the true distances. No storms were encountered, but the men soon became greatly alarmed. Columbus was a stern master and there were many unruly spirits on his ships. Discontented ones began to talk scornfully of his scheme, the sailors grew rebellious and Oc- 
tober 10 they threatened to throw him overboard if he did not return. He met them bravely, declaring he would never turn back until he found land. Already signs of land began to appear, the boughs of trees floating in the water and birds which had their homes on the land. In the evening of the next day, October 11, lights were seen on the horizon, and the roaring of the surf showed that land was before them. The morning revealed a low island on which the ship's company landed. The

Land! natives were understood to call it Guanahani, but Columbus, who was a pious man, named it San Salvador. We are not sure which of the known islands of the new world it was, but it is generally supposed to have been Watling's Island, one of the Bahamas.

The natives were very friendly and made Columbus understand that a great body of land was to the southward. He set sail and discovered Cuba, which he thought the mainland Cuba and of India. Here also he was well received. He noted Hayti that the natives had a plant whose leaves they rolled into a tube and smoked, calling the rolls tobaccos. He next turned eastward and came to Hayti, which he named "La Isla Espanola," or the Spanish Island, whence comes the name Hispaniola. On the shore he lost his best ship, the Santa Maria, and this showed him that he should return at once. If he lost his other ships the world would never know of his discovery, and he would be remembered as a foolish man whose vain scheme only ended in the death of many men. He set sail from Hayti and arrived in Spain March 15,1493 , seven months and twelve days after he sailed on his first voyage.

There was now great rejoicing. India was discovered, so men said; and hundreds of people wished to go to it. The king and queen of Spain were as pleased as the people. They second furnished seventeen ships with which Columbus set out, voyage 1493, to explore the coasts and settle a colony. He had the rank of admiral with power to rule over the land he discovered. Under 
him served many high nobles, who thought they were going to India to get gold and honor. Columbus was lowborn, and they did not like to obey him. He was brave and just, but he did not know how to rule. He landed in Hayti and sent explorers throughout the island. They returned without finding cities or great riches.

As a result disappointment ruled in the colony and the admiral found his subjects on the point of rebellion. He dared not go Gold and home with news that the new world was only a forestsugar covered wilderness. He was lucky enough to discover a little gold in the hills. Mines were opened, and the natives were forced to work them. The small amount of yellow metal that was thus taken was sent to Spain with the assurance that a great deal more would follow. Soon, also, sugar began to be raised. Land was assigned to the Spaniards, who were allowed to force the natives to work on it. Sugar growing became the basis of wealth in the Spanish West Indies.

Columbus returned to Spain in 1496. Two years later he sailed on a third voyage. This time he turned well southward, Third hoping to pass what he still thought was China and voyage reach the spice islands in the Indian Ocean. To his surprise he encountered a great body of land, which neither Marco Polo nor any other person had described. He realized for the first time that he had discovered a new continent. But he did not give up the idea that what he had already visited was a part of Asia. His explanation was that a great continent lay south of India, and that Marco Polo had known nothing of it. He sailed many miles along the north coast of South America, and returned to Spain without learning that the continent he had discovered was connected by the Isthmus of Panama with another great body of land north of it.

In 1502 he made his last voyage. This time he passed Cuba on the north, crossed the Gulf of Mexico, and touched land in Yucatan. Turning southward he expected to reach the Indian 
Ocean. Again he was disappointed; for after many days he sailed past the isthmus and again reached South America. His work was over and he died in 1506, worn out by hard- Fourth ships and disappointed because his great work had voyage of brought him neither riches nor power. He died without Columbus realizing the full meaning of what he had discovered. He knew that out in the great ocean, which in his youth was the dreaded home of mystery and danger, there really existed a barrier of land. How far it ran north and south and what lay beyond it were questions he could not answer.

Before Columbus died many other sea captains began to explore the shores of the new land. They were as brave as he, but he had furnished the idea and shown that it could be other carried out. It was his fate to touch the new world explorers at nearly the middle of its Atlantic coast line. Those who came afterwards explored the coasts above and below that point. They were fired by the hope of discovering a passage around the new continent to India.

Spain was first to explore the eastern shore of South America. In 1499 Pinzon, one of her seamen, sailed to America. A storm blew him out of his course and far southward in the south middle of the Atlantic. When it was over he turned America his prow westward and found land several degrees south of the equator. He then sailed north along the coast of Brazil and returned to Spain with stories of the discovery of a vast continent. How far south it extended he did not know, but in 1519 Magellan, a Portuguese in Spanish service, sailed to find out. He spent the winter on the coast of Patagonia, where the climate was like that of Newfoundland. In the following spring - it was autumn in Spain - he entered the Straits of Magellan, named Pinzon and in his honor. It is a narrow passage three hundred and Magellan twenty-five miles long, with high mountains rising on the sides. The sailors were alarmed by this singular arm of the sea and began to wonder whither it would take them, but it opened at last on 


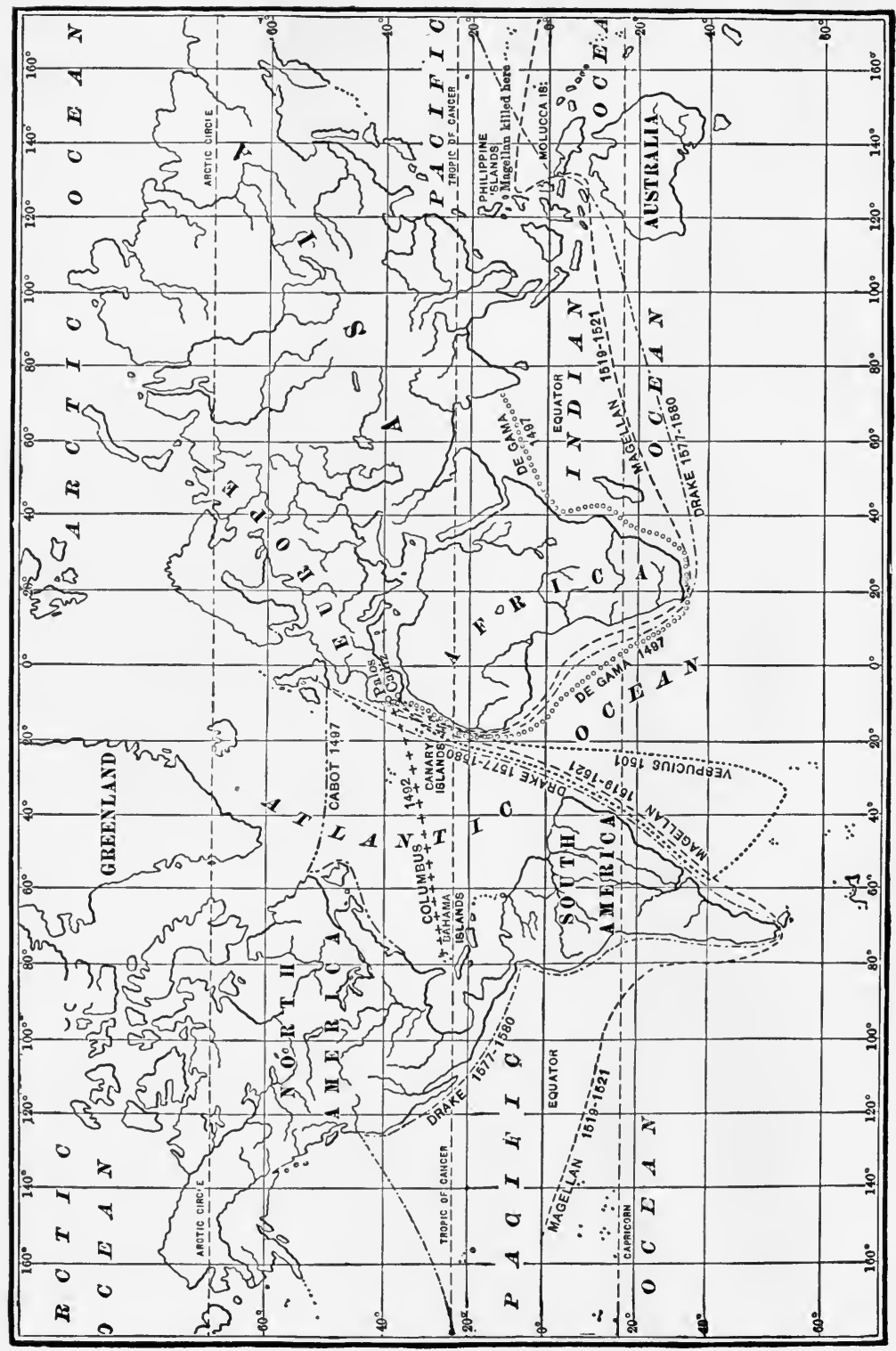


a great ocean, and Magellan boldly struck across it in a northwestern direction. For many weeks he sailed without sight of land. Food ran low, and even the rats in the ship proved a luxury. The sailors sold them to the rich adventurers on board at half a ducat each. After suffering much the explorers came to Guam, where food and water were secured. Continuing the journey they came next to the Philippines, where Magellan was killed in a fight with the islanders. Only one of his three ships reached Spain again. It had proved that the world can be circumnavigated.

Although Spanish ships discovered Brazil, Spain did not get possession of it. The Pope's This brings up a bull story that goes back to 1493 , when Europe was still talking about Columbus's wonderful discovery. Portugal felt herself outdone by Spain and

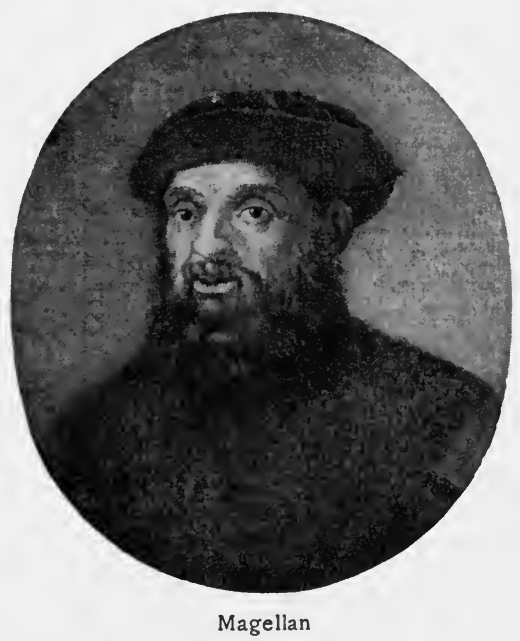
was inclined to be disagreeable. She advanced the claim that the new lands were only some strange coasts which her own ships had reached beyond the Canaries. This was untrue, but a quarrel seemed likely to break out, when the pope interfered by common consent and issued a bull dividing the new world. An imaginary line was authorized three hundred and seventy leagues west of Cape Verde Islands, and the land found to the east of it was to belong to Portugal while that discovered to the west was to belong to Spain. The eastern coast of South America juts out far into the Atlantic and as it extended beyond the pope's line it fell to Portugal. Spain took the coast south of Brazil to 
Cape Horn, and got possession of the western coast of the continent.

It was while South America was being explored that the name "America" came into use. One of the men in Spain who took The name part in exploration was Amerigo Vespucci, an Italian "America" by birth. He wrote an account of a voyage he made to the Orinoco region in 1499 , with another man commanding the expedition, and in it he spoke of a new world he had seen. He falsely gave the date as 1497, a year before Columbus really discovered this region on his third voyage. But Vespucci was not suspected of this fraud, and when his account was published in Latin, in 1503, he was pronounced the discoverer of a new continent, while Columbus, as the world then thought, had only found India. The new country was, therefore, called "America," from Americus, the Latin form of Amerigo. On the maps of the day what is now South America appears as America, while that which is the United States is called India or Cathay. Vasco da Gama sailed around Cape of Good Hope in 1497 and reached the true India. When the geographers came to realize this the name India disappeared from the maps of the new world and North America took its place. Shortly afterwards the southern continent began to be called South America.

Let us now turn to the explorers of the northern coasts. England had as bold seamen as Spain, but her kings were busy at English ex- home and thought little of new countries. At last ploration came John Cabot, a man born in Genoa, who got permission to search for a northwestern route to India under the English flag. He set out in 1497, reached America near Newfoundland, and sailed southward along the coast for a thousand miles. He is said to have made a second voyage in 1498 on which he went as far as the coast of South Carolina. It was seventy-five years after this before England again showed interest in America; but she did not forget Cabot's voyage; and she claimed as her own all the land he discovered. 
Another northern explorer was Corte-Real, a Portuguese who discovered Labrador in 1500 ; but Portugal was intent on following her trade to the Indies by way of Cape of Good French exHope and made no attempt to carry on the work of ploration Corte-Real. France took no part in the earliest explorations but in 1524 one of her sailors, Verrazano, came to the coast, exploring New York harbor and the shore east of it. In 1534 came another, Jacques Cartier. He entered the Gulf of Newfoundland and in a second voyage, 1535, explored the St. Lawrence as far as Montreal. He was looking for a passage to the Pacific Ocean and China; and the name "La Chine" was given to the rapids which stopped his course at Montreal. It was in derision of his belief that China could be reached through the St. Lawrence. It was on the explorations of Cartier that France rested her claim to the St. Lawrence valley.

\section{QUESTIONS}

I. Describe the state of navigation in ancient times. What did the world think of the region south of Gibraltar? How did the Norsemen show their superiority as sailors? How did they come to settle in Greenland? Describe Leif Eriesson's discoveries. Why was Vinland forgotten for centuries? How was its story preserved?

II. What was the medieval idea of geography? Explain the work of the navigators. Describe the services of Prince Henry the Navigator. Show how the west coast of Africa was explored. What did Bartholomew Diaz discover?

III. What was the theory on which Columbus acted? Why was he greater than other navigators of his day? What effect did the stories of Marco Polo have? Describe the efforts of Columbus to get money for his expedition. Describe his first voyage. How was he received when he returned? How did his second voyage bring disappointment with it? Why was sugar an important thing in the early history of the West Indies? What did Columbus discover on his third and fourth voyages? What land did he think he had encountered south of the West Indies?

IV. What land was discovered by Pinzon? How did Magellan complete this discovery? Describe Magellan's voyage on the Pacific Ocean. How did Brazil come into the possession of Portugal? How did the name "America" come into use? What did Vaseo da Gama discover? 
V. Describe the explorations of John Cabot, Verrazano, Corte-Real, and Cartier. Which of these made voyages for England? for France? for Portugal? What claims were founded on them?

\section{SUGGESTED TOPICS}

A Description of Vinland; Routes of Trade with the East; The Adventures of Marco Polo; The Voyage of Magellan. 


\section{CHAPTER III \\ SPANISH COLONIES IN AMERICA}

Although our own country was settled by the English we must feel great interest in the colonies of Spain. They were the first European colonies in the new world, and the great why they amount of money they yielded made other nations are imwish to have colonies of their own. We must not portant forget, also, that Florida, Louisiana, Texas, New Mexico, Arizona, and California were once Spanish colonies. We shall not understand their early history unless we know how Spain explored the vast country Columbus discovered, and how she settled and governed it.

The first colony was Hispaniola, or Hayti. It was colonized by Columbus on his second voyage, and we have seen that it became a prosperous sugar-raising country. From this Hispaniola place it was easy to cross to Cuba, and in 1508 that and Cuba great island began to be settled. The two islands soon contained a number of rich sugar planters with great estates on which the Inclians were forced to work. The natives did not make good slaves. They loved freedom and pined away under their hardships. As they died their places were taken by other Indians, captured by slave-hunters in other islands, and they also fell victims to slavery. By this means the original inhabitants of the West Indies were destroyed. Negro slaves were imported from Africa to take their places, and did not die under slavery as freely as the Indians.

One of the richest men in Hispaniola in 1513 was Ponce de Leon. He was fond of adventure and had explored and settled 
Porto Rico. When that was done he did not wish to remain idle on his estates. From the natives he heard of a rich country Florida beyond the Bahamas, in which was a fountain havdiscovered ing wonderful virtue. One who bathed in it, so it was said, would find his youth renewed. Ponce de Leon believed the reports and thought it would be a worthy adventure to discover so wonderful a country. He fitted out an expedition at his own cost and sailed early in 1513 into the northern seas. Passing the Bahamas, as directed, he came to land on April 2. It was Easter Day, which the Spaniards call Pascua Florida, and the country abounded in flowers; so he named the land "Florida." The spot was north of what is now St. Augustine. He sailed southward along the coast, passed around the end of Florida, and reached Ponce de Apalache Bay on the west coast. He returned homeLeon ward thinking Florida was an island and got permission to settle a colony in it. He now knew it contained no fountain of youth, but he thought great wealth and power would come to him who became its ruler. In 1521 he landed with his followers near what is now Tampa, laid out a town, and prepared to clear and cultivate the fields. But the Indians were hostile. They had now learned enough of the Spaniards to consider them enemies. They concealed themselves around the fort, attacked the settlers, and so wounded Ponce de Leon that he died after a long illness. His followers returned to Cuba, and it was many years before another colony was planted in Florida.

Another explorer of the land was Balboa. He was once rich but had run into debt and was glad to leave Hispaniola to get Balboa away from his creditors. He joined a colony which set out for the Isthmus of Panama and became the leading man in it. From the Indians he learned of a great ocean to the westward, and he started with nearly two hundred Spaniards and some Indians to find it. The jungle was so dense that it took eighteen days to go forty-five miles. When the guides told him the sea was at hand, he caused his company to halt and went 
forward alone, so that he might be the first to see the ocean. Then, as the beautiful surface of the Pacific stretched out beneath his eyes, he fell on his knees and thanked God that he was the first white man to see the Great Sea. This was in 1513, the year Ponce de Leon discovered Florida.

In 1527 de Narvaez left Spain with six hundred colonists for Florida. He landed near Tampa, but so many of his followers deserted or died that he was in despair. Finally he marehed into the interior, fought several battles with

De Narvaez the Indians, came to the shores of the Gulf of Mexico, embarked on some rude boats, and sailed along the coast westward. De Narvaez was finally drowned, and all his men perished but four, who reached Mexico after wandering among the Indians for five years. One of them was Cabeça de Vaca, who wrote a thrilling account of his experiences. He also described in glowing terms the country through which he had wandered, and thus he made others wish to explore it.

One of the men who were fired by these tales was de Soto, who had obtained great sums of money in Peru. He was governor of Cuba and Florida and started out to explore Florida at his own expense. He landed at Tampa in

\section{De Soto} 1539 with more than six hundred men and marched into the wilderness. For three years he went through the interior country, crossing Georgia, South Carolina, North Carolina, Tennessee, Alabama, and Mississippi. In 1541 he reached the Mississippi River near Memphis and crossed it into Arkansas. He wished to march into the great West, but his men refused to go with him and he turned back toward the coast. Sickness overcame him and he died in May, 1542. His followers buried his body in the great river he had discovered and escaped to Mexico after many hardships.

Ponce de Leon, de Narvaez, and de Soto were the three great Spaniards connected with the exploration of what we now know as the Gulf States. They all Iost their lives Their work because of their zeal for exploration, but their work was very 
useful to those who came after them. They revealed the interior of the country east of the Mississippi. For the country west of that river another group of explorers did the same service; and this leads us to speak of Mexico, from which the explorers of the Southwest went out.

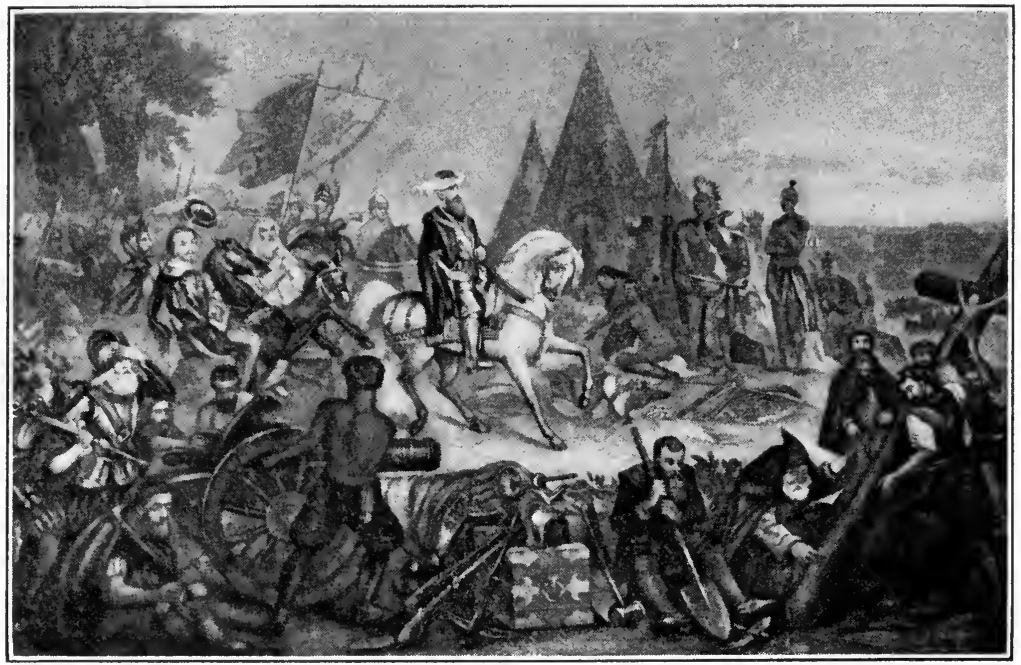

De Soto discovering the Mississippi River

In 1517 Spanish vessels which had been on the coast of Yucatan came to Cuba with stories of towns they had seen, whose streets Mexico con- were paved and whose buildings were of stone. Nothquered by ing like this had been found elsewhere in the new world, Cortez and ships were dispatched to see if the report was true. They returned saying they had not only seen stone houses and paved streets, but they had seen good evidence that there was much gold in the interior of the country to which they had been. This report put all Cuba in motion. In 1519 eleven ships set out having on board five hundred and fifty Spaniards and half as many Indians. They were led by Cortez, as brave a man as one could 
find in any country. When they had landed at what is now Vera Cruz, he burned his ships, lest his men should become discouraged and try to escape out of the country. Then he marched inland to the city of Mexico. By using tact at times and giving hard blows at others, he conquered the country in two years. He found much gold and silver; and rich mines were opened which yielded vast treasures for many years.

From Mexico many explorers went out into other parts of the new world. The Indians did not give much trouble and Spanish colonies were soon settled in Central America. Next From they turned their attention to South America. They Mexico found a very rich country in Peru, where the Incas southward ruled. It was conquered by Pizarro, who sent home from it large amounts of gold and silver. Mines were opened in Peru also. The Spaniards took so much wealth from their mines in Mexico and Peru that they paid little attention to clearing the land.

Explorers went, also, to the northward from Mexico, traveling through our southwestern states. It was the stories of Cabeça de Vaca, who wrote about the trials of de Narvaez and Coronado's his men, that turned attention to this region. Travel- march ers had gone into what is now Texas and returned with stories of seven cities of Cibola, fabulously rich and only awaiting another Cortez to take them. A friar was sent out to investigate, and he, returning after many days, footsore and lean, said he had seen one of the cities from afar. Then a body of men was sent out to plant a colony in the country. Coronado was made its leader, and he had eleven hundred men, whites and Indians. He reached thə Gulf of California and then turned eastward through Arizona and New Mexico, halting near the border of Oklahoma. With a small guard he went as far as the center of Kansas. He found some Indian villages and pueblos, but no rich cities. The seven cities of Cibola were a myth, but it caused much searching through the Southwest, and by that means the world learned a great deal about the geography of that region. 
It may seem strange that the Spaniards could march at will through these large distances without attacks from the natives.

The Spaniards and the Indians

There were two reasons for it. One was the quiet disposition of the Indian in the region from Texas southward. He lived by cultivating small fields of maize, or vegetables, and did not depend on game as much as the tribes north of him. The appearance of white men did not alarm him : on the contrary, it pleased him; for the whites brought articles of trade, things the Indian could not get otherwise. In the second place, we must remember that in most of the colonies in Central America the Spaniards did not pay much attention to farming. They settled at the ports and around the mines. They did not cover the countryside with farms, as the English did in the north, and the natives were not alarmed with the thought that the country would pass out of Indian hands. The Indians and Spaniards did not fight such fierce wars of extermination as the English and Indians fought in what is now the United States.

A very important part was played in the Spanish colonies by missionary priests. The Spaniards were very eager to convert The mis- the natives to Christianity. In Spain king, nobles, sionaries and the church furnished money for this purpose; and friars went out with every colony. A planter would receive a plantation, and to him would be assigned a group of Indians. $\mathrm{He}$ might require them to work on his land, but he was required, on his part, to have them taught in his religion. As fast as colonies were founded churches were established. Bishops were appointed, cathedrals were built in the important towns, priests came over from Spain, and little bands of them went out to distant tribes establishing missions. The first white settlers in California and New Mexico were these missionaries. After a mission was founded, plantations owned by Spaniards who were not priests were apt to be located around it; and the mission thus became the center of a civilized community.

We have seen that slavery destroyed the native population of 
the West Indies. It might have destroyed also the Indians of Central America, if it had not been for the efforts of Las Casas, bishop of Chiapas, in Yucatan. He was one of the great Spaniards of his day, and he gave up a life of

\section{Las Casas} luxury in Europe in order to convert the Indians of the new world. His reputation for wise and benevolent plans was so

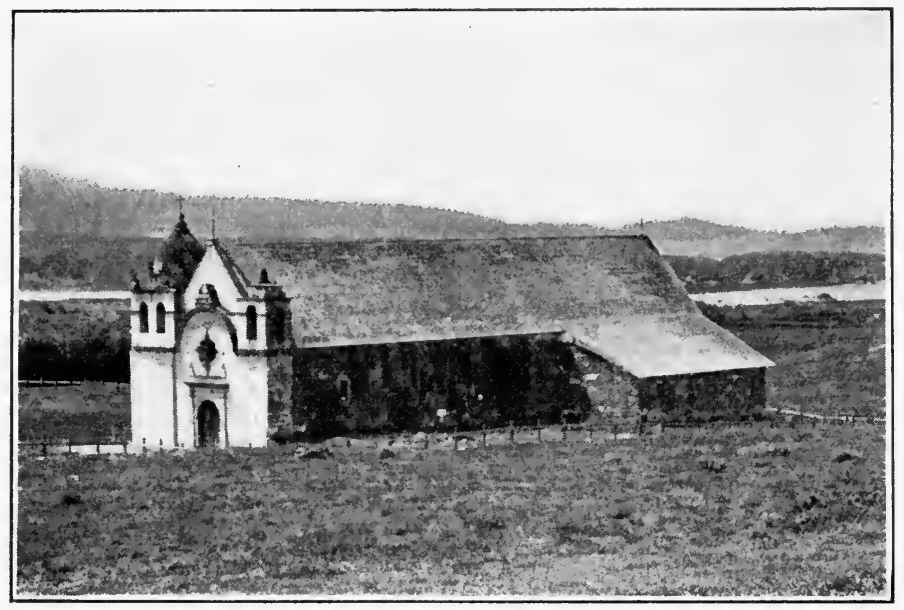

A California mission

great that the king of Spain gave attention to anything he asked; and it was in this way that he saved the Indians of Central America from slavery. Through his efforts an order was issued in 1542 that these Indians should not be delivered into the hands of the Spanish landowners. They were to have their own land and live in villages, paying a small tribute to the Spanish governors. Each village was to have a priest and a schoolmaster and was to keep its own form of government under the authority of Spain.

The colonies of Spain were ruled by officials appointed by the king. There were governors over provinces, and men appointed 
under them who supervised the affairs of the towns and the smaller districts. All these officials were Spaniards. Many of The govern- them bought their offices and handed them down to ment of the their children. To see that they filled their offices propcolonies

erly officials were sent out through the colonies at regular periods to inquire of the people about the conduct of the men in office. We must not think that those who bought offices or inherited them were necessarily bad officials. Some of them were very just to the people, and others were cruel, negligent, or corrupt.

At the head of colonial government was the great council of the Indies. It was composed of high Spanish noblemen, and the The coun- records it has left show that it was ably managed. It cil of the made laws for the general welfare of the colonies, Indies nominated the higher officers, and settled disputes that came up before it. All the Spanish colonies were thus under one supervision, and they were governed in a similar way. The government of the English colonies; as we shall see, differed in some important respects from that of the Spanish colonies. A compari- In the first place, the English colonies were self-governson ing in local affairs. The colonists elected representatives who made up a lawmaking assembly with duties somewhat like those of the parliament in Great Britain. Nothing like this existed in Spanish America. Another difference was in the large number of elective offices in most of the English colonies, especially in those lying north of the Potomac. There were very few elective offices in the Spanish colonies. Still another difference was in the wide variety of government among the English colonies. Virginia and Massachusetts had not the same form of government-for a large part of their colonial existence; and the government of Connecticut was like that of neither of them. Finally, the English colonies were not so closely dependent on the mother country as those of Spain. They used for their own purposes the taxes they levied in their own legislatures. The Spanish colonies yielded a large revenue to the mother country. 


\section{QUESTIONS}

I. Why are we interested in Spanish colonies? In which of our states did Spanish settlements once exist? What important explorations were sent out from Cuba? What was the effect of slavery on the natives of the West Indies? Who replaced them as laborers?

II. Name the leading Spanish explorers of the mainland. Describe the discovery of Florida. How did Florida get its name? Who was the real discoverer of the Pacific Ocean, Balboa or Magellan? Describe the adventures of de Narvaez and de Soto.

III. How was Mexico conquered? What were the most important products that Spain received from Mexico? Who conquered Peru? Describe Coronado's journey. Explain the "seven eities of Cibola."

IV. How did the Spaniards manage to live peaceably with the Indians? Did they drive the Indians out of the country in which Spanish colonies were planted? Describe the work of the missionaries. Describe the service of Las Casas to the Indians.

V. Describe the government of the Spanish colony. What was the Council of the Indies? Compare English and Spanish colonial government.

\section{SUGGESTED TOPICS}

The Career of de Soto ; The Conquest of Mexico ; The Career of Las Casas. 


\section{CHAPTER IV}

\section{THE FIRST ENGLISH COLONY}

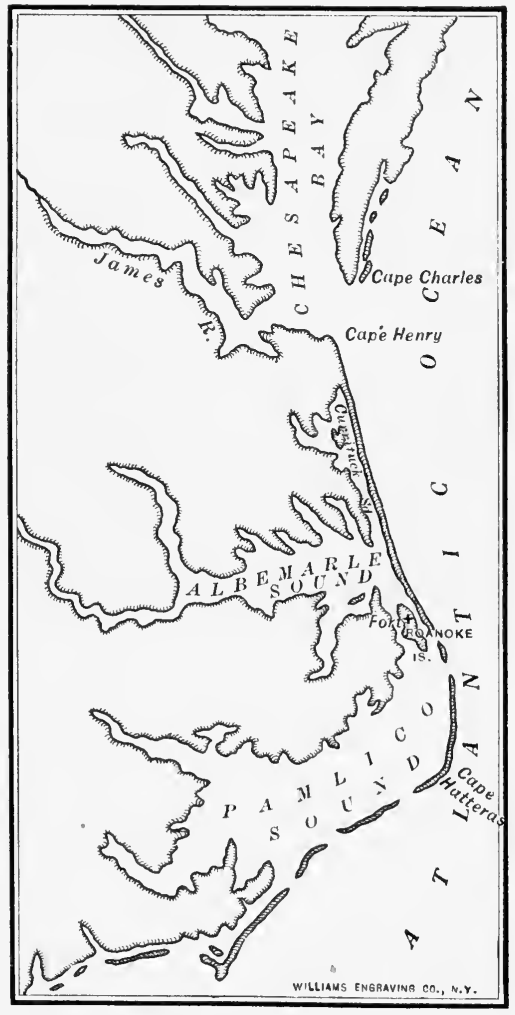

Roanoke Island and Chesapeake Bay

ThE first Englishman to send a colony to America was Sir Roanoke Walter Raleigh. In Island 1584 he sent two ships to find a place at which a colony might be planted. They reached land near Cape Lookout and came to an inlet through which they entered Pamlico Sound, North Carolina, and anchored at Roanoke Island. In a few weeks they returned home with glowing accounts of the country. All England rang with praise, and Queen Elizabeth gave the new land the name "Virginia" in honor of herself, a virgin queen.

Next year Raleigh sent out a second expedition to make a Second ex- temporary settlepedition ment, and to explore the country in order to find the best place for a permanent town. It was attacked by Indians and returned to Eng- 
land, reporting that the entrance of Chesapeake Bay, seventy miles north of Roanoke Island, was the best place for settlement.

No time was lost in sending a third expedition. It contained one hundred and fifty persons under John White as governor and left England on May 8, 1587. White was ordered The "Lost to establish "the Cities of Raleigh in Virginia" on the Colony" shores of Chesapeake Bay. He first reached Roanoke Island, where a small garrison had been left by the second expedition. The captain of the ship on which he came would go no farther, and the colonists were forced to establish their town on that site. Among them were twenty-five women and children, and a few days after they landed a baby girl was born to Eleanor White Dare, the daughter of the governor. The child was named Virginia, the first white child of English parents born in America. A few days later Governor White at the request of the colonists departed for England to get supplies. He was not able to

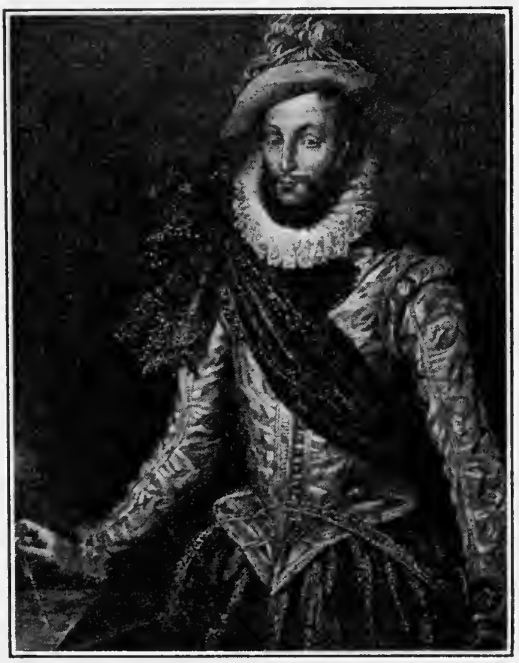

Sir Walter Raleigh return for two years, and when he did come the colony had vanished. Tradition preserved by the Indians said that most of the colonists were slain by the savages and that the rest were taken prisoners and dispersed. The fate of Virginia Dare is as mysterious as that of the "Lost Colony of Roanoke."

Raleigh was now bankrupt and was soon in prison. He had powerful enemies, and his life was finally taken to satisfy their hostility. Without money he could do no more for Virginia. 
But he had friends and they were friends also of Virginia. Among them was Richard Hakluyt, a man of learning who delighted to Richard collect the stories of the bold sea captains who went Hakluyt to the new world. He wrote pamphlets on the advantages of English colonies. Others helped and in 1606 two comTwo com- panies were organized to settle colonies in America. panies One was known as the Plymouth Company, and it was to plant colonies in the northern part of what is now the United States. The other was called the London Company, and it was to plant in the south. The first company failed, but the second kept up its work and out of it grew the colony of Virginia.

Before that time several great trading companies had been created in Europe. They were composed of men who paid money Shares in into the common stock. Ships were then sent out, furs the com- or other articles were brought home and sold, and the pany profit was divided among the men who had bought shares in the enterprises. The London Company was founded on somewhat the same plan. A rich man would pay for several shares, a poor man would take fewer, and every free man who went to settle in Virginia was to have one share without paying anything. The company was to furnish everything needed in the colony, and all the products of the colony were to go into a common store and be sold. At the end of five years the profits were to be divided. A poor man who settled in the colony would have to work for the company, and his only reward would be his food and clothing and the part which would come to him as the owner of one share when the profits were divided. It was not a wise plan; for men do not work well if they do not have what they produce. But we must remember that the English at this time knew nothing of how to plant colonies. They were soon to learn in the sad school of experience.

The first colony of the London Company sailed from England in December, 1606, and entered Chesapeake Bay on May 6, 1607. Before them was a great river which they called the James. 
Thirty miles from its mouth they found a peninsula, two and a half miles long, connected with the mainland by a narrow isthmus, which the river has since cut through. It seemed a good place for a town because it could easily be deJamestown fended and because at the western end the current had cut down the bank and scoured out a channel so deep that the ships could be tied to the trees on the shore and unloaded without docks. They landed on May 14, 1607 , and began at once to build a fort with dwellings and a church within the walls. The houses were of poles covered with bark and grass and placed close together on each side of a little street. In the colony were 104 persons. Half of them The were men of colonists good families who did not know how to do the labor of clearing the forest, but who came to Virginia for

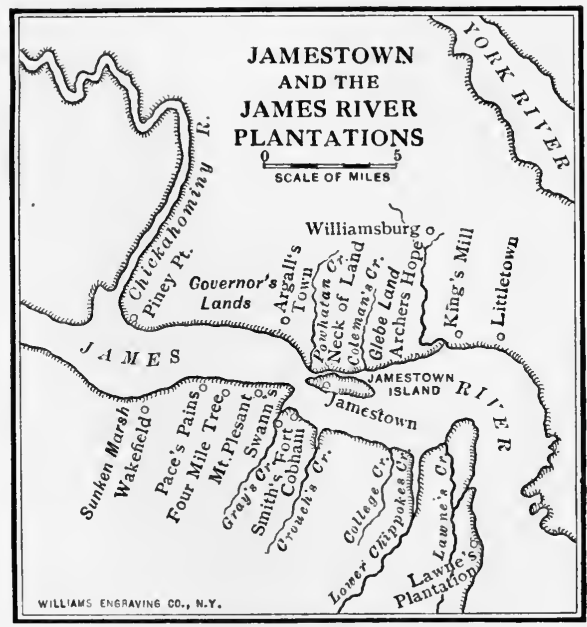
adventure. They were disappointed when they found how hard they must toil. Some would not work, but others proved excellent laborers, doing tasks they had never before been called on to attempt. The other half of the settlers were laboring men before they came to Virginia. At this time there were no women in the colony.

While the fort and the houses were being built land was cleared and wheat was planted. The grain came up quickly but it was too late to ripen. Had they known, they might have Famine and planted the corn of the Indians with better success. disease Thus they raised no food the first season, and as the supply they 
brought with them ran low, they were in distress by the end of summer. To make matters worse chills and fevers appeared. This form of sickness was very prevalent in Virginia before it was known that malaria is transmitted by mosquitoes. By the end of September half the colony was dead and most of the survivors were shaking with ague. They were probably saved from complete starvation by Captain John Smith, who manned a boat and went

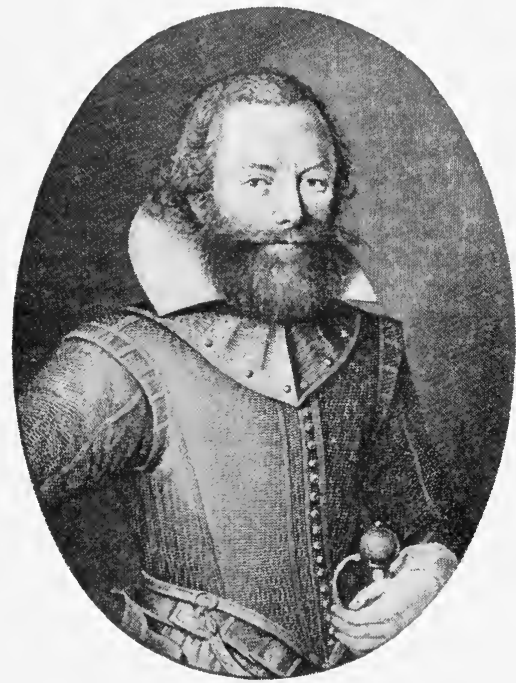

Captain John Smith up and down the rivers trading with the Indians. $\mathrm{He}$ brought in enough corn to support the colony until help came from England.

Seven men were appointed a council to rule the settlers, Smith's and John Smith services was one of them. He was an abler man than any of the others, but he was outspoken. He criticized the plans of his fellow councillors and was accused of stirring up discontent. For a time he was excluded from the council, but when the suffering was greatest the people turned to him for help. By getting corn from the Indians he had shown his fitness to guide the colony, and he now became president of the council. "He put an end to idleness by ordering that no food be given to those who would not work. This course was approved by the majority of the colonists, but there were some who complained. Nevertheless Smith had his way and Jamestown prospered until his departure in 1609. Then returned the old troubles. Idleness, quarreling, and disease brought the colony to the verge of starvation. At 


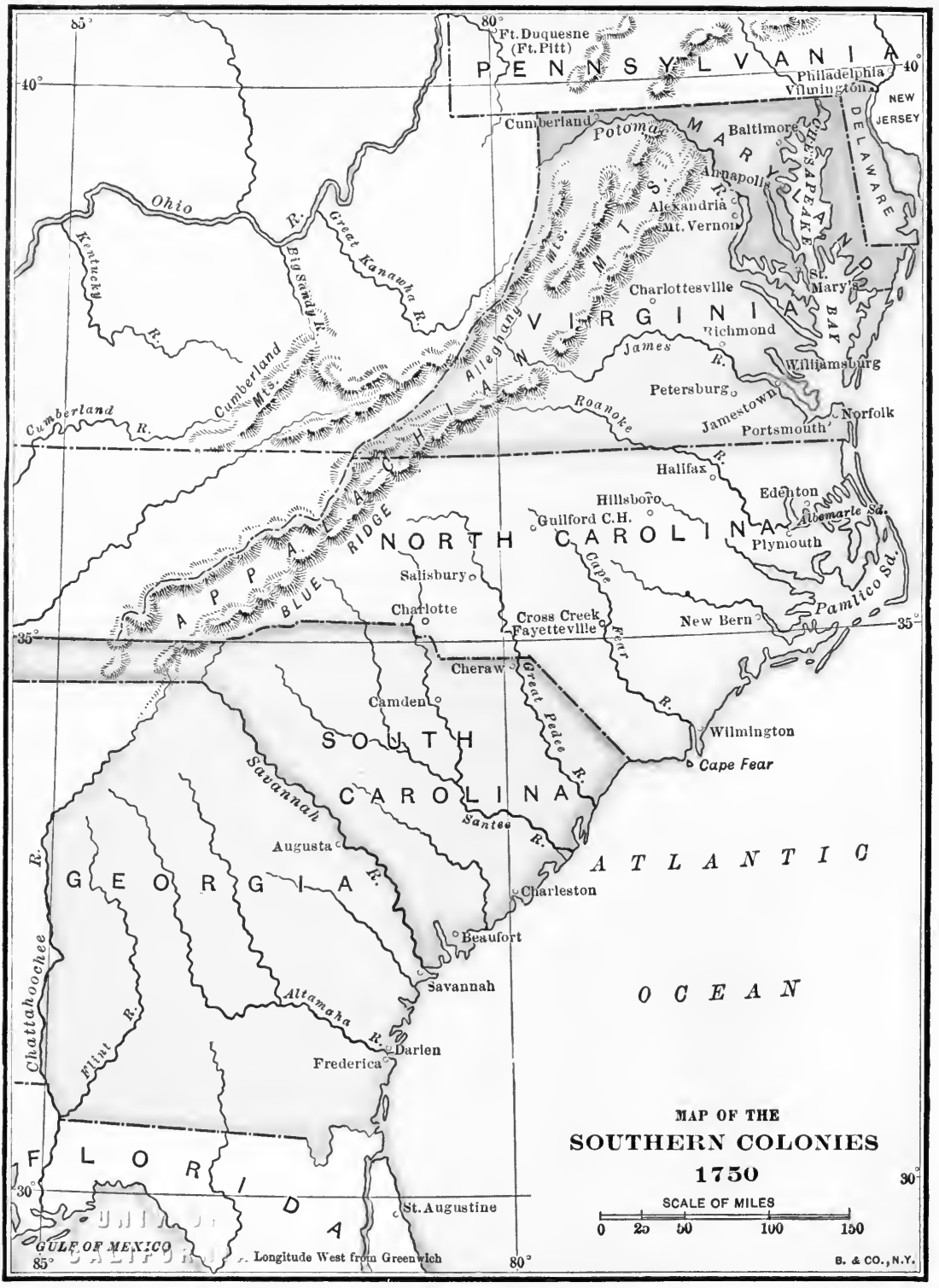


one time the people embarked for England but turned back near the mouth of the river when they met a new governor with supplies.

In 1611 Governor Dale came to rule the colony. He was a hard man but a just governor, and he suppressed the idlers and mischief-makers in a short time. Some he found rest- Governor ing in their cabins, others playing bowls in the streets. Dale All were given tasks and punished if they failed to do them. If a man tried to leave the colony, he was severely punished. The people complained that they were reduced to slavery, but from Dale's time there was always enough food in Virginia.

Dale was governor for five years, and within that period two favorable things happened. One was changing the system of labor. He allotted three acres of land to each of the New labor more important men and required a high rent for it; system but all the produce above the rent was to belong to the man who held the land. The rest of the men had to work as before for the common store, but they were allowed one month in the year in which to raise corn for themselves. This was a small departure from the old system, but it worked wonders. One of the colonists said that a man did more work in one day when he knew the produce would be his than he did in a week when he knew that all he made would go to the company's warehouse. So well did the new plan work that in 1619 the common store was entirely given up. Land was now given to each settler. One hundred acres were given to each of the early settlers who still lived and fifty to each of the later ones.

Another fortunate thing in Dale's time was the discovery that tobacco grown in Virginia would bring high prices in England. Before this time all the tobacco that came to England came from the Spanish colonies. About 1612 it Tobacco began to be raised at Jamestown by John Rolfe. He got the seed from the Indians, who had long had it for their own use. It was so scarce in London that a pound sometimes sold for as much as 
$\$ 12$ of our money will buy. Everybody now wịshed to raise it, and there was danger that the people would plant so much that they would not have enough corn for food. Dale met this difficulty with his usual strictness: he ordered that no tobacco

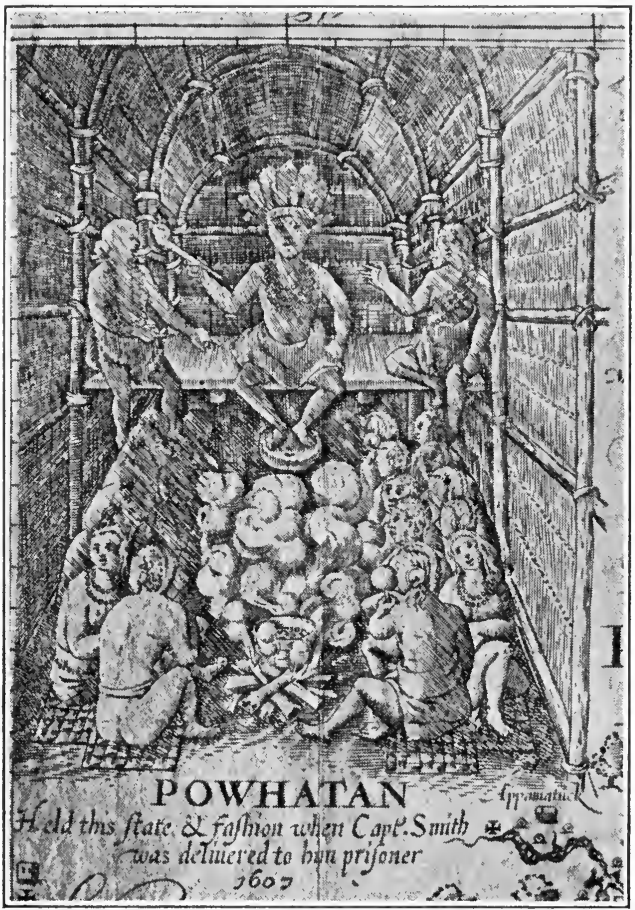

be planted until a sufficient amount of corn was assured. After he departed the very streets of Jamestown were green with growing tobacco. It was a good thing for Virginia to have a crop which could be sold abroad in large quantities. Industrious men made money and some became wealthy.

At first the Indians around Jamestown Services of were hostile. Pocahontas They hid in the long grass around the fort and shot arrows at the whites who strayed away from the town. Over all the tribes in this part of Virginia ruled Powhatan, who lived about eighteen miles from Jamestown. He had a young daughter named Pocahontas, and Captain Smith tells a story in which she saved his life at the risk of her own. He was taken by the savages and carried before the great chief, who ordered the prisoner's brains dashed out. As a club was uplifted to kill him Pocahontas darted forward, threw herself over Smith's head, and begged 
her father to spare his life. Her request was granted, and Smith was sent home with presents. Many people have doubted this story, but it is known that Pocahontas became a good friend of Captain Smith and that she befriended the whites in many ways. In 1614 she married John Rolfe, the first tobacco planter, and then Powhatan made a treaty of friendship which was not broken as long as he lived. Pocahontas went to England in 1616 and was received as a princess. She soon tired of the country and longed to see Virginia again, but she died in 1617 as she was about to return. The people of Virginia never forgot her services to the colony when it was weak and in need of help.

After Powhatan's death the Indians showed hostility. They believed their lands would soon be taken from them, and they made secret plans to destroy the whites at one blow. Indian masThe time selected was a day in March, 1622. For a sacre, 1622 few days before attacking, the Indians visited the whites and showed great friendliness. They thus put their victims off guard and then they struck as hard as they could. Four hundred whites were killed, all of them in the remote plantations. The survivors were not as numerous as the Indians and could not take the vengeance they wished. They drew back to fortified places on the James and planted corn. As soon as they could leave their crops they sallied forth, burned the Indians' houses and growing corn, and killed as many of the enemy as they could reach. But the savages did not submit. They lay in wait for the whites and killed those whom they could cut off. Next summer the settlers again attacked, burning, destroying corn, and killing as they could. The war was renewed in 1624, and in their desperation the colonists used poison, hoping they might thus destroy men who took advantage of every stratagem to kill. After a while the Indians ceased to struggle, and the whites were able to settle in safety on the James. It was not until 1644 that the Indians again attacked the settlements. At that time the colonists were so strong that they were able to send a large force 
against their foes. They slew so many that the natives made a treaty and retired from the region between the James and York rivers.

In 1619 a very important change occurred in the government of Virginia. The first colony was ruled by a council, but the counSelf-government, r619 cillors quarreled so much among themselves that it was abolished in 1609, and its place was taken by a governor, who could do nearly as he pleased. This produced trouble also; for the governor was not always a wise or a just man. In 1619 a third form of government was adopted. There was still a governor, and he had a council appointed in England. But the people were allowed to elect burgesses, or representatives, two from each plantation, who were to come together as a house of burgesses. From that time the governor, council, and house of burgesses were all to sit together and be known as the assembly of Virginia. The assembly was to make the laws. Thus the people gained a voice in their government. They could defeat a bad law, decide how they were to be taxed, and say how the money which came from the taxes was to be spent. It was the beginning of self-government in America.

These reforms were made through the action of the London Company, which exercised authority over Virginia. They were London due to the efforts of several liberal men in the comCompany pany, the leader being Sir Edwin Sandys. King destroyed James I was much opposed to the reforms and decided to destroy the company. He charged it with all the misfortune that had happened in Virginia, and got his high court in London to declare that the company should give up the colony into his own hands. Virginia thus became a royal province, 1624, and after that the king appointed the governor, council, and many high officers in the colony. He did not destroy the colony's assembly. It continued to make laws, but they could be vetoed by the king. After a while counties were laid out, and sheriffs and county courts were appointed to manage affairs in them. The 
county officers were not elected by the people, but were appointed by governor and council, who were careful to name such men as would not oppose the king. This was the form of Royal government later adopted in most of the royal province provinces. But the county officers were men who lived in the colony and knew what was best for the colonists. Under them there was a great deal of prosperity and the people were satisfied.

Virginia, the first English colony in the South, was the center from "Mother of which other States" colonies sprang. When it became a royal province, it belonged to the king, and he had the right to

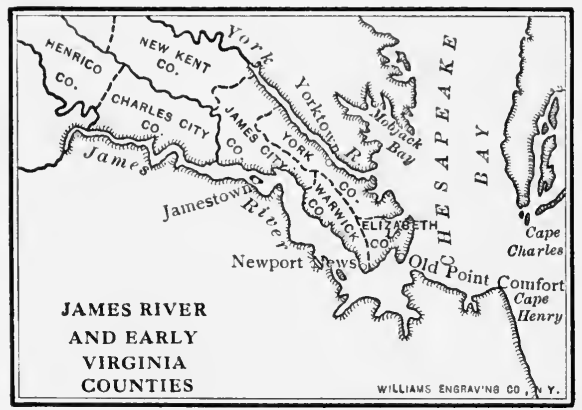
grant its territory as he chose. On the south a vast portion was cut off, and out of it came in time the two Carolinas and Georgia. On the north another portion was taken, and this became the colony of Maryland. Six of the states to the west and northwest of Virginia were once within her boundaries. It is because so many states have thus been made out of her ancient dominion that she is called "the Mother of States."

Maryland was granted by the king of England, Charles I, to Lord Baltimore in 1632. The name was in honor of Henrietta Maria, the queen of England. Baltimore was a Catholic and wished to make the colony a place of refuge

\section{Maryland} for those who believed as he. At that time the Catholics were being persecuted in England, and it was thought that they would come in large numbers to a place in which they encountered no oppression. But Baltimore wisely offered toleration to all churches, and it happened that a great many Protestants came to Maryland. They were at last in a majority, and forgetting the wise example 
that had been set them, they proceeded to put restrictions on those who did not believe as they.

The first settlers in Maryland arrived in 1634 and settled at St. Mary's near the mouth of the Potomac. Mindful of the early First colony hardships at Jamestown, they planted Indian corn and harvested so good a crop the first year that they could spare a ship load to exchange for fish at Boston. The first

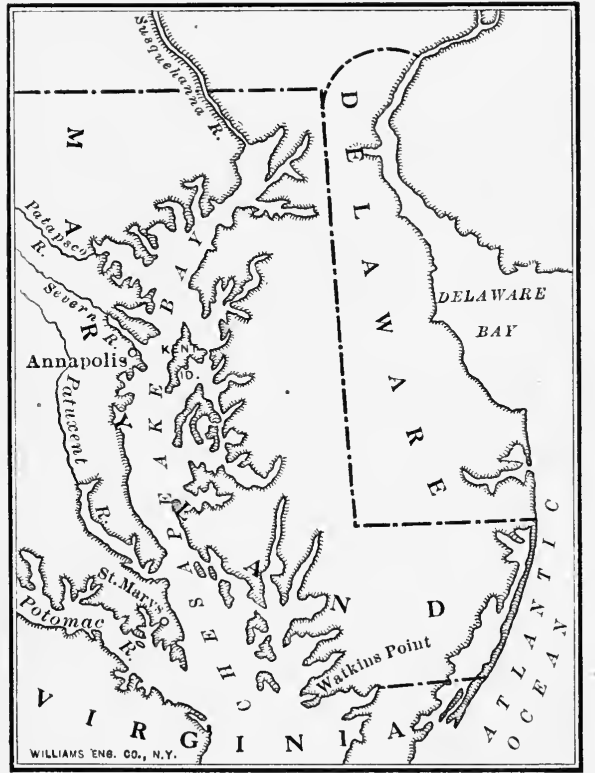

colony consisted of twenty gentlemen and about two hundred laborers. It bought from the Indians the land on which St. Mary's was established, and soon prosperity came through trade and the production of tobacco.

Maryland was a proprietary colony : that is, it The govern- was under the ment authority of the proprietor, Lord Baltimore. He owned the land in the colony and granted it to the colonists, and he was the head of the government. The only restriction on his power was that he must make laws with the advice of the freemen or their representatives. He understood this to mean that he could suggest the laws which would be approved by the freemen. $\mathrm{He}$ was soon to know that he was mistaken. In 1635 the colonists held an assembly and enacted a number of laws for the colony. Baltimore rejected them on sight. Then he sent to Maryland such laws as he thought the colony needed, expecting that the 
assembly would approve them. They were all rejected. $\mathrm{He}$ was a wise and well-meaning man, and he saw that he must yield. From that time the assembly made the laws and sent them to the proprietor for approval. On the other hand, he appointed the governor, high judges, and many other officials.

In 1649 the parliament of England ordered the execution of King Charles. One of the reasons he was so unpopular was that he was believed to be a Catholic at heart. The parlia- Danger ment was strongly Protestant, and it was supreme. averted It was, therefore, natural that its supporters should cast suspicious glances at the Catholic colony of Maryland. Baltimore was greatly alarmed, lest his charter be annulled. He had more reason for his fears because there was stern wrangling between the extreme Protestants and others in Maryland itself. The trouble there finally led to civil war, and a sharp battle was fought in which victory was with the opponents of the proprietor. But Baltimore had great influence in England, and in 1657 the government there allowed him to retain the colony, he showing that he would grant toleration to all.

\section{QUESTIONS}

I. Describe Raleigh's first expedition to America. How did Virginia get its name? What was accomplished by the second expedition? Describe the third expedition. Why was White's colony called "the lost colony"? Who was Virginia Dare? Why did Raleigh give up his efforts to settle Virginia? Who took up his work?

II. What two companies were organized in England in 1606? What was the object? How were the shares distributed? How were the shareholders in the colony to be paid for their labor?

III. Describe the settlement of Jamestown. What kind of men were the colonists? What was the cause of the distress of the first year? How was it relieved? How did Smith rule the colony as president? What was the situation after his departure? How did Governor Dale rule? What was his new system of labor? Describe the introduction of tobacco planting. 
IV. Who was Pocahontas? How is she said to have saved the life of Captain Smith? What were her services to the colonists? Describe the Indian war of 1622 . How did the whites take vengeance? When did the Indians next make war on Virginia?

V. Describe the earliest government of Virginia? How was selfgovernment introduced? Describe the new system. How was the London Company overthrown? What form of government took its place in Virginia? Describe it.

VI. Why was Virginia called "the mother of states"? Describe the origin of the Maryland colony. Describe religious toleration in Maryland. Describe the settlement of St. Mary's. What was a proprietary province? How did it differ from a royal province? How was the proprietor's authority limited in Maryland? How did Baltimore preserve his charter in 1657 ?

\section{SUGGESTED TOPICS}

The Career of Sir Francis Drake; The Spanish Armada ; The Career of Captain John Smith ; Criticism of Smith's Pocahontas Story ; The Plantation Life; The Virginia Trade. 


\section{CHAPTER V}

\section{THE NEW ENGLAND COLONIES}

EARLY in the seventeenth century a great many Englishmen wished to reform the English Church by dismissing the bishops and giving up some of the doctrines of the Book of Reformers Common Prayer. Such persons we may call the re- in England formers. The king and most of the bishops were opposed to their demands and tried to force them to believe in the old way. Ministers who held the reform doctrines were turned out of their parishes, and when they gathered their followers in private meetings, they and their hearers were thrown into prison. Some of the persecuted ones fled to the continent. Others went to New England to found colonies in which they might support themselves by their labor and have governments under which they could worship in their own way.

They came to America in two important groups. The first were the separatists, who wanted to separate from the English Church. They thought each congregation should choose its own minister, and direct its affairs by a vote Two groups of the members. The second group were the Puritans. When they left England, they had not declared for separation from the Church but only asked that the old church be purified in some of its features. But when they got to New England, they adopted the congregational form of church government, refused to have bishops, and became as truly separatists as the first group. We must take up these two divisions separately, for each founded a colony, although the two colonies were later united into one.

The separatist group arrived earliest. We first hear of them 


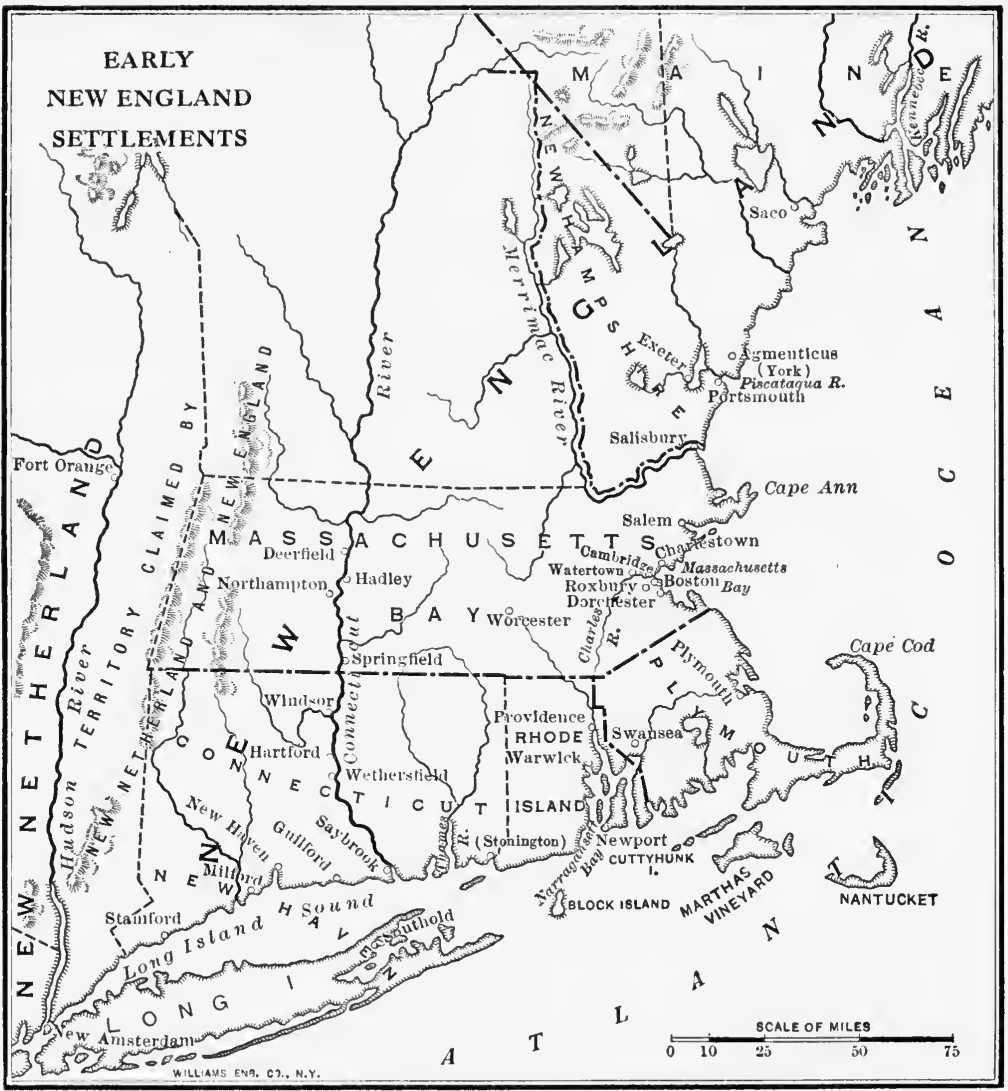

at Scrooby in the eastern part of England, where they worshiped in secret. One of their ministers was Rev. John Robinson, a The exiles gentle and learned graduate of Cambridge University. from Their meetings attracted the attention of the king's Scrooby officers, and the people were imprisoned so often that they fled to Holland. The Dutch treated them kindly, but wages were low and they grew tired of living among foreigners; 
and after ten years among the Dutch it was decided to settle elsewhere. Some wished to return to England, notwithstanding the persecutions there. But the majority decided Holland and to go to Virginia, as all the northern part of America Virginia was then called. The London Company was not yet abolished and gladly granted them a charter. The company had the authority to establish colonies as far north as the forty-first degree

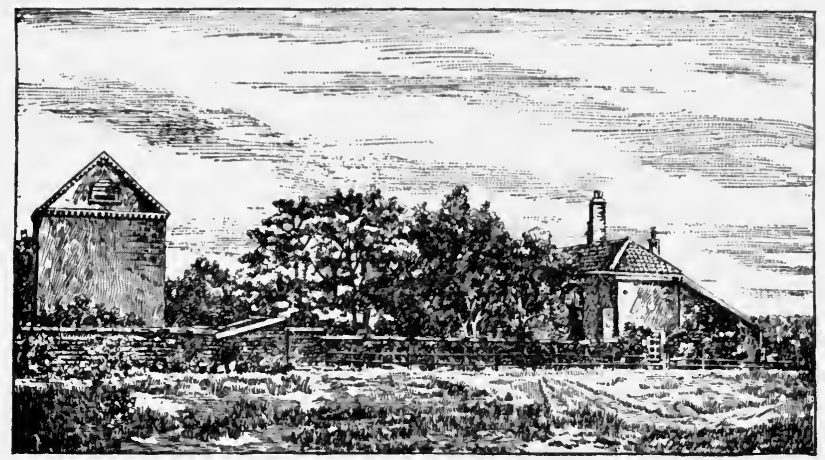

Brewster's house at Scrooby

In the building on the left the Pilgrims held their services.

of latitude, which falls near the northern shore of Long Island Sound. The Scrooby exiles expected to plant their colony in what is now New Jersey.

The people were poor and had much trouble to get money to pay the heavy expense of going to Virginia. At last a company was organized with shares at ten pounds each. The The comexiles who were able took shares, but this yielded only pany a small sum. Then they called on their friends in England. It was thought that the colony would eventually become rich, and with that expectation some merchants and others finally subscribed for the rest of the shares, the whole amount being seven thousand pounds. Each colonist was given one share for going ; and it was agreed that all should work together and allow the 
profits above expenses to go to a common fund which should be divided, at the end of seven years, according to the shares held.

Arrangements were then made for the departure. The youngest and strongest were to go first to prepare a place for the others. The depar- In September, 1620, they set out in the Mayflower, a ture hired ship. They left behind them their beloved pastor, the faithful Robinson, who remained with the weak and aged until he could go with them to America. They never saw him again. The hearts of those who set forth were heavy, but they took comfort from the thought that they were under the care of God. One of them wrote: "They knew they were pilgrimes, and looked not much on those things, but lift up their eyes to the heavens, their dearest countrie, and quieted their spirits." They are called "Pilgrims" to this day.

After sailing nine weeks the Mayflower sighted land at Cape Cod. She turned southward to pass that point, but ran into shoal Arrival at water, and the captain put back and came to anchor Plymouth at what is now Provincetown. The weather was bad and he refused to go to Virginia as he had intended. The Pilgrims decided to seek a proper place and plant the colony in New England. A small boat was sent out and returned after many days reporting that a place fit for settlement was found. It was a small harbor which Captain John Smith had visited several years before and named Plymouth. Here the company landed on December 16, Old Style, 1620. Near the landing place was a great boulder which has become famous as "Plymouth Rock."

The weather was very cold, and the women and children remained on the Mayflower while the men worked hard on the shore First winter to build log houses and to land the supplies. It was soon seen that there was not enough food to last until a supply could be raised; and it was necessary to put the people on half rations. This produced much suffering; and after a while sickness visited them. When spring came, half of the Pilgrims had died, among them fourteen of the eighteen women who had 
sailed with the party. Those who were still alive were so weak that they could hardly plant the grain and build the houses that remained to be built. But not one was discouraged or wished to go back to England.

The first year at Plymouth was a hard one. Enough corn was raised to feed the people during the winter, but another ship came with passengers who had little food, and again there was want. As it happened, the Indians gave no

The Indians trouble. A few years earlier all those living near Plymouth had been carried off by a plague, probably smallpox. One morning in 1621 a single brave walked into the town crying "Welcome !" in English. It was Samoset, who came from Monhegan, where he had learned the English language from the English fishermen who visited that island. He proved a valuable friend to the colony. He brought to them another Indian, Squanto, who taught the whites many useful facts about planting corn and other crops and about catching fish in this region. North of Plymouth lived the Wampanoags, who showed that they wished to be friendly. Their chieftain was Massasoit, and in 1621 he made a treaty of friendship between his people and the men of Plymouth.

To the westward lived a stronger tribe, the Narragansetts. They were jealous of the Wampanoags and distrusted the English. So they sent to Plymouth a bundle of arrows wrapped in Narraganthe skin of a snake. It signified war. The whites setts were not frightened and returned the skin stuffed full of bullets, a hint of what the Narragansetts could expect if they attacked. The Indians understood, and there was no more trouble from them.

The governor of Plymouth was William Bradford, a man of great courage and wisdom. He ruled the colony many years, although he was elected yearly, and might have been Bradford replaced by another man, if the people had found him and a bäd governor. He was much helped by Captain Standish Miles Standish, who had been an English soldier. Standish 
commanded a company formed out of the men who could bear arms. He and his soldiers were of great service; for though they did not have to fight a serious war, they showed the Indians and some rude white men that the men of Plymouth were able to make themselves respected. Bradford wrote an excellent history of the colony.

We have seen that before they sailed the colonists promised to labor in common for seven years and to give the proceeds to Property in the company. Experience showed that this system of common a labor was as bad in Plymouth as in Virginia. Those failure industry. The married men complained because their wives had to cook, wash, and mend for other men. It was not on account of the labor itself; for everybody must work in Plymouth. But the men could not stand having their wives made common drudges for other men. Thus it happened that in 1623 a new agreement was made with the company. First, the town assumed the debt to the company and arranged to pay it out of the proceeds of the fur trade, a plan which resulted in the early payment of the debt. In the next place, each colonist was given a small farm with the understanding that he should have what he made. But he must pay his part of the town's taxes. This system proved to be a great deal better than the common fund.

The land around Plymouth was poor, but the people were very industrious and by hard work raised all they needed. After a New towns while they discovered more fertile lands not far away and groups of them moved off and founded several towns. But for all this the settlements grew slowly. Plymouth Colony was important because it showed Englishmen what New England was like. But the real work of settling the country was done by another colony.

When the Pilgrims decided to settle at Plymouth, they realized that the charter they had received from the London Company was valueless. They were within the limits of the Plymouth 


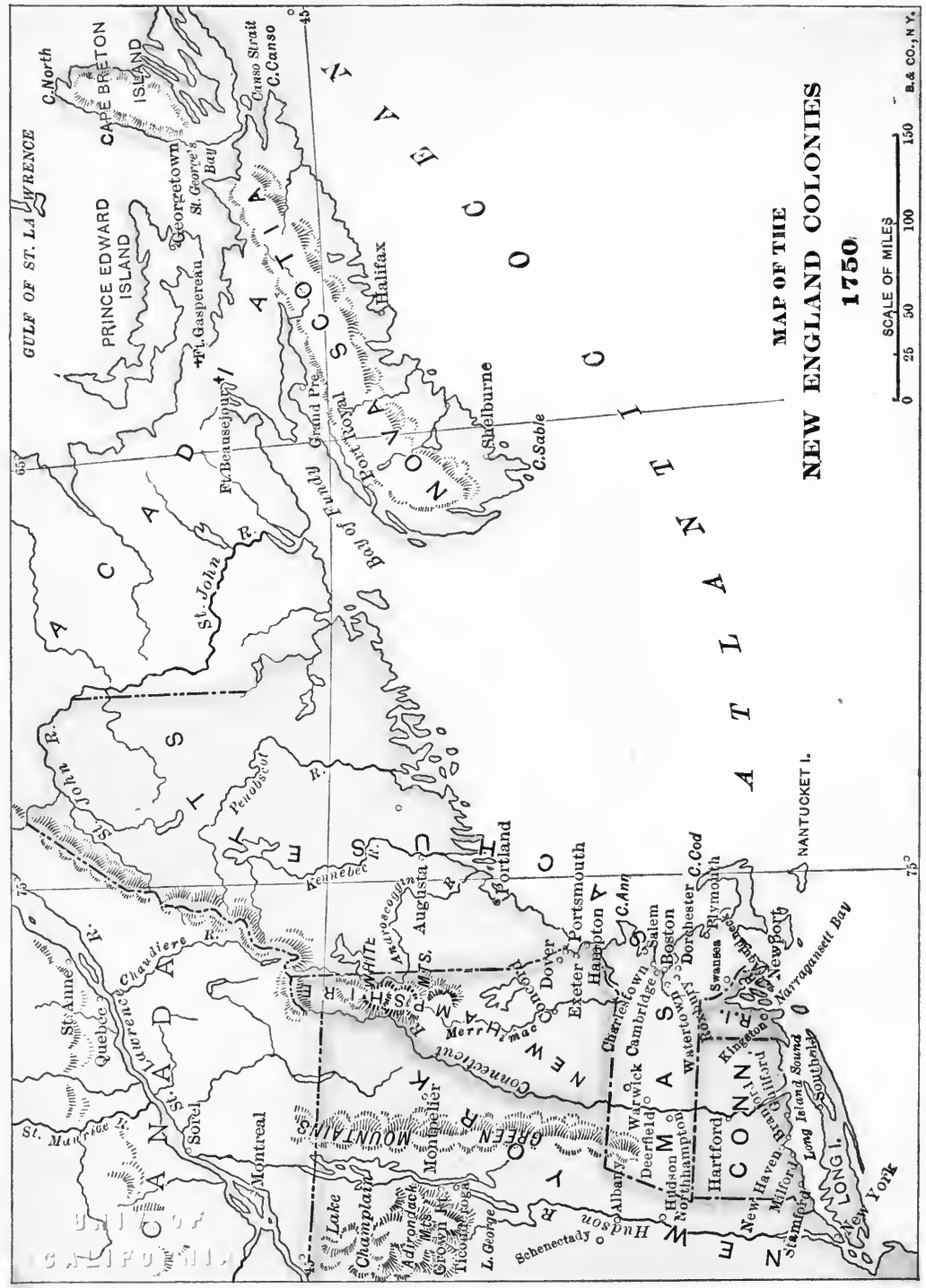


Company, founded in 1606 ; but it would take a long time to get from it a charter under which they could have a legal form of government. To meet this difficulty they drew up The Maythe celebrated Mayflower compact, and each adult free flower man signed it before the Pilgrims went ashore. It was compact a simple pledge that all would live as obedient citizens in one government, and that they would make their own laws and elect their own officers. At this time the Plymouth Company was being reorganized. From its successors the men of Plymouth got a patent enabling them to own their lands, but no charter was issued. The result was that the colony continued to exist under the Mayflower compact until Plymouth was united with Massachusetts in 1691.

In the early years of Plymouth's history British fishing and trading ships were frequently in the New England waters, and several trading stations were established on the coast Endicott's north of the town. Ships made good profits trading charter for fur with the Indians. In 1628 six men, one of whom was John Endicott, got a charter to settle a colony on the shore of Massachusetts Bay, between the Merrimac and Charles rivers. Endicott came over with a small band and founded a town at Salem. He and most of his company were Puritans, but when they got the charter, they did not expect to establish a home for people of that faith. They would have been glad to get settlers of any kind.

Under Endicott's charter was settled the Massachusetts Bay Colony, and the way it came to be a refuge for Puritans is as follows: Charles I, king of England, wished to take taxes without the consent of parliament. Some inde- tans left pendent men refused to pay and were imprisoned for re- England: fusing. The majority of the people sympathized with I. Taxes them; for it is a tradition dear to the hearts of Englishmen and Americans that no taxes shall be taken without the consent of the taxpayers. War finally began between the king and the people 
and the result was that the king was beheaded. Since that time no English king has tried to get taxes without the consent of parliament.

All this was a civil affair, but it was connected with religion. The Puritans were for the parliamentary side and loved liberty.

2. A home for Puritanism
The king and Archbishop Laud, rulers of the English Church, realized that those who would not obey in religious affairs would not obey in affairs of state; and they tried to stamp out Puritanism. Thus, two things led the Puritans to come to New England: the desire to escape the king's unlawful power and the hope of establishing a state in which the Puritan faith would be the religion of the people.

In 1628, when the Massachusetts Bay Colony was John Win- created, the struggle throp's shrewd move against the king was just beginning. A number of Puritans thought it would be well to leave England and establish a colony in which their own form of worship would be the rule.

The leader of the movement was John Winthrop, a learned and wise member of the country gentleman class. He and some friends signed a paper at Cambridge, England, known as the Cambridge agreement, pledging themselves to move to New England and to carry as many others with them as they could. He then made an arrangement with the company that held Endicott's charter. He and his friends joined the company, and all the members agreed to go to New England and carry the charter with them. Other companies had remained in England 
governing the colonies they sent out. In the Massachusetts colony the company was on the spot. All the colonists were members of the company; and thus the people governed themselves when the company made rules for its own affairs. As we shall see, the company became a very large number of people. It was the citizens of Massachusetts.

All this happened in 1629, and early next year Winthrop sailed for America. His efforts to get friends to go with him were very successful, and he was accompanied by nine hundred persons in eleven ships. Salem did not please him, and Charlestown he came in the summer of 1630 to the mouth of the Charles River, where he landed and established a town called Charlestown. We must remember that a settlement in such conditions was only a collection of farmhouses with a stockade around them and the farms lying at convenient distance around the town. If there were many people, the farms would lie so far off that the people living within the walls could not go to them easily. They did not at this time dare build their homes on their farms, because of danger from Indian

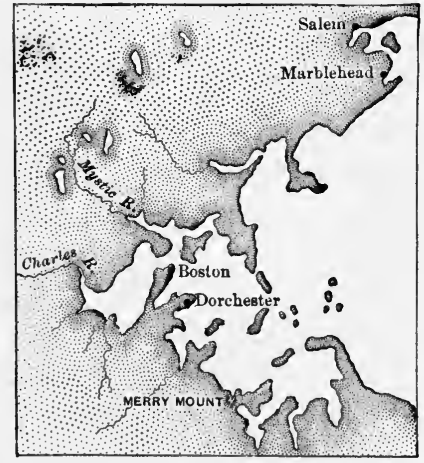

Massachusetts Bay attacks. Thus it happened that nine hundred persons could not conveniently live at Charlestown. They divided into three other groups. One crossed the Charles and settled on a slope where there were three hills and an excellent spring. Boston and They called the place Boston. The other two settled other towns further off, at Dorchester and Watertown. As new settlers arrived they settled in other farming towns, and soon there were many such places in Massachusetts.

While the Puritans were persecuted in England a great many of them continued to come to Massachusetts. In 1643 there were 
16,000 people in the colony, and very few of them were not of the one faith. At this time war began between the king and Rapid parliament, and the tide of emigration slackened. growth of While men fought to break down the great power of the colony the king, all who favored self-government were needed at home. After the war was over the king did not try again to hold the same amount of power, and the rapid emigration of the early days never came back.

A New England town was not a mere collection of houses with the small farms around it. It was also the land lying around the What a town houses for several miles. It was as large as two or was like three of our western townships, and about half or a third as large as one of our southern counties. When the people living in the center became numerous, a part of them would establish a village in another part of the town. In time a large town would be divided into two or more towns. The people settled their affairs in a town meeting, in which all men who were members of the church were allowed to vote. Here they laid the town taxes, elected town officers, and took steps to build roads and bridges.

At first all the voters might go to Boston and vote on the affairs of the company in a great meeting known as the general court. The general But this was inconvenient for those who lived in discourt tant towns, and so it was decided that each town should choose delegates to the general court, which thus became a representative assembly. The general court elected the governor annually. It also elected the councilors, who had the right to The officers assent to laws. The government of Massachusetts had a larger number of elective offices than the government of Virginia.

In each town the minister had a great deal of authority. His Influence of salary was paid by the town, out of the money received the minister from the taxes, and he was looked to for advice in all matters of importance. As none but church members voted, 
it was very hard for a man to be elected if the minister pronounced him unfit for office. The union of church and state then existed in most of the countries of the world, and the Puritans only follow the general rule.

But there were at that time a few men in England who held the view which has later become prevalent in America. They believed that the state should have authority solely over views of secular matters, and that church authorities should con- Roger, trol in religious things. One of these men in New EngWilliams land was Roger Williams, minister at Salem. He taught that civil officers should not enforce the laws of the church, that it was wrong to require an unconverted man to take an oath, and that the whites had no right to take the land in the colony until they got the consent of the Indians. The first of these doctrines was directly opposed to the Puritan system in the colony. Williams was called into court, and when he refused to give up his doctrine, it was decided to send him into exile. It was then late in 1635 , and he was told that he might stay until the winter was gone. But when the officers learned His colony that he was gathering a group of followers to found a colony among the Indians, orders were given to arrest him and send him to England at once. Hearing of this, he fled over the snow to the Narragansett Indians, who received him kindly. In the spring of 1636 many of his friends came to him, and he settled the town of Providence on land he purchased from the Narragansetts. It was the beginning of a new colony.

Another person who gave the Puritan churches trouble was Mrs. Anne Hutchinson. She did not deny the right of the government to regulate religion, but she thought she had Mrs. Hutchreceived a superior doctrine directly from God. She inson preached it fervently and had many followers, which tended to weaken the Puritan churches. Mrs. Hutchinson was a very fervent teacher of her doctrine, and in her earnestness she was led to say that the ministers who did not accept her teaching were 
not possessed of the grace of God. She was very popular in Boston, but the ministers of the other towns were against her. In 1637 she was summoned before the general court, which ordered her sent into exile. The next spring she went with a The Rhode large number of others to Rhode Island, where a settleIsland ment sprang up. Later on, Providence and Rhode colony Island were united into one colony, which was wisely directed by Roger Williams for nearly fifty years. It was always a place in which any form of religion would be tolerated.

The Massachusetts Puritans, so recently persecuted in England, thus became persecutors of others. It was a day when A word for most countries held that there should be only one relithe Puritans gion; and the Puritans had come to New England to make their doctrine the one faith of Massachusetts. It would have been a fine thing if they had been more liberal, but we must not demand that they should be ahead of the other civilized nations of the day. They founded a home for their faith at the cost of much hardship, and they were determined that no other belief should spring up within it. They feared, also, that the existence of many sects in the colony would give it a bad reputation in England and might lead the king to take away the charter under which the colony had self-government.

What is now Connecticut was settled in three small colonies. The first was composed of three towns on the Connecticut River towns River, Windsor, Hartford, and Wethersfield, and was settled about 1636. The towns were outside the colony of Massachusetts, and as they had no charter of their own they proceeded to form a plan under which they governed themselves. In 1639 they adopted a written constitution, the first in America, in which there was to be a governor elected annually and a law-making assembly to which the towns would send delegates. Although the river towns were settled by Puritans, a man did not have to be a church member in order to vote. In this respect the river towns were more liberal than Massachusetts. 
The second small colony was planted at the mouth of the Connecticut River. In 1631 several gentlemen in England got a grant for this region, among them being Lord Brooke and Lord Saye and Sele. Four years later a fort was Saybrook erected at the mouth of the river and called Saybrook, after these two proprietors. Later a town was built near the fort. The enterprise was not prosperous, and ten years after settlement it was united with the river towns and the joint colony was called Connecticut.

West of Saybrook still another group of towns grew up. The most important of them was New Haven, which was settled first. To it came a New Haven group of English Puritans who wished to have a colony in which they could be governed strictly in accordance with the teachings of the Bible. They had no "charter and established a very democratic government. Once a year the freemen elected the governor and a council. For a long time the governor ruled in accordance with

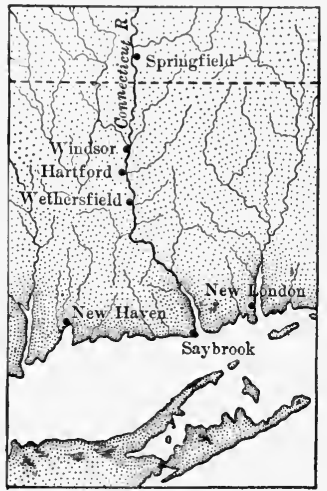

Connecticut settlements what he thought was the biblical way. Under this system the New Haven colony lived happily and prospered.

Several other towns were founded along the shore of the sound west of New Haven. At first they were independent, but when there was a probability that the Indians would attack, Connecticut they were glad to join with New Haven. Neither Con- united necticut nor New Haven existed by authority from the king, but in 1662 King Charles II issued a charter by which Connecticut and New Haven were joined into one, with a liberal form of government. The Connecticut charter was so satisfactory that it became the constitution of the state when the colonies threw off their allegiance to England.

While the Connecticut settlements were being established a 
fierce war broke out with the Indians. The shore between Narragansett Bay and the Hudson River was the home of three groups Three In- of savages. The Narragansetts on the east lived in diannations what is now western Rhode Island and eastern Connecticut. The Mohegans lived in the region from New Haven to New York. In the country between these two extremes lived the Pequots on the lower Connecticut River. The first and second groups were peaceable and gave the whites no trouble. The Pequots were a fierce nation, and they were not willing to be friends with the colonists. In 1636 they began war by killing a white man who had been sent from Boston to collect tribute from them. Then an armed band came from Massachusetts and destroyed some of the Pequot villages. The people of Connecticut declared War against this action unnecessary and predicted that much sufferthe Pe- ing would ensue. Their words came true; for in the quots

spring of 1637 the Indians fell on Wethersfield, near Hartford, and killed several whites and many cattle. Then they besieged Saybrook, boasting that "Englishmen were as easy to kill as mosquitoes." They urged the Narragansetts to join them in an effort to drive every white man from Connecticut, but Roger Williams heard of their plans and induced the Narragansetts not only to remain at peace, but to send some of their young men to help in the attack on the Pequots.

The whites armed as rapidly as possible. Ninety men from the river towns assembled under Captain John Mason and set out The fort on in May, 1637, with two hundred and eighty friendly Inthe Mystic dians, to punish the hostiles, coming upon them in a fort on the bank of the Mystic River. The Pequots could not withstand the firearms of the whites. They fought desperately, but were defeated. The whites threw blazing torches into the wigwams within the fort and shot down Indians who tried to escape. Men, women, and children fell as they darted out or were roasted in the burning wigwams. Of the four hundred persons who took refuge in the fort seven escaped to the forest and seven were taken 
alive. The rest were killed. Only two white men lost their lives.

The lot of the Pequot Indians was now hard. They dared not meet the settlers, and they could not take refuge with their ancient enemies, the Narragansetts and the Mohegans. In End of the despair they attempted to reach the Mohawks, west war of the Hudson. They were pursued and overtaken near the site

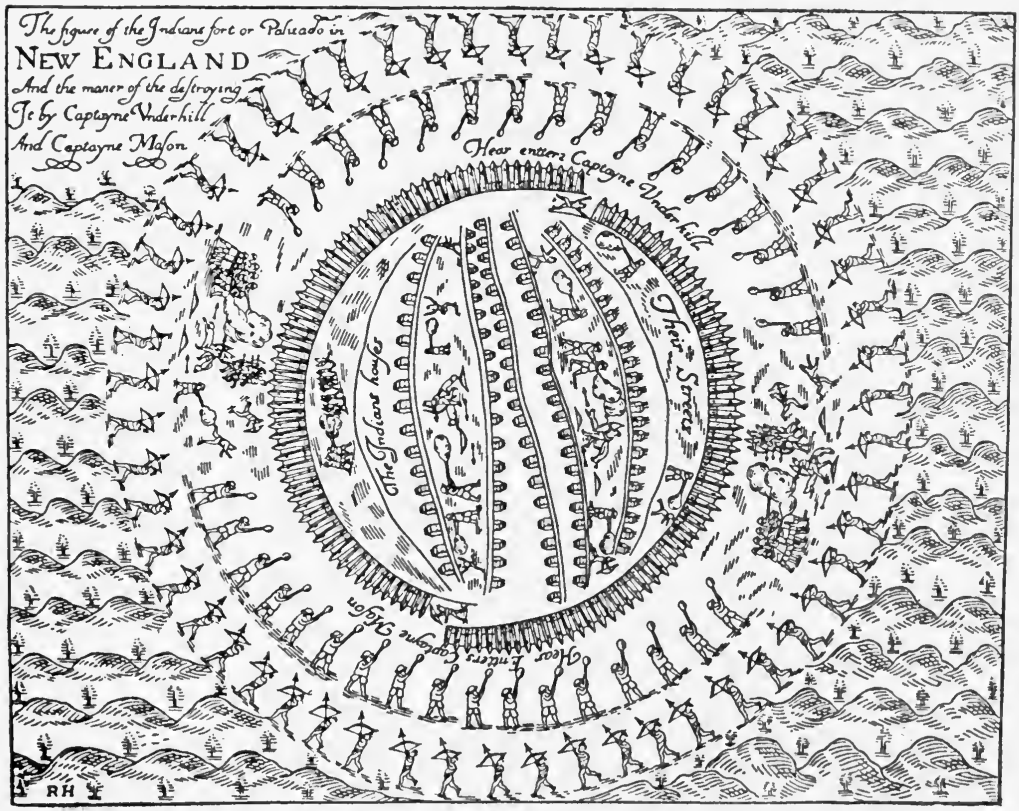

Pequot fort

of New Haven. 'They took refuge in a swamp and tried to beat off their enemy, but were defeated with great loss. Sassacus, their leader, whom other Indians thought a man with a charmed life, managed to escape, but the Mohawks cut off his head and sent it to the settlers on the Connecticut. They did not wish to incur the 
enmity of men who were able to destroy the last vestige of a powerful tribe. It was many years before New England had another Indian war.

While these things happened in Connecticut a number of small towns were being settled on the coast north of Massachusetts. Gorges and Some of them were inhabited by people who had fled Mason from the severe rule of the Puritans in Massachusetts. Most of the northern coast had been granted to Gorges and Mason, two Englishmen of great influence, who expected to derive a profit from establishing colonies. Mason took the country south and west of the Piscataqua, while Gorges got the region lying between that river and the Kennebec. East of the Kennebec the country was unsettled for a long time. Mason's grant was called New Hampshire and Gorges's was called Maine.

Neither man was willing to spend much money to send people to his colony. The result was that the towns which were estabNew Hamp- lished paid little respect to their overlords. They did shire what they pleased, and there was a pretty state of confusion. Mason died in 1635, and his heirs allowed the towns to shift for themselves. Massachusetts had long claimed that New Hampshire fell within the bounds of her charter and now stepped in to rule the towns on the coast. The people were so tired of the confusion that they raised no objection. They were glad to be under a power strong enough to keep order and furnish protection against the Indians.

In 1647 Gorges died also; and Massachusetts did for Maine what she had done for New Hampshire. By her charter her Maine northern boundary was to be three miles north of any part of the Merrimac. As the source of this river is well up in New Hampshire, Massachusetts made this the starting point for a line which was to extend eastward to Saco Bay. Her jurisdiction over both colonies was disputed. New Hampshire was finally taken out of her hands by the king, but as she had pur- 
chased all the rights of the Gorges heirs, she managed to keep Maine. Later she secured full title to the coast east of the Kennebec.

The area which now includes Massachusetts, Rhode Island, and Connecticut is less than one third as large as Pennsylvania. In 1643 it was divided into five colonies, each of which New Engwas so small that it could not hope to win in a war with land Conthe Indians. In this year there was a rumor that the federation savage tribes had made a league to destroy the whites. To meet this danger Massachusetts, Plymouth, New Haven, and Connecticut formed the New England Confederation. It was a league for common defense. There were to be two commissioners from each colony, and they were to decide when the confederation should go to war and how much each colony should contribute to the common cause. Rhode Island was considered a home of undesirable people and was not asked to join the confederation. The service of Roger Williams in inducing the Narragansetts to refrain from joining the Pequots in war against the whites was now forgotten. But Williams was still alive, and his friendship with the Indians was so great that they were not likely to attack his colony.

For several years the confederation was very prosperous. It either overawed the Indians or the rumor that they were plotting a massacre of the whites was false. When the danger seemed past, the colonies began to fall out among themIts history selves. Massachusetts, the largest of the group, felt that the other colonies, having six of the eight commissioners, threw on her shoulders more of the burdens than justly fell to her. The other colonies replied that Massachusetts was satisfied if only her own interests were protected, and that she cared little for the safety of the smaller colonies. These suspicions and bickerings marred the usefulness of the confederation, and it became a weak force for peace. It was revived to take up the defense of the colonies during King Philip's war, 1675-1676, but it declined after 
the war and came to an end in 1684 . The truth is that by 1676 the colonies were so strong that they no longer needed to unite against the Indians.

\section{QUESTIONS}

I. Describe the English religious reformers of the early seventeenth century. What induced some of them to leave England? Into what groups were they divided? Describe each group.

II. Relate the story of the Scrooby separatists before they sailed for America. How did they arrange to remove to the new world? What peculiar form of labor was adopted? Deseribe the voyage of the Mayflower. Why were these colonists called Pilgrims? Describe the landing at Plymouth. What were the experiences of the first winter? Describe the relation of the colonists with the Indians.

III. What did Bradford do for the colony? Miles Standish? How did the original system of labor come to an end? Why did Plymouth grow slowly? What was the Mayflower compact? How long was it in use? Why could the colony not get a charter?

IV. How was Salem founded? How did Massachusetts become a Puritan colony? Explain the origin of the Puritan migration to Massachusetts. What did John Winthrop do for the colony? What was the Cambridge agreement? Describe the effect of the removal of the charter to New England.

V. Describe the settlement of Charlestown and Boston. Why were the early towns small? How did the war in England affect emigration to Massachusetts? What was a New England town like? How was it governed? Describe the general court of Massachusetts. Describe the influence of the ministers in politics.

VI. What is meant by the union of church and state? Give the views of Roger Williams. How did he come to leave Massachusetts? Where did he settle? Describe the expulsion of Mrs. Hutchinson. What settlement did she found? How did the Rhode Island colony come into existence? Why did Massachusetts refuse to tolerate persons who did not accept the Puritan faith?

VII. What Indian tribes lived in southern New England? Describe the origin and the early stage of the Pequot war. What services did Roger Williams render in this war? How were the Pequots defeated? What became of the tribe?

VIII. What region was granted to Gorges and Mason? Describe the conditions in early New Hampshire. What claim did Massachusetts 
have over the New Hampshire settlements? How did she lose her claim? On what ground did she claim Maine? How did she finally get control of it?

IX: What was the New England Confederation? How formed? Its attitude toward Rhode Island? What part did it take in King Philip's war? Why was it abandoned?

\section{SUGGESTED TOPICS}

The Voyage of the Mayflower; John Winthrop as a Colony Founder; The Work of Roger Williams ; The War against the Pequots ; New England Town Government. 


\section{CHAPTER VI \\ LIFE IN THE EARLIEST COLONIES}

BEFORE we go further into the story of the establishment of the English in America we must stop long enough to see how the

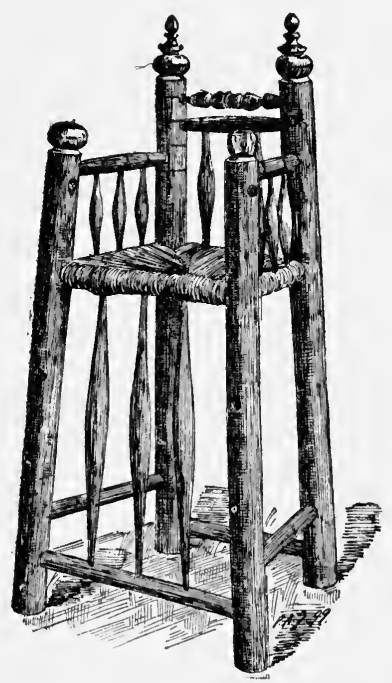

A child's high chair, about 1650
First needs settlers took up the tasks confronting them. Awaiting them was a forest-clad country, into which they must force their way by hard efforts. There must be villages and farms in order that the people might get a foothold, and food must be raised on the newly cleared lands. For clothing, tools, furniture, and a hundred other things that they needed to make life comfortable they must look to England. And to be able to bring over such things there must be some kind of Food and trade. It was a happy day trade for Virginia when it was discovered that tobacco could be raised in the colony; for now there was a crop which yielded money with which merchandise could be purchased. To have trade with Europe a colony must raise something that could be sold in Europe.

We have seen that Virginia and Massachusetts were the centers Two centers from which settlements spread to the surrounding country. Each was different from the other and each gave its own customs to the adjoining colonies. The Virginia life 
tended to be the rule in the South, where plantations were large, and their owners became wealthy. The Massachusetts life tended to become the rule in the North, where the farms were small and the men of wealth were usually engaged in some form of trade. This chapter deals with life in these two central colonies.

When the London Company sent out their colony to Jamestown, Spain had been a colonial power for more than a hundred years. Her sugar-growing colonies were prosperous, and she Gold had received vast treasures in gold and silver from hunters Mexico and Peru. Spanish gentlemen had gone to Spanish America with nothing but their swords, and in a few years they amassed large fortunes. It was natural, therefore, for the English company to think that something of the same nature might be done in Virginia. That is why the first colony contained so large a number of gentlemen. It took but a short time to show them that there was no gold near Jamestown.

In fact, the work before the colonists was purely agricultural. They must clear fields and raise food, work for which the gold seekers were not fitted. Year by year ships arrived Laborers with newcomers, but disease, want, and despair kept needed the number at a mere handful. In seventeen years 14,000 persons arrived in the colony, and at the end of that time but few more than 1000 were living. Many lives were sacrificed to learn that Virginia was only to be settled by men who knew how to labor with their hands.

Like most of the other rivers in America the James is bordered by rich low-grounds behind which rise less fertile highlands. The first comers took up the low-grounds in small strips. LowThey built houses of logs and cleared away the sur- grounds rounding forests as rapidly as they could. Indian corn and corn proved a great blessing to the frontiersman. It grows easily in newly cleared land, whereas wheat cannot be cultivated satisfactorily until the land has been entirely cleared of trees. The whites 
learned from the Indians how to kill the trees by chopping circles around the trunks. Then they dug up the undergrowth by the roots and dropped the seed corn into the soft earth. The plants grew well and yielded good crops under such tillage. Indian corn has this other advantage over wheat: it can be left several weeks on the stalk after it is mature, while wheat must be harvested at once.

There was much experimenting to see what crops could be grown successfully. The mild climate of the South and the presence Silk and of wild mulberry trees suggested that silkworms would tobacco thrive. The king of England welcomed the suggestion. It was his idea that the colonies ought not to raise the things England produced, since that would lower the prices received by the English producers. But if the colonists could produce silk, or anything else that was not made in England, it would make it unnecessary to import such articles from abroad, and by this means British money would be kept within the bounds of the empire. The attempt to raise silk was thwarted by finding that growing tobacco was a more profitable industry.

A few years of tobacco growing made a great difference in the life of the people. Men who made good crops and saved their The planta- money began to be richer than others. They bought tions up several of the small farms, and so appeared the large plantations along the rivers. The log houses were replaced by houses of boards or brick. Handsome furniture and silver plate were ordered from England. Virginia plantations and planters thus came into being. A small plantation might have no more than four hundred acres, but a large one might contain four thousand. There was an abundance of good land on the rivers, and it could be bought cheap.

Every autumn many ships would come into the Virginia rivers No large to take the tobacco to England. Each great planter towns had his own wharf at which the vessels were loaded. The crop would be sent to some English merchant, and along 
with it would go an order for clothing, furniture, tools, and anything else the planter needed. When the ships came for more tobacco, they brought the merchandise that had been ordered on the preceding trip. The small farmers raised tobacco also, but in

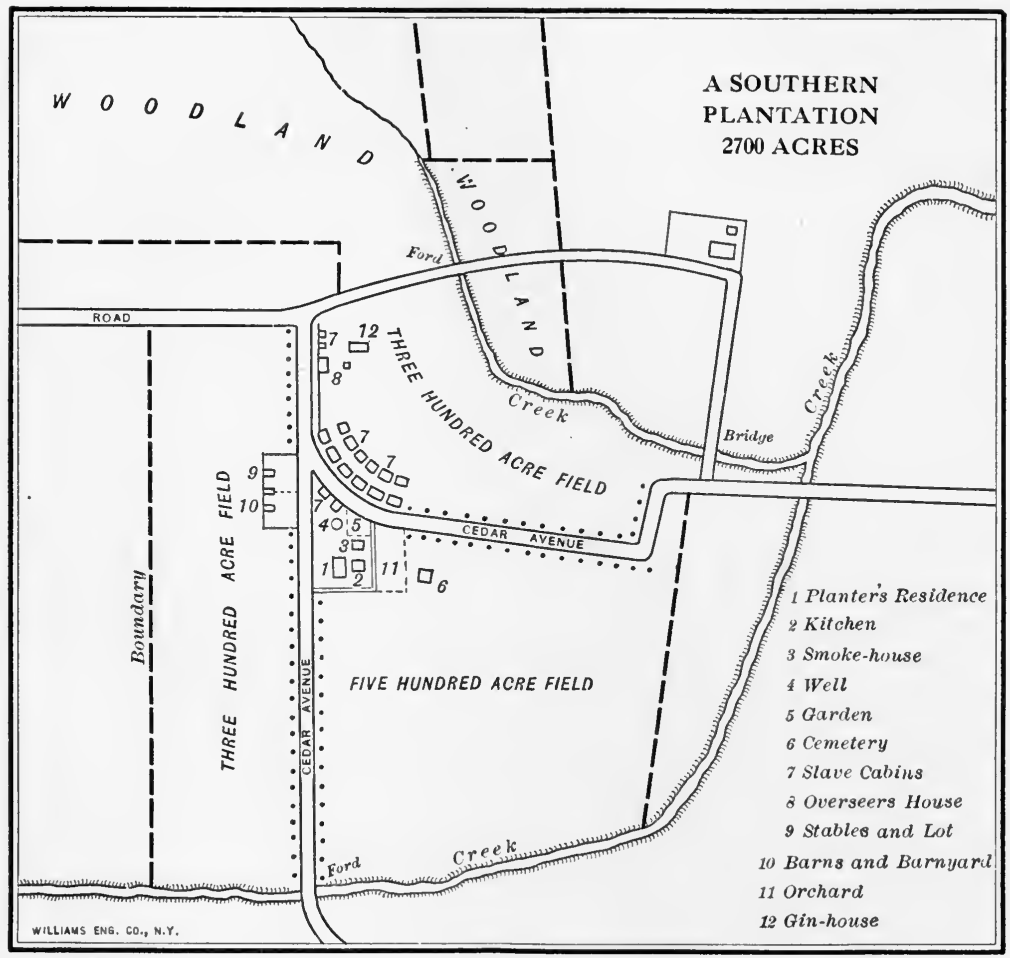

small quantities. They could not afford to send it to London and order goods as the great planters did. So it came about that the planters generally established stores at their wharves, bought the tobacco of the small farmers, and sold them the merchandise needed on the small farms. In this way it happened that no large towns were established in the colony. 
Another result was that tobacco became the money of the colony. The planter paid for his English goods in tobacco. $\mathrm{He}$ Tobacco as sold goods throughout the year at his store and was money paid in the autumn in tobacco. Very little specie came back from England in payment for the year's crop, and so there was very little to circulate among the people. They soon got used to this condition and were satisfied to make their bargains in tobacco. About the year 1700 an ox was sold for four hundred pounds of tobacco, and fourteen hundred pounds were paid a man for a year's labor. The small amount of specie in the colony served for pocket change.

Some of the Virginia colonists belonged to the gentry in England, but many were small farmers or poor men from the towns. Those The planters

of the gentry who survived early hardships were naturally leading men in the colony, for they were the most intelligent class and they had the respect of the others. They came to the top in the planter class and became local officers, and their opinions were followed by the rest of the people. It was natural for these men to try to make their plantation life like the life on the manors in England. They gave names to their homes like the names of the estates beyond the ocean. "Westover," "Lower Brandon," and "Shirley" were famous old homes on the James, while "Eltham" on the York, and "Mount Vernon" on the Potomac were also very well known in colonial times. When the Puritans in England defeated King Charles and beheaded him in 1649, many of his followers of the gentry fled to Virginia. They added to the tendency to establish an aristocracy there. As time passed many a man of the poorer class became rich through industry, thrift, and good judgment. Such persons were eventually received into the planter class. But with all Virginians the ideal life was that of the English country gentleman, and Virginians who rose in life, wherever they lived, in their own colony or in one of the other colonies to which they moved, tried to reproduce the plantation life that was first seen in the homes along the James. 
As soon as the colony began to grow prosperous there was a demand for more labor than the colonists themselves could furnish. A man who had a large plantation could make Laborers a great deal of tobacco if he only had enough laborers. wanted The planters sent orders to their agents in England urging them to send over all the laborers who could be induced to go to Virginia. Attractive notices were published in the English towns, setting forth in glowing colors what an industrious workingman could make in Virginia. He need not have enough money to pay his passage. The captain of some Virginia-bound ship would take him, if he would sign a contract to work for the captain three or four years. When the ship arrived in Virginia, the captain would transfer his contract to a planter, who would pay the servant's passage money. When the ship arrived in the James River, the planters would come down to see what laborers could thus be secured. When such a laborer had served the planter Indented for the term agreed upon, he was given clothing and servants a good gun, and from the colony he received fifty acres of land. Under these circumstances many laborers went to the Southern and Middle colonies. They were called indented servants because the agreement they signed was an indenture.

But this method did not secure all the laborers the planters needed, and the captains got into the habit of kidnapping children, and sometimes adults, and taking them to the colonies. Such persons would be enticed on board just before

Kidnapping sailing time, and frequently the ship would be on her way out of the harbor before the victims knew whither they were bound. Kidnapped children were sold in the colonies to serve until twenty-one years of age. Some of these children found good masters and became important men when they were of age. Most of them never rose beyond the condition of poor men.

Another way of getting laborers was to send certain classes of criminals to the colonies, where, it was hoped, they might reform and become useful citizens. Pickpockets, persons convicted 
of petty theft, and brawlers were sent to the colonies. When they arrived, the planters bought their services from the captains Criminals who brought them over, as other indented servants. The law stipulated how long they should serve, and when the term expired, they were furnished with land, and many of them settled down into steady lives. No large part of the indented servants came from this criminal class.

In Pennsylvania and Maryland the term "redemptioner" was used for an indented servant. A great many Germans arrived Redemp- in these colonies without the means of paying their pastioners sage. They were sold to speculators by the captains who brought them, and then carried in unhappy droves through the farming communities until they were sold to the farmers for terms of years. While there was much suffering in this class, it is probable that the redemptioners, like most of the other indented servants, were better off in America than in their old homes. When their service was completed, they had the opportunity to become landowners, and that was more than they could have done in Europe, where they were generally peasants.

In 1619 a few African slaves were carried to Virginia to see if they could be used as successfully as in the Spanish colonies. Slaves They knew nothing about the white man's methods of labor and were hard to teach. The colonists did not like the experiment, and for many years very few were imported. Meanwhile, the planters tried to get on with indented servants. This was a bad system for the employer ; for as the servants completed their terms of service others must be found to take their places. The advantage of slavery was that it enabled the planters to have a permanent laboring class. As time passed it was observed that the slaves who were born in Virginia were more easily managed and worked better. They were never as good laborers as white men, but they were generally accepted as the best that could be got, and after about 1660 they began to be used freely. After 1700 they became the most common form of labor on the 
plantations of the South. They were never largely used on the farms north of Maryland. The Northern farms were generally small and were worked by the owners and one or two hired men. Slaves were found in these colonies in

In the North small numbers, but they were mostly in the towns, where they were used as domestic servants or unskilled laborers. For many years the Virginians showed that they regretted the presence of slaves in their midst. Several times the assembly voted to have no more brought in, but the king vetoed the laws.

Two very important results followed from the introduction of slavery into the South. One was the wide use of slave labor. It divided the country into two hostile sides and led to a great war. The other was that it brought into the

Two results United States a great many Africans, people of very little progress and intelligence. It would have been better for the peace and harmony of our country if all who came here had been white men.

The first colonists in Virginia settled along the James River. Soon they began to take up land along the York, a few miles north of the James. After a while the settlers ap- Rivers, peared on the Rappahannock and then on the Potomac. roads, and The rivers served as a means of traveling from one place land to another. If a planter entertained his friends, boats would bring most of the guests. It was easier to go by water than to cut roads through the forests. As the plantations were large there were long distances between the residences of the owners. The land was cheap and the planters had a tendency to buy more than they could cultivate. Population in the South was not as dense as in the Middle and New England colonies.

Tobacco was a staple crop in Virginia and in Maryland. This means that it was a crop raised for sale in large quantities. How to grow it and how it would sell became the chief con- A staple cern of the people. Enough land must be given to crop raising food to supply the master and his servants, but all the 
rest that could be cultivated was planted in tobacco. If the crop failed, there was a year of suffering. We have had other staple crops, as rice in South Carolina, sugar in Louisiana, cotton in the South, and wheat and corn in some parts of the West.

So well did tobacco satisfy the Virginians that they did not try to have any but the simplest kind of manufactures. There were

Home manufactures water mills for grinding corn and wheat; but they merely supplied the needs of the neighborhoods in which they were located. Every settlement had its tanner, shoemaker, saddler, cabinetmaker, and hatter. There were hand looms on which the Virginia flax and wool were made into cloth. But the products from all were of the coarser kind. They were used by the poorer whites and the slaves, and for the simpler uses of the well-to-do people. Finer goods, as well as the implements of field and home, were ordered from England.

If we turn to early New England life, we find that it was similar in some respects to life in Virginia, and in other respects greatly No staple different. There, as in Virginia, the first things to do crop were to build houses, clear fields, and produce food for the settlers. Cattle must be introduced, mills must be erected, and something must be made which could be sent to England to exchange for the articles which could not be produced in New England. The farms were not adapted to any staple crop. They yielded wheat and vegetables, but these were raised in England so abundantly that it did not pay to send them thither. The New Englanders were quick-witted, and since they could not secure out of their farms a supply of money for buying merchandise, they sought other means of getting it.

The first thing they turned to was the fur trade. Fur-bearing animals abounded in the cold North, and the Indians knew how The fur to trap them. The white men stimulated the natives trade to hunt, offering them hatchets, trinkets, and blankets in exchange for skins. The profits of this kind of commerce were large, and the traders went far and wide in search of skins. The 
Indians soon became dependent on the trade. Having learned the use of guns, hatchets, and blankets, they never seemed to have enough of them.

The fur trade led the New Englanders to enter a still wider field of commerce. We have seen that the Virginia planters sent their tobacco to England from their plantation wharves. The coastBut there were in the colony many small farmers on wise trade isolated creeks or tributary rivers who could not afford to ship to England. They might sell their crop to the large planters, most of whom had plantation stores, but they had to take such prices as they could get. To them came the New Englanders in small vessels filled with general merchandise, selling what the farmer needed and taking for it tobacco or other products in small quantities. It was peddling by water, but it was profitable, and the New Englanders developed great keenness in it, not only in Virginia, but in all other parts of the South.

The great planters objected to such trade, since it lessened the profits of their own traffic. They called the New Englanders "interlopers." The New Englanders appeared in all "Interthe colonies as soon as settlements were planted. lopers" They also appeared in the West Indies, where there was a staple crop, sugar, and where very little else was grown. It was profitable to sell beef, pork, fish, and vegetables to the sugar growers, who preferred to give all their time to raising sugar. The New England traders became very skillful in finding markets for their goods, and they made much money. Thus there grew up in the towns along the New England coast a class of rich merchants who had great influence in the colonies.

One of the most profitable forms of business was fishing. When the colonists arrived at Plymouth, the cod was found in the bay before the town. It has special value because when salted it keeps better than most other fish. The earliest Fishing colonists took the cod in small boats fishing near the shore. After a time the stock in these waters was exhausted, but the fisher- 
men were bold and followed the cod northward. Finally they had to go beyond the coast of Maine to find any. A large number of fishermen were engaged in this calling throughout the colonial period. The cod fisheries trained a hardy sailor people who were of great importance in the commercial life of New England.

Another form of fishing was taking the whales. These great animals were numerous off the island of Nantucket. They were Whale valued for their oil, which was highly esteemed for lamps fishing before coal oil was used. New England whalers were as enterprising as the codfishers. They sought the whales in every ocean. Sometimes they were as far north as the coast of Greenland, at other times they were as far south as Cape Horn, and they finally were found in large numbers in the northern Pacific Ocean, off the shores of Alaska. There was no sea too stormy for their ships, if only the whales were there. Two, three, or four years were not too long for a whaler's voyage; and many adventures were encountered in their journeys. When a school of whales was seen, the whaling ship came among them. Then the sailors took to the small boats, rowing alongside the whales with harpoon in hand. Once the sharp instrument was fastened in its victim the object was to tire him to his death, as,one exhausts a trout. Sometimes the whale would sink many hundreds of feet in the ocean in order to escape. Then the harpoon's line would be played out. If it was not long enough, it must be cut loose, or the boat would be drawn below the surface. Sometimes the whale would flee, dragging the boat after him for several miles. Incidents are recorded in which the infuriated animal crushed the boat in his great jaws and drowned the occupants. When at last the whale was at the end of his strength, he was killed and towed to the ship's side, where the valuable parts, the fat and the whalebone, were cut out and taken aboard.

The New Englanders sold few manufactured articles, in colonial days. To understand why that was, we must remember that at this time factories had not developed in Europe. The machinery 
then used in weaving, spinning, and in most of the other lines of manufacturing was hand machinery. Charcoal made of wood was burned in smelting iron ores, and steam power had Hand manunot been thought of. Whole villages in England were factures engaged in spinning or weaving by hand. The New England colonists contained many men who in England had been engaged in this kind of manufacturing. In their new homes they continued to make things they thought they could sell. The long winters were frequently spent in such work as they could carry on in their barns. Thus, the New England farmers became very clever in the use of tools, and in later times their skill with them resulted in much inventiveness.

Another source of money was the vast timber supply, especially abundant in New England. With the slow-sailing ships of the day the expenses of shipping ordinary lumber to Europe were so great that profits were wiped out; but masts and Lumber spars, which the New England pines were well adapted to make, were sent to Europe in large quantities. They were soon in use in most of the shipyards of western Europe. Another form in which the timber could be used was staves, much demanded in the West Indies for sugar casks. These islands were not well wooded and took lumber in many forms. Every colony had some share in their trade, but the New Englanders had the largest.

The yellow pines in the region south of Virginia are rich in tar, which has many uses in shipbuilding. Tar, rosin, and turpentine have long been known as naval stores, because they were in great demand for the sailing ships of the

Naval stores British navy. About the end of the seventeenth century they were produced in large quantities in the South. New England pines never yielded them successfully.

The center of life in a New England town was the meetinghouse. It was a plain building, poorly heated in winter, but everybody went to the services. The sermons were Religion long and serious. When the minister began preaching, a boy set 
an hour-glass on the desk. When the sands ran through, he would rise and turn the glass. Often the sermon lasted until the second glass ran through. If a wicked person died, the minister was apt in the sermon to cite his wickedness in order to warn others. The meetinghouse was the chief building in the town, and near it was the house of the pastor. New Englanders had great respect for their minister. He reproved wrongdoers and watched over the Influence of conduct of the people, old and young. Many a ministhe minister ter served in one town from early manhood to death. When the day for the election of officers came, the minister opened the ceremony with a sermon in which he hinted very plainly how good citizens should vote. His advice was usually taken, and it generally proved wise. The minister was the most learned man in the town. He usually knew something about medicine and treated the sick people in the small towns which had no physician.

The early churches were called meetinghouses. They were generally rectangular, with the pulpit at one end and the door at Church the other. The congregation sat in such a way as to services show who were considered the most important people. The selectmen and the deacons sat in the front pews; the latter frequently faced the congregation, with their backs to the high pulpit in which the minister towered above his hearers. Persons of ordinary rank sat in the middle of the building, and the humbler sort, with the boys and the servants, sat near the door. An officer with a long switch watched over the conduct of the servants and boys, and, if one went to sleep, tapped him gently to bring him to attention. "The wretched boys," as they were often called, sometimes gave the officer much trouble. Their most common faults were sticking pins, pinching, and giggling. Cutting out of doors before the minister said "Amen" was another offense of the "wretched boys." We must remember that human nature was the same with Puritans as with others, and though all had to observe the rules prescribed for pious people, there were always some whose piety was only a form. 
Religion in Virginia was administered according to the practices of the Church of England. There was a parish, a minister ordained by a bishop, and a vestry, that is, a board who man- Religion in aged the affairs of the church with the aid of the minis- Virginia ter. The congregation had nothing to say about their church government. The Prayer Book was in use, and the ceremonies of the churches were not as simple as in New England. The clergymen were often careless and lived for their own pleasures. Some of them were dissipated and given to horse-racing and cock-fighting. On the other hand, many Virginia clergymen were noted for piety. The planters were a gay group and were fond of fox-hunting, dancing, and merry entertainment.

In their ideas of education the two sections were very different. In New England education was considered a necessity for all, and steps were taken from an early date to see that every child was taught how to read and write. The legisEducation lature of Massachusetts made it the duty of each town to -tax itself for a public school. The smaller and newer towns frequently found a way to violate this law, but it was observed in the more prosperous and older towns, and after a century public education was general in the colony. In Virginia persons who could afford it educated their children, and some of the rich planters sent their sons to England for higher instruction. Now and again a charitable person would establish a school in which the poor children could be taught. It was a long time before the South came to realize that free public education to all is the only way to have a body of intelligent citizens.

One of the first thoughts of the New Englanders was to have a college in which ministers would be taught. They expected the minister to have great influence over his parish, and to have it he must be a man of intelligence and

Colleges learning. For this reason Massachusetts in 1636 established Harvard College. It was named for Rev. John Harvard, who gave it his library and a sum of money. In 1701 some 
gentlemen in Connecticut started another college, to which the name Yale was given in honor of Eli Yale, who donated a sum of money. These two colleges, Harvard and Yale, have had a wide influence in American education. What they did for New England was done for Virginia by William and Mary College, founded in

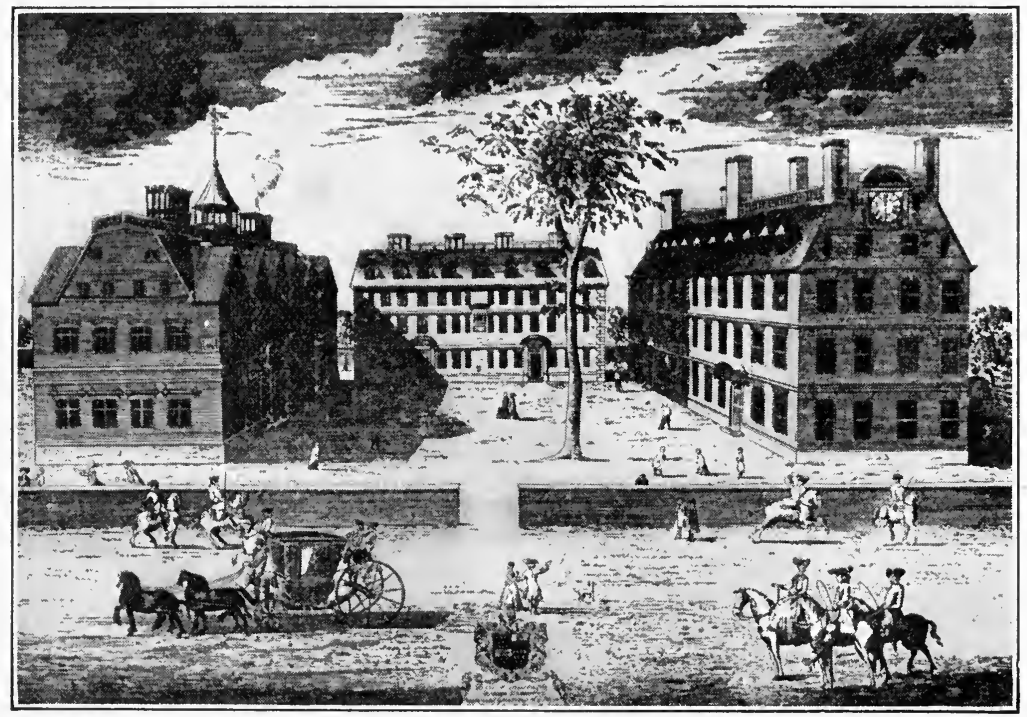

Harvard College in 1726

1693. When a new country is settled, it takes time to perform the hard work of clearing forests, establishing towns, and doing the other things which enable the people to live in comfort. Colleges and universities usually belong to the period that comes after these first struggles.

\section{QUESTIONS}

I. Describe the most imperative needs of a new eolony. What must it have in order to carry on trade? What two centers of colony planting have we noted? Of what sections are Virginia and Massachusetts typical? 
II. Was it foolish in the London Company to look for gold from Virginia? What class was needed more than gold hunters? Describe the hardships of the early settlers. Why were rivers important in the early colony? What made Indian corn a valuable product? What was the idea of the king about silk raising in Virginia? Describe the beginning of tobaceo raising.

III. How did the small farms grow into plantations? Describe the origin of the planter class. What English form did the planters have in mind? Describe the tobaceo trade. Why did Virginia have few towns? Describe the use of tobacco as money. How did the fall of Charles I affect the planter class in Virginia? How was the class renewed?

IV. Why did the planters feel the need of laborers? Who were indented servants? Describe kidnapping. How did English criminals come to be sent to the colonies? Who were redemptioners? What was the first experience with negro slaves? How did they at last come to be acceptable laborers? Why did indented servants prove an unsatisfactory form of labor? Deseribe the condition of slavery in the Northern colonies. What were two evil effects of slavery in America?

V. Trace the progress of settlements in Virginia by rivers. Why was Virginia slow in building roads? What effect had cheap land prices? What is a staple erop? Give illustrations. Describe home manufactures in early Virginia.

VI. Name some ways in which life in Virginia was like that of Massachusetts. Name some points of difference. What was the difficulty about farming in Massachusetts? Name some other forms of industry than farming.

VII. Describe the fur trade of New England. How was the coast trade carried on? What advantage has the cod over other fish? Describe the growth of cod fishing. Describe whale fishing by New Englanders. How were the whales taken? How did manufacturing in the seventeenth century differ from present-day methods? How did the New Englanders develop their skill in hand work? In what forms was timber most profitably exported? Describe the production of naval stores.

VIII. Describe the early New England sermons. Describe the influence of the ministers. How were the people seated in the meetinghouses? How was order preserved? Compare religious life in New England and Virginia.

IX. How did Virginia and Massachusetts differ in regard to education? Describe the founding of Harvard College. Do the same for 
84 THE PLAIN STORY OF AMERICAN HISTORY

Yale College and William and Mary College. What was the object of education in New England?

\section{SUGGESTED TOPICS}

Suffering at Jamestown; Plantation Life; Life of the Servants; The Introduction of Slavery and Its Consequences; The Life of a Fur Trader ; The Adventures of the Whalers; Early History of Harvard College. 


\section{CHAPTER VII}

\section{THE LATER GROUP OF COLONIES}

The year 1660 is an important date in British history because in that year Charles II came to the throne after his family had been excluded for eleven years by the great Puritan leader, Oliver Cromwell. Charles was a good-natured

Charles II ruler, and his chief desire was to remain on his throne and have enough money for his pleasures. He allowed the American colonies to do about as they pleased. He did not propose to spend money on them, but he was quite willing that his subjects should spend it in that way. All the colonies established during his reign were set on foot by individuals who thought they would make money out of their ventures. When he came to the throne, New England, Virginia, and Maryland had been settled. When he died in 1685, New York had been taken from the Dutch and made an English colony, and North and South Carolina, New Jersey, Pennsylvania, and Delaware had been founded. We shall now have to learn how each of these colonies began its existence.

Henry Hudson in a Dutch ship discovered the Hudson River in 1609 , and a few years later some merchants of Holland built a fort on Manhattan Island and began to trade with the Arrival of Indians. The fort proved an excellent trading station. the Dutch Small sailing vessels could go from it up the river to Albany, where they built a trading fort, one hundred and fifty miles in the interior of the fur-producing country. Eastward they traded along the shores of Long Island Sound and up the Connecticut, erecting a fort where Hartford now stands. A trading fort had a small 
garrison for protection, but its most important contents were the trading goods. These consisted of knives, hatchets, guns, ammunition, beads, blankets, and rum, all of which the Indians took eagerly in exchange for skins. The savages were glad to obtain European

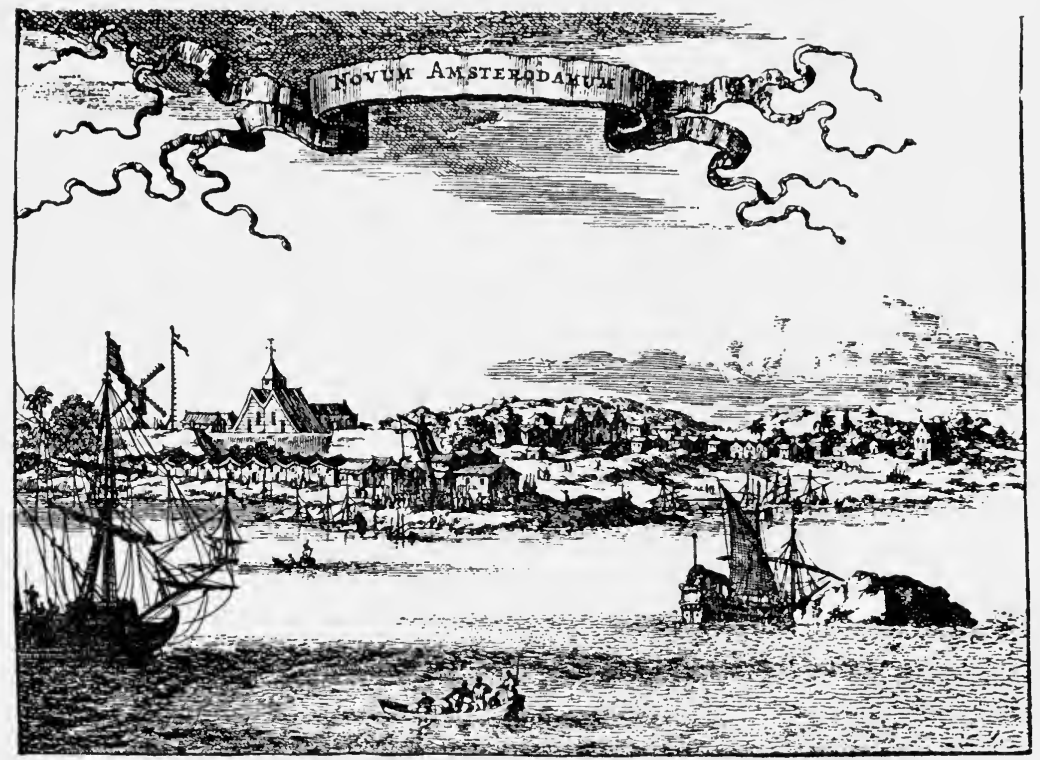

New Amsterdam in 1656

merchandise, but the rum they got from the whites was the source of much trouble.

The Dutch were pleased with the fine harbor of New York, the trading fort became a town, and the whole region a colony. Patroons The town was known as New Amsterdam, 1626, and the colony as New Netherland. Farmers now appeared and settled along the shores of the harbor. To get others to come large tracts were offered to wealthy Dutchmen who, it was thought, would bring tenants with them. These great 
landowners were called patroons, and they had handsome estates along the Hudson. Some of the patroons became the founders of very influential New York families. A patroon lived in a large house, and throughout the estate were scattered the cottages of his tenants. He had his own mill at which the tenants must have their wheat and corn ground. He took rent year by year from the holders of the small farms and in many ways forced them to do as he pleased. The system was unpopular, but it lasted until after the revolution.

The Dutch were sober and industrious, but they were not eager An English to govern them- party selves. The government given them by the authorities in Holland was very simple. A governor was sent over whose power was nearly absolute. New Am-

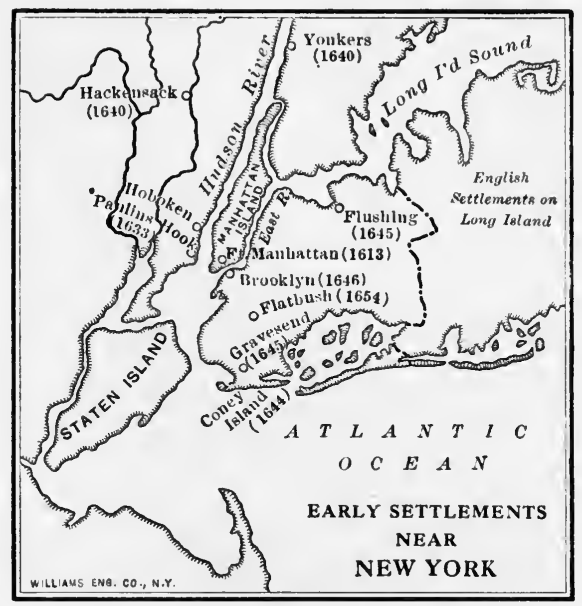
sterdam was so good a harbor that traders from England and New England also settled there among the Dutch. One of the results was much quarreling; for the English were used to selfgovernment, and they were not satisfied with the rule of the Dutch governors. Thus there grew up an English party which hoped that the colony would one day become English. In fact, the kings of England claimed all the coast from Florida to Maine and looked on the Dutch as intruders. They based their claim on the voyages of John Cabot, 1497-1498. Meanwhile, men from New England crossed Long Island Sound and settled at will on Long Island. This land was a part of New Netherland, but the Dutch were unable to drive off the settlers or to rule them. 
The New Englanders were finally allowed to govern themselves in towns, and they paid little attention to orders from Manhattan Island.

In 1664 England was about to begin war on Holland, and it seemed a good time to assert her claim to New Netherland. First, conquered King Charles gave the country to his brother, the Duke by the of York. Then the duke sent out three ships of war, English

which anchored before New Amsterdam. A demand for surrender was sent to the Dutch governor, Peter Stuyvesant. He was a cross-tempered but brave old man who had done many cruel things in his seventeen years of rule. He declared stoutly that he would never surrender the post committed to him, but the people under him were tired of Dutch governors. The men on

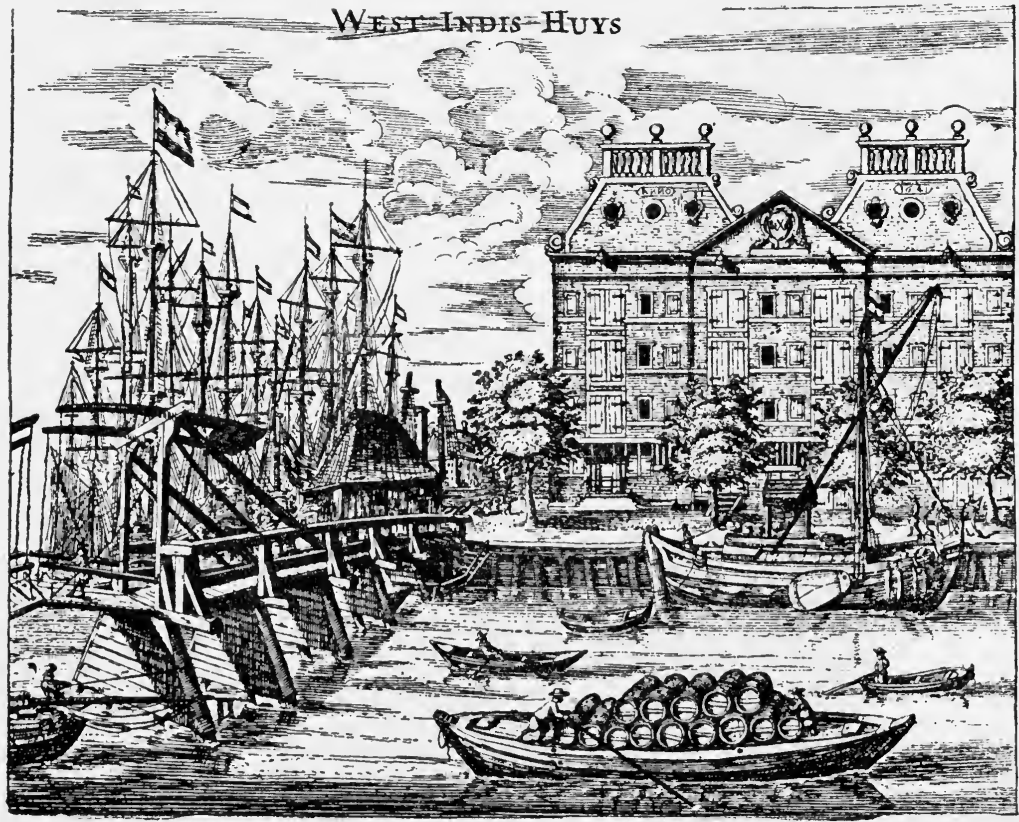

West India warehouses, New York harbor, 1673 
Long Island made active preparations to aid the fleet, and even the Dutch farmers around New Amsterdam let it be known that they thought the colony should be given up. When the English commander heard of this, he sent a letter offering to give all the inhabitants the liberties of Englishmen. Stuyvesant would not let his people read the letter, and when they asked to see it, he tore it into bits, saying he would be carried out dead before he would surrender. But he submitted just as the ships were about to open fire. The town and colony were now called New York in honor of their new owner. The change of rule pleased the inhabitants, but it was over twenty years before they got what they had been promised, the liberties of Englishmen.

Along with the Dutch colony the duke acquired a large territory south of New York; for the Dutch had exercised authority in this region also. In 1638 the Swedes founded a town, Chris- Delaware tina, near what is now Wilmington, Delaware. It was a sold to Penn weak settlement, and the Dutch seized it in 1655, claiming that it was within the bounds of New Netherland. In 1664 it passed into English hands when the Dutch colony was seized. The Duke of York did not keep it long. In 1681 he sold it to William Penn, who allowed the region along the lower Delaware to be a separate colony called Delaware.

The duke sold a still larger region, that which lay between the Hudson and the Delaware, to two of his friends, Lord Berkeley and Sir George Carteret. To this grant the name New Jersey was given. After a while the two proprieNew Jersey tors divided their colony into East and West Jersey, and later they themselves sold their rights to various other persons. "The Jerseys," as this section of the coast was called for some time, were finally reunited into the colony of New Jersey. The inhabitants were of several kinds, Quakers, New England men, and many small farmers from the other colonies and from England. They were very democratic people, and in colonial times their chief occupation was farming. 
When King Charles gave New York to his brother, he intended to reward him for the loss of much property during the period the Carolina Puritans ruled England. There were several others among his chief nobles for whom he had the same feeling, and in 1663 he rewarded eight of them by granting them an immense tract of land south of Virginia, calling it Carolina. It embraced what is now North Carolina, South Carolina, and Tennessee, and three-fourths of Georgia, Alabama, and Mississippi. The eight noblemen were called lords proprietors, and they were authorized to found as many colonies as they chose. They began by establishing one on Albemarle Sound, 1664, where a few men from Virginia had already settled, and another, Charleston, 1670, at a place where the Ashley and Cooper rivers unite and make an excellent harbor.

At first the proprietors expected that other colonies would be planted; for it was thought that a colony would be small. They Two were disappointed. For many years the people who colonies went to Carolina settled on the Ashley and Cooper rivers or near Albemarle Sound, and a broad space between these places was left unsettled. Thus at last Carolina became divided into two large colonies, - North Carolina and South Carolina. After a while the intervening region was settled.

The proprietors were bad fathers of colonies. They did not visit America, nor spend their money on the settlements. When The failure they realized that no profit was to be made out of Caroof the lina, they began to sell their shares. Merchants took proprietors their places and sought to make money by sending their wares to the two colonies. But this plan proved a failure, since the colonists continued to trade where they chose. There was much confusion in each colony for a time; but as the country advanced the leading men took things into their own hands and established order. Finally the South Carolinians began to produce rice in large quantities. It was in great demand in Europe, and the planters became very wealthy. In 1719 South Carolina 
revolted against the governor sent them by the proprietors and asked the king to take the colony into his own hands. The result was that in 1729 the king took over the two Carolinas, and after that they were royal provinces.

South Carolina had good harbors, and the harbors of North Carolina were poor, with the exception of Wilmington, which was in the extreme southeastern corner of the colony. The two To trade with the southern colony was easy, with the colonies northern colony it was difficult. The North Carolinians compared had no large money crop, like rice, and contented themselves with raising tobacco, hogs, and corn in small quantities. After Wilmington was settled about 1725 rice was also raised. The result was that the North Carolina people were generally small farmers, while there were in South Carolina many wealthy planters with great groups of slaves. Charleston was a seat of fashion and luxury, and handsome houses were found on the plantations. After cotton began to be raised in the South, North Carolina prospered more freely, slaves became more numerous, and large planters appeared throughout the part of the state in which cotton is grown.

Seventeen years after Carolina was granted to the eight proprietors, King Charles II

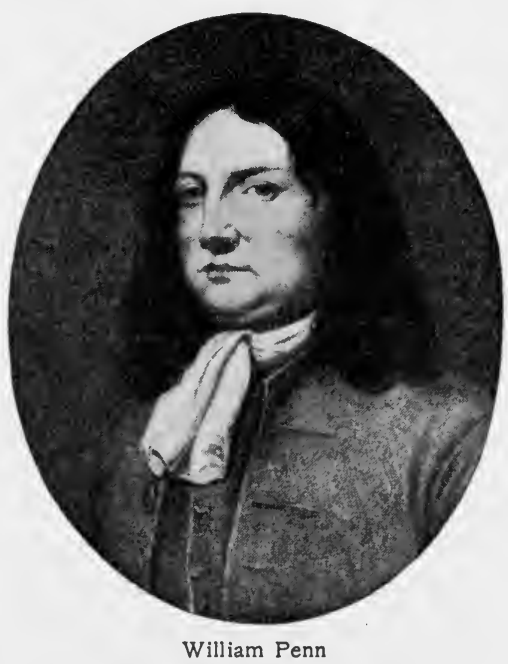
granted Pennsylvania to William Penn, 1680. The man who thus became the proprietor of the new colony was noted Penn and for his justice and good sense. He was a Quaker and his colony induced many Quakers to go to Pennsylvania. He met the 
Indians and purchased from them the lands along the Delaware. His colony was not troubled by Indian wars until many years after he was dead. He wished the settlers to be governed wisely, and gave them permission to make their own form of government. They elected an assembly which prepared what was known as "The Great Charter," a liberal form of government in which the people were allowed to choose their lawmakers. The governors were appointed by Penn and by his family after his death.

Penn arrived in his colony in 1682 . He was received with great respect by those who had come over before him. One of the Philadelphia first things he did was to lay out the city of Philadelphia where the Delaware and Schuylkill rivers meet. He insisted that the streets should be broad and straight and that the house lots should be large enough to allow gardens. He said that he wished the place to be a green country town. It was noted for its regular streets and its generally attractive appearance. Philadelphia grew rapidly, and its trade expanded as settlers came into the colony. The soil of Pennsylvania was fertile and the climate more favorable to farming than the climate in New England. In a short time Philadelphia was the leading city in the colonies.

Penn was one of the most influential Quakers in England, and his colony attracted attention among his fellow Quakers. They The Ger- were glad to escape persecution at home and at the mans same time found estates for themselves in a new world. But Penn wisely offered toleration to all churches, and many people came to Pennsylvania who were not Quakers. Among them were Germans, who first settled Germantown, near Philadelphia, and later were distributed throughout the farming communities of eastern Pennsylvania. They were a thrifty and hardworking body of men, and they have done much to make the state what it is.

Another important part of the population was Scotch-Irish. These people first lived in Scotland, and were Presbyterians. They 


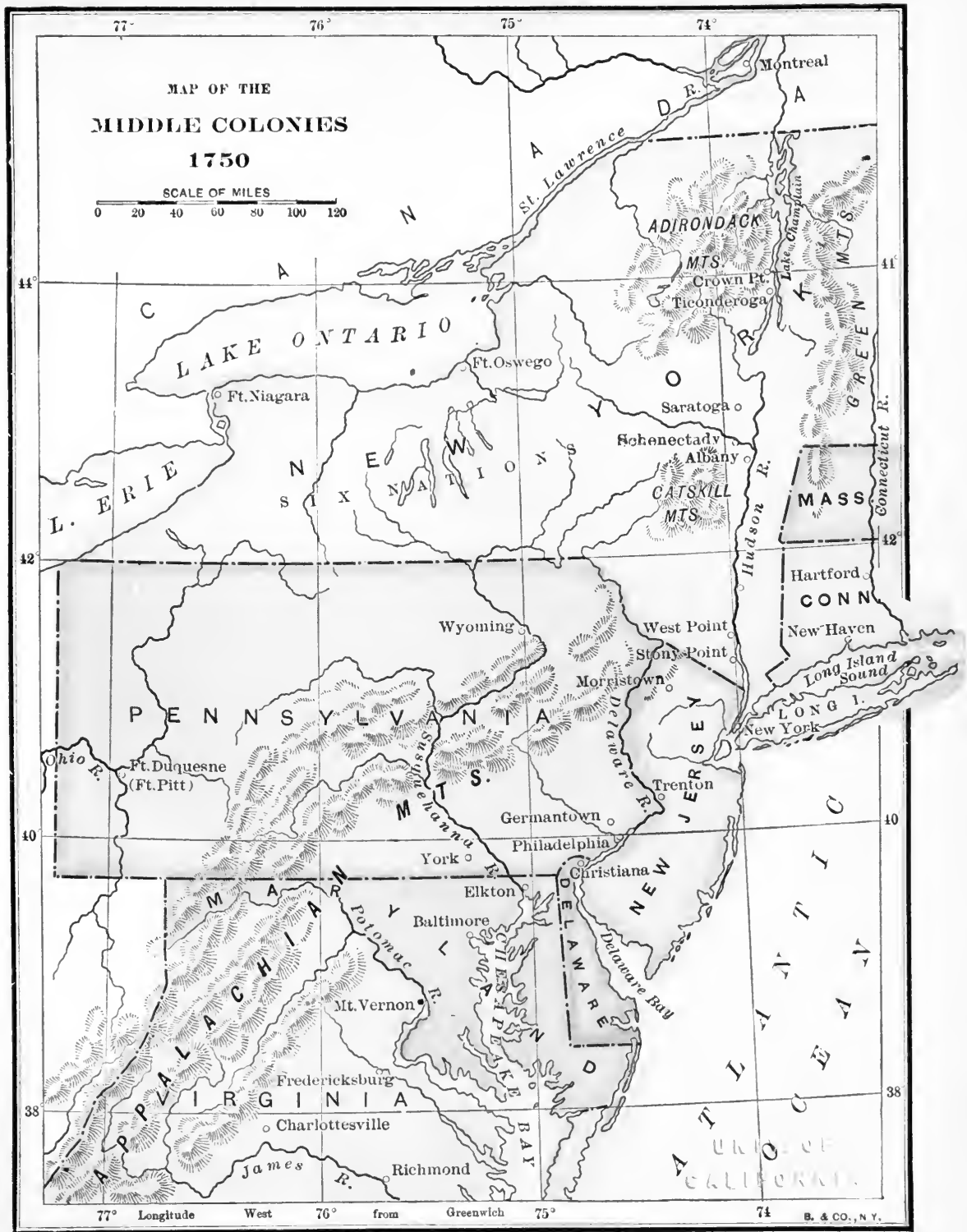




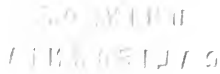


were settled in northern Ireland about the time Virginia became a colony in the hope that they might succeed in making Ireland a country of Protestants. At the end of a hundred The Scotchyears the Irish had not forsaken Catholicism, and the Irish Scotch-Irish - called such because they were Scots who had lived in Ireland - were generally poor and oppressed by the landlords. When Penn's agents came among them offering land, a great many decided to accept the offer. They liked the colony and sent back to Ireland such a good report that a steady stream of immigration was started which lasted until the revolution.

The Scotch-Irish settled at first in the southern part of central Pennsylvania. Then they moved southward across the narrow part of Maryland into Virginia. About 1750 they be- In other gan to fill up the western counties of the Carolinas. colonies Later on, they crossed the mountains and made an important part of the people who settled Kentucky, Tennessee, and Ohio. Their experience in Ireland taught them to endure hardships, and they were well fitted to meet the dangers in the forests of America. They were very successful frontiersmen. Many men who later became distinguished in public life were of Scotch-Irish origin. We must remember that the Scotch-Irish were not Highlanders, nor were they Irishmen. They were Lowland Scots, whose century of residence in Ireland did not change their religion nor their ideas.

When Penn arrived in America, 1682, he seems to have intended to spend the rest of his days in his colony; but he was called home two years later to settle a dispute which had Boundary arisen between him and Lord Baltimore in regard to dispute the boundary between Maryland and Pennsylvania. Each man stood out for his side, and no settlement was reached until both men were dead. It was not until 1760 that an agreement was made on the basis of the present line between the two states. This line was run in 1767 by Mason and Dixon, two surveyors. Thus we have the boundary known as Mason and Dixon's line, long important because it separated the free from the slave states. 
In 1699 Penn made a second visit to his colony. He found the people prosperous but dissatisfied with their government. $\mathrm{He}$ Government stayed two years among them, trying to quiet them. At last they drew up under his oversight a new form of government, which suited the conditions of the colony better than that which was prepared in 1683 . Each county was now to have four representatives in the assembly, and there was to be a governor and council appointed by the proprietor; that is, by Penn himself. When this settlement was made, Penn sailed for England, where much trouble awaited him. He was unjustly sued for debt and went to prison rather than submit. In conPenn and finement his health was injured, and he was never again his sons a well man. He died in 1718, and Pennsylvania bécame the property of his sons. They continued to appoint the governors, but the assembly was elected by the freemen. Penn himself did not make money out of the colony, but it became a valuable estate to his heirs. All the land not sold to the settlers remained in the hands of the Penns. In time the value of land rose as the country became peopled. Vast tracts remained in the possession of the proprietors, who would not let it be taxed as other land was taxed. This provoked a long quarrel between people and proprietors.

When the colony of Pennsylvania was settled, all the Atlantic coast in the hands of Great Britain had been erected into colonies. Two They were New Hampshire, Massachusetts (including changes Maine), Plymouth, Rhode Island, Connecticut, New York, New Jersey, Pennsylvania, Delaware, Maryland, Virginia, North Carolina, and South Carolina. Two changes were to be made in this list which we must now consider.

In 1684 the charter of Massachusetts was recalled by the courts in a manner somewhat like that by which the London Company r. Plymouth was destroyed in 1624. Massachusetts now became absorbed a royal province. This means that it was to be governed by the king, who would send a governor, and appoint a 
council to aid the governor. The king was now James II, and he had made up his mind to combine the New England colonies and New York and New Jersey in one great Dominion, in which there should be no assemblies chosen by the people. He expected that the laws for the Dominion should be made by the council, which would do as he wished. The future seemed dark for the people, who loved their liberties, when in 1688 there was a revolution in England by which the king himself was driven away and William and Mary were recognized as the sovereigns of the New charter country. They undid what had been done in New for MassaEngland, and gave Massachusetts a new charter. But chusetts it was not like that which Charles had taken away. It allowed the colony to have an assembly elected by its inhabitants, the assembly to make the laws. The governor was not to be elected by the colony, as under the old charter, but appointed by the king. Massachusetts thus was a royal province until the revolution. Another feature of the new charter was that Plymouth was made a part of Massachusetts. In this way one of the old colonies disappeared.

About forty years later another colony was founded, cut out of the territory of South Carolina. This came about through the efforts of General James Oglethorpe, a benevolent 2. Georgia Englishman, who sought to help the people whom he founded found in the English debtors' prisons. Many of these prisoners were unfortunate persons who had done nothing worse than get into debt. By the law they could not be liberated until their debts were paid. Oglethorpe and some others formed a company to send them to America, where they might have land and begin life anew. This was in 1732 , and the colony he founded was named Georgia, after the king, George II. The first settlement was made in 1733 at Savannah. Oglethorpe spent much of his time and money in behalf of the colony. The debtors proved poor material out of which to build a colony, and soon they ceased to be sent to Georgia. But various other kinds of men came. Some of them 


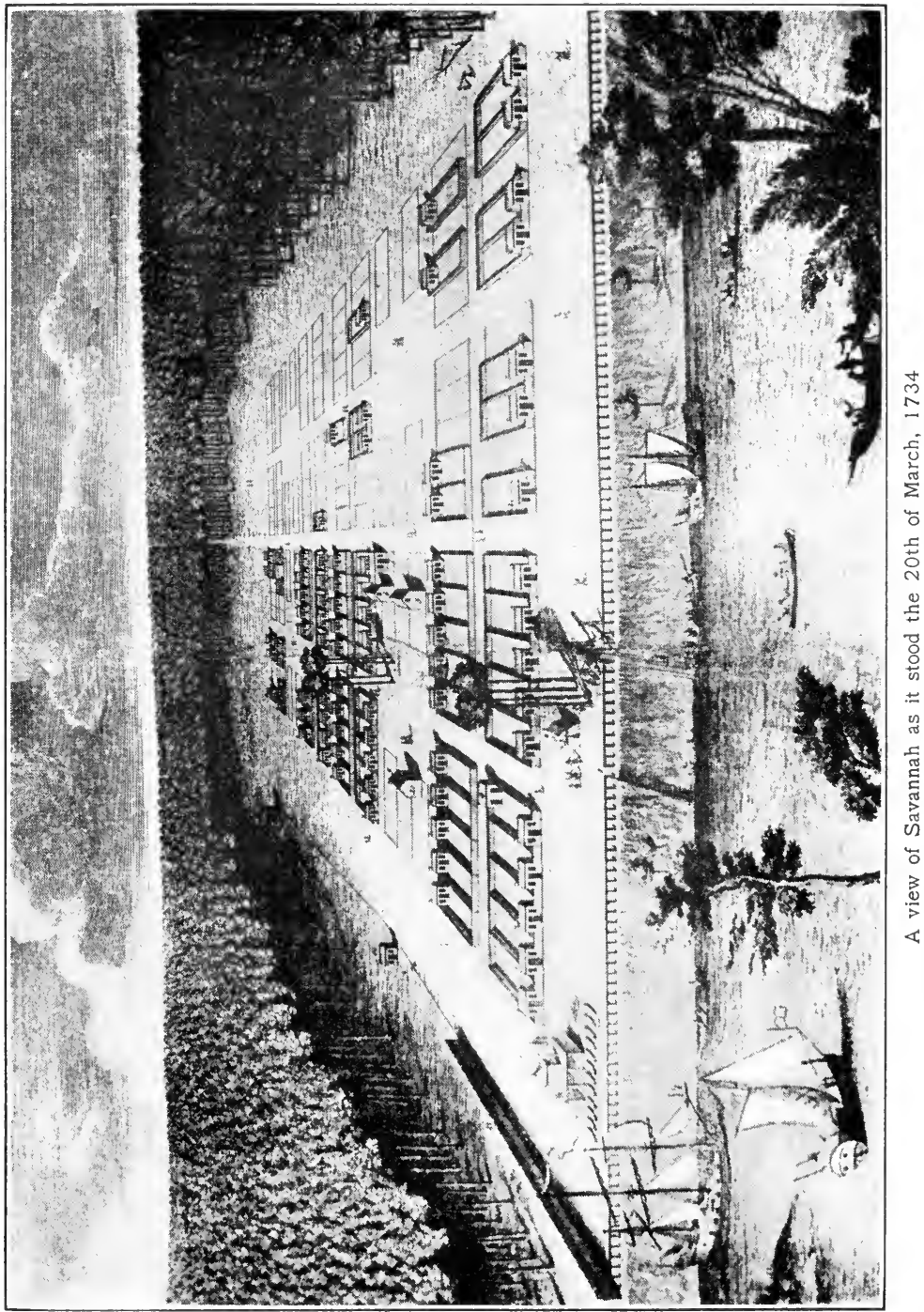


were Germans and some were men from the colonies north of the Savannah. The land of Georgia was fertile, but the settlement grew slowly. The area through which settlers in America were now scattering was so large that the people who wished to leave England, Scotland, and Ireland were not numerous enough to fill it up rapidly. As Georgia was the newest and most distant of the colonies, it got a small part of those who came over.

In 1751 the Georgia Company gave up its charter, and the colony became a royal province. At this time all the colonies except Rhode Island, Connecticut, Pennsylvania, Dela- Three kinds ware, and Maryland were in this class. Of these five of colonies exceptions the first and second were corporation colonies, the others were proprietary colonies. A corporation colony had its government in its own hands, and chose its own governor as well as its own assembly. In a proprietary colony the governor was appointed by the proprietor. In every colony there was some kind of elected assembly which made the laws.

Each colony had a history of its own, but it would take much space to describe them all. The thing the reader of this book must. remember is that the colonies were settled one after another along the coast, each in a particular way. After they were settled they all began to grow in a common way. Farming, trading, clearing away the forests, fishing, and lumbering were nearly the same wherever followed. The first settlers lived along the coast, their sons moved a little further inland. Down the rivers came the produce of the interior. It was sold to the merchants on the coast who had imported merchandise to give in exchange for it. Where the merchants were, towns grew up. In Virginia, as we have seen, the planters sold directly to England, and towns did not grow up there until about the end of the colonial period. But Virginia grew rapidly in population and was the largest, as it was the oldest, of the colonies. In the next chapter we shall consider some of the things which tended to draw the colonies together. 


\section{QUESTIONS}

I. What is the importance of the year 1660 in British history? What colonies had England at this time? How did Charles II feel about the colonies? What colonies were established while he was king?

II. What valuable discovery did Henry Hudson make? Describe the establishment of the Dutch trading fort. What was a trading fort like? What was the effect of rum on the Indians? Give the names of the Dutch town and colony. Describe the patroons and their estates. Describe the Dutch government in New Netherland. How did the English party grow up there? What did it demand? On what did England base her claim to the colony? Describe the conquest by Fngland. What promise was given to the people?

III. Describe the early history of Delaware. What nation settled it? Through what hands did New Jersey pass? Why was it sometimes called "the Jerseys"? Describe the people.

IV. Why did the king grant the Carolina tract? How was it done? What was its extent? What authority was given to the proprietors? What kind of colonies did they propose to have? What two were successfully established? How did they grow? Why did the proprietors prove bad colony founders? What was the result of rice planting in South Carolina? Describe the revolt in South Carolina. How did the two colonies become royal provinces? Compare North and South Carolina.

V. Describe the grant of Pennsylvania. What kind of motives had Penn? What form of government did he give his colony? Describe the beginning of Philadelphia. Describe the growth of Pennsylvania. What was the policy toward various churches? Describe the arrival of the Germans. Who were the Scotch-Irish? Describe the removal to Pennsylvania. How did they expand to other colonies? Why were they good frontiersmen? Explain the Maryland-Pennsylvania boundary dispute. Why was Mason and Dixon's line important? What important settlement was made during Penn's second visit to his colony? Describe the new form of government. How did Penn spend his later years? How was Pennsylvania ruled after his death?

VI. What colonies existed in North America when Charles II died? What two changes in them were about to be made?

VII. How did Massachusetts lose her charter? What kind of government replaced it? What plan did the king make for the northern colonies? How did the revolution in England affect this plan? Describe the new charter of Massachusetts.

VIII. Describe Oglethorpe's efforts in behalf of the debtor prisoners. 


\section{THE LATER GROUP OF COLONIES}

Deseribe the early years of Georgia history. Why did the colony grow slowly?

IX. Describe the three kinds of colonies. In what respects did all tend to grow in the same way?

\section{SUGGESTED TOPICS}

A Sketch of the Rule of Peter Stuyvesant; Henry Hudson's Voyage; The Services of William Penn to Pennsylvania; The Government of a Royal Province; Oglethorpe's Career in Georgia; The Leisler Revolution in New York. 


\section{CHAPTER VIII}

\section{THE EARLIEST SIGNS OF UNION AMONG THE COLONIES}

The people of England believed that colonies were but children of a mother country, who had founded and nourished them when Mother and they could not protect themselves. In return for this, children it was generally held, the colonies ought to respect and help the mother country. They ought to send her their products and buy from her their manufactured goods. In other words, colonies existed for the benefit of the country on which they depended.

The people in America did not agree with this idea. They knew that the king and parliament of England had done very little What the for them. The colonists came across the ocean at colonists their own expense, they made new homes for themthought selves with little help from the British government, and they fought off the Indians through their own strength and sacrifice. They also felt that they were as truly Englishmen as those who lived in the old home, and as Englishmen they claimed the right of self-government. For this reason they resented the idea that they should be more bound to obey the king than the people of England. If Englishmen might trade where they pleased, why should not the colonists do the same?

The king paid no attention to the wishes of the colonies. He knew they were too weak to resist him singly, and he did not Could they think they could ever unite. In this he was mistaken. unite? In trying to carry out his ideas that colonies exist for the benefit of the mother country, he made regulations which were resented by all the colonies alike. One and all, therefore, they 
began to see that the cause of one was that of the others. While they were weak they could not resist, but as they became older and stronger they began to think of means by which they could keep England from using them for her own good. In doing so they came to act together. If one were asked what was the first thing that brought the colonies together in a union, he must answer: It was the unwise action of England herself in seeking to make the colonies a means of enriching her own people.

This policy first appeared in 1651, in the time of Cromwell. It was expressed in what are known as the navigation acts, or the laws of trade. They were a series of laws passed by The naviparliament to force the colonists to deal with British gation acts merchants only and to ship their goods in British ships alone. They were passed to please the British merchants and shipowners, and whenever there was suggestion of repealing them, loud protests came from these favored classes. No ship but a British ship could take tobacco from Virginia to Europe, and even such a ship must take it to a British port or pay a heavy tax before sailing. Manufactured goods, with a few exceptions, must be imported from British ports. In this way the British merchants, who bought colonial produce, those who sold merchandise to the colonies, the owners of British ships, and the king, who collected revenues, profited at the expense of the colonists. If the people of the colonies could have traded as they chose, they could have sold some of their products at better prices, they could have bought merchandise more cheaply, the Dutch ships would have carried their goods for lower rates, and they would not have had to pay the high taxes in British ports. Of course, colony ships were British ships.

An illustration of how the British government treated the colonies in regard to trade is seen in the "molasses act" as it was called (1733). Great Britain owned some sugar- The "moproducing islands in the West Indies, and France and lasses act" Holland owned some also. From all of them the New Englanders got molasses out of which they made rum. After a while the 
English islanders asked that the molasses of the French and Dutch islands be taxed so high in American ports that the rum-makers would not import it. They thought that this would force the New Englanders to buy from them at higher prices. The British parliament did all that was asked by the islanders, and the result was the "molasses act." Now appeared a difficulty. The English islands did not raise as much molasses as was used by the rummakers, so that some of the New England distilleries must close if the law was enforced. This was so evident that the British officers did not pretend to enforce the act for many years after it was passed. But the act made a bad impression in New England.

While the navigation acts were keenly felt by the colonists, there were two reasons why they did not utterly crush the trade Two reasons of the Americans. 1. They applied to only a portion of the products that were exported. It was only tobacco, rice, molasses, copper, and furs that were to be sent exclusively to British ports. There were many other products that might be sent to any place the shipper selected. Among them were fish, pork, beef, and wheat, all articles which the colonists were in the habit of selling at good profit to the West Indies.

2. The British officials in the colonies allowed the laws to be violated. Of course, this was smuggling, and it would not be tolerated by honorable men in our own day. The colonists did not think it wrong to break a law they considered unjust. One way of breaking the law was to unload ships in unwatched harbors. Sometimes the officers were not careful and allowed a ship loaded with sugar or molasses to pass through their hands as though it were loaded with something else. When at last the British government tried to enforce the navigation acts strictly, there was a Smuggling great outcry from the colonies. The trading colonies were most damaged by these acts and felt most indignant on account of them. They were Pennsylvania, New York, Massachusetts, Connecticut, and Rhode Island.

As the colonies grew in power they had less fear of England. 
They were much larger than the mother country and would some day have a larger population. Every settler looked to the future with confidence. Some time, it was thought, they Looking to would have manufactures and be able to get along the future without importing all their merchandise from Europe. They even began to make hats, ironware, and many other things. They were surprised to learn that all this was not to be allowed. The British manufacturers complained that they would be ruined if the colonial manufactures were not restrained. They got what they wished, and parliament ordered the colonies to cease exporting woolen cloth, hats, and ironware which they had manufactured. This was a blow to the infant manufactures, and it created much indignation in America.

The feelings of the Americans were best expressed in the colonial assemblies. To understand this statement we must remember that each colonial assembly looked on itself as a guar- Manufacdian of the interests of the colony in which it existed. tures reIt was composed of delegates chosen by the people. stricted Now the colonists looked on the colonial assembly The asas similar to the British parliament. One of the rights sembly of the parliament was to levy the taxes and to decide how the money that came from them should be spent. A colonial assembly came to the conclusion that it alone could tax the people of the colony and that it alone could decide what should be done with the money that was paid for taxes. Very aggravating disputes grew up out of this conviction.

One was about the payment of the salary of the governor. In some of the colonies the king got the assembly to levy a special tax which was collected year by year, and it was possible The goverto pay the governor's salary out of this. In such nor's salary a colony no quarrel over salary occurred. But most colonies approved the governor's salary annually. In the proprietary colonies the governor was appointed by the proprietor and the salary was paid by him out of the funds he received either from land 


\section{THE PLAIN STORY OF AMERICAN HISTORY}

sales or from the quit-rent, which was a small sum paid by every landowner. In these colonies there was no quarrel over the governor's salary. Where a governor was elected by the assembly, as in Connecticut and Rhode Island, the assembly paid the salary from the money raised through taxation. Here, also, there was no quarrel.

But in other colonies, as in Massachusetts and New York, the king wished to force the legislature to vote a tax from which the In Massa- governor's salary could be paid. Both colonies rechusetts fused to do what was demanded. The king held out stubbornly, and the assembly would pay nothing for more than one year. The people felt that if they could have it understood that the governor's salary depended on them, they could force him to favor the interest of the colony. The quarrel was long and bitter in Massachusetts, but in the end the king had to give way. While this controversy was going on the people learned how to stand up for their side against the king. Other colonies watched the quarrel with keen interest, and everywhere there grew up the feeling that assemblies had a right to demand what they thought their rights. You will see how important this was when the colonies came to resist England in the outbreak of the revolution. Every small struggle that one colony had against the mother country only served to make it more willing to unite with the others in the great struggle which all felt was to come.

A very good illustration of how ready a colony was to act for itself is seen in the way in which the oldest colony resisted its Virginia's governor in what was known as Bacon's rebellion. Virearly loyalty ginia was at one time a most loyal and obedient colony. Her governor was Sir William Berkeley, who loved the king, Charles I, and did all he could to keep the colony true to him. When the king's head was cut off by the Puritans under Cromwell, 1649, Berkeley was dismissed; but he was again made governor when Charles II was received as king of England in 1660. Vir- 


\section{EARLIEST SIGNS OF UNION AMONG THE COLONIES 105}

ginia was delighted with the restoration, and Berkeley was allowed to do about as he chose.

He took advantage of the loyalty of the people to keep in office for fourteen years an assembly that was willing to do what he wished. In colonial times a Virginia assembly was sent Berkeley's home and another elected only as the governor ordered. tyranny Berkeley had his own friends in the assembly and felt very independent. One thing he did was to give to persons who were friendly to him valuable licenses to trade with the Indians north of Virginia. About this time the Indians in that region, alarmed at the advance of the white settlements, had begun to attack the families on the frontier. Sometimes they carried off cattle, and sometimes they killed the settlers. The colonists were alarmed and thought that a strong force ought to be sent to punish the Indians before they attempted open war. But the governor would not let the people march against the savages, and it was said that he did this because he thought that a war would interfere with the profits of his friends, the traders.

This produced great anger among the people, some of whom had plantations on the frontier. At last they found a leader in Nathaniel Bacon, a young man of great boldness and Nathaniel eloquence. He made a speech in which he said he Bacon would lead the people to punish the Indians, governor or no governor. Three hundred men came to his aid with guns in their hands. They set their faces northward, but had not gone far when Berkeley issued a proclamation declaring they were rebels for going out without his permission. This discouraged some and they went home. The others went on and encountered the foe in a severe battle in which one hundred and fifty Indians were slain. Governor Berkeley was in a rage. He had ruled the colony in his own way so long that he feared that if an army once was organized, it would turn against him.

His fears proved well founded. Bacon and his followers came back from the Indian country determined to resis $t$ the governor. 


\section{THE PLAIN STORY OF AMERICAN HISTORY}

The people were with them, and Berkeley yielded. An assembly was elected and met to make laws. They seem to have feared Berkeley's that the governor would not keep their laws; for a fears demand was made that Bacon should continue in command of the army. This made Berkeley very angry; for he saw that it was intended that the army should be a threat held over his head. The quarrel now became violent; some men supported Bacon and some the governor.

Each side took up arms, and civil war was the result. Berkeley was in Jamestown with six hundred men, and Bacon attacked Jamestown the place, intending to starve it into submission. He taken placed his men across the neck of land that connected the peninsula with the mainland and made every effort to throw up breastworks before he could be driven off by the artillery of the other side. It is said that to gain time he sent carriages during the night to the plantations of his enemies and secured many of the leading women of the neighborhood. He assured them they should suffer no harm from his own men. At dawn they were stationed in front of the earthworks on which his men were hard at work, between Bacon's army and that of the governor. When the defenders of the town saw their wives and sisters protecting the lines that confronted them, they dared not fire; and so Bacon finished his defenses and took Jamestown. The place had been true to the governor and now it was not spared. Bacon reduced it to a heap of smoking ruins, and then turned to give his enemy a deathblow. But his race was run. Exposed in the swamps, he was seized by disease and died a few weeks after he won his triumph at Jamestown.

Governor Berkeley now came back to his capital and the war went on. His opponents had no head and submitted or fled. The Berkeley's leaders were hunted down, and thirteen were hanged. vengeance One of them was Drummond, who had once been governor of North Carolina. He was much hated by the angry old governor. When he was taken, Berkeley said to him: "Mr. Drummond, 
you are welcome. I am more glad to see you than any man in Virginia. Mr. Drummond, you shall be hanged in half an hour." "As your honor pleases," said the prisoner, as he was led to the scaffold.

This display of wrath turned his own friends against the governor. Those who had fought for him could not fail to see that he was no longer fit to be governor. The king himself Fall of was disappointed and recalled him to England. The Berkeley old man left the colony with the idea that he would come back

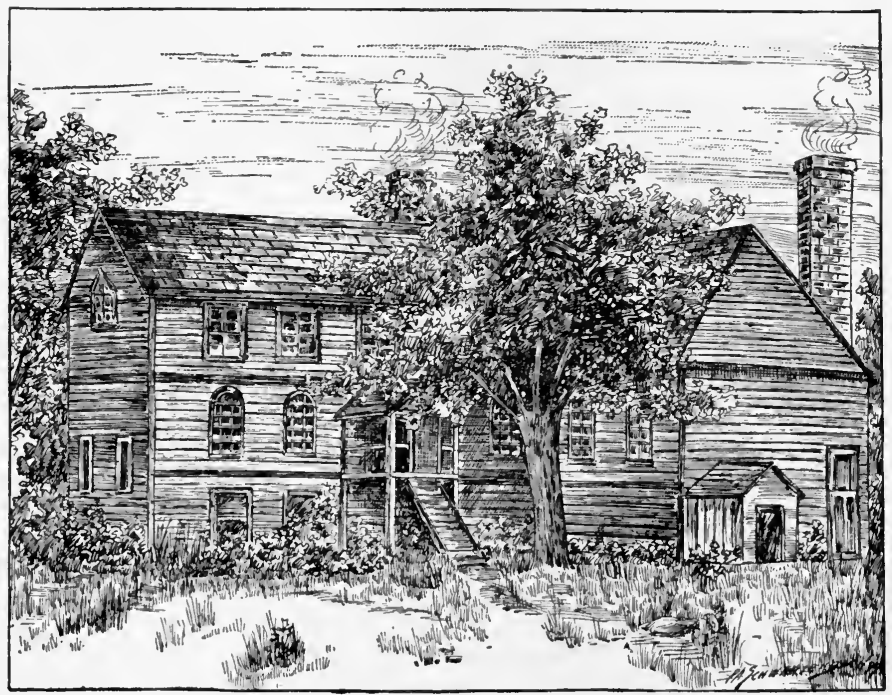

The house in which Nathaniel Bacon died

From an original sketch.

vindicated. In London he found that the king would not see him, and broken in spirit he died a few weeks later. He represented an old type of aristocrat, which was then disappearing in England and was not likely to gain a foothold in a new country where each man must work hard for himself. 


\section{THE PLAIN STORY OF AMERICAN HISTORY}

He did not like to see poor men become influential in government, and he thought the great planters should have the control in Vir-

Berkeley ginia. He did not approve of schools for all the people and Bacon and said, "Learning has brought disobedience and compared heresy and sects into the world and printing has divulged [them]." Bacon was another kind of man. He believed that the Virginians should have the same interest in making their laws through their assembly as the Englishmen had in making English laws in parliament. After the departure of Berkeley the assembly was allowed greater power, and it gradually became the instrument of expressing the will of the people. Bacon's course undoubtedly was largely responsible for this change.

Bacon's rebellion was long remembered in other colonies. It occurred in the oldest, largest, and most loyal of the king's What Bacon American colonies, and it showed what could be done stands for when the assembly was not given the right to make laws in obedience to the will of the people. Nathaniel Bacon's death was not in vain. He was the first man to fight against the claim of England to rule a colony as she chose. He risked his life to prove that the right of government rests with the people who are governed. Washington, Adams, Franklin, Jefferson, and a great many other men did the same thing just a hundred years later. When Bacon fought Governor Berkeley, only one colony was involved. When Washington fought King George III, thirteen colonies stood side by side fighting for independence.

\section{QUESTIONS}

I. What was the English view of the duty of a eolony? What did the colonists think of it? What was their idea of their own future? How did the attitude of the king tend to draw the colonies together? Show how England was responsible for the first steps of the colonies toward colonial union.

II. When did the navigation acts first appear? What did they provide? Why were they adopted? What was the "molasses act"? Why did the navigation acts fail to crush the trade of the colonies? What 


\section{EARLIEST SIGNS OF UNION AMONG THE COLONIES 109}

trade was left open? Which were the trading colonies? In what way did England restrain colonial manufactures?

III. How did the colonial assembly come to speak for the colonial side? In what way did it resemble the English parliament? Describe the controversy over the payment of the governor's salary. Why did the Massachusetts assembly wish to pass on the salary itself?

IV. Describe Sir William Berkeley's career as governor. How did he abuse his power? Why would he not punish the Indians? Describe Bacon's action in regard to the Indians. What effect did this have on the governor? How did the assembly take precaution against Berkeley's future conduct? Describe the attack on Jamestown. Describe Bacon's ruse. How did he punish the town? How did his work fail? Describe Berkeley's vengeance. Describe the overthrow of Berkeley's influence in Virginia. What was the influence of Bacon's rebellion on other colonies?

\section{SUGGESTED TOPICS}

Smuggling in the Colonies; The Operation of the "Molasses Act"; The Massachusetts Controversy over the Governor's Salary ; Lord Cornbury as Governor; The Career of Nathaniel Bacon ; His Attack on Jamestown. 


\section{CHAPTER IX}

\section{THE WARS AGAINST THE INDIANS AND THE FRENCH}

In the preceding chapter we have seen that the colonies began to think of acting together when England began to place burdens Recapitula- on their commerce and manufactures. We have also tion seen that the colonial assembly became a strong power in the colony. It was considered a kind of parliament which protected the people against the king in the same way that the British parliament protected the liberty of the people of Great Britain. We have seen, also, that the Virginians took up arms to show that they had the right to elect their assembly at frequent intervals in order that it might act as a restraint on a despotic governor. We must now take up those wars in which the colonists were called upon to act together against the Indians, and after a while against the French. They were very important because :

Why the wars were important

(1) They cleared the ground of Indians and French and finally left all the country for the English colonies; and (2) they taught the colonies how to support one another in war and made them believe that they could fight as well as the British regulars who fought at their sides.

The first of these wars was fought in New England and was known as King Philip's war, 1675-1676. Philip was the son of

King

Philip's

war Massasoit, the Wampanoag, friend of the people of Plymouth. He was alarmed at the progress of the settlers and came to see that the Indians must fight or lose their lands. Many other Indians felt as he felt, and the war which goes by his name was supported by several tribes, extending from the Connecticut valley to the coast of Maine. In 
WARS AGAINST THE INDIANS AND THE FRENCH 111

June, 1675, the town of Swansea, Plymouth Colony, was suddenly attacked by the Indians. One by one other towns reported that they were beset. How much Philip had to do with these various

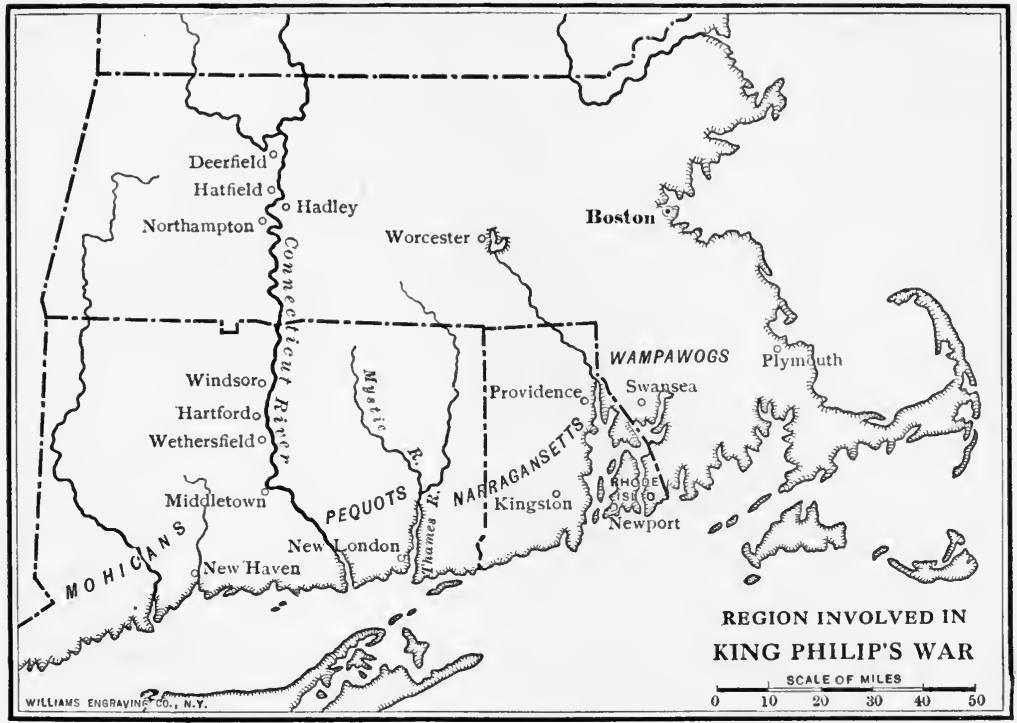

outbreaks is not known. The people of New England thought for a long time that he was the chief person in stirring up war; but historians of our own day are inclined to Philip's part think that he had little to do with any battles except those in which his own people, the Wampanoags, took part.

The attacks came from such a large number of tribes that the whites suspected every branch of the Indian race in New England. News came that the Narragansetts, who had befriended NarraganRoger Williams and helped the settlers against the setts conPequots, were about to take up the war club. We do quered not know that the charge was true, but it seems that the Narragansetts bore themselves in a threatening manner. The whites decided to take no chances with them. Collecting troops from 


\section{THE PLAIN STORY OF AMERICAN HISTORY}

Massachusetts, Connecticut, and Plymouth, they fell upon the chief stronghold of the Indians at what is now Kingston, Rhode Island, surrounded the Narragansetts, and killed so many of them that the tribe was never again a menace.

Both sides were now thoroughly aroused. Town after town was attacked by the savages, and many terrible stories of cruelty are Fate of the preserved. Women and children were killed or capcaptives tured by the Indians, frequently in the dead of winter. If the prisoners submitted without protest and bore up under the hardships, they lived with their captors until ransomed by friends. Weak persons who could not keep up with the march into the wilderness were often killed and left by the side of the trail. One of the narratives tells of a woman who begged piteously to be allowed to go back to her home. Annoyed by her complaint the Indians surrounded her with her child in her arms. When they had sung and danced about her as long as they wished; they crushed her skull and that of her child. Then they made a fire and burned the bodies, calling up the other children among the captives to show them what would happen to them also if they wished to go home. It was reported that the poor tortured woman did not shed a tear while she was within the circle, but continued to pray to God. The Indian thought a man should be indifferent to pain, and he liked to see his enemy, whom he hated, cry and cringe before him. He felt that his triumph was greater if his captives were made to suffer until they begged for mercy.

About midsummer, 1676, the Indians began to be exhausted. They had not been fighting in great bands, and the task of the A long series settlers was to punish one tribe after another. One of battles of the leading Indian fighters was Captain Church, who made it a duty to follow and attack every band of hostile Indians he could reach. Hearing that Philip was at Mount Hope, a peninsula near Providence, Church hastened to the place and seized the neck of the peninsula, so as to cut off escape by land. Philip, not knowing how completely he was surrounded, tried to flee and 
encountered the guards watching for him. He was recognized and slain by an Indian friendly to the whites. His death marked the end of the war in southern New England, but the The death fighting continued several weeks longer on the coast of of Philip Maine. When Philip was dead, his hands were cut off and sent to Boston. His head was placed on a pole and set up in Plymouth, where a day of thanksgiving was observed. The settlers had suffered severely, and their finer feelings were deadened by the brutal practices of their foes. It is the unhappy effect of war that it makes men forget the laws of kindness and generosity.

King Philip's war broke the power of the Indians in New England forever and gave the whites the opportunity to settle where they pleased in the interior. But it did not remove Alarm of the the last danger from Indian attacks. In the St. Law- French and rence valley were many Indians who became alarmed Indians in at the continuous approach of the whites into the Canada northern forests. Among them lived the French, who feared that the English settlements would extend into Canada. The French and the Indians, therefore, acted together to check the advance of the English colonists; and that is why the future wars with the Indians were at the same time wars against the French. 'They began whenever there was war between France and England in Europe and ended when the two nations made peace. There were four of these conflicts: King William's war, 1690-1697; Queen Anne's war, 1701Four wars 1713 ; King George's war, 1745-1748; and the Seven Years' War, which lasted nine years in America, 1754-1763. Before we see what happened in each of them we must see how it was that France came to have colonies in America.

The first French to come to North America were a colony of Huguenots, or Protestants, who tried to settle in what is now Florida, from 1562 to 1565 . They seemed about to succeed in their plans when a Spanish soldier, Menendez, appeared, slew most of the settlers, and

First French settlement in North America 
destroyed the settlement. A French captain, de Gourgues, took vengeance by killing the Spanish garrison at St. Augustine. The trouble arose because both nations claimed Florida. The Spaniards did not give up St. Augustine and sent a stronger garrison to it ; but France made no further attempt to settle in that region.

Her next efforts were in the north, where Jacques Cartier, a bold explorer, sailed up the St. Lawrence as far as Quebec (see p. 25) French fur in 1534. The country was rich in furs and the French traders in decided to open a trade with its inhabitants. AccordCanada ingly, a colony was sent out and a fort built at Quebec, 1541. The Indians gave so much trouble that the place was abandoned. But the river was not forgotten. The Algonquin Indians along its banks were great hunters, and French vessels came there regularly trading for furs. In one of them came, 1603, Champlain, a young man who could see how valuable it would be for his country if the French were established along the St. Lawrence. If you will look at the map, you will see that by going up the river and then through the lakes to Duluth one reaches nearly the middle point of the continent, and travel by water is possible Champlain's through all the distance. Champlain wished France to dream control the vast region reached by this system of transportation. In 1608 he reëstablished a fort at Quebec and began to found trading stations along the river. Farmers also arrived and the country began to take on the aspect of a permanent colony. It was known as New France.

Champlain gave his life to the task he had assumed, dying at Quebec in 1635. There was only one serious mistake in all his His greatest colonial plans. He made friends with the Algonquins, mistake which was wise, since they were more numerous than the colonists. But the Algonquins got him to help them in a war against the Iroquois, their ancient enemies. Champlain wished to show the Algonquins how strong the French were and marched off to the war with his Indian friends. A battle was fought on the shore of the lake which now bears the name of the Frenchman. 
The Algonquins were drawn up in battle lines. The Iroquois formed a line and began to charge. Suddenly Champlain stepped out from the ranks of his friends with a gun in his hand. He shot two Indians dead and wounded another. The Iroquois had not seen firearms before this and fled from the field in defeat. The Dutch were at that time just coming into the Hudson valley. From them the Iroquois got the white man's wonderful arms and

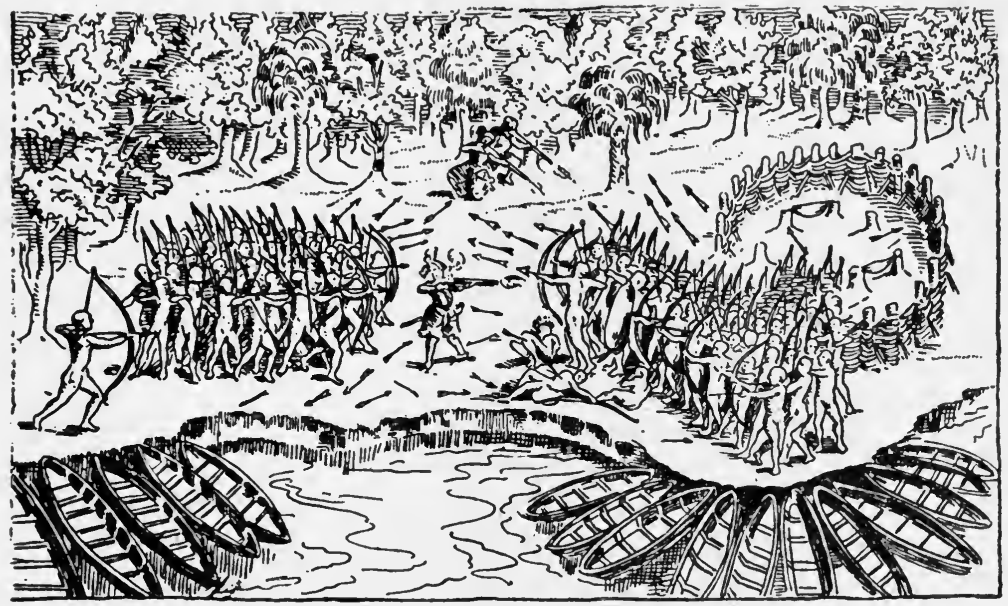

Champlain defeating the Indians

learned how to use them so well that they soon were a terror to the Algonquins. They never forgave the French for the part Champlain took in the battle near Lake Champlain in 1609.

The Iroquois were the most powerful of all the Indians on the Atlantic coast. They lived in central New York and were in a position to turn back the French, who would have Importance been pleased to follow the upper Hudson to Man- of the hattan Island. If France had held this river and the Iroquois land in which the Iroquois lived, she would have cut into two parts the English colonies, which may well have meant that our 
history would have been far other than it has been. The Iroquois were first called the Five Nations, but in the eighteenth century they became the Six Nations (see p. 7).

The French did not come to America in large numbers. In fact, of all the people of western Europe they are most inclined to The French stay at home. The French kings offered much aid to as colonists those who would settle in New France, but the colony grew slowly. This pleased the Indians. They welcomed people from whom they could buy goods and who, being traders, would never dispossess them of their hunting grounds.

One of the things we must remember about the history of the French in Canada is the work of the Jesuits. These priests were The Jesuits eager to convert the Indians to Christianity. They enorder to convert the savages. Their work took them on long journeys, and thus they became explorers of the forest country along the St. Lawrence and the lakes. One of them was Father Marquette, who in company with a trader, Joliet, came to the Marquette upper waters of the Wisconsin River in 1673 and floated and Joliet down its surface until he reached the Mississippi. So great a river high up in the interior surprised them, and they started to go down to its mouth. Days and days they paddled southward, passing the mouths of many great rivers. When they had reached what we now know is the Arkansas, they turned round, lest they should go so far that they could not get back with an account of their discovery.

Their report aroused the enthusiasm of La Salle, a brave explorer. He formed a plan to establish a fur company to trade La Salle with the people in the river valley. He also proposed to establish trading posts, and to collect information about the country. It was a great plan, but many enemies appeared to keep La Salle from carrying it into execution. After much discouragement he set out in December, 1681, to explore the Mississippi to the salt sea. April 6 in the following year he 
passed out one of its several mouths to the Gulf of Mexico. Throughout his long journey he passed through a fertile and pleasant country far more suited for human abode than Canada.

La Salle now went to France, where king and people heard gladly the story of his exploration. Furnished with four ships, with men and supplies for a colony, he sailed in 1684 to His settle at the mouth of the great river. But it was not attempted easy to find one of the small mouths that open on the colony gulf through grassy marshes, on a coast where are many flat islands and twisting channels. He missed the place he sought and at last landed on the coast of Texas. He started overland to find the Mississippi, down which his friend Tonti had agreed to come from Canada. Bad luck still followed him; he lost his way and after wandering for a long time in the interior of the great West he was killed by his own men, who sought to escape out of the land into which he had led them.

La Salle's plans did not fail entirely; for in 1699 Iberville and Bienville, two Frenchmen from Canada, planted a trading post at Biloxi, near the mouth of the Mississippi. Other places were settled, and thus was founded the colony Louisiana of Louisiana, named for the king of France, Louis XIV. The land was very fertile and it could be had very cheap, but the French peasants and farmers were unwilling to come and settle it. For that reason Louisiana grew slowly. A hundred years after it was founded it was merely a series of plantations along the lower Mississippi, with small settlements at St. Louis, Natchez, Baton Rouge, and Mobile. Thus the French held two colonies, Canada and Louisiana. Between these colonies was a vast forest, through which trails ran. On the trails were trading forts in which small garrisons protected the traders.

During all this time the English were busy on the coast. They settled in orderly farming communities, and moved west- The English ward as fast as there were people to settle the frontier threaten the farms. Some day they would reach and pass the French 


\section{THE PLAIN STORY OF AMERICAN HISTORY}

mountains, and then it would be hard fighting between them and the French. The latter had this weakness, that they were thinly settled over a vast region in trading forts. If their forts were attacked vigorously they would fall, and with them would go the French control of the great valley.

In 1690 France and England were at war. Frontenac, a man of great foresight, was governor of Canada, and he thought it a King Wil- good time to get possession of the Hudson River line of liam'swar, communication. The one thing in the way was the 1690-1697 ill-will of the Iroquois, and he tried to overcome this by showing them how powerful the French were. He thought the

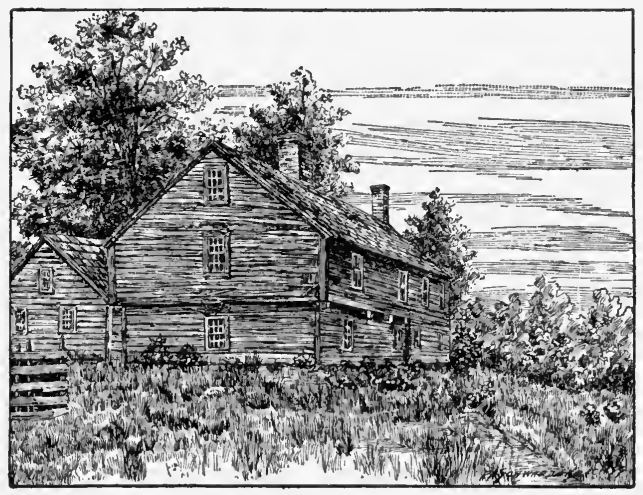

A "Garrison House" at York, Maine, built in 1676 best way to do this was to raid the English settlements before the very eyes of the Iroquois. Frontenac believed that when his raids had been made, the messengers he sent to the Five Nations would have easy tasks to win them over.

The first place to feel his anger was Schenectady, where sixty of the inhabitants were killed and twenty-seven led away Frontenac's captives in a sudden attack over the snow. A second raids successful raid was made against Salmon Falls, New Hampshire, and a third against Fort Loyal, now Portland, Maine. The raiding parties were composed of French and Indians, and they killed and scalped their opponents as freely as if all had been Indians. Frontenac has been much blamed for allowing his Indians to take part in these assaults.

The colonists were alarmed and decided to unite to conquer 
the St. Lawrence valley. They saw there would be trouble as long as the French could set the Algonquins on the Englishmen. Delegates met from Massachusetts, Connecticut, Ply- Movement mouth, and New York. They decided to raise a land against expedition which was to reach Quebec by way of Quebec Lakes George and Champlain, while Massachusetts attacked by a fleet on the St. Lawrence. It was thought that Canada must yield if she were struck two blows at once, one by land and the other by water. The plan was good but hard to carry out. Smallpox appeared in the land expedition and the Iroquois allies failed to join the expedition, so that it got no further than Lake Champlain. Its retreat to the settlements caused the Indians to scoff, and more trouble came to the frontier than ever. The water expedition sent out by Massachusetts arrived so late that Frontenac was able to fortify Quebec, and the attack was a failure. Raids began again, and in one of them Haverhill, Massachusetts, was captured. One of the prisoners was Hannah Dustin, who was led away toward Canada. By watching her opportunity she slew her guard and escaped to her friends. The war ended in 1697 when England and France made peace in Europe. Result of Neither side was satisfied, and it was freely predicted the war that fighting would soon begin again. Thus Frontenac had failed in his purpose. The Iroquois had not deserted the British, and the French had not got possession of the Hudson valley.

As expected, the war soon reopened in Europe and the Indians of Canada made new raids on the New England settlements. In one attack they fell on Deerfield, Massachusetts, dur- Queen ing a bitter night in February. They climbed suddenly Anne's war, over the stockade that surrounded the town, slew fifty- 1701-1713 three of the inhabitants, and captured one hundred and eleven. Among the prisoners were Rev. John Williams and his family. The Indians set out across the snow for their homes, taking the captives with them. Mrs. Williams and sixteen persons were killed because they could not keep up with the travelers, and 
others died of hunger. Those who reached Canada were distributed among the warriors who took them prisoners. At the end of the war many "New England captives" were in Canada from various towns. Most of them were ransomed by their friends, among them Mr. Williams, who returned to the Deerfield church. His daughter, Eunice, had become a Catholic and married an Indian. She liked the forest life and refused to leave her husband and children in Canada.

In 1713 the two sides were tired of fighting in Europe and a treaty of peace was made at Utrecht. Four of its terms we must Treaty of remember: (1) England got Acadia, the part of New Utrecht France east of Maine, and later changed its name to Nova Scotia ; (2) France agreed that the Iroquois should be subject to England; (3) Newfoundland was given to England; and (4) England got the rich fur region round Hudson Bay. England received more benefit than France out of the war.

In King William's war and Queen Anne's war the colonies of the North acted together against Canada, but they had little

King success. In King George's war (1745-1748) they George's showed more strength. Thirty-two years had passed war, 1745- $^{-}$since the preceding war, and in that long time the 1748

British colonies had grown rapidly. They were much stronger than the French colonies, which grew slowly. War was hardly begun before Governor Shirley, of Massachusetts, laid plans to take Louisburg. This was a strong fortress the French had erected on Cape Breton Island to threaten the English in Nova Scotia and to keep them away from the mouth of the St. Lawrence. The place furnished refuge for French ships, which darted out and captured the boats of the New England codfishers and soon drove them from the coast. Shirley's arrangements Louisburg were secret. He collected a force of 4000 men from captured New England under command of Captain Pepperell, of Maine. They found Louisburg unprepared and surrounded it. An English fleet arrived in time to blockade the mouth of 
the St. Lawrence. Help could not come from Quebec, and after a siege of forty days the fortress surrendered. This was the most successful move in the war. England had poor ministers in those days, and the war dragged on until 1748, when peace was made without glory. Louisburg was handed back to France, much to the disgust of the New Englanders.

In the first and second of these wars the first attacks had come from the French side, and they had been delivered by Indians. In the third the first blow was struck by the Britjsh Three wars colonies, and this shows how much stronger they were compared than formerly. In the third war Indians were used on each side, but they were only a small part of the forces engaged. This, also, shows how the war had changed. The British colonists were now a numerous people. They were fast settling the region east of the Appalachians and had begun to cast their eyes to the fine lands beyond these mountains. It was to get possession of these lands that the fourth and last of the wars between the French and English in America was fought.

Both sides wished to hold the fork of the Ohio River where Pittsburg now stands. Here meet the Alleghany, coming from the north, and the Monongahela, coming from the south. The fork of You may reach the Alleghany overland from Lake Erie the Ohio and pass down that stream to the fork. Or you may reach the Monongahela from the Potomac overland and pass down that stream to the fork. From this point you may go by water to most parts of the Mississippi basin.

In 1754 a French force landed at what is now Erie, Pennsylvania, reached out to the Alleghany, and began to build forts to hold the country. Virginia claimed the Ohio valley, and per- The race to haps had a better right to it than any other English get it colony. Her governor sent George Washington, twenty-one years old, to warn the French off the lands they had entered. The warning was not heeded, and immediately a small force of Virginians set out to erect a fort at the fork of the Ohio. They 
had hardly got their work done when a much stronger party of Frenchmen came down the Alleghany in canoes, took the new fort, named it Fort Duquesne, and turned the Virginians out of the country. Before the Virginians went far they met Washington with three hundred men coming to help them. They were not strong enough to retake Fort Duquesne, and so they contented themselves with building Fort Necessity, in which Washington hoped to hold out until help could come from Virginia. Even this he could not do. He was surrounded and forced to surrender, but was allowed to march away with the honors of war, July 4, 1754 . Thus began the American part of a great struggle between France and England, a struggle which we generally call the seven years' war, because in Europe it extended from 1756 to 1762 .

Everybody in the colonies knew this was to be a greater war than either of the others against France, and efforts were made to The Albany get all the colonies to act together. A congress was congress called at Albany, 1754, and delegates were present from New Hampshire, Massachusetts, Rhode Island, Connecticut, New York, Pennsylvania, and Maryland. One of the delegates was Benjamin Franklin, who had long been concerned about the future of the colonies. He saw that if they united, they would be able to defeat France, and if the time ever came when they should be threatened by England, they would be able to deal with her also. With the aid of friends he prepared a plan of union. There was to be a council made up of delegates from each colony. It should have the right to raise money by taxes on the colonies, and to spend it on armies or on other things that were for the general Franklin's welfare. The plan was adopted by the Albany conplan gress, but it did not please the colonies, who did not like to give a council the power to tax them and to raise armies within their borders. It also displeased the king, because he feared that the colonies could not be controlled if they were allowed to unite. The day came when the colonies saw how much wisdom had been concealed in the suggestion of the shrewd Franklin. 
Meanwhile, England made preparations to strike at Canada. General Braddock, with two regiments of British regulars, was sent to drive the French from Fort Duquesne. He Braddock's was a brave man, but knew nothing about wilderness defeat, 1755 fighting, and he was too proud to learn from those who wished to tell him. He marched from the Potomac toward the fork of the Ohio. When eight miles from that place, he was fired at by a body of French and Indians concealed in the forest. The colonial militia broke ranks and leaped behind trees and stones to fight in Indian fashion. Braddock thought they were deserting and swore roundly at them. To his horror he saw some of his regulars doing the same thing. He was more angry than ever and forced his men back into line in an open glade. They were thus forced to become targets to the foe whose whereabouts could not be known. They suffered severely, and the general himself was killed. Washington, who was present, then took command and led the remnant of the army out of the conflict. They lost in killed and

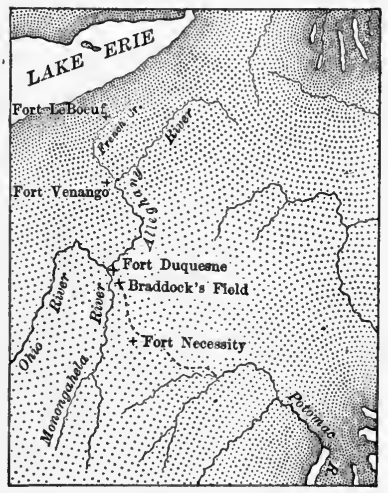

Braddock's campaign wounded 877 of the 1200 men actually in the battle. This unfavorable fight discouraged the English colonies and made the French most confident that they would succeed. Braddock's defeat occurred July 9, 1755 .

Now followed two years of disastrous fighting. England spent money freely and sent armies to America; but there were weak ministers in London, who appointed bad generals, and all their plans in the colonies came to nothing. At last

William Pitt William Pitt, a man of great ability, came to be head of the government, and from 1758 the war took a better turn. He sent good generals to America, among them Wolfe, Amherst, and 
Forbes. Affairs now worked smoothly. The colonies furnished men liberally and the king paid for their support and gave them arms.

Forbes was given the task of capturing Fort Duquesne. He had 1200 Highlanders, regulars, and nearly 5000 colonials from Fort Du- Pennsylvania, Maryland, Virginia, and North Carolina. quesne As he advanced toward the fort, he heard that the Intaken

dians there had deserted and left only the French. He hastened on with half his army to find Duquesne in ruins and

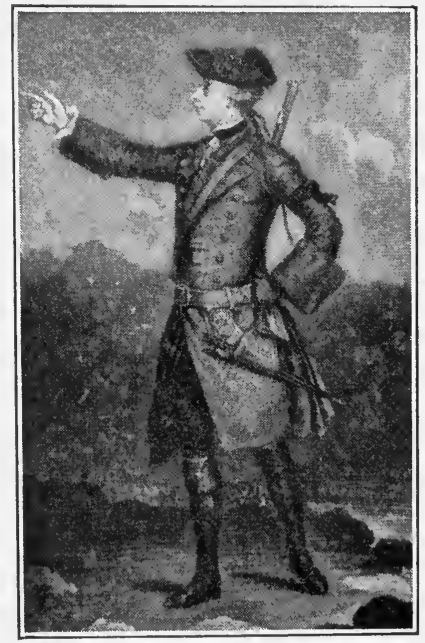

General James Wolfe all the defenders gone. This important post was now rebuilt and named Fort Pitt, after the great minister who showed so much confidence in the colonists. We know the place to-day as Pittsburg. Soon after it was taken, the many smaller forts in the Ohio valley were evacuated and the French power disappeared throughout that large area.

The task which Pitt assigned to General Wolfe was to take Quebec Wolfe's with an army which was expedition to approach by the river. He arrived before the place late in June, 1759, with 9000 British troops and a strong British fleet. Within Quebec was Montcalm, a highspirited and skillful general, with 15,000 men, many of whom were Canadian militia. Quebec is placed on a high bluff which cannot be carried if there is a skillful defense on the crest. Below the city a small river empties into the St. Lawrence. The British landed near this river, hoping to cross and enter the town from the rear. Montcalm met them with most of his army, and by hard fighting kept the British from crossing the river. After 
two and a half months had been spent in this movement the weather began to become cool and Wolfe realized that he must take the place soon, or leave before his ships were frozen in the river.

It was then that the British general formed the plan of approaching Quebec by the Plains of Abraham, above the town. At this place the river bank is steep, but it is possible The Plains to scramble up. On the night of September 12 he of Abraham managed to seize a path up this slope, and by morning 4500 British troops were on the plains in full view of the city. As soon as Montcalm knew what had happened he hurried his troops out of the town and formed them on the plains before the British lines. This was a mistake. The works around Quebec were strong, and if Montcalm had stayed in them, he would probably have held Wolfe back until the weather forced the British to retire. To accept a battle in the open was bad for the French, who were not as good soldiers as

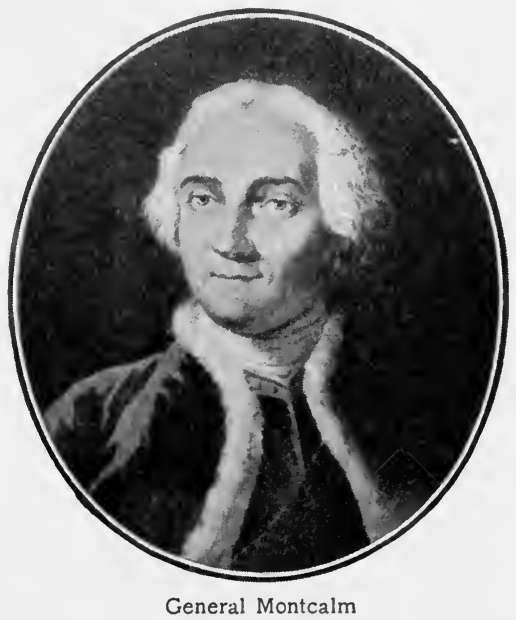
the British. The fighting had lasted only a few minutes when the Frenchmen broke ranks and fled for the cover of the town. In the moment of the heaviest firing both Wolfe and Montcalm fell mortally wounded. The death of their leader discouraged the French and they fled to Montreal. The British entered the fortifications and held them through the winter, in spite of a determined effort to starve out the defenders. A year later Montreal was taken by General Amherst, and with that Canada was lost to the French. 


\section{THE PLAIN STORY OF AMERICAN HISTORY}

In 1763 peace was made in Europe in what was known as the Treaty of Paris. It changed the geography of North America. Treaty of Canada and Florida were handed over to England, who Paris thus had all the Atlantic coast from the Arctic Ocean to Lake Borgne, near the mouth of the Mississippi. Louisiana was given to Spain, who thus acquired the shores of the Gulf of Mexico west of Lake Borgne, including the mouth of the Mississippi.

Thus ended the long conflict between France and England. The French were driven out, and the Spaniards held a vast western country with small forts so wide apart that they could not hold their own against a strong enemy. The English stock was planted along the Atlantic coast, and it was vigorously eating its way into the interior. It was, in fact, so strong that wise men began to wonder if it would not soon be able to free itself from British control.

\section{QUESTIONS}

I. What have you learned about the tendency of the colonies to act together? How was this tendency strengthened by the wars against the French and Indians?

II. What was the cause of King Philip's war? How did it begin? What was Philip's part in it? Describe the fate of the Narragansetts. How did the Indians treat their captives? Why did they torture their victims? How did the whites prosecute the war? Describe the death of Philip. How do you account for the treatment of his body by the whites? What were the effects of his death?

III. How did the Canadian Indians view the advance of the whites northward? How did France come to act with them? Name the wars between the British and the French and Indians. Give the dates.

IV. Deseribe the attempt of the French to settle in Florida. Why did it fail? Describe their early attempt to colonize Canada. What was Champlain's dream for Canada? What great mistake did he make? Describe his attack on the Iroquois. How did the Indians finally get firearms? Why was Iroquois friendship important for the French?

V. Why did the Indians like the French as colonists? Describe the work of the Jesuits for the Indians. What did they do as explorers? Describe the journey of Marquette and Joliet. How did La Salle propose 


\section{WARS AGAINST THE INDIANS AND THE FRENCH 127}

to carry on their work? Describe his journey. Describe his attempt to plant a colony. What was the end of his expedition? How was Louisiana settled? Compare the English and French colonies. How did the English menace the French in the Mississippi basin?

VI. When did King William's war begin and end? How did Frontenac try to win the Iroquois? Why? Describe his three raids. How did the colonies plan a counterblow? Describe the results of the land expedition. Describe the exploit of Hannah Dustin. What was accomplished by the attack on Quebec by water? What was the result of the war?

VII. When did Queen Anne's war begin and end? What was the Indian policy during this war? Describe the attack on Deerfield. Describe the parts of the treaty of Utrecht relating to North America.

VIII. Give the dates of beginning and ending of King George's war. How had the English and French colonies grown since the preceding war? Why was Louisburg built? Why did the New Englanders wish to take it? Describe its capture. Compare the three wars just mentioned.

IX. Why was the fork of the Ohio an important place? How did the French approach it? the English? On what mission was Washington employed? What came of Virginia's attempt to fortify the fork of the Ohio? How was Washington defeated at Fort Necessity? When did the Seven Years' War begin and end in North America?

$\mathrm{X}$. Why was the Albany congress called? Give its date. What colonies were represented? What was Franklin's plan of union? Why did it fail to find approval?

XI. Describe Braddock's defeat. How did Washington save the remnant of the army? What was Pitt's service in the war? Describe the expedition of General Forbes against Fort Duquesne. How was the fort renamed?' What were the immediate consequences of its capture?

XII. What was Pitt's plan to take Quebec? To whom did he intrust the expedition? Who commanded the defense of Quebec? Describe the defenses. How did the attack at first seem to fail? What was the significance of the Plains of Abraham? Why was it an error for Montcalm to offer battle? How was Montreal taken?

XIII. In what particulars did the treaty of Paris affect affairs in North America? When was the treaty made?

\section{SUGGESTED TOPICS}

A Journey from Montreal to New York; The French Colony in Florida ; The Journey of La Salle down the Mississippi ; The Attack on Deerfield ; Hannah Dustin's Exploit; The Capture of Louisburg. 


\section{CHAPTER $\mathrm{X}$}

\section{THE GOVERNMENT OF THE COLONIES}

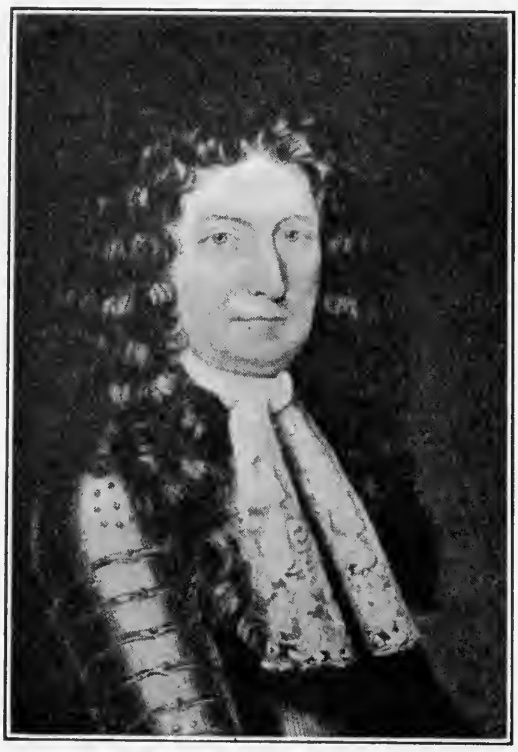

A royal governor-Andros
The Governor. - In eight colonies the governor was apRoyal gov- pointed by the king. ernors They were Virginia, Massachusetts, New York, New Jersey, North Carolina, South Carolina, New Hampshire, and Georgia. A royal governor represented the king in the colony. He was the man of highest honor and was usually an Englishman of high social position. Some of the royal governors were trained army officers and some were untitled relatives of important men in England. Some were men of fine intelligence and courage, while some were no credit to the king nor to the colonies to which they came. Some tried to rule well. Perhaps this can be said of most of them, but others seem to have thought of nothing but their own interests.

The power of the royal governor was great. The theory was that he could do for the time he was in office anything the king could have done if he were in the colony. He could call the 
assembly together or send it home, just as the king could call and dismiss the British parliament. When the assembly met, he suggested laws for their consideration. He could not make Powers in a law, but he could veto one. He must send to England lawmaking all laws that were passed, and they might be disallowed by the king, even after the governor had accepted them. This was a very strong check on the right of the people to make their own laws. It was exercised freely just before the revolution and created much hostile feeling toward the king and his governor.

The governor was commander of the militia. At that time every able-bodied man was liable to be called on to defend his country. He was required to be drilled to some ex- Commander tent in the duties of a soldier. Such men made up the of militia militia. They were organized into companies and regiments, with the appropriate officers, and it was considered an honor to be a militia officer. The governor appointed all such persons and was himself the commander in chief. He was usually flattered by those who desired appointments. By giving places to the members of influential families, and by holding out hopes of what might happen in the future, he was able to surround himself with a strong party of friends. In the last years before the revolution the cause of the king became so unpopular His friends that any man who wished to be thought well of by the people would not seek an office of any kind from the governor.

Besides the militia offices the governor had the right to appoint many civil officers. The justices of peace for the counties were among them. These were honorable places, and other apthe governor who filled them judiciously could make pointments himself many friends. There were some higher offices in the colony to which the governor did not appoint. To fill them was the act of the king, but in these cases the governor would nominate the persons whom he thought the best men for the places, and the king usually followed the suggestions. The higher judges and the members of the council were generally appointed in this way. 
The governor reported regularly to the king's officers who looked after the interests of the colonies. He received a long letter of His instruc- instructions when he was appointed, and from time to tions time, other letters of the same nature. They bound him to the king's interest. Many of the governors would have been more lenient with the colonies than they were if they had not received such strict instructions.

The governors of proprietary provinces, Maryland, Pennsylvania, and Delaware, were in much the same position as royal Proprietary governors. They appointed a large number of officials, governors vetoed the laws if they chose, and commanded the militia. On the other hand, a proprietary governor was appointed by the proprietor, and not by the king. His instructions came from the proprietor. He was less feared than a royal governor, because of the small power that the proprietor had to enforce his orders. If the people defied a royal governor, the royal navy and army could be brought against them. If they defied a proprietary governor, he could call out no force but that which he raised among the people themselves, and this force was not likely to fight against the people. There was a great deal of quarreling between the people and the governor in a proprietary colony.

In Connecticut and Rhode Island the governor was elected annually by the assembly. He did not have great power, partly An elected because he held office only one year and partly because governor the assembly which chose him was careful to keep most of the authority in its own hands. He was little more than a figurehead, and the assembly did not allow him to veto their laws.

In whatever colony he lived, the governor was at the head of the social life. In New York, Philadelphia, Boston, and CharlesHead of ton he lived in state. His dinners and receptions were social life the events of the season. Handsome dresses ordered from London were brought out to honor them; and prosperous merchants with their wives, sons, and daughters danced the 
minuet, drank punch, and passed compliments in his house with as much grace and dignity as one saw at the house of a lord mayor of London.

In Virginia, especially, the governor was a social leader. The colony had no large town. Williamsburg, the capital, was only a country village with a few hundred inhabitants. It The Virginia contained the mansion of the governor, the residences governor of some of the high officials, the homes of the president and faculty

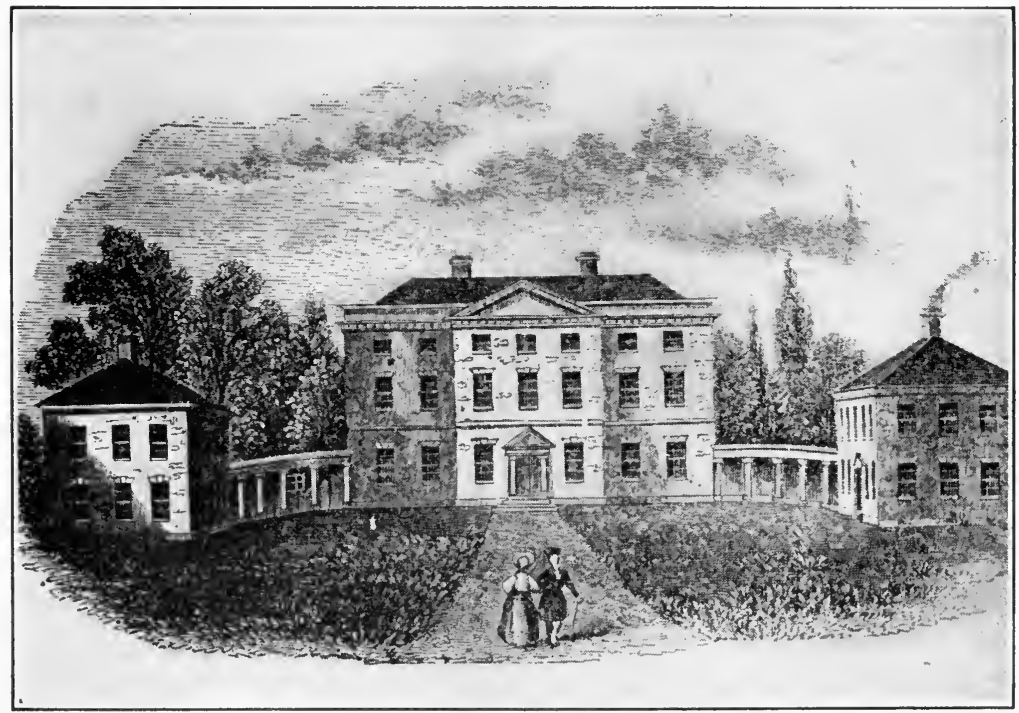

The "Palace" at New Berne

Residence of the royal governor of North Carolina, said to have been one of the finest residences in the colonies. It was built by the people at a cost of $£ 15,000$.

of William and Mary College, the winter homes of a few of the wealthy men in the colony, several taverns, and the humbler houses of the people who looked after the comfort of the persons just mentioned. In this small town the winters were given over to balls and dinners. The governor and his circle made what was 


\section{THE PLAIN STORY OF AMERICAN HISTORY}

pronounced a colonial court. The gay life was modeled after the life in court circles in England. In the summer the gentlemen retired to their estates, where there were other amusements. Among them were deer hunting and fox-hunting. The governor was a leader of outdoor sports; for it was thought proper for him to set the standard in such English customs as were followed by the country gentlemen of England.

To aid the governor with advice a body of councilors was appointed. They varied in number from six to twelve. In every royal

The council colony but one, Massachusetts, they were appointed by the king, but the governor recommended the men the king appointed. As a governor was usually an Englishman sent over for the purpose, the position of councilor was the highest office to which an inhabitant of the colony could aspire, and a councilor was held in high esteem in social matters. $\mathrm{He}$ usually was very loyal to the king. In fact, no man would be appointed to this position who was not a king's man. In the quarrel between king and people, the governor and council were held to be the enemies of the interests of the people. This refers to the royal and proprietary provinces only. In Connecticut and Rhode Island the council was elected by the assembly. Massachusetts had a peculiar system. Although it was a royal colony and the governor was appointed by the king, the council was elected by the assembly. This weakened the power of the king in the colony and was a source of disappointment to the governor in many matters.

In every colony except Pennsylvania the legislature had two branches, or houses: the assembly and the council. Sometimes The as- the word "assembly" was used to indicate both houses. sembly The lower house in Virginia was called "the house of burgesses," and in Massachusetts both houses were known as "the great and general court." The members of the lower house The voters were elected by the voters; but we must not think that every man in the colony could vote. It was generally thought that none should vote but those who were wise enough 
to take part in government. In most colonies people who had no property were not to be allowed to take part in selecting the men who decided what taxes should be laid. The rule was, therefore, to require that every man who voted should first show that he possessed a certain amount of property. By this means a large part of the men could not vote. It seems, also, that a great many who could have voted took little interest in the elections. We have no accurate way of estimating the exact number of votes cast in the elections ; but it is believed that the actual voters never numbered more than eight per cent of the population and that they often were as few as two per cent. In 1912 the number of voters was seventeen per cent of the entire population.

In every colony but Pennsylvania the council was an upper house of the legislature, or assembly. Every law passed must have its approval before it was binding. As the The upper council was appointed by the king and under the in- house fluence of the governor, any law that was not in accordance with the policy of the king could be defeated in the council. This power was often exercised in the long struggle preceding the revolution. In some colonies the assembly and the council became so much opposed on matters they thought of the first importance that the assembly would not pass any law at all until they got what they wanted from the council. But the other house, under strict instructions from England, would not yield an inch of their former contention, and thus the legislature came to a standstill. In such cases the people sided with their elected representatives. This state of affairs only added to the unpopularity of the king in the colonies.

The assembly had a speaker who presided over its sessions. He had powers like those of the speaker of the house of commons in England. He was the highest officer in the colony who was elected through authority derived from the The Speaker people, and the colonists looked on him as their leader against the king. He was selected for his ability in defending the cause of 
the colony. He was not in favor with the governor, but the esteem of the colonists made up for the loss.

Although we speak of the king's part in the government and of his appointment of officers, we should remember that actually The board he took a small part,in the affairs of the colonies. To of trade have settled in person the many matters that came to England from America would have taken a large part of his time. All this kind of business was intrusted to a committee with various names, but it was generally known as the board of trade. It advised the king what colonial laws he ought to veto, what men should be appointed governors, and what ought to be the general policy in the management of the colonies. It prepared the instructions sent to the governors and received the reports of these high officers. Few of its members were ever in America or knew what the colonies needed, and they did not often try to find out what they could do to promote the welfare of the colonies. They Its policy were more anxious to know how the colonies could be made to contribute to the welfare of England. It was this blind policy that showed the colonists that they must look for their own advantage in an independent government.

In order to protect their interests the colonies appointed agents to live in London and see that no injury was done them without Franklin protest. Their sole power was in persuasion. Benjaas agent min Franklin was agent for several colonies. He was a man of great shrewdness, and his reputation as a scientist opened to him the doors of the learned men of London. In Philadelphia, where he was long an editor, he made his first scientific discovery. By sailing a kite in a thunderstorm he proved that the electricity of the atmosphere was the same as the electricity we get from a frictional machine in a laboratory. From this he deduced the theory of lightning rods as a means of protecting houses from damage. The theory was well received in all the leading countries of Europe, and when Franklin arrived in London it aided him in his service as agent. But all that he could do did not 


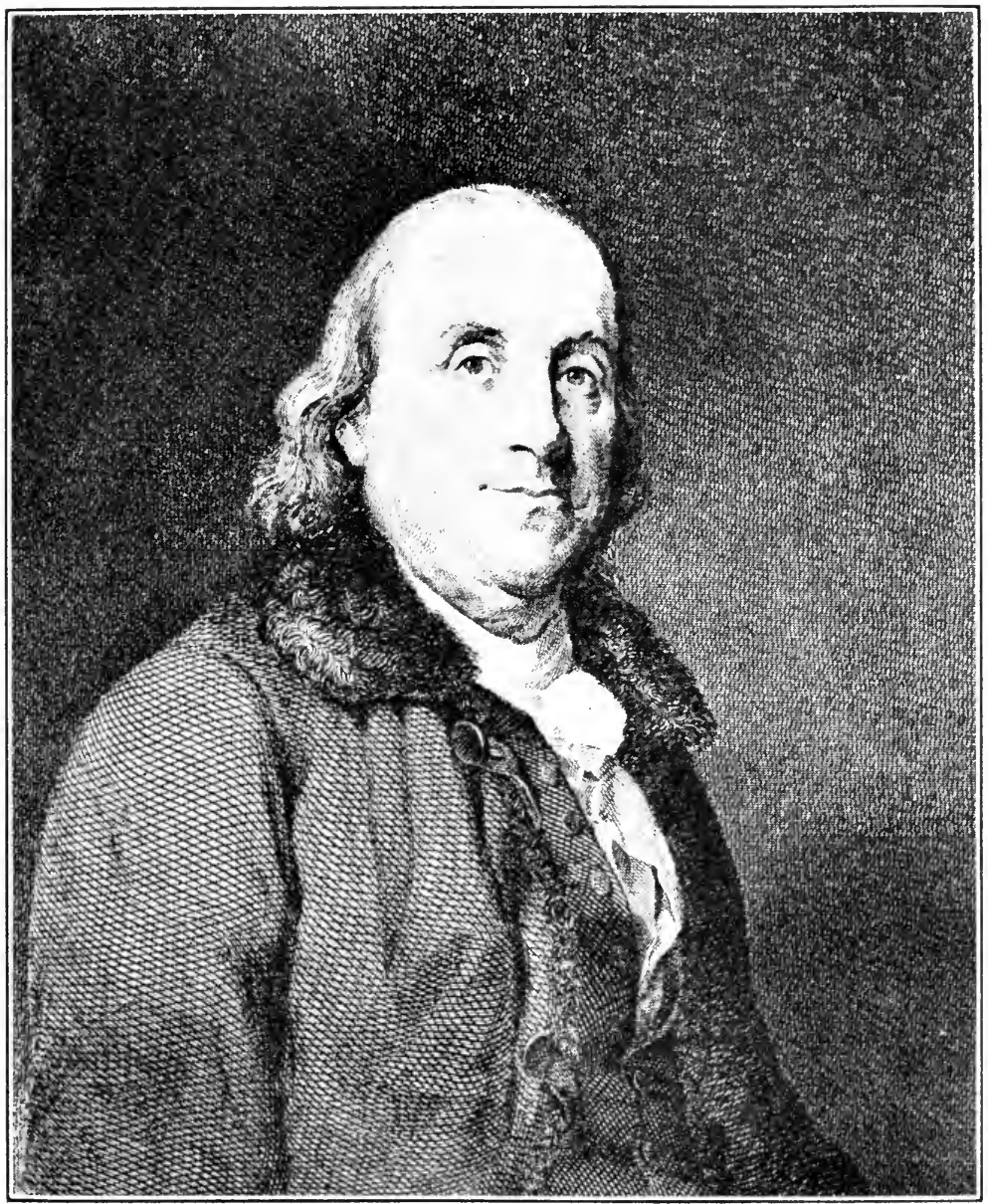

Benjamin Franklin 
break down the determination of the king and the board of trade to make the colonies contribute to the prosperity of the British merchants.

The colony was divided into counties or towns. In the South it was counties and in New England it was towns. Virginia The Virginia adopted the county in imitation of the English county, county and the other Southern colonies followed her example. A county in the South is relatively a large division. The ideal is that it shall not be so large that the inhabitants cannot all go conveniently to the courthouse, at a central point. One of its sides was rarely more than forty miles, and generally it was much smaller. It had no townships. At the head of county affairs was the sheriff. He arrested those who broke the laws and placed them in jail until trial could be had in a court. He collected the The sheriff county taxes, summoned the juries, and executed the decisions of the court. He was a man of great influence and had a number of deputies who served under him. $\mathrm{He}$ was looked upon as the friend of the poor and the guardian of the peace.

The able-bodied men of each county were required to serve in the militia. In most counties there was one regiment, but very The county large counties had more than one. The regiment was militia divided into companies. Over the regiment was a colonel and a lieutenant colonel, over each company a captain. Two or more regiments made a brigade with a brigadier general. The law required that there should be regular musters of the militia; that is, regular meetings for drilling in marching and firing. Muster day was a general holiday. Horse racing, cockfighting, wrestling, and frequently more violent kinds of physical encounter occurred at most musters. The militia system was not confined to the Southern counties. It was established as truly in the New England and Middle colonies as in the South.

The New England town was built up around the meetinghouse, as the Virginia county was built up around the courthouse. It 
was small enough to make it possible for all the inhabitants, including the women and children, to attend services in the meetinghouse. A town was rarely more than ten miles across, The New and frequently it was smaller. In such a town no England man would live more than five miles from the center. town All the men of the town who had the right to vote took part in the town government directly. This means that they met at fixed times in town meeting, decided what taxes they should lay and how they would spend the money they collected, and did whatever else they thought necessary for the welfare of the town. The town meeting also selected the selectmen, a kind of executive committee to carry out the measures that had been adopted. It chose the other officers of the town and elected the two men who represented it in the colonial legislature.

In the Middle colonies a mixed form of local government was in use. We find a county about as large as the Virginia county, and also a town, existing as a subordinate part of the county. A mixed Many of the settlers in New Jersey and Long Island form were from New England and established the town as soon as they settled. But the proprietor was not willing that the towns should be as independent as in New England. He established a county to have oversight over the towns and took away from the towns most of their independence. This mixed form was found in its most perfect condition in Pennsylvania. All the western and northwestern states have adopted this system of local government, the town changing its name to township.

Each colony had its own system of courts, the lowest of which was that held by the justice of the peace. It had authority to try small cases, criminal and civil. The justice of the peace was generally appointed by the governor. In some Three courts colonies all the justices of the peace in a county would meet and hold what was known as a court of quarter session. It took up both judicial affairs and ordinary county business. This court was very important in the South, where there was no town meeting. 


\section{THE PLAIN STORY OF AMERICAN HISTORY}

It laid the county tax, appointed road overseers, directed the expenditure of county money, and performed many other administrative duties. A third rank of courts was the ordinary county court, in some colonies called a superior county court. It was held by judges appointed by the governor or elected by the assembly. In this court was tried the large majority of criminal and civil cases. A civil case is one that concerns property and a criminal case is one that has to do with a crime. Here a jury must be called if it was demanded by one of the parties. Above the county court was a high court to which appeals were made. It corresponds to our state supreme courts. It was held by judges of high station. The highest court of all was held by the king, to whom every man might appeal his case if he did not like the decision of the courts in the colonies. But the expense of making the appeal to the king was great. It meant that the man making the appeal and his witnesses must go to England; and by this means it came about that only rich men could make such appeals.

\section{QUESTIONS}

I. What colonies had royal governors? What power had such governors in lawmaking? How did the king have power over lawmaking? Deseribe the governor's authority over the militia. How did his appointments increase his influence? What officials did he appoint other than military? Describe his right to nominate certain officers. What was the nature of the instructions sent to a royal governor? Describe the power of proprietary governors. Why was he less respected than a royal governor? What was the position of a governor elected by the assembly? In what colonies was the governor chosen in this way? Was the governor of any colony elected by the people? What was the relation of the governor to the social life of the colony? Describe the life in the capital of Virginia.

II. What was the council? How were the members selected? What was the social importance of the members? What side did the council take in the dispute over the power of the king? How was the council appointed in Massachusetts? 
III. Describe the two houses of a colonial legislature. Who might vote? Did all vote who had the right? Compare the vote of colonial times with the vote of present times. What was the upper house? What were its powers in lawmaking? How did the council defend the interests of the king? What were the results? Describe the office and power of the speaker.

IV. Why did the king not supervise the colonies in person? To whom did he leave the duty? Describe the purpose of the board of trade. Did the board understand the real needs of the colonies? Describe the position of colonial agent. On what was Franklin's reputation as a scientist founded? How did it help him serve the interests of the colonies?

V. Name three forms of local government. What was the origin of the Virginia county? Into what colonies did it extend? What was the center of county life? How large was a typical county? What was the position of the sheriff? How was the militia organized? What officers did it have? Describe the musters. What was the center of the New England town? How was it governed? What did the selectmen do? Describe the mixed form of local government. How did it originate? In what colony was it most developed? In what ways has it survived?

VI. What grades of colonial courts ean you mention? Describe the lowest. What was its duty? How was it held? How were the justices of the peace appointed? What was the court of quarter, session? What business did it do which was not judicial? What was the county superior court? How was it held? How were the judges selected? What is the difference between civil and criminal cases? What was the court above the county court? What kind of business went to it? What judicial authority had the governor? What kind had the king? Why was appeal to England difficult?

\section{SUGGESTED TOPICS}

The Salary of the Massachusetts Governor; Governor Shirley of Massachusetts; Governor Tryon of North Carolina; Colonel William Byrd as a Member of the Council. 


\section{CHAPTER XI}

\section{THE CAUSES OF THE AMERICAN REVOLUTION}

THE American revolution occurred because two groups of men, one in England and one in America, wished to do exactly opposite Position of things. The king, ministers, and parliament wished to the king rule the colonies for the advantage of the merchants and other people in Great Britain. They thought the colonies owed obedience to the mother country, forgetting that the day comes when every child is so large that he cannot be directed solely by the commands of his parents. They thought, also, that the king and parliament could make such laws and other rules for the colonies as the former thought wise. The king was very sincere and did not understand why the colonists thought their liberties would be lost if they did as he wished. Parliament and most of the British people agreed with him.

Two things stand out in all the replies of the colonists to the king. One was the conviction that America would some day be a Position great nation, but that it could not be great if it existed of the for the advantage of the mother country. The other Americans was the belief that they had as much right as the people of England to make the laws under which they lived. It is true that they had never entirely made their own laws; for all that the assemblies did was liable to be defeated by the governor or by the king, who could annul laws; but the colonists grew yearly more and more confident that there were some things that not even the king should have a voice in. They thought that if they gave in on these points, they would never cease to be the tools of the king and the British merchants. 
In 1763 the war with France came to an end and Canada was handed over to England. From Georgia to Maine the inhabitants joyfully celebrated when they received the news; for they knew no more Indians raids would fall upon them from Canada. At that moment they were very loyal to

A new colonial program Great'Britain. Suddenly came an announcement which changed all their joy into anxiety. Two harsh laws had passed parliament (1764) and another was threatening. One was a law for the more rigid collection of duties in America. At the same time the "molasses act," a law so bad that the government had not tried to enforce it, was revived and instructions given for its execution. A second law provided that an army should be kept in America, whose expenses were to be paid out of the revenues collected at the colonial ports. Putting the two laws together, the colonists concluded that an army would be sent over to watch them and that it would be supported by money collected from the Americans themselves.

The third law was a stamp act, providing that stamps must be affixed to newspapers The stamp and legal documents. act

The stamps would be sold by the king's officers and the proceeds
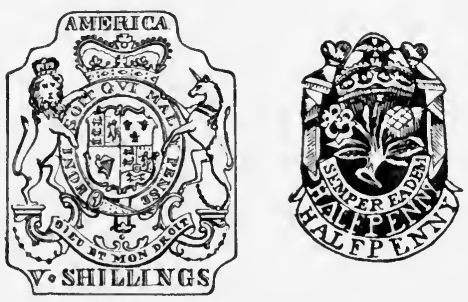

Stamps issued under the stamp act would go into his treasury. It was not passed at once, but was only suggested, with the statement that it might be passed later. Meanwhile the colonies were invited to say what form of taxation they would like better than a stamp tax. Grenville, the British minister, promised to give due attention to any suggestion from the Americans. He waited a year, but all he heard from the colonies was the declaration that parliament had no right to lay taxes on them. Both he and parliament took this for defiance and met it by passing the stamp act in 1765 .

Everywhere in the colonies were now heard words of wrath. 


\section{THE PLAIN STORY OF AMERICAN HISTORY}

The men who were most prominent in the assemblies took the lead in declaring that the stamp act would be resisted in all possible Henry and ways. Meetings were called, and the young men formed Otis themselves into societies called the "sons of liberty."

Two men did much to arouse the people, Patrick Henry, of Virginia, and James Otis, of Massachusetts. They were both great orators and painted in vivid pictures the fate of the colonies when bound hand and foot and forced to pay taxes at the command of England.

From hot words the "sons of liberty" turned to violent deeds. The offices of the agents appointed to sell the stamps were beViolent re- sieged, the officials themselves were hooted on the sistance streets, windows were broken, and the agents so threatened that they preferred to resign office rather than take further risk. When the day came for the law to go into force, there was nobody to sell stamps, except in South Carolina and Georgia, where the people showed their disappointment by refusing to buy or use stamps. Any one could see that if the act was enforced, it must be at the point of the bayonet; and for such a course the king was not ready.

While these things were happening the colonies called what became known as the "stamp act congress." It was a meeting of The stamp delegates from all the colonies but New Hampshire, Viraet con- ginia, North Carolina, and Georgia; and from these gress, 1765 four colonies came words of sympathy. The meetingplace was New York, and the year was 1765 . Petitions were prepared and sent to the king asking for the repeal of the stamp act, and resolutions were adopted declaring that parliament had no right to tax the colonies. The congress was the first step of the colonies to act together against England. The petition sent to London was written in respectful terms, but it was a firm protest against what the colonists considered a wrong.

The firm stand taken in America opened the eyes of the king and his ministers. They did not think it worth while to make 
THE CAUSES OF THE AMERICAN REVOLTION 143

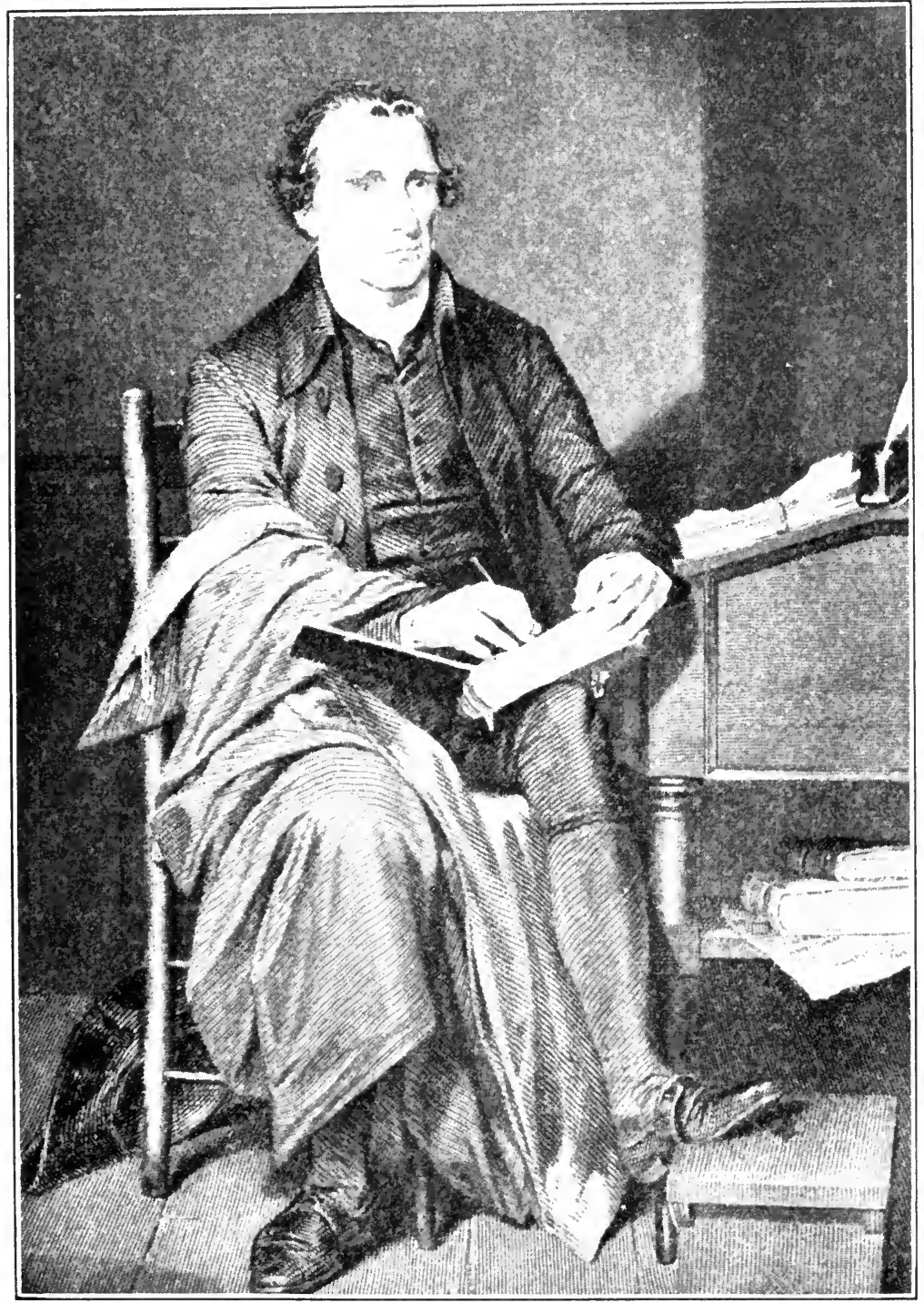




\section{THE PLAIN STORY OF AMERICAN HISTORY}

unyielding enemies out of the colonists merely to sell a small quantity of stamps. On this account parliament changed its attitude The act and repealed the stamp act a year after it was enacted. repealed Shouts of joy burst from the lips of the Americans when they got the news. They believed that the king had a good heart, and for once he was popular with his American subjects. If he had been wise, he might from this time have made the colonists his most loyal friends.

But George III was never a wise man. He was narrow minded and stubborn. He loved to have his way, and when he once The de- came to feel that the colonists were resisting him, he set claratory act his heart on maintaining his authority. It was to please him, therefore, that parliament passed what was known as the declaratory act. It announced, although the stamp act was repealed, that parliament had power to tax the colonies.

At first it seemed that the declaratory act was merely a way of saving the king from a complete backdown, and there were Townshend's duties, 1767 persons who thought it would amount to nothing. But in 1767 Townshend, one of the ministers, gave it a act to lay duties on tea, red and white lead, glass, and paper. The money thus received was to be spent on salaries in America. Townshend's plan was as bad as Grenville's, and the colonies were thrown into a state of terror. It could not be doubted that the king and his ministers would not desist until they forced the colonies to pay taxes laid in England. This was something the Americans were determined not to do, and from 1767 the two sides drifted farther and farther apart until war was inevitable. With one accord the Americans refused to import the articles on which Townshend proposed to collect duties.

In Massachusetts Samuel Adams was the leading advocate of

Samuel

Adams's circular resistance. He believed that America must be independent in order to reach her high destiny. Above all, he wished to get the colonies to act together. He wrote a 
circular letter with this object in view, and the Massachusetts assembly adopted it and sent it to the other colonies. It called upon them to unite in support of the principle that Americans should pay. no taxes which they had not themselves imposed. When the king saw this circular, he was very much aroused. $\mathrm{He}$ considered it a call to rebellion. But Adams's bold spirit found much support in all the colonies. Virginia received the circular favorably and replied that she would stand with Massachusetts. The other colonies were equally outspoken.

The king was firm and sent General Gage with a thousand soldiers to Boston Troops sent to see that the to Boston revenue laws were enforced. The troops arrived in September, 1768 , and were received by the town in silence. Gage wished to avoid trouble, and the leaders of the people were of the same mind; and for eighteen months peace reigned.

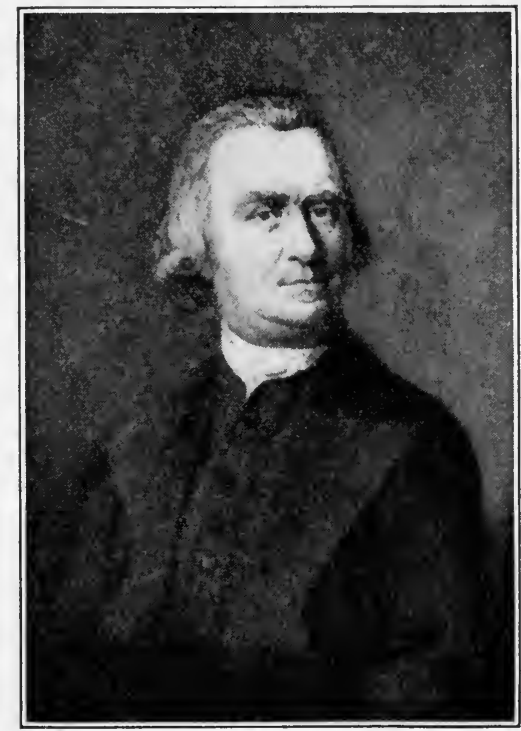

Samuel Adams But March 5, 1770, a serious outbreak occurred. The people were engaged in their ordinary affairs when the bells rang out as for fire. Crowds gathered to find that a small mob was worrying a group of British soldiers commanded by Colonel Preston. Taunting words were shouted and snowballs were hurled. One of the soldiers struck by a stick fired his gun, probably without orders. The crowd rushed on him and were received with a fire from the rest of the soldiers. Five of the mob were killed and six were wounded before the angry people were quieted and 
induced to go to their homes. Next day the troops were removed from the town and placed in the castle that comThe "Bos- manded the entrance to the harbor. This was done at ton mas- the request of Samuel Adams and John Hancock, sacre" who were the recognized leaders of the colonial party in Boston. Had the troops remained in the town it seems likely

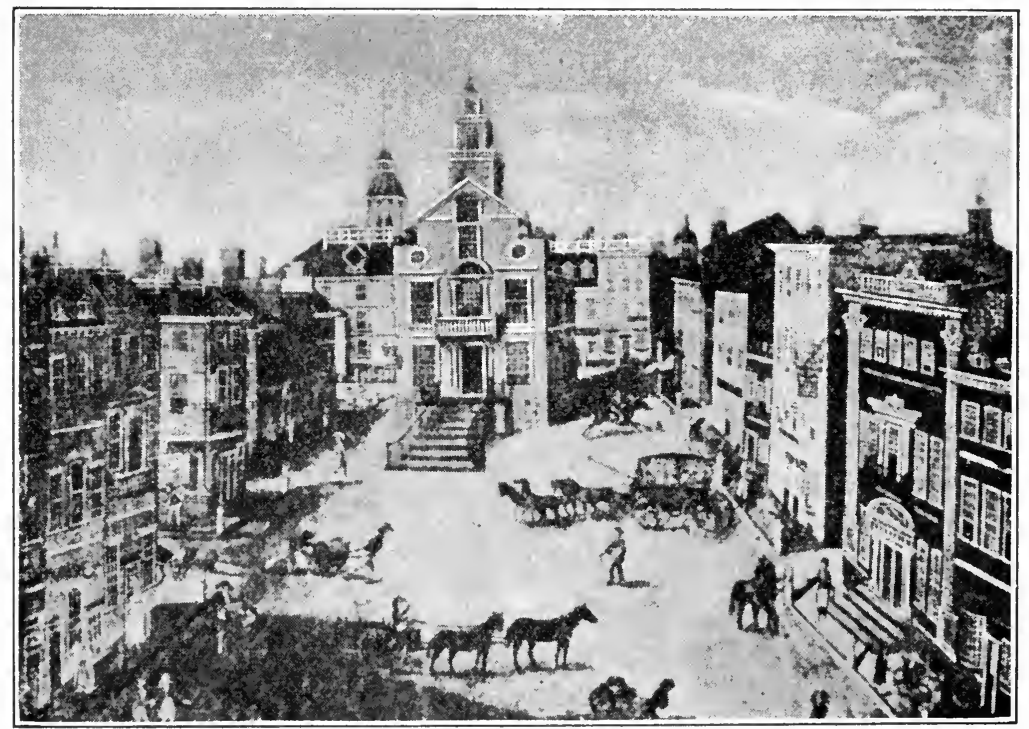

State Street, Boston, about 1790

Scene of the "Boston massacre."

that fighting between them and the townsmen would have begun again. Thus happened the "Boston massacre," an event which was described far and wide as an act of British tyranny, and which did much to make the colonists hate the face of a British soldier.

By this time it was clear that the Townshend duties were a failure. In fact they brought the king but $£ 295$ a year above the 
cost of collection; for the colonists had agreed to import no dutiable articles. Recognizing that the duties were a failure, parliament now voted to repeal all but the tax on tea, Townshend which was retained as a matter of principle. The duties Americans were pleased at this sign of good will and modified began to buy freely all kinds of British merchandise but tea. Of that commodity they would have none.

There was no way of making the people buy tea if they did not choose to buy it; and so for three years the situation remained unchanged. But in 1773 the East India Company, "Boston which was nearly bankrupt, got permission from the tea party" British government to ship a large amount of tea to the colonies at very favorable rates. It was thought that they would offer their goods so cheap that the Americans would not refuse to buy. To the colonists this was but an attempt to bribe them to desert their principles; and they met it with scorn. When the ships loaded with tea arrived, nobody could be found who would undertake to sell it. Agents who had been appointed were glad to escape the wrath of the people by resigning their appointments or by fleeing to places of safety. In Boston the tea ships lay at the docks for many days. The governor would not let them go home with the tea on board; for that would show that the people had won. The people did all they could to keep them from landing the cargoes. Finally the ships were boarded by a band of young men whom Adams had gathered, whose Indian disguises hardly concealed their identity. They threw the tea overboard into the harbor so quickly that it is evident they had rehearsed their parts before they came to the docks. Three hundred and forty-two chests of tea were destroyed, and the members of the famous "tea party" went to their homes without interference. They were not punished for destroying private property. The incident aroused the attention of the people far and wide. Some persons laughed at it, others thought it an act of justice, and most of the people were glad that the king had been defied. 
The quarrel between the colonies and the king had now been going on ten years. First came the three harsh acts of Grenville, Steps taken, at which the Americans protested so strongly that one I764 to 1773 of them, the stamp act, was repealed. Next were the Townshend acts, 1767, imposing duties on five kinds of merchandise. They also aroused the opposition of the people, who agreed to stop importing British goods. So great was the failure of the acts that the duties were repealed on all but tea. This led to the "Boston tea party." In all these years of quarrel there was no colony that did not oppose the wishes of the king. Virginia, the oldest and largest, and Georgia, the youngest, felt equally that parliament should not be allowed to lay taxes at will on the colonies. But Massachusetts was most outspoken in her opposition, due, it seems, to the efforts of Samuel Adams, and she was the first to feel the weight of England's displeasure.

News that the tea had been thrown overboard at Boston was duly carried to London. The king considered it defiance and deThree harsh termined to make his authority respected. At that laws time parliament was controlled by men whom the king had in the hollow of his hand. It did not hesitate to do all he wished, and at his suggestion it passed several harsh laws. The first fell on Boston. It was voted to close the port of that town, which meant that no ship could lawfully sail from Boston to any other place in the world. This restriction was to continue until payment was made for the tea thrown overboard. Another law struck at self-government in Massachusetts. The power of the town meeting was reduced, and many officers hitherto elected by the people were now to be appointed by the governor. A third act was the Quebec act. It erected a great colony in the region west of the Alleghanies, with Quebec as the center. The government of this colony was to be kept strictly in the hands of the king, and it was felt in New England that the new colony would be a check on the action of the seacoast colonies. These acts of parliament convinced the Americans that the British government would use all its power to make itself obeyed. 
The colonists knew they must choose between submission and war. The more independent minded welcomed the idea of war, believing it would lead to independence. But A policy of there were many who thought that war was the worst delay possible calamity. They knew that the British government was the best in Europe and hesitated to rebel against it until the last hope of reconciliation was gone. They wished to send petitions to the king urging him to relent. Lest these men might say that war had been begun too rashly, it was decided to adopt a policy of delay.

Meanwhile, the news that the port of Boston was to be closed aroused indignation in every colony. Supplies A call from were sent to relieve the poor Virginia people thrown out of employment, and the Virginia assembly ordered that the day on

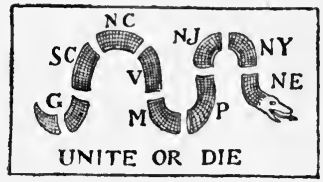

Franklin's political cartoon, 1754

(An allusion to a mythical snake supposed to have the power of uniting after being cut into pieces.)

which the Boston port bill went into force should be observed as a day of fast and prayer. The governor of Virginia became very angry at this and sent the assembly home. Before the members left the town of Williamsburg, the colonial capital, they met in a famous old inn, the Raleigh Tavern, and passed resolutions calling on the colonies to send delegates to a congress to consider "the united interest of America."

The call found a ready response, and delegates were chosen in all the colonies but Georgia. They met in Philadelphia, September 5,1774 . They represented the whole continent, First conas they put it, and the meeting is, therefore, called the tinental first continental congress. Its chief work was to publish congress a statement of the rights of the colonies in which the claim was made that the assembly alone could make laws for the colony, subject to the king's veto. If George III had agreed with this idea, the colonies might have been allowed a government something like that of Canada to-day, and the whole controversy would have been 


\section{THE PLAIN STORY OF AMERICAN HISTORY}

settled. The congress also sent a petition to the king and another to the British people, asking that they be allowed the ordinary rights of Englishmen. The colonists who still supported the king

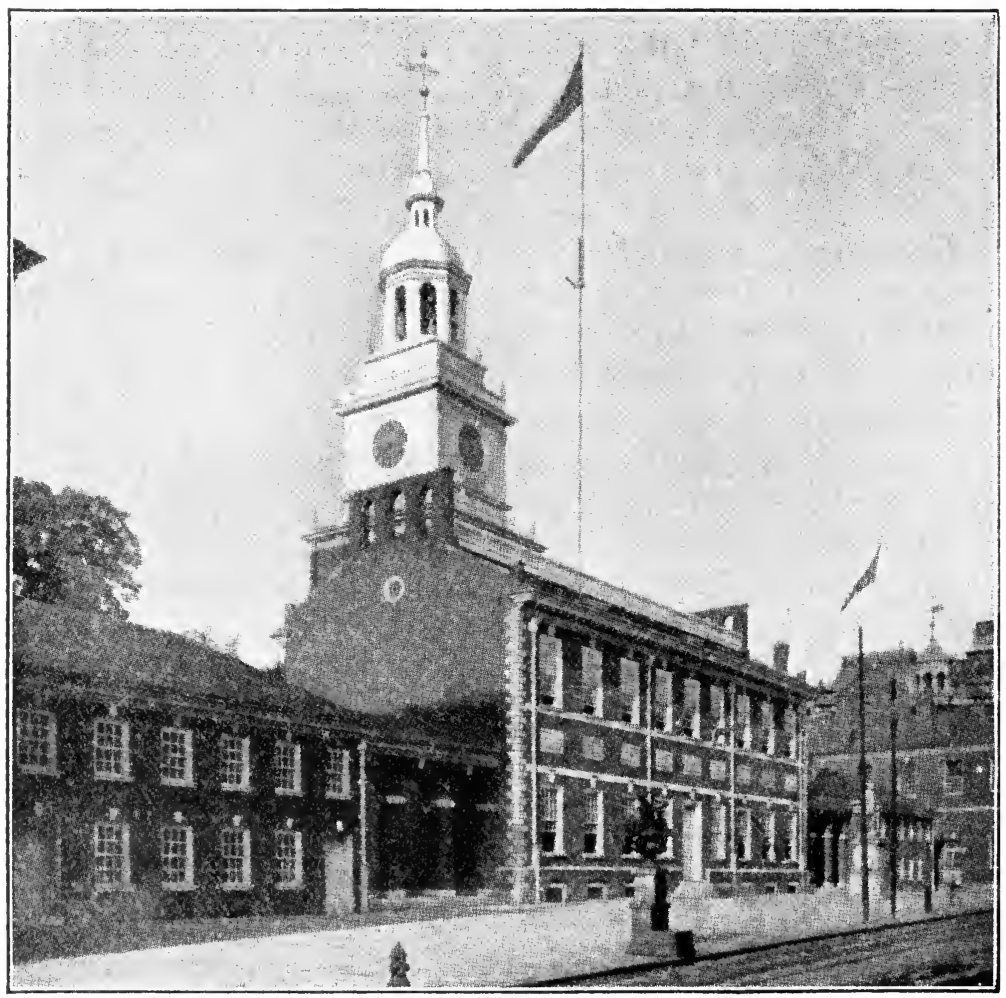

Independence Hall, Philadelphia

now began to be called "tories," while those who favored resistance were known as "whigs."

Before there was time to see what effect the addresses of the congress would have, fighting had begun in Massachusetts. General Gage was in Boston with four regiments of regulars. 
He had been ordered to put down the discontented element throughout the colony; but he found so much opposition among the people that he dared not move away from his forti- Battle of fications around the town. At length he learned that Lexington the patriots had collected some military stores at Concord, eighteen miles from Boston, and in the evening of April 18, 1775, he sent a force to seize them. Paul Revere, riding ahead of the troops,

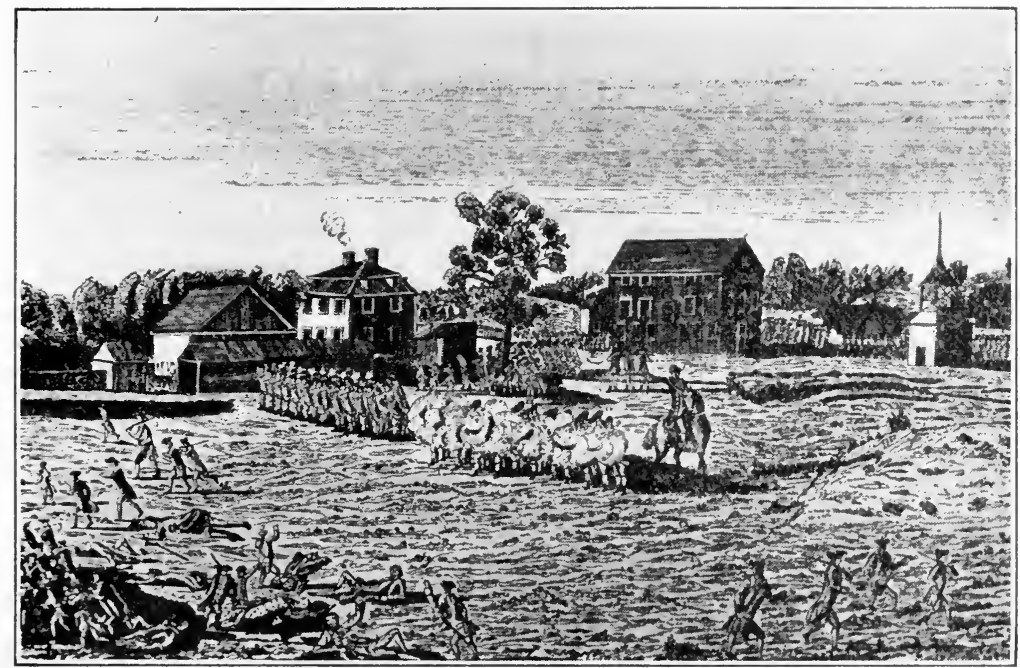

The Battle of Lexington, April 19, 1775

dashed along the roads past the farm-houses, shouting, "The redcoats are coming!" and the people flew to arms. At dawn sixty militiamen stood on the commons at Lexington. It was a small force to oppose the column of regulars, but it refused to disperse at the command of the British officer. A volley was fired by the regulars, killing eight and wounding ten of the militiamen. The rest retreated, and the British proceeded to Concord, only to find that the stores they sought had been removed. At Concord bridge there was another fight, and then the troops began to withdraw 
to Boston. By this time the whole countryside was aroused. Farmers left their plows in the field and rode at full speed to Retreat Concord. Every stone or available fence from that from place to Boston is said to have concealed a man bent Concord on killing the soldiers. The British were pressed so hard that they reached their fortified lines with a loss of two hundred and seventy-three, killed, wounded, and missing. The militia followed in great numbers and began at once the siege of Boston.

Gage had 7000 men, not enough to defeat the besiegers. He was safe behind the strong intrenchments he had thrown up, Bunker Hill and for a time gave himself little concern about the Americans. On the seventeenth of June he was surprised to see that the despised militia had taken possession in the

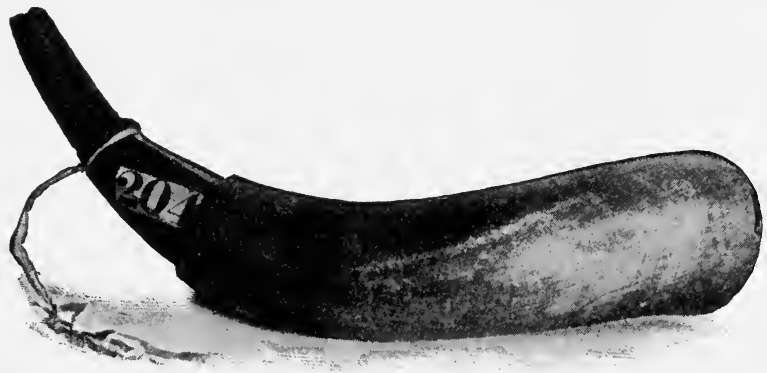

A powderhorn used at Bunker Hill

night of a high hill behind Charlestown. The place commanded his own lines, and if it were held and fortified, he would be forced to withdraw from the town. He therefore made all haste to seize the hill. A strong body of troops was thrown across Charles River, landing at the foot of the heights. They slowly formed a line of battle and began to march up the slope, expecting that the defenders would retreat. Near the top they received such a heavy fire that they broke and rushed to the safety of their boats. Their officers rallied them and brought them again to 
the charge, and again they were driven back. The British officers were deeply ashamed that their men had fled before the Americans and secured more troops before they made a third charge. But when they neared the top of the hill, the militiamen retreated because their ammunition was used up. In this action, known as the battle of Bunker Hill, the British lost more than a thousand men, the Americans four hundred and forty-one. It was the first time the colonials had met the British on a battle field. They fought so well that they felt they had no reason to dread another engagement. General Gage continued inactive behind the defenses of Boston.

A month before the battle of Bunker Hill the second conti- Second connental congress tinental met in Phila- congress delphia. Although the

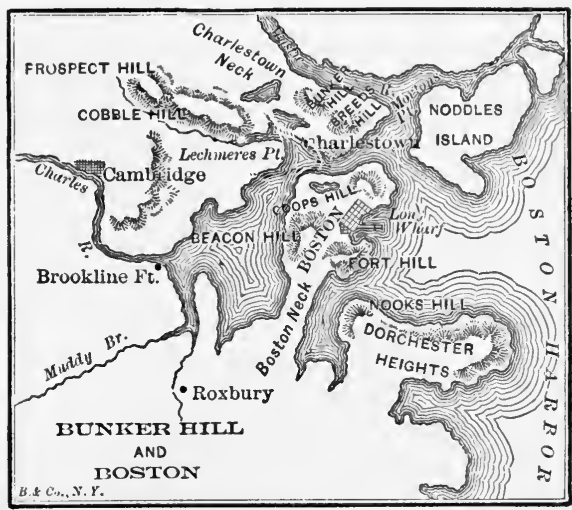
battle of Lexington had been fought, the more timid patriots were still unwilling to take bold steps against England. The other wing of the patriot party were still loath to go forward without their aid, and the result was further delay while a last appeal was made to the king, although there was little hope that the appeal would be granted. Meanwhile, congress took up the task of defense. All that Massachusetts had done in that way was approved; the army that surrounded Boston was taken under the direction of the continental government, and George Washington, of Virginia, was appointed its commander-in-chief. Thus, the country was /being put in a state of war, regardless of the assertion that it desired peace.' The next chapter will deal with the story of the war. 


\section{QUESTIONS}

I. What was the king's idea of the duty of a colony? What two principles stand out in the American contention? Were the colonies ever entirely self-governing? What would have been the effect on their history had they yielded to the king?

II. What new colonial program was adopted by the British government in 1764? Why were the colonists taken by surprise? What change occurred in their feelings? What was the "molasses act" (See p. 101)? What was the stamp act? Why was its passage delayed? What was the nature of the argument against it? Who led in the argument? How did the colonists take its passage? Who were the "sons of liberty"? What was the stamp act congress? What did it do? Why was the stamp act repealed?

III. What was the declaratory act? Why was it passed? What duties did Townshend levy? How did the colonies receive the Townshend duties? What was Samuel Adams's position among the colonists? Describe his famous circular letter. How was it received in England and in the colonies? How were the Townshend duties modified?

IV. Why were troops sent to Boston? How was their arrival greeted by the people? Describe the so-called "Boston massacre." What effect did it have in the colony?

V. What privileges were granted to the East India Company? How was its tea received in America? Describe the "Boston tea party." What impression did it make? Recall the steps in the quarrel between the king and the colonists, 1763 to 1773.

VI. How did the king interpret the "Boston tea party"? What was his relation with parliament? Describe the measures taken to punish Boston. How was the Massachusetts charter changed? What was the Quebec act? Why was it disliked? What choice of conduct was now left to the colonists? What course did they adopt temporarily? Why?

VII. How did the other colonies help Boston? What call was sent out from Virginia? How was it received? What famous body now met? How did it get its name? What position did it take about the rights of the colonies? What would have been the result if the king had accepted? What appeals were sent to England? Who were called tories? whigs?

VIII. What was Gage expected to do in Massachusetts? What was his success? What was the object of the expedition to Concord? How were the country people aroused? Describe the skirmish at Lexington. What happened when the British reached Concord? Describe 
their retreat. When did the siege of Boston begin? Describe the battle of Bunker Hill. What effect did it have on the Americans?

IX. Describe the work of the second continental congress. Why was another appeal made to the king? Who was appointed to command the continental army?

\section{SUGGESTED TOPICS}

George III, in his Relation to the Colonies; The Services of Patrick Henry; The Services of James Otis; The Reception of the Stamp Act; Paul Revere's Ride; William Pitt and the Attempts to Tax the Colonies; The Battle of Bunker Hill. 


\section{CHAPTER XII}

\section{THE REVOLUTIONARY WAR}

When George III was told that the petition of the second continental congress was in London, he refused to receive it. Other harsh When he heard of the battle of Bunker Hill, he promeasures claimed the colonists rebels, and parliament closed all the American ports. This was additional evidence that the Americans must yield to the will of the king or fight. They had no idea of submitting. Jefferson said: "I will cease to exist before I will yield to a connection on such terms as the British parliament proposes."

In May, 1776, the continental congress was again in session in Philadelphia. Very few of the members desired to make any States further appeal to Great Britain. The one word that created was in every mind was independence, but every one dreaded to declare for it. To do so was to take the step from which there was no withdrawal. While congress thus hesitated, North Carolina, a colony noted for its democratic spirit, took the lead and passed resolutions instructing her delegates at Philadelphia to vote for independence. Other colonies took the same step, and on May 15 congress advised the colonies to change themselves into states.

Three weeks later it appointed a committee to prepare resolu-

The dections declaring the thirteen states free and independlaration of ent. The committee reported the noble declaration independ- which we have preserved as one of our most precious ence documents, and it was passed on July 4. It was written by Thomas Jefferson, of Virginia, but the leading ideas 


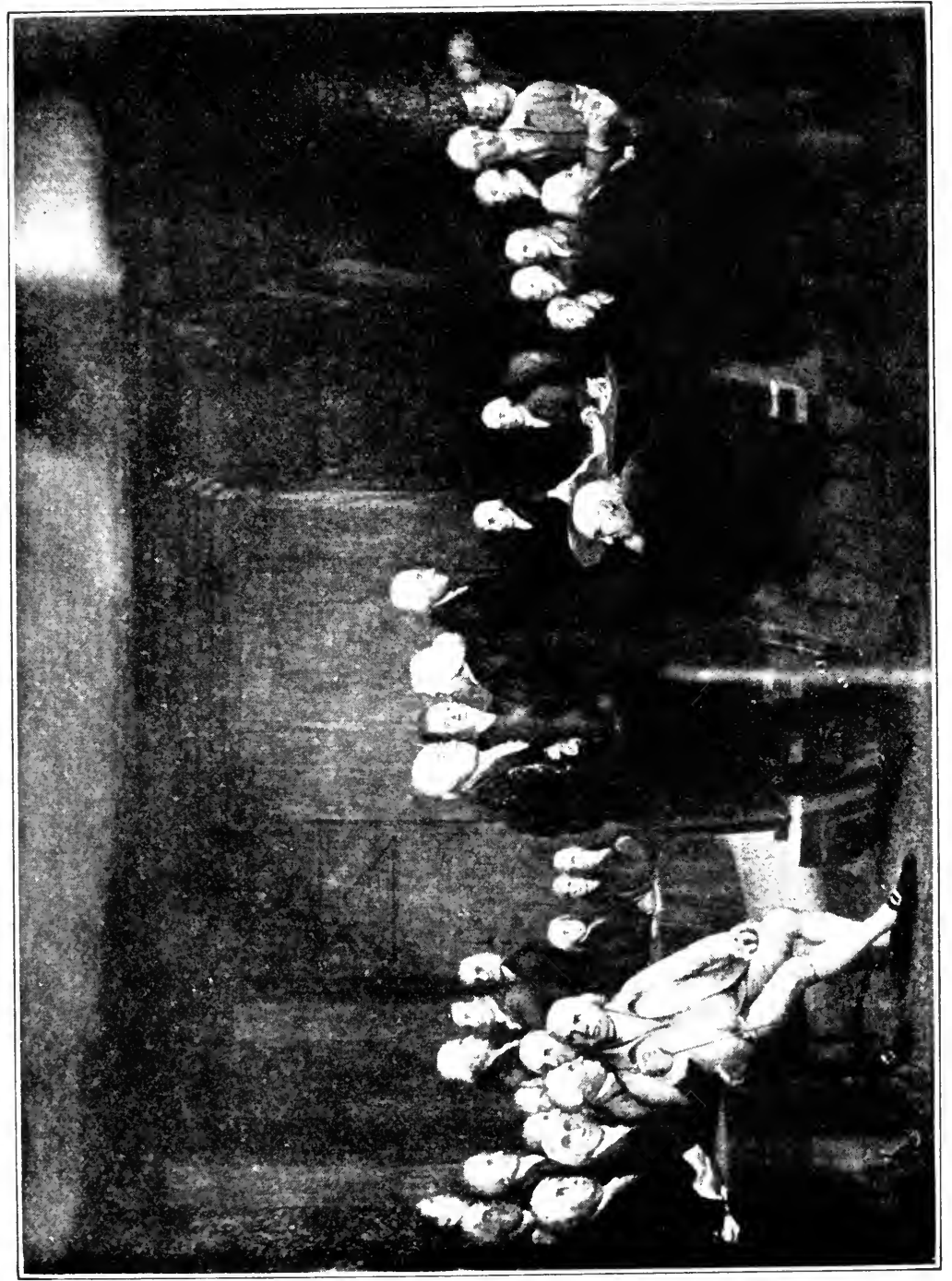

Congress voting independence. July 4, 1776

From the original painting he Robert Edge Pine and Edward savage, belonging to the Historical Society of Penneylvania. 
in it were those of all the members of the congress. When it was adopted, the bells of the town rang out joyously; and from town to town, from colony to colony, the glad news was carried.

The thirteen states could not win the war that was now well begun if they acted separately; and congress took steps to form How much them into a united government. At once two sides union? appeared. Some people thought that the newly made states should give up enough of their powers to make a

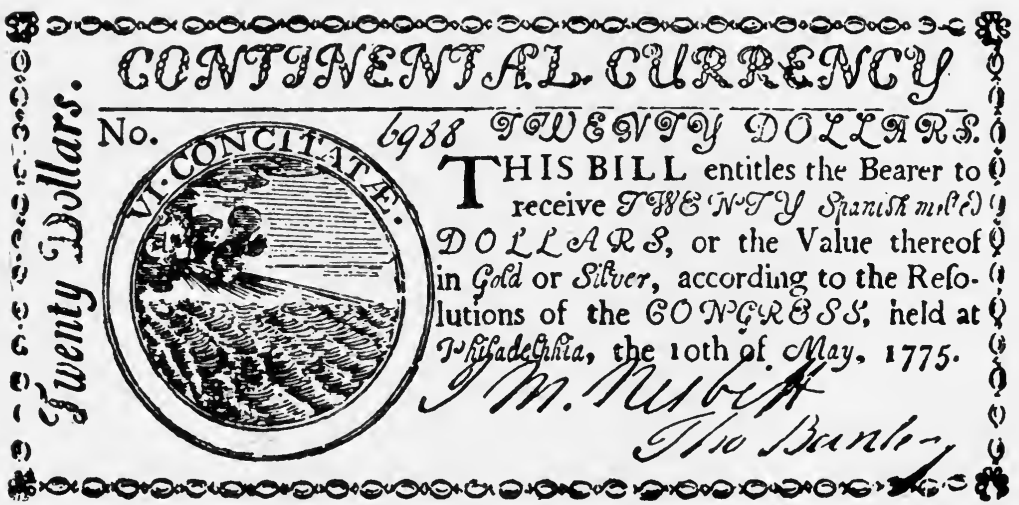

Continental paper money

central government that could compel the people of the states to pay taxes and furnish the troops that were needed. Others thought that it was sufficient to have the states agree to act together in congress, and they said that the call of congress for money and soldiers would be enough to secure all the funds and troops that would be needed. They were attached to the state governments, and believed that if the central government were given great power, the result would be to break down the power of the state. The small states were especially strong in this opinion; for they thought that in a strong union they would be at the mercy of the large states. The time was so critical that nobody dared 
offend a small state, and so all thought of a strong central government at that time was given up.

The result was the adoption of a plan of union known as the articles of confederation. It left each state free to manage its own affairs. Congress was to call on the states for Articles of troops and money for the common cause, but it could confederado nothing if the call was not obeyed. It happened tion that the states often refused to give what was asked, and sometimes the central government was on the point of breaking up for lack of money to support an army.

Let us now turn to the military side of the revolution. When the people became convinced in the spring that war was certain to come, the siege of Boston had been going on through- Evacuation out the winter. Washington, who commanded the of Boston Americans, was so vigilant that the British did not dare show themselves outside of their fortifications. During winter he secured a supply of cannon and ammunition from the forts of upper New York, which Ethan Allen had captured, Forts Ticonderoga and Crown Point. These heavy guns were taken to Washington's camp on sleds, and mounted on Dorchester Heights, overlooking Boston. The British were now in great danger. Not only their ships in the harbor, but they themselves could be destroyed if the Americans opened fire. They offered to go away if they were not attacked from these frowning heights. So it happened that on March 17, 1776, the British sailed out of Boston harbor, they and a thousand loyalists who either did not wish, or did not dare, to remain in the town when it passed under the control of the whigs.

While the siege of Boston went on, important matters came up in the South. In North Carolina were many loyalists, and the governor, who had been driven out by the patriots, Battle of reported that if a British fleet appeared off the coast, Moore's they would rise, overthrow the whigs, and restore the Creek king's authority. A fleet accordingly went forth, while officers 
well provided with gold appeared in the interior, calling on loyal men to rally to the standard of the king. A great many came out and were formed into regiments. The meeting place was Cross Creek, now Fayetteville, on the Cape Fear River. February 18, 1776, they set out, 1600 strong, for the mouth of the river, where they thought a fleet was waiting. These movements alarmed the whigs, who did all they could to call out their friends. February 27 they met the tories at Moore's Creek Bridge and delivered a stinging defeat, although the whigs numbered only a thousand. For a time this battle ended the hope that the North Carolina loyalists would aid England in regaining control in the South. Later in the war the tories became very active in the two Carolinas and Georgia.

When the British fleet reached the mouth of the Cape Fear River the commander heard of the fight at Moore's Creek. He Charleston proceeded to Charleston, South Carolina, thinking he attacked would easily take the town. He laughed at the forts built to guard the entrance of the harbor. Against one of them,

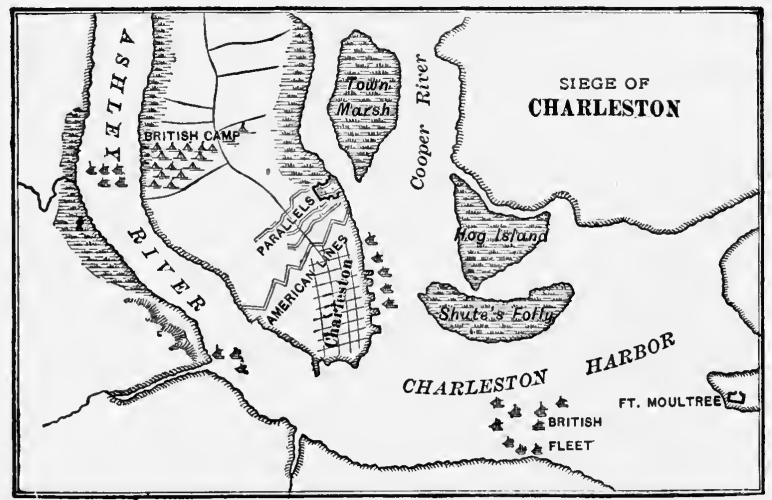

Fort Moultrie, the British ships opened fire, June 28, expecting to reduce it with a few broadsides. But the South Carolinians had constructed its walls of green palmetto logs, into which the 
cannon shot sunk without doing serious damage. On the other hand, the guns of the forts were aimed with deadly effect; and after a hard battle one of the ships was sunk and the rest were so much damaged that they were glad to withdraw from the fight. They returned northward a few days later, and the whole South remained in the hands of the patriots.

The next attack of the British was made against New York. Washington foresaw that it would come, and moved his army from Boston to meet it. His enemy was very strong, and New York landed near what is now the popular summer resort attacked of Coney Island. Washington placed a large part of his army across the road to New York along a crest of hills two miles east of Brooklyn Ferry. The British were commanded by General Howe, who acted with caution; for he had learned to respect the ability of the American commander. The battle which fol-

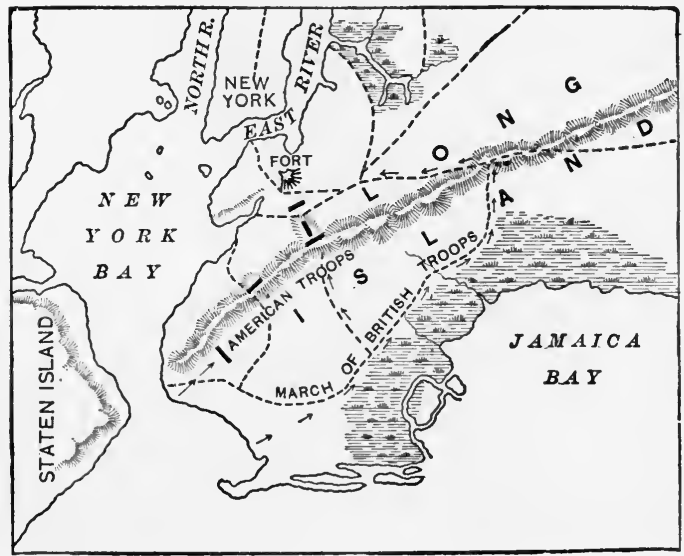
lowed was a victory for Howe, who pushed on toward Brooklyn. Washington knew that if the enemy placed cannon on Brooklyn Heights overlooking the town of New York, the Americans must withdraw, and he made every effort to hold the heights. Then Howe played a clever trick. He threw his own troops around the Americans on the heights and made ready to bring his fleet up the river between the heights and Manhattan Island. It seemed that the Americans were to be surrounded on land and water and 
forced to surrender. If their army was taken, it was not likely that another could be got together to oppose the British. Escape from But Washington proved more clever than Howe. He Brooklyn saw his danger, and used a lucky opportunity to escape. A sudden storm came up, followed by a heavy fog. It kept the British fleet from moving up the river, while Washington by hard efforts gathered every boat he could find and moved his troops across East River so noiselessly that he was in safety before the British knew what he was doing.

Howe was disappointed, but he followed Washington across the river and seemed about to close in around him in the lower Washington part of Manhattan Island. Again the American marches commander acted quickly, and withdrew from the northward trap. As the British occupied New York the Americans marched northward. The two armies fought a sharp battle at Harlem, near where Columbia University now stands, and another at White Plains, twenty-five miles farther north. In each case the Americans were defeated, but they withdrew in good order. It was at this time that Nathan Hale, a Connecticut schoolmaster, was shot as a spy. He had volunteered to go into New York to obtain information, was captured, admitted that he was a patriot, and was sentenced to be shot. His last words were: "I only regret that I have but one life to lose for my country."

Washington now found that he was being forced away from New York, and he crossed into New Jersey so as to be in a position Washington to threaten the British in New York. Two forts had in retreat been built on the Hudson, Forts Washington and Lee. Howe took both, seizing the first before the garrison of 2600 men escaped. In the second he took a large quantity of supplies. The Americans were discouraged, and moved southward in New Jersey. Howe thought them beaten, and returned to the city, leaving General Cornwallis to follow Washington and capture the last of the army. Cornwallis was a good soldier, but Washington was better, and won in the race across 
New Jersey. At last he crossed the Delaware River, secured the boats for many miles, and had an opportunity to restore the strength and spirits of his men.

Cornwallis felt that his task was done, and placed his troops at various towns to overawe the country people. A force was at Trenton, 1400 strong. Washington, on the opposite Battle of side of the river from Trenton, planned a bold blow. On Trenton Christmas night, while the enemy were still under the effects of

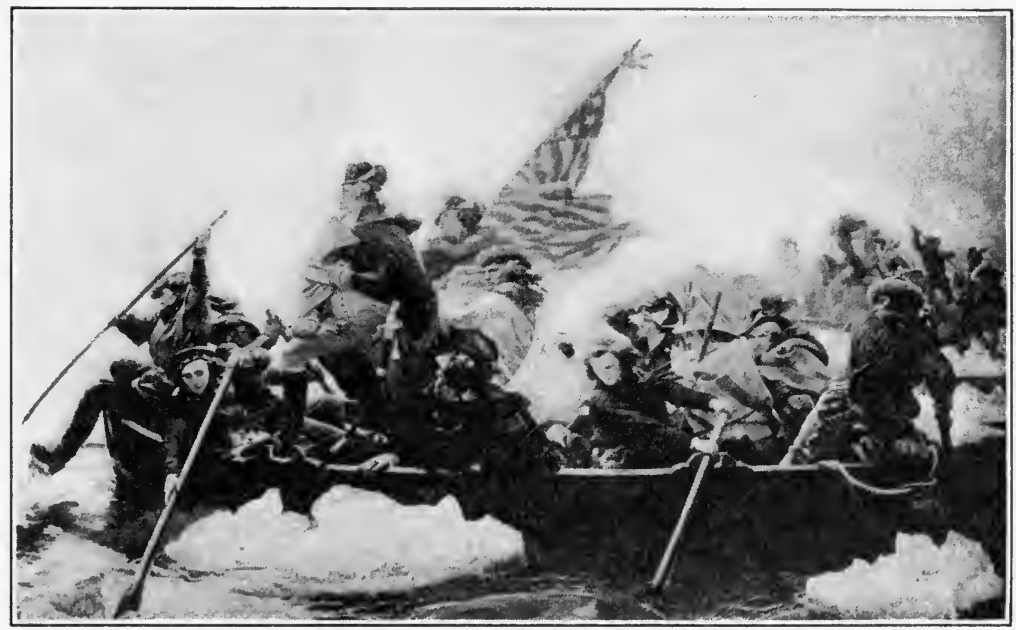

Washington crossing the Delaware

their holiday carouse, he crossed the river, filled with floating ice, and fell unexpectedly on the British camp in the early morning. His enemy were surrounded, and forced to a fight in which their commander was killed and a thousand men were captured and carried into Pennsylvania.

The spirits of the Americans rose at once, and their commander recrossed the river to Trenton. Cornwallis called up Battle of his reënforcements to crush him. At nightfall on Princeton January 2, 1777, he lay in front of the small American army, 
confident that he would win a great victory with the coming of dawn. But Washington again outwitted him. Leaving his camp fires burning brightly, he slipped away in the night and took the road to the north. At Princeton in the early morning he met a strong body of troops coming up to help Cornwallis, and defeated them in a quick encounter. Cornwallis heard the guns just as he learned that no army was before him. He followed as fast as he

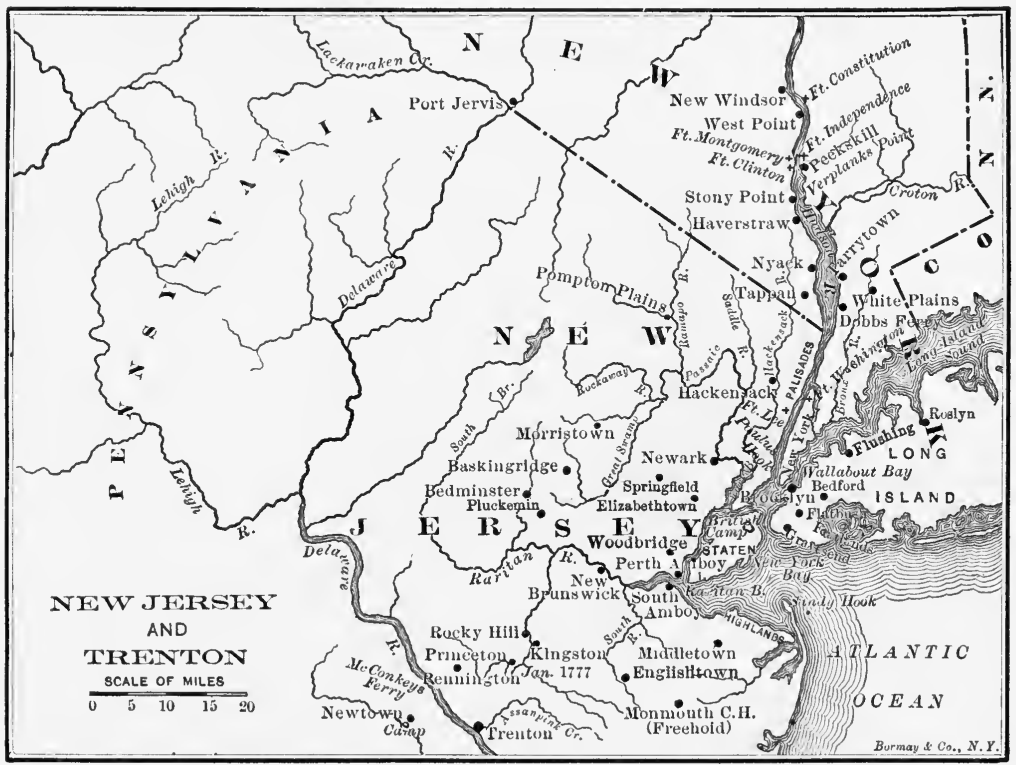

could go, but Washington moved off into northern New Jersey. The British did not dare attack him in a winter campaign, nor would they divide their army in garrisons throughout the state. They drew back to the neighborhood of New York, and the rest of the winter passed in quiet. At the end of the campaign of 1776 the British held New York and Newport in Rhode Island, and the Americans held the rest of the country. 
Early in 1777 the British made plans for a great campaign. The main object was to gain the Hudson River from New York to the source and to cut off New England from the rest of the states. Three large expeditions were to

A great plan try to carry out this plan. One was to start from Montreal and proceed by Lake Champlain and Lake George. Over it was placed General Burgoyne. Another was to start at Oswego, on Lake Ontario, and march through the Mohawk valley. It was commanded by General St. Leger. A third was the army under Howe, which was to move up the Hudson from New York. It was expected that all the forces would meet near Albany. The plan was made in England, and orders were sent promptly to Burgoyne and St. Leger. By some mistake they were not sent to Howe, who, having no directions as to what he should do during 1777, thought he might move as he saw best. He chose to move against Philadelphia, where the continental congress was in session. He thought it would have a good effect for the British if he could seize the capital of the Americans. His failure to act with the other two expeditions was fatal to their success.

Howe decided to reach Philadelphia by water. He embarked on two hundred and fifty ships and sailed down the coast. Washington was vigilant and moved southward rapidly. Battle of Howe thought he would outwit him by landing at the Brandywine head of Chesapeake Bay and not on the shore of the Delaware Bay, as one would naturally expect. He put his army ashore as he planned, but he had not gone far on the road to Philadelphia before he found Washington in front of him at Brandywine Creek. Howe had a large number of troops, and his men were regulars, while most of the Americans were raw militia. Nevertheless, the Americans fought hard until nightfall, and withdrew in good order. Each side lost about 1000 men; but the British moved into Philadelphia without further opposition.

They were delighted to see the continental congress in utter flight, and Howe became so confident that he left a portion of his 
army exposed at Germantown, seven miles from Philadelphia. Washington, hovering near, saw his opportunity, and threw Battle of himself on these troops with all his force. He carried German- everything before him, driving back the British in town flight. When all seemed won, a small body of British took refuge in a stone house and held off the Americans until some

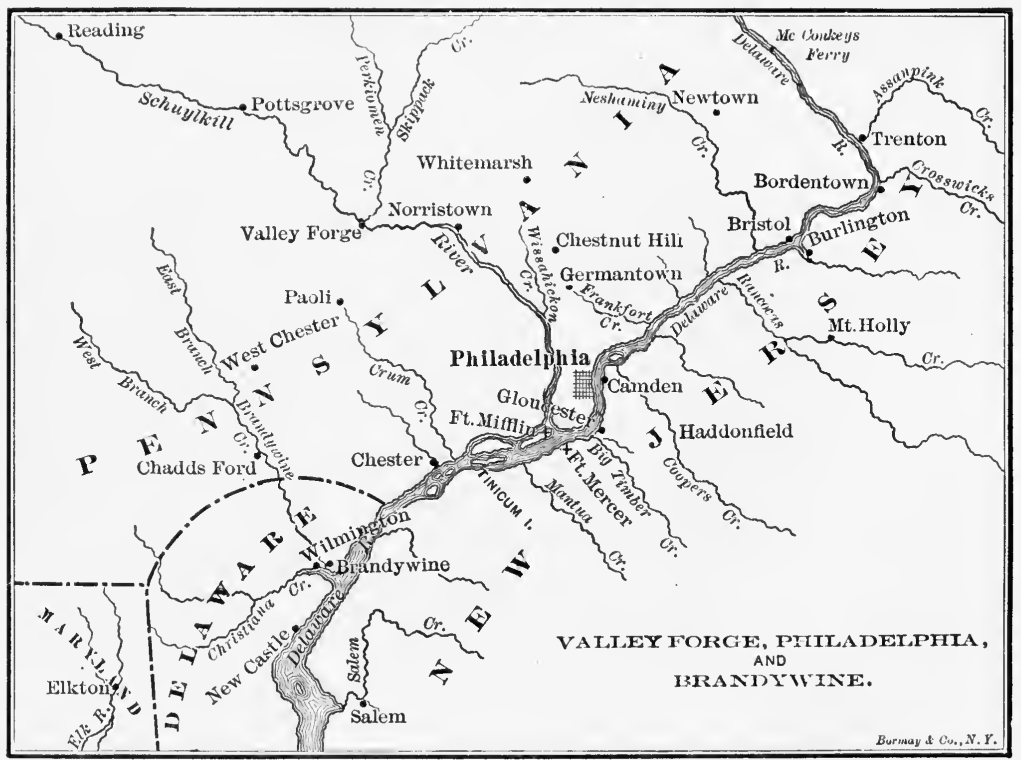

of the retreating regiments could be turned about. These resisted until Howe could send other troops from the city. Thus Washington lost again; but he had nearly won the victory, and he had taught Howe to be careful. It was evident to the British generals that they could not afford to station men in exposed positions, and although Howe remained in Philadelphia for a year, he was too prudent to go far into the surrounding country. By this means rural Pennsylvania escaped the visits of the British. During 
the winter the American army was encamped at Valley Forge, where it could keep a good eye on the British. The At Valley men suffered much from lack of clothing and food, but Forge their trust in Washington did not falter.

While these things happened in Pennsylvania Burgoyne's campaign was in progress in the North. He marched in June with 7300 men and was soon before Fort Ticonderoga, The expediat the head of Lake George. The garrison fell back tion from rather than risk a siege. The militia of New England Canada and New York now swarmed into the northern forest to meet him. They felled trees across the roads, and cut off any small bodies of men that got separated from the army. They would not risk a decisive battle, and Burgoyne floundered along very slowly as far as the headwaters of the Hudson. His men consumed their rations more rapidly than wagons could bring them up from Lake George.

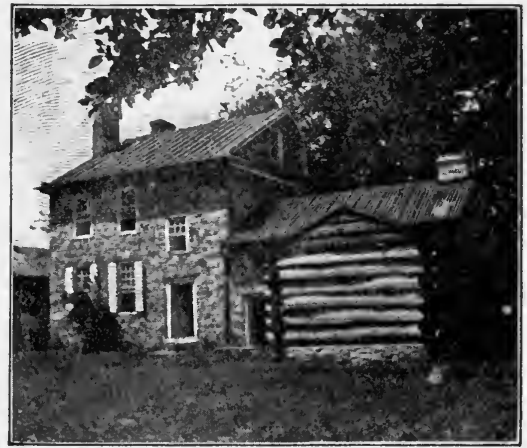

Washington's headquarters at Valley Forge

In despair he sent out five hundred German troops to gather supplies in Vermont, where he supposed there were many loyalists. It was a very unfriendly reception the Vermonters Battle of gave them. They assembled under Colonel John Bennington Stark, in number eight hundred, and met the Germans at Bennington, killing or capturing nearly all of them. A second body of British troops came up to reënforce the first, and these were also beaten by Stark and his Vermonters. The total British loss was eight hundred.

The news from Bennington was a sad blow for Burgoyne. He learned within a few days of another misfortune which was equally 
unfortunate. St. Leger had been met at Oriskany by a band

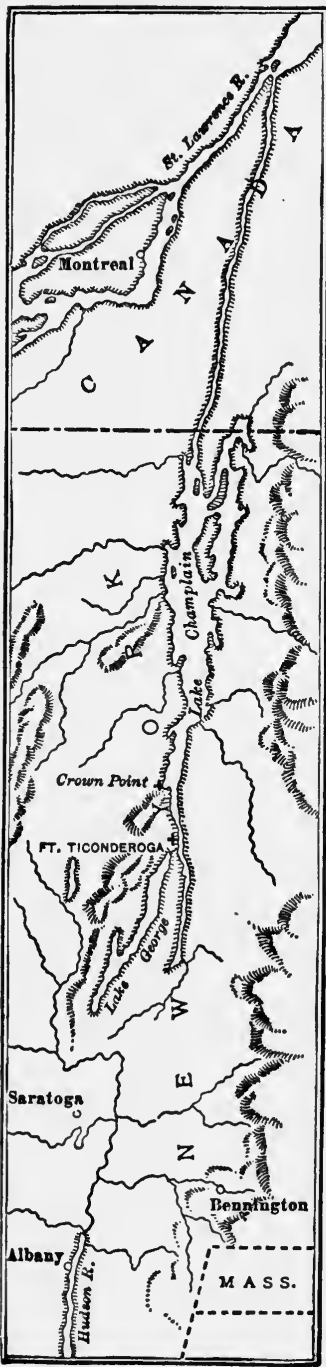
of German settlers and defeated after a Battle of severe battle. He hesitated for Oriskany a few days, but when he learned that 2000 men under Benedict Arnold were marching against him, he retreated to the safety of his ships at Oswego.

Burgoyne was now in a critical position. His army was reduced to 5000 men withSurrender of out adequate supplies. News Burgoyne came that Howe was in Philadelphia, and not, as Burgoyne supposed, approaching Albany. Before him lay an army of more than 10,000 which daily grew in numbers. He dared not retreat before it. He made two hard efforts to break through and scatter his opponents, but both were failures. Then he accepted the inevitable, and at Saratoga on October 17, 1777, he surrendered his entire army. It was agreed that the soldiers should besent to Boston and embarked for England, not to serve again in America during the war.

The defeat of Burgoyne was important in several ways. It was a great thing to Effects break up England's plan for cutting off New England from the rest of the states; but it was a still greater thing to overpower and take prisoners an army as large as Burgoyne's. The Americans were filled with hope and courage, and gloom hung over the British camps.

The greatest impression, however, was 
in France, where the progress of the revolution had been watched closely. France remembered the seven years' war and was pleased to see England humiliated. She began to give help Help from secretly, and the king only awaited some great victory to France come out openly for the United States. The surrender of Burgoyne was the deciding event. All Paris rejoiced, and early in 1778 the king made two treaties, one recognizing the independence of the American states and making a defensive alliance with them, and the other regulating commerce between the two nations. France hoped that the states would in the future buy from French merchants the supplies they had previously obtained in England.

England was now thoroughly alarmed lest she lose her colonies, and even stubborn George III was willing to yield something. Commissioners were appointed to go to America with King offers of compromise. If the Americans would sub- George's mit, and throw over France, their new friend,'they might, offer said the commissioners, have pardon for all they had done; and all the reforms they had asked for in 1775-1776 would be granted. The offer came too late. Independence seemed certain, and no state was willing to give up the hope of securing it.

The year 1778 was a quiet one. England wished to strike a blow against France in the West Indies and left the Americans in comparative peace. She decided that it was risky Battle of to try to defend both Philadelphia and New York and Monmouth ordered that the former place be given up. Clinton, who was now in chief command, obeyed the order, marching overland with his army through New Jersey. Washington followed him closely, anxiously watching for an opportunity to attack. The right moment came when the British lay at Monmouth, New Jersey. Washington prepared to charge vigorously and gave General Charles Lee the honor of leading the attack. Lee, who was secretly a traitor, fell back before the enemy. By the greatest efforts Washington checked the retreat of his own men and saved his army from defeat. Lee was tried by a court-martial and suspended from the 
army for a year. He was a British officer who early took the side of the Americans in order to get a high command. He was jealous of Washington and intrigued to get the chief position. Letters discovered in later times have made his treachery certain.

A more noted act of treason occurred two years after the battle of Monmouth; that is, in 1780. Benedict Arnold was one of the Arnold's bravest generals in the patriot army. He made a treason glorious fight in Canada in 1775 and 1776, trying to take Quebec and beating off an attempt to invade upper New York. He was one of the boldest of those who faced Burgoyne, and he lost a leg in the campaign. In 1780 he was in command of West Point, a strong fortress built to command the Hudson. He had been badly treated by congress and was in debt. Major André, Clinton's adjutant, became his correspondent and persuaded him to desert the American cause and surrender West Point, offering for his treachery the position of brigadier-general in the British army and a large sum of money. In September André came up the Hudson and had a conference with Arnold. All arrangements were made for handing over the fort, and André started to ride down the river road to New York. Near Tarrytown he was arrested, taken to an American post, and after trial hanged as a spy. Arnold learned of the arrest and knew he would be implicated. He jumped into a boat and escaped to a British ship, where he received the price of his crime. West Point, however, was saved from Clinton's grasp. Arnold served his new masters well, but in his old age he had much reason to regret that he had deserted his country. It is said that just before he died he called for his old American uniform, saying, "May God forgive me for ever putting on any other."

The battle of Monmouth was the last important action in Georgia and the North. The British had concluded to try in anSouth Carolina other field. There were many tories in the Carolinas and Georgia, and it was believed that they would come to the help of the king if a royal army was in that section. The 
rest of the war was devoted to an attempt to conquer this region. First, Savannah was seized, December, 1778, and the interior of Georgia overrun. The next year South Carolina was invaded. The American general unwisely allowed himself to be shut up in Charleston, where in 1780 he surrendered with 5000 men. South Carolina was now without defenders and fell a victim of the enemy's hatred. Small British columns rode against whatever group of the people was armed in self-defense. The governor of the state fled because he had no government to administer, and General Cornwallis, who commanded the British, had the two states at his mercy.

Congress sent General Gates to gather what troops he could and drive out the enemy. He was a rash and vain man and was defeated by Cornwallis in the battle of Camden. Gates rode so rapidly from the field that his own army thought him a coward. He was succeeded by General Nathanael Greene, a general whom Washington himself selected. Greene was expected to keep Cornwallis from overrunning North Carolina and if possible drive him from South Carolina. To do this he had the broken handful of troops left from Gates's defeated army, with a few newly arrived men, in all 2300. He could also call out the militia of the states in which he was operating.

Two months before he arrived, the militia of North Carolina and Virginia won a brilliant victory, which showed that they could be depended on. Cornwallis sent Major Fergu- Battle of son into the country west of Charlotte, North Carolina, King's to collect tory recruits. To the whigs of the region Mountain this was a challenge, and they gathered to the number of 1800 to defeat Ferguson. They pursued him so closely that he took refuge on King's Mountain, a hill most of which lies in South Carolina. The whigs surrounded the hill and charged up its slope so vigorously that Ferguson and his men were glad to shield themselves on its crest behind any stone or tree that was found there. Finally the leader with two hundred of his men was shot, and the rest, 


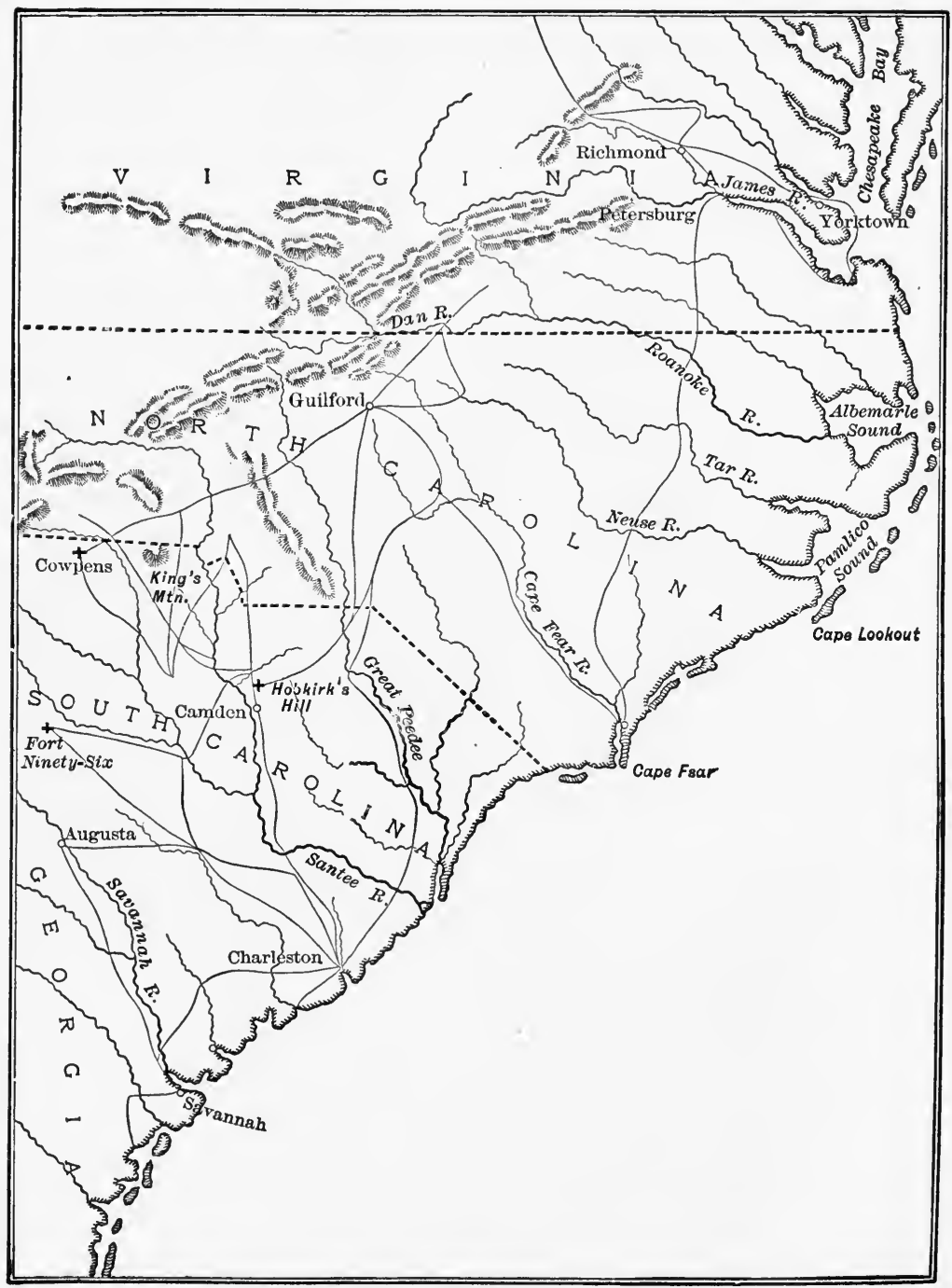


seven hundred in number, became prisoners of war. This victory, won by the men of western counties of North Carolina, Virginia, and South Carolina, October 7, 1780, without help from the state or continental government, caused Cornwallis to fall back into South Carolina.

He was ready to move again early in 1781. He sent Colonel Tarleton with more than 1000 troopers to attack General Morgan, whom Greene had placed where he could watch the Morgan at British. Morgan with eight hundred men did not Cowpens hesitate to fight Tarleton at Cowpens, January 17. He was an excellent soldier and his men had great confidence in him. They received the British with a withering fire, and in a short engagement killed, wounded, and captured seven hundred and eighty-four of them. Tarleton with the rest was driven from the field. Morgan's army was composed of frontiersmen, all excellent marksmen.

Cornwallis was very angry and flew at Morgan with his superior army. The American general was too good a soldier

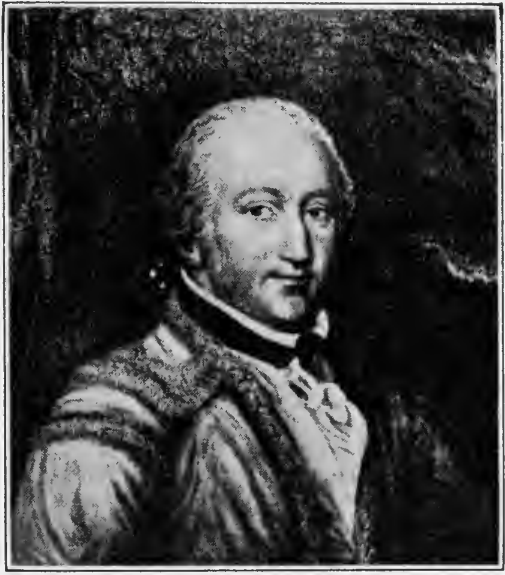

General Morgan to be caught. He retreated rapidly into North Carolina, with the British following as fast as they could. The chase was continued for many days. Greene also moved rapidly northward and was at last able to unite with his lieutenant and get safely into the southern part of

Cornwallis foiled in North Carolina Virginia, while the British army remained in North Carolina, calling the tories to its standard. Greene received reënforcements and gave his tired troops a rest. Then he reëntered North Carolina 
and fought a severe battle with Cornwallis at Guilford Courthouse, March 15, 1781. Both armies suffered heavily, and at nightfall Greene drew off, leaving his foe on the battle field. Cornwallis sent out a proclamation in which he claimed the victory, but a few days later he fell back to Wilmington, on the seacoast. He had lost so many men and used up so much am-

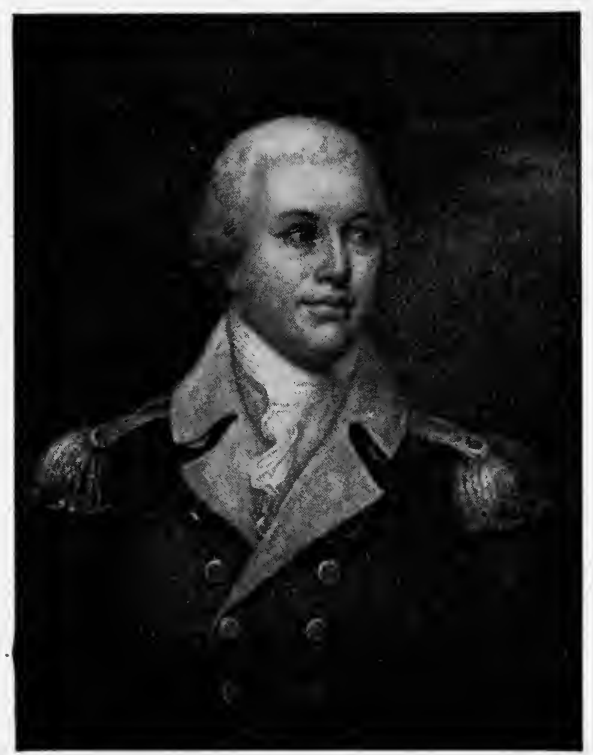

General Greene munition that he dared not stay in the interior with so vigilant an opponent as Greene before him. Practically all North Carolina remained in the hands of the Americans.

Greene now returned to South Carolina and atsuccess in South
Greene's Carolina

tacked the various posts the British had fortified throughout the state. One after the other was taken, thus forcing the garrisons to fall back to the seacoast. Several battles were fought in this process, in both South Carolina and Georgia. At the end of the year 1781 the British held only Charleston and Savannah in the two southernmost states.

Meanwhile, Cornwallis had decided to give up the hope of conquering North Carolina. In April he left Wilmington and marched to Virginia, where Lafayette commanded the Americans. $\mathrm{He}$ met no serious resistance, and for three months went where he pleased. At length he took position at Yorktown 
on the south bank of the York River, at that point a broad stream.

When Washington heard of this, he was before New York, watching Clinton. Rochambeau, with a fine army of French soldiers, was at Newport, and a French fleet was at hand. Yorktown Washington quickly formed a plan to trap the taken British at Yorktown. First, he asked the French fleet to blockade Chesapeake Bay in order to keep a British fleet away. Next he brought Rochambeau to New York so as to make Clinton think that place was to be attacked. Then he suddenly departed with the united army, 6000 strong, for Virginia. Other forces joined him, and early in September he closed in around Cornwallis with a regular siege attack. October 19 Yorktown was taken and the British army of 7500 men was made prisoners.

The American revolution had now been in progress more than five years, and Great Britain

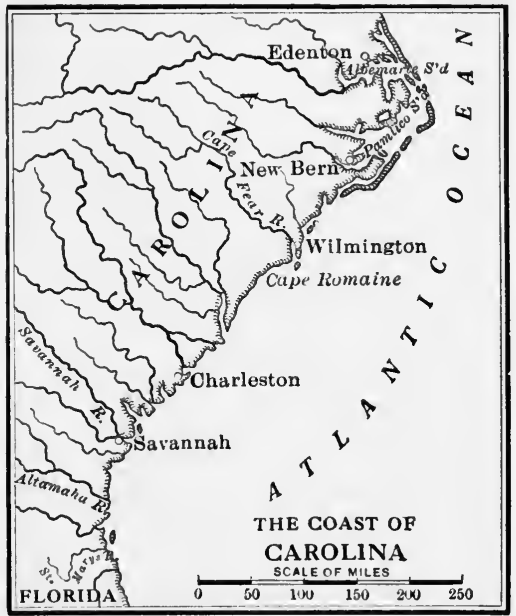
held of her former colonies only the seaports of Savannah, Charleston, Wilmington, and New York; and these A treaty of she held because of her naval strength. In the course peace of these years two of her armies had been taken captive and a vast amount of money had been spent. The people of England saw that America was no nearer submission than at the beginning of the struggle. They were tired of the war, and March 15, 1782, parliament passed a bill to make peace. Commissioners were appointed by each side; they met in Paris and prepared a treaty, which was finally ratified September 3,1783 . After the 
surrender of Cornwallis there was no more serious fighting in America.

The terms of the treaty of peace were as follows: 1 . The United States should be recognized as free and independent. 2. The The terms country should have its former outer limits, and the Mississippi and the Great Lakes should be the boundaries on the west and the northwest. 3. The navigation of the Mississippi should be open to both the United States and Great

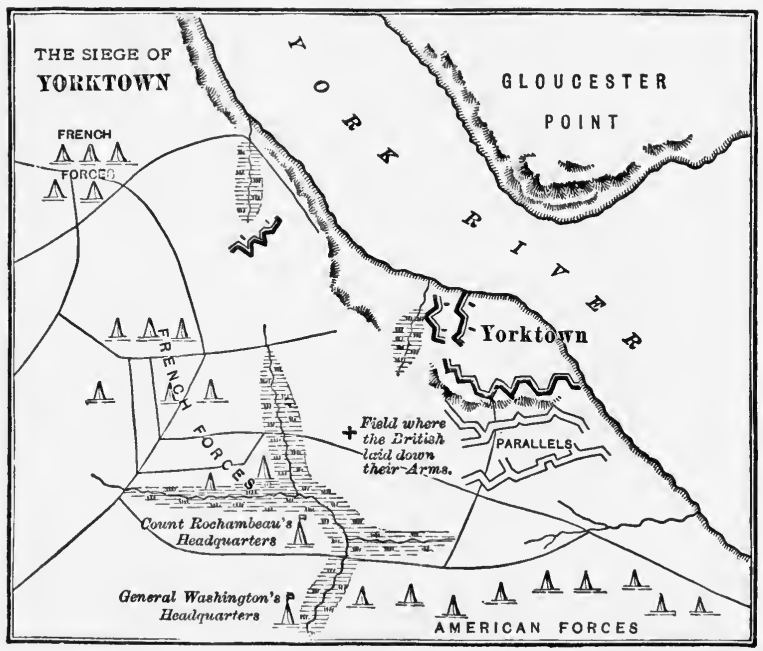

Britain. Had France been left to fix the boundary she would have given us much less of the western region. She was very friendly to Spain and that country owned Louisiana and did not wish the strong American republic to come near to its boundaries.

Two facts are worth remembering about the revolutionary war. One is that we should never have won it but for the help we got Two im- from France. She acted undoubtedly from her dislike portant facts for England, but she treated us generously, sending us men and money and only asking in return that we remain her 
friend. The other fact is that the great distances they must travel through a thinly settled country weakened the British armies quite as much as the actual fighting of the Americans. It was in this way that Burgoyne was defeated and Cornwallis forced to fall back after he had won the day at Guilford Courthouse.

The Americans began the war with much enthusiasm, but after the first year their ardor cooled. It was then hard to keep the army up to its full numbers, and the states became A small very slow in voting money to pay expenses. When army Washington gathered all the troops he could muster to surround Cornwallis at Yorktown, he had what was a vast army for the revolution. It contained 16,000 men, 7500 of whom were Frenchmen. If all America had been united to carry on the war, it should have been easy to have armies much larger than this.

The tories were very numerous in some parts of the country. They were conscientiously opposed to the whigs, whom they considered only an ambitious group of men who wished Tories and to acquire influence. The whigs controlled the state British legislatures and retaliated on the tories, confiscating debts their property and causing them great distress. They also passed laws making it difficult for British merchants to collect debts due them at the beginning of the war. When the treaty of peace was made, the British insisted that congress should order the property of the tories restored and that the laws against the collection of debts owed to British subjects should be repealed. It was impossible for congress to order a state to do anything; but it was agreed that congress would recommend that the laws complained of should be annulled. The recommendation was promptly made, but most of the states paid no attention to it. This caused disappointment in England, where it was generally believed that the Americans had not kept faith.

We must not turn from the story of the revolution without knowing how the rich country north of the Ohio River was con- 
quered. Virginia claimed most of this region, but it was occupied by British posts at the beginning of the war. In 1778 George George Rogers Clark marched boldly into it with about two Rogers hundred soldiers sent out by the state of Virginia. Clark He captured the important settlements of Kaskaskia, Vincennes and Cahokia. They were weakly defended, and Clark's greatest trials were to overcome the difficulties of a long march

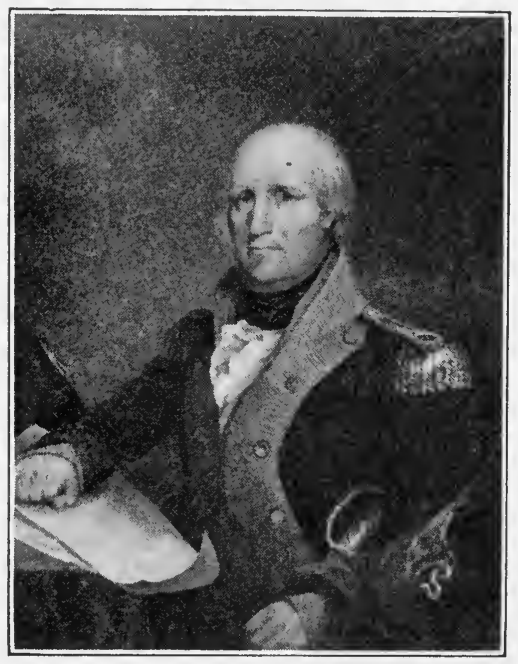

George Rogers Clark through a wide wilderness. The British commander at Detroit with a considerable body of troops retook Vincennes, and then, feeling safe in the winter, sent away all his men but eighty. Clark heard of this misfortune and lost no time in recovering what was lost. He marched nineteen days over the prairies, wading much of the distance through icy water, and forced the British governor to surrender. That officer, Hamilton by name, was popularly called the "Hair Buyer" because he had paid Indians for the scalps of white settlers. He was much hated on the western frontier, and a great outburst of joy came from that section when Clark came home with the "Hair Buyer" a prisoner. From that time the northwest remained in American hands.

Another thing which must not be omitted from the story of the revolution is the career of John Paul Jones, the first hero John Paul of the American navy. He entered the navy in 1775 Jones and quickly became a captain. He was in France soon after that country decided to help the Americans. With much 
difficulty he got command of a squadron of four small ships and boldly sailed around the northern part of Scotland, coming down on the eastern coast. He had destroyed many British ships, and the royal navy was anxiously looking for him. Near Hull he encountered the Serapis, a larger ship than the Bonhomme Richard, his best vessel, and joined in a furious battle. Finding that his cannon were bad, he laid his ship by the side of his opponent, lashed his spars to those of the Serapis, and fought desperately with muskets and bombs. At the end of two hours the British ship was on fire and struck her colors. The Bonhomme Richard was so badly damaged that she sank, and Jones went back to France in the captured Serapis, accom-

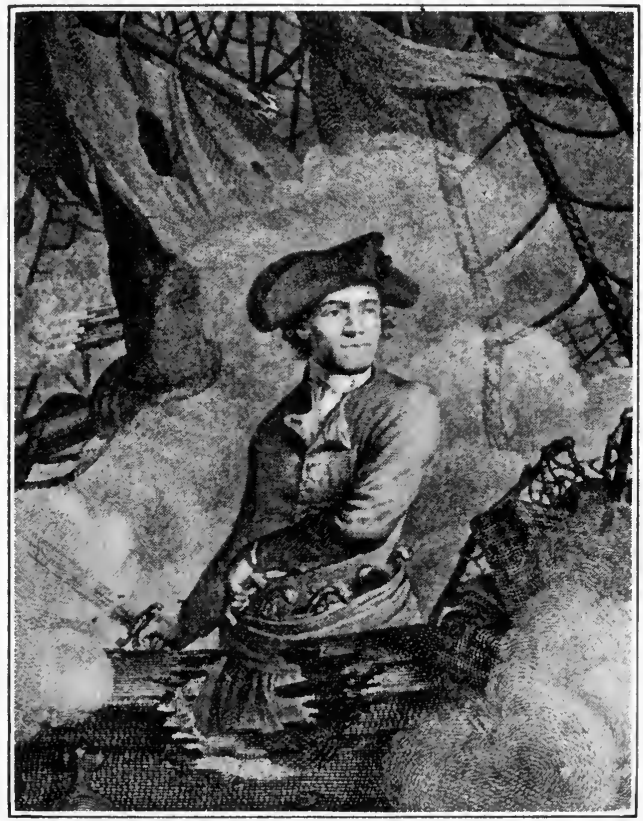

John Paul Jones panied by a smaller vessel which one of his squadron had taken while the commander was fighting. John Paul Jones set the standard for bravery and persistence in the American navy.

\section{QUESTIONS}

I. How did George III treat the petition of the second continental congress? What steps were taken in England after the battle of Bunker Hill? How did Jefferson express the purpose of the colonies? 
II. Why did congress hesitate to declare independence? Which colony took the first step? What advice was given on May 15? Describe the adoption of the declaration of independence. Who were the loyalists? the whigs? How did the loyalists justify their position?

III. How did congress prepare a plan of union? What prevented the formation of a strong union? Describe the adoption of the articles of confederation. What did they say about raising money and armies? How did they affect the power of the states? Did they satisfy all classes?

IV. How did Washington maintain the siege of Boston? How did he get heavy guns? For what purpose did he use them? Describe the departure of the British.

V. What plans were made to reëstablish British authority in North Carolina? Describe the campaign of Moore's Creek. To what place did the British then turn their attention? Describe the attack on Charleston? How was the town saved?

VI. From what region did Howe attack New York? Describe his first battle. How did Washington twice elude Howe? What two battles were fought when Washington withdrew from the town? Relate the story of Nathan Hale.

VII. Why did Washington move into New Jersey? What two forts were lost? Describe his retreat to the Delaware. How did he escape Cornwallis? Describe the battles of Trenton and Princeton. What effect did they have on the Americans? What was the effect on the British occupation of New Jersey? What parts of the continent did the British hold at the close of the year 1776 ?

VIII. What wide campaign was planned for the year 1777? Why did Howe act on a plan of his own? Describe his expedition to Philadelphia. What was the result of the battle of Brandywine? Describe the battle of Germantown. What kept the British from ravaging Pennsylvania? Describe the condition at Valley Forge.

IX. Describe Burgoyne's march southward. How was he opposed? Describe the expedition to Bennington. How did the expedition of St. Leger fail? In what respects was Burgoyne's position critical? How did he try to break through the American lines? What were the terms of his surrender? What effects did it have on our relations with France? How had France given aid to America before Burgoyne's defeat? Describe the treaties now made. What offers did she make to the Americans?

$\mathrm{X}$. Why was the war not pressed early in 1778? Why was Philadelphia given up? Describe the battle of Monmouth. How did Lee prove wanting? What was the early career of Arnold? Explain the origin and end of his treason. What was the story of André? 
XI. To what field did Great Britain turn her attention in the latter part of 1778? On what was her hope based in the new field? Deseribe the results in Georgia and South Carolina. What became of the regular government in South Carolina? Describe Gates's attempt to defend South Carolina. What were Greene's resources? Why was Ferguson sent to North Carolina? What men determined to drive him out? Describe the battle of King's Mountain.

XII. Describe the battle of Cowpens. Describe the chase across North Carolina. Describe the battle of Guilford Courthouse. What were its effects on the campaign of Cornwallis? Describe Greene's further campaign in South Carolina. In what direction did Cornwallis march from Wilmington? Deseribe his early eampaign in Virginia. In what place did he take his stand? What plan did Washington make? Tell how it was put into execution.

XIII. What had Great Britain gained by five years of fighting? When and where was the treaty of peace made? What were the terms? How would France have limited the boundaries? What two important advantages favored the Americans? What conclusion do you draw from the size of the American armies? How were the tories treated during the war? What was said in the treaty of peace about the tories? the British debts?

XIV. Describe the conquest of the Northwest by George Rogers Clark. Who was the "Hair Buyer"? Why was he hated? What part did the navy take in the revolution? Describe the eareer of John Paul Jones. What has been his influence on the navy?

\section{SUGGESTED TOPICS}

The Adoption of the Declaration of Independence; The Articles of Confederation; Ethan Allen; Israel Putnam's Exploits; The Attack on Fort Moultrie; The Treatment of the Loyalists ; The Career of Nathan Hale; The Trials of the Continental Army; Our Aid from France; The Defeat of Burgoyne; Making the Treaty of Peace; The Victories of George Rogers Clark; The Cruise of the Bonhomme Richard. 


\section{CHAPTER XIII}

\section{REMODELING THE GOVERNMENT}

ThE people of the United States were happy to dismiss their armies and turn their attention to the affairs of peace, which A state of were in great need of reform. In three fields there was confusion confusion. 1. The continental congress had borrowed a large amount of money at home and abroad, and it was necessary to provide for its payment. 2. Since the states paid no heed to the calls of congress for money, it was necessary to devise some means by which the general government could collect the money it needed. No government can be respected that does not have the right to collect taxes. 3. There was much jealousy between the merchants and the country people. In this chapter we must discuss these three states of confusion and learn how the good sense of the people gradually established order.

The revolutionary debt was of two kinds, bonds and continental money. The bonds were promises to pay certain sums at some The bonds future time with interest at a specified rate. They were in writing, and were signed by the high officers of the government. For example, a bond might be for $\$ 1000$, payable in twenty years with interest at six per cent. Such a bond would be signed and offered for sale. It was unusual for it to bring face value. If it were to sell for only $\$ 600$ it meant that interest was really ten per cent. These bonds had been sold in Europe, some to the French government, some to Spain, who at first was willing to help the colonies revolt from England, and some to bankers in Holland. The Americans were especially anxious to pay their interest on their foreign debt, for it was damaging to their reputa- 
tion to let it go unpaid. Other bonds were sold to people who lived in America. When the war ended, we owed nearly $\$ 8,000,000$ in Europe and about $\$ 35,000,000$ at home.

Another kind of debt was paper money, which was in reality the government's promises to pay sums of money to the holders of the bills, when they should present the same at the Continental treasury. A great quantity was issued during the money war, so much that no one believed that it could be paid. It gradually fell in value, until late in the war it took one hundred dollars of this money to purchase as much as one silver dollar would purchase. "Not worth a continental" was a current phrase, and referred to the continental money. A man in Philadelphia pasted it over his dog and led him along the streets, to the amusement of the onlookers. Some of this money was redeemed at the rate of forty to one, and some was never redeemed.

A country as great and as rich as ours could easily have paid this debt if there had been a proper means of collecting such taxes as the people were able to pay. The difficulty was The taxthat in 1783 congress had no right to levy taxes on indi- levying viduals. If it called on a state to pay its part and the power state refused, there was no way of making the state pay. To force a state to pay meant civil war, and no states would help congress in a war on the other states. If congress had the right to call on the individual and the individual refused, he could easily be made to pay. Many men saw that it was necessary to give congress the power to lay taxes on citizens, and attempts were made to amend the articles of confederation so as to confer the power. But all these attempts failed. It was necessary for every state to consent to an amendment of the articles, and there was always at least one state that would object.

There were several causes of the hostility between the country people and the trading class. In the first place, the Class former were generally in debt to the traders, and they jealousy wished to have the states issue paper money with which they could 
easily pay their debts. The merchants, on the other hand, objected to paper money, and tried to defeat the demands for it. Another thing was that the merchants were wealthy and lived in fine houses, while the farmers were mostly poor and had to work hard.

Still another was the dispute over the duties on imported goods. The merchants wished to abolish such duties between the states The collec- and to make them uniform in all states when collected tion of im- on goods brought from foreign countries. They realport duties ized that the only way to secure these changes was to allow the general government to collect all the imports. As long as each state might collect what it chose there would be great differences between the rates. The country people, on the other hand, liked the import tax. Since they did not actually pay it out of their pockets, they thought it was paid by the merchants. They forgot that the merchants always added the tax to the price of their goods, so that the people of the country were sure to pay their part of the duties on imports. The rural classes, therefore, were outspoken in opposition to the suggestion that congress should lay all import duties. They thought that such a course would deprive the state of a valuable source of revenue and increase the amount of the direct tax. The opposition between the two classes that grew up from the causes mentioned was very intense, especially in Massachusetts and Rhode Island. In the former of these states it led to the Shays rebellion, of 1787, which was not suppressed until the governor called out an army of four thousand men.

The time was full of perils. We had won independence with the aid of France : should we now quarrel among ourselves? And The peril of if quarreling began, was there not danger that some of dissension the states would put themselves under some foreign power rather than submit to the rest of the states? Occasionally one read in an English newspaper that the former colonies were quarreling among themselves and would soon come back one by 


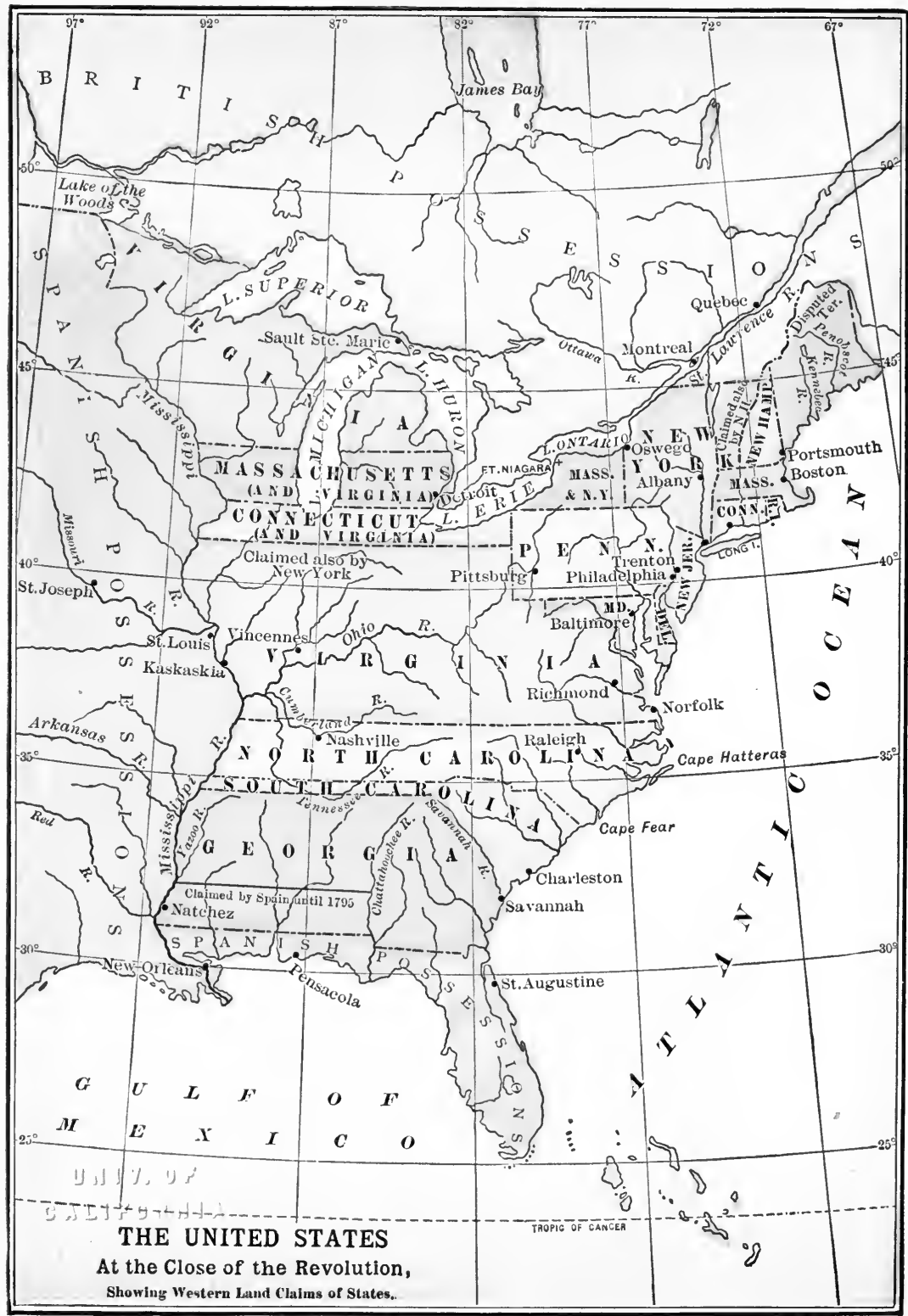


one for protection under the British flag. This state of affairs alarmed the wiser Americans, and they did all they could to get congress to mend matters. But congress moved slowly, and in spite of such men as Washington, Adams, Hamilton, and Madison, it would do nothing.

A trivial incident set people thinking, and finally led to a new constitution. Maryland and Virginia were collecting differing duties on each side of the Potomac, and there was Smuggling smuggling from one state into the other. Madison on the learned of this condition, and got the Virginia assembly Potomac to invite Maryland to send delegates to meet Virginia delegates in a conference on the subject. As each state was losing money, it was the interest of each to make uniform rules and duties. When the delegates met, 1785, they found that any new duties Virginia and Maryland laid might not suit the states on their outer borders. This fact showed very clearly that duties ought to be the same throughout the states. The delegates from Virginia and Maryland, therefore, urged that a convention to take up the matter be called at Annapolis in 1786. Annapolis was selected because it was not a great trading town and was remote from New York, where the continental congress met. It was seen that the convention would be unpopular if it seemed to be under the influence of the trading class, and it was not thought that it should be in close contact with the continental congress.

Nine of the states accepted the suggestion and the convention met, with delegates present from Virginia, Pennsylvania, Delaware, New Jersey, and New York. As soon as they assem- Annapolis bled the question was asked: "How can the regulations convention for uniform duties be enforced, even if we agree on a plan to levy such duties?" It was evident that no plan, however good, would be worth trying unless there was a stronger general government. The convention, therefore, adjourned after calling on the states to send delegates to a constitutional convention in Philadelphia, in 
May, 1787. The states approved of the suggestion, and elected delegates.

When the convention met, it took a bold course. It was called to amend the articles of confederation, but its first act was to A bold step throw aside the articles and make a new constitution outright. It did this without regard to the congress in session in New York. It trusted to the states for approval.

The first important matter taken up in the convention was how to make the small states feel safe against the large states. First conflict Rhode Island, Delaware, Maryland, New Jersey, and in the constitutional convention Connecticut had long been suspicious of their great neighbors, and they had insisted that the states should have equal voice in the affairs of government. This would give a small state as much power as any other. To the large states it seemed absurd that the small state of Rhode Island should have as much voice in making laws and levying taxes as the great state of Virginia, then nearly twice as large as any other state. The delegates from the large states declared that they would never set up a government in which a great state put herself at the mercy of the small states, who by combining might defeat any measure which was for the good of the whole country. They added that rather than form a union on this basis, they would establish one of themselves. They thought that if the small states found themselves left out for a time, they would see how weak they were, and be glad to come into the union on the terms laid down by the large states. On the other hand, the small states declared that they would never join such a union as their colleagues proposed.

This difference of opinion came up when the convention was considering the nature of the congress under the proposed conThe first stitution. It was first decided that congress should compromise be made up of two houses, a house of representatives and a senate. Next, the question was how the members of the house of representatives should be chosen. The large states 
wished them selected according to population, so that a large state would have a larger number than a small state. The small states wished an equal number from each state. After debate it was decided to select them according to population. By this decision the large states got control of this house. Then the convention took up the question of choosing the senators. There was again a warm debate. The delegates from the small states declared their people would never approve the constitution if the great states controlled both houses of congress. They suggested as a compromise that there should be two senators from each state, whatever its size. The large states spoke vigorously against the compromise, saying they would never submit to such a plan, since it would confer upon the small states the power to defeat any measure they disliked. But at the very last some of the delegates who had voted for the plan of the large states changed their attitude for the sake of harmony, and the compromise was adopted. The large states were very angry, but in a few days they became reconciled to their defeat, and the work of the convention went on. Thus, it was decided that the representatives should be elected by the people and that the senators should be elected by the state legislatures.

Another dispute arose when the convention came to decide whether or not slaves should be counted in allowing a state her representatives in congress. If slaves were counted, Slave reprea Southern state would have more representatives than sentation if they were not counted. The South argued that slaves were but laborers, and that it was as fair to count them as to count the laboring population of the North. But the North replied that slaves did not vote, that they were only property, and that it would be unfair to give the white men of the South the right to vote for themselves and for their slaves as well. Suppose, they said, that a state has as many slaves as whites,.and suppose that, if the slaves are not counted, it has five representatives, elected by the whites. If the slaves are counted, it would have ten representatives, 
elected by the same number of white men. That would mean that a white man in that state would have twice as much voting strength as a white man in the North, where there were so few slaves that they could have no influence.

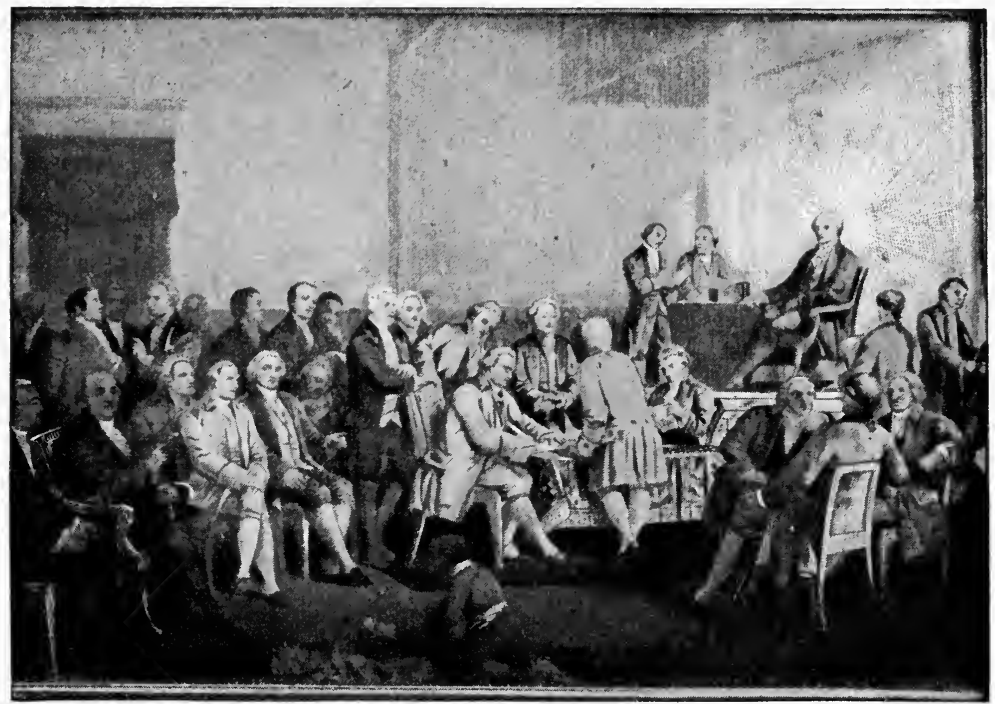

Signing of the Constitution, September 17, 1787

While this point was being discussed, a compromise was thought of. Suppose congress should wish to call on the states for direct The three- taxes, how should it decide how much each state should fifths com- raise? The natural answer was that a state that had promise one-tenth of the entire population should pay onetenth of the amount that was to be raised from all. But should the state's slaves be counted as a part of its population? The Southern states objected, for it would make their parts of the whole sum larger. It was finally decided that in each case, that is, in deciding what should be a state's share of representation and what should be its share of the direct taxes, three-fifths of the slaves 
should be counted. This compromise satisfied most people at that time, but when the slavery question became a prominent matter the three-fifths clause of the constitution was freely denounced by all who opposed the power of the slave states.

Another question which alarmed the slaveholders was the foreign slave-trade. It became important when the convention was about to give congress the right to regulate navi- Importation gation. The three states farthest south contained much of slaves unsettled land and lacked slaves to clear and cultivate it. They feared that congress, having the right to control navigation, would forbid the importation of slaves, and they declared that they would not accept a constitution which made such action possible. It was finally decided that the importation of slaves should not be forbidden before 1808, by which time, it was thought, every state would have as many as it needed. That being determined, the slaveholding states withdrew their objection, and congress was given full power over navigation.

These three compromises removed the important difficulties before the convention, and the rest of its discussions were harmonious. Before adjournment it was voted to send the The convencompleted constitution to the states and to consider tion adit the law of the land when it was adopted by nine of journs the thirteen states. Most of the members of the convention approved what had been done, and went home to persuade the people that the plan of government now laid before them was the best that could be prepared at that time. Some of the members objected to the constitution, and went home to try to defeat it. They thought it would be better to have the existing confusion than adopt a constitution which took so much power from the states.

Conventions elected by the people met in the states to pass on the question of adoption. The first state to adopt was Delaware, whose delegates in the convention had been Constitution very outspoken against the plan of the large states. the states 
She was now glad to be the first to come under the "new roof," as the phrase of the day ran. The greatest opposition was in Virginia, New York, North Carolina, Massachusetts, and Pennsylvania, all large states. They did not like to give up their independence, as they said, in order to become parts of a centralized government. Against this the argument was made that it was necessary for each to give up something for the good of all. When the votes were finally taken, all these states voted to accept the constitution except North Carolina, which voted to postpone action.

\section{The Ninth $P I L L A R$ erected !}

"The Ratification of the Conventions of nine States, thall be fufficient forthe eltablifh. ment of this Conftitution, between the States fo ratifying the fame." Art. vil.

\section{INCIPIENT MAGNI PROCEDERE MENSES.}

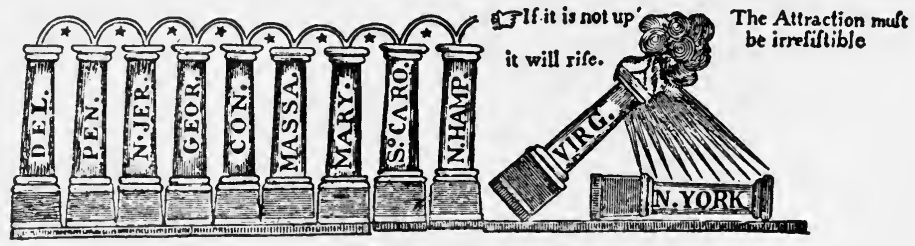

Adoption of the Constitution, 1788

From the Independent Chronicle.

She hoped that the union would be formed, but thought that amendments might be made in the constitution if three or four of the states would hold off for a while. Rhode Island rejected the constitution outright. Thus eleven states had voted for the new union.

While the country had been going through this stage of progress very important things had happened beyond the mountains. The western This rich region was claimed by seven of the states belands

cause their boundaries by colonial charters had run into the West. Virginia claimed most of the region west of Pennsylvania and north of Tennessee, Connecticut claimed the region south of Lake Erie, North Carolina claimed what is now Tennessee, 
and Georgia claimed all the region between her present western border and the Mississippi. The other claims were not very important. Before the war ended several of the states surrendered most of their western land to the United States. It was agreed that the lands should be settled and formed into new states. One

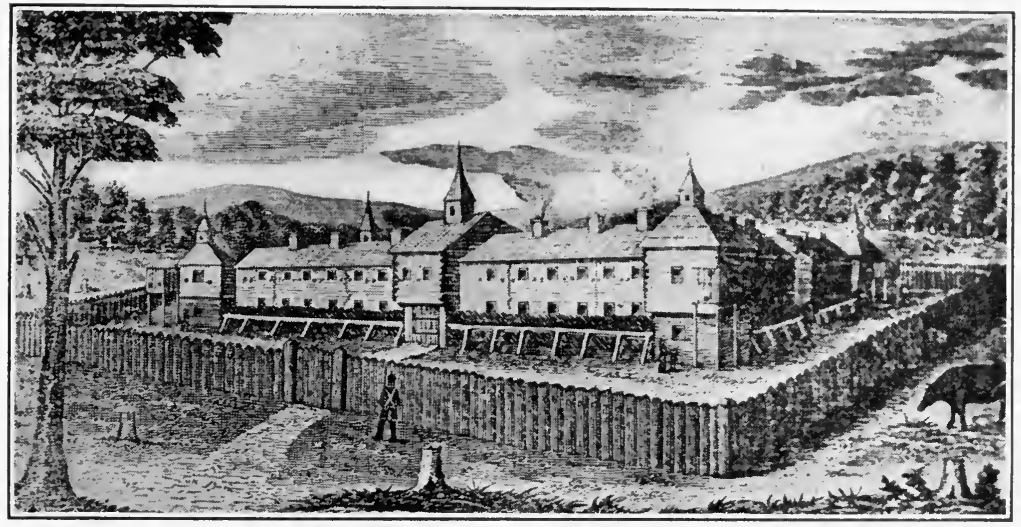

Campus Martius-Marietta, the oldest settlement in the Northwest

From American Pioneer.

of the things that the old congress had to consider was how to dispose of this land.

In 1784 congress had before it what has been called the first Northwest ordinance. It provided that the western region north of the Ohio River should be divided into nine, and the First Northregion south of it into seven, states. They were to be west ordiadmitted into the union as they became settled, and nance until they were large enough to be states they were to be ruled under laws passed by congress. One of the rules proposed in the ordinance was that slavery should not exist in this region. This rule was defeated by the states of the extreme South. The rest of the ordinance was adopted by congress. It was the work of Thomas Jefferson, who was very anxious at this early time 
to put a check upon slavery. At that time most of the leading Virginians were opposed to the extension of slavery.

In 1787 congress again took up the question of settling the Northwest, passing what is known as the Northwest ordinance of

Second 1787. Jefferson was not present at the time, but he Northwest would have approved of the ordinance had he been there. ordinance It was now agreed that the region north of the Ohio should be divided into not more than five territories. When a territory had a population of 5000 free males, it passed into what came to be called a territory of the second class. It then had a legislature of its own to make laws for the territory. When it had a population of 60,000 , congress might admit it to the union on equal footing with the other states. While this plan was made only for the territories of the Northwest, it was later adopted for all the other territories. Another important part of the second Northwest ordinance was that it forbade slavery in any part of the region north of the Ohio. Out of this area were created the states of Ohio, Indiana, Illinois, Michigan, and Wisconsin. The South did not oppose the second ordinance; for it said nothing about the region south of the Ohio.

In 1785 congress adopted a plan for laying out the public lands The town- offered for sale. The land was first laid out in townships ship system six miles square. A square mile, or 640 acres, was called a section, and thus there were thirty-six sections in a township. The township system adopted at this time was followed generally in all the West. It was first applied to a strip of land in eastern Ohio, to which settlers began to come about 1787 .

At that time two other large settlements were well begun beyond the mountains. The first was Kentucky, and Daniel Boone was Kentucky the man who discovered its advantages. He was a hunter from North Carolina, who loved the calm of the great forest. Crossing the mountains in 1769, he came at length to a fine blue-grass country full of buffalo and deer. It was the Indian's best hunting ground, and Boone was warned to leave 
under penalty of death. But he liked the land and would not give it up. He returned to his home and spread such glowing reports of its beauty that many of his neighbors in North Carolina came back with him to make their homes in Kentucky. They were beset by the Indians, but managed to defend themselves. Soon the fame of the country had gone far and wide and settlers began to arrive from every direction. Kentucky was within the bounds of Virginia, and most of its later settlers came from that state. In 1792 it was admitted to the union as a state.

The other western community that was then planted was Tennessee. It lay within the bounds of North Carolina, and the first settlers came from that state. They crossed the mountains about 1772 under the leadership of James Robert-

\section{Tennessee} son. They settled a pleasant valley in the mountain region, along the Watauga and Holston rivers. When they found they were not within the bounds of Virginia, as they first thought, they set up a local government of their own with the name, "the Watauga association." In 1784 they organized a separate state government, calling it the "State of Franklin," and hoping that it would be admitted into the union. But North Carolina objected and sent officers to arrest John Sevier, governor of the new state. The result was the collapse of the "State

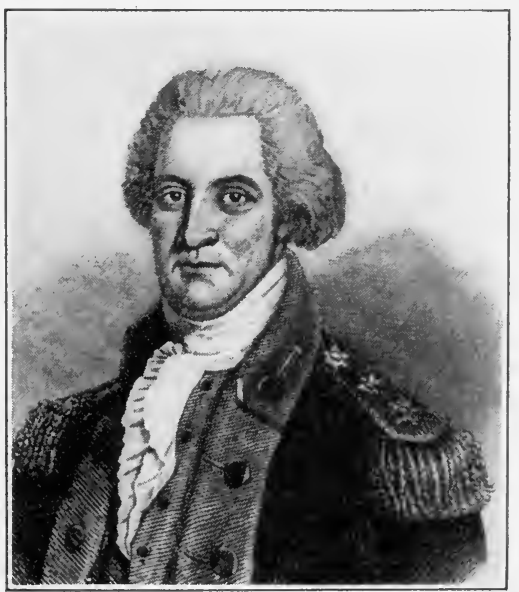

John Sevier of Franklin." But the tide of settlers continued strong, and in 1796 congress allowed Tennessee to become a state.

Many Indian wars occurred in Kentucky and Tennessee before 
they were states. Rarely did a settler go to bed without fearing that he would be attacked before morning. The Cherokee InJohn Sevier dians, who lived near what is now Chattanooga, were especially troublesome, until the whites marched on them in their stronghold, slew those who did not flee, and burned the houses and grain of the Indians. John Sevier, called "Nollichucky Jack," was the most prominent leader in these wars, and he was greatly loved by the Tennesseeans. He was one of the leaders who defeated Ferguson at the battle of King's Mountain, 1780 .

\section{QUESTIONS}

I. In what special fields was there confusion after the revolution? Explain the nature of a bond. Where were the revolutionary bonds held? What amount was outstanding? How did continental money differ from continental bonds? In what respect was continental money a part of the revolutionary debt? What became of this money? How was revenue raised by congress? Why was it not well for congress to try to coerce a state? What came of the attempts to amend the articles?

II. What was the cause of the hostility between townspeople and country people? Explain the demand for paper money. What was the demand of the merchants in regard to the import duties? How did the country people regard these demands? How did the opposition of these classes result?

III. What danger lay in these dissensions? How did Virginia and Maryland come to hold a conference in regard to smuggling? What was the result? Why did the Annapolis convention do nothing about trade? What did it accomplish?

IV. When did the constitutional convention meet? Where? What bold step did it take? Explain the nature of the first important conflict in the convention. How was the compromise made on the question of representation? Describe the dispute over the representation of slaves. How was it compromised? Why did some states hesitate to give congress power over navigation? What compromise was made on this question?

V. Describe the adoption of the constitution by the states. Why did some of the people oppose the constitution? What states failed to adopt when the constitution was first submitted?

VI. What states claimed most of the land west of the Appalachians? By what authority? To what government was this land surrendered? 
For what purpose was a portion of the land reserved? Describe the first Northwest ordinance. To what region did it apply? Who was its author? What did it propose in regard to slavery? What was the result in congress? What did the second ordinance provide? Through what stages would a territory normally pass? What did this ordinance say about slavery? Why did the South allow it to pass? Describe the township system.

VII. Describe the work of Daniel Boone for Kentucky. When did Kentucky become a state? Who was James Robertson? What was the Watauga association? What was the "State of Franklin"? How did it fail? When did Tennessee become a state? What were the services of John Sevier?

\section{SUGGESTED TOPICS}

The Nature of the Revolutionary Debt; Shays's Rebellion; The "Know Ye" Men ; the Men of the Constitutional Convention; The Struggle for Adoption in Massachusetts; The Adventures of Daniel Boone; The "State of Franklin" ; John Sevier as a Typical Frontier Leader. 


\section{CHAPTER XIV}

\section{THE ACTUAL GOVERNMENT}

IF we turn to the government under which the people lived in 1789 , the year that the new constitution went into operation, we A double see that it had two distinct and important parts. On government one hand was the state with a complete set of laws, officials, and duties; on the other was the United States, the union, with another set of laws, officials, and duties. The state was organized to do certain things, and the union or federal government to do other things. We shall now consider the most striking things that each had to do and show how they were done.

With the revolution the state replaced the colony and took under its authority most of the things the colony had been doing. It The duties saw that the people kept the peace and respected the of a state rights of their neighbors. If a man killed or injured another, or stole something, it was a state officer who arrested him. If two men disputed the ownership of property, it was to the state they appealed. State courts tried all such cases, and sheriffs, policemen, local tax collectors, and county officers all acted under the authority of the state. Thus, most of the things one saw before his eyes, things which seemed the chief actions of government, were within the realm of the state authority.

When the union was created, it was expected that it would not interfere with the power of the state over state affairs. EveryDuties of thing that could safely be left to the state was to be left the federal to it. But things that concerned all the states taken government together were to be given over to the federal government. Thus, no one state should have a right to declare war 
against a foreign power; for if it could do so, it would bring on war in which all the rest of the states must take part. Since all must join in fighting the war, it was right that all should consent to make the war. Therefore, the right to declare war was left to the union; and in the constitution it is stated that it shall be left solely to congress. Post offices and the mails, foreign affairs, coin-

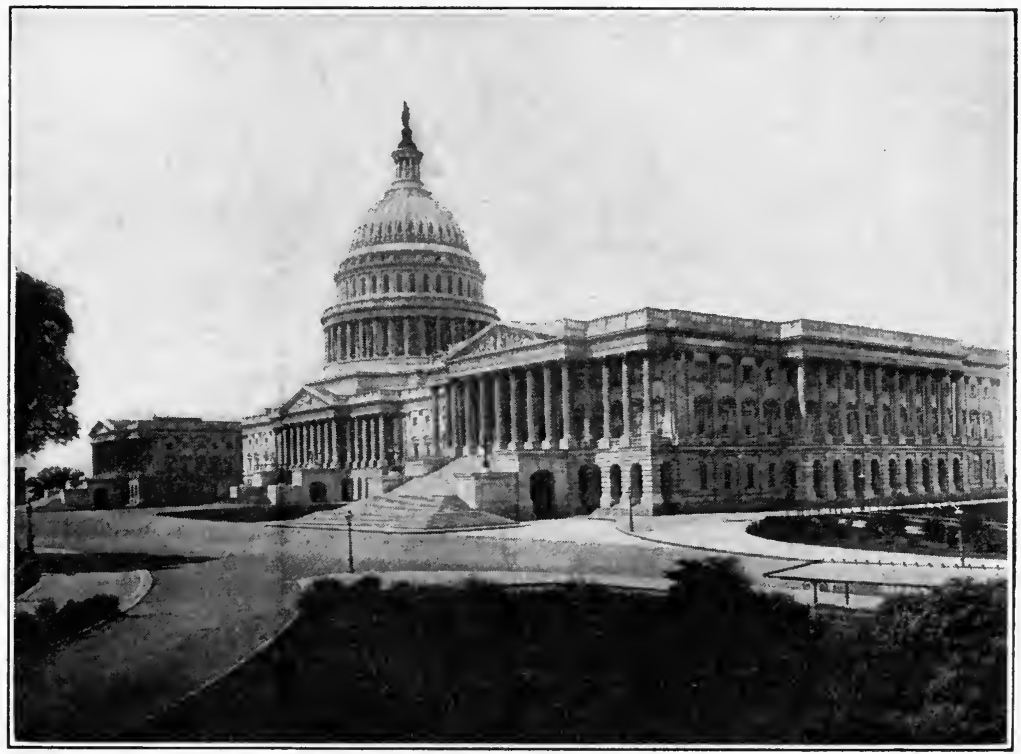

The Capitol at Washington

In this building meet the two houses of congress and the supreme court.

age, common standards of weights and measures, rules for commerce between the states, and the power to create and keep up a navy, were also left to the federal government.

The states have assemblies, or legislatures, to make laws on subjects that fall within their power. When a state law works badly, the legislature may make changes in The governit or replace it by a new law. The legislature meets the state 
at the state capital, in what is generally called the statehouse. It meets yearly in some states and once in two years in others. The people elect the members of the legislature by ballot. The legislatures consist of two houses, generally known as the senate and the house of representatives. In 1789 every state had some restriction on voting. In some of them a voter must own a certain amount of property; in others he must be a taxpayer. It was thought that a man who owned no property should not be allowed to take part in choosing the men who were to levy the taxes on men who did own property. None of the states now restrict the vote to property holders, but many of them deny it to men who cannot read and write.

The lawmaking part of the federal government is the congress. It makes laws on all matters which fall to the central government. The fed- Like the legislature it consists of two houses, a senate eral con- and a house of representatives. The senate is made gress up of two senators from each state. They are chosen for six years each, but they are so chosen that one-third go out of office every two years. The constitution of 1789 left the election of the senators with the state legislatures, but in 1913 it was decided that they should be elected by the people of the states. The representatives are elected by the people every two years, and they make up the house of representatives.

A bill is a proposed law when it is still being debated: as soon as passed it is a law, or an act. When introduced in congress, it must How a law is first pass the house in which it originates. If it fails made there, it is dead. If passed, it is sent to the other house, and if it passes there, it has passed congress. Then it goes to the president, and if he signs it, the bill becomes a law. If he vetoes it, he sends it back to the house in which it originated and gives his reasons for the veto. If two-thirds of each house passes it again, it becomes a law, notwithstanding his veto; otherwise it is dead. A law passes through a state legislature in the same way that it passes through congress. In all the states but one the governor has the power of veto. 
The senate of the United States does some things the house of representatives cannot do. For example, it approves or rejects treaties with foreign nations after the treaties have been Exclusive prepared by the president. The senate also approves power of the or rejects many of the high officers of the government. 'senate; The officers are selected by the president, and their names are then sent to the senate, which passes on them. If the president or other high civil officer is accused of wrongdoing, the charge is argued before the senate, which decides whether or not the charge is true. Such a trial is called an impeachment trial. The house of representatives does one important thing that the senate cannot do. It alone can orignate a bill to levy a tax. But of the the senate may amend the bill in the most extreme way house of when it comes from the house. The most important representtax bill is a bill to lay a tariff, and several of our atives tariff bills have been made over again when they got to the senate.

That part of the government which sees that the laws are carried out is called the executive. The sheriff is an executive in the county, and the mayor is the executive of a town The execuor city. There is a chief executive of a state and a tive of the chief executive of the United States. The former is state called a governor. In many states, in 1789 , he was elected by the legislature, but at present the governors are elected by the people. His term is usually four years. He cannot perform all the executive duties, and other executive officers take some of them. One such officer is the secretary of state, whose chief duty is to keep the records of the state government. Another officer is the treasurer, who keeps the money paid in by the people and pays out the money that the legislature orders spent. Still another is the auditor, who examines the accounts to see that the treasurer has not paid out what was not authorized. The auditor must report to the legislature how he has audited the accounts. The governor supervises all these and many other officers. His position 
is one of great honor, and the people look to him to see that good government exists.

Of greater honor still is the office of the president of the United States. He is elected for a term of four years. Those The federal who made the constitution did not think the people executive were wise enough to elect the best kind of man for president. They, therefore, arranged it so that he should be

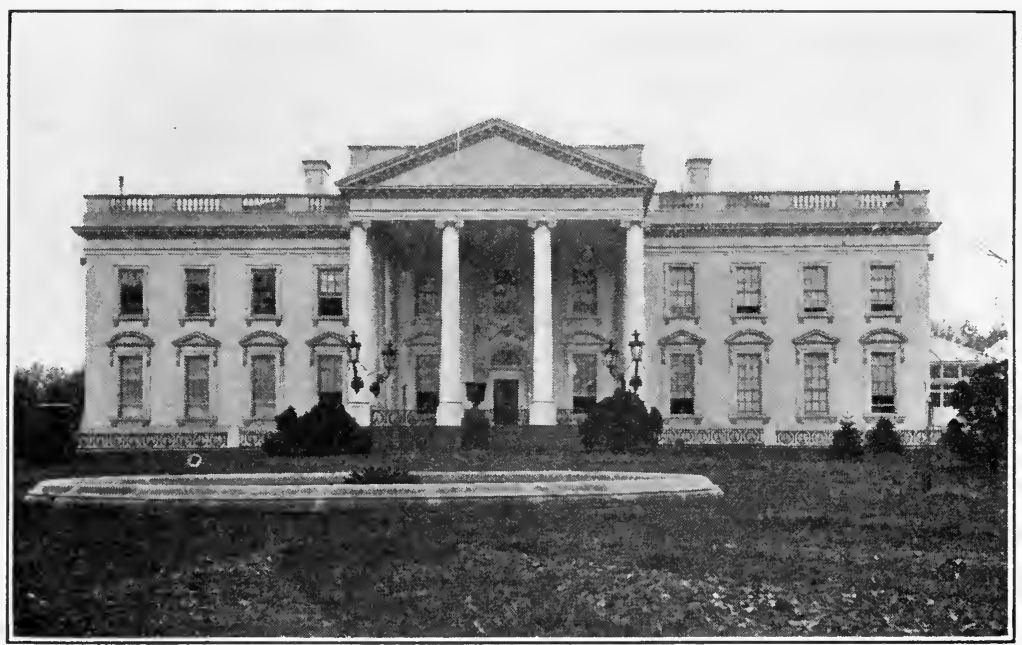

The president's mansion, popularly called The White House Built in 1800 and several times enlarged.

selected by a group of men known as presidential electors, who are now chosen by the people. Add together the number of senators and representatives allowed to a state, and you will have the number of presidential electors allower to that state. On a given day the people of all the states choose their electors. Then the electors of each state meet and vote for a man for president and another for vice-president. They send a statement of how they have voted to the senate in Washington, which counts all these 
votes and declares who is to be president. On March 4 after the election the man chosen is inaugurated president with great ceremony. He swears to see that the laws and the consti- Election of tution are enforced. At first it was thought that the a president electors would act on their own judgment and select the man they thought best; but it was soon seen that they were only agents of their parties and would vote for the men whom their parties had determined to have. The custom has arisen that a man may be chosen president a second time, but not a third time. Some people think this a bad custom, but the majority of the people seem unwilling to change it.

The duties of the president are many. Since he must approve all the laws of congress, he must know whether or not they are good laws. At first it was not expected that he would The presihave much to do with a bill until it passed congress and dent and came to him. But the custom has arisen of submitting lawmaking many laws to him in a private way before they go to congress. By this means he gives advice on the way a bill shall be written. $\mathrm{He}$ has much to do with the origin of the important laws.

Another important thing he does is to nominate the higher officers of government, subject to the confirmation of the senate. There are thousands of these officials, and much time is The appoint given by a president to this part of his duty. He can- ment of not know who is the best man for every place. He, officers therefore, takes advice from the senators and representatives, who are usually ready to suggest candidates. If there is a bill before congress which the president wishes to see passed, he may let it be known that he will not appoint a senator's friends to office unless the senator votes for the bill. Sometimes a senator is not willing to support the bills favored by the president unless he knows that the president is willing to take his advice freely in regard to appointments. This feature of our government sometimes leads to the appointment of men who do not make good officers.

The president is also commander-in-chief of the army and 
navy. He never goes into the field at the head of the army, but appoints the general who leads it. In time of war this becomes Commander- a most powerful function. But we must remember in-chief that the army and navy cannot exist without the money to support them. As long as congress alone can appropriate this money there is no danger that the president, whomever he puts at the head of the army, can make, the army do as he wishes.

A great many men are necessary to perform the duties that the government must do for the people. These duties are classified The great in departments of administration. One relates to depart- foreign affairs, another to financial affairs. The conments stitution gives congress the power to create these departments as they are needed. When the government was established under the constitution, three departments were created; that of the secretary of state, which has oversight of foreign affairs, that of secretary of the treasury, and that of the secretary of war. At the head of each was placed a prominent man. After a while a secretary of the navy was established. We now have ten departments, and the heads of them are as follows: secretary of state, secretary of the treasury, secretary of war, attorney-general, postmaster-general, secretary of the navy, secretary of agriculture, secretary of the interior, secretary of commerce, and secretary of labor.

The president calls these heads of departments together to give him advice about important matters. He is not obliged to call The cabinet them or to follow the advice they give; but he usually is glad to have their opinions. When they meet in this way, they make what is called the cabinet. To be a member of the cabinet is a great honor, and the men selected for the position are usually the leading men of the party which has elected the president. If the president dies, the vice-president takes his place; and after him the cabinet members one after the other are to fill out the unexpired term. No cabinet member has ever come into the presidency by this means. 
If the president or one of the higher officers is guilty of a crime, he may be impeached. The house of representatives first takes up the case, and if it decides that the officer is guilty of Impeachwrongdoing, it presents charges against him before the ment senate, which proceeds to hold a trial. This step is the impeachment. If two-thirds of the senate vote to support the charges, the person impeached is pronounced guilty, and the senate fixes the punishment. Judges, members of the cabinet, and one president have been impeached. The states also impeach officials who have committed wrong in office. We must not forget that to impeach is only to bring charges.

The constitution of the United States says that there shall be a supreme court and such other courts as congress shall create. In the beginning, congress thought fit to establish two The federal grades of courts below the supreme court. One is a dis- courts trict court to which ordinary cases go in the first place. If the party who loses is not satisfied with the decision of this court, he may appeal to the circuit court of appeal, higher than the district court, and from that he may appeal to the supreme court. There is no appeal beyond the supreme court. Other courts have been created by congress for special purposes, as the court of claims. The object of these courts is to allow to every citizen the fullest opportunity to get justice. In doing this, the courts have fallen into the habit of giving every one a great deal of time to make appeals, and persons who are guilty have taken advantage of this to make appeals merely to postpone the day of punishment. The courts held under the constitution are known as federal courts.

Each state has its system of courts. Among the lowest are the mayor's court and magistrate's court and the police courts of the towns. Above these are the superior courts of the counties, and highest of all is the supreme court of State court the state. Not all the states use these names for their courts, and in some of the large cities the courts are so many that it is difficult to keep them in mind; but they all come within the 


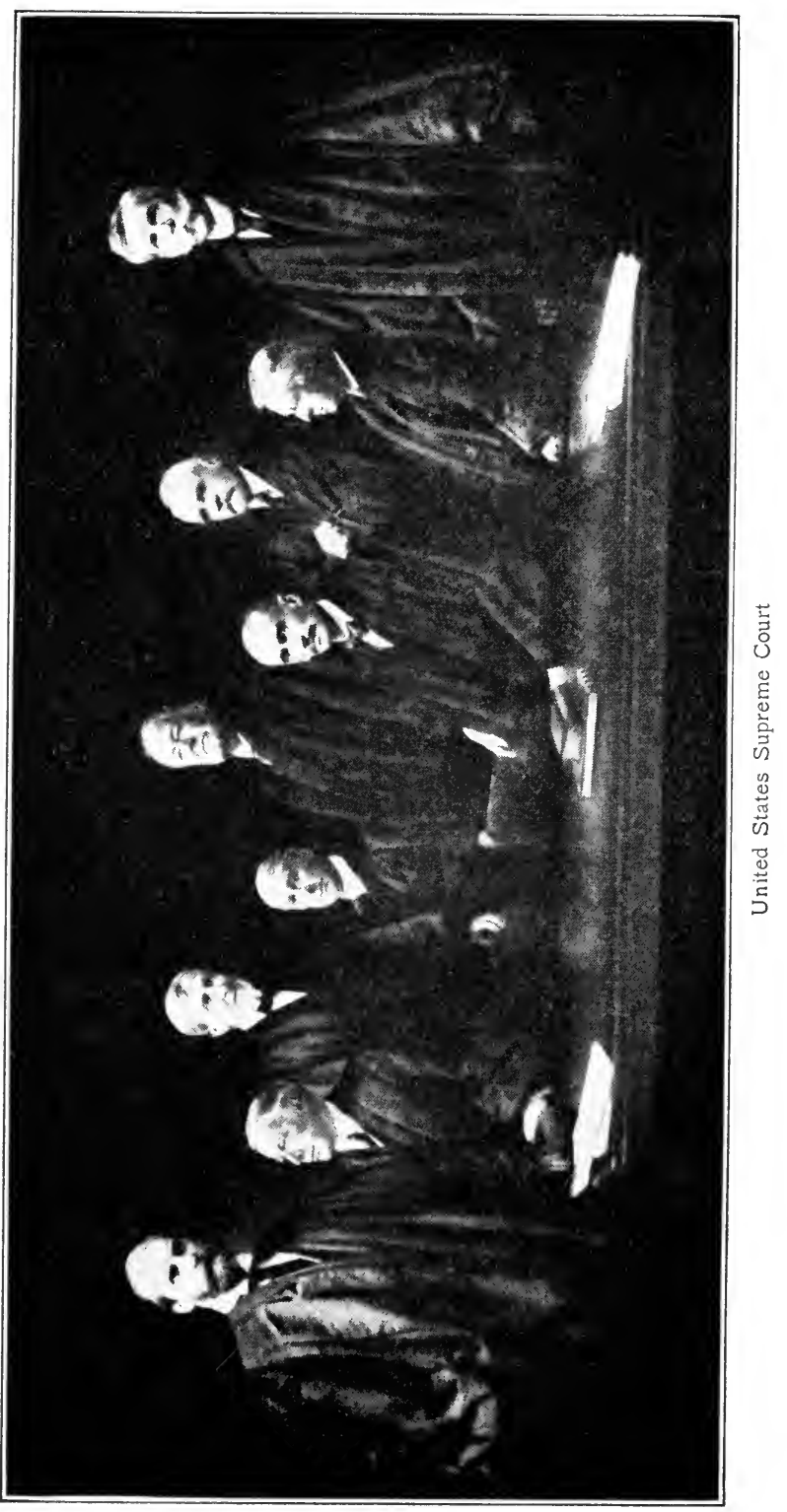


general classification just mentioned; that is, a lower court for trivial offenses, a superior court for ordinary offenses, and a supreme court for final appeal.

We must be sure to distinguish between a state court and a court of the United States, or a federal court. The first tries cases under the laws of the state, the second tries cases under the laws of the United States. The post office

\section{A caution} is under federal supervision, the laws that carry it on are federal laws: if a man robs the mail or a post-office clerk takes the money he receives at the stamp window, he violates federal law, he is tried in a federal court, and if imprisoned, he is usually sent to a federal prison.

The judge presides over the court. He hears the evidence at the same time that the jury hears it, and he determines whether or not it is legal evidence. After the evidence has been offered, the lawyers for each side make speeches to the

A trial jury, each trying to make the jury think that the evidence favors his own client. Then the judge sums up the case on its legal side, leaving the jury to say what the evidence is worth. He will frequently use words like these : "The legal point for you to decide is : Did such and such a thing happen as claimed? Certain witnesses assert that they saw certain acts committed. If you believe they spoke truly, you must find that the charges are true. It is for you to say whether or not the evidence is sufficient to prove the charge." It is the duty of the citizens to select good judges and to give them the greatest respect when they are in office. The federal judges are not elected. They are nominated by the president and approved by the senate. In most states the judges are elected by the voters.

The constitution of the United States may be amended in two ways. A new convention must be called when two-thirds of the states ask for it, and if two-thirds of each house of con- Amendgress pass an amendment and it is then approved by the ments legislatures of three-fourths of the states, it becomes a part of the 
constitution. All the amendments made to the constitution have been made in the latter of these two ways. The state constitutions are amended more freely than the federal constitution, and some of the states provide for conventions at regular intervals to take up the question of amendment.

The American government is a wonderful piece of machinery. Since every citizen at some time must take part in directing this machinery, it is his duty to know all he can about its construction. The merely general description that has been given in this chapter ought not to satisfy any wide-awake pupil. He ought to read further in some larger description, and especially he ought to find opportunity to visit the courts, the election booths, and, if possible, the legislatures, so that he may see the machinery of government in actual operation.

\section{QUESTIONS}

I. In what respect is our government dual? What kind of duties fall to the state? Give illustrations. Describe generally the duties of the federal government. Give illustrations.

II. Describe the work of a state legislature. How is the legislature made up? how elected? What restrictions were formerly placed on voting? What is the duty of congress? How many houses has it? How are the senators chosen? the representatives?

III. What is a bill? a law? an act? How does a bill become an act? What power has the president in making laws? How may a law pass against his will? How does a law pass in a state legislature?

IV. Name some things the senate may do that the house of representatives may not do. How are the higher federal officials appointed? What may the house of representatives do that the senate may not do?

V. What do you mean by the executive? Name some local executives. What officer is the chief executive of a state? of the United States? How was the governor elected shortly after the revolution? How long is his term? Name some of the other executive officers of a state. What are their duties?

VI. Who is the federal chief executive? How long is his term? How is he elected? How are presidential electors chosen? What custom exists in regard to the reëlection of presidents? What does the president have to do with the passage of a law? Describe his power in making 
appointments. How does it work? What is his military power? How can he be kept from using the army as he pleases?

VII. What is a department of state? What is the head of a department called? Name the heads of the departments now existing. What is the cabinet? Who succeeds the president? For what is a high officer impeached? What are the proceedings in such a case?

VIII. What does the United States constitution say about eourts? How many grades of courts exist under this constitution? What is the order of appeal in these courts? Name some special courts. What are federal courts? Describe the state courts. What is the difference between a state and a federal court? How is a trial conducted? What part does the jury take? What is the part of the judge?

IX. How may the constitution of the United States be amended? Which method has always been used? Why is it important that all should know how our government is conducted?

\section{SUGGESTED TOPICS}

Write a Bill on a subject assigned by the teacher ; write a veto message of the said bill; The Impeachment of President Johnson ; The Nomination of Abraham Lincoln ; Chief Justice Marshall as Interpreter of the Constitution. 


\section{CHAPTER XV}

THE NATIONAL GOVERNMENT UNDER THE FEDERALIST PARTY

There was much bitter opposition to the adoption of the constitution in the years 1787 and 1788, when it was before the states.

The conSome men opposed it because they thought it took stitution too much power away from the states, others because supported by they thought it enabled the central government to inthe people terfere too much with the liberty of the citizen, and others because they thought a strong central government would become a despotism. Most of these men were honest in their views, but they were needlessly alarmed. They were disappointed because adoption had been carried, and it was freely predicted that they would make trouble sooner or later. This prediction was not fulfilled; for as the years passed and none of the expected evils came to pass they became good friends of the new government.

Two parties soon appeared. One was composed of those who had long favored a stronger government. They used the name The feder- federalist because it was popular. It was the name alist party taken in 1788 by those who favored "federating," or drawing the states closer together. Among its members were the merchants, wealthy planters of the South, and many men of education and conservative ideas everywhere. As these men were the leading men of any community in which they lived, they were able to carry many of the middle and poorer classes with them. When a country is beset by dangers, the people of every class naturally turn to the men they can trust. Thus the first senators and representatives elected under the constitution were the most 
respected men in the country; and that is the way the federalist party got control of the government. We shall see how an opposition party was formed against it.

The first president was Washington. No elector voted against him, and he was inaugurated April 30, 1789, with the approval of all the people. He was a man whom any one could washington understand, plain-spoken, honest, and unselfish. He as president held office for eight years, at the time when the new government was being put into operation. During this critical period the people felt that their affairs were in steady hands and were satisfied. Washington preserved the dignity of the government, and he did not hesitate to show that it was strong enough to make itself obeyed. He did not wish to take sides with any party, and took men of all opinions into his cabinet. He was, nevertheless, in sympathy with the federal-

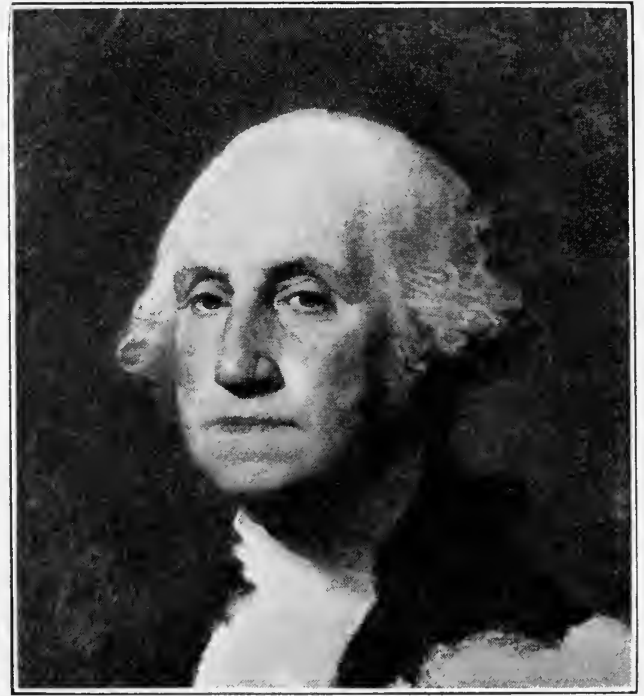

George Washington ists, and before he ceased to be president he began to lean to their party.

The leader of the federalist party was Alexander Hamilton, of New York, whom Washington made secretary of the Hamilton's treasury. He was a very able man and understood plan for the finance better than any other prominent man of his day. debt He had to prepare a plan for paying the national debt and getting 
money to run the government. His principles were simple. Let us pay all our debts at par, he said, just as we promised to do in time of war. Most bonds had recently been selling for much less than their par value. As soon as Hamilton proposed to pay them in full, speculators began to buy them up at the market price and they would make money if Hamilton could finally get congress to take them at par. Hamilton's plan was opposed by some of the best men in congress. They said it was only a scheme to enrich the capitalist, and it was

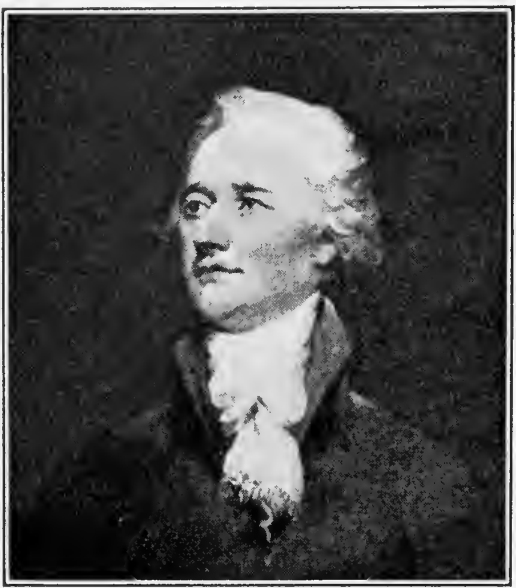

Alexander Hamilton charged that members of congress were buying up the bonds cheap and voting to have them paid at par. To all that was said Hamilton had one reply: It was none of his business what the speculators did. There was the plain fact that the people held the promises of the government to pay certain amounts of money, and if the credit of the government was to be respected in the future, the promises must be redeemed dollar for dollar. He was right in his contention, and the people saw it. Congress passed his bill and the debt was paid as promised. From that time he had the earnest support of the business men of the country.

Hamilton's next proposition was that congress should pay the debts which the states had incurred to carry on the revolution. Assumption These debts, he said, were made for the common cause, of state and all the states should unite in paying them. Much debts can be said for this plan, but it met with violent opposition. Some thought it was only offered to make Hamilton and 
his friends popular in the states which found it hard to pay their debts, others thought it a bad example for the future, and Virginia, which had already paid her revolutionary debt, thought she should not now be called on as a part of the union to help pay the debts of other states. After a warm debate it was voted that the federal government should assume the debts. The total national debt at that time was $\$ 77,500,000$.

Hamilton's third suggestion was a great national bank. It was opposed by his enemies because it gave too much power to the federal government; but congress adopted it, and A national Washington approved. The bank's greatest service bank to the country was that it issued a large amount of its own bank notes, which the people were willing to take as money. This gave the country a sound paper money, and that was an advantage to a people who had no gold and silver mines and whose small banks issued notes that were of very doubtful value.

Hamilton proposed to get the money he needed for the expenses of the government from duties laid at the ports. He also suggested that these duties be made high on all kinds of Protection manufactures so that the Americans would find it prof- of manuitable to establish factories of their own. This is the factures doctrine of protection of American industries. It was not adopted by congress when Hamilton suggested it. The only thing congress would do of that kind was to lay moderate duties to get a revenue. Twenty-five years later it adopted the policy of protection.

Another plan of Hamilton was to lay an excise tax. This was a tax to be collected on spirituous liquor, and it was payable at the distilleries. His idea was that the excise would not only An excise yield revenue, but that it would also make the people tax who paid it realize the authority of the new government. They would respect, he said, a power which could make them pay taxes. Congress passed the excise bill, and soon the back counties from Pennsylvania to Georgia were highly dissatisfied. They had been 


\section{THE PLAIN STORY OF AMERICAN HISTORY}

making whisky for years. It was the only thing they made that they could send to market with profit.

Pennsylvania went farther than any other state in protest. The people of the western counties refused to pay the excise, Whisky whipped some of the officers who tried to collect it, and insurrection held large meetings denouncing the government. This event, which was called the whisky insurrection, was used by Hamilton to make a demonstration of the power of the federal government. He persuaded Washington to call out 15,000 troops from the adjoining states, and marched with them into the western counties of Pennsylvania. It was three times as many as were needed, and before them the western farmers gave up all thought of resistance. From that time the excise was paid regularly. But the people of this region were stout opponents of Hamilton in politics, and one of the first things done after congress passed out of the control of the federalists was the repeal of the excise act.

Hamilton's leading opponent was Thomas Jefferson, of Virginia, whom Washington appointed secretary of state. He was as able Thomas a man as Hamilton, but his ability was of another kind. Jefferson It was as a leader of men of average intelligence and motives that Jefferson showed his greatness. He rejected the idea that only the best informed and most intelligent classes should rule. He felt that while the men of average minds might sometimes fail to do the best things in government, they were not likely to have bad motives. He believed that we may trust the people, and he set out to show the people that they could rule themselves. He believed that Hamilton's policy of bringing into the federalist party the men of wealth tended to form a government which had no sympathy with the people. Jefferson called his party the republican party.

In 1796 it became necessary to elect another president. WashThe election ington had been in office through two terms, and reof $\mathbf{1 7 9 6}$ fused to serve another. He was worn out in body, and wished for rest on his plantation at Mount Vernon. The 
federalists voted for John Adams, of Massachusetts, and the republicans for Jefferson. Hamilton could not be a candidate because his financial reforms had made him unpopular. The electors chose Adams president and Jefferson vice-president. It showed that the country was not yet willing to give up the federalists, who had established the government wisely under Washington.

Adams had one term, 1797-1801. He was a very honest man, but Adams and he did not know Hamilton how to make himself popular. He made many enemies, among them Hamilton, who wished to lead the party. Hamilton showed his dislike of Adams very plainly, and finally was at open war with him. The result was the complete defeat of the federalists in 1800. After that they were never again able to have a president.

The most important

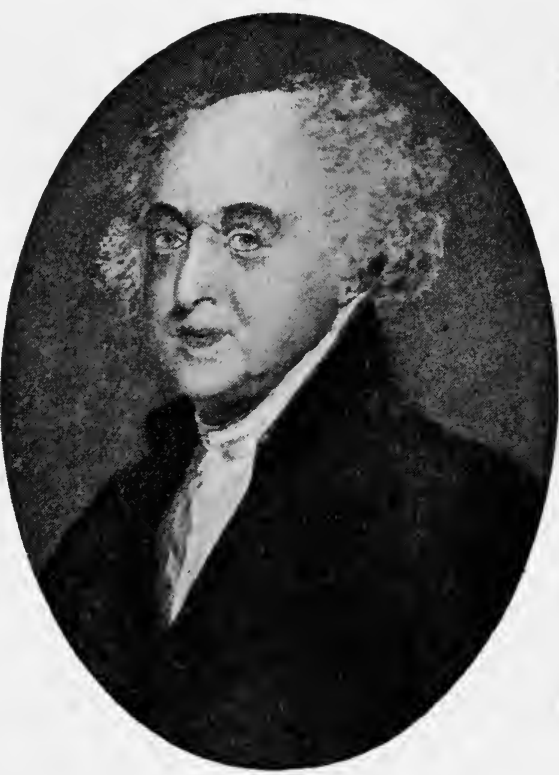

John Adams thing in Adams's presidency was the quarrel with France. It is a long story, and goes back to the presidency of Washington. In 1793 the Beginning of French people beheaded their king, and were at once the quarrel attacked by the other kings of Europe. They thought with France they had a right to expect American sympathy, first because France had helped us in our struggle against England, and secondly because France was now a republic and the war was 


\section{THE PLAIN STORY OF AMERICAN HISTORY}

really fought by the kingdoms of Europe to put an end to republicanism in Europe. But Washington saw that we were too young a nation to risk a war with any power. Although there was a great outburst of feeling for France in the Southern and Middle states, he issued a proclamation of neutrality and kept it strictly:

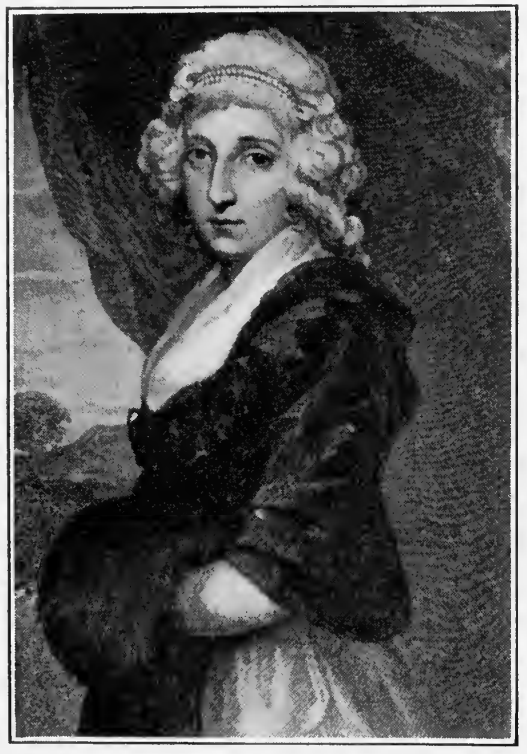

Abigail Adams, wife of John Adams

She was noted for her wit and beauty.

Soon after the war began Genêt (pronounced Zhennay), Genêt in minister from the America French republic, arrived in Charleston. He acted as though he were in his own country. He gave licenses to ships to become privateers and seize British trading ships, and he took steps to organize an army of Americans to attack Spain in Louisiana. This conduct aroused England, for it meant that Genêt was using our shores as a base from which to injure the nations at war with France. If we allowed this to continue, we were not truly neutral. Washington gave orders to stop the activities of Genêt, and when that gentleman at last arrived in Philadelphia, the seat of government, Washington received him with cool politeness. Genêt became very angry. He called Washington an "old dotard," and talked about appealing from the president to the American people. This threat was too much; for no nation can allow a minister, who is a guest within its borders, to take part in its own domestic politics. Washington sent a letter to Paris requesting the republic to call home its minister and send another. The 
request met a speedy acceptance. Orders came that Genêt be arrested and sent home for trial. His enemies in France were now in power, and it was evident that he would be put to death if he returned. Washington acted most generously, and refused to let Ġenêt be sent back a prisoner.

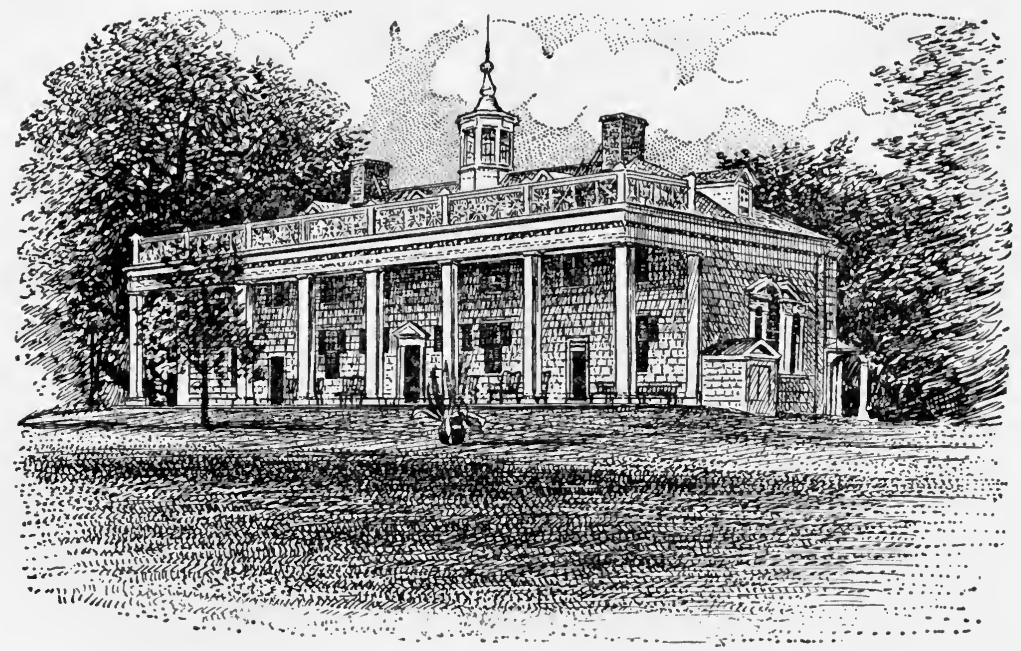

Mount Vernon

A year later, 1794, we negotiated the Jay treaty, a commercial treaty with England. Its terms were hard, and made it very difficult to carry on trade with the British West Indies, The Jay one of the most important fields of our commerce. It treaty was humiliating to make such a treaty, but Washington signed it because he thought it would keep us from a war with England. He said that if we could remain at peace for twenty years, we should be so strong that we need not fear war with any nation.

When the French learned that we had made a treaty with England in which we gave up so much to England's claim of superiority, 
they were very angry. The United States, they thought, had forgotten their old friends and were turning to that nation Indignation which was trying to stifle republicanism in Europe. of the

French The treaties we made with France in 1778 were still in force, and as they pledged us to an alliance with France against her enemies it seemed to the Frenchmen that we were violating our treaties.

In 1796 Pinckney, a new minister, was sent to France, only to be insulted. He was told that no American minister would be Pinckney received, and a hint was dropped that he had better insulted leave France. He did not choose to go on a mere hint, and lingered in Paris for two months, when he was plainly told that he was liable to arrest if he remained longer.

When the people of the United States knew how their minister had been treated, they were very angry. The insult was aimed

Three commissioners sent to

France at the whole nation, and everybody felt it. The more impetuous ones wished to declare war, but Adams was a prudent man. He acted on the principle that it is well to avoid war if possible. At his suggestion congress sent an extraordinary commission of three to see if France could be persuaded to patch up the difficulty. Pinckney was made a member of this commission, and Marshall and Gerry were appointed as his colleagues. They arrived in Paris in the autumn of 1797. They were not excluded from the country, but they could make no progress in their mission. The French minister of foreign affairs was the corrupt Talleyrand, who sent some of his friends to the commissioners with the private assurance that nothing could be done in France until money was paid to Talleyrand. Pinckney and his friends pretended not to understand. They were told plainly that money was needed, and suggested that $\$ 250,000$ paid to Talleyrand would enable the commissioners to begin their treaty making. The suggestion was met with a stern refusal, and the commissioners sent a full report of their experiences to President Adams. 
The matter was now laid before congress, 1798. The reports of the commissioners were published with only one change in them. Adams substituted the letters $\mathrm{X}, \mathrm{Y}$, and $\mathrm{Z}$ for the The XY Z names of the agents who had told the commissioners papers that money would have to be paid. He was very indignant, and said that he would not send another minister to France until he was assured that he would be received as the representative of a powerful and independent nation. The reports from the commissioners are referred to as the $\mathrm{X} \mathrm{Y} \mathrm{Z} \mathrm{papers.}$

Congress was as indignant as the president. It passed an act allowing the president to raise an army of 10,000 men to defend the country. It also created a navy department, warthreatand ordered that three new frigates and thirty smaller ened ships be built. The few ships we had in the navy were authorized to take any French ships that interfered with our commerce. These warlike measures did not go quite to the point of waging war against France. They might have gone that far if France had continued her course of contempt for the United States; but when she saw that we were in earnest, she became more pacific.

While war seemed probable, several sharp fights occurred in which French ships were defeated by American men of war. One of the ships was L'Insurgent, that had seized several American trading vessels. She was en-

Sea fights countered by the Constellation, whose captain, Truxtun, had been ordered to capture any French ship that interfered with our commerce. He gave chase and forced the Frenchman to fight him. In an hour the American ship was victorious, and the French captain came on Truxtun's deck as a prisoner. Within two years eightyfour French ships were taken by American ships. Had France wished war, she would now have declared it. But she allowed matters to drift along, and in 1798 she let it be known that she would receive commissioners to make a favorable treaty. Adams was too wise to refuse this opportunity.

A new treaty He sent new commissioners to France, and the result was a treaty 


\section{THE PLAIN STORY OF AMERICAN HISTORY}

from which the two nations had many years of peace. Thus by patience Adams saved the country from a war with France.

When the war feeling was at its highest point the federalists were very popular, and they became over-confident. They seemed to Overcon- think they could do anything they wished. While they fident were in this frame of mind they passed what was known federalists as the alien and sedition laws. The first was intended to deal with aliens, or foreigners, who were criticizing the president and the men who assisted him in carrying on the government. Some of these aliens were Frenchmen, some were Irishmen, and others were Englishmen. The law gave the president the power to send out of the country in times of peace any aliens whom he thought dangerous to the country. Another alien law was passed The alien to deal with aliens in time of war. It gave the presilaws dent the power to order aliens whom he thought dangerous out of the country, or to imprison them. These laws encountered a storm of criticism from the republicans, who pointed out that they enabled the president to persecute, if he wished to do so, any alien who dared state that he or his friends were in error. They held that in every free government there ought to be ample liberty to discuss the actions of the rulers, for in so doing it was possible to point out the evils of government and to give the people an opportunity to correct them through the elections. The right of free discussion of public affairs is ne of the chief means of protecting the liberty of the people.

Another law passed by the overconfident federalists was the sedition law. It applied to our own citizens, and forbade them to Sedition law say things which reflected on the wisdom of the government. The law declared that if a man was charged with this kind of offense he might be acquitted if he could show that what he had said about the officers was true. But it is hard to prove that such things are true, although they are strongly suspected. The sedition law was aimed at citizens of the United States and the alien laws at persons who were not citizens. They 
were all passed in 1798. They were bad laws because they lessened the right of discussion.

The republicans said a great deal against these laws. They declared that the purpose of the federalists was to make every man afraid to say that the president and the other men Political in office should not be reëlected. If this was allowed, capital it would make it hard to defeat for reëlection any bad officials who might be able to get into office. They said plainly that the federalists meant to persecute all who opposed them and thus secure their own reëlection through many years. One of the means the republicans employed to make it seem that the federalists were about to wreck the government was to adopt the Kentucky and Virginia resolutions.

The republicans were in control in the legislatures of Kentucky and Virginia and felt that if these two states issued strong resolutions concerning the alien and sedition laws, the people of the country would be aroused to defeat the federalists. The resolutions announced it as a doctrine that the states had the right to prevent the enforceKentucky and Virginia resolutions ment of an act of congress which it had no authority to pass. The Kentucky resolutions went further than those passed by the legislature of Virginia, since they seemed to say that a state could declare that a law of congress should not be enforced if its legislature thought the law was not authorized by the United States constitution. The contention that a state could do this would not be accepted now; for we should hold that it is for the federal supreme court and not for the legislature to say whether or not a law of congress is constitutional. In 1798 the power of the supreme court in such a matter was not so well established as later. The action of the Kentucky and Virginia legislatures made a deep impression on the people. It convinced many men that congress had gone too far, and the elections of 1800 showed that a majority of the people distrusted the federalists.

The Kentucky and Virginia resolutions were important for two 
reasons. They helped defeat the federalist party in the election of 1800 and they stated a doctrine which was later on widened into the South Carolina doctrine of nullification. Still later it was enlarged into the doctrine that a state may leave the union if it believes that the acts of congress are not constitutional. In its later form the doctrine was known as secession.

\section{QUESTIONS}

I. Why was the adoption of the constitution feared by some of the people? What predictions were made? In what respect were they not fulfilled? What classes came to the support of the constitution? How did the word "federalist" come to be a party name? What classes of society made up this party? Why was Washington the best man for the presidency? To which party did he lean?

II. Who was the leading man in the federalist party? What was his position in the cabinet? Describe his political views. What was his first task as secretary? What was his idea about paying the national debt? What objection was made to his plan? What did congress do about it? Why did he think the state debts should be assumed? What was done about this? What was the total amount of the national debt in 1790 ? What was Hamilton's third suggestion? Why was a great national bank needed? What was Hamilton's idea in regard to the upbuilding of manufactures? How long was it before it was adopted? Describe the excise tax. Why did the people of the back counties consider it a hardship? Describe the course of the whisky insurrection. How did Hamilton use the incident to increase the popular respect for the power of the federal government?

III. What position did Jefferson have in the cabinet? Compare him with Hamilton. Describe his political ideas. What party did he found? What was the effect on political feeling? Describe the election of 1796.

IV. What kind of man was John Adams? What were his relations with Hamilton? Describe the beginning of the quarrel with France. Why did Washington insist on neutrality? In what ways did Genêt abuse his position as minister? How was his mission terminated? What was the Jay treaty? Why did Washington accept it?

V. Why did France resent our acceptance of the Jay treaty? How did she treat Pinckney? What prudent course did President Adams follow? How were the three commissioners treated in Paris? What 
proposition came from Talleyrand? How was it received by the commissioners? Explain the X Y Z papers. What warlike steps did congress take? Was this war? What was the effect on France? Describe Truxtun's fight. How did the French government treat these attacks? How was the French quarrel at last ended?

VI. Describe the federalists' feeling of overconfidence. What is an alien? What were the alien laws? How were the alien laws received? Why should we allow the people to criticize their officers freely? What was the sedition act? At whom was it directed? On what grounds were these laws denounced?

VII. What were the Kentucky and Virginia resolutions? Why were they passed? In what respect did the Kentucky resolutions go farther than the Virginia resolutions? Why are these resolutions important? How were they related to the later announced doctrines of nullification and secession?

\section{SUGGESTED TOPICS}

The Inauguration of Washington; The Financial Plans of Alexander Hamilton ; Social Life at the Capital in Washington's Time; The Whisky Insurrection; The Trial of Dr. Cooper under the Sedition Act. 


\section{CHAPTER XVI}

\section{THE GOVERNMENT UNDER THE EARLY REPUBLICANS, 1801-1811}

ThE republicans defeated the federalists in 1800 and remained the victorious party through every election until 1824. During The Virginia this long period every president was a Virginian and supremacy every vice-president but one was a New Yorker. The reason for this remarkable success is not hard to find. The federalists were chiefly men of wealth and social influence, and these classes are always a minority of the people. Among the republicans was the great mass of farmers, naturally the larger part of a nation whose people were mostly devoted to agriculture. Jefferson was wise enough to unite the small farmers in his party, and he and his Virginia friends were able to lead the party for twenty-four years. After a while it seemed that nobody but a Virginian could be elected president. When this became apparent, the republicans of the North came to feel resentment for the Virginians, and the Virginia leadership came to an end. The reader must not confuse the republican party of Jefferson's day with the present republican party, which was founded in 1854 .

The twenty-four years of republican control may be divided into two periods. The first extends from 1801, when Jefferson Two periods was inaugurated, to 1811. During this time the active leadership was Jefferson's. He was reëlected president in 1804 with a large majority of the electoral votes, and in 1808 he was so influential that he got his friend Madison elected to succeed him. In 1811 a group of young republicans came into congress determined to oppose the ideas of Jefferson. They 
thought the country had submitted too long to the overbearing attitude of England and they demanded war. They were republicans in principle but they were not Virginians. They were so strong that Madison let them have their way; and in 1816 they allowed Monroe, another Virginian, to be chosen president. But they controlled the action of congress in many respects and enacted laws which Jefferson would not have supported. The period during which the war republicans were at the head of the party lasted from 1811 to 1825. This chapter deals with the events of the earlier of these two periods.

The first thing that Jefferson took into consideration was Gallatin's the payment of financial the national plan debt. He very wisely appointed Albert Gallatin, of Pennsylvania, secretary of the treasury. Gallatin was born and educated in Switzerland, a country

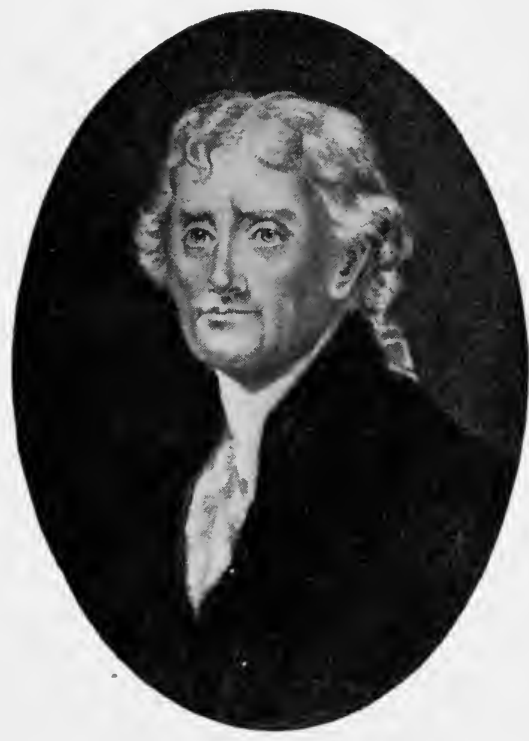

Thomas Jefferson from which many excellent financiers have come. It was his purpose to cut down all possible expenses and use the money he saved to reduce the debt. He thought too much had been spent on the army and navy and began his economizing in these departments. It was a great disappointment to the officers to find themselves dismissed and their regiments or crews disbanded. Gallatin did not think that we should never have a strong army or navy, but he thought we could get along without 
them for a while, and in the meantime the debt could be reduced. He made his calculation to pay off the debt in sixteen years. Jefferson approved all that Gallatin proposed and congress passed the bills to carry it out.

The plan succeeded better than Gallatin had claimed. The country was growing fast, and every year the government got Success of more money from taxes than it got under the federalists, the plan so that Gallatin not only did what he had expected to do, but had a large surplus. Had it not been for the wars in Europe, which after 1807 began to cut off our foreign commerce and thus reduce the amount we received from duties, the debt would have been paid earlier than predicted.

In 1803 the United States purchased Louisiana from France, gaining in this excellent bargain more territory than was formerly Purchase of comprised in all the states and territories. We were Louisiana lucky to get this vast region, and the way it happened was as follows: Napoleon, emperor of France, got the territory from Spain in 1800 to establish a great colonial empire in it. In 1803 he gave up the plan, partly because he found it would cost too much and partly because he was about to begin war on England and thought in such a war England would seize his colonies. He was, therefore, willing to sell Louisiana for a small sum, but he told his minister to get as much as possible.

Livingston, the American minister in Paris, was at this time trying to buy for his government a small strip of land on the The terms Mississippi where New Orleans is situated. One day he was talking with Talleyrand, the French secretary of foreign affairs, when Talleyrand said, "What would you give for all Louisiana?" Livingston was so much surprised that he did not feel like making an offer. He asked for time to confer with Monroe, who was expected in Paris in a few days. The negotiations were soon resumed; and, three weeks from the time the matter was first broached, a treaty was signed by which we were to have all Louisiana for $\$ 15,000,000$. Its western boundaries 
were not very clear at that time, but as they were finally settled they gave us all the territory west of the Mississippi as far as the Texas boundary and the Rocky Mountains. Jefferson was not responsible for the purchase: he only accepted a very favorable opportunity; but the people thought the purchase was due to his ability, and his popularity was greatly increased.

Just as this large area was added to our territory the explorations of Lewis Lewis and and Clarke, two Clarke American officers, gave us a claim to Oregon. They set out in 1804 to find out all they could about the country to the west of the Missouri valley. After suffering many hardships they reached the mouth of the Columbia on November 7, 1805. They took possession of the rich Columbia valley in the name of the United States and returned to the East in the following year with an account of what they had seen and done. Before this time the

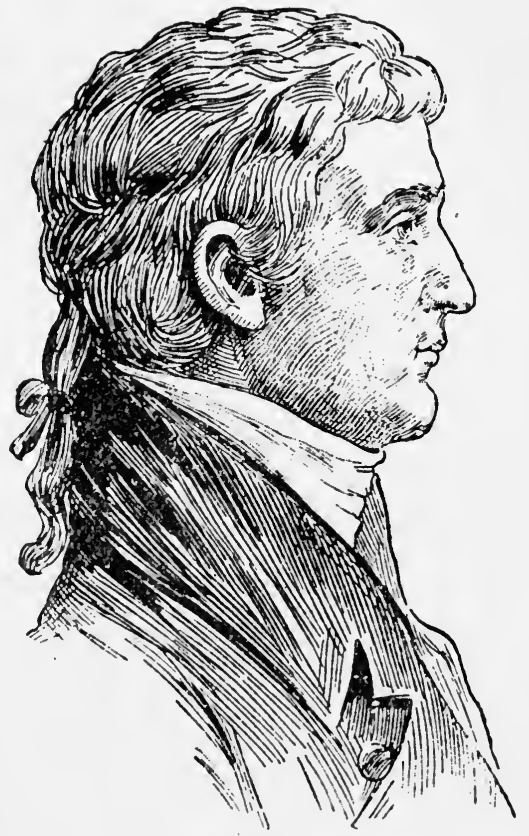

Meriweather Lewis Oregon coast had been visited from the ocean by English, Spanish, and Russian explorers. It soon became a question who had the best right to it. We claimed that as we had approached from the interior and explored the Columbia valley we should own and settle all that region. It was not until 1846 that the dispute was finally settled, when England agreed to take the region north of the forty-ninth degree while we took that south of it. 
In 1804 came another presidential election. The republicans renominated Jefferson, and the federalists took C. C. Pinckney, Election of of South Carolina, for their candidate. The record 1804 of the republicans was, so good that they carried all before them. When they came into office, the federalists declared that the country would suffer many evils. Not only had this failed to come true, but there had been very great prosperity. The

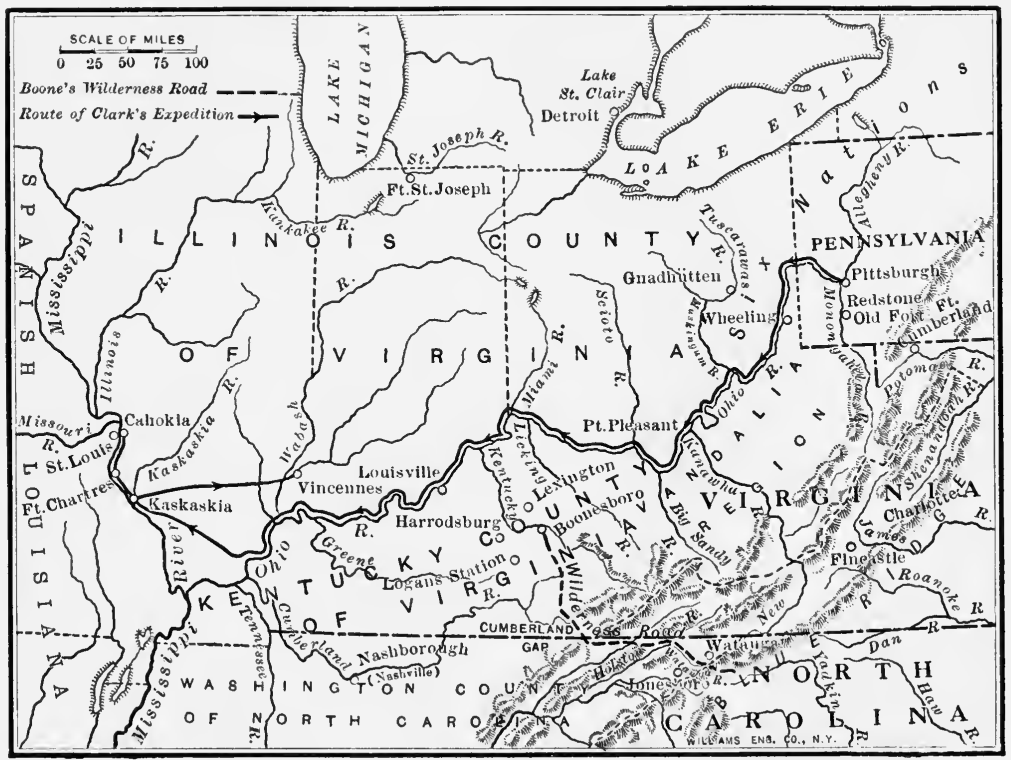

The Western country and the route of George Rogers Clarke

debt was being reduced, Louisiana had been acquired, and everywhere Jefferson had shown that he meant to treat friends and foes fairly and impartially. The result was that he received 162 electoral votes and Pinckney had only 14 .

Soon after Jefferson was inaugurated for the second time the country became full of reports of a scheme by Aaron Burr to 
create trouble in the Southwest. We have never been able to find out just what he had in his mind; for he told different stories to several persons to whom he went for aid. He told the Burr's bait English minister in Washington that he was going to for England raise an army of hardy men on the Ohio River, seize New Orleans, and make a separate government out of the region in southern Louisiana. Such a country, he said, could never manufacture its own goods and would be dependent on England for merchandise. This, he argued, made it England's advantage to help him. Let her only advance money enough to pay his army, and station ships at the mouth of the Mississippi to keep the United States ships away, and she would some day have a fine trade in the Mississippi valley. But England was engaged in war with European nations at that time, and offered neither money nor ships.

Then Burr turned to Spain, saying that he intended to seize New Orleans and set up a state which would be friendly to Spain and which would serve to keep the United States away from Mexico, then in the hands of Spain. The Spanish For Spain minister was pleased with this scheme, but his government would not furnish enough money to pay the army that Burr proposed to raise.

Burr was a very persuasive man and had great ability in scheming. He was soon in the West, that is, in Kentucky and Tennessee, talking with influential men and hoping to For the get them to raise the force that he wanted. These western men were too loyal to take part in an open attack on people New Orleans, and another story must be told them. Burr had it ready. He purchased an old land claim on the Red River and caused it to be known that he was raising a band of colonists to settle on it. As there would be much danger that his colonists would be attacked by the Indians they must go armed. To some of the influential men of the West he lifted the veil from a still more enchanting prospect. He told them that he would settle his colony near the Texas line, and then cross the line, wrench 


\section{THE PLAIN STORY OF AMERICAN HISTORY}

Texas and Mexico from Spain, and establish a great state in the rich lands he proposed to acquire. This was a very popular idea in the West, where Spain was much disliked.

Burr was thoroughly untruthful. As we see, he told whatever story he thought served his purpose with the person to whom he obscured was talking. It is very hard to say which of the by lies several stories expressed his real purpose. The people of the day believed that most of them were merely told to win support. He was a poor man and needed much money and a large number of bold men. He tried to get them by telling a network of lies. We shall, perhaps, never know just what was his real intention, but it is evident that he was a desperate and unprincipled man.

Burr named November 15, 1806, as the time he would set out from his meeting place on the Ohio on his mysterious voyage.

His journey

When the day came, the whole country was talking about his scheme. An indictment was issued against him in Kentucky, but it failed because nothing could be proved against him. Then reports reached Washington that he was going to attack New Orleans, and President Jefferson sent out a proclamation for the arrest of all who were planning treason against the United States. Burr heard of this order and did not dare wait longer on the Ohio. He placed what men he had, about sixty, on flatboats and started down the river. At Natchez, Mississippi, he learned that he would be arrested if he arrived at New Orleans. He deserted his followers and fled overland toward Florida, then held by Spain. Just before he could cross the line into safety he was arrested and sent to Richmond, Virginia, for trial. The charge was treason in levying war against the United States. To prove this it was necessary to show that he had collected an army with the intention of attacking New Orleans or other AmerAcquitted ican territory. The witnesses testified that the army assembled and set out for New Orleans, but that Burr was not actually there at the time. The court decided that this 


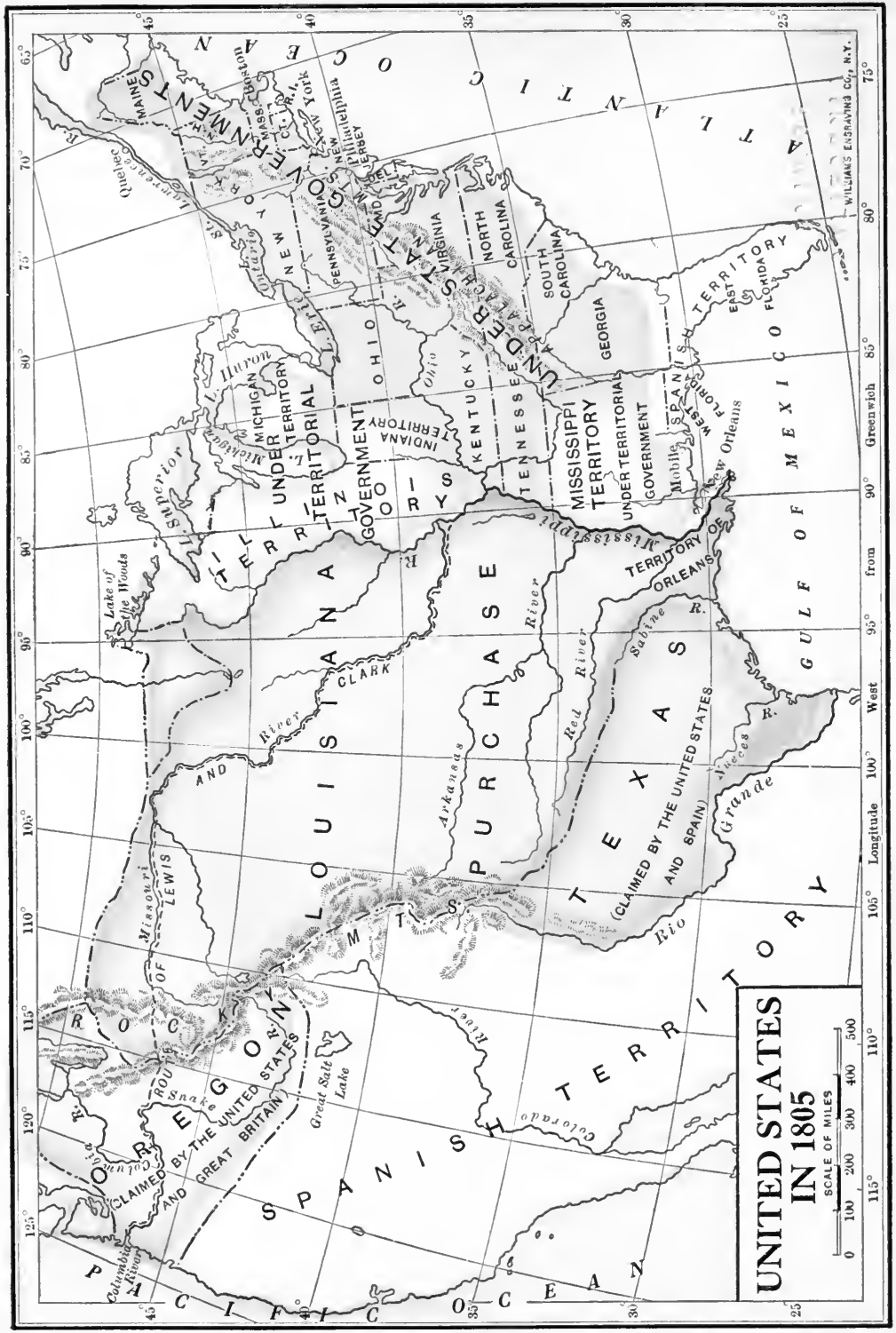




-4
$\vdots$
1
1
1


was not treason by Burr, since he was not actually present when the treasonable act was performed; and on this ground he was acquitted. The chief witness against Burr was General Wilkinson, who, it was generally believed, was at first in partnership with Burr and turned against him only when he saw that the scheme would fail.

The most important and the most troublesome matter in Jefferson's second administration was England's practice of seizing our merchant ships and impressing American sailors Jefferson's wherever she found them on the high seas. Jefferson peace policy was intent on preserving peace. Like Washington ten years earlier, he felt that the country was not strong enough to go to war. He thought, also, that war was a profitless waste of life and money and that any dispute could be settled by peaceful means if the rulers were only wise enough to try it. Many prominent men hold these views of war and peace to-day; but Jefferson was ahead of his time in holding them in 1806. When he tried to carry out his ideas, he failed, because the rest of the country was not so pacific as he. They would not put up with the insults of England, and they demanded war. Let us follow carefully the story of Jefferson's dealing with the wrongs we suffered at the hands of England.

Impressment was taking American seamen to serve on British ships on the ground that they were British sailors who had deserted. It is true that many British sailors did desert in Ameri- Impresscan ports, and they found many friends to aid them in ment escaping from the British service, which at that time was very hard. Such deserters would take the first steps in naturalization and claim the protection of the American flag. This practice should not have been allowed, and, of course, deserters were handed back to the ships when it could be proved that they were deserters. But there were so many opponents of England in the ports that it was hard to get evidence to prove desertion. The captains of British ships of war were not willing to wait on the slow process of 
the courts. They ran their ships alongside of American ships whenever they came across them and took off the deserters by force.

This was bad enough, but it went much further. The British captains had very little respect for our navy, because it could not Impress- meet the great navy of England. For this reason ments they did not stop with taking real deserters, they took abused whatever sailors they pleased, many of them persons who had long been American citizens, and sometimes they took native-born Americans. No American sailor on the high seas could be sure that he would not be seized and made to serve in the British navy. We made many complaints to England about this conduct, but we received only discourteous refusals to do justice. Impressments were in reality only a kind of bullying of a weak state by a strong one. They caused much hard feeling on the part of the American people.

The other cause of feeling against England was her restraint on our trade. From the beginning of her war with France she had Restrictions tried to keep American ships from carrying the sugar on American of the French West India Islands to the markets of trade

Europe. Many ships were seized because they did not observe her orders in this respect, but Jefferson was not ready for war and he was content with presenting claims for the damages done, in the hope that England might be induced to pay them.

In 1806 England took a more hostile attitude toward our ships. She was trying to starve France into submission by cutting off Blockades the American supply of foodstuffs. She declared a large number of French ports blockaded. This meant that British ships of war would capture and hold any neutral ships going to those ports. Napoleon, emperor of France, replied by declaring all the British ports blockaded. Then followed two British Orders in Council, and another French decree, the essence of which was that neither nation would allow an American ship to sail in European waters. If she was not taken by one nation, she would hardly escape the other. 
More of our ships were now being taken than ever, and there was danger that our people would get so angry that they would carry the government into war against its will. Jefferson was The emgreatly concerned and made a plan of his own to deal bargo with the situation. He proposed to lay an embargo on all American ships. This meant that he would let no American ship leave an American harbor as long as the embargo lasted. He thought that both England and France would need our wheat, corn, pork, and cotton and would change their laws in order to get it. $\mathrm{He}$ knew that to keep our ships at home would mean great loss to our shipowners and merchants; but he felt that the loss would be only temporary, and he thought that all true patriots should be willing to sacrifice something to save the country from war.

Congress passed the embargo at the request of the president and made stringent laws to execute it. It went into operation late in 1807 , but there was great trouble in enforcing it. America was then almost the only neutral nation that Its effects could take part in the carrying trade for Europe. Freight rates were very high, and the American skippers were reaping large harvests by carrying goods for the nations at war. They preferred to take chances on the sea rather than have their ships tied up at the docks. As many as could do so escaped to sea, but the majority remained at home unemployed.

At the end of a year England showed no signs of giving way. In fact, it seemed that she was satisfied with things as they were. France, also, was determined to enforce her decrees. But the Americans were suffering greatly. By the Repealed autumn of 1808 the farmers who made up the greater part of the republican party began to feel the pinch of the embargo, for they had just harvested their crops and could not export them. They complained so much that the leading republicans begged Jefferson to repeal the embargo. He replied that if the country would hold out a little longer, England must yield. But they became so insistent that he at last consented, and the embargo 
act was repealed in 1809 . In its place congress passed the nonintercourse act, which declared that our trading ships should not go to either Great Britain or France; but it gave the president the power to repeal this rule for the first of the two nations which repealed her restrictions on our trade. This act did no good. England and France were too bitterly at war to make concessions to what they believed a weak nation.

The failure of the embargo was the failure of Jefferson's hope that he could by peaceful means force England to give up her Drifting to- restrictions. He had suggested it in order to preserve ward war peace. Now that it was a failure, the country drifted into war. Every month something occurred to increase the hostility of the Americans for Great Britain. On the other hand the conduct of the British ministry was most unpleasant. They showed plain contempt for us, and did not take ordinary pains to remove our feelings of distrust. Thus throughout the United States the war spirit was slowly kindled and England was needlessly the cause of it.

While the people were talking about the embargo the presidential election of 1808 was held. Jefferson announced that he would not The election serve another term, and said that it would not be well of 1808 for any candidate to be elected more than twice. His action established a precedent from which we have not departed in any later election. But he was able to have James Madison, of Virginia, elected in his place. Madison was a republican, and carried out the Jeffersonian policies.

\section{QUESTIONS}

I. How long did the Virginians keep the presidency without interruption? What state usually had the vice-presidency? What was the cause of the republican success? Why did the Virginia influence at last break down? When was the present republican party founded? Into what two divisions was the period of republican rule divided? What new group of republicans appeared about 1811? What was their attitude toward a Virginia president? 
II. Who was Albert Gallatin? What was his plan to pay off the national debt? What was his attitude toward the army and navy? How did his plan work?

III. Why did Napoleon acquire Louisiana? Why did he decide to sell it? How was the bargain made? What were the boundaries? What was Jefferson's part in the purchase? How did it affect his popularity? Describe the explorations of Lewis and Clarke. What other nations had claims to the Pacific Northwest? How were these claims settled?

IV. Describe the election of 1804 . What were the reasons for Jefferson's popularity? Why can we not be sure about the scheme of Burr in the Southwest? What was his proposition to the English minister? How was it received? What did he tell the Spanish minister? How was it received? What did he say to the people of the West? How did his plan concern Mexico? Why are we justified in pronouncing Burr untruthful? Describe his journey down the Mississippi. What induced him to make it before he was ready? Deseribe the trial. On what ground was he acquitted?

V. In what manner was Jefferson embarrassed by our relations with England? What was his theory in regard to peace? Why did it fail? What was the practice of impressment? In what way were Americans in the wrong? How did the British ship captains show their opinion of the American courts? To what extent did they carry their misconduct?

VI. What was England's attitude toward our carrying trade with the French islands? What more severe regulations were made in 1806 and afterwards? How did Napoleon reply to them? What were the effects on the American trade? What was the embargo? Why did Jefferson. lay it? Which classes suffered most? How did the shipowners feel about it? What caused its repeal? What act took its place? How did the situation indicate war? How was England responsible for it?

\section{SUGGESTED TOPICS}

The War with Tripoli ; The Explorations of Lewis and Clarke; Pike's Journey into the Southwest ; The Two Sides of the Impressment Question ; The Trial of Aaron Burr. 


\section{CHAPTER XVII}

THE WAR OF 1812

ENGLAND's conduct caused many Americans to cry out for vengeance; but the men who directed the government were

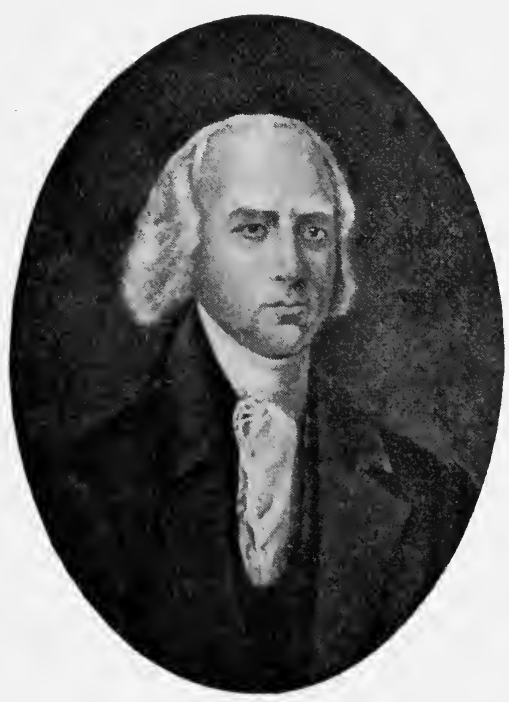

James Madison

Rise of the against war. Jeffer"war son, Madison, and hawks " their leading advisers had seen the dark days of the revolution. They remembered how hard it was to win independence, and feared to imperil it by beginning a war we might not win. It was better, they said, to endure insults a little longer. But there were many young men in the country who did not share their feeling of caution. They believed that we could defeat England, and demanded that we should give her fair warning, and then declare war if she did not relax her hard treatment. The

older leaders pronounced these arguments rash, and dubbed the young men "war hawks"; but the people were pleased, and in 1810 so many of the "war hawks" were elected to congress that they were able to control its action. By reason of our peculiar 
system they did not take their seats until late in 1811, but from that time the attitude of our government was warlike.

Madison himself became alarmed, as well he might be, for 1812 was an election year. He could not hope to be reëlected if he clung to the policy Madison's of peace at any change of price. After a while position he began to favor the war party, and soon afterwards the leaders of the war party announced that they were for Madison's reëlection. Among the young men who now took a strong hold on public affairs the most prominent were Henry Clay, of Kentucky; Grundy, of Tennessee; Peter B. Porter, of New York ; and three promising young men from South Carolina, - Calhoun, Lowndes, and Cheves.

The rise of the war feeling in the United States was known in England. The England ministers there did relents not wish war with us, but they

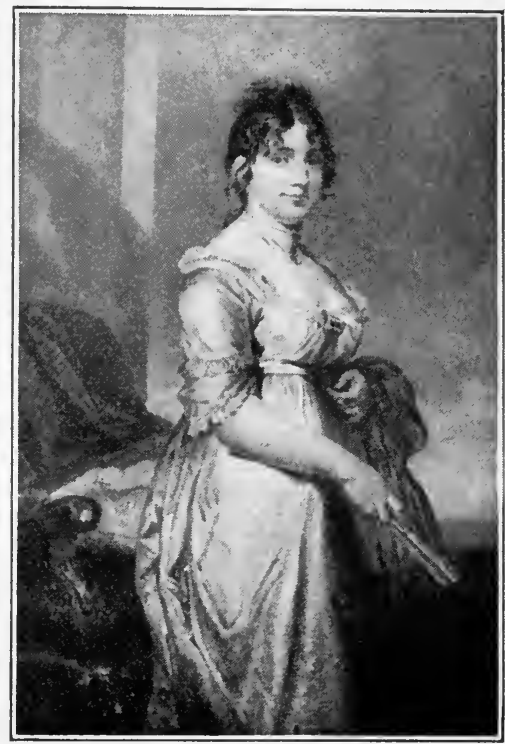

Mrs. James Madison

For many years the most popular woman in Washington

knew how pacific Madison was, and they thought they could do as they wished without arousing him to the fighting point. Now that the "war hawks" were in control these ministers began to show more courtesy. When they heard that congress had passed laws to raise a larger army and were about to order new ships for the navy, they knew the situation was serious. Then they began to talk of repealing their restrictions on American trade. June 16, 1812, they announced that the restrictions would 
be withdrawn, and a week later the withdrawal was actually made.

If a cable had connected the two countries, the war of 1812 would probably have been avoided. As it was, the American conWar de- $\quad$ gress passed a declaration of war on June 18, two days clared after the British ministry had given notice that they would repeal the chief cause of the war, the restrictions on our commerce. When the British heard that we had declared war in spite of their yielding, they thought that we might be induced to make peace without beginning to fight; but the American people were so thoroughly aroused that they would not think of peace. Great Britain was then straining every nerve to defeat Napoleon, and did not want war with the United States.

Most Americans believed that Canada could be taken in a few months. England was not able to spare from the war beyond the Our attack Atlantic enough troops to hold the country against a on Canada strong army from our side of the Great Lakes, and Canada herself was thinly settled. It seemed certain, therefore, that we should soon carry our boundaries far northward. Throughout the three years of the war we made our greatest efforts on this boundary. At first we were badly beaten, and then we were able to hold our own, but during the war we were not able to carry on a successful campaign in Canada itself. The cause of this failure was the weak organization of the American army and the poor commanders placed at its head. The soldiers were raw militia who had not been trained to serve against seasoned troops. The officers were appointed through political influence The army and knew not what a battle was like. As the war progressed the men learned better the business of the soldier. The good officers in the lower grades were gradually promoted to higher command, while the older commanders lost enough battles to insure their dismissal from high places. Had the war lasted another year, the army would probably have given a better account of itself. 
The second place at which we sought to injure our enemy was on the sea. England had many times as many ships as we, and she had swept her enemies from the seas in Europe so completely that she could send a large number of ships Our navy into American waters. But when the war began, she did not expect severe fighting from Americans and carelessly allowed her inferior vessels to meet us. The result was a series of brilliant American victories which opened the eyes of Englishmen. The

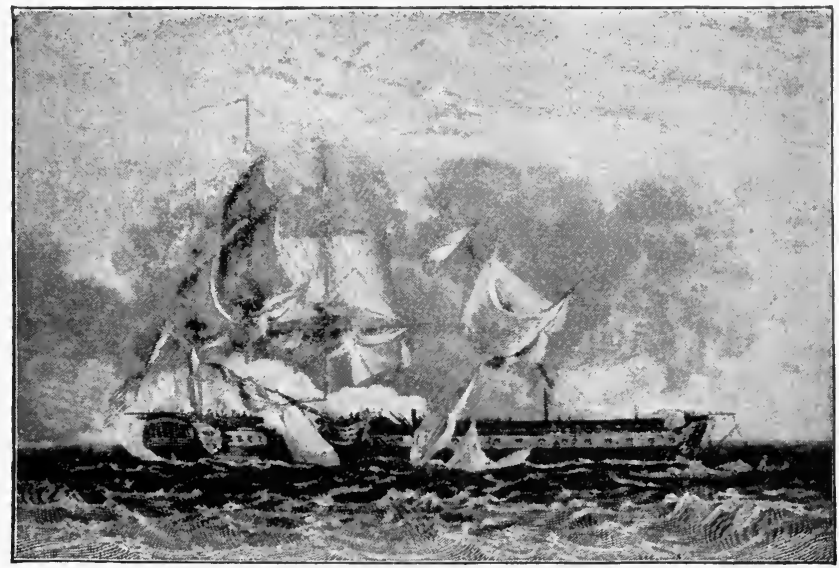

Battle between the Guerriere and the Constitution

first was the victory of the Constitution, commanded by Isaac Hull, over the Guerrière, a British ship which had become noted for impressments of American sailors. The American vessel was a little the larger, but Hull fought with fine skill and courage. No other antagonist, it was said, had ever overcome a British ship on the same conditions. As news of victory after victory came in, American pride in the navy reached high pitch, and before the war ended congress ordered that many new ships be built.

The American victories put England on her mettle, and she sent out her best ships. One of them was the Shannon, whose 


\section{THE PLAIN STORY OF AMERICAN HISTORY}

captain burned to redeem the honor of the British navy. $\mathrm{He}$ waited outside of Boston harbor until he met the American ship The navy Chesapeake, commanded by Captain Lawrence. A checked battle followed, in which Lawrence was defeated and killed. He was not prepared for battle, and should have avoided it; but he was too bold to run away. His last words as he

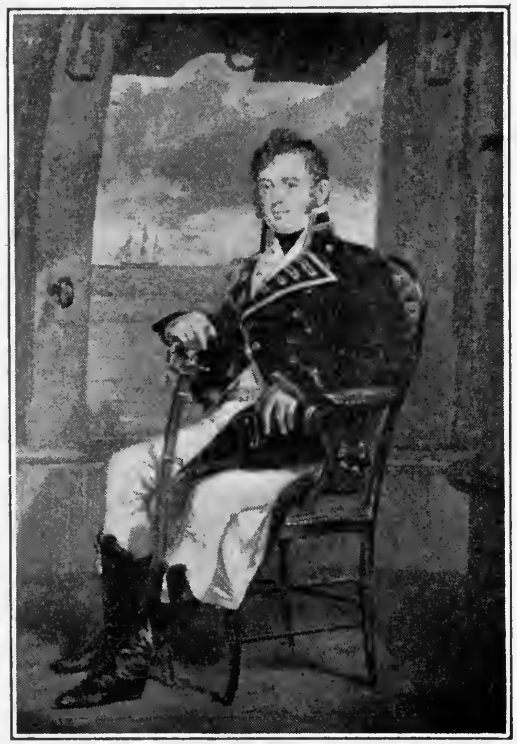

Captain James Lawrence

Commander of the Chesapeake was carried below, mortally wounded, were "Don't give up the ship"; and they became the motto of the navy in many a campaign. By 1813 the British had many ships in America, and they blockaded our ports so closely that our navy was able to do nothing more on the sea during the war.

On the Lakes, however, the American navy won two imOn Lake portant victories. Erie One was in 1813 on Lake Erie, when Perry, who had worked night and day to build his ships, met a British squadron and defeated it by hard fighting. The British ships were destroyed, captured, or driven into hiding, and the American flag went where it would over all parts of the lake. The result was that the British could not hold their forts at the western end of the lake, and all the region round Detroit fell into American hands. The other victory was won on Lake Champlain in 1814. The British had invaded upper New York with a great army, hoping to cut off New England from the rest of the country 
by taking the Hudson River. The expedition was like Burgoyne's invasion in 1777 , but it did not get so far southward. It was met on the lake by a small American fleet commanded by McDonough. In the battle the on Lake enemy concen- Champlain trated their attack on the Saratoga, the largest American ship. Two hours of hard fighting left her disabled, but McDonough skillfully turned her around and presented an uninjured broadside to the enemy. In a short time the

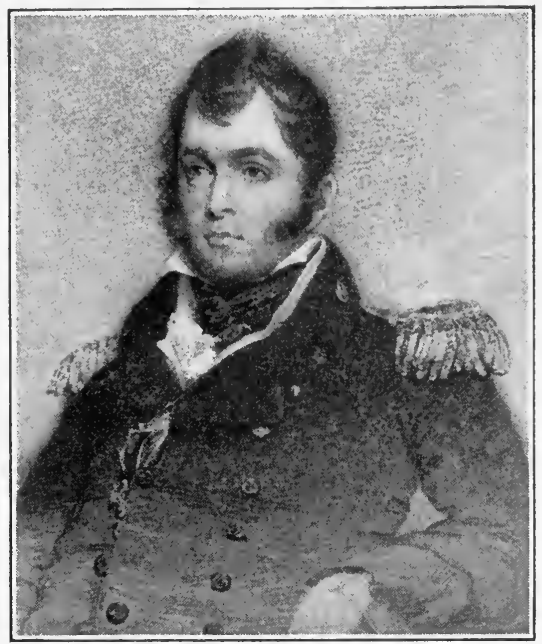

Captain Oliver Hazard Perry largest British ship struck her colors and the squadron drew off defeated. The result of the action was that the invasion of New York was abandoned.

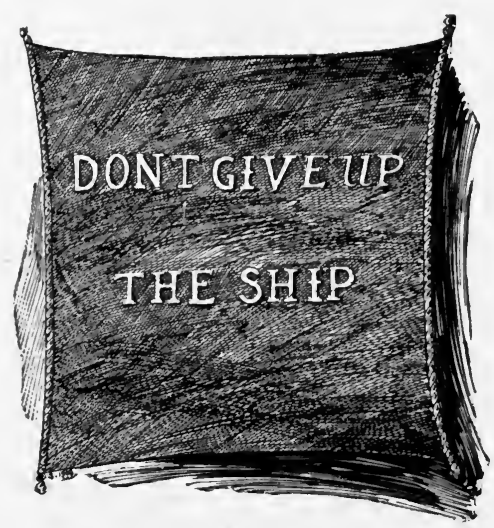

Perry's battle flag

While this campaign was being conducted, 1814, a strong British force was operating Washington around Washington. taken Landing on the shore of Chesapeake Bay it marched across the intervening country to attack Washington. The militia was hastily called out, but they had a poor commander. He posted them at Bladensburg, five miles from the capital, across the road by which the enemy was advancing. The battle was a 
disgraceful defeat for the militia. They had no confidence in their commander and ran at the first fire. The British followed them and took Washington without further opposition. They burned the capitol, the president's mansion, and the offices of the secretaries of the departments. They claimed that it was legitimate retaliation for the destruction of buildings in what is

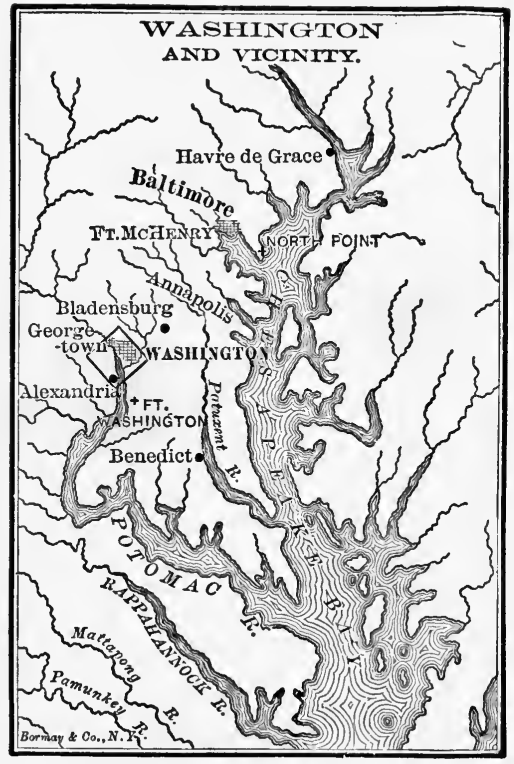
now Toronto, which had suffered in an American raid in 1813. But the damage they did was much greater than we had done in Toronto, and the pleasure with which the British general burned the buildings in Washington showed that he wished to do as much damage as possible.

From Washington he turned to Baltimore, a place from Failure to which many fast take Balti- ships had gone out more to destroy British merchant vessels. He was very anxious to make it smart; but the people were aroused by the fate of Washington and made heroic efforts to save their town. They threw up breastworks before the British army and sunk ships in the harbor. The enemy tried to destroy Fort McHenry, which commanded the harbor, but failed after an all-night bombardment. Nor could the troops carry the breastworks. The campaign proved a failure, and the army was placed on its transports to be sent against New Orleans later in the year. It was during the night attack on the fort that Francis Scott Key wrote "The Star-Spangled Banner." At the time he 
was a prisoner on a British ship and waited the dawn with great anxiety to know if the American flag still floated over the fort.

Let us now turn to the Southwest, where a more fortunate campaign was fought by the militia. Tennessee and Kentucky were very eager for the war to be declared, and very cautious willing to take part in it. They hoped it might lead Spain to the expulsion of Spain from Florida, but Spain was too cautious to give us an opportunity to attack her. She was a close ally of England in the European war, but was careful not to take part in the struggle on this side of the ocean. This did not keep us from seizing Mobile in 1813. We claimed that it belonged to the United States by the Louisiana purchase treaty.

Late in the same year news came that the British were furnishing arms to the Creek Indians, in what is now Alabama. These Indians had begun to attack the settlers on the war with Tennessee border. The president immediately called the Creeks out a body of Tennessee troops to subdue the Creeks. They were led by Andrew Jackson, a militia general, who conducted his campaign amid the greatest difficulties. He remained in the Indian country throughout the winter, and in the spring of 1814 defeated the Creeks in a decisive battle at Horseshoe Bend. Most of the surviving Creeks fled into Florida, and the rest made a treaty ceding more than half of their land to the United States. This was so well done that the president made Jackson a majorgeneral in the regular army and appointed him to command the district in which lay New Orleans and Mobile.

In the autumn of 1814 Jackson learned that the British were about to attack the gulf coast. He made what arrangements he could to place his district in a state of defense. He The British was greatly puzzled to know where the enemy would before New land, but when they cast anchor before New Orleans in Orleans December he was in the city busily planning fortifications and calling to his aid all the available militia of the Southwest. After twelve days' hesitation the British army began to land on the banks 


\section{THE PLAIN STORY OF AMERICAN HISTORY}

of the Mississippi on December 23. The moment Jackson knew of the British movement, he ordered his army to attack. They fought a vigorous night battle; but the British were heavily reinforced during the night.

In the morning the enemy were too strong to be driven into the water, and Jackson decided to fall back a mile and intrench across Strong in- the strip of high ground by which New Orleans was trenchments reached. For two weeks each side prepared for the final test of strength, the British bringing up all their men to the

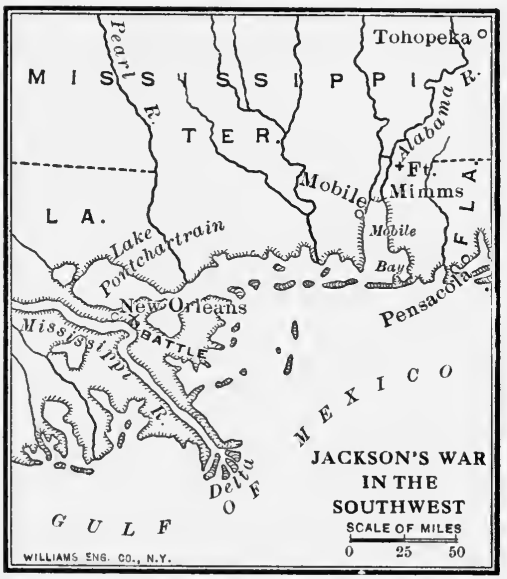
number of 10,000 and the Americans constructing excellent breastworks, behind which were nearly 6000 men, mostly Tennessee and Kentucky riflemen, noted for their good marksmanship.

The final attack was made at dawn, January 8, 1815. The Battle of British had defeated New our militia so often Orleans that they no longer respected it. One of their officers went into the battle clad in a red overcoat, and when told to remove it replied with disdain that he would never take off his coat before Yankee militia. At the close of the action he was found dead on the field. Had the British been cautious, they would have tried to get into the city by some other way than by scaling the works which the Western riflemen defended. As they rushed forward in strong columns they received at close range a steady and well-aimed fire that drove them back in confusion. A second and third charge were also driven back, and the troops refused to advance again. As the smoke of battle drifted away the ground before the American lines was seen to be strewn with dead 
and wounded. On it were the bodies of 1971 men, and the loss behind Jackson's lines was only 13 . The British commander, Pakenham, was among the dead. His successor was glad to embark the army and leave the coast.

The battle of New Orleans was fought after commissioners from the two nations had signed a treaty of peace at Ghent, December 24,1814 . Actual fighting should have ceased at Treaty of once, but it was not until February 11, 1815, that the Ghent good news reached New York in a vessel much delayed by storms. The terms of the treaty were favorable to. neither party. Both nations agreed that the war should cease, and that territory seized on each side should be given up. Nothing was said about impressment of sailors or trade restrictions. In fact, it was not necessary to mention these subjects; for England was now at peace in Europe and she had ceased to impress our sailors or to endeavor to interfere with our trade.

Two important results came out of the war: 1. It broke the power of the old republicans and placed in control of the party the leaders of the war movement. The old republicans were honest but timid, and they were afraid to underNew policies take new policies lest something happen to destroy the liberties of the people. The new leaders were not timid, and they were practical men. They believed that liberty was not in danger and were willing to make any law which the good of the country seemed to demand. We shall see in a later chapter that this spirit resulted in some very important legislation.

2. The war of 1812 , together with the four years of restriction that went before it, gave a great impetus to the growth of American manufactures. Through seven years it was difficult Manufacto import merchandise from Europe, and prices for tures manufactured goods rose. This gave the small manufacturers in New England and the Middle states an opportunity to make money. They enlarged their factories and built new plants, and before the end of the war they were making most of the things the 


\section{THE PLAIN STORY OF AMERICAN HIS'TORY}

people needed. A great deal of the capital that had been invested in commerce and shipping before the war was now drawn into manufactures.

\section{QUESTIONS}

I. Why did the older republican leaders hold to the policy of peace? Who were the "war hawks"? What influence did they get in congress? How did this strike Madison? What bargain was probably made? Who were the leading men of the war party? How did England view the rise of war feeling in America? What relaxation did she make? Show why it came too late. Was it possible to make an early peace?

II. Why did it seem certain that we should take a large part of Canada? What came of the attempts? What was the matter with our army? In what way did it improve?

III. What was England's strength at sea? Why were we able to win victories? Describe Hull's brilliant victory. What effect did this have on congress? on England? Describe Lawrence's battle with the Shannon. What was the effect of the British blockade on the American navy? Describe Perry's victory on Lake Erie. Describe McDonough's victory on Lake Champlain. What was the effect of each?

IV. Describe the attack on Washington. How was the place defended? What punishment was inflicted on it? How did the British justify their conduct? How were the British checked before Baltimore? What famous song was now written? By whom?

V. Why did the men of the West hope that Spain would take part in the war? What course did Spain follow? How did we get possession of Mobile? Describe the war with the Creeks. What was the result? Did all the living Creeks take part in the treaty that ended the war? Who won the Creek war, and what promotion did he obtain? How did Jackson receive the British when they first landed? Describe the battle of New Orleans. How did the British show contempt for the militia?

VI. What were the terms of the treaty of Ghent? What was won by the war? Why did impressment cease to be a matter of dispute? What change was now apparent in the policies of the republicans? To whom was it due? How did the war help the manufacturers?

\section{SUGGESTED TOPICS}

The Chesapeake-Leopard Incident; The President and the Little Belt; General William Henry Harrison; The History of the Flag; The Fight between the Constitution and the Guerrière; The Battle of New Orleans; Making the Treaty of Ghent. 


\section{CHAPTER XVIII}

\section{THE SETTLEMENT OF THE WEST, 1783-1820}

-While these difficulties occupied the time of persons connected with the government, the people were passing through a stage of great prosperity. The rich unsettled lands of the An era of West attracted the poor men, who were glad to establish prosperity farms of their own. The population grew rapidly, and there was always an increasing amount of trade to enrich the merchants. In 1790 the first census was taken. It showed that the entire population was $3,929,214$. Thirty years later, in 1820 , the population was $9,638,453$, an increase of nearly six millions. During this period the wars in Europe had produced so much confusion there that few immigrants had come to America. Most of our population, therefore, was of native American stock.

At the end of the revolution several thousand people had crossed the Alleghanies into Kentucky and Eastern Tennessee. Besides these two small groups no one but Indians lived in the Moving vast forest from the Great Lakes to the French and westward Spanish settlements along the borders of the Gulf of Mexico. In 1820 more than two millions of white men of English stock had made their homes there. As far west as the Missouri River the ax rang against the great tree trunks as forests fell in order that farms might be cleared. From the South and the North alike went emigrants to this region.

The movement of the Southerners was westward and southwestward. Most of those who went west settled in Kentucky and Tennessee. Every road across the mountains was full of wagons loaded with the household erners

Migration of the South- 
goods of men going to form homes in the rich lands they had heard about. In the older counties of the East appeared sharp men offering the western lands for sale at low prices. Sometimes a wealthy planter would buy a large tract and send his son with a group of slaves to clear and cultivate it. Sometimes it would be bought by small farmers who owned no slaves. Sometimes it was bought by rich speculators who expected to sell it after a while at a profit. In this way a great deal of the strength of the

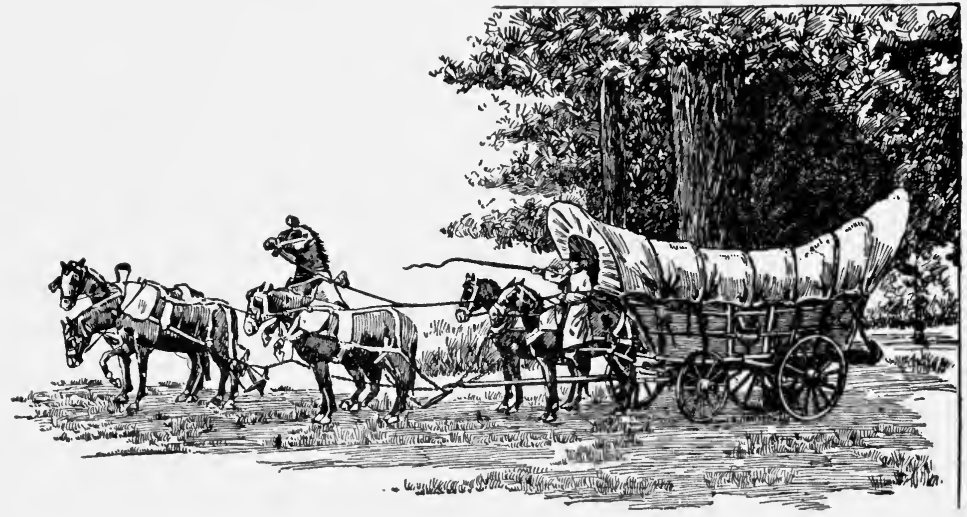

Conestoga Wagon and Team

Ordinarily used by people moving to the West.

East, both in population and in money, went away into the West. Those who stayed at home saw the process with regret. They did not believe in building up new settlements at the expense of the old.

In 1793 the cotton gin was invented by Eli Whitney. It was a machine to remove the seed from cotton, and it proved a great The cotton boon to the South. Before that time rice was grown gin in the swamp regions of the Carolinas and Georgia, and sugar in Louisiana. But most of the land of the South is sandy uplands, on which neither rice, sugar, nor tobacco was grown. 
It was adapted to the growth of food, corn, forage, and hogs; but there was no market for large quantities of such products. It was also well adapted for the growth of cotton, but no one had dreamed of giving it over to cotton because of the expense of removing the seed by hand. Cotton cloth at that time was sold at a higher price than the ordinary grades of woolens and linens. The invention of Whitney's gin made it possible to give this great interior region over to cotton cultivation. From North Carolina to southern Texas, and up the Mississippi River to northern Tennessee, lies the region in which our cotton crop is now raised. It brings more money into the country than any other crop we have. No other region has been able to take

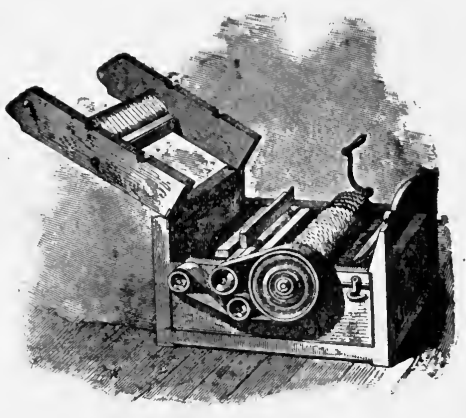

The First Cotton Gin away from our Southern states their position as the greatest cotton-growing region in the world.

The people of the Middle states who moved to the West turned naturally to the Ohio valley. Since the Virginians had preceded them into Kentucky, most of them took the country Middlenorth of the Ohio River. Great covered wagons carried states mithem over the mountains to Pittsburg and then across gration the plains to the southern parts of Ohio, Indiana, and Illinois. By this route came also a great many Virginians, particularly those who did not own slaves and wished to live where a poor man had equal opportunity with his neighbor.

The people of New England took a route still further north. They were charmed by the stories of lands so much Migration more fertile than their own and migrated in large from New numbers. They generally went first to Albany and England thence westward through the Mohawk valley. Western New York 


\section{THE PLAIN STORY OF AMERICAN HISTORY}

was unsettled at the close of the revolution, and it was here that the New Englanders first made their homes in the march to the frontier. By 1800 they had reached Lake Erie and were passing along its southern shore into Ohio. Connecticut had an old claim to land in this region, but she had ceded it to congress, reserving a generous slice in northern Ohio, which she sold to build up her school fund. This strip was called "the Western Reserve," and a large part of its settlers were from Connecticut. Thus it happened that the country between the Ohio and the Lakes was settled by two bands, or zones, of population: one from the Middle states and the South, and the other from New England.

Travelers who passed from one zone to the other before the civil war noticed a wide difference in manners. Near the Ohio Two zones the people lived in the good-natured ease of the of popula- Southerners. They had horse races when their tion hardest work in the fields was finished, shooting matches, country dances, and many other vigorous games. They settled as the land seemed good, and it was several years after a neighborhood was peopled before the rough frontiersmen began to think of schools and churches. In the northern zone the New Englanders settled in a very orderly manner. They were Puritans in their old homes, and they built churches and established schools as soon as they got their own cabins erected. They tried to build up the New England life in their new homes.

At first the only way of getting across the mountains was the roads which ran through unsettled wilderness. Of course, these Travel in roads were not kept in repair. They were used not the West only by the travelers who sought new homes, but great wagon trains moved along them, carrying merchandise to the settled communities beyond the mountains. In the rainy seasons they were nearly impassable. The inns were rude wooden buildings in which the guests had little comfort, and the food was often bad. Rich men organized the business of taking freight across the mountains, sending out wagons in groups. The drivers were 
the terror of unprotected women and girls. At first there was much rough living on the frontier, north and south, but the progress of civilization was steady, and rude manners yielded gradually to the influence of refinement.

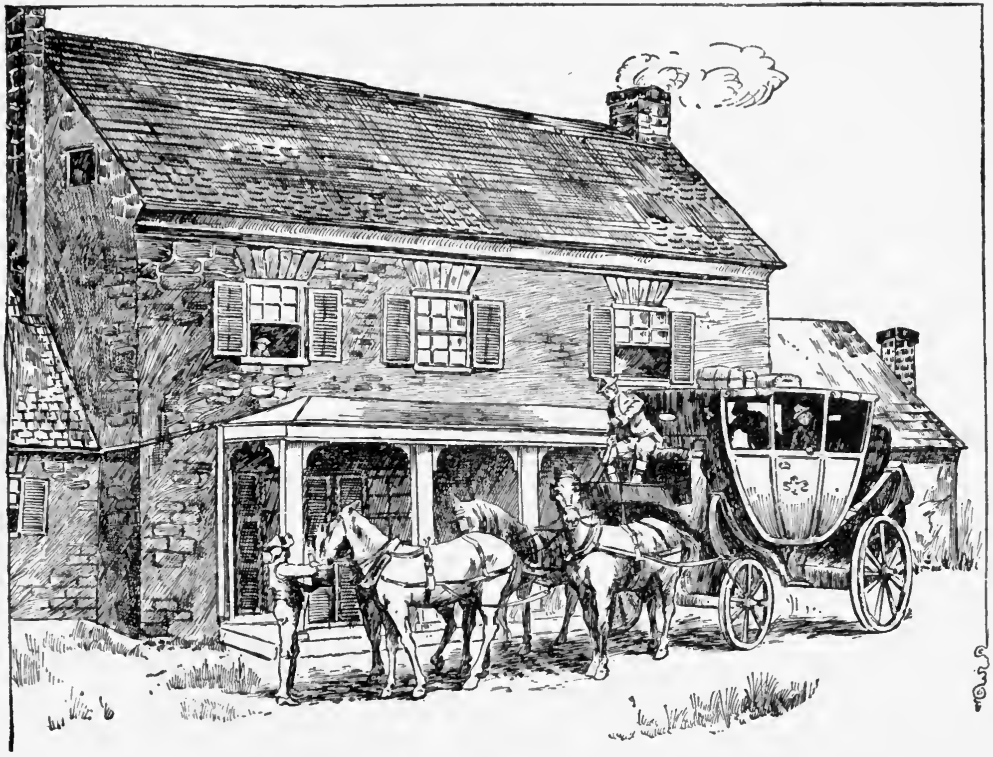

An Old Stagecoach in Early Kentucky

As population advanced into the West towns sprang up. Pittsburg, the western end of the wagon route over the Pennsylvania mountains, became a place of great importance. Near Towns in it were iron ore and coal, and it soon became an iron- the West manufacturing center for the Ohio valley. Further down the river was Cincinnati, which became the distributing point for merchandise throughout southern Ohio and part of Indiana. Still further on was Louisville, built at the falls of the Ohio, where the flatboats that came down the river must unload their produce. 
It was a place where the country produce of the interior was collected, and many a fine cargo was here made up and sent to New Orleans, where it passed into other hands before it went out to sea, to the markets of Europe. St. Louis was an old French town established where the Missouri River flows into the Mississippi. It was a sleepy-looking place under the French; but when

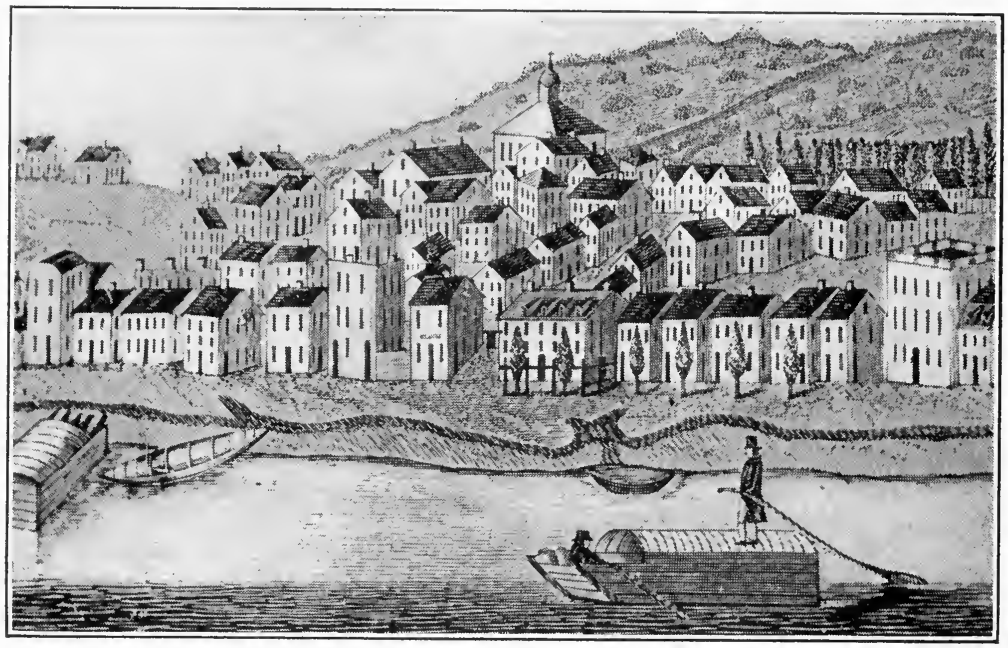

Cincinnati in 1810

From Howe's Historical Collections.

Louisiana became an American possession, American settlers began to arrive. They built warehouses, laid out streets, and gave the town such a bustling air of progress that the French inhabitants were shocked and declared that the strangers were spoiling their nice old town.

New Orleans was the most important place in all the West. New Here, also, the incoming Americans gave the place a Orleans new life of activity. The produce of the interior came down to it in great flatboats which could never expect to 
return against the current to the places whence they came. The cargoes were sold, and the hulks were taken to pieces and sold as lumber. In 1807 Robert Fulton invented the steamboat. It was a great thing for the whole world, but an especially great thing for New Orleans and the Mississippi valley. Ships could now go upstream, carrying manufactured goods to all parts of the valley. New Orleans not only received the produce from the

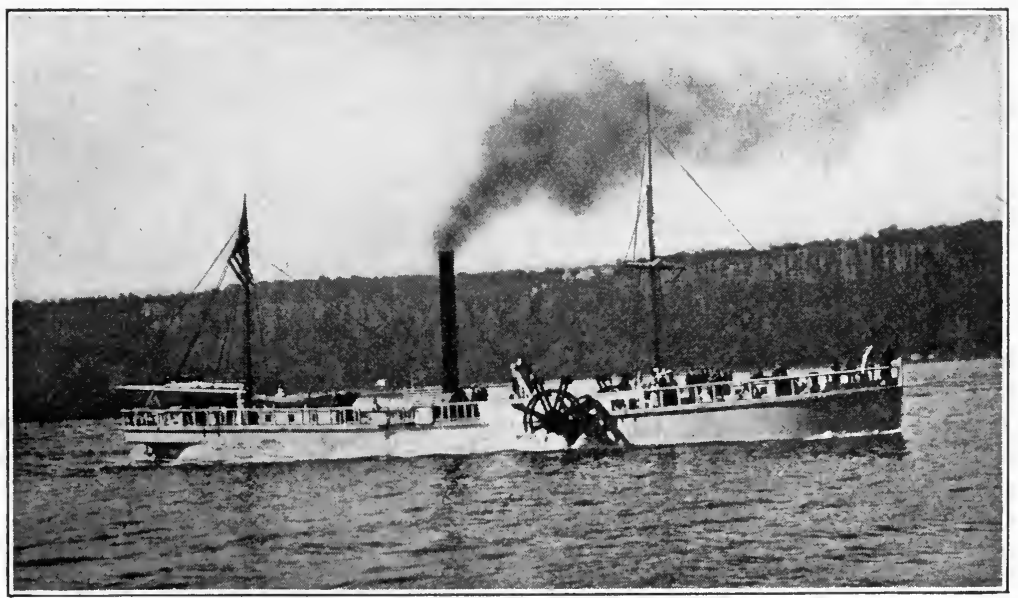

The Clermont, the First Steamboat

interior, but began to send back the merchandise the people of the interior needed. By 1820 steamboats were running on most of the important rivers in the Mississippi valley. They made New Orleans the center of a very large trade.

Thus all the life of this great valley was drawn down to the Gulf coast. From New Orleans the produce was shipped to all parts of the world. At the same time the merchants Its foreign of New Orleans imported from Europe the manu- trade factured goods that they sold to the people in the interior. It seemed to the merchants of the seaboard that the interior trade 
was likely to be lost to them indefinitely, and they did all they could to keep it in their hands. They could never hope to do this if they had to send their goods over the mountains in wagons.

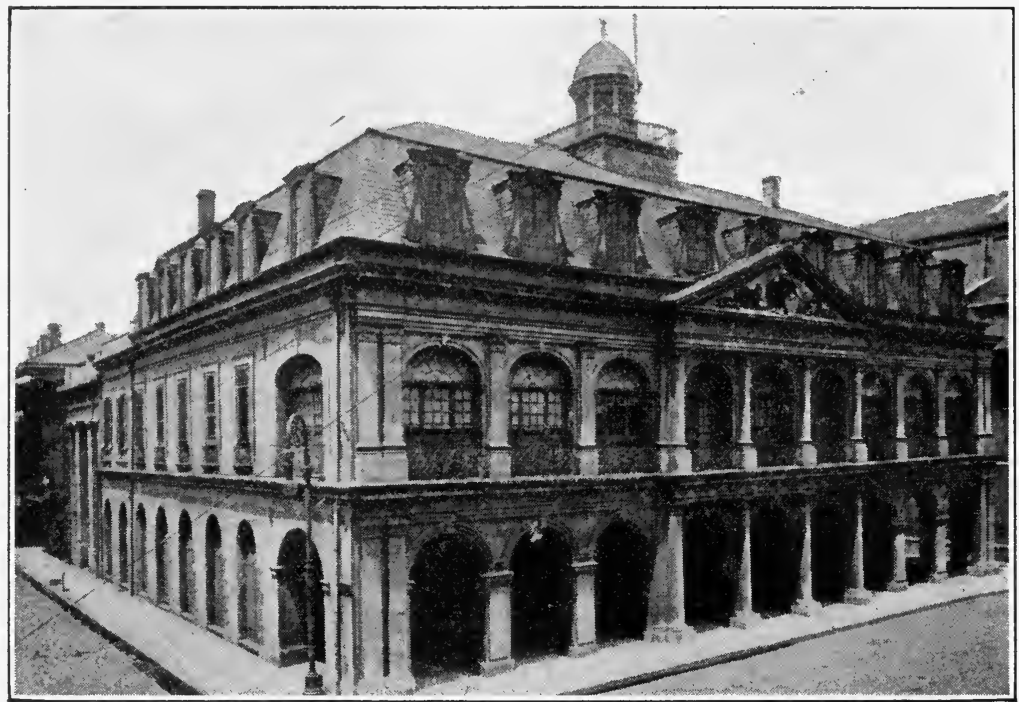

The Cabildo, New Orleans

Their only hope was to have a cheaper means of transportation to the watercourses of the Northwest.

If you will turn to a map of this region, you will see that nature has provided two means of reaching the Northwest by water. From Phila- One is by way of the Ohio River and the many smaller delphia to streams flowing into it. The key of this system is Pittsburg Pittsburg, and the seaboard city that was most convenient to it was Philadelphia, whose merchants set out to build a canal to the foot of the Alleghanies, going along the small tributaries of the Susquehanna. On the western side of the mountains another canal ran along the Monongahela to Pittsburg. By this means a water route was secured all the way to the Ohio, 
except for the short distance over the mountain ridge. How to get over that ridge was a serious problem. One ingenious man suggested that a tunnel be cut through the mountain at the canal level, so that the boats might go through, but nobody was willing to undertake so long a tunnel. The best that could be done was to make a good road over the ridge and trust to wagons. When

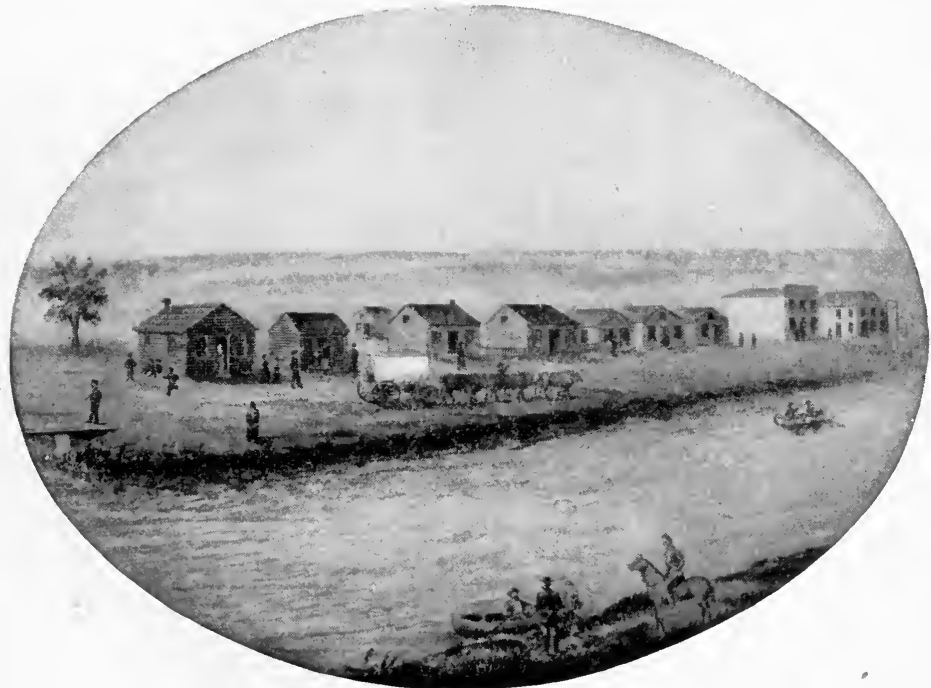

Chicago in 1834

railroads began to be built, about 1828 , it was easy to find a substitute for the wagon road.

The second advantageous way of getting to the watercourses of the West was through central New York to the Great Lakes. The merchants of New York were interested in this The Erie route, for it would deliver to them a very rich trade. Canal Governor De Witt Clinton, after much effort, got the New York legislature to supply the money for a canal from Albany to Buffalo. Thus was begun the Erie Canal, completed, after eight years of 
labor, in 1825. It runs through a region in which there are no mountains, and the water for it comes from the Mohawk River and a series of lakes in western and central New York. From Buffalo the produce of all the region that touches the Great Lakes can be

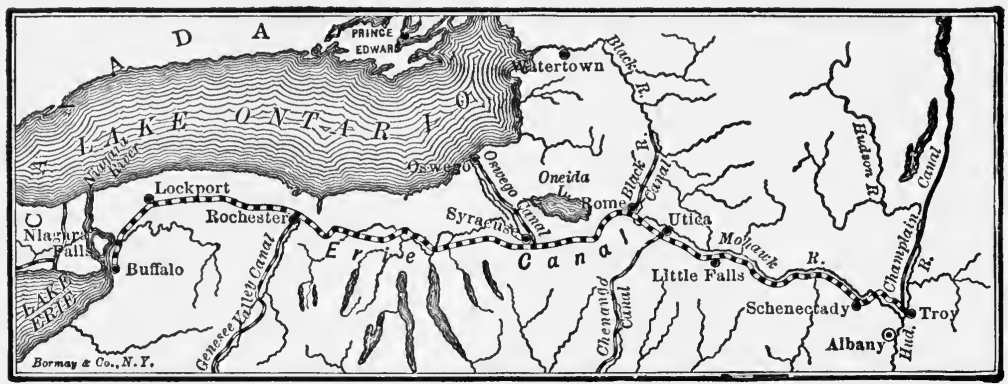

The Erie Canal

carried to the city of New York at cheap freight rates. Its construction vastly increased the amount of business done in the city of New York. Before that time Philadelphia was the largest city in the union, but it now dropped to second place, and although

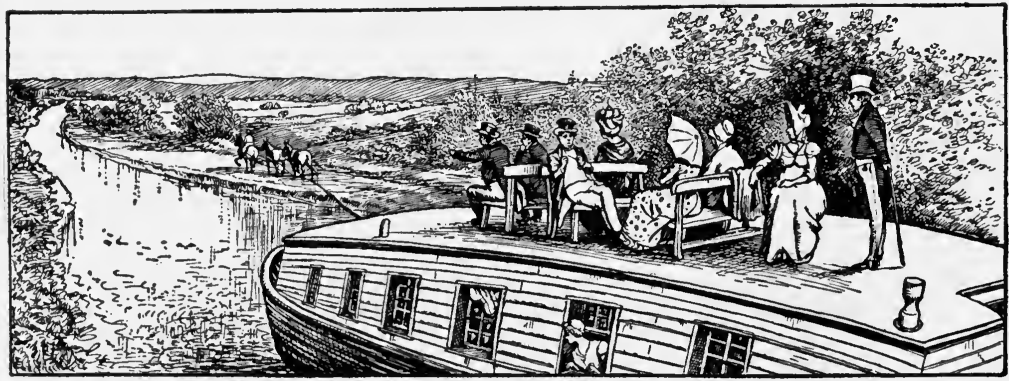

Traveling on a Canal Boat, 1825

its merchants have tried hard to preserve the business of the city, the first place has never been recovered. New York became the greatest importing city in the union. To it came large stocks of merchandise from Europe, and here assembled the Western 
merchants to buy the goods they expected to sell in their stores.

One of the most important things for the West was the regulations by which the government sold the public lands. Before the revolution the usual method of selling western Land land was to grant them in large tracts to rich men who speculators sent agents to Europe or through the older states to sell them in small farms. Such men were land speculators, and sometimes they made a great deal of money. Washington, Jefferson, and many other leading men of the revolutionary period secured large tracts of land beyond the mountains, expecting to sell it at a great profit.

This method of selling the public lands pleased the people of the East. They did not wish to see the laboring men of their own section moving away to the West to get farms at Eastern and small prices, since this lessened the supply of labor. western They thought that as long as the speculators dealt in interests the lands the prices would be high enough to restrain the poorest man from buying them in large quantities. They felt that the fairest way to all sections was to sell the lands to people who came from Europe. The people of the West wished to have their country settled rapidly. They always favored a liberal policy of selling the lands. It was not well, they thought, to hold back the West to serve the purpose of the East. There are two sides of most questions.

The demands of the West were so strong that in 1796 congress made a concession. It passed a law allowing any one to buy 640 acres or more at two dollars an acre, but no smaller More liberal tract would be sold. Hitherto the speculators had laws gone to Philadelphia to make purchases, but now two land offices at which purchases could be made were opened, one in Pittsburg and one in Cincinnati. In 1800 four other land offices were opened in the West, and it was provided that a man might buy as small a tract as three hundred and twenty acres at two dollars an acre, 
but the purchaser might have four years to make his payments. By this means a poor man might secure a farm and pay for it out of the produce he raised on it. These laws led many persons to move to the West, and that section began to grow rapidly.

The credit system encouraged men who were not properly settlers to buy land. They were really speculators on a small scale Creditsales and hoped that the incoming tide of immigrants would abolished raise the price and enable them to sell at a profit before they paid their debts to the government. A great deal of such land was never paid for. The purchasers continually bought more than they could sell, and in 1820 congress made a law by which all lands were to be sold for cash. In order to help the poor man and to encourage actual settlers the price was fixed at one dollar and twenty-five cents an acre and the smallest tract that would be sold was eighty acres. A small farm could thus be bought for $\$ 100$, which seemed as much inducement as the government ought to offer to any one.

It was expected that these prices would apply to moderately good lands. For the sale of exceptionally fertile tracts another Sales at provision was made. When the government decided auction to open a given region for sale, notice of an auction would be posted, at which land would be offered to the highest bidders, none to be sold for less than the regular prices just named. All that was not sold in such an auction could be had afterwards at the regular prices at a land office. Sometimes the best tracts sold for high prices. This was especially true of the rich cotton land in Alabama and Mississippi. Such high prices were offered by some bidders that the purchasers were not able to make their farms yield a profit. But in most cases the auctions were not a success. The people knew that all the land could be had for the regular price after the auction, and they preferred to take their chances under these terms.

In 1862 the government passed the homestead act, a law more favorable to the West than any previously made. This act pro- 
vided that every actual settler should receive without cost 160 acres of the public land. To others the price remained one dollar and twenty-five cents an acre. It was enacted The homethat timber lands should not sell for less than five stead act dollars and mineral lands for not less than ten dollars an acre.

Looking carefully into the history of the Western settlements, we see three classes of settlers. The first was the pioneer. $\mathrm{He}$ was a roving man who did not like to live close to the settlements. He always moved on when he found that The pioneer others were beginning to settle near him. He was not a farmer but a hunter and trapper. He went through the forests before they were well known to white men and was frequently as uncivilized as the Indian, in whose wigwam he was a welcome guest. His service was to discover the location of the good land, find out how the small streams ran, locate the Indian trails, open paths to the white man's country, and create in the settlements an interest in the particular district which he himself knew.

After him came the squatter. $\mathrm{He}$ was a The farmer squatter as well as a hunter. He moved into the wilderness before the government opened land for sale. He paid no attention to land offices, for he did not intend to buy. What he found he took, building his cabin where he liked, and making

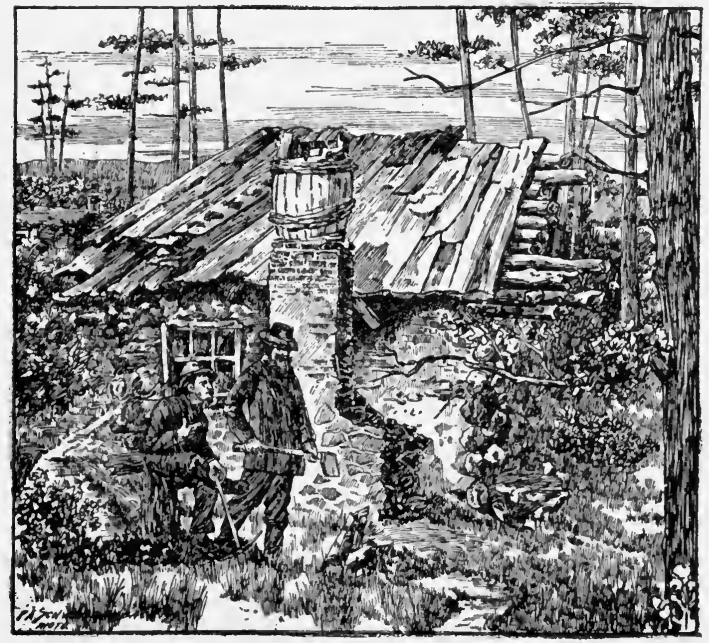

Home of a Squatter 
a small field that would raise the corn and wheat he needed for food. He did not expect to sell his products and raised only what he and his family needed. He had no church, school, or government. He hunted the deer, wild turkey, bear, and beaver while he was not digging in his small field. When the land on which he lived was open for sale, he either bought it and became an actual settler, or moved to the frontier after selling the buildings and other improvements he had made on the land.

Last of all came the settler, the man who owned his farm and got his title from the government. He widened the trails into The settlers roads, built bridges, enlarged the fields, and formed a regular community under the rules of labor, law, and sober living. Sawmills now appeared, and the log cabins of the earliest settlers began to give place to frame houses.

Preachers followed the settlers, traveling on horseback and carrying their saddlebags filled with Bibles and hymn books. Pioneer The first preaching places were the homes of the settlers. preachers When a preacher arrived, he would get his host to notify the neighbors that a sermon would be preached. Those who wished were taken into the church, and perhaps a congregation would be formed. Frequently the preacher found in the community men and women who had belonged to the church he represented. In the settlements of the New Englanders congregations were organized more quickly than in the places in which Southerners and Middle-states men settled. We cannot praise too much the earnest work of these early preachers. There was a great deal of wild living before they arrived in the settlements, but their influence was for gentleness, and the settlers yielded to it. The states now began to establish schools; after them came newspapers, and soon universities were founded.

As the settlements advanced the Indians fell back. In one The Indians treaty after another they sold their lands to the governdriven back ment and confined their hunting trips to the lands lying farther west. At first the Indians of the Northwest were in- 
clined to oppose the white man's approach. In 1791 they attacked Governor St. Clair, of Ohio, and defeated his force with heavy loss. The president sent against them a strong force under General Wayne, which inflicted such a heavy loss that there were no more Indian troubles in Ohio and Indiana. General Jackson's victory over the Creeks in 1814 did the same thing for the Indians of the Southwest. But there was this peculiarity in the history of the southwestern Indians : they were not being continually thrust back to the unsettled West. They remained in Georgia and Alabama long after the lower Mississippi was settled. They were thus surrounded by white settlements, and it was finally a difficult thing to get them to give place to white men. Their removal was not accomplished until 1835, after there had been many years of angry discussion.

\section{QUESTIONS}

I. In what ways was the period from 1790 to 1820 an era of great prosperity? What was the condition of immigration during these years? In what parts of the region west of the mountains were settlements planted in 1783 ? How far had they extended in 1820 ?

II. Into what parts of the interior did the people of the South migrate? Describe the process. What effect did this process have upon the older communities? Describe the invention of the cotton gin. What effect did it have on the life of the South? What is the cotton-growing part of the South?

III. By what route did the men from the Middle states reach the West? What class of men settled the region immediately north of the Ohio? What large town was founded there?

IV. Describe the migration of the New Englanders. What was Connecticut's Western Reserve? Compare the life in the two zones of settlement in the region north of the Ohio. Describe the means of travel to the West. What was the condition of the roads? Describe the development of towns in the West. Explain the development of New Orleans. When were steamboats invented? What was their importance to the West?

V. How did New Orleans threaten to absorb the whole trade of the Mississippi valley? How did this affect the trading towns of the Atlantio coast? In what way did they seek to protect themselves? Describe the 


\section{THE PLAIN STORY OF AMERICAN HISTORY}

efforts of the Philadelphia merchants to reach Pittsburg. Describe the construction of the Erie Canal. What effect did it have on the growth of New York?

VI. Describe the methods of the land speculators. Why did the people of the East approve the sale of land through speculators? Why did the West object to it? What were the provisions of the law of 1796 ? What further changes were made in 1800 ? What was the effect on the settlement of the West? What abuse came through sales on credit? What were the provisions of the law of 1820 ? What plan was adopted to make the best land bring better prices than poorer land? How did it work? Describe the homestead act of 1862 .

VII. What three classes of settlers do we find in most Western communities? Describe each class. Describe the arrival of the pioneer preachers. What influence did they have? How did the settlements of the New Englanders differ from other settlements in this respect?

VIII. What happened to the Indians during this period? What two Indian wars broke their power? Why was the case of the southwestern Indians different from that of the Indians north of the Ohio?

\section{SUGGESTED TOPICS}

Western Roads and Travel; The Invention of the Cotton Gin ; Early Use of Steamboats; The Erie Canal; General Wayne's War against the Indians; The Removal of the Cherokees. 


\section{CHAPTER XIX}

THE GOVERNMENT UNDER THE LATER REPUBLICANS, $1811-1825$

We must now turn again to political history, in order to see how the country took up its life when the war of 1812 was over. The republicans were still in control of the government The new and Madison was president. The "war hawks" were republicans at the head of the party, and the old republicans gave them support rather than have a quarrel within party ranks. The war had taught the country some lessons. We were no longer afraid to have an army and navy, and we were willing to take any other steps which seemed necessary to carry on the government in an effective way.

Meanwhile the federalists were growing weaker every The Hartyear. The ford conthing which vention injured them most was the Hartford convention, which met late in 1814 . They were most nu-

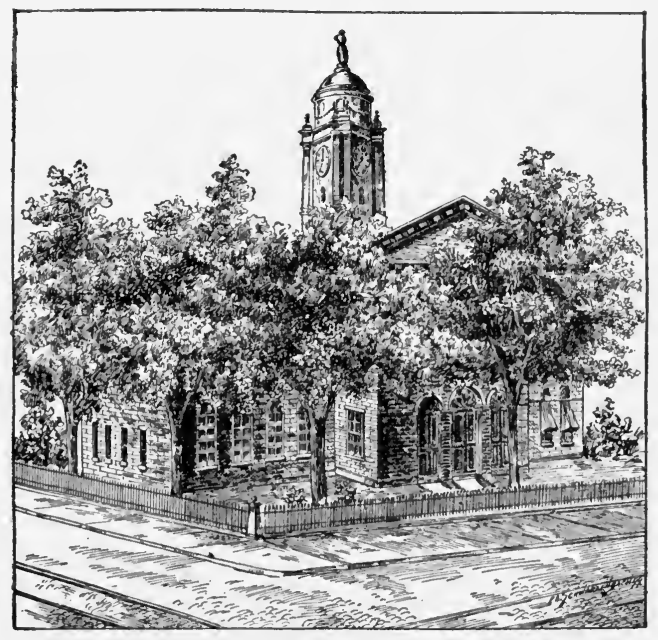

The Old State House

Where the Hartford convention met.

261 
merous in New England, and as the war progressed they opposed it strongly. They did not wish to send troops to help carry it on, and they declared openly that it was an unjust and unwise war. Finally the states of Massachusetts, Connecticut, and Rhode Island sent delegates to a convention at Hartford to take steps in regard to the situation. The convention met in secret, and it is not known what the members really intended to do ; but most people believed it was called to induce the New England

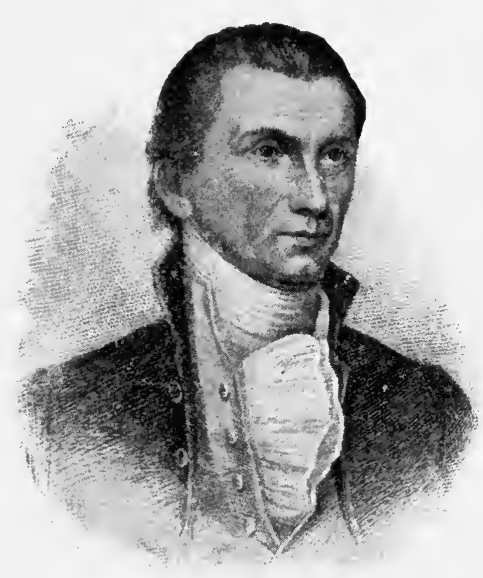

James Monroe states to leave the union and join England. We ought not to suspect what we cannot prove. It is certain that none of the measures announced by the convention were as bad as its opponents charged.

The republicans had no serious opposition in the presiThe elec- dential election of tion of 1816 1816. Their only trouble was to decide which republican they would support. The new leaders were young men and they did not push themselves forward very boldly:

It was agreed that all should support Monroe, an old republican whom men knew for a gentle but industrious man. He was not likely to oppose the new republicans, and when he had served through his term, it would be time enough to think of bringing one of them forward. James Monroe was elected president and Daniel D. Tompkins, of New York, was elected vice-president.

One of the first acts of congress after the war related to the deMeasures fense of the nation. It provided for a larger army than of defense the old republicans thought necessary. It also enlarged the courses at the academy at West Point, which was now 
made a regular military school in which officers studied military science. It was believed that we ought to have at all times a well-instructed body of army officers who might train the private soldiers when war began. Another law provided for an increase in the navy. It was not until 1845 that the naval academy was founded at Annapolis to train naval officers.

Another measure was to create a second Bank of the United States to do the work of the old bank, which had gone out of existence in 1811. The old republicans had disliked the first bank, which was one of Hamilton's ideas. But they The need for now said little, for it was evident that the country a great bank had suffered sadly during the war because it had no such institution. A bank was needed for two main reasons. One was to furnish a safe and convenient place in which the government could keep its money from the time it was collected until it was needed for government expenses. The other reason was even more important. It was the need of a great bank whose notes would be received at par by the whole country. A great many small and unsafe banks were then in existence, whose notes were offered in every market as money. No one knew what they were worth, and, in fact, they varied widely in value. If there was a central bank, in which the government had a part, its notes would be wisely issued, and they would furnish a currency acceptable to all parts of the country.

The new bank was chartered in 1836 . It was to keep the government money in its vaults, and could lend that part which was not in active use. This was a valuable thing for the bank. It paid a bonus of $\$ 1,500,000$ for the privilege, but Its nature the interest it received on government deposits was much more than the amount of the bonus. The bank had its headquarters in Philadelphia, but it had branches in many other cities.

Another measure that the new republicans carried through congress was our first protective tariff. Before that time the government had obtained most of its money from tariff bills; but 
they were always passed to get money. In 1816 congress passed a tariff bill in which high duties were laid on things manufactured First pro- in the United States. This would make it necessary tective for merchants who imported those articles to sell them tariff higher than they were selling before. Woolen cloth, for example, was now to sell higher than before, and by this means the American manufacturer could sell a little cheaper than the forcign manufacturer and still have a profit. The American factory owners urged congress to pass this bill to protect them. They had established factories during the war and declared that they would have to close them if they had to compete with cheap British goods. Their argument seemed a good one, and the people generally approved of the protective tariff. In order to help the newly established manufacturers, they were willing to pay higher prices for the goods they needed. All parts of the country united in voting for this bill.

The manufacturers soon discovered that they needed more protection and asked congress for still higher duties. Now apMore pro- peared opposition to higher protection. The South tection de- especially showed that it was opposed to more protection manded

than had already been given. It did not have manufacturers, and probably would not have them for a long time. To increase the duties, therefore, only meant that the South must pay higher prices in order to aid the manufacturing parts of the North. We shall see how this led at a later time to a great deal of hard feeling.

A fourth matter which the new republicans undertook to carry through congress was what was known as a policy of internal Internal im- improvements. It meant that the federal government provements was to construct roads and canals, for which there was then a great demand. Many of the old states were building their own roads and canals, but the newer states were thinly settled and could not construct such public works. They wished congress to take up the task and pointed out that if there were 
good means of travel in the West, the government could sell the public lands at a more rapid rate and at higher prices. The reply was that the constitution did not give congress power to collect money to spend in building up one part of the country at the expense of the other. It was also thought that if congress began to make such grants, it would be overwhelmed with similar demands.

Government aid to roads began several years before the war of 1812 , but the requests were not large, and most of them were granted. Many men shook their heads and said that The bonus the demands would get larger and larger. After the bill war the new republicans showed that they meant to take up the subject as a regular policy. In 1816 one of them, Calhoun, introduced a bill to set aside the bonus of $\$ 1,500,000$ received from the national bank as an investment, the interest from which was to be used for internal improvements. Both houses of congress passed the bill, but Madison, whose term of office had not yet expired, vetoed it because he thought the constitution did not authorize congress to spend money in such a way. For some years the demand for internal improvements was checked, although money was given by congress in small sums for many roads and canals.

Monroe wished to have the leading new republicans in his cabinet, and John Quincy Adams, of Massachusetts, became secretary of state; Crawford, of Georgia, secretary of the treas- Monroe and ury; and Calhoun, secretary of war. Clay was offered Clay a place also, but refused. He preferred to stay in congress and lead those who were sure to appear as opponents of the president's plans. He was a brilliant debater and had great influence as speaker of the house of representatives. He watched for something to criticize, but Monroe was very cautious. While he did not do many great things, he rarely did foolish things, and Clay was not able to find good ground for building up a party in opposition. In 1820 everybody was satisfied with Monroe, and he was reelected president with only one opposing vote. The presidential elector who cast that vote explained that he was satisfied with 
Monroe, but that he voted against him so that the election would not be unanimous. Washington is the only president who has been unanimously elected, and the elector said he did not propose

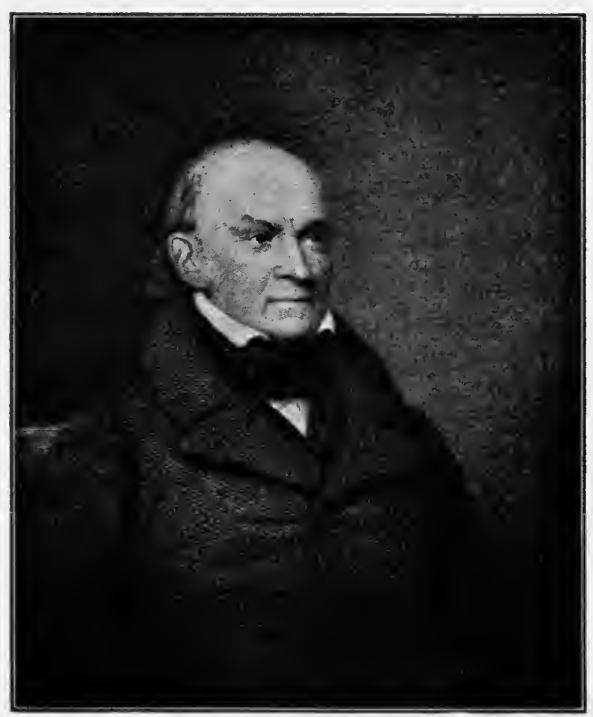

John Quincy Adams to let Monroe have the same honor. These harmonious years of Monroe were called the "era of good feeling."

One of the good things Monroe did was to buy The desire Florida from for Florida Spain. We desired this territory because it would round out our possession on the coast from Maine to the western boundary of Louisiana. It was worth little to Spain, who at this time was gradually losing her. colonies in America. They had revolted one after the other and she was not able to reconquer them. Florida was a great stretch of forest containing a few fortified posts held by garrisons. Around the oldest posts one might see plantations, but the rest of the country was unsettled. Its few inhabitants were not able to defend it without help from over the sea. The people of the United States kept sharp eyes on the territory; for they thought the time would come when they might dash across the boundary line and conquer all Florida. Monroe, however, preferred to buy it. He tried hard to get the Spanish government to sell the province, but for many months the efforts were not successful. Then came an incident which seems to have opened the eyes of the Spaniards. 
Many of the Creeks were in Florida, having fled thither after they were defeated by Jackson, at Horseshoe Bend, in 1814. They took refuge with the Seminoles, a kindred tribe. They Beginning of did not accept the treaty Jackson made after the battle, the Semiby which the Creeks ceded a broad belt of land just nole war north of the Florida boundary. They continued to look on the land as their own, and when white settlers began to establish homes on it, the Creeks crossed the Florida line, stole the stock of the settlers, and sometimes killed the white men whom they met. The whites retaliated, one thing led to another, and late in 1817 there was war on the border.

General Jackson was sent to put down the disturbances. He found that the Indians had fled into Florida and pursued them into that territory, regardless of the fact that he was Jackson in marching into Spain's territory. The Indians fled into Florida the forest. He burned their towns and destroyed their grain. When he was told that the Spaniards had furnished arms and ammunition to the Seminoles he seized the garrisons, hoisted the American flag, and sent the captured soldiers to Havana.

Spain was greatly offended, and declared that she would not say another word about selling Florida until the American troops were withdrawn and Jackson was punished for what he spain enhad done. Monroe handled the matter with great raged cleverness. The American troops were recalled, and Florida was handed back to Spain. This could be done in all fairness, since Jackson had acted on his own responsibility in seizing the forts. But he was not punished. Monroe pointed out that since Spain would not restrain the Seminoles from raiding on American lands, she had no right to complain if we went into her own territory and punished the offenders. Spain could not dispute the argument. Moreover, a year's reflection showed her that since she could not defend her province she had better sell it. In February, 1819 , she agreed to a treaty in which we acquired all Florida sold Florida. A feature of this important treaty was that the western 
boundary of Louisiana was fixed at the Sabine River. Beyond it was Mexico, still a Spanish colony.

The Missouri compromise was one of two other important events occurring while Monroe was president. It decided that a part of Two impor- the territory purchased under the name Louisiana tant events should be opened to slavery, and a part should not be so opened. The incident belongs to the story of the slavery controversy, and it will be described in another chapter (see p. 292). The other incident was the announcement of the Monroe doctrine in 1823.

The first suggestion of this important matter came from Canning, England's foreign secretary. At that time Spain had just Origin of gone through a revolution in which the people had set the Monroe up a republic, but a French army had come into the doctrine country and restored the king. He had no money to pay for this service, but it was proposed that he should allow France to pay herself by seizing some of her revolting Spanish colonies. Most of the European governments were willing for France to do this, and France herself was pleased at the prospect of reëstablishing colonies in America. England, however, did not like the prospect. She had given much secret aid to the revolting colonies, and in return for it she expected that they would prove a market for British goods. As these colonies were not likely to have manufactures of their own it was most probable that they would trade with Great Britain for many years.

It was at this point that Canning's important suggestion came across the Atlantic. Let the United States, he said, join England Canning's in an announcement that the two nations would not suggestion allow any European power to establish a colonial empire in America. Monroe had recognized the revolting Spanish colonies as independent states. He knew, also, that they had the sympathy of the American people. He saw that if a great French power was built up in Mexico or in Central America, we might have trouble to get on with it. For all these reasons he was pleased at Canning's suggestion, and was for acceptance. 
But Secretary Adams gave him a valuable hint. If there was to be an announcement, said he, why should Canning make it? We were the nation most interested, and it was for us America to make the announcement. Adams added that he takesleaddid not like to see his country "come in like a cock-boat ing place in the wake of the British man-of-war." Canning was not displeased at this turn of the affair. He was chiefly interested in preserving British trade, and he did not care who spoke first. The trade advantages to Great Britain would be the same in either case.

The announcement was made in the president's message to congress, December, 1823. It declared that we would not stand by and see a European power impose its system of govern- Monroe ment on any of the American governments. Monroe doctrine said: "With the existing colonies or dependencies of any European power we have not interfered, and shall not interfere. But with the governments who have declared their independence, and maintained it, and whose independence we have, on great consideration and on just principles, acknowledged, we could not view any interposition for the purpose of oppressing them, or controlling in any other manner their destiny by any European power, in any other light than as a manifestation of an unfriendly disposition toward the United States."

The meaning of these words was clear. Our government was a democracy, just the opposite of the despotism that then ruled in all the old world countries except Great Britain and Switzerland. It meant that we would fight before we would see these despotic countries get a foothold in America. This was the famous Monroe doctrine. When France knew what Its meaning stand Monroe had taken and realized that England would support us in it, she gave up all hope of taking territory in America. It cannot be doubted that the Monroe doctrine has saved from extinction some of the states south of us.

The year 1824 was an election year, and several candidates 
wished to succeed Monroe. In fact, the "era of good feeling" was turning into a hard fight between those who had formerly The election been Monroe's friends. Adams, Crawford, Calhoun, of 1824 Clay, and General Jackson were the most prominent candidates. When the election was over, it was seen that nobody had a majority of the electoral votes. In such a case the constitution directs that the election shall be decided by the house of representatives, who must choose one of the three men who had the highest votes in the election.

Now followed a state of rivalry among the friends of the three highest candidates, Jackson, Adams, and Crawford. Clay was The election very popular in the house of representatives, and alof 1825 though he was not one of the three, he was able to have much influence over the final choice. He favored Adams, who was more experienced in public life than Jackson, and Adams was elected. Crawford had been left nearly helpless by a stroke of paralysis, and it was not wise to make him president in his existing state of health. Adams made Clay his secretary of state. It was a good choice, but immediately the friends of Jackson raised a cry of corrupt bargain. Clay, they said, made Adams president, and Adams made Clay the chief man in the cabinet. It is evident that Clay had a perfect right to think that Adams was the right man for president, and Adams in making Clay secretary of state took for that office the best man among his supporters.

John Quincy Adams was president only four years (1825-1829), for he was not fortunate enough to get a reëlection. He was very conscientious, and tried hard to make a good president, but he did Adams and not know the art of making friends, and he became more Jackson and more unpopular as the years passed. He had the support of New England, and most of the old federalists voted for him. He was also supported by most of the Clay men, but he had very few warm admirers. His strongest opponent in 1825 had been Jackson, who was now supported by those who formerly 
favored Crawford and Calhoun. Jackson was a popular hero. He was liked because he had won victories over the British at New Orleans. He was an outspoken man, whom the people believed very honest.

Jackson's supporters attacked Adams in every possible way. They called him an aristocrat, and said the government was no longer in the hands of the people. They said he placed none but his own friends in office, an The bitter accusation which was attack on not true. They made Adams the people at large believe that it was necessary to turn out Adams in order that government by the people might be restored. The result was that Jackson was elected president in 1828 by a large majority. The important events of Adams's administration were the tariff of 1828 (see p. 277), the Panama congress, and the reappearance of the strict and loose construction theories of the union.

The Panama congress was called at the invitation of the state of Colombia, in South America. It

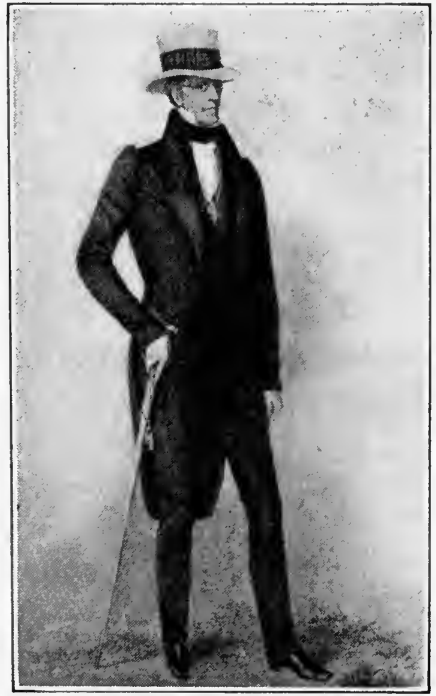

Andrew Jackson

At the time he was president.

was to meet to consider matters relating to the states north and south of the isthmus, and the United States were invited to attend. Clay was eager that Adams should send dele- Panama gates. He liked to think of our influence going out to congress the other parts of the continents. He thought that since we should be the greatest power at Panama we should be able to get the smaller states to do as we wished. Adams was more cautious. He hesitated, but finally appointed delegates when he was 
assured that they would not bind us to fight the battles of other states.

When the Panama congress met, our delegates had not sailed. They were waiting for Congress to vote the money to pay their The debate expenses. Adams reported what he had done, and asked for the necessary funds. Immediately arose a storm of criticism from the Jackson men. The Panama congress was denounced at every possible point, and the debate that ensued was so long that although the money was voted, the delegates arrived at Panama too late to take part in the congress. One of them died on the way to Panama, and the other came home without accomplishing anything. The Panama congress gave the opponents of Adams an opportunity to show how strong they were. It was said that Adams would not have lost if he had only taken the other side of the question.

About this time much began to be said about loose construction and strict construction. The latter meant that we should follow Constitu- the words of the constitution very strictly in deciding tional con- upon the powers of congress, and the former meant that struction we should interpret the words of the constitution liberally, or loosely. For example, the constitution says that congress shall lay taxes "to pay the debts, and provide for the common defense and general welfare of the United States." The question came up :- Do the words "general welfare" apply to any policy congress may choose to approve, or do they mean any small and unforeseen expenses that the government may encounter in its career. Some persons wished to give the words a strict meaning, and some thought they should be interpreted liberally. The strict constructionists contended that a protective tariff is not authorized in the constitution. The loose constructionists replied that a protective tariff is for the "general welfare," and therefore congress has a right to levy it.

The Adams men were loose constructionists generally, and the Jackson men were divided between strict constructionists and 
men who did not care one way or the other. One of the ideas of the strict constructionists was that all the powers which are not given to the federal government in clear and

State rights positive words of the constitution are to be retained by the states. When strict construction assumes this form, it is called the doctrine of state rights. Opposed to it is the doctrine of a strong federal government, sometimes known as the doctrine of nationalism. The Adams men of 1828 may be called nationalists and the Jackson men were turning toward the doctrine of state rights.

In reality, two new parties were now forming. Adams ceased to be his party's head after the election of 1828, and Henry Clay took his place. He was a loose constructionist and a Newparties; nationalist, and the party he led became known after $\mathbf{r}$. Whigs some years as the whig party. Adams acted with it, but a more important man than he was Daniel Webster, of Massachusetts, whose great distinction was his oratory. He is considered by most men the greatest American orator.

The supporters of Jackson felt the necessity of taking a new party name. They held as long as possible to the name republican, which Jefferson made popular. But that did not mark 2. Demothem clearly enough, and after a short period of doubt crats they began to call themselves democrats. The whig and democratic parties were for twenty years the great American parties. Clay founded the first and Jackson the second. The whigs in all this time elected only two presidents, Harrison, in 1840, and Taylor, in 1848. Both died in office. All the other elected presidents from Jackson to Lincoln were democrats.

\section{QUESTIONS}

I. What group of politicians were in control when the war of 1812 ended? What was their purpose? What was the condition of the republican party? What was the attitude of New England toward the war just ended? What do we know about the Hartford convention? What is charged but not proved about it? Deseribe the election of 1816 . 
II. What measures of defense were carried through congress by the practical republicans? Why was a great bank needed? Why was the privilege of keeping the public money a valuable one?

III. When was the first protective tariff bill passed? What was the nature of the tariff bills passed before that year? Why did the manufacturers think they needed protection? What parts of the country favored the bill? What was the attitude of the manufacturers after the first law was passed? Why did the South object?

IV. What was the policy of internal improvements? Why was appeal made to congress in such cases? What objection was made to the policy? What was the bonus bill? What was its fate? Who was its champion?

V. What efforts did Monroe make to preserve harmony among the republicans? What attitude did Clay take? In what way did Monroe disappoint his expectations? Describe the election of 1820 . What was the "era of good feeling"?

VI. Why did we wish to acquire Florida? Describe the condition of the province under Spain. What expectation was entertained by Americans? What was Monroe's policy? What caused the Seminoles to begin their attacks on the whites? What did Jackson accomplish in Florida? What demands did Spain make? How did Monroe treat them? What at last induced Spain to sell Florida? What were the terms of the sale?

VII. Name two other important occurrences in Monroe's administration. What events in Europe led up to the Monroe doctrine? Why did England oppose the plan to reconquer the Spanish colonies? What was Canning's suggestion? How did Monroe receive it? What caution did Adams show? How was the Monroe doctrine announced? Give its substance. What effect did it have on France?

VIII. Describe the election of 1824. Describe the election of 1825 . What do you think about the charge that a corrupt bargain was made? What kind of president did Adams make? What factions now united in support of Jackson? Why was Jackson popular? In what manner did his friends attack Adams? What was the result of the election of 1828 ?

IX. Describe the summons to the Panama congress. What were the attitudes of Clay and Adams toward the congress? Describe the debate in congress over the Panama delegates. What was the outcome? What was the political effect of the incident?

$\mathrm{X}$. What is the difference between "loose" and "strict" construction of the constitution? Give illustrations. What was the doctrine of state 
rights? What two new parties were forming? How did they divide on the question of construction? How many presidential elections did the whigs win?

\section{SUGGESTED TOPICS}

The Seminole War; Clay's Opposition to Monroe; The Monroe Doctrine; The Charge of Bargain and Corruption; The Effects of the Tariff, North and South; Jackson as Governor of Florida. 


\section{CHAPTER XX}

\section{THE GOVERNMENT UNDER JACKSON AND VAN BUREN}

ANDRew JACKson was president for two terms, 1829-1837, and after him came his friend, Martin Van Buren, who was president Jackson's for one term, until 1841. Jackson was a man of great power determination, and his enemies in derision spoke of this period as the "reign of Andrew Jackson." He had power because a majority of the people had confidence in him.

His supporters were generally the small farmers and country people. Most of the rich men in the cities and the large landThe spoils owners were whigs. Jackson's followers believed that system the government under Adams had fallen into the hands of aristocrats. They demanded that the old officeholders should be dismissed to make room for men whom they called "friends of the people." Therefore under Jackson there was a great changing of officers. Many ignorant men were put into office merely because they had worked for the election of Jackson. The idea that offices should be used to reward faithful party workers was called the "spoils system." For many years it was a very bad feature of our public affairs.

One of the first things Jackson did was to give a blow to the policy of internal improvements. He thought congress was not Against in- authorized by the constitution to spend money for ternal im- roads and canals which were purely local in character. provements It seemed to him that the people of the states were trying to get the federal government to do what they themselves should do. Each year more and more pressure was brought to bear on congress, and he feared that the demands for help would 
become so great that a large part of the revenue would be required to meet them. Jackson felt that the process ought to stop. When a bill to aid what was known as the Maysville road came to him after passing both houses of congress, he vetoed it and gave out his reasons in words that won the support of the people. The Maysville road began and ended in Kentucky and was, therefore, a local road.

Another important matter that belongs to Jackson's administration is the adjustment of the tariff question. After the passage of the bill of A growing 1816 there was con- tariff tinual demand for higher rates. An important bill was passed in 1824 , another in 1828 , and still another in 1832. There was much dissatisfaction in the South on account of these laws. They gave protection to the North, but the South was forced to pay higher prices for many articles in order that the North might have this advantage. If it was said that the South might have had as much benefit as the North if she had established manufactures herself, the reply would be the South

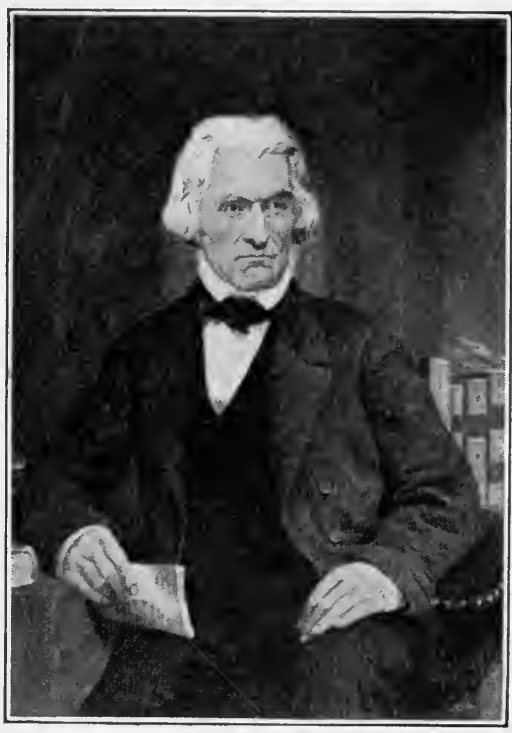

John C. Calhoun

was an agricultural region and could not well have manufactures. The slave labor of the South could not be used profitably in factories.

Most of the Southern states were against the tariff, but South Carolina was most outspoken in her opposition. Each step in building up the high tariff policy of the nation was received in 
this state with an outburst of indignation. The people were Opposition thoroughly convinced that the constitution gave no of South power to congress to make a law which bore unCarolina equally on a large part of the union. But it was hard for any one to suggest a means of defeating the tariff men until John C. Calhoun came forward with a plan.

This strong leader was originally the most national of the new republicans. But as his own state turned to the state rights Calhoun policy he turned with her. He could not afford to stand out against what a very large majority of his fellow South Carolinians wished; and from 1828 he was the leader of the state rights and strict construction men of the South. All these were opposed to a protective tariff on principle.

His argument against the tariff men was as follows: the federal government, of which congress is a part, was created by the states. The nulli- All the power it has it got from the states. The constification tution, which was made by the states, is the document doctrine in which are laid down the powers of the federal government. When that government does something which the constitution does not authorize, it is proper for the states to refuse to obey it. And it was for the states and not for the federal government to say whether or not the constitution was violated in any law of congress. Applying this to the case before the country at that time, South Carolina, in the words of Calhoun, announced that the tariff laws were not authorized by the constitution, and that South Carolina had a right to say that they should not be enforced within her borders. The theory that a state could nullify an act of congress by declaring it unconstitutional was called nullification. It was similar in some respects to the ideas in the Virginia and Kentucky resolutions of 1798. The doctrine of nullification was very fully stated by Calhoun, first in 1828, and later in 1832 . We shall see by what means Webster became the great opponent of it.

The South Carolinians were confident that Jackson would not 
oppose them. He was a Southern man, a resident of Tennessee, and a cotton planter; and they thought he would surely Jackson's help them in their attack on the protective tariff. But attitude Jackson was first of all loyal to the union and the constitution; and he did not propose to sit idly by and see a state flout the laws of congress, laws he had sworn to enforce. It was at a dinner in Washington to celebrate Jefferson's birthday, April 15, 1830, that he let it be known where he stood. He was asked to give a toast and responded with these words : "The federal union: it must be preserved!" Calhoun and many other nullifiers were present and were much disappointed with the toast. They now knew that Jackson would oppose them if they attempted to nullify the tariff laws.

Another quarter to which the nullifiers looked for help was the other Southern states, all of whom were given to agriculture and felt the burden of the tariff as much as South Carolina. But they were not ready

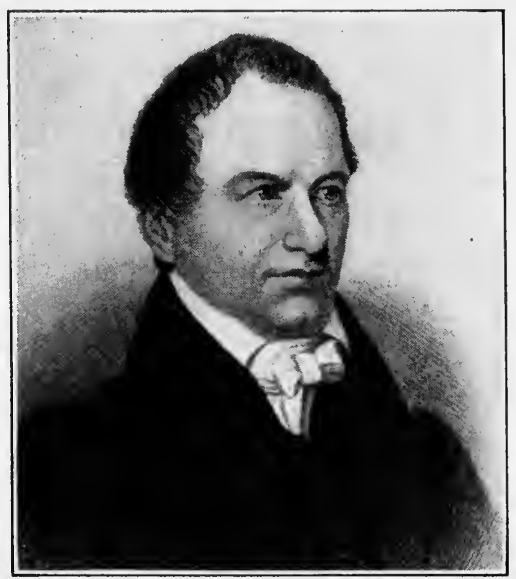

Robert Y. Hayne at that time to resist the national authority, and The other they knew that Jackson would make war if the laws Southern were resisted. So the South Carolinians were left to states try nullification through their own efforts, if it was put into force at all.

In January, 1830, the South Carolina idea came up in a most conspicuous way in the United States senate. Senator Hayne, of South Carolina, a polished and popular orator, was Hayne's making a speech on the land question. The Western clever move people were still complaining that the manufacturing states of 
the East adopted a niggardly policy in selling the public land. Hayne thought he could make the Western people friends of the South Carolina theory. He spoke of the unfairness of allowing a majority in congress to make laws for their own advantage at the expense of the minority. Then he announced a plan that would protect the minority. It was nullification, as good to

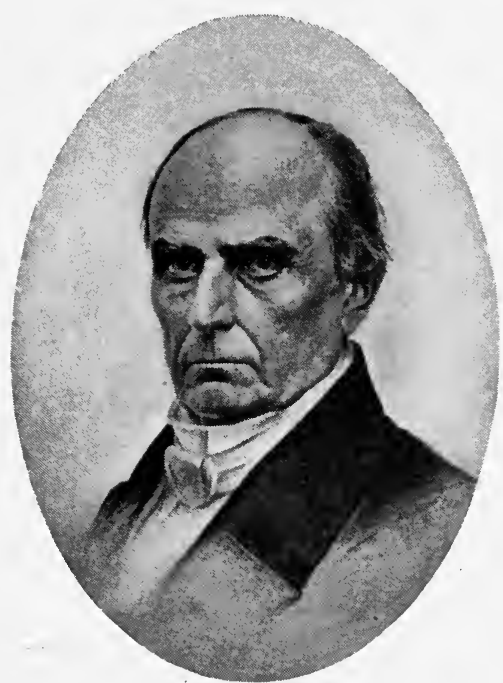

Daniel Webster protect the West in regard to the sale of the public land as to protect the South from a tariff law. If the West took up nullification, it would be a great gain for South Carolina.

Hayne's speech was well received by his friends. But it alarmed the North, who turned Webster's to Daniel Webster great reply of Massachusetts for a reply. They were not disappointed; for Webster's speech in reply to Hayne was probably the greatest speech ever made in congress. The keynote was the union. The people, said Webster, and not the states made the union. It was a consolidated government, not a government depending on the wills of the states. If a state resisted the will of the federal government, it would be treason and its resistance must be put down by force, if necessary. He said that the doctrine of nullification was absurd. If South Carolina might declare the tariff laws null, another state might declare null any law that did not please it. The result of such a condition would be that we should have a government which could make no law without first finding out how the states liked it. If this idea were to prevail, the union, he said, 
would become "a rope of sand." The speech gave joy in the North.

South Carolina now stood alone, fighting against the high tariff policy of the majority. Her weapon was nullification, and the president and the other Southern states would have Two years of nothing to do with it. Would she really try to enforce hesitation it by her unaided efforts? Her people were greatly aroused and were convinced that they were right. They hesitated for two years after the Hayne-Webster debate, not because they were afraid, but because they hoped that a new president might be elected in 1832. When they found that Jackson was to be his own successor, they decided to try to put nullification into force.

They called a state convention to take up the matter. It was warmly supported by the people of South Carolina and did all that the leaders expected of it. One thing was to de- Jackson's clare that congress had no right to make the recent proclamatariff acts and to order that they should not be en- tion forced after February 1, 1833. President Jackson saw that the laws were likely to be defied and issued a proclamation warning the people of South Carolina that what they proposed to do was treason and that he would enforce the laws against them.

The reply of the nullifiers was: Let congress make a tariff that will bear fairly on all, and nullification will be given up. Both sides were ready for the worst, and to many persons it Clay's seemed that war was certain to begin. Peace came compromise through congress, under the leadership of Clay. Through his influence a law was passed by which the duties were to be lowered slightly each year for ten years, when they were to remain stationary at a moderate rate. Through the slow reduction of the duties the manufacturers had time to adjust their selling prices; and Clay persuaded them to be satisfied with the compromise in order to avoid civil war. The passage of his bill pleased the men of South Carolina, and nothing more was heard of nullification.

As soon as nullification was disposed of Jackson turned his at- 


\section{THE PLAIN STORY OF AMERICAN HISTORY}

tention to the Bank of the United States. Many reasons have

Jackson's dislike of the bank been given for his dislike for this bank; perhaps the best is that he disliked all monopolies, and the bank was so big that he thought it was a peril to the political life of the country. He thought that its notes, which were used as money in large quantities, were not a satisfactory currency, and that the government deposits were not safe in its hands.

Most of the business men of the country were satisfied with the bank. It was in a sound financial condition, its notes were Was it good, the people of the whole country were glad to justified? receive them as money, and the public funds which were deposited with the bank were perfectly safe. It does not seem that the bank took a large part in politics, as the democrats charged; but it is certain that it took part against Jackson in some states and that it might have come to take a larger part in the course of time. The only sound criticism against it is that it was a very big institution that was continually tempted to try to influence the action of the government, and that such an institution may become a bad influence in the politics of the country. It was probably on this ground that the majority of the people supported all that the president did against it.

Jackson's attacks on the bank began in a mild way, in 1829, soon after he became president. The charter under which it A new char- existed was to expire in 1836, and he wanted to show the ter vetoed people that it ought not to be renewed. In 1832 congress passed a bill to renew the charter. Jackson vetoed it. This was in the summer of the year in which there was a presidential election. Jackson was the democratic candidate for reëlection. Clay, a friend of the bank, was the whig candidate. Thus there was a clear contest between an opponent and a friend of the bank, and it was felt that the election would show how the people stood on the bank question. When, therefore, the election went for Jackson by a large majority, he concluded that he had the support of the people and prepared to destroy the bank. 
His plan was to remove the government deposits from the bank. He did not do this all at once; for he knew that the bank had lent the money to private borrowers and it would cause Removal of these borrowers much distress to pay at one time all the deposits they owed. When banks lend money, most of it goes to merchants, manufacturers, and other business men. To pay a large part of this money suddenly means that these merchants, manufacturers, and others must take the money out of their various enterprises, and that means they must do less business. All this makes what are known as "hard times." As it was, Jackson's action made it necessary for the bank to call in so much of the money it had lent that there was serious suffering by all classes. He was much criticized by the business men, but he held firmly to his decision, and the year 1836 came and went without another bill in congress to recharter the bank. Thus, the bank died because its charter expired. The whigs resented Jackson's course, and let it be known that if they came into power again, they would have another Bank of the United States.

While Jackson was president we had serious trouble with the Indians. The Creeks and Cherokees lived in Georgia and Alabama, while west of these, and nearer the Mississippi, The southlived the Chickasaws and Choctaws, all large tribes. western Georgia and Alabama were anxious to get the Indians Indians out of their bounds, so that the lands on which the savages lived might be settled by whites. These Indians were more advanced in civilization than most tribes, but they were still far below the level of the whites. They had their own tribal government, and although they lived within a state they were not subject to its laws.

Georgia and Alabama thought it unfair that they should be forced to have these separate Indian governments within their bounds, something that was expected of no other gov- Georgia and ernment. They began to make laws for dissolving the the Cherotribal governments. The Cherokees appealed to the kees supreme court of the United States which decided in their favor; 
but Jackson was in sympathy with Georgia and would not execute the verdict of the supreme court. He was much criticized by the many persons who felt that the verdict of the supreme court ought to be final, but he gave no heed to his critics. He let the Indians know that he would not restrain Georgia from taking their lands, and advised them to move west of the Mississippi, where congress,

Removal at his suggestion, set aside a large amount of land for them. The Indians finally decided to follow his advice. The federal government paid them for the lands they gave up.

It was in this connection that congress created the Indian Territory, properly not a territory. It was a large district staked out Indian in the rich valley of the Arkansas River, in which the territory Creeks, Cherokees, Chickasaws, and Choctaws were settled on reservations lying side by side. Each tribe had its own government, but there was no territorial government over them, as in the normal territory. A few years later the Seminoles were also removed to the Territory. These five groups of Indians constituted what later became known as the five civilized tribes. They are to-day the most advanced Indians within the limits of the United States.

The removal of the Seminoles was the cause of much trouble. It happened that many negro slaves had run away and taken refRemoval of uge with the Seminoles in Florida. Some of them had the Semi- married Indians, and were well treated by the Seminoles. noles When the tribe agreed to remove to the Indian Territory, 1833, these fugitives became alarmed. Their former owners naturally expected to recover them and hold them as slaves. The fugitives preferred to fight rather than go back to slavery, and they joined with some of the Seminoles in a war against removal. Their leader was Osceola, a brave chieftain, whose wife was a daughter of an escaped slave. She was treacherously arrested, and her husband went on the warpath at the head of the discontented ones. He and his bands lived in the swamps, sallied out and attacked the white settlements, and escaped before they could be captured. 
This fierce struggle was waged from 1835 to 1837 , when Osceola was seized by the white soldiers at a conference held under a flag of truce. He was sent to prison and died a year later in confinement. The Seminoles continued the war, and it was not until 1842 that the last resistance was overcome. Most of the tribe now left Florida, but a small remnant were allowed to stay in the Everglades.

A less important Indian war was what was known as the "Black Hawk war," which began in 1830. Most of the Sac Indians crossed the Mississippi River as the Indians were being pushed slowly westward in the Northwest. But one Black Hawk branch settled in the valley of the Rock River, where war the land was very fertile. The neighboring white men wanted to possess this valley; and in 1830, while the Sac hunters were absent, they came into it, drove the Indian women and children into the forest, and established themselves in the rich corn land at the mouth of Rock River, where now stands the town of Rock Island. When the Indian hunters returned, they attacked the white intruders and retook their lands. Then came United States troops to subdue the Indians. The Sacs were headed by Black Hawk, a man of great ability. He led his people across the Mississippi but came back in 1831 and fell on the white settlements. He was pursued and defeated in a battle at Bad Axe. The Black Hawk war was the last Indian war of the Northwest until white men, thirty years later, began to invade the gold fields of the distant mountains.

As Jackson's second term of office neared a close he was greatly concerned to have a president succeed him who would not yield to the Bank of the United States. The man he se- Election of lected for this purpose was Martin Van Buren, of New ${ }^{1836}$ York, vice-president from 1833 to 1837 . The whigs were disunited, and they thought it best to divide and vote for such men as were strongest in the various sections of the country. In New England they voted for Webster, of Massachusetts; in the South 
for White, of Tennessee; and in the Northwest for Harrison, of Indiana. They thought that by this means neither Van Buren nor one of their own candidates would have a majority, and the election would have to be decided in the house of representatives, where the chances would favor the whigs. But Jackson threw all his strength to Van Buren, whom he loved greatly, and the result was that in the election Van Buren had more votes than all of his opponents combined. He thus became Jackson's successor and was in office from 1837 to 1841 . He was a democrat.

Soon after he was inaugurated the country was in the midst of the long-remembered panic of 1837 . It was caused by the Panic of collapse of a period of wild speculation. Men had 1837 borrowed money from local banks to buy land which they expected to sell at a handsome profit. The local banks had borrowed this money from the great banks in New York, Philadelphia, Boston, New Orleans, and other large cities. Many people had gone to the grain and cotton growing lands of the West and South and opened farms on borrowed money, expecting that the high prices of produce would enable them to pay their debts quickly. In 1836 the prices of produce were low, and the farmers could not pay their obligations. This caused distress to all classes. The farmers could not pay the merchants for the supplies sold on credit. Now the banks had lent money to the merchants and began to press for its payment. As nobody could pay, the small banks began to lose money. Lands ceased to sell, and the land speculators began to fail, and this was another source of loss to the local banks. The failures of these banks affected the large banks, which had lent them money. Thus the panic, which began in the new parts of the country, was rapidly transferred to the older parts. Men who owed money had to sell property at less than it was worth in order to pay their debts. There was much distress; persons who held bank notes took them to the banks of issue and demanded silver and gold, not knowing what bank would fail. The banks thus quickly paid out all the specie they had, and 


\section{GOVERNMENT UNDER JACKSON AND VAN BUREN 287}

as more and more was demanded they announced that they would cease to give specie for their notes. The banks of the entire country made such an announcement, and there was a time when the only money in use was bank notes. Here was seen the ordinary course of panics. They usually come after a period of violent speculation, when men become too confident and buy and borrow more than is wise. A collapse is sure to come, and it is likely to cause much hardship.

One of the first things that the country thought of when the panic came was to recharter the bank. The whigs declared such a bank would give the country plenty of money, and Effect on the be strong enough to lend as much as the sound bor- election of rowers needed. Van Buren was opposed to the bank, ${ }^{\mathbf{1 8 4 0}}$ and he spent the first part of his administration keeping down this demand. In 1840 another presidential election was upon the country. The whigs were very hopeful. They declared that the democrats were responsible for the panic of 1837 , and they made a great many people believe that if the whigs were placed in office prosperity would return. They nominated William Henry Harrison, of Indiana, for president and John Tyler, of Virginia, for vicepresident. Try as they might the democrats could not get the good will of the voters, and Harrison was elected by a large majority. The democratic candidate was Van Buren.

\section{QUESTIONS}

I. Who were the presidents from 1829 to 1841 ? Recall all the presidents from 1789 to 1829 . Explain the expression "reign of Andrew Jackson." Who were Jackson's supporters generally? What did they say about the government under Adams? What was the "spoils system"? What kind of men did Jackson appoint?

II. What was Jackson's idea about internal improvements? What danger did he fear? What was the Maysville road bill?

III. What was the story of tariff legislation after the law of 1816 was passed? How did protection affect the North and South? Why could the South not be benefited by it? What position did South Carolina take? 
IV. Describe Calhoun as a state leader. Explain the following steps in the nullification doctrine: the source of the power of the federal government ; in what document are its powers expressed? who may say that it has violated its powers? What rights, therefore, had South Carolina, by this doctrine, in regard to the tariff laws? What former declarations did it resemble? Why did the nullifiers count on Jackson? What was his attitude? Under what circumstances was it made known? What attitude did the other Southern states take?

V. Why did the West feel itself wronged by the East? How did Hayne try to make it a friend of nullification? Why did this alarm the Northern men? To whom did they look for a reply to Hayne? On what did Webster make the authority of the union rest? What did he pronounce resistance to the union? How did he show that the doctrine of nullification would produce confusion? How was his speech received in the North?

VI. Why did South Carolina hesitate to put nullification into force? When did she decide to go ahead? What was done in her state convention? How did Jackson meet it? What bill was introduced into congress by his friends? Why was the first blow against South Carolina feared? What compromise tariff was made? What were its features?

VII. Why did Jackson dislike the bank? Was the bank unsound? Did it take part in politics? In what respect was it a monopoly? What was Jackson's early attitude toward recharter? What action did he take on the question in 1832? Describe the removal of the deposits. Why did this cause distress in the country? What became of the bank?

VIII. What Indians lived in Georgia, Alabama, and Mississippi? Describe their condition. What objection was made by the whites? What did the Cherokees do to protect themselves? To which side did Jackson lean? How did he treat the decision of the supreme court? What was the end of the controversy? What was the Indian Territory? How was it governed? What were the five civilized tribes? How was the removal of the Seminoles connected with the question of slavery? What was the part of Osceola in the affair? How long did the Seminoles resist removal? What part of the tribe remained in Florida? Describe the Black Hawk war.

IX. Why did Jackson feel great concern about the election of 1836 ? What course did the whigs pursue? What was the result of the election?

X. Describe the state of speculation in the country before 1837. How did the process begin to be checked? Deseribe the panic of 1837 . What 


\section{GOVERNMENT UNDER JACKSON AND VAN BUREN 289}

position did the whigs take? What charge did they make against the democrats? Describe the election of 1840.

\section{SUGGESTED TOPICS}

The Operation of the Spoils System; Calhoun as a Southern Leader ; Jackson's Defense of the Union; The Hayne-Webster Debate; Removal of the Georgia Indians; The Career of Osceola. 


\section{CHAPTER XXI}

\section{HOW SLAVERY DIVIDED THE NORTH AND THE SOUTH}

BEFORE the revolution every colony contained slaves, but there were many more in the South than in the North. The Slaves in negroes did not thrive in a cold climate and were not the North adapted to the labor of the North. The small number in this part of the country were generally domestic servants in the homes of the wealthy inhabitants of the towns.

During the revolution and soon after its end there was a general movement in the North for the liberation of slaves. It seems that Emancipa- the people who were struggling for their independence tion in the felt that it was becoming in them to give personal North liberty to all who lived in their midst. By 1800 every Northern state but Delaware had abolished slavery or decreed its gradual removal. This result was not gained by convincing the Northern slaveholders. They remained as formerly, thoroughly satisfied with slavery. But they were only a small part of the population, and the opponents of slavery got so many of the nonslaveholders to combine that it was easy to enact laws to check slavery. Some of the slaveowners of the North felt that they were badly treated, and sold their slaves to the Southerners.

In Virginia the same question came up, but here it had a different meaning; for the people asked what should be done with the Virginia re- freed negroes. In the North they were not numerous fuses to enough to make an impression on the population, but adopt it they were over one-third of the population of Virginia. Many Virginians were willing to free them, but none wished to 
have a large part of their population composed of free blacks. They believed that if negroes must continue to reside in Virginia, they could be controlled better if they were slaves. If Virginia could have started again with only white men, she would probably have been willing to liberate the negroes. But it was not possible to send the negroes to Africa, first because it was too expensive, and secondly because they would probably starve in Africa, where there was no arrangement for receiving them. When the Virginians realized these conditions they determined to go on as they were, and they gave up the hope of ridding their state of slavery. Thus it happened that the North became a free country and the South remained a land of slavery.

In 1807 congress passed a law to forbid the importation of slaves from foreign countries. By the constitution such a law could not go into force until the beginning of 1808 . It was an Foreign unpopular law in the cotton-growing portion of the slave trade South, where there was much undeveloped land and a prohibited great many slaves were needed to clear it. The planters did not hesitate to smuggle slaves into the country. The demand for them steadily increased and the prices steadily rose. In 1800 an able-bodied man who worked in the fields would bring about $\$ 300$; twenty years later he was worth $\$ 500$.

At this time most Northern people cared little whether the South had slaves or not. They did not wish to have slavery in their own states, but they were willing that the Southerners should do as they pleased about it. The day of sharp and bitter controversy had not yet arrived.

The first outburst of feeling came quite suddenly in 1820, in the very calmest part of the "era of good feeling." In that year congress was debating a bill to admit Missouri to the union. "The MisWhile it was under discussion a Northern man moved souri to amend the bill by requiring that no more slaves question should be introduced into the state and that all the slave children born there in the future should be free after they reached a certain 
age. This proposition caused the South to rise up in indignation. Before this there had always been a slave state ready to ask for The balance admission about the time a free state applied, and the of states members of congress from the North and the South, not willing to stir up sectional feeling, had allowed them to come in together. So it happened that in the senate the North was as strong as the South, and not stronger; and one section could

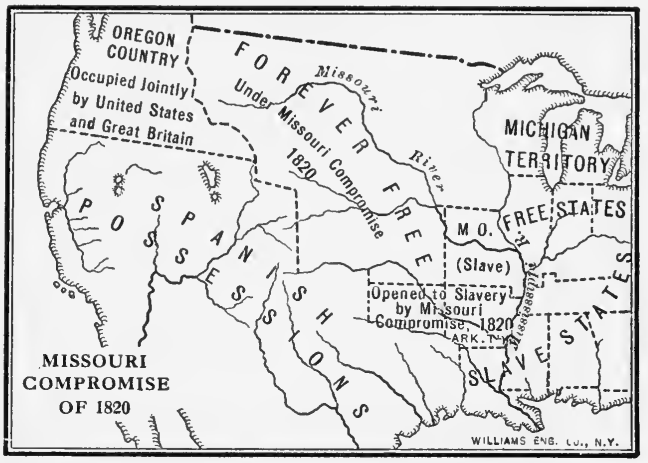
thus check the other in any measure it thought injurious. But if Missouri, already a slave territory, should be made a free state, the majority in congress would be on the side of the North, and it was believed that free states only would be admitted in the future.

After a hot debate a compromise was adopted. It was agreed that Missouri should be admitted as a slave state, but that all The com- the rest of the old Louisiana territory north of $36^{\circ} 30^{\prime}$, promise line north latitude, should be free territory. No slaves could be taken into it while it was in the territorial stage, and of course, if none were there when it became a state, it would come into the union without slavery. By this compromise the North was sure to gain in the future; for a great deal more of what was the old Louisiana purchase was north of the compromise line than was south of it.

When the compromise was adopted, Maine, a free state, was Maine a admitted into the union, so that the old balance was state preserved between free and slave states. The Missouri compromise was largely the work of Henry Clay, of Ken- 
tucky. He was opposed to slavery on principle, but he came from a slave state and had much sympathy for the slaveholders' point of view. Most people were glad a compromise was made, for it removed the question of slavery from the political field. It was nearly twenty years before it came up again in a serious form.

There were always men and women who sought to remove slavery from every part of the country. Some of the Benjamin churches were openly opposed to it, especially the Lundy Quakers, who at an early day gave up slavery in the South as well as in the North. One of their number, Benjamin Lundy, tried hard to get the Southerners to repudiate slavery. He traveled throughout the South, organizing emancipation societies in many states. At first Lundy's work seemed very promising, but it soon became evident that most of the members of his societies were persons who did not own slaves. He did not win over the slaveholders themselves into the societies, and so he became discouraged. It seemed that no amount of persuasion would induce the slave owners to give up slavery of their own accord.

In 1816 was founded the American Colonization Society. Its purpose was to solve the slavery question by sending negroes to Africa when freed. A strip of coast was secured and named Liberia, and it was erected into a republic under American protection. The capital of Liberia was called Monrovia, after the president of the United

The American Colonization Society States. The supporters of this plan were from all parts of the country. Some of them had dreams of a powerful black colony of civilized Africans, out of which should go men who would bring all Africa to Christianity. As time passed these hopes proved futile. Liberia was a plague spot, and many of the American negroes who went thither died. Those who lived did not prove that they were able to carry on the government of a prosperous colony. On the other hand, the American slaveholders did not show that they wished to emancipate a large number of their slaves. For these reasons the colonization society proved a failure. 
In 1831 came another attempt to solve the slavery problem. Its leader was William Lloyd Garrison, who edited a newspaper Garrison's called The Liberator. He was a man of intense feelings, plan and believed that the proper course was to denounce slavery at every turn. He did not try to change the opinions of the slaveholders, but sought to arouse the people of the North. The people of the South believed that he wished to have the slaves rise against their masters, and they were very angry at him. The people of the North were divided in opinion. Persons strongly opposed to slavery sympathized with him. They began to form antislavery societies under his leadership. In a short time these societies were organized in most parts of the North. They served to call the attention of the North to slavery. At first the majority of the Northern people were opposed to Garrison, and he was sometimes roughly handled by the public. But as his influence grew his movement won respect, and after a few years of early struggle he was no longer molested. The Garrisonian form of antislavery agitation was generally called abolitionism, and his followers were called abolitionists. As they grew in numbers they established many newspapers, and published a great number of pamphlets and books.

One of the weapons they employed against slavery was what was called the underground railway. An abolitionist would go The Under- into the South to help slaves escape into the North, ground Rail- where they might live as free men. Starting during the way night, he would arrive with two or three fugitives at the house of some friend before dawn, where the party would lie concealed until night fall. Then another stage of the journey would be made under cover of darkness. Thus night after night the railway ran, until its human freight was delivered at last beyond the reach of the masters. The abolitionist who accompanied the slave on the way to freedom was called the "conductor" on the underground railway ; the men who concealed them during the day were called "station agents." It is estimated that between 
the years 1830 and 1860 as many as 60,000 slaves escaped from the South by means of the underground railway.

In two ways the abolitionists were soon disturbing the peace of the politicians. Garrison had hardly begun to publish The Liberator when complaints came to the postmaster- Use of the general that his paper was mailed to negroes, free and mails slave, in the South. All his writings would make the slaves wish to be free, and some were likely to make some slaves feel like attacking their masters. The most serious complaint came from Charleston, South Carolina, where the postmaster reported that he had not delivered the papers in question. Southern congressmen urged the president to order that no more such papers be accepted by postmasters for mailing to persons in the South. Immediately came protests from the North saying the post office was free to all citizens, and no paper should be excluded from it because it opposed slavery. If the postmaster-general took either side, he would offend the other. He was fortunate enough to hit on a middle course, and by doing so he avoided difficulty. He said that the postmasters in the North must accept abolitionist literature for mailing, but that Southern postmasters were not bound to deliver it to the persons to whom it was sent.

At the same time the abolition societies began sending to congress petitions to restrict slavery in one way or another. They did not expect congress to grant what was asked, but by Antislavery sending the petitions they kept their cause before the petitions public, and the societies grew in membership. The Southern congressmen became indignant, and through their influence a rule was made in 1836 stating that no antislavery petitions should be received in the house of representatives. Now came more petitions than ever. The antislavery orators could say that they were denied the right of petition, a right as old as English liberty, and in saying so they aroused great sympathy for their cause. The Southerners themselves soon saw that they had made a mistake, for antislavery was growing in the free states, and in 
1844 the rule against receiving these petitions was dropped. It was called the "gag rule."

The abolitionists made no distinction between slavery and the slaveholders. They disliked both most fervently, and they used Two errors abusive language against the masters without realizing
that anything could be said in behalf of the slave-holders. Two arguments might, in fact, have then been made for the Southerners : 1 . The men then living in the South were not responsible for slavery there. They inherited it from preceding generations and believed they were doing the best they could with it. 2. They were not worse than other people. Among them were as large proportions of excellent, ordinary, and inferior people as were found among the people of other parts of the world. The good men made good masters, the ordinary men made ordinary masters, and the inferior men made bad masters. Some men were careful to feed, clothe, and train their slaves well, and some neglected to do either. The abolitionists did not make allowances for the good masters. They poured out their wrath on the heads of all who owned slaves.

The Southerners replied to their critics in hot words, and the quarrel became bitter. They believed that the abolitionists aimed Restraints to make the slaves take up arms and thought that the on the slaves should be restrained lest they catch the spirit of slaves the abolitionists and try to fight their way to freedom. Then followed a number of state laws imposing restrictions. The slaves were no longer allowed to have their own preachers, no man might teach them to read or write, they were watched to see that they did not assemble secretly, and the roads were patroled at night by men whose business was to arrest all slaves found out without written permission. These harsh rules were made in the belief that it was necessary to forestall any efforts of the slaves to rise against the whites.

Thus we see that slavery flourished in the South while the North threw it off before 1800. It then became sectional, and 
the two sections began to be antagonistic. Lundy's plan for persuading the slaveholders to give up slavery having failed, and the colonization society having proved a disappoint- Leading up ment, the abolition movement under Garrison became to war the most accepted form of opposition to slavery. It was carried on in a violent spirit and aroused hot feelings in the South, thus driving the two sections into dislike one for the other. If we remember these steps in the progress of the controversy, we shall understand how the two sections finally thought it necessary to go to war to settle the differences between them.

\section{QUESTIONS}

I. Why were there fewer slaves in the North than in the South? By what time was slavery abolished in the North? By what methods? What was the attitude of the Northern slaveholders toward emancipation? How was the question of emancipation dealt with in Virginia? Why could not the negroes be sent back to Africa? When was the importation of slaves forbidden? What did the constitution say about such a prohibition? How was the situation affected by the invention of the cotton gin? How were the prices of slaves affected?

II. How did most Northern men originally feel about slavery in the South? How did the proposition to admit Missouri to the union arouse strife? How had the number of free and slave states been kept equal up to that time? Why did each side insist on this? What compromise line was adopted? Which side won the advantage in this matter? What free state came into the union with Missouri? What man took prominent part in the compromise? How long was it before the question of slavery restriction was again before congress?

III. What was the attitude of the Quakers toward slavery? Describe the purpose of Lundy. How did it succeed? What was the object of the colonization society? For what object was Liberia founded? Why did it fail?

IV. What was Garrison's purpose? What was his newspaper called? How was he received by the people of the North? By what name were his followers known? What was the underground railway? Describe its operations.

V. In what two ways did the abolitionists take their cause into the political field? What was the compromise in regard to the use of the 


\section{THE PLAIN STORY OF AMERICAN HISTORY}

mails? How did congress look upon the antislavery petitions? What was the "gag rule"? How did these two matters work in favor of the abolitionists?

VI. What two errors did the abolitionists make in regard to the conduct of the slaveholders? Into what classes can you divide the masters? Why did the slaveholders think they should put restrictions on their slaves? In what respects did they restrain them? Show how these various steps led to war.

\section{SUGGESTED TOPICS}

The Quakers and Slavery; The Execution of the Law Prohibiting the Foreign Slave Trade; The Admission of Slave and Free States up to 1861 ; Presenting the Antislavery Petitions in Congress; The Management of a Slave Plantation. 


\section{CHAPTER XXII}

\section{THE EARLY HISTORY OF TEXAS AND THE SOUTHWEST}

WE have already seen that the French settled in Canada and in the Mississippi valley from the Great Lakes to the shores of the great gulf. At the end of the Seven Years' war Louisiana they lost both of these regions. Canada went to Eng- goes to land together with the Ohio valley; and Louisiana was Spain transferred to Spain, who at the same time gave Florida to England. By this means the British thought they had consolidated their power along the whole Atlantic coast, and Spain thought she had gained firm hold on all the region west of the mouth of the Mississippi. She also thought she had consolidated her power by uniting Louisiana to her province of Mexico.

This promising relation was broken up by the American revolution. At the final treaty England was forced to give up Florida to Spain, who thus came to own all the shores of the Returns to Gulf of Mexico. But Spain was bullied by Napoleon France and into ceding Louisiana to France in 1800 , and, as we have is sold seen, Napoleon transferred it to the United States in the treaty of 1803. Spain retained only Florida and Mexico. We thus gained the mouth of the great river which drains the interior, and at the same time held an important part of the gulf coast separating two of Spain's ancient possessions, Mexico and Florida.

The people of Louisiana were not asked to consent to the transfer of the province to Spain, France, or the United States. Life in Most of them were of French blood, and the whole Louisiana population, even the negro slavés, spoke French. They were an agricultural people, raising sugar on great plantations located 
along the rivers. It was a profitable business, and the planters became wealthy. They lived in great comfort, sent their sons to

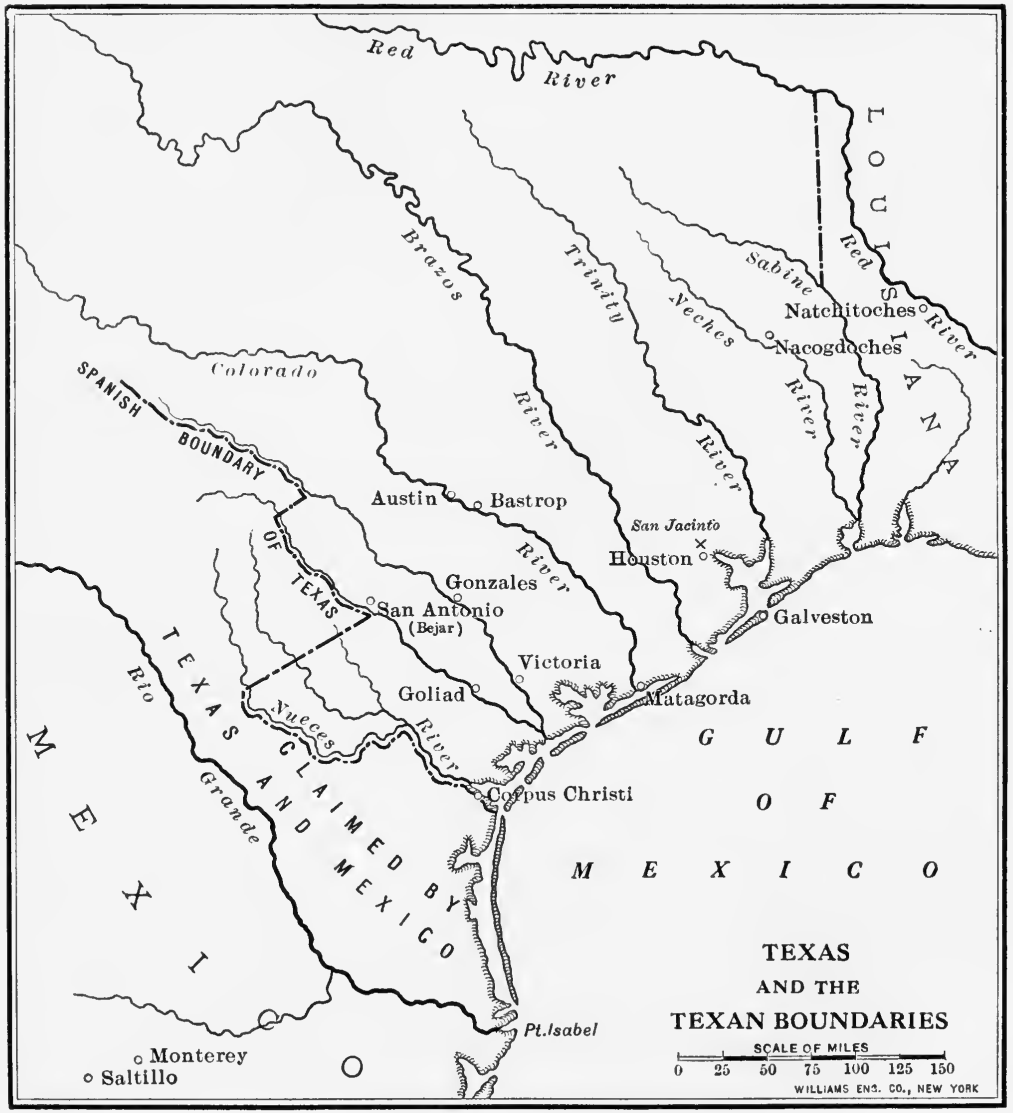

France to be educated, and spent a part of each winter in New Orleans, where life was made gay by balls, theaters, and polite social intercourse. The French life of Louisiana was known far and wide for its charming amusements. 
When Louisiana passed into American hands a large number of Americans moved into the province. They appeared as planters in the interior and as traders in New Orleans. They Two classes had the characteristic bustle of the American frontiers- in Louisiana men. To the quiet and satisfied French inhabitants they seemed a crude company ; and for many years there was little intercourse between the two classes. The white people of the French and Spanish stocks were called creoles.

The boundaries of Louisiana were not defined in our treaty of purchase, which only said we were to get from France as much as she got from Spain in 1800. When the American minister asked how much France got from Spain, the French Boundaries minister replied that he did not know; and we could not get a more exact statement from him. It was not like Jefferson to lose something through claiming too little. He announced that the eastern boundary of Louisiana was the Perdido River, a small stream east of Mobile, and the western boundary the Rio Grande.

Spain disputed both claims. When she sold us Florida, in 1819, she got us to agree that we would give up all claim to the western coast beyond the Sabine River. We thus got Florida, and rounded out our possessions east of the Mississippi ;

Texas but we gave up our claim to Texas, the region between the Sabine and the Rio Grande, which Spain held as one of the provinces of Mexico. It was a very fertile country, and the people of the West were eager to see it settled by Americans. They were disappointed when they learned in 1819 that it was to go to Spain. They felt that the West had been sacrificed in the interest of the East.

They did not give up their hope of settling in Texas. In 1821 Moses Austin and his son, Stephen F. Austin, of Missouri, undertook to lead a colony thither. Mexico had just de- Austin's clared her independence of Spain, and felt kindly toward colony the United States. She gave the Austins a grant for a large tract of Texas land at twelve and a half cents an acre. Moses Austin died just as the bargain was completed, but his son took his place, 
and led many immigrants to Texas. He was a man of courage and practical wisdom, and he was the most important leader of the

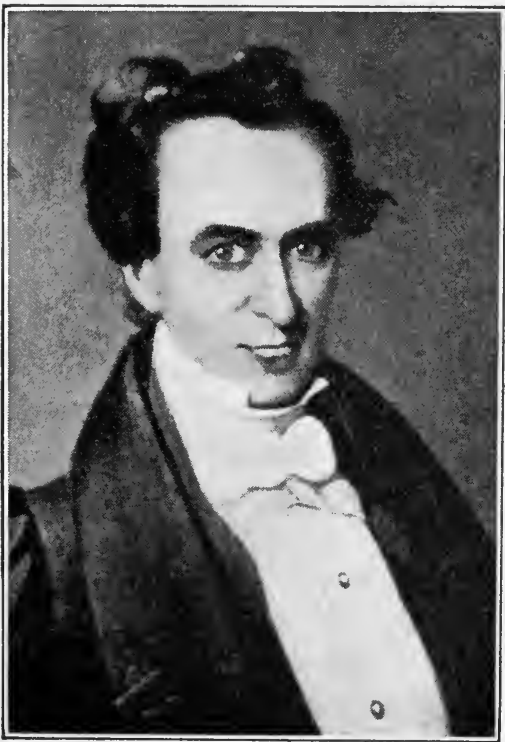

Stephen F. Austin early Texans. No sooner had he arrived in Texas than many other men got grants for large tracts in Texas. In a few years all the best land of the coast region was thus granted to men who declared that they were about to bring large numbers of American settlers into the country.

By this time Mexico had become alarmed. The Americans in Texas showed plainly that they did not like Mexican rule, and it seemed certain that they would try to Fears of the throw it off when Mexicans they became strong enough. Moreover, they were arriving so rapidly that it would not be long before they would have the necessary strength, unless something was done to restrain their immigration.

Now followed several annoying restrictions. Texas was one of the states of the Mexican republic, and the settlers had been Restrictions promised that they should have their own legislature to on Texas direct their local affairs. Regardless of this promise Texas was united with the state of Coahuila, whose population was Mexican. By this means the English-speaking representatives in the legislature of the combined state would be out-voted by more numerous Spanish-speaking representatives. This would put a check on the action of the Texans. Another annoyance was a proclamation abolishing slavery throughout Mexico. As slavery 
did not exist in any Mexican state but Texas, the order was undoubtedly aimed at the Texans, who had brought slaves from the United States. After a while the Mexican government ordered that no more immigrants be admitted from the Slavery United States. By this time the Texans were strong enough to defy the Mexican officials on the border, and they continued to come into the forbidden region.

As the Texans grew in numbers they became more inclined to assert themselves. They hated the Mexican garrisons planted throughout Texas, and in $183 \jmath$ they took up arms The war of and drove the soldiers out. Then a strong Mexican independforce came into the country, led by General Santa ence Anna. The Texans gathered in small detachments to defend their homes. Nowhere were they strong enough to drive back

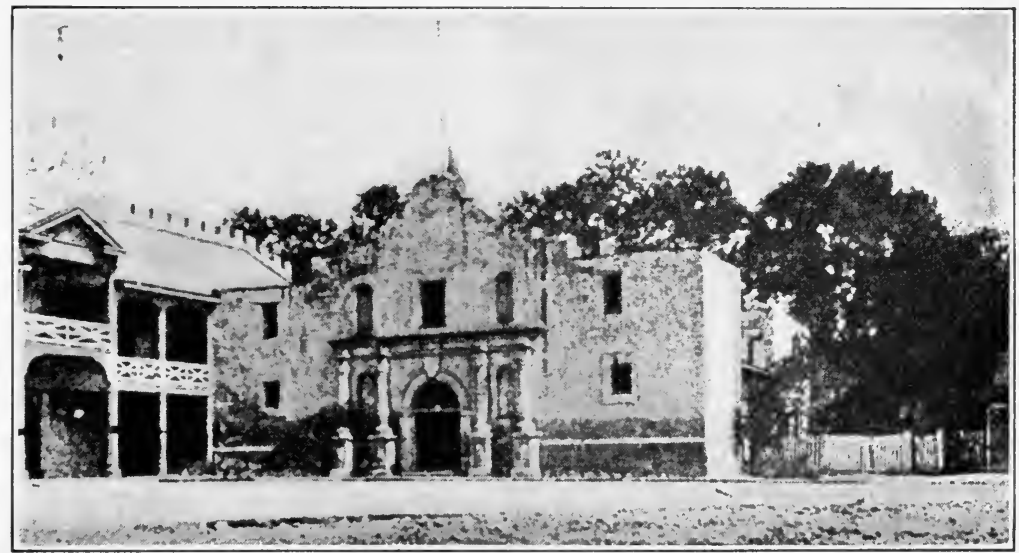

The Alamo

Santa Anna, who advanced steadily into Texas. A band of one hundred and eighty-three men, led by William B. Travis, occupied the Alamo, an old fort in the outskirts The Alamo of the mission town of San Antonio. They allowed themselves to be surrounded, hoping that by a brave resistance the rest of the 
Texans would rally and drive back the Mexicans. But help did not come, and the Alamo was stormed after a siege of thirteen days. All but a handful of the defenders died fighting, and those who managed to escape the final assault were captured and shot by Santa Anna. Shooting his prisoners was not unusual conduct in a Mexican general.

The splendid courage of Travis and his men, aided by the cruelty of the Mexicans, aroused the Texans to the most heroic resistance. San Jacinto They had hitherto been disunited: now they thought of nothing but a combined effort to crush their foes. All the troops were placed under the command of General Sam Houston, whose plan was to fall back and lure the Mexicans away from

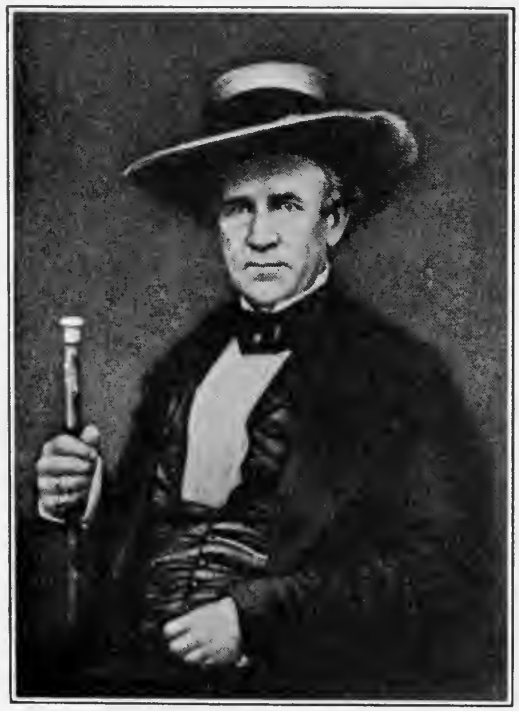

Gen. Sam Houston their base of supplies. Day after day he retreated, until the Texans themselves began to despair. But at San Jacinto Houston turned and fought. The Mexicans expected a victory. They had seen their opponents in flight so long that they did not think serious resistance would be offered. They were surprised to see Houston's men rushing forward without regard $:$ to danger, shouting, "Remember the Alamo!" Before the Texan charge the Mexicans could not stand. They broke into a disorderly flight and were pursued and cut to pieces. Of the sixteen hundred men whom they had, eight hundred and thirty-eight were killed or wounded and seven hundred and thirty were captured. Among the prisoners was Santa 
Anna himself. The Texan loss was two killed and twenty-three wounded.

The battle of San Jacinto ended the war. Santa Anna was president of Mexico and made a treaty while he was prisoner. This treaty recognized the independence of Texas, so santa far as he could secure it, with the Rio Grande for the Anna's southern boundary. The general commanding the treaty rest of the Mexican army in Texas accepted the treaty and marched across the Rio Grande with his troops. The Texans well knew that the treaty signed by a captive president would be violated when he was free. But they meant to be ready to resume the war when necessary. Fortunately for them, there was almost immediately another revolution in Mexico, and the government had no time to continue the war against Texas. But it did not give up its intention of subduing the country, and year after year the Texans were obliged to maintain an army and navy in order to be ready for Mexico, if she attempted to carry out her threat.

Texas declared her independence as Travis gave up his life in the Alamo. She sent agents to Washington immediately to confer about annexation. Throughout the Southwest the idea was very popular. Texas was a large and valuable state, and the people of the Mississippi valley rejoiced in her success. In fact, many of those who fought

Independence without annexation under Houston had recently gone from this region to help in the struggle against Mexico. But the suggestion that we annex Texas was received with disfavor in the North and Northwest. If it became a part of the union, it would be open to slavery, and it was large enough to give the slaveholders four additional states. Such was the opposition of the North to slavery that President Jackson did not dare bring up the matter. After some hesitation he consented to recognize the independence of Texas, and that was all he would say. Van Buren, who succeeded him, would do no more. Texan annexation eventually became an important 
question at Washington, but before we take it up, we must consider some of the other political affairs of the time.

In March, 1841, President Harrison, the first whig president, was inaugurated. He was surrounded by a multitude of poliA Whig ticians hungry for office, and so much did they annoy president him that his health was weakened. A month after the inauguration he fell ill and died. Tyler now became president. He was not a whig and was as much opposed to a national bank

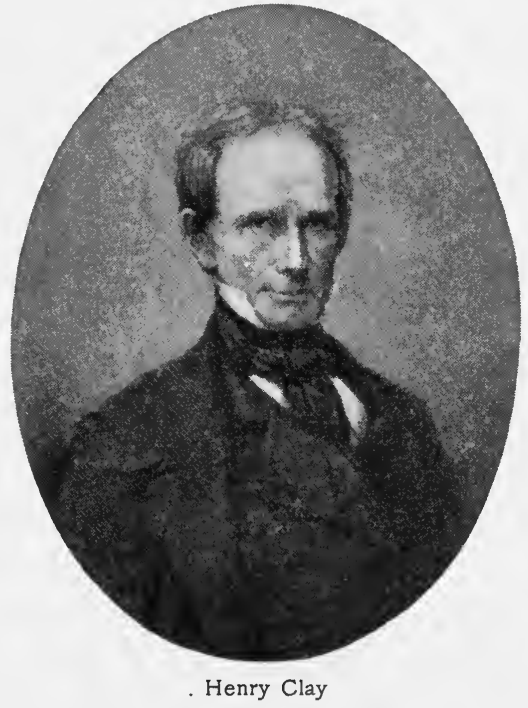

as Van Buren. He vetoed a bill to incorporate a new bank and the whigs became so much disgusted with him that they refused to recognize him as a whig. Tyler was more popular with the democrats than with the party which had elected him; but not even the democrats would receive him as a leader. In selecting the candidates in the election of 1844 he was completely ignored by both parties. The Election of whigs took a man I844 whom they were sure of, Henry Clay. The democrats chose one who had always been a faithful party man, James K. Polk. Between these two men the campaign was waged hotly.

Tyler and the democrats could unite on the annexation of Texas. Annexation He was a Virginian, and the South wished for annexation and the because Texas was Southern in sympathy and would be South sure to support Southern policies. The most important thing that came up at that time in regard to the South was the protection of slavery. Every year showed that the North 
was becoming more hostile to it and the South was anxiously preparing to meet whatever attack might come from that quarter.

In 1843 reports began to circulate in the United States that England was making plans to get possession of Texas, and it was said that if we did not annex it then, we should soon find that we could not get it. At once Tyler tried to get the senate to make a treaty of annexation. Many Annexation treaty defeated of the members expressed themselves favorably, but when the country learned that a treaty was being considered in the secret sessions of the senate, so much opposition came from the antislavery men that the treaty could not pass the senate by the necessary two-thirds majority. The Southerners generally voted for it, and the South was keenly disappointed at its defeat. The people there felt that it was unfair to them to refuse a fine country like Texas merely because it would become the home of slavery. On the other hand, it seemed to the North that the South was urging the annexation of Texas solely because it would add to the strength of slavery.

The Texas question next came up as one of the disputed points in the election of 1844. Clay was the whig candidate for president, and while speaking in the South he was asked what he The election thought of annexation. His replies only succeeded in of Polk offending his Northern friends, and he lost the election by a small number of votes. The successful candidate was James K. Polk, democrat, who favored annexation, but had at last no opportunity to secure it. A few days before he was inaugurated congress declared for annexation by a joint resolution. This method was employed because a joint resolution does not require a two-thirds majority. It was the last important act of Tyler as president. He wished to be remembered as the man who secured Texas for his country. Congress provided that Texas should be a state in the union and that with its own Annexation by joint resolution consent it might be divided into five states at some future date. Texas has not been divided and it is territorially our largest state. 


\section{THE PLAIN STORY OF AMERICAN HISTORY}

Its history since 1845, the year of annexation, has been a story of steady progress, and it seems likely that it will eventually have a larger population than any other state.

The first serious business that Polk had to dispose of was what was known as the Oregon question, a perplexing affair which had The Oregon come up in the following manner: the United States question claimed the valley of the Columbia River through the explorations of Lewis and Clark in 1805. England claimed the country also, and as neither party would give up its claim it was agreed that each of the two nations should have the right to hunt and trade in Oregon, as the country was called; that neither should attempt to colonize it without giving one year's notice for ending the arrangement now made. The plan worked well for twenty years, but it could not last. When Oregon began to attract the attention of the immigrants, it was felt that it was time to determine to which country it should belong.

During Tyler's presidency the Northwestern members in congress urged that we should take over Oregon as our own, create a Demand of government for it, and open it to settlement. They the North- would have defied England to war. Congress thought west the demand too rash and took no action. The men of the Northwest were disappointed and wished to bring up the Oregon question in the presidential election of 1844. Polk and the democrats took their side, saying that all of Oregon was rightly ours and we should take it. "Fifty-four forty or fight" now became a popular cry. It meant that England should give up all the coast to the southern boundary of Alaska, which is $54^{\circ} 40^{\prime}$ north latitude, or face our armies.

After the election Polk felt obliged to redeem his party's promise. A com- He first asked England to make a treaty by which promise the dispute might be settled, but she replied that she boundary was satisfied to have matters remain as they were. Then Polk began to think of force. He asked congress to give England notice that the joint occupancy of Oregon must end in a year 
and to take steps to govern and defend that region. After a long debate congress did what he asked. At first England had thought that we would never appeal to arms ; she now changed her opinion and made a treaty in which the forty-ninth degree was taken for the boundary. The men of the Northwest were displeased because we had not stood out for $54^{\circ} 40^{\prime}$, but the rest of the country felt it was well to close the dispute without war.

The Oregon treaty was not completed before we were at war with Mexico. Texas claimed that her southern boundary was the Rio Grande, and now that she was a state we felt War with obliged to defend her claim. Mexico disputed it, and Mexico when Polk ordered an army under General Taylor to the northern bank of the Rio Grande, a Mexican army crossed the river in April, 1846, and attacked him. Taylor defeated his opponent and carried on a brilliant campaign south of the Rio Grande. He beat the Mexicans in several battles, the most important of which was at Buena Vista, where his army was far outnumbered.

It was soon evident that the war would go on many months if we continued to fight battles in northern Mexico. To force the enemy to make peace it was Mexico City necessary to strike captured at his capital. That is why Taylor was allowed to halt

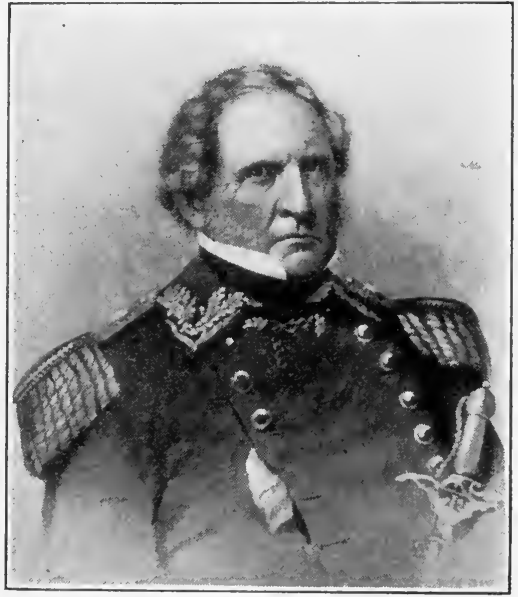

Gen. Winfield Scott where he was, while a great army under General Winfield Scott landed at Vera Cruz in March, 1847, and marched overland to Mexico City. Scott won several important battles before he entered the capital on September 14. Mexico was now at our 
mercy, and some Americans began to urge that we take it all. Polk put aside every such suggestion. He made a treaty in which the Rio Grande was recognized as the southern boundary of Texas Terms of and in which California, Arizona, Nevada, Utah, and the treaty parts of New Mexico and Colorado were ceded to the United States. For this region we agreed to pay $\$ 15,000,000$.

The most important result of the Mexican war was the acquisition of California. It came in the same year in which we got Our Pacific the Oregon boundary settled, and we thus found ourcoast selves possessed of a great region facing on the Pacific Ocean. The expansion of the Southwest had grown into the conquest of a great empire. Four years were enough to add to our possessions Texas, California, and all the lands between them, and they had seen our title to Oregon become clear and certain. These are, perhaps, the most important events in Polk's presidency.

In the beginning of 1846 California was a Mexican province, and most of the inhabitants were Indians. There were a few missions California in which the priests sought to teach Christianity to in $\mathbf{8 4 6}$ the savages; and around these one might find some ranches. Every seaman on the coast knew that the bay of San Francisco, Vancouver Sound, and San Diego harbor were the only good harbors in a long stretch of the coast. It was to get possession of the first of these harbors that Polk had been most concerned in his plan to buy California. If we were to have Oregon, it was necessary to have good ports on the coast which should become the center of our trade on the Pacific.

In 1846 a few Americans had arrived in California from Oregon. When they learned that the United States was at war with Mexico, California they attacked the Mexican garrisons and drove them conquered into the southern part of the province. Immediately there appeared American ships on the coast, and a small force was sent overland from the East to seize the province. By such efforts as these the weak Mexican rule was overthrown, and long 
before the treaty of peace was signed California was under the American flag.

A few months later a Mormon walked down one of the streets of San Francisco holding aloft a bottle of yellow dust and shouting, "Gold! Gold! Gold from the American river !" The Discovery people of the town crowded around him; and as soon of gold as they satisfied themselves that it was really gold that he carried they hurried off to the place where it was found. It was the beginning of a great rush toward California. San Francisco was deserted. Servants left their masters, clerks left the stores in which they were employed, and crews deserted from their ships as soon as the anchors had dropped in the harbor. All were bound for the happy places at which, as the report ran, a man might scoop up more than a hundred dollars worth of gold in a day. Late that year, 1848, the news reached the Eastern cities, and here the same feverish anxiety was shown to get to the gold fields as had been shown in San Francisco. By 1850 the population of California was 92,597 , which was enough to warrant her admission into the union. We shall see in the next chapter the difficulties that arose over the admission of California.

\section{QUESTIONS}

I. What nations held the coast of the Gulf of Mexico after the Seven Years' war? Who took Louisiana in 1800? in 1803? Who owned the territory on each side of Louisiana? Describe life in Louisiana before American occupation began. What was the relation between the new and old stocks in Louisiana? Who were the creoles?

II. Why were the boundaries of Louisiana doubtful? What claims did we advance? How did we come to give up the claim to Texas? How did the people of the West feel about this action?

III. Describe the plans of the Austins. How were the plans carried out? Why did the Mexicans become alarmed at the arrival of Americans in Texas? In what way did they try to take from the Texans the control of their local affairs? How did the abolition of slavery affect the Texans? Why did it not inconvenience the Mexicans? How did the immigrants treat 


\section{THE PLAIN STORY OF AMERICAN HISTORY}

the orders that no more persons should come to Texas from the United States?

IV. How did the Texan war of independence begin? Describe the defense of the Alamo. Describe the campaign of San Jacinto. What treaty was made after it? Why was it rejected by the Mexican government? Why was actual fighting suspended?

V. How was the suggestion of Texan annexation received in the South and West? in the North? Why did it fail? What did Jackson do about Texas?

VI. How did the death of Harrison prove a calamity for the whigs? What was Tyler's position on the bank question? How was he regarded by the two great parties? Who were the presidential candidates in 1844 ?

VII. Why did Tyler favor annexation? Why did the South favor it? What was England's plan for Texas? What was the fate of the annexation treaty? How did the South feel about the outcome of the vote? How did the North feel? What were the positions of Clay and Polk on annexation? Who was elected? How was annexation accomplished and by whom? What provision was made for the division of Texas?

VIII. Describe the claims of England and the United States to Oregon. What agreement was made with England? What part of the country showed special interest in Oregon? How did the matter play a part in the election of 1844 ? How did Polk settle the question?

IX. How did war begin with Mexico? Describe Taylor's campaign on the Rio Grande. Describe Scott's march to Mexico City. What were the terms of the treaty of peace?

X. How did our Pacific coast possessions develop during Polk's administration? Describe the California of 1846. What harbor appealed to us? What three movements were concerned in the conquest of California? What was the effect of the discovery of gold? How did it influence the California life?

\section{SUGGESTED TOPICS}

The Creoles of Louisiana; The Life of Stephen F. Austin; General Sam Houston; Attempts to Recharter the Bank under Tyler; California in the Early Days of American Rule. 


\section{CHAPTER XXIII}

THE CONTROVERSY OVER SLAVERY IN THE TERRITORIES

The line which first divided the area of slavery from the area of freedom was the Maryland-Pennsylvania boundary. It was commonly known as Mason and Dixon's line, from the Two dividnames of the two surveyors who ran it in 1767. It was ing lines long the boundary between freedom and slavery, and that is why the region south of the line came to be called "Dixie." West of the Alleghanies the Ohio River served the same purpose as Mason and Dixon's line in the old states. It was adopted as the boundary when the Northwest ordinance of 1787 excluded slavery from the territories north of the Ohio and left it in existence in the region south of that river. For many years the North and the South seemed satisfied with this division.

When the admission of Missouri came up in 1820, it was necessary to decide about slavery in the region formerly called Louisiana. We have seen that it was agreed that slaves should be The Misexcluded from all the Louisiana purchase north of the souri Comparallel $36^{\circ} 30^{\prime}$, except Missouri, which already had promise line slaves and was allowed to keep them. This dividing line ran, of course, no farther than the boundary of what had been Louisiana; that is, no farther than the Rocky Mountains. If you will look at the map, you will see that the second of these lines was a little farther south than the first and the third was still farther south than the second. Had Mason and Dixon's line been extended due west from the Alleghanies to the Pacific, the South and the North would have divided the western region nearly equally. As it was the South got a smaller share of the West with each division. She was fully conscious of this in 1848, when the ques- 
tion of slavery in the territory acquired from Mexico came up for settlement.

Soon after the Mexican war began President Polk asked congress to put into his hands a sum of money which he could use in making peace with

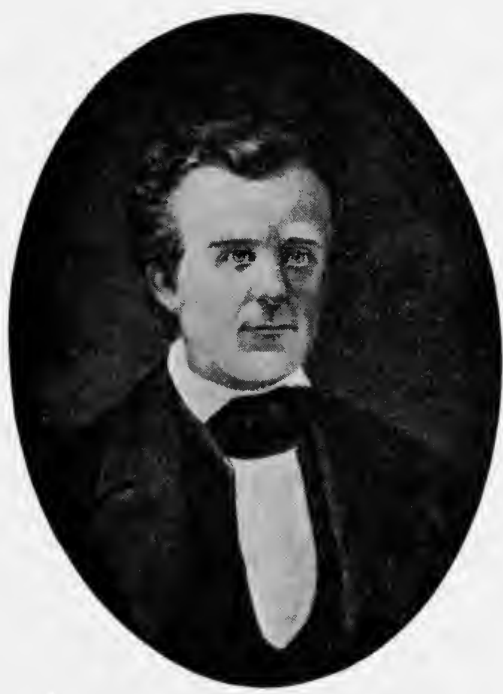

James K. Polk

Mexico. While congress was The Wilmot discussing this matproviso ter Wilmot, a representative from Pennsylvania, moved that the money be voted, provided no territory acquired from Mexico should be open to slavery. This amendment was the celebrated Wilmot proviso. It passed the house of representatives; for the North had the majority there, since it was the more populous part of the union. But it was defeated in the senate, where the states had equal strength.

Now began a bitter controversy. The extreme Northern men declared that they would never allow another slave state to be created out of the territories. They were willing, they said, to allow slavery to continue in the states in which it was already established, Two op- but it should not go into the unsettled Far West. posite The Southern men declared they would not submit opinions to a restriction which made it impossible for them to go with their property to any part of the national domain. Did not Southern men, they said, shed their blood freely in the war, and should they alone be excluded from the land acquired by that war? 
The South looked far into the future. It realized that if slavery was excluded from the territories, there would come a time when these territories must be admitted as free states. When Fears for that time came, there would be a free-state majority the future in both houses of congress, and whatever the North might say in 1846, restrictions would be made on slavery as soon as the equality of states in the senate was destroyed. The South would never agree that the North should have a majority in the senate. This fact is the kernel of all that later occurred in the controversy between the two sections.

The Wilmot proviso was before the country when the election of 1848 came upon the voters. Neither of the old parties was willing to advocate it. The whigs were stronger in the North, but they had The election many voters in the of 1848 South, and they knew they would lose them if they indorsed the proviso. The democrats were stronger in the South, but they had so many voters in the North that they dared not make any declaration against the proviso. Under these circumstances each party felt it was best to say nothing about slavery in the territories and to fight the campaign on other issues. The democratic candidate was Lewis Cass, of Michigan. It was thought

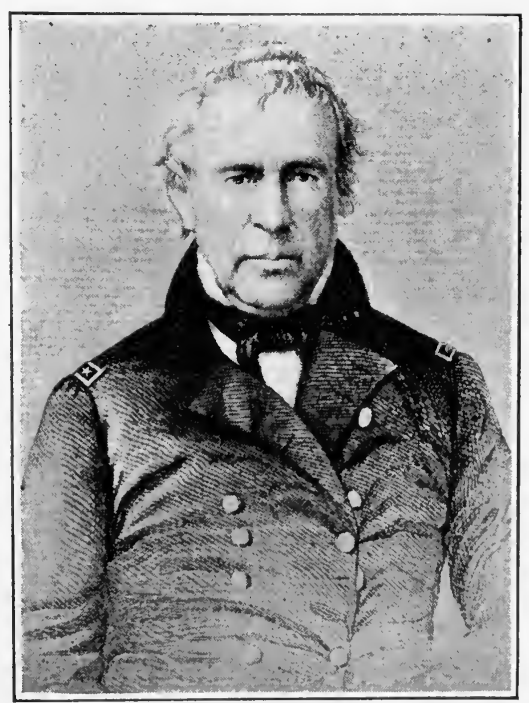

Zachary Taylor that he would carry the South on account of the slavery question and that the Northwest would support him because he was from that section. The whigs nom- 
inated General Zachary Taylor, who had won the victories over the Mexicans on the Rio Grande. He was popular on account of his military record, and the whigs believed this popularity would win many votes. Their expectations were fulfilled. Taylor was elected by a small majority.

The rapid migration of settlers to California and Oregon made it necessary to establish government there. In 1848 a bill was

Oregon, before congress to create three territories, Oregon, CaliCalifornia, fornia, and New Mexico. The South demanded that and New slavery should be permitted in all of them, and the Mexico

North would have it excluded from all. Finally the South gave way on Oregon, and that territory was created without slavery. But there was no yielding on the other two, and congress adjourned without making provision for any civil government in them. The results were serious for California, because her population was not only becoming large, but it was composed of adventurous men who were hard to restrain even when they lived in a settled government.

The year 1849 was full of sharp discussions. The president was a man of peace and suggested that all the trouble would end An angry if the Missouri compromise line was extended to session of the Pacific, but his words were useless. Neither side congress wished to give in, and the day of compromise seemed past. Then came a bill to abolish the slave trade in the District of Columbia. It was supported by the Northern members of congress, who felt it a disgrace to look out of the windows of the capitol at gangs of slaves driven to the auction rooms. Such words as these made the Southerners very angry, and they replied by demanding that congress pass a bill to insure the return of runaway slaves to their masters. The "underground railway" was carrying off two thousand slaves a year, and it was impossible to get them back after they reached the North. Neither of these bills was passed at that time, and congress adjourned without arriving at a settlement of this troublesome matter. 
In the South at this time there were two kinds of opinion. One was held by a group of extreme men who felt that the North was bent on abolition, and they proposed to meet the move Two Southof the North by having the slave states leave the union ern groups and establish a new government in which slavery would be safe. The other was held by people who loved the union too well to leave it. They were as much opposed to restricting slavery in the territories as the other group, but they did not think the situation was so bad that separation was necessary. The first group was strongest in the states bordering on the Gulf of Mexico and in Georgia and South Carolina. The moderate Southerners were strong in the states that lay nearest to the free states.

The talk of secession on the part of the South greatly alarmed all who loved the union, North as well as South. It is true that the extreme abolitionists were not alarmed The spirit of at such talk. They disliked slavery so much that they compromise would be willing to see the slave states have a government of their own; for that would leave the union entirely without the stain of slavery. But the extreme anti-slavery men were not very numerous in the North. The great majority of the people there were moderately opposed to slavery, and they were willing to unite with the moderate men of the South in making a compromise which would settle the controversy. It was in this way that the compromise of 1850 originated.

The man who took the lead in this matter was Henry Clay. He had much to do with the Missouri compromise of 1820 and the tariff compromise which solved the problem of clay as a nullification in 1833. He was now an old man in retire- comproment in Kentucky, but at the special request of his miser friends he consented to become a member of the senate in order to try to bring congress to adopt a plan that would secure permanent peace. It was the last great deed of his life. He appeared in Washington late in 1849 and took his seat in the senate.

Early in the following year Clay brought forth his plan for 
peace. He proposed to give something to each side, and he urged that it was necessary for each to give up something that it The com- wished if the good of the whole country was to be promise of secured. His plan was for the South to give up its con1850 tention about California, allowing it to come into the union as a free state, and for the South to consent to exclude the slave trade from the District of Columbia. He asked the North, on the other hand, to agree to a law which would enable a slave owner to recover his runaway slaves and to agree that congress could not pass a law to forbid the sale of slaves from one state to another. He also proposed to erect territories in New Mexico and Utah without forbidding or permitting slavery in them, leaving the future to decide, when these two territories became states, whether or not slavery should exist in them. This meant that each side should give up its contention in regard to slavery in these two territories; for you will recall that the North wished slavery forbidden and the South wished it protected in every new territory. A fifth measure was supposed to favor the South, although the South as a whole was not very much concerned about it. It was a plan to pay Texas $\$ 10,000,000$ in return for a large tract of land which she claimed on the upper Rio Grande.

Many men spoke in favor of this plan, but two speeches were greater than all the others. One was made by Clay and the other Three great by Webster. Both spoke for the union, pleading for a speeches spirit of harmony and mutual good will. They were heard with great respect by the moderate men. But Webster was severely criticized by the abolitionists, who were numerous in Massachusetts, his own state. Calhoun made the greatest speech for the South. He paid no attention to the plea that the union should be preserved. For him the chief thing was to preserve the interests of the South, and he reviewed at great length the process by which the South had come to believe that slavery was threatened. He said that if the North did not give up its 


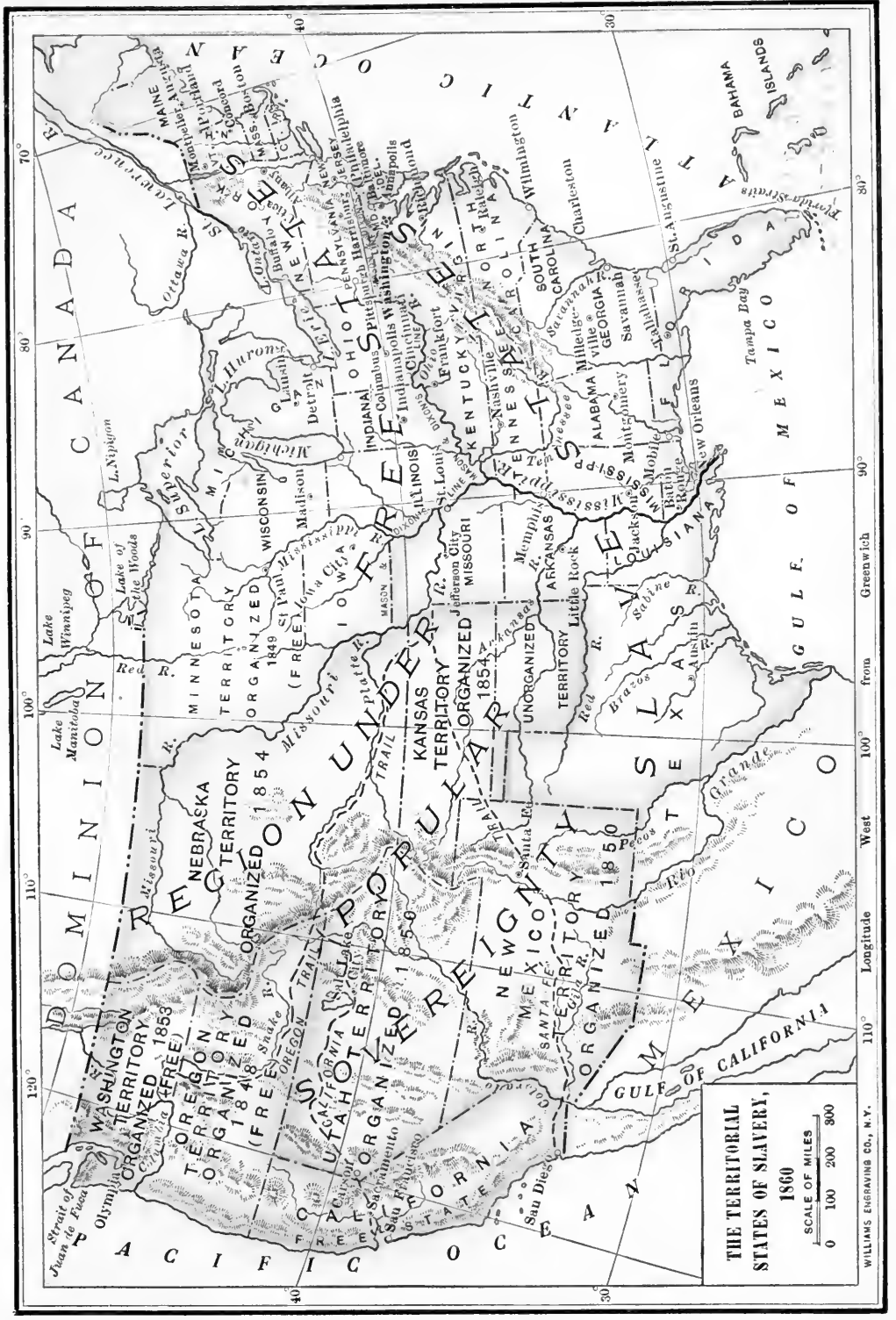


-

15

$\therefore \quad$ 
policy, the South would separate from the union. It was the last speech of Calhoun's long and distinguished life. He was so weak that he could not deliver it, but sat on his chair exhausted while a friend read it to the senate. Four weeks later he was dead.

After a long debate Clay's compromise plan was carried, and it has passed into history as the great compromise of 1850 . It was well received by the people generally. They were compromise tired of the hot discussions that had been going on. It adopted was agreed that the compromise should be a final settlement of the slavery dispute. Early in 1852, when another presidential election was approaching, the house of representatives voted by a safe majority that the compromise should be accepted as final, and both parties agreed to stand by it. It was hoped by the moderate men that this spirit would prevail during the future.

Nevertheless, the compromise was not acceptable to the extreme men, North and South. The latter did not believe that it would be long before other Northern territories would Rejected by become states and slavery begin to feel the effects of the exrestrictions. They declared that the only thing they tremists had got out of the compromise was the new fugitive slave act, and they waited anxiously to see if it would be enforced.

Nothing can show better how difficult it was to get human justice out of slavery than the question of recovering runaway slaves. If a Southern man appeared in any Northern state and claimed that a negro residing there was his slave, it would seem that he ought to be required to prove it beyond the shadow of doubt. But the old law The early law of fugitive slaves on the subject provided that he only need take his case before a justice of the peace, the lowest judicial officer, who was to hear his statement and after hearing it decide as he thought fit. From the decision of this officer there was to be no appeal; the trial was to be without jury, and the negro was not allowed to have a lawyer. If a man had been accused of stealing a pig, he would have been tried in a higher court, with a jury and a 
lawyer, and he would have been allowed to appeal the case to a higher court if he did not like the first decision. Was a man's liberty of less importance than the ownership of a pig?

On the other hand, there was a reason for the law as it existed. If a master claiming his slave whom he had located in a Northern Why it was state had to go into court in the ordinary way, the lawharsh yer for the slave could create such delays and expenses in the trial that the slave would not be worth the costs of recovery. He could require the master to bring witnesses from the South; and when they were at hand, he could have the case postponed, so that the witnesses would again have to be brought North. Finally he would try the case before a jury on whom were persons who believed that slavery was wrong. In view of these difficulties the first fugitive slave law, 1793, provided that there should be no appeal, no jury, no lawyers, and only the judgment of a justice of the peace was required. The purpose was to have the case decided as quickly as possible, with little expense to the master.

In the course of time it was seen that this might lead to hardship. Any impostor who came to a Northern community might Abuse claim as his slave a negro who had lived there for several possible years, and if he could bribe a corruptible justice to give him the verdict, he could take back to the South as his slave a negro whom he could sell for several hundred dollars. It was claimed that many such cases occurred. The foundation of slavery was the bondage of the slave and it was hard to build on that foundation any laws that would secure perfect justice to all who had to do with it.

The new fugitive slave law was like the old in principle, but it directed that the trial of cases for the surrender of fugitives should New fugitive be before federal officials. It was thought that these law officers, not being elected by the people of the North, would be independent of public opinion in the communities in which they lived. They were appointed by the president and 
could be removed by him if they did not do strict justice, regardless of their feelings in the case.

The abolitionists were strongly opposed to the law and showed that they wished to defeat it. When slaveholders appeared claiming slaves, they surrounded the courthouses and inter- The law a rupted the hearings. If the officer decided that the failure negro about whom the suit was brought was a slave, they took him from the federal marshal and carried him off secretly to Canada, or some other place of safety. Of course, these "rescues," as they were called, were in defiance of the law, but they were conducted by men of good intentions, who felt that it was proper to lead a mob in order to strike a blow at slavery. Some of these violent "rescue" parties were led by ministers.

All this was well observed by the Southerners. The only thing they got in the compromise of 1850 , the right to recover their runaway Indignation slaves, was nullified in the South by the action of the abolitionists. They were very indignant, and the feeling spread through the South that the North could not be trusted to carry out the great compromise which, it was hoped, had healed the slavery controversy forever. From the time the South came to this conclusion, it was certain that there would be a reopening of the old controversy.. Clay and Webster died in 1852. Both had done what they could to

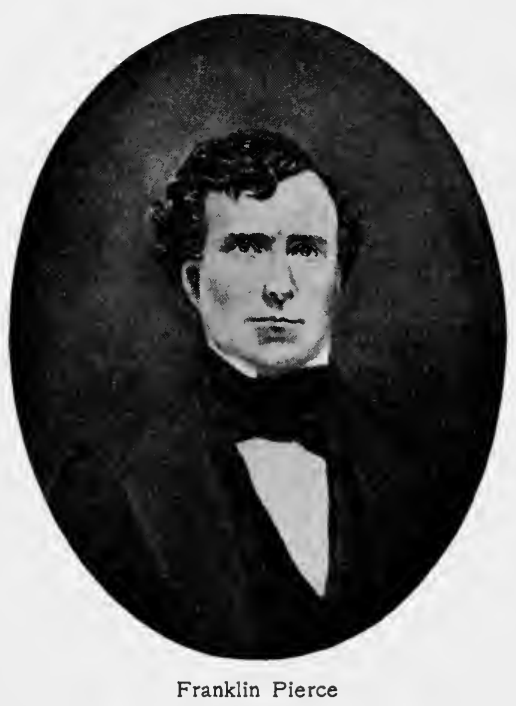
restrain the passions of the radical men, and there were none like them left to exercise the same influence. The leaders 
who remained had grown up in the days of violent sectional New leaders discussion, and they were not prepared to sacrifice the interests of their sections to the interests of the union.

In the future the two sections drifted farther and farther apart, until war was the result.

In 1852 the spirit of distrust was not aroused, and the election passed off without angry feeling. The democrats nominated The election Franklin Pierce of New Hampshire, a Northern man of $\mathbf{1 8 5 2}$ who did not agree with the general Northern opposition to slavery. The whigs nominated General Scott, thinking that his popularity as a general would enable him to win the election. The result showed that they were mistaken. Pierce was elected on the ground that he would carry out the compromise of 1850 .

\section{QUESTIONS}

I. Explain the significance of Mason and Dixon's line. What was the boundary in the region between the Alleghanies and the Mississippi? When and how was it adopted? What was the boundary line between the Mississippi and the Rockies? How was it adopted? Show how the South secured a little less of the West with the adoption of each line.

II. How did the Wilmot proviso come up? What did it propose? What was its support in each house of congress? What was the position of the North on the question of slavery in the new territories? What was the position of the South on the same point? Why did the South fear for the future? What part did the Wilmot proviso play in the election of 1848 ? Why was each party afraid to say anything about it? Who were the candidates for the presidency? Which was elected?

III. What three territories were proposed in congress? Why was it important to give them settled government? What happened to the propositions? How did California suffer? How did Polk propose to settle the controversy? Why did the suggestion fail? What demand was made about the slave trade in the District of Columbia? With what demand did the South reply?

IV. Into what two groups was Southern opinion divided? Explain the views of each group. Where was each strongest? How did the 
prospect arouse the moderate men? What compromise was the result? What was Clay's part in it? What did he ask the South to give up? What did he ask the North to give up? What did he propose about slavery in Utah and New Mexico? What was Texas to have? What three senators made important speeches? What were the effects of Webster's and Calhoun's speeches? Show how it was believed that the compromise would be final.

V. What two groups refused to accept it? What important part of it was not executed? Explain the early law for the recovery of fugitive slaves. In what respect was it harsh? Give the master's side of the case. What form of wrong was possible under the existing law? Where was the right in the matter? In what way was the new law different from the law of 1793? How did the new law prove a failure? What kind of people resisted the execution of the new law? What was the conclusion of the South in regard to the fugitives? How did a new group of leaders now appear in political life?. What were their purposes? Describe the election of 1852 .

\section{SUGGESTED TOPICS}

The Wilmot Proviso; Clay's Service in the Compromise of 1850 ; Calhoun's Speech on the Compromise; Webster's Seventh of March Speech; The Rescue of the Fugitive Slaves after 1850. 


\section{CHAPTER XXIV}

\section{THE STEPS LEADING TO WAR}

We have now to describe the events by which each side, the South and the North, came at last to open war. These events The anger begin in 1854 with the Kansas-Nebraska act, and they of nations lead straight to the secession of the South in 1861 . Probably neither side felt in 1854 that the end would be war. Each seems to have thought that the other would yield before it came to that. But neither was in a mood to yield, and each was very much excited. When two great divisions of the human race get angry, they act much as individuals act when angry. One violent act leads to another until it has gone so far that there is no retracting.

The Kansas-Nebraska act was carried through congress by Stephen A. Douglas, of Illinois. He was a very able democrat Kansas- and had his eye on the presidency. Many Northern Nebraska democrats admired him greatly and would do anything act to have him elected president. He thought that if he did the South a great favor, it also would support him in the election of 1856. For this reason he got congress to pass an act creating two new territories, Kansas and Nebraska, into which slavery might go while they were territories, but the inhabitants were to determine whether or not it should remain when the territories became states. This idea was called "popular sovereignty" by Douglas, but his opponents dubbed it "squatter sovereignty." Kansas and Nebraska were within the Louisiana purchase and were parts of the region which by the Missouri compromise had been dedicated to freedom. The Kansas-Nebraska act was, 
therefore, in opposition to the compromise. Douglas defended his bill ably. The Southerners gave him their support, and although some of the Northern democrats voted against the bill, he got enough votes from those who believed in him personally to carry the measure triumphantly through congress.

There was now great indignation in the North. The abolitionists were especially aroused and said many vehement things. Kansas was no sooner a territory than many people Two groups from Missouri, slaveholders, began to take up land of Kansas there. It was generally expected that this would be- settlers come a slave territory while Nebraska would become free. The abolitionists formed a plan to defeat this expectation. Money was raised and freely lent to men from the North who would go to Kansas to live. By this means a large free population was taken to the territory within two years after the passage of the Kansas-Nebraska act.

Now followed a period of confusion. The Southern party in Kansas held elections for a territorial legislature, and it was claimed that a great many Missourians crossed the bor- Civil war in der and voted in the elections, carrying them for the Kansas slave party. The Northern men in the territory refused to recognize a legislature chosen in this manner. They called elections of their own, chose a legislature, and there were thus two bodies claiming to be the legislature of Kansas. Each prepared a constitution and sought admission to the union as a state, but congress was so divided in sympathy that it did not accept the constitution of either faction. This state of confusion led to armed strife in which men were killed on each side. It did not cease until a greater war was about to begin.

Meanwhile, let us return to the state of national politics. The whigs, as well as some of the democrats, voted for the compromise of 1850 . This displeased the extreme anti- The whigs slavery men, most of whom were whigs up to that time, divided and they turned so strongly against the party that it could not hope 
to carry another national election. In 1852 the democrats nominated Franklin Pierce, of New Hampshire, for president and elected him with ease. His term of four years, 1853-1857, was a period of uncertainty and conflict.

Although he was a Northern man, Pierce felt that he ought to take the Southern side in the slavery controversy, a decision

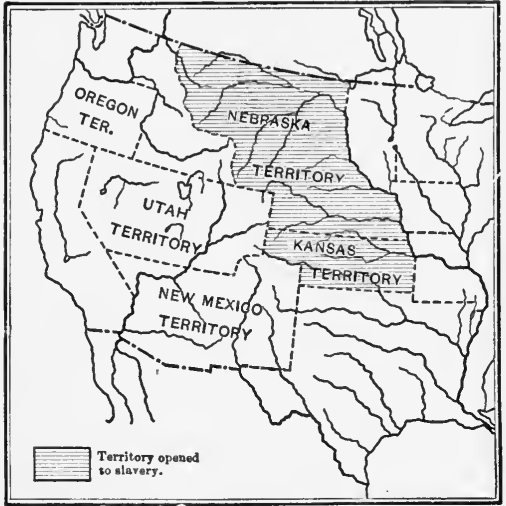

The Kansas-Nebraska Territory for which he was severely blamed in the North. He did Pierce and not veto the Kansasthe South Nebraska act. If he had done so, he would have turned against him the Southerners who formed the greater portion of his party, and he would have been as much without a following as Tyler after he vetoed the bank bills. When the question of what to do with Kansas came up, he again showed that he was on the Southern side. He appointed Southern sympathizers to the territorial offices and favored the admission of Kansas with a slave constitution. At this time the word "dough-face", came into use. It was used to indicate a "Northern man with Southern principles." It denoted a Northern man who claimed the confidence of the North because of his place of residence, but who did, nevertheless, what the South wished done in an emergency. The term probably came "Dough- from the "dough-faces," or grotesque masks that the faces" children of the day were in the habit of wearing in the Christmas holidays. A political "dough-face" was a man whose Northern home was only a mask for his Southern principles.

As it became evident that the democratic party was the defender of the slaveholders, a demand arose for a party which 
would oppose them. This could not be the old whig party; for it had a strong Southern wing which would leave the party if anything was done to restrain slavery. Another reason was A new party that the Northern democrats were bitter enemies of needed the whigs and would not go over to that party. If the men of the North were united in a party opposed to slavery, it must be a new party, with a new name.

As early as 1840 a part of the abolitionists organized what they called the liberty party. William Lloyd Garrison would not join it because he did not think the opposition to slavery Early antiought to be political. This party cast 7069 votes in slavery 1840 and 62,300 in 1844 . In 1848 there was a reor- parties ganization and the liberty party was taken into a new movement, called the free-soil party. It cast this year 291,263 votes, but in 1852 its vote fell to 156,667 . These votes show that thus far the parties were not successful. They had demanded the abolition of slavery, which most men considered an impossible dream. The question of checking the spread of slavery in the territories was not a dream; but the free-soil party was too much disliked in 1854 for it to be taken as the party to oppose slavery extension.

The passage of the Kansas-Nebraska act showed the North that a new party was necessary. In July of that year, 1854, at Jackson, Michigan, a convention met to which all who The repubwished to check the advance of slavery in the territories lican party were invited to send delegates. It resolved that there founded should be a new party and took the name "republican." It nominated ten candidates for state offices, five of whom were formerly whigs, three free-soil men, and two democrats. The convention invited members of all the old parties to vote for these men on the ground that they would resist the introduction of slaves into the territories. Other states followed the example of Michigan, and as the months passed the new party showed much strength. The struggle of the Southerners to get control 
of Kansas aroused great feeling throughout the free states, and as a consequence many men joined the republican party.

In 1856 the republicans nominated John C. Frémont for president. It was their first presidential campaign, and the leading The election members of the whig party came forward and joined of 1856 the new party so rapidly that it seemed for a time that Frémont would be elected. The democrats found themselves in an awkward situation. They had passed the Kansas-Nebraska act, and it was evident that many Northern democrats would not vote for a man who had been responsible for that law. But they had a leader, James Buchanan, of Pennsylvania, who had no part in making that law; for he was minister to England at the time. He was nominated and defended as a conservative and Frémont was pointed out as a radical. The result was that the democrats won the election and made Buchanan president. It was many years before the party elected another man to this high office.

Buchanan's four years, 1857-1861, were as stormy as Pierce's ; for the Kansas struggle went on as fiercely as ever. He, also, leaned to the South, as Pierce had leaned to it. 'It was in his administration that the celebrated Dred Scott case was decided.

In the discussions over the right of Southerners to take their slaves into the territories, the question had often been asked, "Let the "Why not let the supreme court of the United States courts decide the matter?" The slave owners had raised decide" the question: Are not slaves property? and has congress any more right to say a slave owner shall not carry one kind of property than another into a territory? You cannot take a man's cattle away from him because he goes into a certain place with them. How can you, then, take his slaves from him when he goes there? This kind of argument was very clear to the Southern lawyers, who had always held that a slave was only property in the eyes of the law.

In 1857 the supreme court passed on just this principle in the 
Dred Scott case. Scott was a slave whose master had taken him into free territory and brought him back to Missouri. He sued for his liberty on the ground that he became free when The Dred he went into free territory, and once free he could not Scott debecome a slave again by coming back to Missouri. cision The most important point in the case was this: Did the constitution give congress the power to exclude slavery from the territories? The court held that congress had no right to make such a law. It thus overthrew the Missouri compromise and opened all the territories to slavery. Seven of the judges of the court took this view. They were all democrats and five were Southern men. The decision was received with an' outburst of scorn in the North. The judges were charged with being prejudiced, and it seemed that the supreme court had lost the respect of the people in that part of the country. In fact, the controversy had gone to such a stage that however the question had been decided it would have aroused the violent denunciation of the side that lost. The South was greatly pleased with the decision.

In the summer of 1858 occurred the famous debates between Abraham Lincoln and Stephen A. Douglas, both of Illinois. LincolnThe former had Douglas been nominated debates by the republicans and the

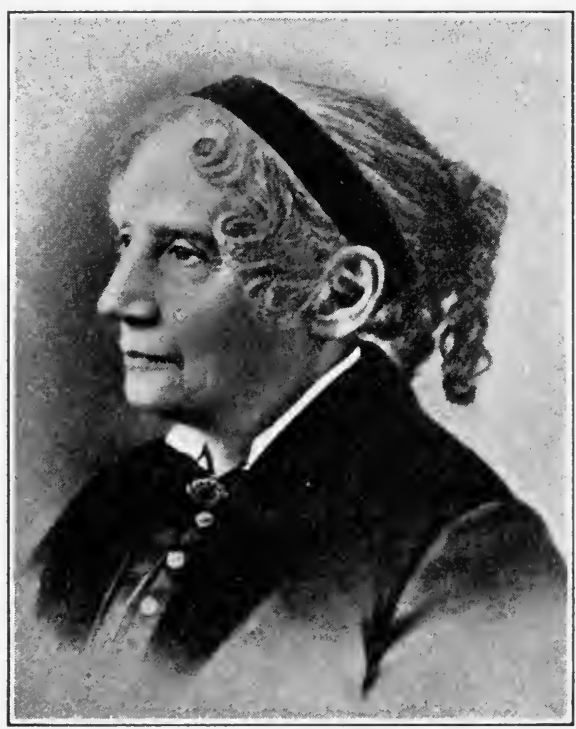

Harriet Beecher Stowe latter by the democrats for election to the senate of the United 
States. They held a series of debates, and the chief question they discussed was slavery in the territories. The subject was well presented and when the debates were published, they had great influence North and South.

But the Lincoln-Douglas debates did not have as great influence as "Uncle Tom's Cabin," by Harriet Beecher Stowe, published in "Uncle 1852. Many thousands of people who did not care Tom's about politics read this touching picture of life in the Cabin" cabins of the slaves, and were deeply moved by it. They were apt to think that this was what happened with all the slaves. We should remember that Mrs. Stowe did not mean to say that all masters were as bad as Uncle Tom's, nor were all slaves as good as her hero. But the book showed how slavery might work in the worst conditions, and it had a wonderful effect on the Northern people. The Southerners were highly indignant that it should be taken as a fair picture of slavery. It is probable that the book turned them as much against the North as it turned the North against the South. It called forth several replies from Southern writers, but none of them were as well received as Mrs. Stowe's book.

In 1859 came John Brown's raid on Harper's Ferry, Virginia. Brown was a man of very earnest purpose. He hated slavery so John Brown much that he thought anything, even the taking of life, was justified in those who warred against it. His scheme was to establish a depot of arms in the mountains of Maryland, near the Potomac, and then seize Harper's Ferry. He thought the slaves of the neighborhood would join him as soon as they knew he had taken the place; and he expected to give them arms and lead them through the hills into Pennsylvania, or Ohio, before the Virginians could stop them. He made his preparations secretly and seized a railroad roundhouse in the town during the night. The white people of the town were thoroughly alarmed. They besieged the roundhouse with arms in their hands. No slaves joined Brown. Meanwhile, regular troops 
were hurried to Harper's Ferry, and John Brown and his followers were captured. He was tried for inciting the slaves to kill the whites, and was convicted after a fair trial. The sentence of the court was death by hanging. He did not deny that he had violated the law, but he held that the law was bad because it was made to uphold a bad institution. He went to his death calmly, as one who voluntarily gives up life in order to benefit his fellow men.

Those who agreed with Brown that slavery was the worst of evils had nothing but admiration for the way he had given up his life. Those who took the Southern side of the ques- Effect on tion felt that Brown was a madman, crazed by the the South violent utterances of the abolitionists. Of this class were most of the Southerners. They had long foretold that some abolitionist would at last try to arm the slaves to destroy the masters, and they saw in the attempt at Harper's Ferry a fulfillment of their prophecy. Nothing else did so much to make the Southern people willing to begin the war as the belief that some day the North would come into the South and set the slaves to murdering the white people.

Six months after John Brown was hanged the country was holding conventions to nominate candidates for another presidential election. The republicans met in Chicago and nominated Abraham Lincoln Lincoln, of Illinois, nominated who in 1858 made the great

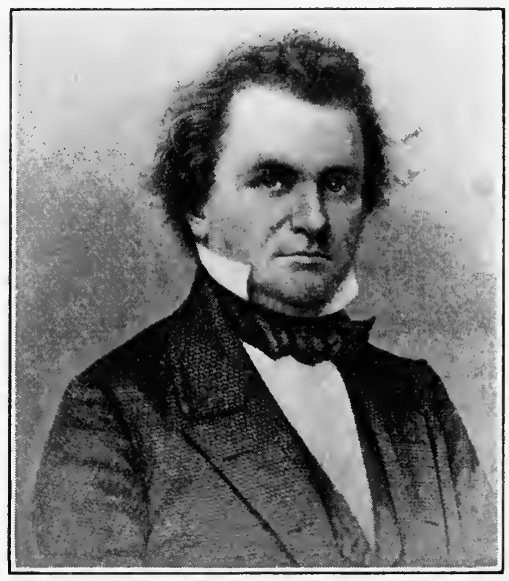

Stephen A. Douglas speeches against Douglas. He was unknown in the East, but soon after the nomination he came to New York to make a speech 
and by his honesty and good sense pleased all who met him. It was generally thought that he would carry the free states. The whig party in these states was reduced to a small part of its old strength. A majority of its members had gone over to the republicans, and a large number of the democrats had followed their example.

The democratic party was divided. Many Southerners asked that the party should declare for the protection of slavery in all Division of the territories. Of course, the party could not carry the demo- a single Northern state on that platform, and the crats Northern democrats refused to agree to it. The democratic convention remained in Charleston several days, trying to make some kind of settlement; but most of the Southern delegates continued firm and finally left the convention and took steps to nominate a Southern candidate. The result was two democratic candidates for the presidency: Douglas, of Illinois, the Northern candidate, and Breckenridge, of Kentucky, the Southern candidate. No one expected that either would win.

The result of the election was the success of Lincoln. $\mathrm{He}$ did not have a majority of all the votes cast by the people; but The election he had a majority of the electoral votes, and that made of 1860 him president. Had the war not occurred the country would have had a republican president, a republican house of representatives, and a senate in which democrats and old whigs, now called "unionists," would have been in control.

Throughout the campaign the South had declared it would leave the union if a republican president was elected, and now it States se- was as good as its word. The first state to secede was ceding South Carolina, in which a convention declared the state out of the union on December 20, 1860. The South Carolinians celebrated the event with great joy. The state, they held, was now an independent nation, and the Charleston papers began to print the news from Washington under the heading, "Foreign News." Other states followed, and by the end of February, 1861, 
six more had declared themselves out of the union. They were Georgia, Alabama, Mississippi, Louisiana, Florida, and Texas, all cottongrowing states.

The seceding states took steps at once to establish a united government. At Montgomery, Alabama, on February 4, they formed themselves into The Con"The Confed- federate erate States of States of America," with America a constitution that was nearly like that of the United States. They elected Jefferson Davis, of Mississippi, president and invited other Southern states to join them. But for several weeks none of the

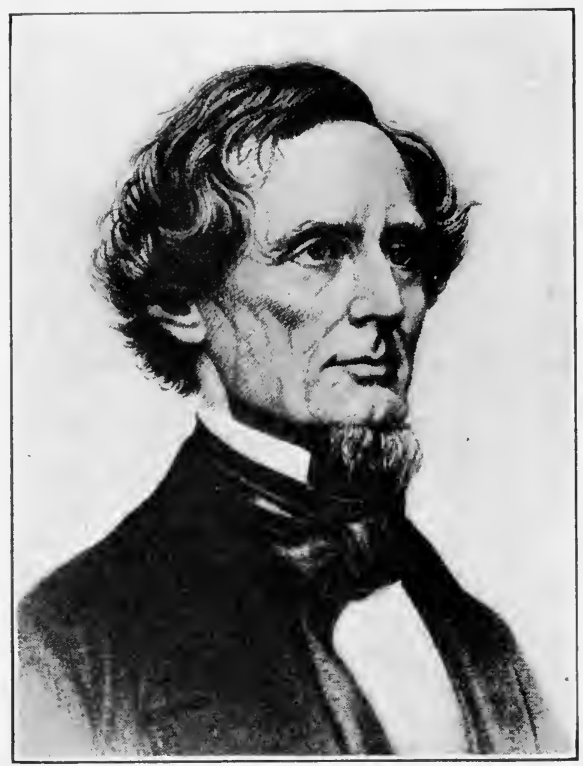

Jefferson Davis other slave states, seven in number, showed a willingness to leave the union.

\section{QUESTIONS}

I. With what law did the last stage of the slavery controversy begin? What was the ambition of Douglas? How did he propose to win the favor of the Southern democrats? What did the Kansas-Nebraska act provide? Define "popular sovereignty." What other term is used for the same thing? How did the act violate the Missouri compromise? How was it carried through congress?

II. What two streams of settlers went into Kansas? Which arrived first? What abuse was charged in the first elections? Show how each 


\section{THE PLAIN STORY OF AMERICAN HISTORY}

side organized a form of government. What attitude did congress take? What was the result for Kansas?

III. What was the effect of the compromise of 1850 on the whig party? Describe the election of 1852 . Which side of the slavery controversy did President Pierce take? Why? What would have been the result if he had taken the other side? Why was he called a "dough-face"? Define the term.

IV. Why must a successful antislavery party be a new party? Describe the courses of the various parties founded to oppose slavery before 1854. Why did these parties fail? Describe the convention at which the republican party was founded. Describe the election of 1856 . In what respect was Buchanan fortunate in being minister to England in 1854 ? What was his attitude toward the South?

V. On what ground was the supreme court asked to decide the question of slavery in the territories? What were the facts in the Dred Scott case? What was the chief point decided? What did the court say about it? How was the decision received?

VI. Describe the Lincoln-Douglas debates. What was their effect?

VII. What was the influence of "Uncle Tom's Cabin"? Why did the South dislike it? Describe the attempt of John Brown to liberate slaves in Virginia. What was his plan? What purpose did the South attribute to him? How did they think it fulfilled their expectations?

VIII. Describe the nomination of Lincoln. How did he impress the country? Show how the democratic party was divided. What two candidates were nominated? What was the result of the election? Name the presidents from 1829 to 1861 and give dates and parties.

IX. Describe the secession of the Southern states. Which states were in the first group that seceded? What united government did they establish? Whom did they make president?

\section{SUGGESTED TOPICS}

The Kansas-Nebraska Act; The War in Kansas; "Unele Tom's Cabin" ; Early Career of Abraham Lincoln; John Brown's Raid; The Charleston Convention; The Organization of the Confederate Government. 


\section{CHAPTER XXV}

\section{THE WAR IN THE WEST}

The conflict about to begin was the greatest war fought in the western hemisphere. It began in April, 1861, and why it was ended in April, 1865. The South fought for independ- fought ence, and it sought to secure independence in order to preserve slavery from the attacks of the North. The North fought to preserve the union, but its success secured the overthrow of slavery and made certain that our great country should not be divided.

When Lincoln was inaugurated, March 4, 1861, the newly formed confederacy held all the forts within the borders of the states that had seceded, except Fort Pickens, in Florida, and Attack on Fort Sumter, at the entrance of Charleston harbor. Fort Sumter The confederacy felt in honor bound to take and hold all the forts within its limits. President Lincoln felt equally bound to hold all the forts of the union. There was a long period of waiting, neither side wishing to strike the first blow. Finally President Lincoln decided to send a ship with supplies to relieve the garrison in Fort Sumter. The confederates took this as a hostile act and fired on the fort from the batteries they had built around it. At the end of thirty-four hours of bombardment Fort Sumter surrendered, and the garrison marched out with the honors of war. Nobody was killed on either side, but the war which everybody had feared was actually begun.

President Lincoln now called for 75,000 troops to put down the resistance of the South. In every Northern state Raising an his call was received with enthusiasm, and he found he army could get many more men than he asked for. So many volun- 


\section{THE PLAIN STORY OF AMERICAN HISTORY}

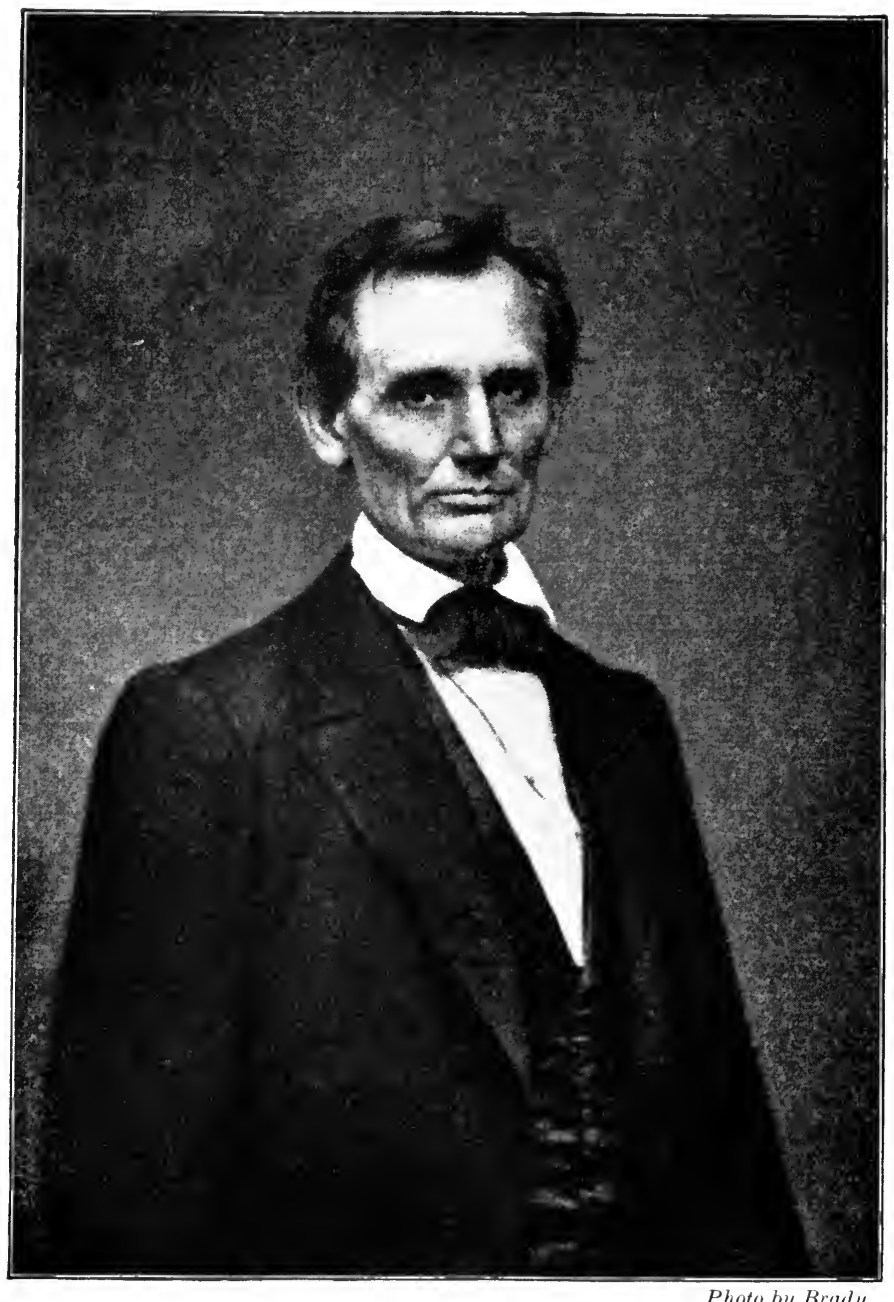

Abraham Lincoln 
teered that by the end of June he had an army of 310,000 men. The confederate president also called for troops, and the Southern people rushed to arms as eagerly as the men of the North. The Southern states which had not seceded were now in a sad po-

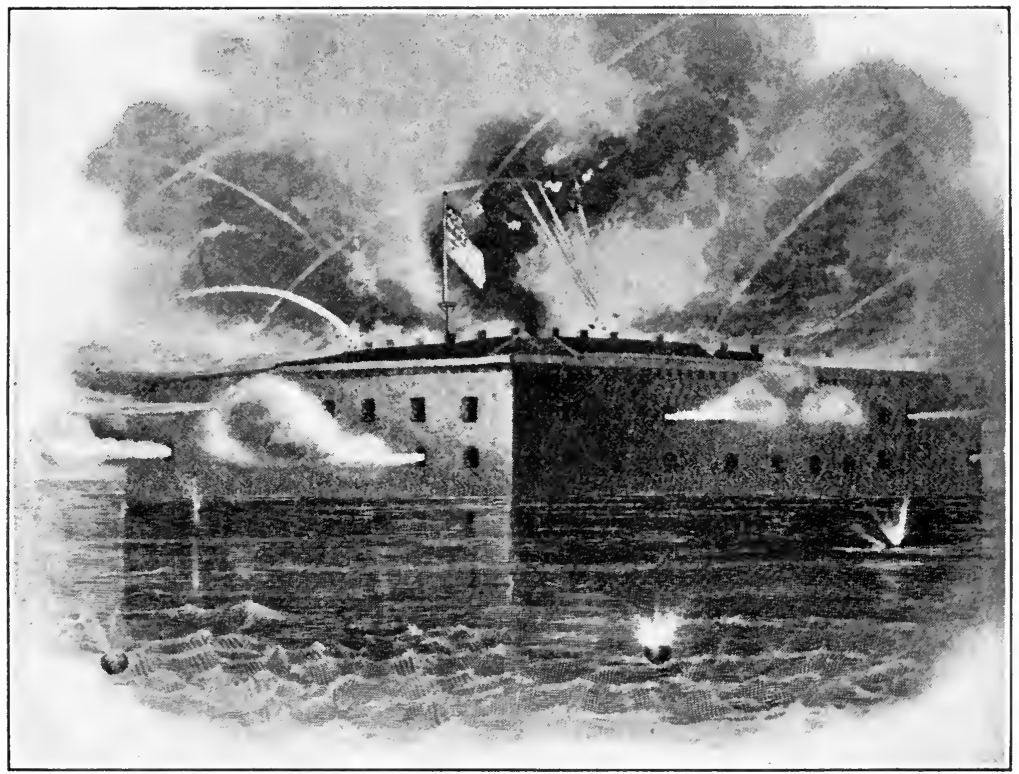

Bombardment of Fort Sumter

sition. They had shown that they did not wish to leave the union; but they found that they must fight for the other states confederacy or against it. When they realized this, secede they felt compelled to go with their own people. Virginia, North Carolina, Arkansas, and Tennessee all seceded and joined the confederacy. Maryland, Kentucky, and Missouri seemed about to do the same, but Lincoln found means to keep them from giving their main strength to the confederacy. In Missouri and Kentucky Southern sympathizers held conventions, declared their 
states out of the union, and sent delegates to the confederate congress at Richmond. But these movements were not very important. Each of these three "border states" sent troops to both armies.

The first important battle was at Bull Run in Virginia, thirty miles from Washington. A union army of 30,000 men, commanded by General McDowell, was marching southward in re-

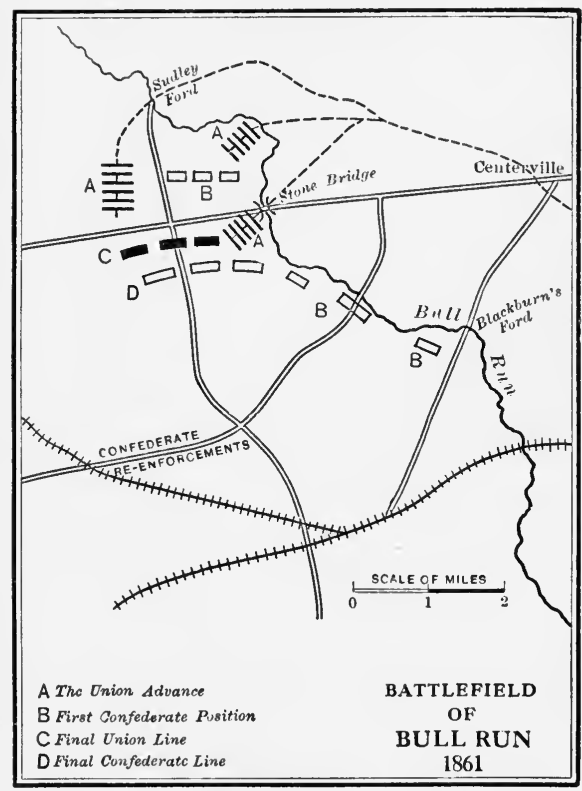
sponse to a cry of "On to Richmond!" from all the North. Richmond was the Battle of capital of the Bull Run confederacy, and the opinion was common that it could easily be taken. McDowell knew his soldiers had not yet been trained into good fighters, but he thought the Southern troops before him were as raw as his own men. At Bull Run a confederate force commanded by General Beauregard offered him battle. July 21, 1861, from 10 A.M. until 3 P.M. the fight raged fiercely. The union men gradually pushed the confederates back in spite of strong resistance. McDowell at three o'clock thought the victory his when a strong body of fresh confederate troops rushed on the field and threw themselves into the battle. The tired union soldiers fell back, and then became discouraged and broke into disorder. Had they been seasoned troops, they would have retired in good order, forming new lines near the battle field and holding back those 
who pursued. But their confusion gave place to panic, and through the night they fled, not stopping until they reached Washington.

The battle of Bull Run dispelled the belief that the South could be conquered in a few weeks. It was followed by a long period of preparation on each side. Troops were collected, A period of camps of instruction were formed, and week after preparation week the slow process of drill went on. It was necessary to do this, because up to that time we had maintained only a small regular army, and the men needed for the war then beginning were to be drawn from the farms and cities of the country, North and South. It was not until the beginning of 1862 that the opposing armies were again in active motion.

The men who directed affairs in the South realized that the problem on their side was to defend their territory from attack. They did not have to conquer the North, but to keep Task of the North from conquering them. It was their advantage each side that they could fight at home, where they knew the roads and rivers. On the other hand, the North must move into the South, push back the confederate armies, and put down the resistance of the confederates in one state after another until the authority of the union was again recognized from one end of the South to the other. More soldiers are needed to invade a country than to defend it.

The Appalachian Mountain system runs from Canada to the northern part of Alabama. It divided the confederacy into two parts. For this reason the urion armies had to move A double in two great divisions, one on the east and the other on invasion of the west of the mountains. It was hoped that they the South would carry all before them and speedily unite somewhere south of the mountain system. But this hope was not entirely realized. The western division moved more slowly than was expected, but it made steady gains of territory. At the end of each year it had gained something which it did not lose, and at the end of the summer of 1864 it took Atlanta and was victorious in Georgia. 
But the eastern division was not so successful. Year after year it failed to push back the confederates; and when Atlanta was taken the eastern division was still trying to take Richmond, only

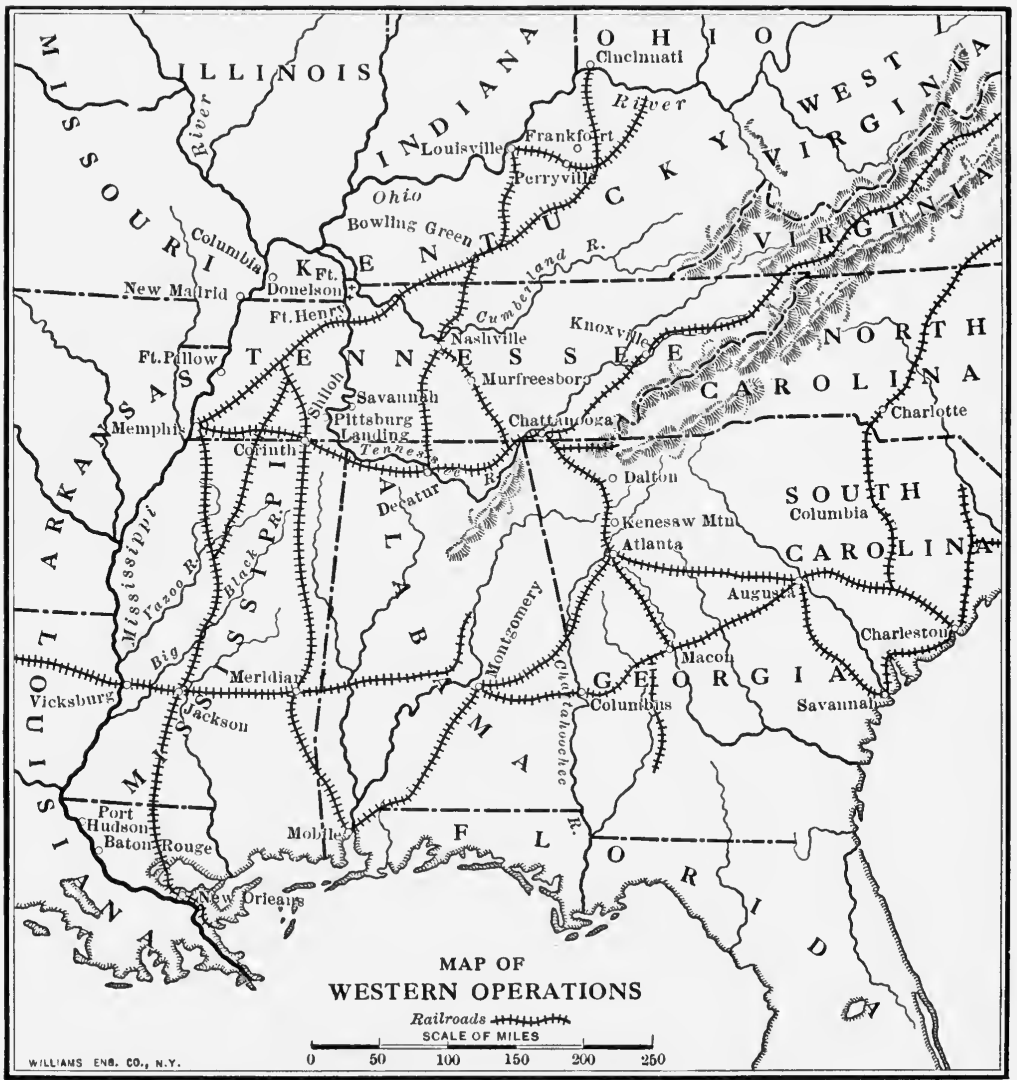

seventy-five miles from the Potomac River. When the western division, with its special task accomplished, swept northward from Atlanta to the aid of the eastern division then before Richmond the confederate forces were caught between two great armies 
and the war was brought to a close. In this book the western and eastern expeditions will be described as distinct movements, each in its entirety; and the western invasion will be taken up first.

The western union armies assembled along the Ohio River and the confederates awaited them in a series of posts running east from the Mississippi through southern Kentucky The western and northern Tennessee. These posts were placed on lines river and railroads, because it was known that the attacking armies would have to march along such routes in order to carry their supplies. Behind this series of posts was Nashville, the capital of Tennessee and a railroad center. If it were taken, a large portion of western Tennessee would be freed from confederates.

Early in 1862, General Grant, who had not yet shown his military ability, was in command of an army on the Ohio, and General Buell commanded another in central Kentucky. Grant's first Before Grant were two rivers, the Tennessee and the campaign Cumberland, which run parallel through Kentucky and a part of Tennessee and empty into the Ohio quite close together. The confederates, not knowing by which river the union armies might come, had erected Fort Henry on the Tennessee and Fort Donelson on the Cumberland. Grant saw that he had the advantage of them, because they must divide their forces, placing some in one fort and some in another, while he could attack each separately with all his men. He first moved against Fort Henry, and its defenders were glad to escape before he surrounded them. They fled to Fort Donelson; and Grant, following them, attacked so quickly and vigorously that they did not have time to get out of the place. They had not supplies enough to enable them to resist, and were forced to surrender nearly 15,000 prisoners. Grant was now within seventy-five miles of Nashville, but he did not try to take it. That task was left for Buell, who marched into the city. The confederates did not wait to be surrounded, 
342 THE PLAIN STORY OF AMERICAN HISTORY

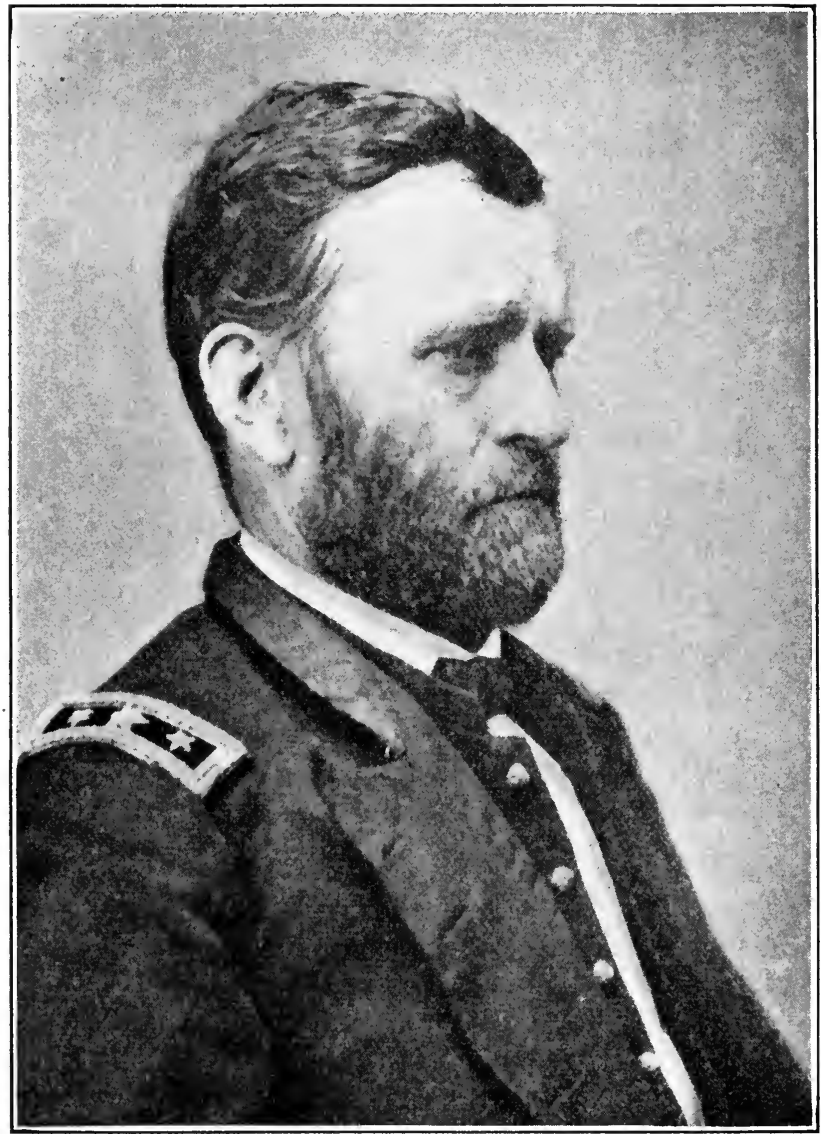

General U. S. Grant

(c) Underwood and Underwood. 
but retreated in a southwestern direction, and finally took position at Corinth, in the northern part of Mississippi. Grant followed close after them, but kept along the line of the Tennessee

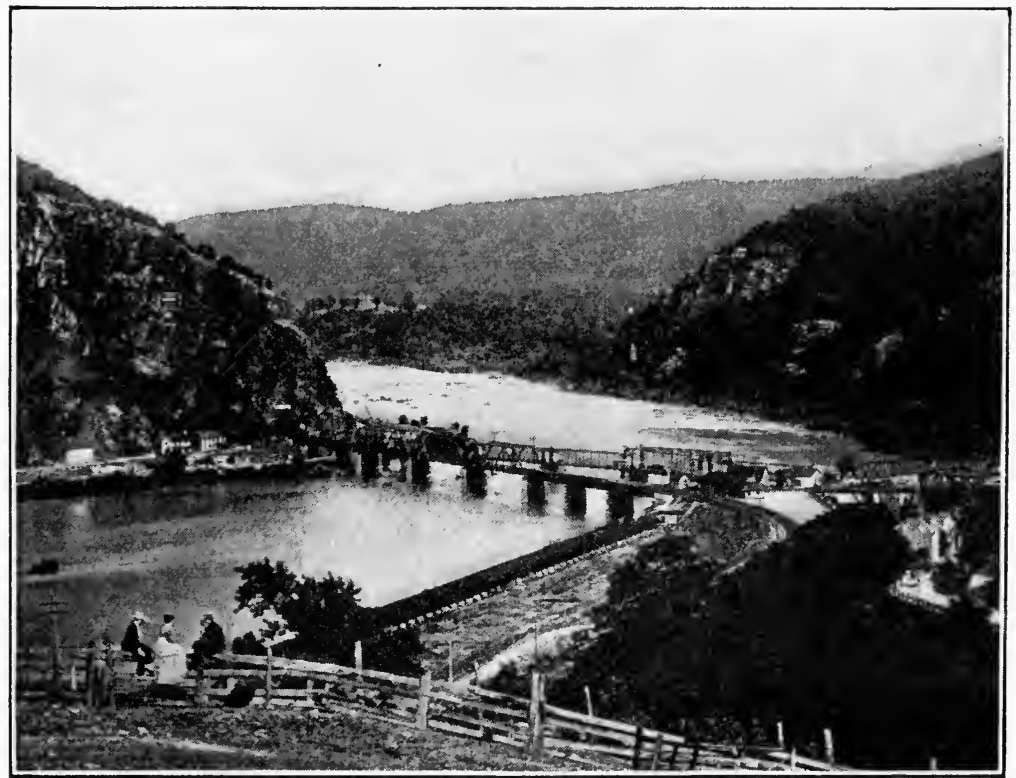

Harper's Ferry

The place was important, both because it commanded the entrance to the Shenandoah Valley and because it was here that an important railroad connecting Washington with the West crossed the Potomac.

River, for he must use that stream to transport his supplies. An army can go no faster than its supplies; and of these Grant's army needed a vast quantity.

The confederates now united were under the command of General Albert Sidney Johnston, one of their best generals. Grant thought them so crushed that they could not offer battle, and advanced leisurely. He was expecting Buell to join him 
from Nashville, and when that was done, he intended to throw the united army against Johnston at Corinth.

The confederate general realized that his best chance with Grant was to attack before Buell came up, and a good opportunity to do this was offered him by his opponent. April 5, 1862, Grant's army was lying along the Tennessee River, twenty-three miles from Corinth. One of the divisions was five miles from the main body, and Grant himself was nine miles away. On this day Buell came within nine miles of the main body and was allowed to halt without joining.

At this moment Johnston was moving out of Corinth. He had 40,000 men, whom he led swiftly forward. In the early dawn, Battle of May 6, 1862, he opened battle on that part of the Shiloh union army nearest to him. It was only 37,500 strong, and its commander was not on the field. Johnston wished to overwhelm it at once and fought desperately, but the union forces resisted stubbornly. At three o'clock in the afternoon Johnston fell, mortally wounded, but the battle continued. At nightfall Buell's army arrived to find the confederates fighting hard to drive Grant's men from their last position. Their aid was greatly needed, and saved the day. On the seventh the united union army renewed the battle and the confederates were outnumbered and forced from the field. This encounter has been called the battle of Shiloh, from the name of a church around which there was much hard fighting; but sometimes it is called the battle of Pittsburgh Landing. The confederates withdrew to Corinth and were followed by Grant, who entered the place late in May.

The union army had now taken all of eastern Tennessee except the Mississippi River bank, and that was about to be taken. Forces Parts of the operating on the river came down in the wake of Grant, Mississippi who moved through the interior, a hundred miles River east of the Mississippi. They surrounded the forts guarding the river and forced them to surrender. June 6 Memphis was taken, and federal gunboats went unchecked as far south as 
Vicksburg, Mississippi. To make this victory greater, a union fleet under Farragut took New Orleans two weeks after the battle of Shiloh, first running past the confederate forts on the river in a most dramatic manner. By this success the North now held the mouth of the river, and her gunboats could pass up as far as Port Hudson, Mississippi. Between that place and Vicksburg was a distance of one hundred and fifty miles, and this was the only part of the great river which the confederates controlled after June 6, 1862. We shall soon see how they lost it.

During the latter part of 1862 Grant remained in northern Mississippi, and the chief scene of operations in the West was East Tennessee. Buell was given a large army at Nashville and ordered to drive the confederates out of

Buell's task the region southeast of him. The key of this part of the state was Chattanooga, situated on the edge of a hilly upland through which the railroad opened the way into northern Georgia. As long as Chattanooga was in the hands of the confederates Atlanta was safe. There was a strong confederate army in Chattanooga under General Bragg.

Buell was a deliberate general, and the confederates took such liberties with him that he was made to seem ridiculous. He first marched out of Nashville, in a slow and cautious outwitted manner. Bragg left Chattanooga as though he would by Bragg meet him. Suddenly he swerved to the east. Buell thought he was trying to get into Nashville by the northeast and only looked more carefully to its defenses. He was soon to learn that Bragg had a greater game in view. Courier after courier came tearing into Buell's camp to report that the confederates were rushing northward into Kentucky and about to get between Buell and Louisville. The union army now turned about and made for the Ohio River. For some days it was doubtful who would reach Louisville first, Bragg or Buell. But the confederate general loitered two days in eastern Kentucky and was out-distanced by his opponent. 
Bragg then turned round in an indecisive way and Buell moved against him with a strong army, forcing him to fall back toward Battle of Chattanooga. The long march gave the confederates Perryville no advantage, but it thoroughly frightened the people north of the Ohio. On his retreat a portion of Bragg's army encountered a portion of Buell's at Perryville, and there was a hard battle, at the end of which the confederates had not driven off the federals, as they tried to do, and they were forced to continue their retreat into Tennessee. For his slow movements in this campaign Buell was removed and General Rosecrans took command.

Late in the year Bragg sallied out of Chattanooga and met Rosecrans at Murfreesboro, fifty miles from Nashville. It was a Battle of hard-fought struggle, but at its close the confederates Murfrees- withdrew to Chattanooga, although they had the boro best of the actual fighting. Rosecrans remained where he was, and for six months more Bragg was undisturbed in Chattanooga.

The first move in 1863 was to take that part of the Mississippi which was still in confederate hands. Its key was Vicksburg, a strongly fortified town on a bluff on the eastern bank of the river. Grant moved on the place from Memphis early in 1863 . He saw that the proper way to attack it was first to get to the dry ground south and east of the town, and then to establish lines and starve the garrison into surrender.

How to get his supply ships south of Vicksburg was his first problem. After some delay he decided to run past the confederate Preliminary batteries, believing that the ships would pass the campaign danger zone before more than one or two could be destroyed. The feat was safely performed, with the loss of only one transport. Then the union army was marched down the west bank of the Mississippi and carried over to the east bank twenty miles below the town. Grant now began a brilliant campaign. First, he marched quickly to Jackson, thirty-five miles 
east of Vicksburg, and defeated and drove away an army which the confederates were sending to help the force in the fortress on the river. Then he turned on General Pemberton, commanding the defenders of the fortress, and drove him back into the town. Grant followed quickly and at once began the siege of Vicksburg.

From that time Pemberton's fate was sealed. He was largely outnumbered, and the confederates did not have soldiers enough to drive away the besiegers. Starvation did its work, and Siege of on July 4, 1863, Pemberton and his army, 30,000 Vicksburg strong, with a vast amount of arms, surrendered as prisoners of war. It was the greatest blow the confederates had received thus far in the West. They were now cut off from their territory beyond the Mississippi, a region from which they had drawn large supplies of beef. Soon after Vicksburg fell Port Hudson was taken, and all the great river was in union hands.

While Grant besieged Vicksburg Rosecrans lay in Nashville waiting for a signal to march against Chattanooga, where Bragg kept watch. Late in June the signal was given, and Advance on Rosecrans moved forward. Chattanooga was well Chattanooga fortified and the ground favored the defenders. In front of the town is the Tennessee River, and behind it rise high ridges which enabled the confederates to hold back an army coming from the north. Rosecrans did not dare approach that way. He decided to make a wide turn to the south and arrive through the hills that lay in that region. It was a hazardous movement; for Bragg, who knew the country well, might attack him while his army was divided, some on one side and some on another of the ridges.

Bragg showed a disposition to accept the opportunity given him. He moved to the southward, but traveled so slowly that when he met Rosecrans at Chickamauga, twelve Battle of miles from the town, the union forces had become chickaunited. Now followed a hard battle which was a mauga union defeat, although General Thomas, by seizing a pass in the hills, allowed the federal troops to enter Chattanooga and re-form 
their lines. Bragg followed behind them, and had the disappointment of seeing his opponents sitting down in his own town, while he assumed the task of besieging it from the high ridges south of the place. He brought up his guns, took a portion of the river

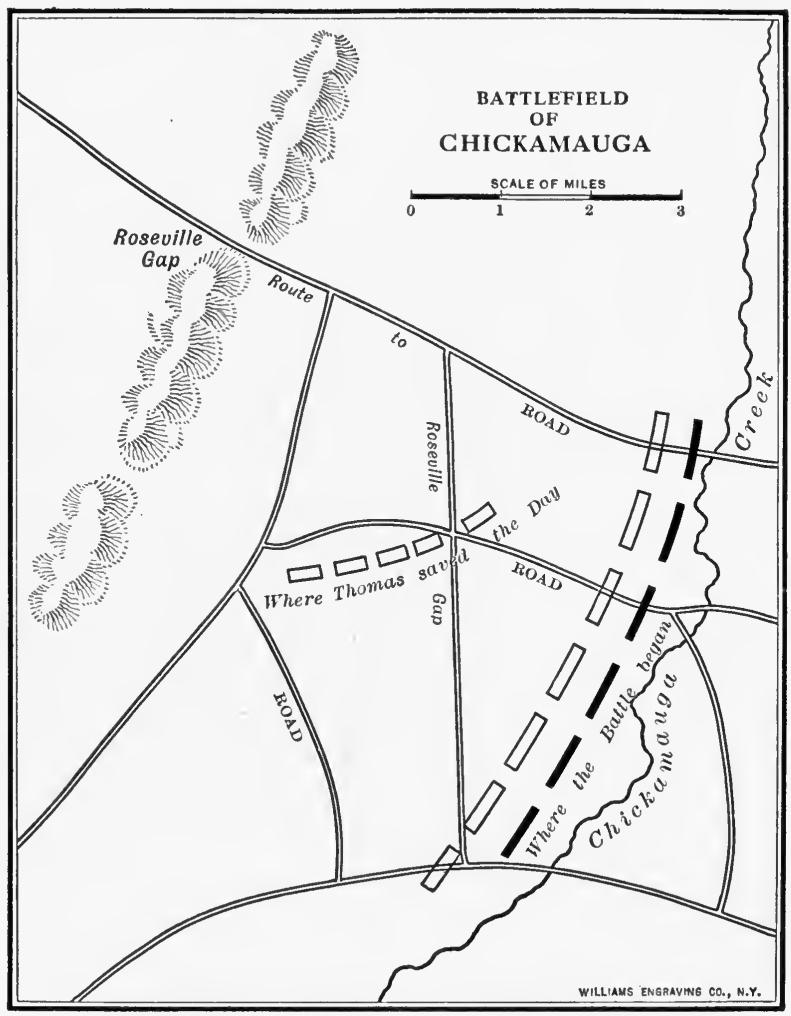

on which the federals must bring up their supplies, and waited for hunger to force them out of the town.

The process of starvation began speedily. All the supplies that could be brought into Chattanooga for the great federal army that now occupied the place had to be carried in wagons 
over wretched roads for a distance of sixty miles. They were hardly sufficient for the daily use of the men, and gloom settled on the army. Confidence in the commander was weak- Gloom in ened, and President Lincoln appointed Grant to the Chattanooga command, believing that he could bring about a better feeling.

Grant's first care was to open a new means of getting supplies by driving the enemy away from the river. This put his men in good spirits. Reënforcements were sent, and November 24, 1863, Grant's plan Grant began a great of battle battle against the confederates on the ridges above him. On the western end of their line was Lookout Mountain, a high peak overlooking the whole region. On it was a confederate force. Eight miles east of it was Missionary Ridge, which ran for six miles parallel with the river and looked down on the union camp. It was crowned with confederate batteries and troops. Grant's plan was to send a superior force commanded by Sherman, up to

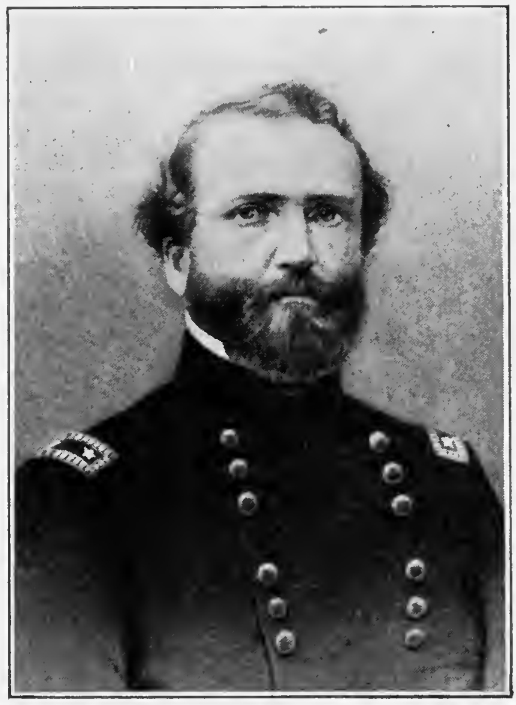

General Thomas the top of the northern end of Missionary Ridge to sweep that crest through its entire six miles, driving away its defenders. While this was attempted by Sherman he ordered the rest of his army to make a feigned attack on the front of the confederate lines. The object was to keep the confederates in their positions, lest they should concentrate against Sherman and overwhelm him. The part of his forces that were to make the feint against Lookout Mountain were under General Hooker, and those which were to 
threaten the southern part of Missionary Ridge were under General Thomas. A glance at the map will show what an interesting scheme this plan of battle was.

Each general set out to carry through the part assigned him.

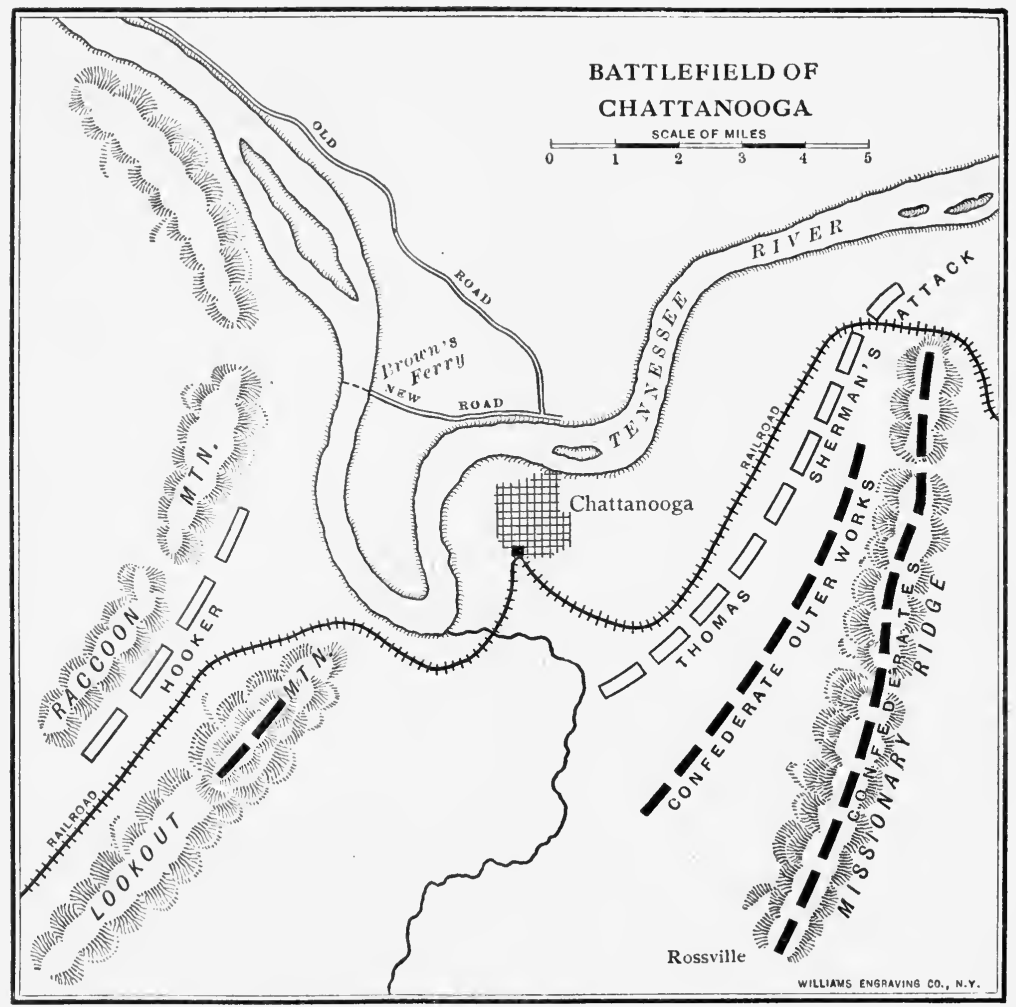

Hooker, to everybody's surprise, found the forces before him The battle of weaker than was expected, and his men rushed up the Chattanooga steep sides of Lookout and soon had the stars and stripes floating in that position. This action has been called the "battle above the clouds." It did not have an important result 
on the rest of the field, for Lookout was too far away for its guns to bear on Missionary Ridge. Sherman began his attack on the northern end of the Ridge in good style. He was, however, halted by a hidden ravine which cut across the ridge. While he waited, Thomas's men began their feigned attack along the bottom of the rest of the ridge. Their orders were not to go up the sides, but the fire from the top was heavy and the soldiers forgot their orders, rushed up the slopes four hundred feet high, and drove the confederates away from their batteries and trenches on the crest. Grant was irritated when he saw the blue lines begin to scale the heights, and said sharply, "By whose orders is this?" Thomas, who stood by him, replied, "By their own, I fancy." When Bragg saw that Missionary Ridge was lost, he withdrew his army from the neighborhood of Chattanooga, and went into winter quarters at Dalton, Georgia. The key to northern Georgia was now in union hands.

The year 1864 opened with

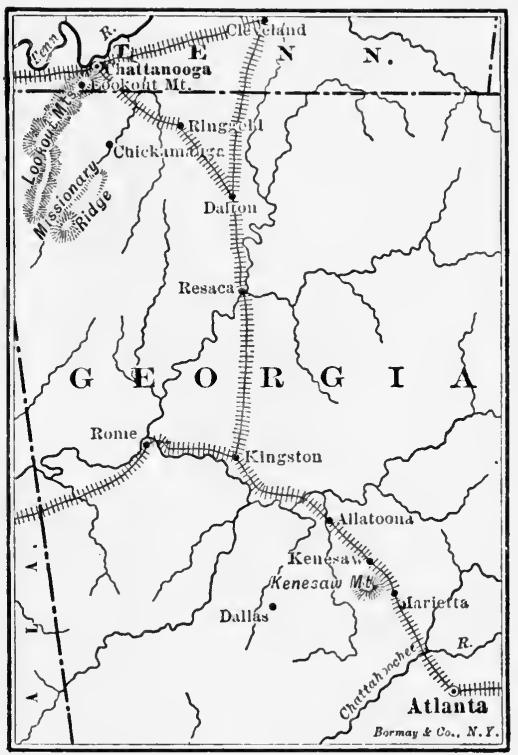
gloomy prospects for the confederacy in the West. Do what it could, it could not place more than 75,000 men in the field to protect Atlanta. This town was an important place; Importance for through it passed the railroads which carried the of Atlanta supplies to the confederate armies in Virginia. If it fell into union hands, it would be very difficult to support Lee's army. Its conquest would, also, mean that Georgia, as well as Tennessee, was lost to the confederacy. It was for the interest of the South to strain every effort to save Atlanta from capture. 
When the fighting began, each army had a new general. Bragg was removed, and in his place was General Joseph E. Johnston, one New com- of the best Southern commanders. He was a cautious manders general and fought on the defensive. General Grant had shown such ability that he was called to the East and placed in command of the army opposed to General Lee. Over the force in Chattanooga was placed General Sherman, who had been one

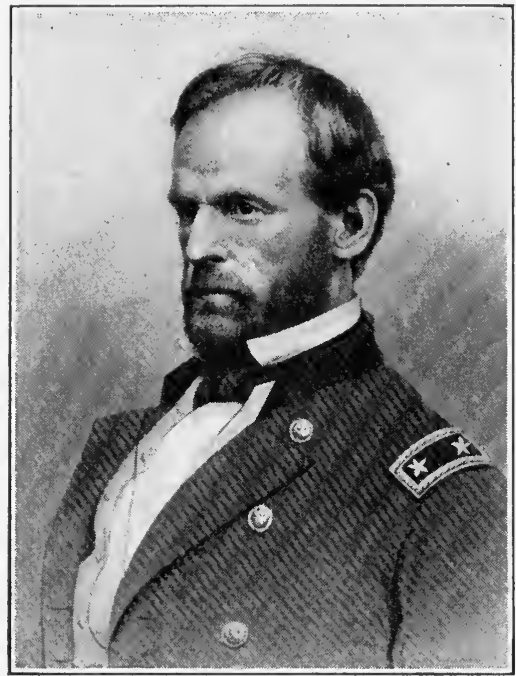

General W. T. Sherman of Grant's best subordinates. He had about 100,000 men, well organized and confident of his ability. He had a good corps of railroad constructors; for he must carry his supplies over the railroad, and he knew that Johnston would destroy the track and bridges as he fell back.

Early in the spring Sherman marched against Johnston. He found him in such a strong position that he dared not attack, Marching but moved as if he and flanking would pass around the left flank of the confederates. Johnston could not afford to let his enemy get between him and Atlanta, and so fell back in order to keep between Sherman and the town. But when Sherman came up, Johnston was in front of him, and so well fortified that it was not wise to attack. Sherman wished for nothing more than an open fight, for his army was larger and would probably win. But Johnston was too clever to give him that advantage. At Kennesaw Mountain, twenty miles from Atlanta, Sherman determined to make an effort to get through his opponent's lines. A fierce charge was all that was necessary to show that such an at- 
tempt was useless, and he again resorted to flanking tactics. By every such movement he gained a few miles on the road to Atlanta; and, by repeating them, he came at last to the Chattahoochee River, six miles from his goal.

Now a fortunate thing happened for the union side. The Southern people had not understood why Johnston kept falling back, and there were loud calls for his removal. July 17 Hood in he was replaced by General Hood, a man who liked to command give battle. Sherman was glad to hear the news of this change, and predicted that there would be no more confederate retreat. He was right. Hood fought and was beaten in three battles, and, on September 2, 1864, he evacuated Atlanta rather than allow himself to be shut up in the place and starved into surrender. Hood was now outside the town, and thought he could play havoc with Sherman by cutting the railroad by which the union supplies came up. But Sherman had enough troops to hold Atlanta and protect the railroad as well. Hood next planned a great raid on Nashville through which Sherman's supplies must pass on their way to the front. If he could take this place he would, he thought, bring Sherman back into Tennessee in a great hurry. But before Nashville he was utterly defeated by General Thomas, and his army was so badly shattered that it was no longer feared.

Sherman was satisfied that Hood would be crushed at Nashville and did not wait in Atlanta to see the outcome of the campaign. He had another plan in his mind. November 15, 1864, Marching he set out to march to Savannah, two hundred and through sixty miles away. No army was in front to hamper Georgia him, and he divided his forces so that they marched by parallel roads, presenting a front sixty miles wide. He ordered his men to "forage liberally," and they more than obeyed him. Railroads were destroyed, supplies were taken, and the soldiers were so little restrained that they pillaged residences freely. Jewelry, silverware, and anything that had value and could be carried off was taken away, while much property that could not be transported 
was destroyed. Sherman's needless severity in Georgia and South Carolina was a mistaken policy. The people whom he reduced to distress were going to be American citizens when the war was over, and it took them a long time to forget how Sherman reduced them to distress.

Marching northward from Savannah, Sherman passed through South Carolina and a part of North Carolina. At Goldsboro, in the latter state, he learned that Lee had left Richmond. He halted for two weeks, and then turned westward. In April Lee surrendered, and a few days later Sherman received the surrender of the small army under Joseph E. Johnston that was trying to impede his march. The war of the Western armies was over.

\section{QUESTIONS}

I. When did the war between the North and the South begin and end? Why did the seceding states feel that they must control the forts? What was Lincoln's attitude? What precipitated the attack on Sumter? Describe the attack. Describe the call for troops. For what purpose was a blockade established? What choice was now left to the Southern states still in the union? How did they act in reference to it?

II. Why did McDowell feel that he must fight the battle of Bull Run? Describe the battle. What was the result? What did the battle show? How long after it was fought before there was a resumption of serious fighting?

III. Compare the tasks of the South and the North in the war. Show why the Northern invasion must be a double one. How were the two great forces to coöperate? In which force was progress most marked? How did the campaigning finally end?

IV. Describe the position of the two armies in the West at the beginning of 1862. What was the significance of Nashville? Describe the relative location of the Tennessee and Cumberland rivers. How were they defended by the confederates? How did Grant take the two forts? In what direction did he then turn? Where did the confederates await him? Why are rivers and railroads important in war?

V. Who was now in command of the confederate armies facing Grant? How did Grant fail to appreciate his capacity? Describe the plan oï the confederates in the battle of Shiloh. What was the result of the battle? 
Describe the operations by which the confederates lost the upper and lower parts of the Mississippi. What part was left to them?

VI. What task was assigned to Buell? Why was Chattanooga an important place? How did Buell open his campaigu? How did Bragg elude him? What race now began? How did it terminate? Describe the battle of Perryville. Who succeeded Buell? Describe the battle of Murfreesboro.

VII. Describe the position of Vicksburg. In what way did Grant decide to approach it? How did he effect a landing at the desired place? What rapid campaign then followed? Describe the siege of Vicksburg. How did the fall of the place affect the confederacy?

VIII. On what eampaign did Rosecrans now enter? Describe the position held by Bragg. How did Rosecrans proceed to attack it? To what danger did he expose his army? How did Bragg meet him? What was the result of the battle? How did Bragg expect to force the federals out of Chattanooga? What was the state of feeling in the place? What new commander was appointed? Describe his plan of battle. Describe the "battle above the clouds." How did Sherman proceed to carry out the part assigned him? How was the crest of Missionary Ridge carried? To what position did the confederates retire?

IX. Why was Atlanta an important place? Describe the new eommander on each side in 1864. How strong were the armies? What was the nature of the eampaign that was now fought? What battle was fought in it, and with what result? Why was a new confederate commander appointed? What was his plan of eampaign? What was the result? How did he first try to eut Sherman's communications? On what long expedition did he then start? What was the result?

$\mathrm{X}$. What daring plan did Sherman now form? Why was he able to earry it out? How did he treat the country through which he marched? Why was a policy of severity unwise in the South? What did Sherman do after he reached Savannah? What was his object? How was his march diverted to another direction? Where did it end?

\section{SUGGESTED TOPICS}

The Attack on Fort Sumter; The Battle of Bull Run; The Capture of New Orleans; Lincoln and the Border States; Lincoln and Grant; General Butler as Commander in New Orleans. 


\section{CHAPTER XXVI}

\section{THE WAR IN THE EAST}

THE story of the federal campaigns in the East, unlike that of the Western campaign, contains a great deal of failure. In Eastern 1862 and again in 1863, there was one defeat after campaigns another until the people of the North, who had given life and money freely to preserve the union, became heartsick. It seemed that nothing could break down the confederate armies in Virginia. But in 1864 General Grant was placed in command of the union forces there and by great effort the army under him was made very large. The result of his labors was that he wore out the strength of his opponents and early in 1865 forced them into surrender. His work was greatly aided by the presence of Sherman in Georgia and the Carolinas, the region from which the confederates in Virginia drew their supplies.

We have seen that the first battle in Virginia, Bull Run, was won by the South. After it came a long period of getting ready. McClellan's The union commander was General McClellan. He preparations made drill and organization his chief aim ; for the confusion that followed Bull Run showed that the bravest men were poor soldiers if they did not know how to face reverses. The seven months he gave to drill made his army a great machine which could be used at will by a good general.

In April, 1862, he began what is known as the Peninsula Campaign against Richmond. From colonial times that part of On the Virginia between the James and York rivers has been peninsula called "the Peninsula." McClellan landed at its eastern end and marched westward, keeping in touch with his 


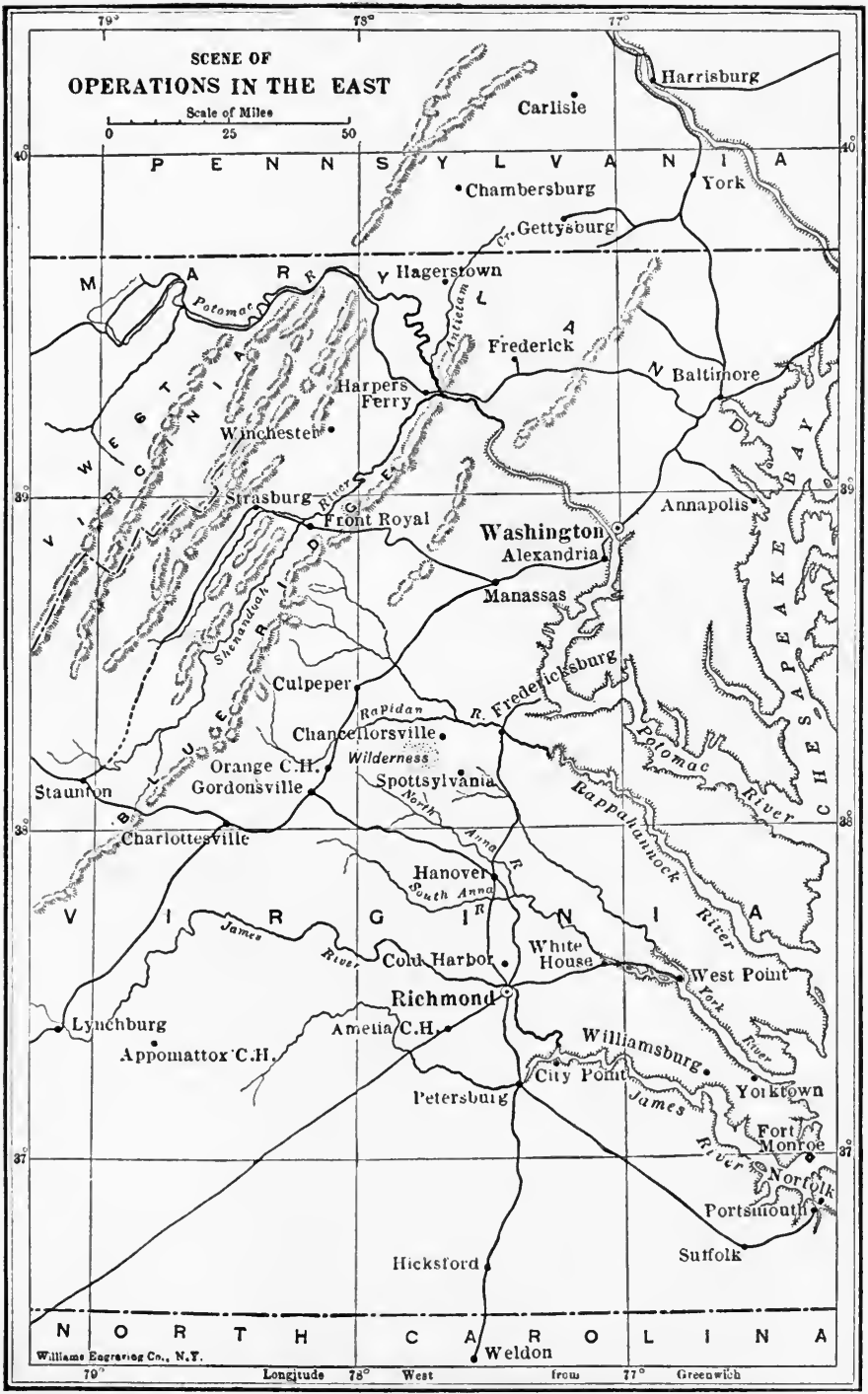


supply ships on the York River. He met little opposition, but marched so slowly that it was the middle of May before he was in striking distance of Richmond. He had 120,000 men and

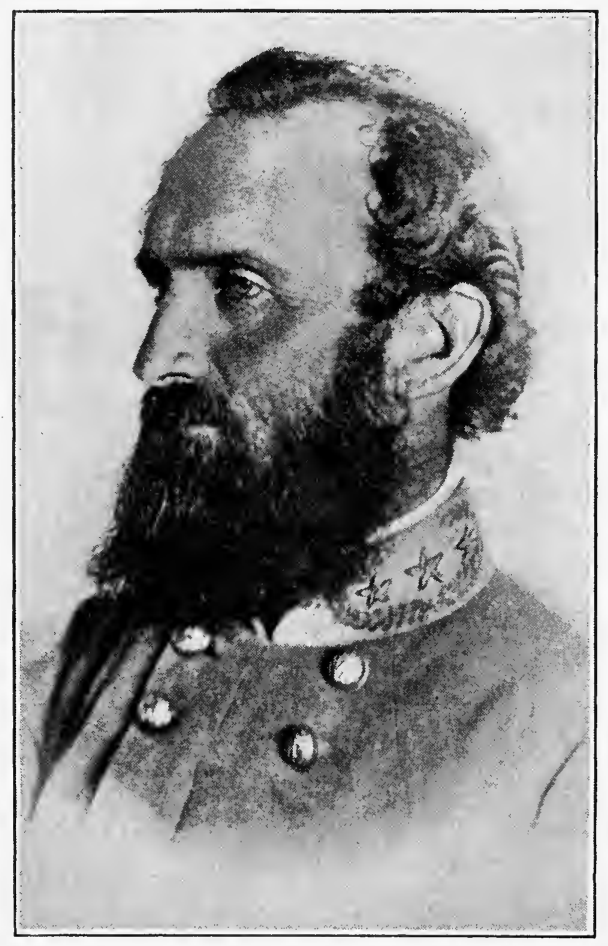

General "Stonewall" Jackson the confederates in Richmond had less than 70,000, commanded by Joseph E. Johnston, who later opposed Sherman before Atlanta.

McClellan was awaiting a body of troops which were to be sent from Washington overland, and while doing so Battle of he carelessly Seven Pines divided his army, placing about twofifths of it at Seven Pines, on the west side of a small river, while the rest were four miles away and on the east side of the river. Johnston was a few miles away and pounced down on the exposed part of the union army, hoping to surround and cut it to pieces before the main body of the army could come up. He met a stronger resistance than he expected. All through the day he charged against the federal troops, who fell back slowly toward the river, looking anxiously for reënforcements. In the afternoon help came and the success of the confederates was checked. Although the advanced troops had been caught unprepared and badly 
handled, there had been no confusion. The lesson of Bull Run had been well learned.

General Johnston was wounded in the battle of Seven Pines

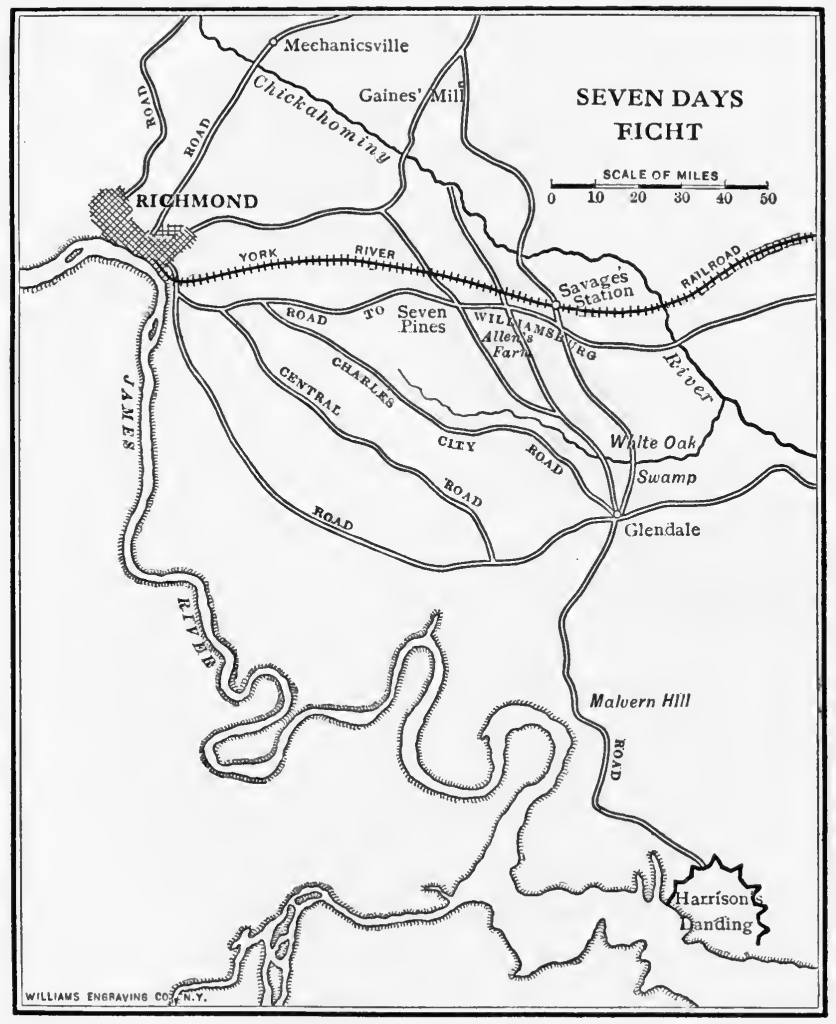

and General Robert E. Lee was appointed in his place. He soon made a plan to drive McClellan from his position Seven days' north of Richmond. He called General "Stonewall" fight Jackson, with 20,000 men, to come to his aid from the Shenandoah valley, and together they began the "seven days' fight around 
Richmond." Three great battles and three smaller ones marked these seven days of contest. Lee's object was to get between McClellan and York River, in order to cut off his supplies. This was done on the second day of the fighting. He thought that the union forces would then become discouraged and be forced to surrender. But McClellan was too resourceful to be crushed. When he was cut off from York River, he turned toward the James, moving rapidly to its bank and fighting four of the six battles as he went. His supply ships were moved from the York to the James River, and he prepared to make a new advance from a wellprotected base only twenty miles from Richmond. But the Mcclellan North had lost confidence in him and was calling for removed his removal from the command of the army, and President Lincoln yielded to the demand. McClellan's troops were hastily withdrawn from the James, and a new advance on Richmond was attempted along the line of railroad which McDowell had followed to Bull Run.

The next great battle was on the ground on which the first was fought, and it is called the second battle of Bull Run. The union Pope in commander was General Pope and against him was command Lee, who had moved from Richmond as soon as McClellan's army was withdrawn from the James. Pope was an overconfident man, and his soldiers suspected that he was not able to lead them to victory. It was a great mistfortune; for soldiers will not risk their lives resolutely when they think that their orders come from a man who does not plan well. Lee, on the other hand, had just finished a brilliant campaign, and his soldiers idolized him. Besides this, Lee had with him "Stonewall" Jackson, an exceedingly able commander for a quick and bold flanking movement. It was he who played the decisive part in the game that defeated Pope at second Bull Run.

By Lee's orders Jackson marched unobserved around Pope's right wing, as Pope was collecting his men about thirty-five miles south of Bull Run. Jackson reached the railroad that brought up 
Pope's supplies, cut the telegraph wires, tore up the track, and destroyed a vast depot of food and clothing that had been collected for the union army. Pope gave up all thought of Jackson's fighting and turned about to protect his rear. Jackson flank march had about 20,000 men with him and was in a dangerous situation, for he had marched three days ahead of the rest of the confederate

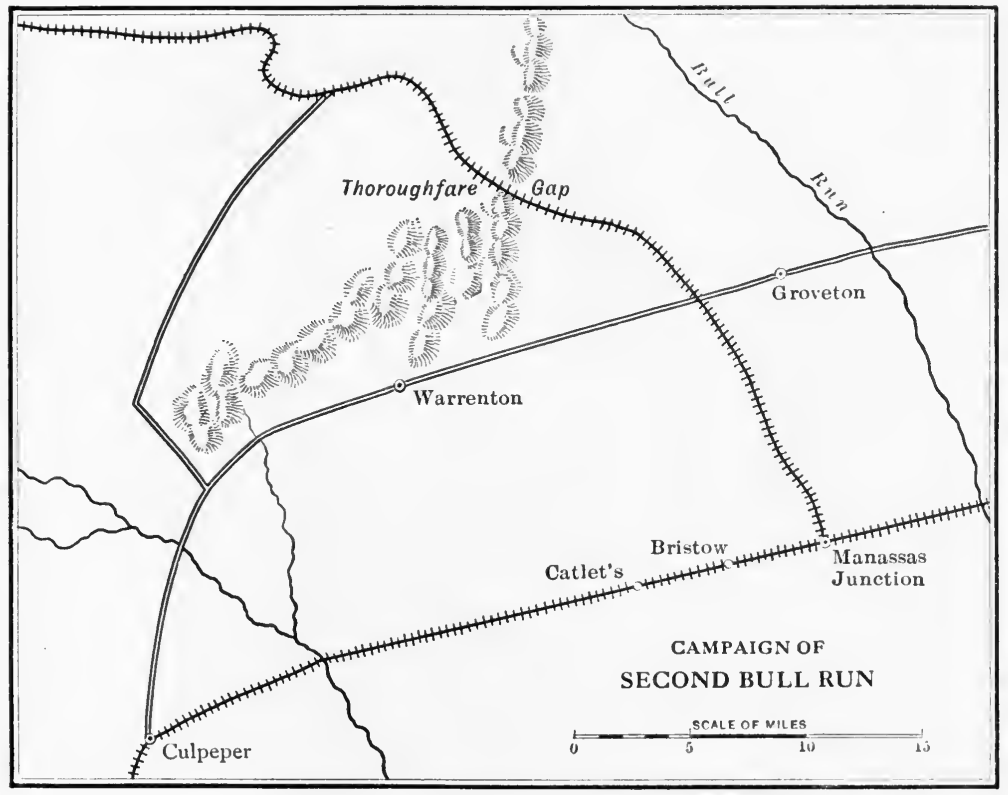

army. If Pope were wise, he would come in between him and Lee, who was coming up as rapidly as he could, and if this were done, the active Jackson would have to move fast indeed to save himself from being surrounded by a superior army.

But Pope did not act wisely. He went any way but the right way, and Jackson was able to conceal his troops in a body of dense thicket looking down on the field of the first battle, until 
362 THE PLAIN STORY OF AMERICAN HISTORY

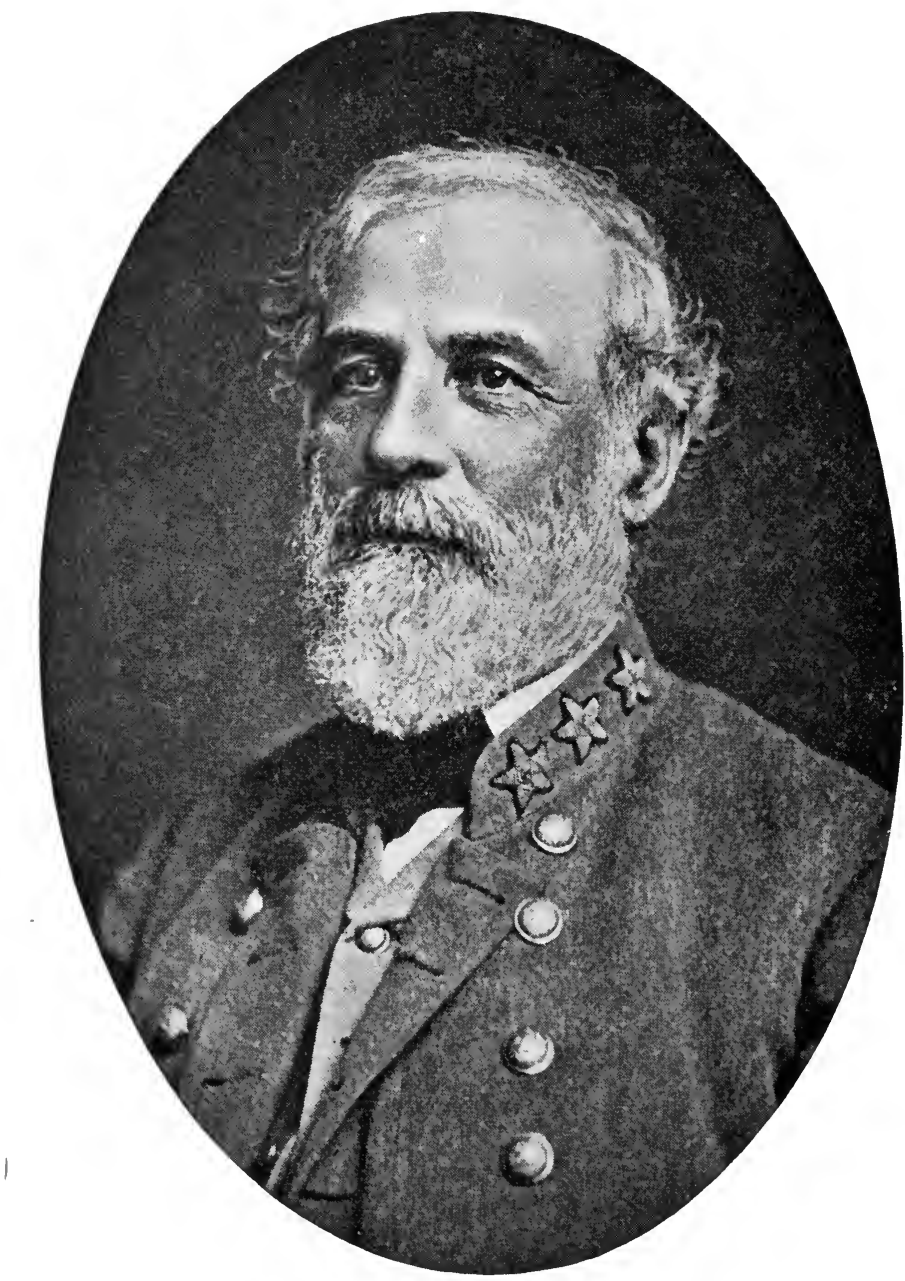

General Robert E. Lee 
he was assured that Lee was at hand. Then he rose from his covert and began to attack the columns of union troops that moved along the road below the wooded heights. The second federal troops formed battle lines and fought with great battle of courage, but they were not able to withstand the efforts Bull Run of Lee and Jackson united, and after two days' fighting, August 29 and 30, 1862, they retreated toward Washington. Pope was removed from command and McClellan was restored.

He had his hands full at once; for Lee did not hesitate a moment after crushing Pope but moved into Maryland. He probably intended to strike at Harrisburg, the capital of Pennsyl- Battle of vania. He thought that the union army was so badly Antietam shattered that it could not be brought to face him for several weeks. But the restoration of McClellan worked wonders with the men, and when he met Lee at Antietam, September 16 and 17 , his soldiers were anxious for the fray. It was a hard battle. One division after another fell on the confederate ranks, but all were driven back. At the end .Lee stood in his

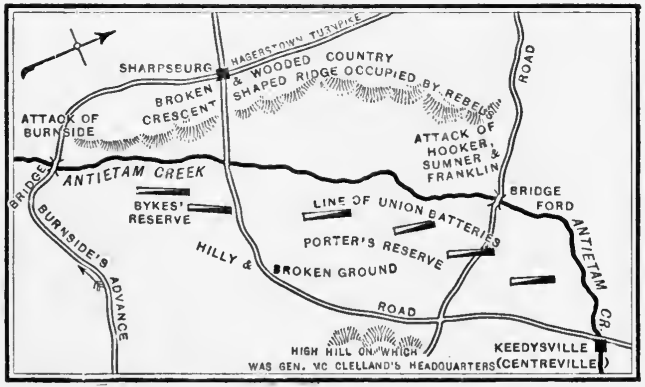

Antietam (from a War-time Sketch)

tracks, but he was so badly used that he marched back into Virginia to recover. McClellan was severely criticized for not crushing Lee before he could cross the Potomac. He was removed from command and General Burnside was put in his place.

The next battle was at Fredericksburg, on the Rappahannock River, December 13, 1862. Burnside had a great army on the north side, and Lee awaited him on the south side. Burnside threw his divisions across the river, formed his lines on the south 
bank, and charged against the hills on which were planted the confederate cannon. He was repulsed at every point. A part Battle of of Lee's lines was very strong, and here, by some cuFredericks- rious chance, Burnside made his hardest charges. burg His columns fell before the enemy's fire like grain before the scythe. At the end of the day the union army drew back to the north bank, and all the loss of life at Fredericksburg was for nothing.

At this time four generals had been tried as leaders of the Eastern armies and all had failed: McDowell, who commanded The unsuc- at first Bull Run; McClellan, who commanded in the cessful peninsula campaign and at Antietam ; Pope, who comgenerals manded at second Bull Run; and Burnside, who made the blunder of assaulting at Fredericksburg. Lincoln was greatly discouraged. Burnside resigned his command, and General Hooker took his place. With a new general and a new year the country hoped for better success.

Hooker was very popular in the army and he had shown a great deal of fighting ability ; but he was to prove a failure as the comBattle of mander of a great army. He moved forward toward Chancellors- Richmond as soon as the spring sun dried the roads. ville

Lee met him at Chancellorsville, and the result was another great confederate victory. Hooker's army was driven back in its course and the advance to Richmond was checked. But the confederates suffered a severe loss in the death of "Stonewall" Jackson, who was shot in the darkness by his own men just. after he had made a brilliant move around the right wing of Hooker's army. The battle of Chancellorsville was fought May 2, 1863. It was the last great confederate success.

The victory filled the South with rejoicing, and it was decided to make another invasion of the North. Lee's army moved forLee in Penn- ward as soon as possible, so that the blow might be sylvania given before the union army recovered from the effects of their defeat. Lee moved rapidly across the narrow part of 
Maryland, and late in June his forces were in Pennsylvania going straight toward Harrisburg. His advance guard reached the bank of the Susquehannah opposite the town, but went no farther. The turn of events behind him warned Lee that he was in danger and he drew back.

The danger came from the union army which was drawing together and coming up behind Lee in great numbers. Hooker had been removed and General Meade was appointed in his place. The sol- Concentratdiers were in good ing at spirits and showed Gettysburg that they were determined to wipe out the stain of their recent defeat. As the confederates turned southward they followed roads that led to the town of Gettysburg, in southern Pennsylvania. The federals marching northward followed roads that led to the same place.

It was July 1, 1863, that the advanced parts of the two armies came together two miles north of the town. They

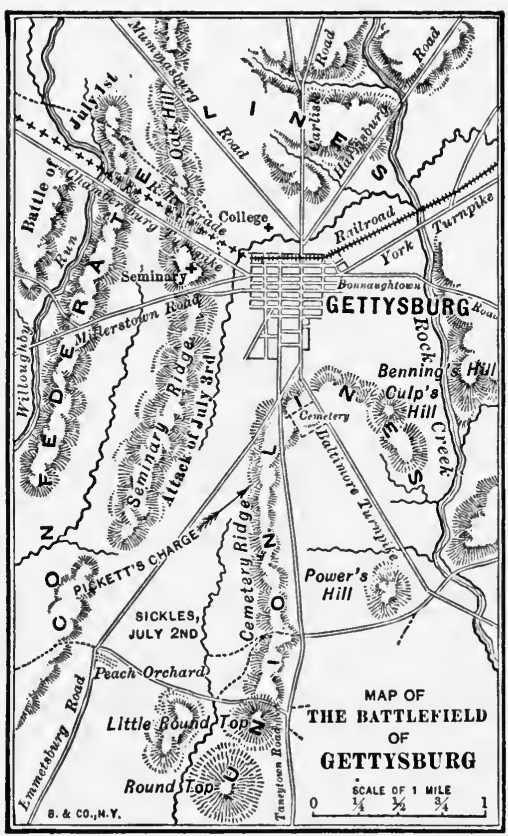
formed battle lines across the road and began to fire on one another without a moment's delay. Each hour the lines grew stronger as fresh regiments came up behind. But the confederates arrived in larger numbers than their opponents, and their lines swung around the The first day federal lines, which were forced back throughout the afternoon until they retreated through the streets of Gettysburg and took 
position on a ridge just south of the town. On the ridge was a cemetery, hence the name Cemetery Ridge. During the night troops arrived on both sides in great numbers and the lines on each side were extended with the fresh arrivals.

On the second day of July the two armies were stronger than on

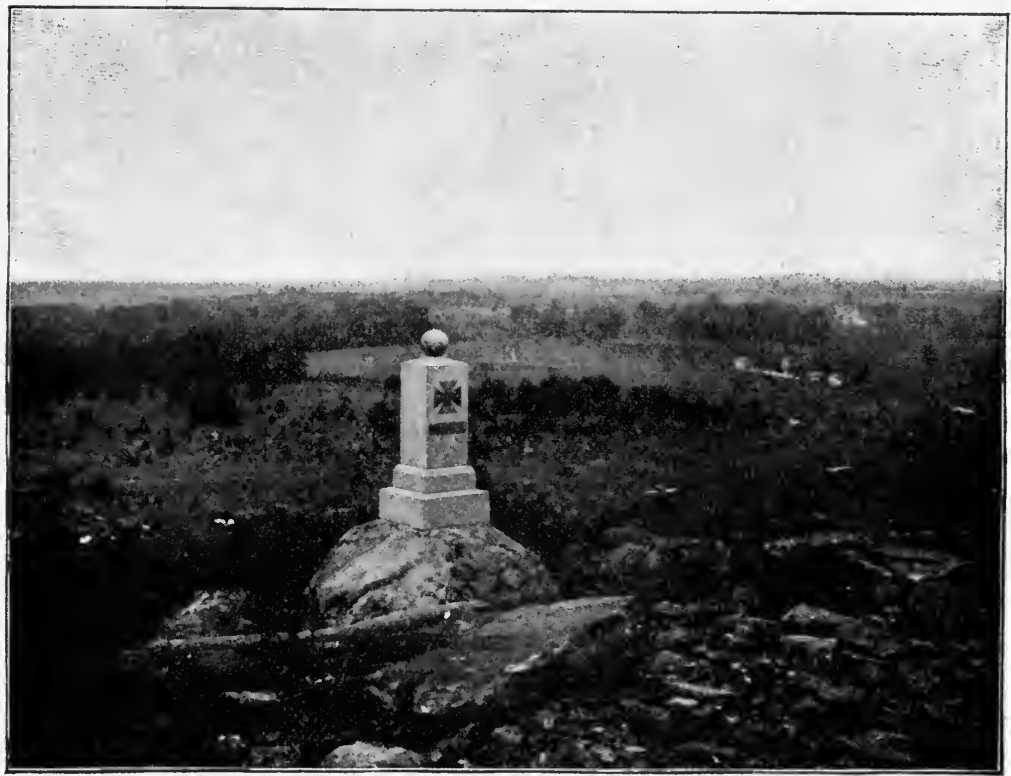

Battlefield of Gettysburg, looking South from Round Top

the day before. Lee had noticed a small round hill about a mile The second south of Cemetery Ridge and thought if his cannon day could be placed there they would sweep the ridge and drive the federals out of their strong position. He ordered that it be taken early in the morning of the second day, but the troops sent to take it moved so slowly that they did not try to carry it until the middle of the afternoon. By that time the hill, 
known as Little Round Top, was firmly held by the union soldiers, and the confederates were not able to take it, although they fought desperately. There was other hard fighting this day, but the union lines held fast, and at nightfall each army was still in its position, the federals on the crest of the ridge and the confederates on another ridge, parallel with the first and about a mile away.

The third of July was the third day of this great battle. Lee was determined to fight it out in his tracks. He was going to stake all on a great effort, and he believed that when The third it came to such a test, soldier against soldier, regiment day against regiment, his men, who had won so often, would sweep their opponents before them. He massed 15,000 men, one-third taken from Longstreet's, and two-thirds taken from Hill's corps, ordering them to charge at the center of the union lines. Longstreet's men were lead by General Pickett, but Hill's men marched beside him and bore their full share of the charge.

"Pickett's charge," as it is usually called, was the most famous charge of the war. When the gray lines rose from their position of safety behind the confederate guns and marched into Pickett's the open fields between the two armies, they were in charge plain view of both forces. Not a gun was firing, and every eye on each side was watching to see what would be the next move. After a moment eighty union cannon opened on them. An eyewitness who was watching the field with glasses reports that every union shell knocked over at least five confederates as it fell and exploded among them. But the gray lines did not falter. When there was a gap, the men closed up and moved forward. Suffering horribly, they reached the crest of Cemetery Ridge and pressed back the federal soldiers for a few moments. But they were now only a small detachment against a great army. The union regiments formed around them, captured a large number, killed many others, and forced the rest back to the positions from which they had started. This splendid charge had been splendidly 
repulsed. It was Lee's last effort. He could do no more, and he drew back from Gettysburg, as he drew back from Antietam in the preceding autumn, in order to recuperate the army on the southern side of the Potomac. Forty-three thousand four hundred and fifty-four men were killed, wounded, and captured on both sides in this battle. The South was already straining to raise men, and the veterans lost here could not be replaced. Gettysburg was won the day before Vicksburg surrendered. That fourth of July, 1863, was the most important of our national birthdays since that original birthday, when the declaration of independence was signed. During the rest of the year each army remained inactive in Virginia.

At the beginning of the year 1864 the federals and the confederates lay facing each other seventy-five miles south of WashingGrant's plan ton. On the Southern side Lee was in command, and he had 62,000 men, all he could get from the weakened South. He knew well that the men he lost in battle could not be replaced, and so he planned to fight only on the defensive. The union army was twice as large as Lee's, and it was commanded by Grant, whose success in the West had made him the most trusted general in the Northern armies. He proposed to throw his vastly superior army on Lee's smaller force and crush it.

Grant's first attack was the engagement known as the battle of the Wilderness. It was fought in a strip of thick scrub oak Battle of the through which Grant must march to reach the rear Wilderness of the place occupied by Lee. While he was lost in the mazes of the roads through this region, he was hotly attacked by the confederates, who knew the roads better. The union troops could see only those confederates who opposed them, and it was not possible to use the federal artillery. Grant thus lost the advantage of his superior numbers and suffered severe loss before he at last got out of the Wilderness.

He then moved eastward, hoping to gain Spotsylvania CourtHouse, a place that was valuable because two important roads 
met there. But Lee was too shrewd to be caught. When Grant arrived at the little town, he found the confederate army in front of him, holding the roads Battle of and ready for Spotsylvania battle. Grant ordered an attack, thinking he could push the enemy away from his front. But all he could do failed.

Grant now made another flank movement, but Lee was vigilant, and every time the fed- Flanking eral army and flanked, the advancing confederates turned about and faced their foe. It was the same kind of movement that was occurring at that time in Georgia, where Sherman was advancing on Johnston. It had this advantage, that it always brought the union army a little nearer to Richmond. June 2, the two armies were at Cold Harbor, ten miles east of Richmond. The prospect was that Lee would retire

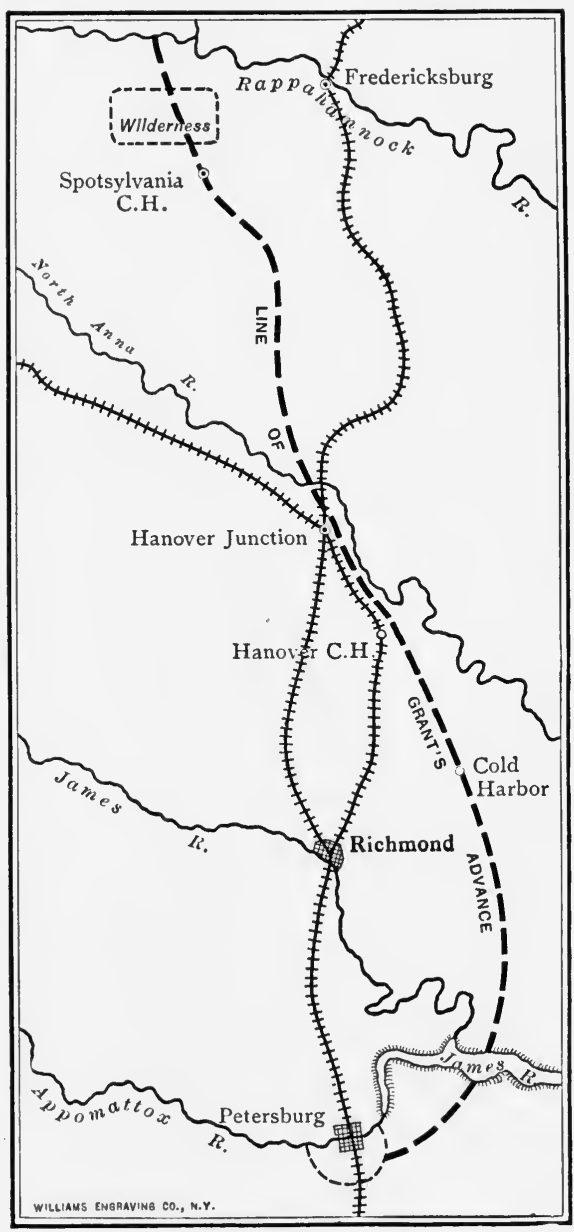

Grant's Operations in Virginia during 1864 behind strong earthworks and the city would have to be besieged. Grant was loath to have a siege, and he determined to make a 
mighty effort to break through the confederate lines and end the war in a few days. He thought that his adversaries had been so weakened that they could not withstand a grand charge by his superior force. The result showed that he was mistaken. In a brief hour at dawn he threw 80,000 men against Lee, and they were repulsed with a loss of 6000 , while the confederates fighting behind earthworks lost not more than 600. From the battle of the Wilderness to that of Cold Harbor, a period of four weeks, Grant lost Two points about 55,000 men and Lee lost 19,000. Two points gained had been gained by this terrible sacrifice of Northern soldiers. One was that Lee's army was materially weakened, and the other was that the federal army was before Richmond.

The last act of the war was now about to begin. Grant left Cold Harbor, crossed the James River, and began the siege of Siege of Petersburg, twenty-five miles south of Richmond. If it Petersburg was taken, the capital of the confederacy would fall. The siege went on all through the autumn and winter. Sherman's operations in Georgia cut off supplies, sickness and hunger wasted the strength of the confederates within the town, and early in the spring it was evident that the place could not be held when the roads were dry enough to permit the federal troops to attempt wide marches around the confederates. At the end of March the roads were passable, and the union army became active. A heavy force fell on the confederates at Five Forks, eighteen miles southwest of Petersburg. They carried the place and captured 5000 of Lee's soldiers. He at once saw that if he stayed in PetersLee in burg and Richmond he would be surrounded, his retreat supplies cut off, and starvation would force him to surrender. Without a moment's delay he marched out of both places during the night of April 2-3 and turned toward Lynchburg, where he hoped to get fresh supplies and make another stand.

Grant was as active as Lee, and his troops, well provided with 
food and horses, could move faster. He pursued day and night and succeeded in getting between the confederates and Lynchburg. On the eighth of April, Lee encamped at Appomattox courthouse. Next morning he gave orders to proceed westward. In a few minutes an orderly eame to report that union The retreat cavalry were in front, and Lee ordered his infantry blocked to charge the cavalry. As the charge was made, the horsemen drew aside and revealed solid ranks of infantry across the road. To charge infantry was more than the thin ranks of the confederates could do. Convinced that any further resistance would mean the needless sacrifice of life, Lee sent a note to Grant to ask the terms of surrender.

In the end the army of the confederacy laid down their arms and were allowed to go to their homes, giving their words that they would not fight again against the union until they Terms of were exchanged as prisoners of war. Grant offered the surrender easiest terms he could offer. He allowed those soldiers who owned their horses to take them with them, in order, as he put it, that they might have them "for the spring plowing." These generous terms made a favorable impression on the Southern people, whose spirits were crushed by their defeat, and they long remembered Grant as a generous foe.

Lee surrendered on April 9, 1865. On the 26th of the same month Johnston surrendered to Sherman at Durham, North Carolina, the terms being the same that Grant allowed to Lee. In May two confederate armies that were keeping up a slight resistance in the Gulf states also surrendered, and the war was over.

\section{QUESTIONS}

I. How did the Eastern campaigns differ from those of the West? How was the confederate army in Virginia at last conquered?

II. What was MeClellan's service for the army in the autumn of 1861 ? What is the Peninsula of Virginia? Describe MeClellan's march up the Peninsula. On which river wore his supply ships? Compare the two 
opposing forces. How did the battle of Seven Pines begin? How did it end? How did the conduct of the troops compare with their conduct at Bull Run? Describe the seven days' fight. Who was the confederate commander? How did MeClellan save his army from defeat? Why was he removed from command?

III. By what route did the next expedition try to reach Richmond? Who was the union commander? What kind of general was he? What plan of attack was made by Lee? Describe Jackson's part in its execution. How did he elude Pope after striking the union line of communications? Describe the second battle of Bull Run.

IV. What was Lee's purpose in going into Maryland? How was he disappointed in the condition of the union army? Describe the battle of Antietam. What criticism was now made of MeClellan? Who succeeded to the command of the union army? Describe the battle of Fredericksburg.

V. What union generals had now been tried at the head of the army? To whom did the command go after Burnside's failure? Describe the battle of Chancellorsville. What heavy blow here fell on the confederates? Recall Jackson's chief successes.

VI. On what campaign did Lee now start? Trace the movement of his army in the North. Why did he concentrate his forces at Gettysburg? Describe the movements on the union forces toward Gettysburg. Describe the first day's fighting at Gettysburg. Where did the union army take its stand at nightfall? What happened during the night? Describe the confederate operations of the second day. What was the result? What was the most important feature of the battle on the third day? Describe "Pickett's charge." What were the total losses at Gettysburg? Who was the union commander in this battle?

VII. Describe the position and strength of the two armies in Virginia at the beginning of 1864 . Who was the union commander? What was his plan of campaign? Describe the battle of the Wilderness. What was the Wilderness? To what point did Grant next march? What was the result of the fighting there? What kind of campaign then followed? Why did Grant attack at Cold Harbor? Describe the attack. What were the results of the fighting from the Wilderness till the end of the battle of Cold Harbor?

VIII. How did the last struggle of the war begin? Before what town did Grant begin a siege? How did Sherman's operations in Georgia have an influence on the siege? What was the importance of the battle of Five Forks? What was the city to which Lee wished to retreat? 
Where was his army surrounded? What convinced him that he could go no farther? What terms of surrender were allowed by Grant? What other armies surrendered?

\section{SUGGESTED TOPICS}

The MeClellan Controversy; Jackson's March around Pope's Army ; Pickett's Charge at Gettysburg; Grant's Campaign of 1864; Sheridan's Campaign in the Shenandoah Valley; Lee's Surrender at Appomattox. 


\section{CHAPTER XXVII}

\section{MEASURES SUPPORTING THE WAR}

GRANT's victory saved the union from division, but it was not by battles alone that success was won. Behind the armies was the Part taken civil government, and behind the generals were the by the civil president and congress. It was their duty to raise the government money with which the armies were paid and with which supplies of arms, ammunition, food, and clothing were bought. If money had not been on hand in large quantities, the armies could not have defeated their opponents. This was true of the South as well as of the North. A larger history than this would have a long account of how each government met these problems.

There were four ways of raising money. One was to increase

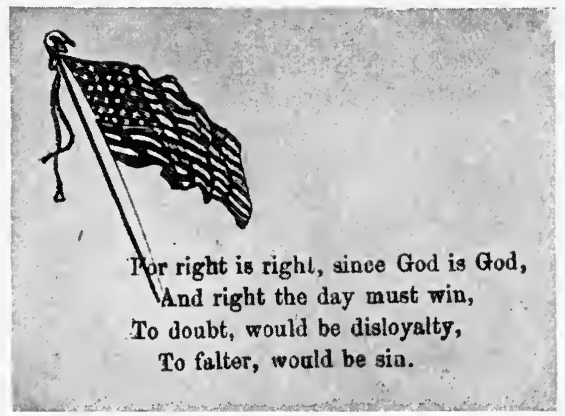

A War-time Envelope the duties on imports, which means to raise the tariff. The rates were gradually raised, until at the end of the war they were excesTariff and sive. Onlyasmall internal rev- part of the money enue needed could be secured in this way. A second way was internal revenue taxes, laid on tobacco, intoxicating liquors, and other articles. They were paid by the manufacturers and added to the War bonds prices of the articles taxed. A third way was to borrow, which is the same as issuing bonds; for a government bond is only a written promise of the government 
to pay a certain sum of money in a certain number of years, with interest at a specified rate. Many millions of dollars were derived from loans. When the government decided to borrow money, it had the bonds printed and signed by officers of the treasury department. They were then sold to the bankers. A bond for a hundred dollars was sold for as much as the government could get for it. Sometimes it would not bring more than eighty dollars. This was because so many bonds were issued that there was no great demand for them.

Another way of getting money was to issue the notes of the government, which were the same as paper money. By this means the government merely printed the money in small bills. Paper A bill would pledge the treasurer of the United States to money pay to the bearer so many dollars on demand. They were printed in green ink, with elaborate engraving so as to make it hard for them to be counterfeited. The public called them greenbacks. They were used for money freely. The government did not pay specie for them during the war nor for nearly fourteen years after the war ended. They were issued in such large quantities that the people did not want to take them in equal exchange for gold and silver, and finally it happened that a hundred dollars in gold would bring a hundred and forty dollars, or more, in greenbacks.

After the war got well started the cost of it averaged two million dollars a day. This, you will see, amounted to a great deal of money for the four years the war was waged. At the Total war end the unpaid bonds of the government amounted to debt nearly $\$ 2,300,000,000$, and there were $\$ 433,000,000$ in greenbacks in the hands of the people. As the greenbacks were promises to pay money they were a part of the war debt. Most of them, however, have been left unpaid and are now a part of the money of the people. A large part of the bonds have been paid.

Next to raising money, the matter that caused the president most anxiety was slavery. By the constitution congress had no right to abolish slavery. Lincoln had great respect for the laws and 
the constitution and he early announced that he would not interfere with slavery in the states. This was highly important, for Lincoln and three slave states had not legally seceded. They would slavery haveleft the union if they had thought the war was fought to destroy slavery. But Lincoln's announcement displeased the former abolitionists, who hated slavery, and thought that the war gave the country an opportunity to get rid of it once for all. They urged Lincoln to proclaim the death of slavery; but for a long time he would not do as they wished.

Finally, in 1862, he made up his mind that the South would not be as able to carry on the war so vigorously if he declared the Emancipa- slaves free. He gave fair warning of what he intion proc- tended to do, and then, on January 1, 1863, he issued his lamation celebrated emancipation proclamation. It was a war measure; that is, it was used as a means of weakening the fighting power of the South. It declared that the slaves should be free in all parts of the country then engaged in war against the union. This had nothing to do with slaves in other parts of the union. .

If the abolitionists thought the proclamation would force the confederacy to employ some of its soldiers in keeping the slaves Its effects from insurrection, they were mistaken. The negroes showed no disposition to make trouble. The North was fighting to set them free, and if they had armed themselves, they might have done much damage in the portions of the South to which no union army could penetrate. But the slaves remained quietly on the plantations, working as usual, producing the food that was to support the armies that fought to perpetuate slavery. The negro was attached to his master, and by nature he was too peaceful and good tempered to become a rioter.

Lincoln himself, and many of his friends, were not satisfied The thir- that a president could abolish slavery by a mere teenth order, even though it was done as a war measure; amendment and they got congress to pass an amendment to the constitution declaring that slavery should not exist in the United 
States. This is known as the thirteenth amendment; it was ratified by three-fourths of the states, as the constitution requires, and went into full operation on December 18, 1865. It abolished slavery in the states which had not seceded as well as in those which had seceded.

Another serious matter for the president and congress was our relations with Europe. The Southerners thought that the nations of Europe would be glad to see the United States The feeling divided into two powers. They were right in this in Europe respect. Both France and Great Britain would have been pleased to learn of the success of the confederate states. But the Europeans disliked slavery, and when the war became a struggle to abolish slavery, it became certain that the European governments would not take the Southern side.

The South thought that the dependence of the British and French cotton mills on the Southern states for their supply of raw cotton would make it necessary for those powers King cotton to interfere in behalf of the confederacy. "Cotton is king," said they. This idea was so often repeated in the South that the people came to accept it as a certainty. The course of the war showed that the idea was erroneous. It is true that the European cotton mills suffered greatly when the supply of American cotton was cut off. In the region around Lancaster, England, there was great distress on account of the large number of workmen thrown out of employment. But at that time few of the working people of England had the vote, and they had no voice in parliament. The men who controlled parliament were landowners, who had little sympathy with suffering mill workers. In fact, the English landowners were more likely to sympathize with the Southern planters, who resembled them somewhat in life and interests.

One of the needs of the confederacy was a navy. All the old navy remained true to the union, and the ships that Confederate fought under the Southern flag had to be built or bought. ships of war It was to England that the confederacy turned most naturally 
when it wished to buy vessels. Several fast cruisers were ordered of the British shipbuilders, although by the laws of nations England had no right to furnish ships in time of war to a power at war with the United States. The British government paid $\$ 15,500,000$ after the war for the damage done by the confederate ships she

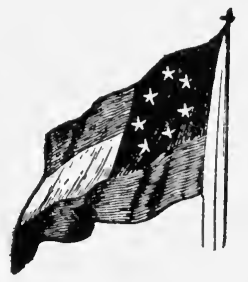

"Stars and Bars," 1861

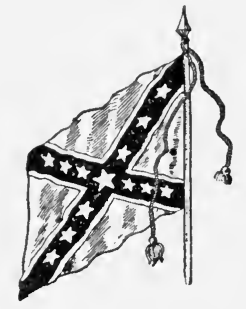

"Southern Cross," 1861

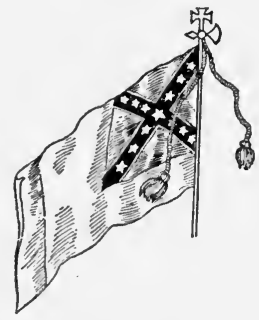

Official, 1863

\section{Confederate flags}

The "Stars and Bars" was given up because it could not easily be distinguished from the flag of the union. The "Southern Cross" was the Confederate battle flag. The ground was red with white stars on a blue cross.

allowed to go to sea. The most famous of these ships was the Alabama, a very fast and well-built vessel that was allowed to get out of the British harbor of Liverpool, although it was well known that she was intended for the confederates. She went out for a trial trip and did not return. She soon appeared on the high seas, heavily armed and flying the confederate flag. She destroyed many of the merchant ships of the United States.

One of the projects of the confederates was to build an ironcoated vessel at Norfolk, Virginia. A merchant ship, the MerriBattle be- $\quad m a c$, was cut down to the water's edge and a slanting tween iron- roof of railroad rails was built over her. Holes in this clads

roof allowed heavy cannon to project. In this service she was known as the Virginia. Up to that time the ships of the world were of wood, and when the Virginia steamed against the federal ships near Fortress Monroe she sank three speedily and withdrew, expecting to destroy the rest the next day. When she 
returned, she encountered the Monitor, a strange looking craft nicknamed "a cheesebox on a raft." She was built with deck level with the water, and in the middle was a revolving round turret in which were heavy guns. Deck and turrets were covered

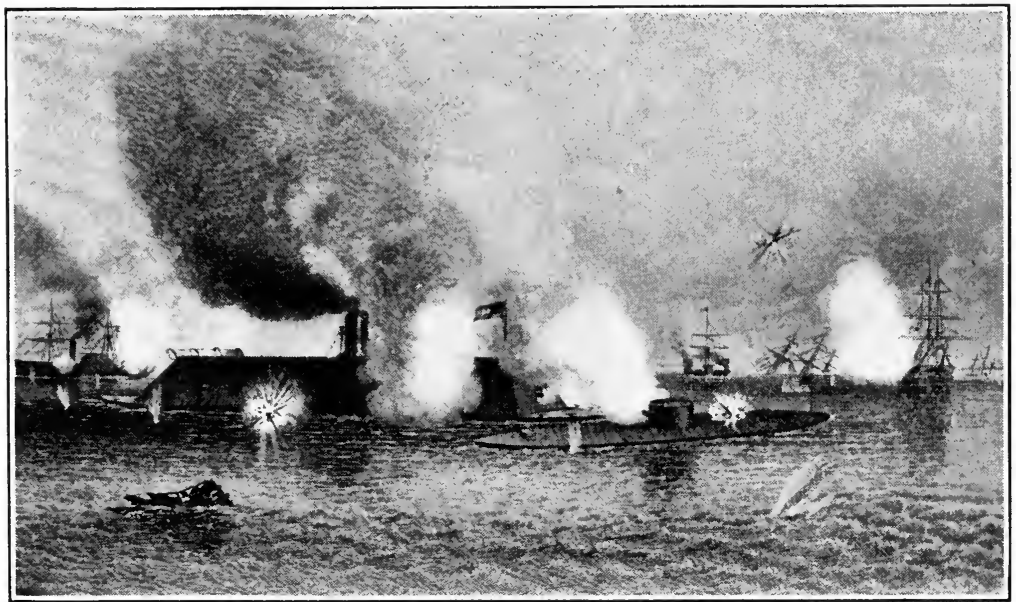

Battle between the Monitor and the Virginia, or Merrimac

with iron. Now followed a battle between the two ironclad boats. Neither was destroyed, but the Virginia withdrew to Norfolk and did not again renew the battle. She was later blown up by her owners. This battle was the first encounter in which ironclad vessels were used. It opened a new era in naval warfare.

One of the most serious disadvantages of the South in this war was the blockade. As soon as fighting began President Lincoln proclaimed a blockade of the ports of the South. Ships The blockwere stationed off these ports to see that no ship came ade enforced in or went out. The Southern states had many resources for manufacturing, but they had been so much devoted to cotton raising that they had not established factories. They depended on the outside world for everything except the mere necessities of life. 
The blockade, therefore, deprived them of many comforts. Coffee, sugar, hats, fine clothing, medicines, books, and a thousand things which seem to-day a part of our ordinary needs now became very scarce.

To bring in such supplies there appeared a class of ships known as blockade runners. They were very fast, built low, and painted Blockade as nearly as possible the color of the water. It was runners their business to dart through the group of blockading ships, and carry supplies into the confederacy or bring cotton out. By this means the confederacy got a slender supply of arms, powder, medicine, and military supplies, but there was always a great lack of other things.

Both the North and the South made great sacrifices in this war. The people on each side were deeply in earnest. The Sacrifices North had a population of 22,000,000 and the South had $9,000,000$, of whom only $5,500,000$ were white people. To meet the great numbers the North could bring into the field it was necessary in the South to order out every man able to bear arms. Surgeons went throughout the country examining the men who claimed they were not able to serve in the army. There were many communities in which not an able-bodied white man was left at home. It is not possible to see how they could have carried their resistance farther; and when the confederacy fell, it fell only because it was exhausted.

In the beginning of the war there were some prominent men in the North who did not believe that the union was worth a war. Lincoln and They thought that it was better to let the seceding the union states go than to waste blood and treasure in overcoming them. If the Northern people had foreseen how long the war was to last and how bloody it was to be, they would probably have refused to go into it. The man who kept the government from yielding on this point was Abraham Lincoln. He insisted that the union should not be divided. If he had not been so earnest about this matter, it seems likely that those who wished to avoid 
war would have had their way. In that case the territory which is now our great republic would have been two or more nations. It is in this way that we can speak of Lincoln as the preserver of the union.

During the war many Northern men did not understand the good qualities of Lincoln, and as the year 1864 approached they planned to defeat his reëlection. They were mostly Election of in the democratic party, and they nominated for 1864 his opponent General McClellan, who had been a democrat before the war. But the great question was union, and as Lincoln stood for that above all else, he was reëlected by a large majority.

The people of the South were bitterly opposed to Lincoln in 1860, and believed that he was a man of the worst passions. They had no opportunity of knowing his real qualities, and Lincoln asthey listened too sassinated readily to men who were prejudiced. All through the war they continued to denounce him because it was he who kept the union armies battering away at the confederacy. When the South was at last conquered, some of her people were very bitter toward Lincoln. One Southern sympathizer was especially ex-

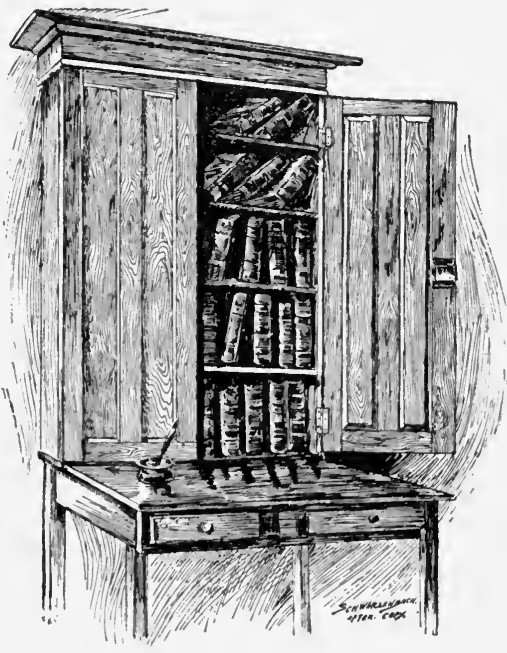

Lincoln's Bookcase

From the Keyes-Lincoln memorial collection, Chicago. cited. He was John Wilkes Booth, an actor, member of a family then prominent on the stage. He brooded over the situation and came to believe that it was his duty to kill Lincoln. He accomplished his object on the night of April 14, 1865, when 


\section{THE PLAIN STORY OF AMERICAN HISTORY}

the whole country was rejoicing over the surrender of Lee's army. Booth entered the president's box at a theater in Washington, fired at the president, and leaped to the stage shouting "Sic semper tyrannis, so may it be with tyrants!" Lincoln died the next day. His murderer was pursued and shot, and four persons were hanged on the charge that they had aided him in his work.

This wicked deed threw the whole nation into mourning. Men who had opposed Lincoln in politics came to see how he had The nation's served the nation in its most trying time, and he was loss pronounced a martyr for the cause of the union. The South, too, changed its opinion of him. Men began to remember that he had never been known to utter a harsh word toward the Southern people, although he knew how much he had been abused in that part of the country. A prominent Southern general who knew Lincoln before the war exclaimed when he heard of Booth's deed: "The South has lost her best friend and protector, the surest, safest hand to guide and steer her through the breakers ahead!" Only a few months had passed before all thinking men in the South began to realize that these words were true.

\section{QUESTIONS}

I. What was the financial task of the government? In what four ways was money obtained? Describe the war tariff. What are government bonds? How were they sold? What other form of borrowing was employed? What were the greenbacks? How many were outstanding at the end of the war? What was the daily cost of the war? How much did the government owe at the end of the war?

II. What power had congress over slavery in the states? How did Lincoln act in this respect? Why was he so careful? What position did the abolitionists take? What was the emancipation proclamation? When did it go into force? On what ground was it defended? What was its effect in the South? Why was the thirteenth amendment thought necessary? What does it provide? When was it completely adopted?

III. What was the feeling of Europe in regard to the secession of the Southern states? Why did it not help the South?. Why did the 
Southerners think that cotton was "king"? How were they disappointed? Why did the suffering in England fail to find an expression in parliament?

IV. What was the condition of the confederate navy? From what country did the confederates expect to purchase ships? What was the law on this point? How did England finally make satisfaction to the United States? Describe the career of the Alabama.

V. Describe the construction of the Virginia. What did she accomplish? How was the Monitor built? Describe the battle between these two ships. Why was it important? What was the reason for the blockade of Southern ports? How did it affect Southern living? What were the blockade runners? How did they serve the confederacy?

VI. How did the strength of the South compare with that of the North? What class of people in the North were at first inclined to agree to the South's secession? How did Lincoln's course serve to make the war a struggle to preserve the union? Describe the election of 1864. What were the issues? What was the opinion of the South about Lincoln during the war? Describe his assassination. How did Southern opinion now change?

\section{SUGGESTED TOPICS}

The Trent Affair; The Confiscation Acts; The Execution of Military Law ; The Copperhead Movement; Lincoln and the Antislavery Movement, 1861-1862; The Escape of the Alabama; Lincoln and the Border States; The Assassination of Lincoln. 


\section{CHAPTER XXVIII}

\section{THE RECONSTRUCTION OF THE SOUTH}

When the war ended, it was generally agreed that government in the conquered Southern states was suspended. Three years passed Two steps in before it was restored to its former condition. The reconstruc- process of restoration is known as reconstruction, and tion

the years during which it was in operation are the reconstruction period. There were two steps in restoration. One was to readmit to congress the senators and representatives of the Southern states, and the other was to reëstablish the government of the states. The second of these steps was very important, for it is the state government that make the laws under which individuals ordinarily live, and it was feared in the North that these governments would make laws which would undo much that had been won by the war.

This was especially true of the question of the negro's future. Free he was by the thirteenth amendment, which everybody was What will be sure would be adopted. In fact, the South was willing done with to accept that. But the negro might escape from the negro? slavery and still not be fully free. He might be denied the right of owning land, which would mean that he should work for the whites as long as he lived, or he might not be treated in the courts as white men were treated. Rights like these are fixed by the state. The North feared that if the Southern states regained full power, they would make laws against the full freedom of the negroes. That is why it was insisted that these states be kept out of the union until something could be done to make it 
impossible for the restored states to discriminate against the freed negroes.

Let us now look on the Southern side. The people of the South were willing to grant that the war was over and that slavery was dead. But they felt that it was a great problem to The Southknow what to do with the negro in a state of freedom. ern side He was untaught, and they thought that a very long period must pass before he could be educated into a good citizen. The Southerner did not dream of making a voter out of a man who was uncivilized in Africa and who had not been trained in the ways of civilization, except as he got a glimpse of them while a slave. The Northern man, on the other hand, thought that the only trouble about the negro was that he had been deadened through his long enslavement, and that when he was free and had been sent to school for some time, all inequalities would disappear. He had great confidence in the quick development The reply of of the negro under proper circumstances. Each the North side was deeply convinced that it was right.

Lincoln had a plan of reconstruction, and when he died, he had started to put it into operation in those parts of the South which were occupied by the union armies. He proposed to Lincoln's allow a state to hold elections for delegates to a plan constitutional convention, but for a time he would exclude from voting the men who had taken most prominent part in the confederate government and armies. When such a convention had met and revised the constitution of the state, he was willing to withdraw the union troops from its borders and allow it to manage its own affairs.

Lincoln was succeeded by Andrew Johnson, of Tennessee, who was elected vice-president in 1864 without a thought that he would be president. He was a democrat before the war, but became a union man when his state seceded. He tried to carry out Lincoln's plan of recon-

First attempt to reconstruct the South struction. As soon as the war was over he appointed temporary $2 \mathrm{c}$ 
governors in the Southern states. Constitutional conventions were also held which generally accepted the thirteenth amend-

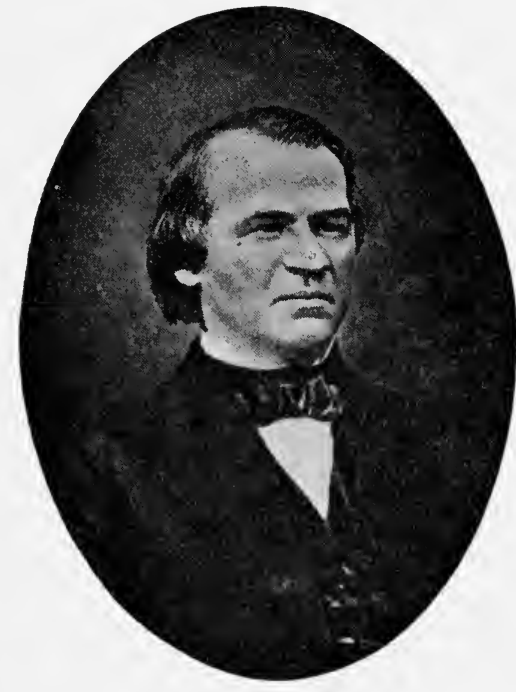

Andrew Johnson ment. Then legislatures met in these states and began to make laws to regulate the lives of the negroes. Some of these laws were very hard on the negro. Mississippi especially showed that she had no thought of allowing the freed blacks to have equal rights with white men. It may have been her honest belief that the negro was not a person who should have the same privileges as the whites; but in the North it was believed that her laws were evidences of a determination Severe laws to keep the negroes as nearly in a state of slavery as possible. It was thought that if congress did not fix his position beyond the power of the states to interfere, he would surely fall into a condition of half freedom.

This idea was popular in the North, and the leaders of the republican party were those who most widely advocated it. In Freedmen's 1866 they began to pass laws to protect the negro in bureau bill the South from the action of the Southern courts. One was the Freedmen's Bureau bill, to allow the trial of many offenses by negroes before officers of the Freedmen's bureau. This bureau was established to have an oversight over the freedmen. Its officers were Northern men, and they rarely knew law. President Johnson vetoed the bill because it interfered with the right of the state courts to settle the disputes of all the inhabitants of a state, and it was not passed over his veto. 
The republican leaders in congress were aroused and passed what was called the first civil rights act. It provided that certain cases in which negroes were concerned should come The civil under the jurisdiction of the federal, and not the state, rights act courts. President Johnson vetoed this bill also; but it was now generally believed that he was acting from partiality for the South, and he had a smaller following in congress than before. The civil rights bill was passed over his veto, a thing which may be done by a two-thirds majority. From this time there was bitter opposition between the president and congress, and in this contest the president generally lost.

The next step taken by the victorious republicans was to frame the fourteenth amendment to the constitution. Its The fourobject was the same as the civil rights bill. It teenth provided that negroes should be citizens of the United amendment States, and it stipulated that their rights as citizens should not be abridged by any laws passed by a state. This was intended to make it so that the freedmen might take their cases out of the state courts and have them tried in federal courts, if they found that the laws of the states discriminated against them. The fourteenth amendment also provided that if a state took the vote away from any portion of its inhabitants, its number of representatives in congress should be reduced in a like proportion. The

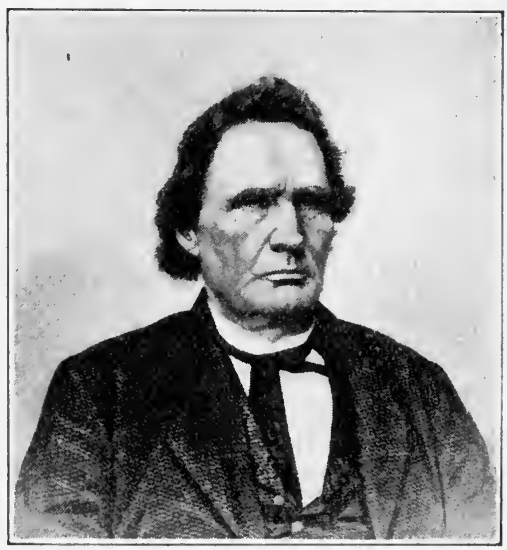

Thaddeus Stevens

amendment passed both branches of congress and was sent to the states for approval. The North accepted, but the Southern states rejected it. Had they accepted it, the moderate Northern men 
would have been satisfied, and it is believed that would have been the end of reconstruction. But the South was desperate, and felt that she was being asked to consent to her own chastisement, something a proud-spirited people never willingly accept. The refusal of the Southern states to vote for the fourteenth amendment defeated its ratification for the time.

The action of the South strengthened the arguments of the Northern men who favored negro suffrage. Such people had said The acts of from the beginning of the controversy that the only 1867 way to protect the negro was to give him the ballot. They now became the controlling power in congress and passed what are known as the reconstruction acts of 1867, passed in March and July. The main features of these acts were as follows: 1. The state governments which had been established in the South by President Johnson in 1865 were to be abolished. 2. Military governors were to be appointed in their places, army officers, who were to keep order in those states for a time. 3. New constitutional conventions were to be called, the members to be elected by all the freemen, including negroes, but not including anybody who voluntarily had taken part in the war against the union. In other words, all that had been done was to be wiped away and a new form of reconstruction was to be adopted by which the negro was to help elect constitutional conventions in which was to be decided the question of his right to vote. Of course, by this means he would be given the right to vote. 4. When the constitutions made by these conventions had been adopted by the people who could vote in the respective states, when they had been approved by congress, and when these states had accepted the fourteenth amendment, congress would admit to its own membership the senators and representatives of the seceding states. When this was done, reconstruction would be complete.

These acts were put into force at once. Five military governors The states were appointed and federal troops stationed in all readmitted parts of the South while the elections were held. 
President Johnson did not approve of the plan, but it had passed congress and he considered it his duty to enforce it. One by one the Southern states now adopted the fourteenth amendment and made constitutions in which the negro's right to vote was recognized. In 1868 all but three were received into the union, and in 1870 these others were admitted. And thus the union was restored.

Congress feared that in the future some Southern state might change its constitution so as to take away the vote from the negro, and to make sure that such a thing was not done The fifthe fifteenth amendment was passed. It provided that teenth the right to vote should not be denied on the ground amendment of "race, color, or previous condition of servitude." This amendment was also ratified by the states. The Southern states were under the power of the negroes and voted for the amendment.

By this time the leaders of congress were bitterly angry at President Johnson and impeached him. They mentioned several grounds on which they contended that he had violated the laws; but the most important was that he had tried to remove Stanton from the office of secretary

Impeachment of the president of war, contrary to a law of congress. Johnson said in reply that he believed this law was not constitutional, and that he removed Stanton in the hope that the supreme court would step in and pass judgment on the point. It was admitted that the president has the right under the constitution to dismiss cabinet members.

The charges against the president were prepared by the house of representatives, which appointed a committee to conduct the trial. In such cases the senate sits as a court to hear the evidence and decides whether or not the charges

The trial are proved. This is the only time in our history that a president has been impeached, and it attracted a great deal of attention. As the trial progressed sympathy began to turn to Johnson. He was so bitterly hated by those who prosecuted him that calm-minded people began to think that he was being persecuted. In the end 
the senate refused to declare him guilty of breaking the laws maliciously. The constitution requires a vote of two-thirds of the senate to convict in a case of impeachment. If one more senator had cast his vote against Johnson, the verdict would have been "guilty."

Let us now see how the reconstruction plan of congress worked in the South. Of course, most of the white people in that part The feeling of the country felt that a great wrong had been done. of the South It was as though they had been gagged and bound while the thing they most disliked had been forced upon them. They were determined to resist the execution of the plan in every way possible.

Moreover, the negro showed from the first that he did not vote for the good of the community in which he lived. He was not intelligent enough to understand the needs of good government, and he fell into the hands of white men who had their own advantage in view. He voted as they advised, without knowing what he was doing. In a short time the governments of these states were filled with grafters, and there followed such a series of acts to help railroads, or to make jobs for contractors, or to furnish public offices extravagantly, that most of the conscientious republicans were disgusted. The negro vote enabled the republicans to carry several of the Southern states; but the corrupt practices that grew up in these states under this kind of management put the great majority of the whites against that party and created what is known as "the solid South." By this expression is meant a united Southern white population which feels that it must vote against the republican party in all state politics, and which, being united in state affairs, is also strongly democratic in national affairs.

About 1867 the attention of the country was drawn to a society of white men in the South known as the Ku Klux Klan. In reality Ku Klux several societies existed with the same object. There Klan was much disorder in the country and some of the negroes began to show resentment against the whites. Since 
the local officers were generally elected by negroes or by whites in sympathy with them, the majority of white people felt that something else besides the local officers was needed to preserve order.

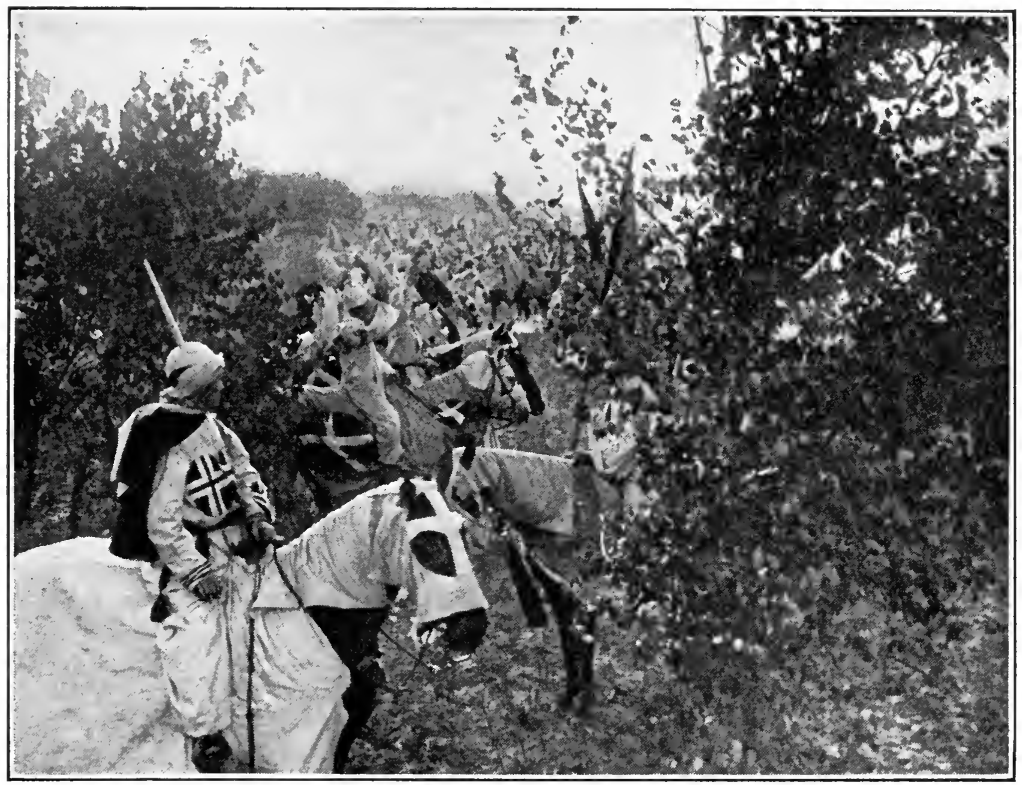

Assembling the $\mathrm{Ku} \mathrm{Klux} \mathrm{KIan}$

Taken from The Birth of the Nation by the courtesy of the management.

As a result they formed these secret societies, the purpose of which was to restrain the negroes. But we should not forget that in these difficult times the majority of the black race remained quietly at their homes in peace with the white neighbors.

The $\mathrm{Ku}$ Klux originated in fun. A number of young men of Pulaski, Tennessee, all of them having been in the confederate army, organized a secret society, the chief object of which was to amuse themselves initiating members. Its origin They had their initiations in an old house which was said to be 
haunted. When the negroes saw the windows of this house filled with light at midnight and heard sounds of laughter coming from it, they were terrified, and it was noticed that they were subdued in appearance. This gave the members of the society the idea of increasing the terror of the negroes. They adopted ghostly costumes, draped their horses in white sheets, and rode silently through the streets at night. They gave it out that they were the spirits of confederate soldiers who, having observed that the negroes were inclined to misbehave, were come back as a warning of what might happen if there was not better conduct.

After a short time the effects of this wore away. The negroes soon ceased to fear ghosts they saw so frequently. Then the Its visits $\mathrm{Ku}$ Klux resorted to more forceful methods. A negro supposed to be a leader in disorders would be visited in the night, taken from his house, and whipped in the way in which the unmanageable slaves were whipped before the war. This kind of treatment, it is said, had a very quieting effect on the state of society around Pulaski. When the rumor of what had occurred here went abroad, many adjoining communities organized Ku Klux Klans of their own.

At first the Klan was satisfied to investigate each case before punishment, and it is probable that most of the men who were Its severity whipped, or otherwise dealt with, had been doing the things they were charged with doing. But there was a tendency to act with increasing severity. Not only negroes, but white men who were supposed to aid them, were whipped or tarred and feathered. So bad did this become that the best of the members of the Klan began to withdraw, which only left the harsher men inside the Klan to do as they wished. Things went so far that the men at the head of the organization decided to disband it; but their orders were not obeyed in all localities. It was not until congress appointed a committee to inquire into the reported outrages in the South that the remnant of the Ku Klux Klan was finally disbanded. It undoubtedly did some good in its 
day, but it was a dangerous example, and it is to be hoped that we shall never have another such organization. It disappeared about 1873 .

Two words of contempt were freely used in these years in the South in these days. They were carpet-bagger and scalawag. The former was a Northern man who came South after the carpetwar and took part in politics. A carpet bag was a baggers and valise made of carpet. It was cheap, and the term scalawags carpet-bagger implied that these Northern men were only seeking to line their pockets at the expense of the South. Many of these men were adventurers, and they deserved all that was said about them. But we must not forget that there were others who came with the best intentions. Some of them were lawyers, some were business men, and some were teachers and ministers; and it was natural that they should be republicans. But the Southern people were not much disposed to distinguish between the good and bad carpet-baggers. The same thing was true of the scalawags, who were Southern-born men who joined the republican party after the war. Some of them were thoroughly convinced that the best interest of the South was to accept the republican party. Undoubtedly others were as ready to use their political power to make money for themselves as any of the carpet-baggers.

Many republicans thought that their party would gain a strong position in the South when the negroes were allowed to vote; but they were to be disappointed. By 1870 all the overthrow Southern states had been readmitted to the union. of the When one of them came in, the former confederates negro voters within it were allowed to vote, with the exception of a small number who had been very'prominent, and these were gradually restored to their old privileges. But the white men generally went into the democratic party, whose cry was the recovery of the state from the party of the negro, the carpet-bagger, and the scalawag. This cry made a strong appeal to the whites, who did all they could to overcome the votes of the negroes. They worked 


\section{THE PLAIN STORY OF AMERICAN HISTORY}

so hard that in 1877 the last Southern state passed out of the hands of the republicans, although for many years afterwards a small number of republican congressmen continued to be elected in the South.

About twenty-five years after the overthrow of carpet-bag governments the Southern states passed amendments to their constitutions providing that no one should vote who could not read and write or did not own certain property. Most of the negroes thus lost the right to vote. This, it was held, did not conflict with the fifteenth amendment to the federal constitution, since that amendment says that no man shall be kept from voting on account of "race, color, or previous condition of servitude." One result is that the large majority of the republican party in the South is now composed of white men, another is that election frauds are no longer alleged to exist as common occurrences.

\section{QUESTIONS}

I. What was reconstruction? What two steps were there in reconstruction? Why was the second-named step important? In what way might a Southern state limit the freedom of the negro? What was the demand of the North on this point? In what special form did this demand finally take shape? Why was it thought that the negro should have the ballot? How did the Southerners feel about the capacity of the negro? What was the reply of the Northern men?

II. What was Lincoln's plan of reconstruction? Where was it first put into operation? What were Johnson's ideas on reconstruction? How did he proceed to carry them out? Describe the laws now passed in the South in regard to the negroes. How did the North interpret these laws?

III. What political party controlled congress? What was its position in regard to the negro? What was the Freedmen's bureau? What was the Freedmen's bureau bill of 1866 ? On what ground did the president veto it? Describe the first eivil rights act. What happened to its veto by the president? To what did his opponents attribute the veto?

IV. How did the fourteenth amendment guard the rights of the negroes? What did it say about denying the ballot to a portion of the 
inhabitants of a state? What would have been the result if the South had accepted this amendment? Why did it refuse to accept?

$V$. What was the effect in the North of the refusal of the South to accept the amendment? For what purpose were the reconstruction acts of 1867 passed? What did these acts provide? When was reconstruction to be complete? Show how this plan was put into execution. How was the fifteenth amendment adopted? What did it provide?

VI. What was the most important charge against Johnson in the impeachment trial? What was his reply to it? Why did he think his constitutional power was imperiled by the act regarding the dismissal of a eabinet member? Describe the trial. What was the result?

VII. How did the Southern whites look upon reconstruction under the acts of 1867? What determination was made by the whites? How did the negro show that he did not know how to vote properly? What was the effect on Southern politics? Explain the term "solid South."

VIII. What was the Ku Klux Klan? How was it defended by the Southerners? Describe the attitude of the negroes. How did the Ku Klux originate? What was its original purpose? How did it become a society to keep order? Describe its visits. Show how it became too severe. How did it end?

IX. Who were called carpet-baggers? How did the term originate? Who were the scalawags? Distinguish between good and bad men of each class.

$\mathrm{X}$. How were the republicans disappointed about the negro vote in the South? What was the main object of the democrats when the Southern states were readmitted? What was the nature of the suffrage amendments later passed by the Southern states? Why did they not violate the fifteenth amendment? What two results have followed?

\section{SUGGESTED TOPICS}

The New Black Code of the South; The Working of the Freedmen's Bureau; The Policy of Thaddeus Stevens; The Impeachment of Andrew Johnson; The Ku Klux Klan; The South Carolina Legislature under Negro Control. 


\section{CHAPTER XXIX}

\section{THE POLITICAL HISTORY UNDER JOHNSON AND GRANT}

The elections of 1864 were carried by republicans on the ground that the union was in danger. After the war ended the union

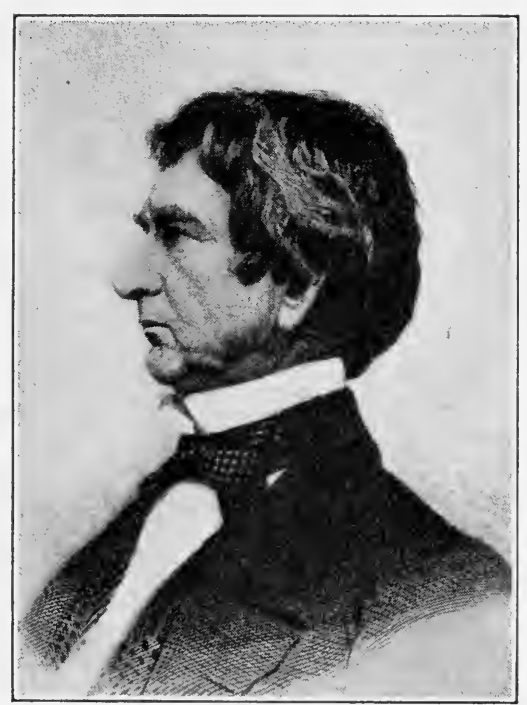

William H. Seward
The great was no longer in political danger, and the chief issue

publican party became the reconstruction of the South in such a way as to preserve all that had been won by the war. We have already seen that the party had its way in congress and passed its plan of reconstruction in spite of the veto of President Johnson. So much time was consumed in this matter that very little else was taken up.

Another thing that has much interest for us is the purchase of Alaska Alaska from Russia purchased in 1867. The price agreed upon was $\$ 7,000,000$ which many people thought a very large price for what was believed to be a frozen wilderness. It was further from the center of the American population than India seems to the people of 1915. Scoffers said that if Alaska ever became a state, a representative would take all his time in going and coming 
from his constituency to the capital. No one foresaw the improvements in travel that would come with the construction of railroads to the Pacific. Neither did we know that Alaska was rich in gold, coal, and other minerals. It has been worth to us many times as much as the price paid. Its purchase was chiefly due to the foresight of William H. Seward, secretary of state.

In 1868 the election of a president was the most important thing. The republicans disliked Johnson so much that they could not think of nominating him. They put forward The election General Grant, whose military successes made him of 1868 very popular. The democrats nominated Governor Seymour, of New York. They were very unpopular at this time, because they had opposed the way the war had been conducted. Some of them had denounced Lincoln so bitterly that they were arrested for treason. During the war they were freely called "copperheads," a term of great reproach. Now that the war was over they showed much sympathy with the South and opposed the republican plan of reconstruction. In spite of the fact that their candidate had a fine record, they were badly beaten. General Grant received two hundred and fourteen electoral votes and Seymour received only eighty.

At the same time the republicans carried both houses of congress and were able to do as they pleased. All went smoothly for two years, and then a split began to appear. A The liberal group of republicans became dissatisfied. They felt republicans that the interests of the people were neglected in order to advance the interests of the politicians, and they began to demand reforms. Some of the leaders of the reform movement were men who had once been the warmest supporters of Lincoln. They were especially strong in Missouri, where they went so far as to unite with the democrats and elect a governor in 1870. President Grant was not in favor of the reformers. He was a practical man and thought that the men who criticized the politicians were only hard to please. He was renominated by the republicans in $\mathbf{1 8 7 2}$. 


\section{THE PLAIN STORY OF AMERICAN HISTORY}

The reformers called themselves liberal republicans and tried to found a new party. They made an alliance with the demo-

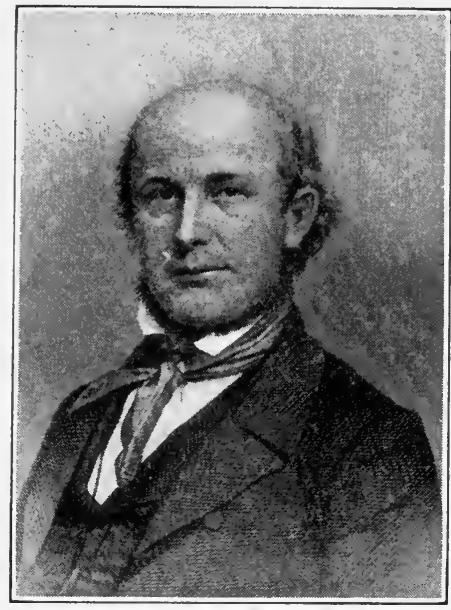

Horace Greeley crats, and both parties voted for Horace Greeley, editor of the New York Tribune, for president. But Election of no one could break down 1872 the popularity of Grant, and he was reëlected. Greeley was mercilessly ridiculed in this campaign. Fun was made of his old gray coat, his white hat, and his speeches. He took it to heart most seriously and died three weeks after the election was decided. He carried only six states, and they were in the South, states which had shaken off negro rule and were solidly democratic.

One of the most notable events occurring while Grant was president was the settlement of the claims we had against England for The Ala- allowing the confederate states to purchase ships of bama claims war in England. We held that she was responsible for all the damage that was done by such vessels, and we presented our claims with a long list of ships that had been destroyed. As the confederate cruiser Alabama had destroyed most of the ships for which payment was demanded, all the American claims were spoken of as "the Alabama claims." After a great deal of discussion it was at last agreed, 1871, that the whole matter should be left to five persons, for arbitration. They met in Geneva, one an Englishman, one an American, and one each from Switzerland, Italy, and Brazil. All but the Englishman voted to support the American side of the case, and decided that Great Britain should hand to our government $\$ 15,500,000$, with which we agreed to satisfy all the claims of the men who had suffered. The decision 
was very unpopular in Great Britain, but the rest of the world received it with pleasure. The other nations did not know at what time they might be at war; and they knew that if the decision had gone the other way, England might have sold ships to their enemies in time of war and worked a great amount of damage. As it was, a principle was established at Geneva which will live a long time. In time of war a neutral nation must not furnish ships of war to one of the powers that are fighting.

Another event of Grant's administration was the Virginius affair, which for a while seemed about to get us into war with Spain. At that time there was in progress in Cuba what The Virginwas known as the "ten years' war," a struggle of the ius native Cubans to overthrow the rule of Spain. The Virginius was a vessel used to smuggle arms into the island for the rebels. She carried an American flag and was registered as an American ship ; and the captain was an American citizen. She many times escaped the Spanish ships watching on the coast of Cuba, but in 1873 she was captured and taken into Santiago harbor, where fiftythree of the men on her were shot as pirates. Among the victims were eight Americans and some British and French citizens. They were not given a fair trial, and when the Ameri-

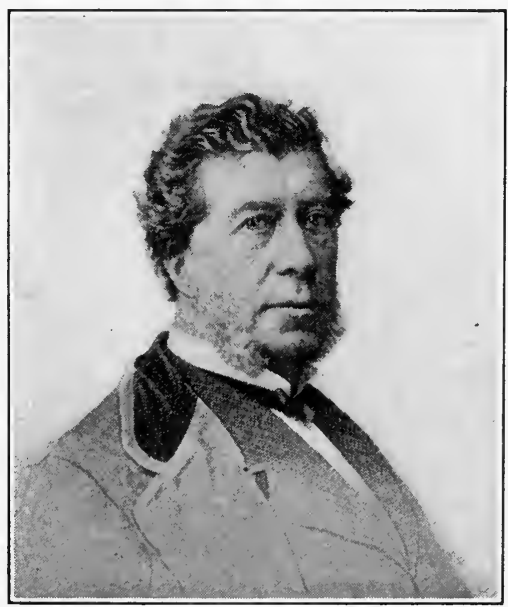

Hamilton Fish can consul protested against what was done, the protest was ignored.

When the news of this affair came to the United States, there was an outburst of wrath. The people had much sympathy for the 


\section{THE PLAIN STORY OF AMERICAN HISTORY}

Cubans, and they now demanded that we should declare war against Spain and drive her from Cuban soil. But there were War threat- calmer heads in Washington, and the calmest of all ened was Hamilton Fish, the secretary of state. He managed the affair very wisely, and got Spain to agree to make apologies if a fair investigation showed that the Virginius was an American ship. When the facts were known, it was evident that the Virginius was not a real American vessel. She was owned by the rebels, and her registration was, therefore, fraudulent. We withdrew our demand for an apology, and Spain gave $\$ 80,000$ to the families of the Americans who had been shot. This incident shows how well it is to act coolly before going into a war. President Grant approved all that Fish did in the Virginius affair, and soon the people who had clamored for war were praising the calmness of Secretary Fish.

While Grant was president the country showed an increasing amount of sympathy for the South, and it came out in the passage Amnesty for of the amnesty act of 1872 . There were then 160,000 confeder- former confederates who could not vote or hold office. ates

The act of 1872 gave a general pardon to all but the most prominent men in the class, thus leaving about five hundred still without the right of suffrage. As the years passed these others were gradually pardoned, and finally a general law gave amnesty to all in 1898. The South received amnesty in the spirit in which it was offered; but the gift was so much delayed that it did not wipe out all the feeling the reconstruction period had created. The pardoned confederates were the natural leaders of the South, and depriving them of their votes had only increased their influence among the people with whom they lived.

About this time the country received a severe shock when it learned of several political scandals, which for a while made the Political people think that worse evils existed than came to scandals light. Grant himself was not responsible for these matters. But it was generally agreed that if he had not listened 
too easily to some of his political advisers, he would have been more careful to appoint men who would have been free from any suggestion of wrongdoing. The most distrusted of his advisers was Benjamin F. Butler, who seems to have been acting merely for his own interests in most that he did ; but Grant had confidence in Butler.

In 1874 a new secretary of the treasury was appointed. He began to look into the affairs of his office and found that his predecessor had been very lax. One of the things that The whisky came to light was a series of frauds by a ring of whisky ring distillers in St. Louis. The tax on liquors is paid at the distilleries at so much a gallon. What happened here was that the distillers made false reports of the number of gallons manufactured and paid a smaller sum than they should have paid. They gave a part of the money they withheld to the officers who should have seen that they paid tax on every gallon manufactured. It was supposed that the government lost a million dollars a year through these frauds. The men responsible for them were indicted, and some were punished. Among those imprisoned was the man who had held the office of supervisor of internal revenue. It was believed that several of the chief offenders escaped punishment.

While the public were still talking of this affair, they learned that a member of the president's cabinet was to be impeached on the charge of taking money for making an appointment The Belknap to office. The man concerned was Belknap, secretary frauds of war. The position of post trader at Fort Sill, Indian Territory, was a very profitable one; for the trader supplied the Indians at a handsome profit. In 1875 it was learned that for five years the man who held the place had been paying a large sum annually to Marsh, a friend of Mrs. Belknap, and that Marsh gave half of what he got to Mrs. Belknap, and after her death to her husband. Marsh had thus given up $\$ 20,000$ to the secretary and the secretary's wife. These facts became known, and Belknap was impeached by the house of representatives. As the vote was about 2 D 
to be taken he sent his resignation to the president, who accepted it at once. The impeached secretary was finally acquitted on the ground that a secretary who was no longer in office could not be convicted on a charge of wrongdoing in office. Grant was severely criticized for accepting Belknap's resignation while charges were about to be made against him.

These scandals in politics seemed to show that something was radically wrong. A great many people thought they grew out Civil service of the spoils system. When men were appointed to reform office merely for political reward, it was inevitable that some bad men should hold office. The remedy seemed to be to appoint officials solely on merit, as they were appointed in most other countries. Thus arose a demand for civil service reform. It was proposed that persons who desired government positions, except the highest, should first be examined to see if they were prepared to take the office. Having passed the examinations, they were to be appointed in order of merit without regard to party.

When Grant was running for the presidency in 1868, he announced that he would support civil service reform. After he was Grant and elected, a law was passed to allow the president to the re- make rules for the appointment of persons to the civil formers service, and $\$ 25,000$ a year was appropriated for two years to pay the expenses of applying the rules he should make. Grant was in sympathy with the reformers and named a civil service commission which reported rules for the examination of candidates for appointment. He ordered that these rules be put into force in the departments in Washington and in the federal offices in New York. Now was seen how deep were the roots of the old system. Members of congress had been in the habit of getting the president to appoint their friends, but they found that their friends must stand examinations as other people. They complained to Grant and sometimes he made exceptions to his rules to satisfy the congressmen. This course displeased the reformers, 


\section{POLITICAL HISTORY UNDER JOHNSON AND GRANT 403}

who criticized the president bitterly. George William Curtis, the head of the civil service commission, resigned as a means of calling the attention of the people to what he considered Grant's repudiation of civil service reform. The president naturally became angry, and the congressmen, most of whom did not like the rules, seized the opportunity to strike a blow at the cause of reform by withholding money for the examinations. All this happened from 1871 to 1874 . It is hard to say just who was most to blame, but the effect was to make the reformers more hostile to the leaders of the republican party than they had been before. We shall see that civil service reform continued to occupy the attention of the people and finally triumphed. It was a muchneeded reform. Under the spoils system, when a new president took office, nothing could be done for months but remove and appoint officials; and the official no sooner got to know his duties than he was turned out to make room for some one else.

The many criticisms that were being made of the men who led the republican party gave the democrats the hope that they could triumph. Democratic In 1874 they carried successes the elections for the house of representatives by a large majority. It was the first defeat

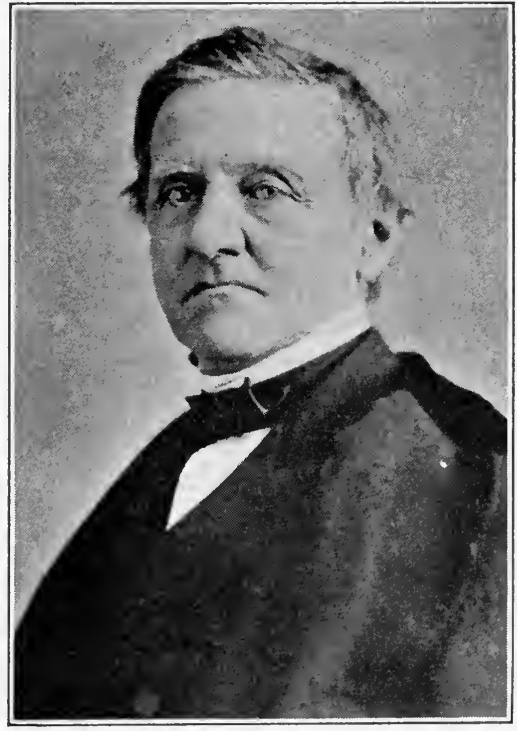

Samuel J. Tilden the republicans had met since they elected Lincoln in 1860. It increased the expectations of the democrats and they began to look forward to the presidential election of 1876. In 1874 they also 


\section{THE PLAIN STORY OF AMERICAN HISTORY}

elected Samuel J. Tilden governor in New York. He was an able lawyer who had rendered the public a great service by his hard work in overthrowing the corrupt Tweed ring. It was foreseen that he would be the democratic candidate for the presidency, and it was known that his popularity with the reformers would give him an important independent vote.

We cannot understand how much this work of Tilden's impressed the people of his day unless we know how great was the Tweed's evil doing of Tweed and his friends. They had obtained frauds in control of New York City by a system of bribery and New York by the support of the ignorant vote. They befriended City the immigrants and found work for the unemployed, but they expected that all who received their help would vote for Tweed and his friends. By this means they were able to take from the treasury many times as much as they needed to pay for the acts of assistance they gave to the poor voters. Tweed got much of his money by awarding contracts at high prices and forcing the contractors to pay him a part of the money paid by the city for the contracts. It is said that a man had a bill of $\$ 5000$ against the city. One of the ring told him that the bill would be paid if it were $\$ 55,000$. Immediately the change was made and the claimant got his $\$ 5000$ while the ring took the rest, $\$ 50,000$. The ring decided the county of New York needed a new courthouse and ordered it built. When the bills had been paid, they amounted to $\$ 11,000,000$. Investigation showed that the work actually cost about three millions; and it was so poorly done that repairs had to be made before the courthouse was occupied. The carpeting that was paid for to go into this building was enough to carpet the City Hall Park three times over. It was never possible to determine how much money the ring got: the estimates ran from $\$ 45,000,000$ to $\$ 200,000,000$.

Two newspapers, the New York Times and Harper's Weekly, waged a long war against the ring. They charged that the money 
of the people was being stolen, but at first they could not prove it. Tweed was able to get three rich landowners to look at the books and swear that the city's accounts were kept The ring properly. It was said that he reduced their taxes to broken up reward them for their services to him. He offered one of the editors who denounced him $\$ 5,000,000$ to cease attacking, and to another $\$ 1,000,000$ to be quiet. When these editors refused to accept the bribes, he could not understand what they were aiming at. At last complete evidence was obtained against the ring. Samuel J. Tilden was one of the leading lawyers in New York. He took it upon himself to break up the ring, and did not rest until he saw Tweed in prison and other members of the corrupt group in flight or locked up in jail. He was a democrat, and his work against the ring so raised him in the esteem of the people that in 1874 he was elected governor by a majority of 50,000 . It was because of his great popularity that he became the democratic nominee for president in 1876 . The republican party nominated Rutherford B. Hayes, of Ohio.

The election was a close one. At first it seemed that Tilden was chosen. He carried the important Northern state of New York and the early returns showed that he had carried A disputed the South. But later returns showed that three South- election ern states, South Carolina, Louisiana, and Florida, were disputed. One electoral vote in Oregon was also disputed. If Tilden got one of these disputed votes, he was elected. If Hayes got them all, he was elected. The question was, who should say whether the disputed votes were really democratic or republican votes. The constitution does not say how a dispute like this is to be settled. It only says that the president of the senate shall receive the electoral votes and count them.

The weeks following the election were filled with threats, and it began to look as though the two political parties would become so angry that the members would take up arms against one another. Finally congress adopted a compromise. A commission 
was appointed to hear all the evidence and decide how the disputed votes should be counted. It contained five men from the The elec- house of representatives, five from the senate, and toral com- five judges of the supreme court of the United States. mission As it turned out, eight of these fifteen men were republicans, and seven were democrats, and when they met, they voted according to their party feelings. The eight republicans voted to give every disputed vote to Hayes, and the seven democrats voted to give to Tilden the votes from Louisiana and Florida, and to Hayes the votes from South Carolina and Oregon. The result was that Hayes was declared president. Many people thought that he should not have had the office. He was a man of great personal honesty, and it is certain that he would not have taken an office if he had not believed he was elected to it.

\section{QUESTIONS}

I. What was the dominant political issue immediately after the war? Describe the purchase of Alaska. How was it eriticized? How has the purchase been justified by later events? Deseribe the nominations for the presidency in 1868 . Why was the democratic party unpopular? What was the result of the election?

II. How did the republican party eome to be divided? What did the reformers stand for? In what state were they very strong? Describe the election of 1872 . To what was Greeley's death due?

III. How did the Alabama claims arise? To whom was the dispute finally left? What was the decision? Why were other nations interested? What principle was here established? What was the ten years' war? For what purpose was the Virginius used? What seemed to show that she was an American ship? What followed when she was eaptured? How did the American people take the news of the events in Santiago? How was war avoided? How did the affair end?

IV. Describe the amnesty act of 1872 . Why was it unwise to exelude so many of the former confederates from office? Was Grant in any sense responsible for the political scandals that were discovered while he was president? What was Butler's influence over Grant?

V. Describe the operations of the St. Louis whisky ring. What was done with the guilty ones? What was the ground of the Belknap im- 
peachment? What were the facts in the case? How did Belknap escape punishment? Why was Grant criticized for his connection with Belknap?

VI. What was the spoils system? How did it work? What was the purpose of the eivil service reformers? What method of appointment did they wish to see tried? What was Grant's early attitude toward civil service reform? What step did congress take? How was the spirit of the law sometimes violated? What criticism was made of Grant? How did congress seize the opportunity to strike a blow at the reformers?

VII. What effect did these things have on the election of 1874 ? What hopes were created for the democrats? How did the election in New York have a bearing on the situation? How did Tweed get control of New York City? Deseribe his method of getting money. How much are he and his friends supposed to have secured? Describe Tweed's attempts to defeat investigation. How was he at last run down and punished? How did Tilden's part in this process affect his political reputation?

VIII. Whom did the democrats nominate for the presidency in 1876 ? Who was the republican nominee? Describe the election and show how the result was in dispute. What is the provision of the constitution about counting the vote? What compromise was made? How did the commission decide the dispute?

\section{SUGGESTED TOPICS}

The Liberal Republicans; The Origin of Civil Service Reform; The Virginius Affair; The St. Louis Whisky Ring; The Settlement of the Alabama Claims; The Work of the Electoral Commission; The Expulsion of the French from Mexico. 


\section{CHAPTER XXX}

\section{THE GROWTH OF THE NATION AFTER THE WAR}

WHEN the war ended, the army of the union numbered about one million men. Some European writers predicted that these The army men would never be willing to disband and go quietly disbanded to their homes. The prediction was a foolish one; for the American soldiers wanted nothing more than to get out of the army and settle down as farmers, mechanics, and business men. As soon as they were disbanded they returned to their homes and became workers again in the fields of peace. So large a number of men thrown back into the tasks of business greatly increased production in all the forms of industry.

One of the causes of prosperity was the homestead law, made in 1862. It provided that the government would give a farm of The home- 160 acres to any man who would settle on it. If a stead law in soldier had been thrifty, he had saved enough of his pay operation to buy the stock and tools he needed to begin work on his farm. At this time wheat and corn were dear, and they remained so for five years or more on account of the wars in Europe. Thus it happened that a great many of the old soldiers, and many other people, moved to the grain-growing West in the years between 1865 and 1870, establishing farms and increasing the annual yield of wheat by a great amount.

These years were also favorable to the manufacturers. The war tariff was very high, and it was retained after the advent of Growth of peace. It kept out cheap foreign goods, and the Amerimanufac- can factories ran on full time and sold at high prices. tures

They enlarged their plants and sold more goods than ever. Wages also went up, for the factory owners were prosper- 
ing so greatly that they could afford to pay higher wages. When the farmers, manufacturers, and wage earners had money, prosperity came to merchants, bankers, railroad men, and all others in the business world.

The best grain-growing section of the country was in the Northwest. Illinois, Wisconsin, Michigan, Minnesota, Iowa, Nebraska, Kansas, and Missouri were now going through a rapid The Northdevelopment. Railroads were built into the grain west counties, farmers moved in, and fields replaced the prairies. The population of these eight states grew very rapidly. In 1860 it was $5,601,940$. Ten years later, in spite of the losses of the war, it was $8,621,033$. Of course, this gain was not made without a great deal of immigration.

The higher prices of wages in America attracted great multitudes of laborers from Europe. From 1865 to 1875 the average number was 350,000 a year. At that time it was the northern countries of Europe that sent us the largest portions of

Immigration our immigrants. They came from Norway, Sweden, Germany, and Denmark, as well as from Ireland and Scotland. The immigration from the southern countries of Europe was not at that time as large as at present. Some of the immigrants settled on the farms of the West. The Swedes and Norwegians were farmers in their own countries, and went readily to farming regions in the United States. But most of the others preferred to settle in the towns and manufacturing districts. They were too poor to buy land or to settle it if it were given them. Weekly wages appealed to them. Their course was to take the vacant places of Eastern men who had moved to the West.

In the South was no such state of prosperity. The people had suffered great loss of wealth through the war. Those who owned slaves suddenly found themselves deprived of their value. Most of the people had felt it their duty to In the South invest all their money in confederate bonds and currency while the war was being fought, and after the war, bonds and money 


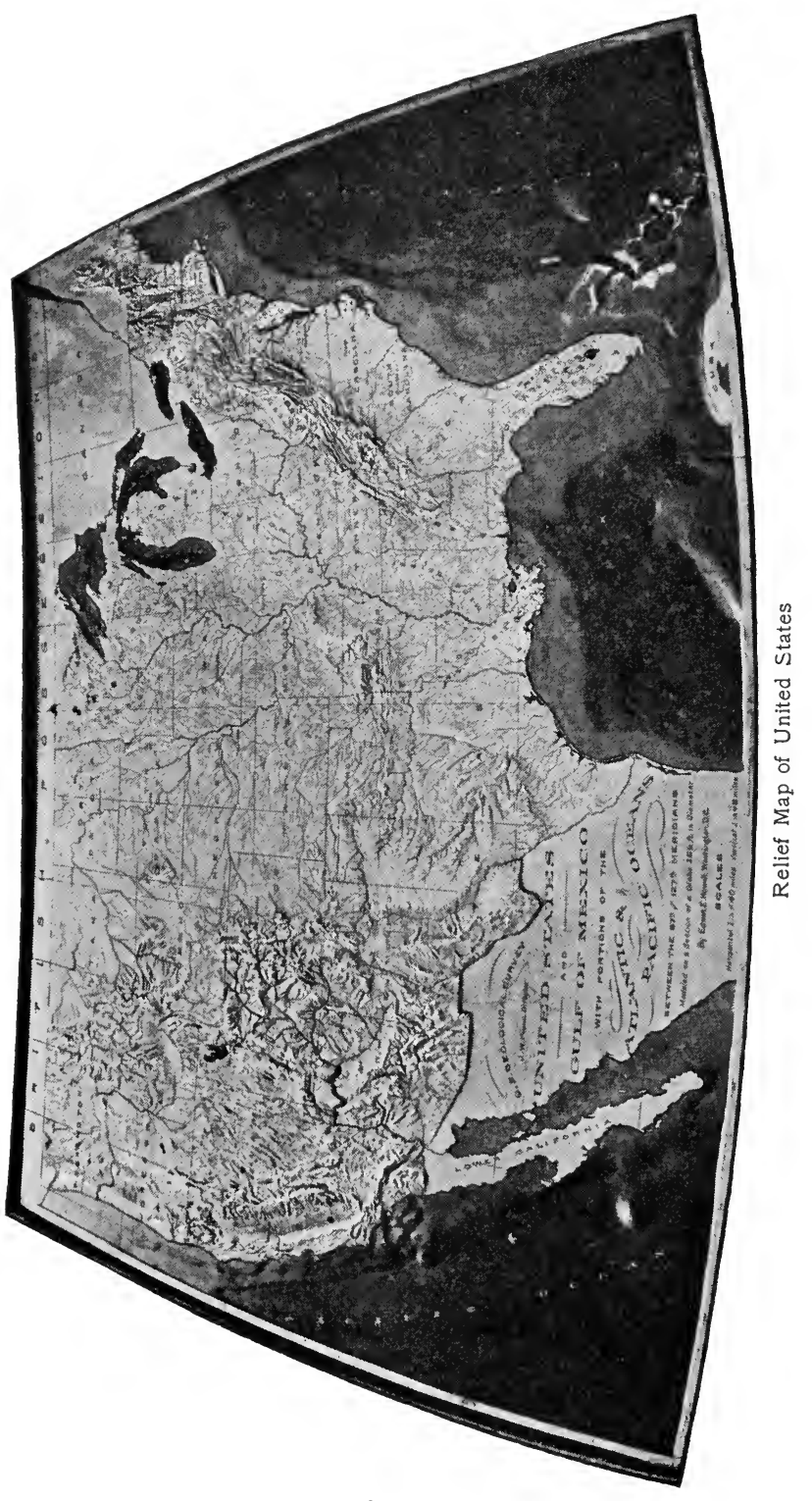


were worthless. The banks and all who had money to lend had become bankrupt. The Southern farmers were thus without stock, tools, or money to begin life again, and their capitalists were unable to lend.

To add to their troubles, the freedmen were much disturbed by the hope that the government would take the lands of the former masters and distribute them among the former slaves.

A rumor got abroad that at Christmas, 1865, each negro

Labor

man would receive "forty acres and a mule." Nobody knows just how the idea started, but for a time it made the negroes unwilling to work for wages. When they did not get the lands they had expected, they were dissatisfied. Soon afterwards they secured the right to vote, and then came the $\mathrm{Ku}$ Klux troubles. All this kept laborers excited, and the farmers suffered as a consequence.

It was at this time that the cropping system became established in the South. The landowner did not have enough money to hire laborers, and so he agreed with a negro man to cultivate The cropa small tract of land on shares. The landlord would ping system generally furnish the tools, team, and seed, and at the end of the year have half of the yield. If the negro was thrifty and owned his own team, he usually had three-fourths of what was made. This system is widely used in the South to this day.

In these days began to appear a new class of whites. Men who had owned no land before the war now found that it could be purchased cheaply. They seized the opportunity and bought as much as they could pay for, and as the old planter class disappeared a new class of well-to-do farmers took their places. This process has gone on steadily during the last fifty years. Very few of the old planter class survived without losing a large part of their holdings; but in their places has grown up a new class whose success has been made under the new conditions.

One of the noted changes that the war made possible was the building of towns. Under the old system there was not much 
retail trade. The large planters shipped their cotton and tobacco to a few central trading ports and had supplies sent them in return. Trading They paid no wages, and there was not much money towns in circulation in the communities. Under the new conditions the wages of the negro were spent in the small stores of the neighborhood in which he lived. The large planters no longer existed, and the small farmers were also content to sell their crops and buy their supplies at home. The result was that merchants prospered, trading towns began to grow into busy little centers of business, and the South began to have a larger town life than it had before the war. In this way the prosperity of the South was gradually restored after about fifteen years of great suffering. The progress which came to every part of the North and West in these years produced a great deal of railroad building. This Building was especially true in the grain-growing region, where railroads new lines were extended into the unsettled parts in the belief that settlers would follow in great numbers. It was thought that the money received from the grain crops would pay the freight charges and enable the railroads to make large profits. So rapidly were railroads built that there was not enough capital in the country to pay for them, and money had to be borrowed in Europe.

For a time all went well, and then there came a sudden check of prosperity. First, the wars in Europe ended in 1871 and the men who had been in the armies were sent to the grain fields, so that Europe began to raise her own grain again. At the same time some vast grain fields were opened in southern Russia, which produced wheat more cheaply than it could be produced by our farmers. The result was that the price of grain began to fall in 1871 , and in 1872 it fell still more. So great was the confidence of the Western farmer in wheat that he did not reduce his acreage. He planted more and more each year, while the price kept going down. From 1872 to 1879 was a period of hard times for the farmers. 
Of course, the fall of wheat had its effect on the grain-carrying railroads. They did not get enough profits to pay the interest on the money they had borrowed. Then their stocks The panic and bonds began to go down, and it was impossible to of 1873 borrow enough money to carry on the building operations that had been planned. Jay Cooke and Company was the greatest banking house in the country. It was furnishing money to build the Northern Pacific Railroad, and taking the bonds of the road, which it expected to sell. When the bonds began to fall, the house borrowed money in Europe and went on lending it to the railroad. After a time its hands were full of Northern Pacific bonds which it could not sell, and the European creditors demanded their money. There was nothing for this great house to do but to declare that it could not pay its debts and close up its business. This important failure brought on what is known as the panic of 1873 , one of the great panics in our history. Before it was over many a business man had to close up his business, losing all he had. It came because the period just before it was a very prosperous one in which there had been too much speculation. All the important panics in our history have followed periods of great prosperity and excessive speculation.

The panic of 1873 and the six years of hard times that followed it did not destroy the healthy growth of business. Such periods usually are marked by moderate progress. In this Progress in case there was too much energy in the business life of hard times the country for the people to suffer great hardship. Population grew as rapidly as ever, railroads were built as the conditions demanded, and manufacturing and agriculture went forward steadily. The period of hard times was only a period in which there was not the rapid boom of the period just before 1873 .

During all these years from the war to 1880 the finances of the national government were in excellent condition. The national The national debt in 1865 was $\$ 2,758,000,000$. At debt the beginning of the war it had been only $\$ 57,000,000$; and to 
many people living in 1865 it seemed that it would never be paid. But it was so well managed that in 1868 the government had wiped away $\$ 519,000,000$, and people no longer predicted it would never be paid. By 1880 it was reduced to $\$ 1,919,300,000$; and in that year began a period of very rapid payment. Between 1880 and 1890 the amount paid was more than a billion dollars. No other nation has paid off a great debt so rapidly.

Meanwhile, much was being said about the tariff, a subject which is still discussed very earnestly in the field of politics. We The war have seen that it was necessary during the war to tariff impose very high taxes. It was expected that they would be lowered when peace returned. In fact, they were lowered on some things, but on most articles the duties remained what they had been during the war. The reason given for this was that to lower the tariff would injure manufactures. There can be but little doubt that to lower the tariff on articles highly protected would mean smaller profits for the manufacturers of those articles; and it would probably mean that the laborers in Argument such factories would not get as high wages as they got for, under a high tariff. Thus, both the factory owners and their employees were interested in having the tariff remain as it was.

On the other hand, the farmers and other people who did not depend for their living on the factories would have to pay higher and against prices for the manufactured articles they bought. This question then arose: Should we tax the people who were not protected to benefit the people who were protected? No one seriously objected to a tariff that would raise the revenue needed to carry on the government, and that, they said, would give the manufacturers all the protection they needed. Much more was said, but these were the chief arguments, and they will show that there was something to be said on each side of the question. Those sections of the country in which manufactures abounded were strongly for maintaining the high tariff. They 
saw that to lessen the production of the factories would throw men out of employment, close up the least prosperous of the factories, lower the prices of real estate, and injure every kind of business that got a part of its money from the mills. The New England states, the Middle states, and some of the states north of the Ohio River made up the manufacturing section of the country, and here protection had its strongest friends. The people of the South were almost entirely farmers, and the same thing was true of the people living west of the Mississippi. They felt, for the most part, that it would be better to have cheaper merchandise, and they did not wish to contribute to the prosperity of people in remote parts of the country.

The republican party became the defender of protection and the democrats the defenders of a lower tariff; although there were always a few democratic representatives in con- How the gress who opposed a reduction of the duties, and a few parties took republicans from the West who wanted to lower the sides tariff. In 1870 there was a strong demand for lower rates and a bill to that effect was passed, and in 1872 another bill passed, taking off ten per cent of all duties. Soon after it went into operation came the panic of 1873 , which caused the people to import less merchandise than before. By this means the money received by the government for duties fell off so that there was not enough for expenses. For this reason it was believed necessary Three tariff to raise the tariff again. In a bill passed in 1875 the bills ten per cent taken off in 1872 was restored. When this was done, the tariff question was dropped for several years.

During these years the business men of the country were much concerned about the fluctuation in the price of gold. If a man of that day said that his horse was worth two hundred Depreciation dollars, he would mean two hundred dollars in green- of greenbacks. That is, values were ordinarily expressed in backs greenbacks. But the government did not give specie for the greenbacks, and they were never worth par in gold. Often two 
hundred dollars in gold would not be given for less than two hundred and seventy-five dollars in greenbacks. The practice had grown up for most notes, and some accounts, to be written payable in gold. Thus it came about that when a man had to pay such notes or accounts, he must find a dealer in specie and pay him what he asked for the gold. It was very annoying, for one never knew when he signed a note payable in gold just what he would have to pay to get gold when the time came to settle. When he signed the note, gold might be worth 110 per cent., and when he came to pay, it might be selling for 120 per cent. The few men who had most of the gold in the country kept it close in their hands and managed to put up the price when there was great need for it in the market. All this trouble would disappear the moment the government began to redeem the greenbacks in gold on demand.

In 1875 congress passed a law to begin to redeem the greenbacks in specie on January 1, 1879. Bonds were to be sold for Resumption gold until there was in the treasury as much as $\$ 100$,of specie $\quad 000,000$ in gold. From this fund the government was payment to begin on January 1, 1879, to redeem the greenbacks in gold. At that time there were $\$ 380,000,000$ in greenbacks in the country used as money; and the question at once came up: What will keep people from presenting these notes to the treasury in such large quantities that all the gold there will be drawn out? The reply was that when the people know that a paper dollar is as good as a gold dollar, they will not wish to have the gold, since it is more convenient to carry the paper money in the purse. The saying of a Frenchman who had a deposit in a savings bank was now often told to illustrate the situation. He was told that there was a run on his bank and started for the bank to withdraw his deposit. When he asked for his money, he was surprised at the readiness with which it was handed to him. Looking at it for a moment he burst out: "If I can't get my money, then I want it ; but if I can get it, then I don't want it!" The people, it was said, would not demand gold if they knew they could get it. 
As the year 1878 drew near its close the price of gold dropped. December 17 it sold for par for the first time since 1861. January 1,1879 , the resumption act went into force without the slightest difficulty. The gold brokers and speculators now went into other business, and from that day to this there has never been a time when the greenbacks were not worth face value in gold.

\section{QUESTIONS}

I. Describe the disbandment of the federal armies. What was the effect of the homestead law? What opportunity did it offer to the disbanded soldiers? What caused the prices of grain to remain high? Why were the manufacturers prosperous? What was the effect on wages? on other branches of business?

II. Describe the development of the Northwest. Show how immigration progressed from 1865 to 1875 . Where did the immigrants settle?

III. What was the general financial condition of the South? How was emancipation one of the causes? Why were the Southerners not able to borrow money to restore their farms? What had become of Southern capital? What became of the confederate money? Show how labor was disorganized. To what fanciful expectation was this partly due? Describe the cropping system. Describe the rise of a new class of Southern farmers. Why did the plantation system not favor towns? In what respect did the conditions of trade change after the war? Show how the result favored the development of towns.

IV. Describe railroad building in the newer parts of the country. What was the expectation of the builders? How did they get the money? Why did the price of wheat continually drop after 1871? What was the effect on our farmers? How did the farming situation react on the railroads? What was the story of Jay Cooke and Company's failure? What was the consequence? What is the general cause of panics? Show how progress was made even in hard times.

V. What kind of tariff was maintained after the war? Why? What was the argument for it? the argument against it? What sections favored each side? How did the parties take sides? Describe the three tariff bills of the seventies.

VI. What was the value of greenbacks as compared with gold? How was the value of a promissory note or an account a matter of doubt? Explain the fluctuation in the price of gold. What would remedy all 


\section{THE PLAIN STORY OF AMERICAN HISTORY}

these troubles? Explain the resumption act of 1875 . Why could a comparatively small sum of gold serve to redeem a large sum of notes? How was resumption at last effected?

\section{SUGGESTED TOPICS}

The Homestead Law; The Final Review of the Union Armies ; Financial Condition of the South, 1865-1875; Jay Cooke and Company ; "Black Friday" ; The Resumption of Specie Payment. 


\section{CHAPTER XXXI}

\section{THE SETTLEMENT OF THE FAR WEST}

Most of our Western country was settled by waves of population, each of which rolled a little farther than the preceding wave. For example, people from Indiana moved on into Illinois, people from Illinois into Wisconsin and MinneFirst settlers sota and Iowa, and people from Iowa into Nebraska. That was not the way the Rocky Mountain states got their first white settlers. The first people who settled there were miners, who had gone first to California, and from that country drifted backward into the Rocky Mountains, seeking the places in which nature had concealed gold and silver.

While these metals were found in many places, the most valuable

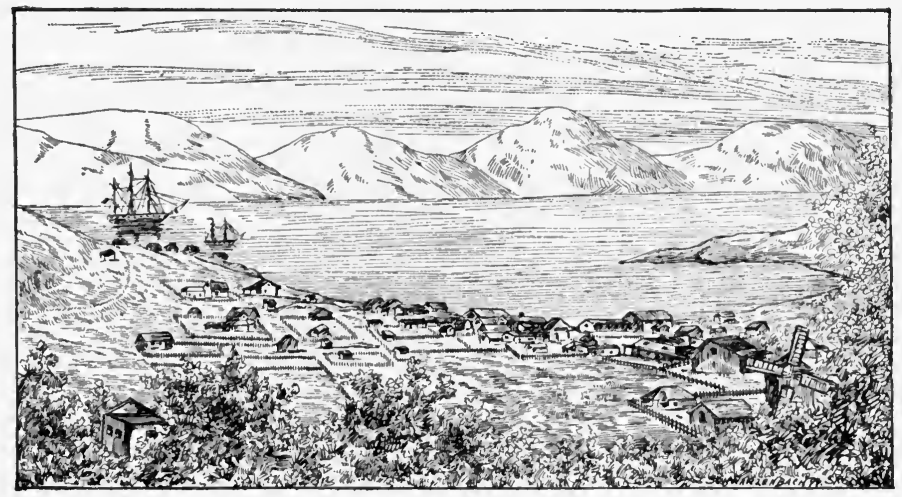

The Site of San Francisco in 1847

From an original drawing.

deposits were in Nevada, Colorado, and Montana. In 1859 some 419 
miners discovered a rich deposit of gold ore on the side of Mount Davidson, 6000 feet above sea level. The place was nearly 300 Nevada miles northeast of San Francisco, but it soon swarmed settled with a busy mining population. The ore paid well for a while and then began to fail. Here as in all cases in this region the first miners were untrained adventurers, who knew little about the science of minerals. While they washed the Mount Davidson gravel for gold dust they encountered a heavy dark metal which clogged their pans and which many a miner threw down the side of the mountain impatiently. When the mines began to show signs of failing, the unskilled miners went off to other fields. After them came men who knew the qualities of minerals. They examined the heavy metal that had been so liberally discarded and found it to be rich silver ore. The silver mines of Mount Davidson proved far richer than the gold mines. Around them grew up a town to which the name of Virginia City was given. Settlers came in large numbers, and in a short time there were many mining villages in the vicinity.

How to govern these people was a difficult problem. The region was so far from Salt Lake City, the capital of Utah, that Becomes a officers acting under Utah authority could do little. state In 1861 it was decided to create a new territory with the name of Nevada, and in 1864 this territory was admitted into the union as a full-fledged state. It was thought that other mines would be opened and that Nevada would become a prosperous state. But it contained very little farming land, and for many years its development was slow. In recent times irrigation has been applied to its dry plains and parts of it have been converted into fertile agricultural districts. Still there are vast stretches of dry plains which, it seems, will not be made fertile by irrigation.

Gold was discovered in 1858 at Idaho Springs, seven hundred and fifty miles east of Virginia City. The announcement brought a great many miners to the spot, and several deposits were dis- 
covered in the neighborhood, especially at Boulder, Denver, and Leadville. Here, also, it was seen that some kind of government was necessary, and in 1861 the region was erected into a territory with the name of Colorado. In 1876

Colorado the territory became a state. At Leadville silver was found in connection with lead, and the lead proved more valuable than the gold.

A third rich gold field was discovered in 1861 six hundred miles northwest of Denver. It proved very rich in the precious metal. From one spot, known as the Alder Gulch, the miners took $\$ 25,000,000$ worth. In the midst of this rich

Montana group of mines grew up the town of Helena. To give the region a proper government it was made the territory of Montana in 1864. Mines do not demand a large number of people to work them and for many years both Colorado and Montana attracted few farmers. It was not until 1889 that Montana became a state. In our own time irrigation has been introduced into many parts

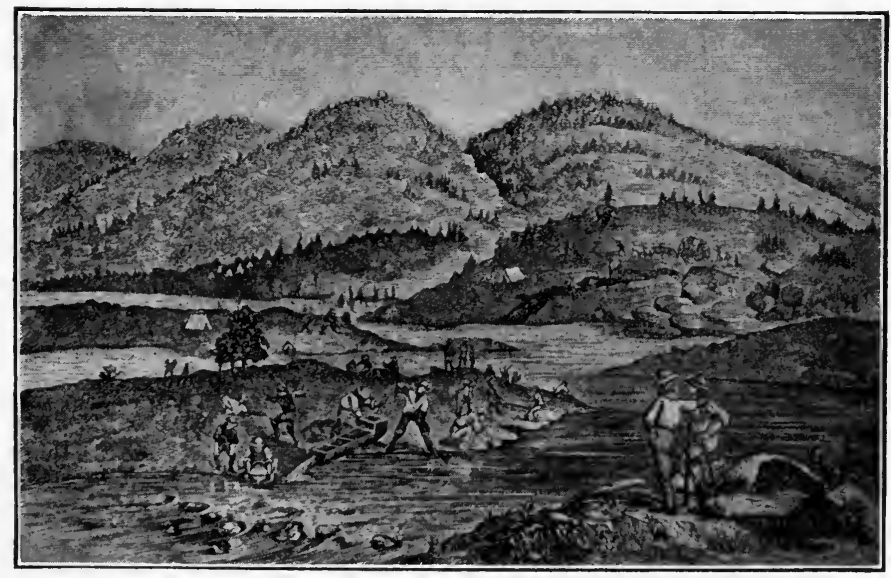

Mining with Pan and Long Tom

of the Far West, and wherever it has been employed the soil has proved very fertile. 
The first miners in California found the gold in the sands at the bottom of the streams. It had been washed down from the The miner's neighboring hills through many years and was found pan as dust or small nuggets. The miner would place some of this earth in a pan, fill the pan with water, and shaking it back and forth till the earth had been washed off the top, he would find the heavy gold dust at the bottom. When a miner had worked in a place until it no longer yielded gold, he moved on to another place where he thought he could find it. By the law a miner could stake out a claim, as much as he could dig over, and he owned it unless he abandoned it.

The pan proved a heavy and slow instrument in the hands of the miner, and he soon invented the cradle, a shallow box on The cradle rockers. Into it the earth was placed and water poured on. While the miner sat by it and rocked the cradle the water washed the earth over the sides. A still greater improvement was the long tom. It was a long cradle, with cleats nailed to the bottom. With the gold gravel on the inside it was set so that one end was higher than the other. A stream of

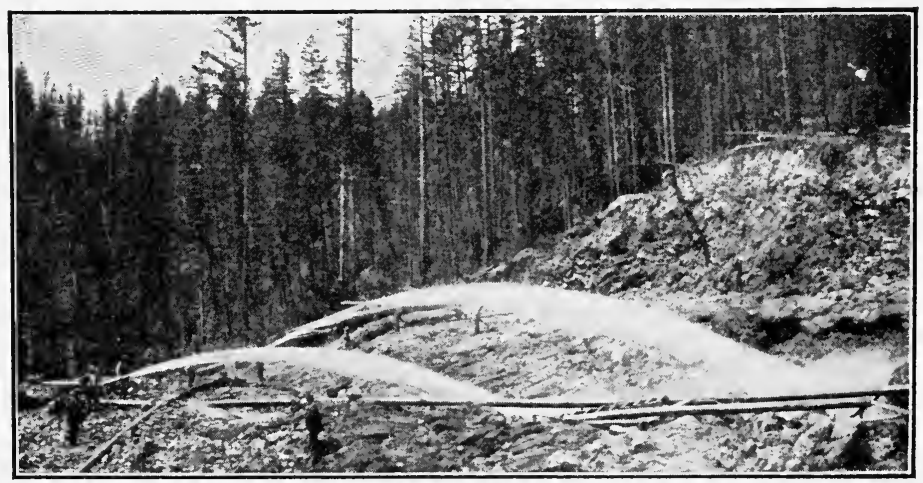

Hydraulic Mining

water was led by a pipe into the upper end, and the miners rocked the long tom as the water flowed down over the contents 
and gradually washed out the earth, the gold being caught behind the cleats.

In this kind of mining there was great waste, and when better methods came to be adopted, the discarded dirt of the early miners was washed over again and much gold was found. The Mining better methods came with the advent of mining com- companies panies. They generally bought up the claims of the miners and consolidated them into large mines. Machinery was now installed, and water was carried many miles in pipes. Instead of digging the earth with a pick, heavy engines sent powerful streams of water against sides of mountains and hills and made them crumble. After a while crushing machinery was employed to reduce to powder the hardest rock that might contain gold, and the precious metal was extracted by chemical processes. The individual miner never could have done this. His work was to explore the valleys, and find the places in which the gold was hidden. He usually got only a small part of the gold.

The miners were the pioneers, showing what the country was like and opening the way for a larger number of settlers. Wyoming and Idaho were seen to be capable of supporting grazing and Farming agriculture, and grazing and settlers gradually came in to take up these forms of business. New Mexico and Arizona were also entered first by miners and then by farmers and ranchers. From 1860 to 1880 was

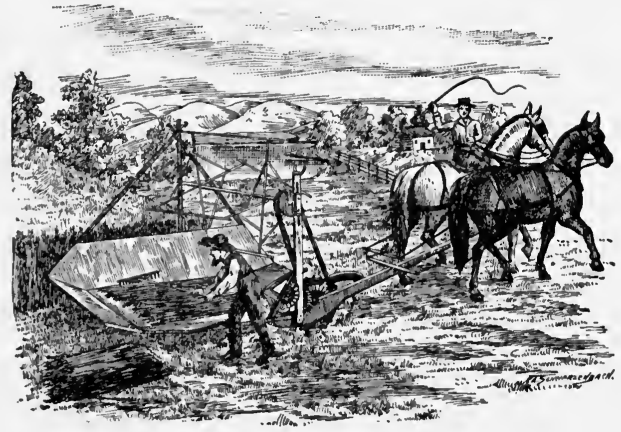

The First McCormick Reaper

a period of great expansion in this general region.

The settlement of Utah was not due to the efforts of the miners. It was a refuge for the Mormons, whose peculiar religious views 
had aroused the hostility of those who knew them in the older states. They practiced polygamy, and their central church was Utah a powerful moneyed corporation. They disliked the people around them, and in 1847 they settled on the shore of the Great Salt Lake, in what was then called the Great American Desert. By hard work they built houses, irrigated the

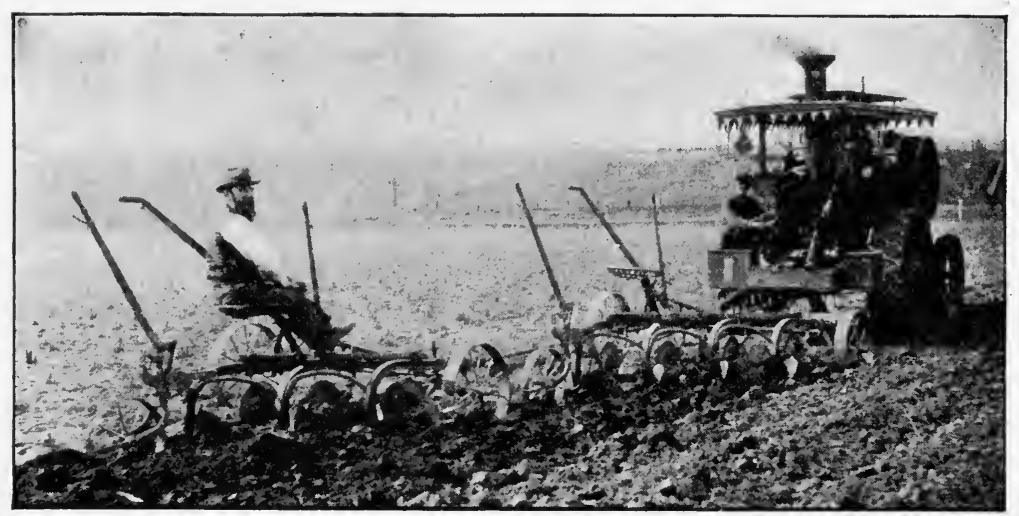

Modern Machinery in the Corn Belt

dry soil, and established a thriving settlement. When the California gold seekers came across the plains after 1848, the Mormons sold them wheat and cattle at good prices and continued to prosper. The settlements were erected into a territory in 1850 , but congress would not admit Utah as a state until the Mormons gave up polygamy. For this reason Utah had to wait until 1896 to escape from the territorial condition.

Meanwhile, important changes occurred on the Pacific coast. California was not entirely given over to the production of gold. Agriculture It was a rich farming region, and its delightful climate on the made it especially suited for the growth of fruits. Pacific coast Oranges, olives, grapes, and many other fruits which ordinarily grow in the tropics are here found in a latitude as far north as North Carolina, on the Atlantic coast. Oregon and 
Washington contained fine supplies of lumber, and the soil was adapted to the production of wheat and other grains. Washington Territory was created in 1853, but for a long time the country did not progress as rapidly as its resources warranted. But in 1883 it completed its first great railroad, the Northern Pacific, and in 1889 it became a state. The development of Alaska has also been of great benefit to Washington.

This progress could not have been achieved without the aid of railroads. Gold and silver once mined could be carried to market on pack horses over the most difficult trails. Relation to But grain, fruits, and cattle must be carried to market railroads on railroads. The growth of the Far West was closely bound up with the construction of the railroads across the continent, and with their many branches.

The first railroad across the Rocky Mountains was the Union Pacific, completed as far as Ogden, Utah, in 1869. Here it met the Central Pacific, which had been constructed from The first California eastward. The federal government gave Pacific railland liberally to each of these roads. It was located roads along the tracks, and the roads borrowed money on the land as security, expecting that the opening of the country would make the land valuable. To each road the government also lent bonds, at the rate of $\$ 16,000$ a mile for the parts that ran through level country, \$32,000 a mile for the parts running through hilly country, and $\$ 48,000$ for each mile constructed through the mountains. Experience proved that this was an extravagant grant. The Union Pacific started at Omaha, Nebraska, and ran westward in nearly a straight line. Many branch lines have been constructed from this first great line.

Other railroads were soon being built to the Pacific coast. The Northern Pacific was begun in 1870 and passed through the states south of the boundary line between the United States.and British America. The panic of 1873 forced Other roads its builders to stop work for a while, but later it was carried to 
the point of destination, in Oregon. Another important road was the Great Northern built several years after the Northern Pacific, and running from Duluth, on Lake Superior, to Puget Sound. A fourth was the Southern Pacific, whose main line passes through Texas and enters California through Arizona. Finally, we must mention what is generally called the Santa Fé system, which starts for the coast from St. Louis, going by way of Kansas, New Mexico, and Arizona. Each of these great lines has played a wonderful part in the development of the country through which it runs.

The appearance of the miners, and after that the construction of the railroads, showed the Indians that their day was nearly Destruction past. In the first place, it meant the destruction of the of the game game on which the Indian relied for food. Passengers on the first trains across the plains of Kansas could see herds of buffalo from the car windows, and it was reported that these animals had been known to stop the trains by getting on the tracks. In a few years the hunters had made an end of this situation. Sometimes they killed for sport, shooting for the mere pleasure of hitting the animal shot at. The greatest damage was done by men who slew for the sake of the hides, killing as many as they could stalk, and taking the skins only. This wanton waste of his food supply made the Indian very indignant.

The railroads were signs that the white man had come to stay, and the Indians began to show hostilities. Many a gang of tracklayers had to stop work to fight off the attacks of the savages. As the roads continued to creep onward the Indians became more troublesome. The government did not wish war and tried to prevent it by making treaties. But the treaties were broken, as often through the faults of the whites as through those of the red men; and the result was a series of wars. From 1864 to 1867 there was continual fighting on the great western plains, with the Cheyennes, the Arapahoes, the Comanches, the Apaches, and the Sioux. The government sent soldiers who took terrible 
vengeance when they could. It was the theory of the soldiers that peace could not be established until the Indians were thoroughly crushed.

The way in which the war was fought finally aroused the horror of the country. It seemed that we were waging a war to destroy. So many protests were made that congress appointed The Indians an Indian commission to visit the Indian country and crushed see if some reasonable way could not be found for securing a permanent peace. The tribes were tired of the war, and one after another made treaties. This happened in 1867 and 1868, but in 1868 the war was renewed. General Sheridan, now in command of the army in the Northwest, gave orders for severe punishment, and his commands were carried out rigorously. One of his officers was General Custer, who surrounded a sleeping village of Cheyennes and killed and captured nearly three hundred men, women, and children. Another officer, Colonel Baker, surprised an encampment of Piegans against whom no wrongdoing was alleged, and killed thirty-three men, ninety women, and fifty children. Hard blows like these broke the spirit of the Indians, and the war came to an end soon after 1870 .

The next outbreak was the Sioux war of 1876 . The Black Hills were the hunting range of the Sioux, confirmed to them by a solemn treaty. In 1874 General Custer led a band of war with explorers thither and discovered that the hills were rich the Sioux in gold. The report brought forth a crowd of miners and adventurers. According to the treaty they had no business on lands set aside for the Indians. They were warned off by the government, but continued to stay in the country. The older Sioux were displeased, but did not go to war. However, there was a large party of younger Sioux who were not willing to put up with a violation of their treaty. They found a very able leader in Sitting Bull, who went on the warpath.

General Sheridan now sent three armies into the Sioux country. They carried everything before them, and many burning villages 
showed where they marched. An accident gave one striking victory to the Sioux. Custer was sent with six hundred men to disDeath of perse what seemed a small force of Indians. In reality Custer this force was very large and was commanded by Sitting Bull himself. The Indian commander was about to retreat, but when he saw how small was the American column, he offered battle. He concealed some of his warriors in ravines at the foot of a hill and placed the rest on its crest. Custer was completely deceived. He sent part of his men to attack on the flank, and charged with the rest, two hundred and sixty in all, straight up the hill. As he passed its foot the warriors surrounded his column, and not one of the white men escaped. They all died fighting. Custer was a popular soldier, and his death was greatly lamented. But the war went on, and Sitting Bull lost so many men that he could no longer make a stand. He and his followers fled to British America, where they suffered many hardships. In 1879 he was allowed to return to the United States, where he lived quietly for several years. In 1890 he was ordered under arrest because it was feared that he was plotting to begin another war. He resisted the officers and was killed. He was a remarkable Indian, and his losing struggle to save his people from destruction has won him sympathy in all parts of the world.

During all these troubles the five civilized tribes had lived quietly in Indian Territory. They were gradually absorbing Civilizing the ideas of civilization. The government would have the Indians been glad to have all the tribes in a similar condition; but the Indians of the Northwest would not go to Indian Territory. They loved the free life of the reservations, where they could hunt and live as they pleased. As treaty after treaty was made with them, the government promised them ever increasing amounts of supplies. Schools were established for their children, in the hope that education would make them less hostile. Much good has been done in this way; but the Indian is wedded to the ways of his fathers and acquires civilization very slowly. 


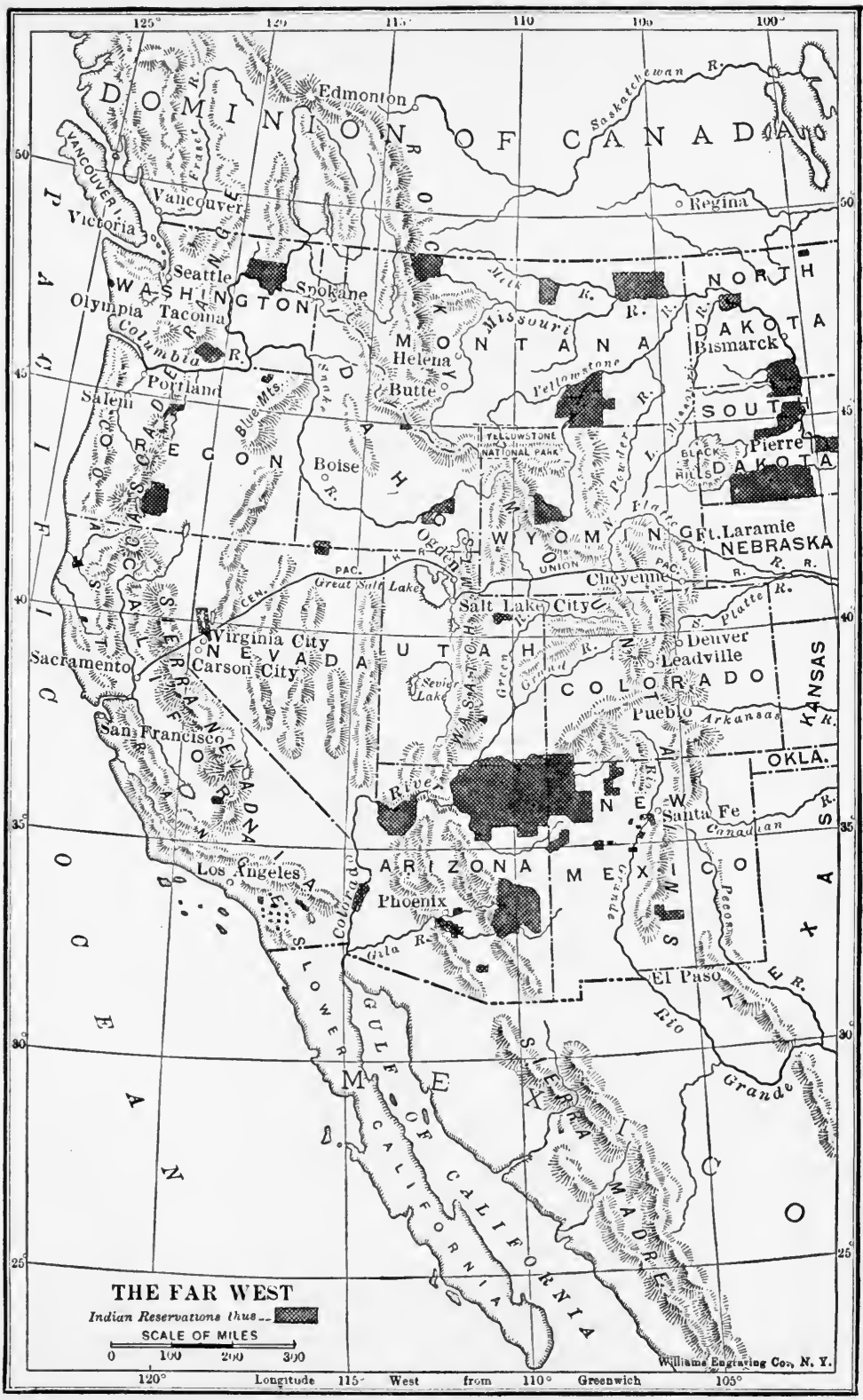


The government desires that all the Indians become citizens as rapidly as they show that they will be good citizens. Laws Acquiring have been passed by which they are assigned land of citizenship their own when the president of the United States thinks they are ready to become landowners. The Indians in the country do not increase rapidly in numbers. There are now about 300,000 in the country, and 122,000 of these still live on reservations in the old tribal way. When Oklahoma became a state, in 1907, the five civilized tribes of Indian Territory were incorporated in its population. They gave up their tribal councils and their distinct governments and became parts of the government of the state. Some of them have become prominent in politics.

\section{QUESTIONS}

I. How did the settlement of the Rocky Mountain states differ from the settlement of the older Western states? Who were the first settlers? In what three areas were the richest deposits of gold and silver? Describe the early mining operations on the slopes of Mount Davidson. What two classes of miners usually appeared? How was silver ore discovered in Nevada? Show how Nevada became a state. What was the nature of its development?

II. Describe the early days in Colorado. What minerals were most important in this region? Describe the discovery of gold in the Montana region. How did Colorado and Montana become territories and states? What has been the effect of irrigation in the Rocky Mountain states?

III. Explain the method of mining with a pan. What was a mining claim? How was it taken up? Explain mining with a cradle. What was the long tom? How was it worked? Show why these methods were wasteful. How did mining by large companies come into existence? Describe the methods of mining by the companies. Why could the early miner never do this? What was his service in the development of gold and silver mining?

IV. In what parts of the Rocky Mountain states did grazing and farming first appear? Describe the settlement of Utah. Why was the territory long denied statehood? Describe the introduction of fruit culture in California. What forms of agriculture were developed in the states north of California? Explain the relation of this kind of 
development to railroad construction. Which was the first transcontinental line of railroads? Describe the construction. What aid did it get from the federal government? What other great roads were constructed to the Pacific coast?

V. Why did the Indians become alarmed at the appearance of the railroads? Describe the destruction of the game. How did the Indian feel about it? How did he try to stop railroad building? How did the government try to prevent trouble? Show how the efforts failed. What was the attitude of the army toward the Indians? Show how the feeling of the East was awakened. Describe the work of the Indian commission. How was the war waged under the direction of General Sheridan? What was the result?

VI. Describe the outbreak of the war with the Sioux. What was the Indian side of the contention? How was the party favoring war led on? Describe the last battle of Custer. What was the later history of Sitting Bull?

VII. How have the tribes received civilization? What has been the result with the reservation Indians? What steps are taken to convert them into landowners? What laws have been made in reference to the acquisition of land by Indians? What is the Indian's tendency in population? What is the present status of the five civilized tribes?

\section{SUGGESTED TOPICS}

The History of the Comistock Lode; Life of the Gold Miners; The Mining Laws; Destruction of the Game; Career of Sitting Bull ; Last Fight of Custer; Construction of the Union Pacific Railroad. 


\section{CHAPTER XXXII}

\section{THE POLITICAL HISTORY FROM 1877 TO 1897}

WE have now come to the history of the two great political parties within recent times. We must see how the leaders of The aim of each tried to win the elections, and in what way they the parties governed the country when they had been successful at the polls. We shall not understand this history unless we keep in mind that each side was working, as it saw best, for the good of the country. A fair-minded

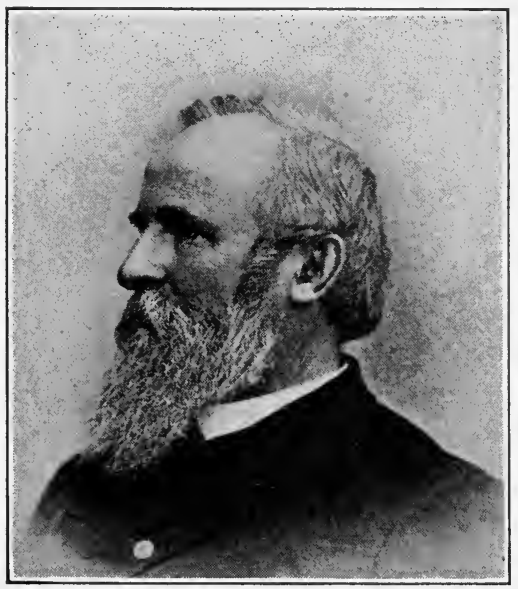

Rutherford B. Hayes student will see the good in the party opposed to his own.

President Hayes was inaugurated in 1877 and held office

Hayes and the spoils system for four years. He was a man of excellent character and had made a good governor of Ohio. But he was not popular with the political leaders in his own party. He wished to put civil service reform into operation, but congress would not vote money to support the examinations. He did what he could, however, without the aid of congress, and he was able to introduce a system of examinations for the appointment of clerks in the customhouse and postoffice in New York City. Carl Schurz, a member of his cabinet, acting on his own responsibility, adopted 
the same system in making appointments in his department, and Hayes supported him in it. In these and other ways he managed to check the spoils system slightly.

Hayes also withdrew the troops from the South. The soldiers in this region Hayes and had come to be em- the South ployed to enable the republicans to bring out the negro vote. Hayes thought that the Southern states should be allowed to regulate their own elections. If wrong was done, it was the people of those states and not the federal government who should right it. He be-

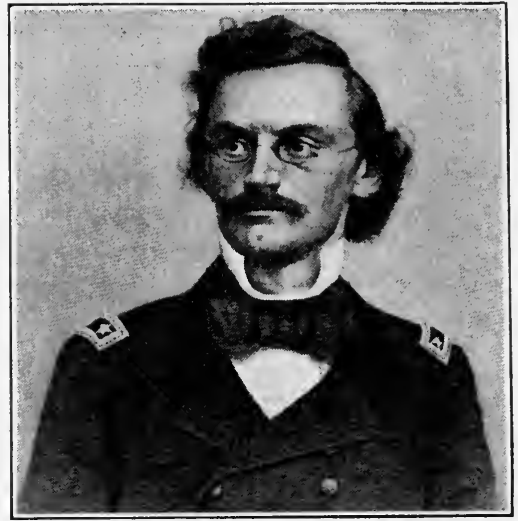

Carl Schurz lieved that in due time the South would do as well as it could by the negro, and most of the people of the North agreed with him. As a result of the withdrawal of the troops, the republicans lost control of the last Southern state in which they had power.

Some of the republicans considered Hayes's course a bad one and declared he was not true to his party. Many who had been liberal republicans in 1872 were now his supporters, and Hayes took one of them, Carl Schurz, into his cabiTwo factions net. His open leaning to these men led his opponents to call his followers the half breeds, while they themselves were known as stalwarts because they stood for the stricter kind of party loyalty. To the end of Hayes's term there was much wrangling between the half breeds and the stalwarts, both claiming to be the only true republicans.

When the time for the election of 1880 approached, strong efforts were made to unite the two sides. The stalwarts were mostly for nominating General Grant again, but they were not 


\section{THE PLAIN STORY OF AMERICAN HISTORY}

able to control the nominating convention. After some division Grant's opponents finally nominated James A. Garfield, of Ohio. The stalwarts were displeased at first, but after a while they,

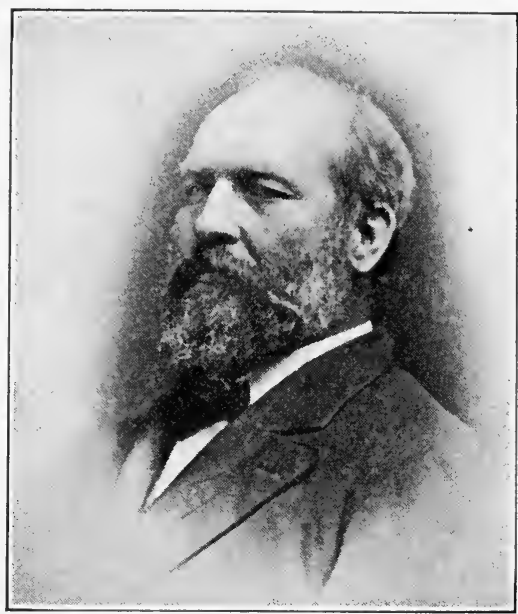

James A. Garfield smothered their anger and supported the man whom the The election party had taken for of 1880 its candidate. The democrats nominated General W. S. Hancock, a brave officer in the civil war. He was not experienced in political affairs, and the people showed by their votes that they preferred his opponent, who had long been a prominent man in Washington. Garfield was elected by a safe majority.

His administration was a short one. July 2, 1881, he was shot by a half-crazy man, who had been refused an office in the civil service. The wounded president lingered two months and a half and died on September 19. During his illness the newspapers published daily bulletins from his sick room, and all the people were drawn closely to him as they watched his brave fight against death. He was succeeded by Chester A. Arthur, of New York, who had been elected vice-president in 1880. Two important things happened while Arthur was president, 1881 to 1885.

First, Congress at last gave way, 1883, and passed an act for civil service reform. It provided for examinations for applicants The civil for government positions. The names of those who service law passed the examinations were to be placed on a list, and of 1883

when it was necessary to make an appointment, one of the three highest on the list was to be taken. When a man was once appointed, he could hold office as long as he was capable of 
doing the work. By this means we have gradually secured a faithful body of government clerks who do not live in fear of dismissal with every change of administration. The death of Garfield at the hands of a disappointed officeseeker showed the evil of the old system and had much to do with inducing congress to pass the civil service law.

The second important matter was the passage of a new tariff law. The years 1879 to 1882 were prosperous years. Wheat, cotton, and most other articles that we exported brought The surgood prices, and the country bought large quantities of plus foreign merchandise. The duties received on these articles as they came through the customhouses raised the federal revenue to a large sum. It was soon evident that we were getting much more money than was needed for government expenses. The surplus was used in paying the debt, but it became so large that many people began to think it would be better to lower the rates of duties and thus leave some of the surplus money in the pockets of the taxpayers.

This opinion was taken up by the democrats, who have generally favored lower tariffs, and in 1882 they carried the elections for the house of representatives. It was understood The tariff that they would pass a bill to reduce the rates as soon as of 1883 the new congress came into power. The friends of protection were alarmed and concluded that it would be better to reduce the tariff themselves, since they could do it in such a way that it would injure the protected manufactures least. Thus it happened that the tariff of 1883 was passed in the last days of the republican congress. It lowered the rates slightly, and it satisfied the popular demand for tariff reduction. When the new democratic congress came into power, late in 1883 , it was not able to pass a law for further reductions.

In 1884 the parties were again arrayed in a contest to elect a president. The republicans nominated James G. Blaine, of Maine, a brilliant orator. He had been speaker of the house of represent- 
atives for several years and had a great many devoted friends. But he had made some very strong enemies, who would not vote The candi- for him under any conditions. He made many telling dates, 1884 speeches in the canvass. The democrats nominated Grover Cleveland, of New York, well known as a fearless reformer. He had been elected governor of the state in 1882 by a very large majority, and during the two years of his office he had shown a fearless determination to do his duty. It was believed that he could carry the state of New York, in itself a most important thing.

There were at this time a large number of independent voters. Many of them were men who had been liberal republicans in 1872,

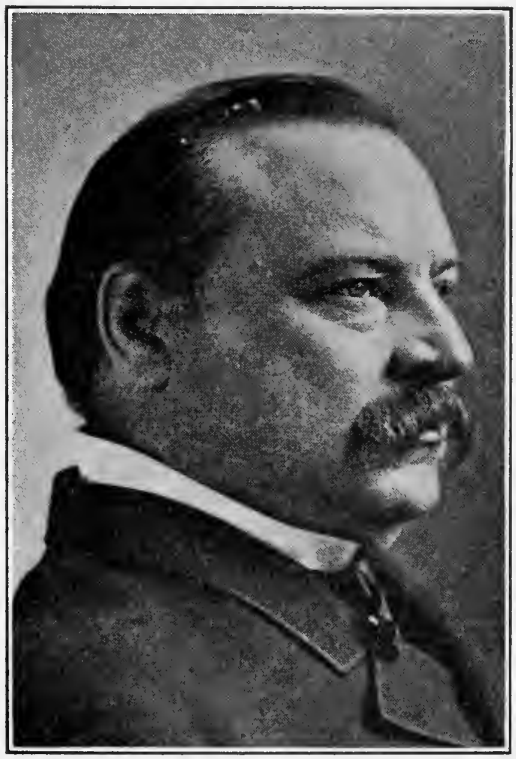

Grover Cleveland and many more were young men who believed in tariff reElection form. The independresults ents did not like Blaine, and they turned all their strength to Cleveland. They had much influence in the important states, where a few voters could decide how the state voted. They were especially influential in New York, which went for Cleveland and thus insured his election by a small majority of the electoral vote. It was the first democratic victory since 1856 .

Gloomy prophecies had been made for the country if it Cleveland should have a demoas president cratic president. To the surprise of these prophets affairs went on under Cleveland in much the same way as under Arthur. The United States is so great 
a country that a change from one party to another is not a serious thing. The new president showed that he was a man of good sense. He tried to enforce the civil service reform law, although it was very hard to refuse the demands that many who had worked for his election now made. The republicans had filled the offices with their friends, and the democrats did not like a law which left these men safe in their places. Cleveland enforced the law as well as he could; but sometimes he could not refuse the demands that came from his own friends. The reformers were disappointed because he appointed some of his political supporters to high office ; his own party became dissatisfied because he did not appoint more of them. Thus he was blamed on each side; but he kept on as he began and the more reasonable part of the people realized that he was doing his best.

Cleveland wished congress to pass a law for a lower tariff. He thought the bill passed in 1883 did not go far enough. He urged the democrats to pass a bill through the house of repre- cleveland sentatives, but the party would not do as he wished, and the and the country began to say the talk of the democrats tariff about tariff reform was merely to get votes. The president was aroused at this, and in December, 1887, sent a long message to congress urging tariff reform. The outspoken appeal showed he was in earnest, and his party saw they must either support him or repudiate their own leader. The latter they could not afford to do, and so they suppressed their feelings against Cleveland and took a stand for a lower tariff.

The presidential election of 1888 was now at hand. The democrats nominated Cleveland for a second term and declared that the tariff was the leading question. The republicans The election were pleased to have the tariff for an issue; for they of 1888 believed the people did not wish to lower the duties. To do so would cause suffering to the manufacturers, who would have to reduce wages. That would mean that a large part of the people would have less money to spend, and so the prices of farm products 


\section{THE PLAIN STORY OF AMERICAN HISTORY}

would go down. A lack of money with any large class of people is bound to cause trouble to many others. So well did the republicans present their side in the campaign that Cleveland was defeated, and Benjamin Harrison, the republican candidate, was elected presi-

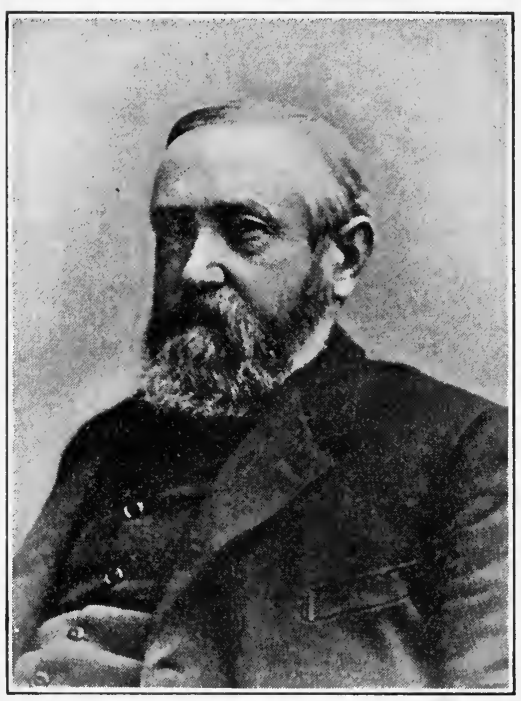

Benjamin Harrison dent. The fact that the independents did not voteso strongly for Cleveland as in 1884 had much to do with his defeat.

President Harrison, a citizen of Indiana, was the grandson of William Henry Harrison, whom the whigs elected president in 1840. He was a man of the best character, but he was cold President in disposition and Harrison not popular. The democrats declared that he got his chief glory from his grandfather, and the humorous papers represented him as a small man wearing an immense hat, bearing the words, "Grandfather's Hat." This form of caricature was repeated so often that it became the common description of President Harrison. But it did not do him justice.

While Harrison was president, 1889 to 1893, the republicans controlled both houses of congress and could make what laws A new navy they wished. There was now a large surplus in the treasury and they had to decide what to do with it. Since the surplus was the difference between the amount the government collected and the amount it spent, it was easy to see that it would disappear entirely if the government would only spend more freely. This kind of argument was made in good faith, and congress undertook to carry it into practice. One thing it did 
will ever make its work remembered: it passed liberal appropriations to build a new navy. Up to that time little had been done since the civil war to make our navy worthy of the country. The feeling was general that a navy would bring on trouble with other nations, and that if we would merely strive to develop our own country, we need not fear attacks on the sea. In this way the years passed quietly, and our small navy attracted little notice among the navies of the world. Meanwhile, iron was being used in the construction of warships, and the type of vessel was growing in size. The men who felt that our nation should keep up with the times felt that we should build a new navy on the most modern plans. They had their way in 1890 ; and the ships then ordered played an important part in the war with Spain eight years afterwards.

Another measure was the law passed to pay service pensions to civil war soldiers. From the beginning our government has given pensions to its disabled soldiers, the intention service being that no man who suffered loss of limb or health pensions fighting for his country should be allowed to come to want. After the civil war liberal pensions were given to disabled soldiers. But the new law, 1890, provided for a pension to every man who had served, whether he was disabled or not, if he was willing to be classed as a dependent. The result was a large increase in the amount paid for this purpose. In 1889 the government spent $\$ 89,000,000$ for pensions. In 1893 the amount was $\$ 159,000,000$, and it has remained about the latter sum ever since.

Other liberal expenditures were made. The money appropriated by congress was more than a billion dollars for the two years that this congress existed; and for that reason the phrase was coined, "a billion dollar congress." It was used as a term of reproach by the democrats.

Another important measure of congress at this time was the McKinley tariff law, passed in 1890. It took its name The McKinfrom William McKinley, Jr., of Ohio, the chief author ley tariff 
of the law. It was the purpose of the makers to have a law which would give the manufacturers ample protection. It raised the rates on most articles, and the impression went abroad that it was the highest tariff we had ever laid. The law was not passed until a few weeks before the day on which the country was to elect another house of representatives. At that time the people were very much aroused, and the result was a house largely democratic. The billion dollar congress and the McKinley tariff gave the republicans a sharp setback; and the democrats began to believe that they might elect the president in 1892 .

They had much difficulty to make up their minds as to their candidate. It was evident to a great many members of the party Election of that Cleveland was the most distinguished democrat; 1892 but the friends of the spoils system were against him. In New York the leaders of Tammany Hall, a very powerful political society, were against him, and several leading members of the United States senate used their influence to prevent his nomination. But he was the man the voters in his party wanted for their leader, and after a while his opponents saw they could not defeat his nomination. They gave way, and Cleveland became the democratic candidate. The republicans renominated Harrison. He had made a good president, and they wished to show their confidence in him. A warm campaign followed, and the result was the election of Cleveland. He is the only president we have had who has held a second term which did not follow immediately on his first term.

Those who voted for Cleveland knew that he wished to undo the McKinley law and to reduce the tariff to a lower basis. He Wilson- was no sooner president than he began to make plans Gorman to carry out this purpose. Both houses of congress were tariff democratic, and a bill known as the Wilson tariff bill was quickly passed by the house of representatives. It was a lowtariff bill and sought to collect only the amount of money that was necessary to pay the expenses of the government. In the 
senate this bill was opposed by the republicans and a small group of democratic senators, who were able to change it greatly. The leader of these men was Senator Gorman, of Maryland. When the bill finally passed, it had so little tariff reform in it that Cleveland thought his party was disgraced. But he did not veto it, for it provided for lower rates than those of the McKinley act. The new law was called the Wilson-Gorman act, and it was passed in 1893.

Soon Cleveland had overwhelming trouble of another nature. For several years a movement had been going on to force the government to coin and accept as money all the silver that Free coinwas offered in bullion form. Prices of wheat and cotton age of silver had been unusually low, and many people thought it was because there was not enough money in the country. The West and the South wished to have the silver coined, since it would increase the amount of money in circulation. The East was opposed to the demand. It held that the increase of the money supply by means of silver dollars, which were becoming less valuable as silver bullion daily became cheaper, would disturb business and force gold coins out of the channels of trade. The question was very hard for the people to understand. To them it seemed that silver was good money and the more of it the better.

The advocates of free silver were most numerous in the rural states and its opponents were strongest in the cities. Gradually the contest settled down to a battle between the East, in East and which city life dominated, and the West and South, in West which rural life was common. The republicans, long the friends of the manufacturers and bankers, became the opponents of the cause of free silver, and the democrats of the West and South became its friends. But there were many democrats in the East, Cleveland among them, who did not think that the government should coin free of charge all the silver bullion that was offered it.

Cleveland's second term was hardly begun when a great deal of anxiety was shown lest the government should lose all the gold 
in the treasury. Europe was continually calling for gold from every part of the world, and she was offering high prices for it. Demand for American speculators would take to the American treasury gold

United States notes, that is, greenbacks and other notes of the government, which the treasury must redeem in specie. Soon there was very little gold left in the hands of the government. Then Cleveland ordered the treasury to borrow gold by selling bonds in the markets. But the demand for gold kept up and it was necessary to borrow more gold. In all, the government got by this means over $\$ 250,000,000$ in gold before the European demand was checked.

When the speculators demanded gold of the treasury, they always got it. The friends of silver were very indignant and declared Cleveland's that the treasury ought to redeem its notes in silver as democratic well as gold. They denounced Cleveland, saying he was foes

the friend of the speculators. In their anger they even went so far as to say that he was bribed by the speculators. The charge was not true, but it could not have been made by democrats if there had not been a bitter fight within their party. During the last two years of Cleveland's second term he was more disliked by the majority of the Western and Southern democrats than by the republicans themselves.

When the two parties came to select candidates for the campaign of 1896, the division among the democrats showed itself Nomination plainly. Those who lived in the West and South deof Bryan clared they would never again support a man from the East. They demanded a true friend of free silver, a man who would not be friendly to Wall Street. They were in the majority, and as soon as the nominating convention met they showed that they meant to control it. The men of the East were thrust aside, and William Jennings Bryan, of Nebraska, was nominated for the presidency. He was unpopular in the East, but the democrats of the West and South were his warm admirers. He was a good orator, and his campaign speeches were heard by great multi- 
tudes. From 1896 to 1912 Bryan was the most influential democrat.

The republicans profited by the division in the democratic party. It was certain that many democrats would not vote for Bryan nor indorse his views. Since the democrats were openly for the free coinage Result of of silver, the repub- the election licans felt that they could afford to come out openly against it. Up to this time they had usually tried to please the free-silver men by saying they were friendly to silver. In 1896 they threw this mask aside and declared openly for gold as a money metal. William McKinley, Jr., of Ohio, author of the McKinley tariff act, was nominated for the presidency. $\mathrm{He}$ carried every state north of the Potomac and Ohio rivers and east of the Mississippi. He also carried Kentucky, West

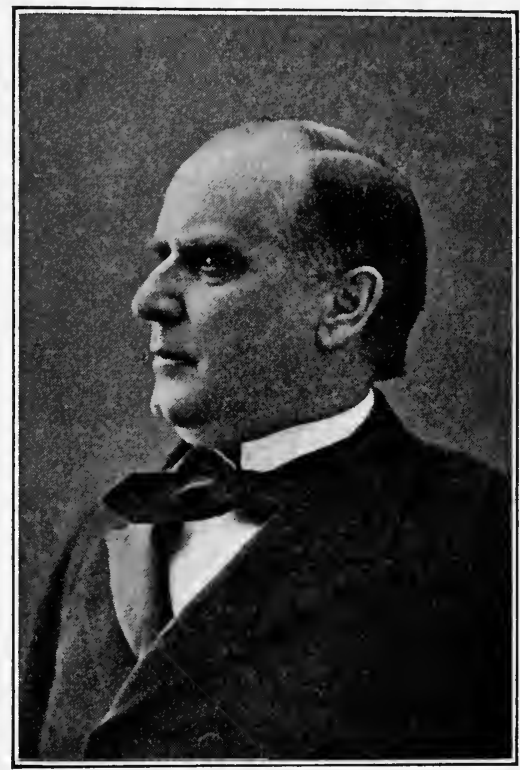

William McKinley Virginia, Minnesota, Iowa, California, and Oregon. He had two hundred and seventy-one electoral votes to Bryan's one hundred and seventy-six.

\section{QUESTIONS}

I. Why should we be able to see the point of view of each political party? What kind of man was Hayes? From whom did he encounter opposition? What was his attitude toward the spoils system? How did he begin to establish eivil service reform?

II. What was his Southern policy? How were the troops used in the South? What was Hayes's view about the Southern elections? What 


\section{THE PLAIN STORY OF AMERICAN HISTORY}

was the result of the withdrawal of the troops? What two factions now appeared in the republican party? How did they get their names? For what did each stand? Describe the parts taken by each in the nomination of the party's candidate for president in 1880. Whom did the democrats nominate? What was the result of the election?

III. Describe the short presidency of Garfield. Who succeeded him? What are the chief features of the civil service law of 1883? How did Garfield's death influence the passage of the law?

IV. How did the surplus in the treasury come into existence? For what purpose was it used? What suggestion was made? Which party took up the cause of a lower tariff? What was the result of the congressional elections of 1882 ? What course did the republicans now take? What kind of tariff was made in 1883 ? What happened to the efforts of the democrats to make further reductions?

V. Whom did the republicans nominate in 1884 ? What was his strength and weakness? Whom did the democrats nominate? What was his record? Who were the independent voters? What was the result of the election?

VI. Why were some of the people disappointed in the beginning of Cleveland's administration? What was his attitude toward civil service reform? What two classes were displeased? What was his position on tariff reform? How did his party stand on this question? What was the effect of his message of 1887 ?

VII. Who was the democratic candidate in the election of 1888 ? On what platform? Why did this please the republicans? Whom did they nominate? What was the result of the election? What kind of president was Harrison?

VIII. What new suggestion was now made for the reduction of the surplus? What was the condition of the American navy before Harrison? What policy was now adopted? On what ground were pensions paid before 1890? What new principle was introduced? What difference did it make in the expenditures? What kind of tariff was passed in 1890? Why did the elections come at an unfortunate time for the republicans? What was the result?

IX. How did Cleveland come to be nominated in 1892? Whom did the republicans nominate? What was the result of the election?

$\mathrm{X}$. Describe the enactment of the Wilson-Gorman tariff. What did Cleveland think of it? Why was free coinage of silver demanded? What was the argument against it? How did the sections take sides on the silver question? Describe the withdrawal of gold from the treasury. How did Cleveland meet it? Why did he arouse the dislike of the silver men? 
XI. How did the division among the democrats show itself in the convention of 1896? What did the silver men demand? Who was nominated? What kind of race did he make? How did the republicans profit by the democratic quarrel? What did the party say in regard to money? What had hitherto been the position of the party on silver? What did it now do? Describe the result of the election.

\section{SUGGESTED TOPICS}

The Spoils System at Work; President Garfield ; The Presidential Canvass of 1884; The Growth of the American Navy; The Pension System. 


\section{CHAPTER XXXIII}

\section{A NEW ATTITUDE TOWARD FOREIGN NATIONS}

In the early days of our government it was generally held that we ought not to concern ourselves with the affairs of other nations. Isolation At that time the theory was a good one. We were not strong enough to make other powers respect us, and we ought not to run the risk of attempting something that might lead to war. By 1885 many Americans had come to believe that we had outgrown this early stage of isolation. We were quite strong enough to take any part we chose in the affairs of the world, and they felt that we should be more respected by other powers if we cast aside our self-restraint.

This feeling was made stronger by the growing conviction that we must take an important part in the affairs of the people who lived on the islands in the Pacific and in the countries that border that ocean. Through the Monroe doctrine we had pledged ourselves to have nothing to do with the quarrels of Europe, but we had demanded that European powers should not meddle with the affairs of any nation in the western hemisphere. If we keep Europe away, it is our duty to see that the smaller American states do not wrong the European nations. It is for these reasons that we have been forced to play a stronger part in foreign affairs during the last twenty-five years.

The first indication that we were adopting a new policy came out in what was known as the Samoan incident. The Samoan Samoan Islands are situated in the southern Pacific Ocean 4700 Islands miles from San Francisco. They have no importance commercially, but are valuable as a coaling station for ships that 


\section{A NEW ATTITUDE TOWARD FOREIGN NATIONS 447}

ply in the southern seas. They are on the route from California to Australia. As early as 1854 the Germans appeared in the islands, trading and establishing rich business firms. Soon afterwards American and British traders also appeared, and between them sprang up much rivalry. The native king of the island feared that Germany would get so strong a foothold that she would never be put out, and offered to place the islands in our hands. But we refused to take them, because we did not wish to have to defend territory so far away. The king was so much opposed to the Germans that they used their influence to overthrow his power. A rival claimant to the throne appeared, and he was welcomed by the Germans as the rightful king. The Americans and the British supported the old ruler.

A warm quarrel now arose, and in 1886 three German warships arrived at Apia, the chief town of the islands. The Germans in the islands were stronger than either the English or A threatenthe Americans, and they showed that they meant to put ing situation their candidate on the throne. They gave him arms and ammunition, and allowed the Samoans to see that he had their powerful support. On one occasion they sent a ship to bombard a native seaport that was in rebellion against him. An American gunboat was in the harbor. Her commander, Captain Leary, weighed anchor and followed the German boat, taking position so that the fire from the German guns would have to fall on the American boat. This was Leary's way of showing that the United States would take part in the war. The commander of the German boat would not fire on the American flag and went quietly back to Apia.

This incident showed that the Samoan affair might lead to war with Germany, and the government at Washington was convinced that it ought to be settled at once. Nobody wished to The work of go to war over so small a thing as the Samoan Islands, a hurricane but nobody wished the government to sacrifice its honor before the demands of any other power. For over a year the diplomatists tried to solve the question and made no headway. Early in March, 
1889, three German, one British, and three American warships were in Apia harbor, Samoa. Each nation strongly desired peace, but it was feared that a rash blow in this distant spot would precipitate an armed conflict. March 16 a great hurricane descended on the harbor, blowing fiercely into the open roadway. All the warships but one, the British ship Calliope, were driven on the beach and destroyed. The Calliope only escaped by steaming out to sea when the storm was at its worst. This great calamity cooled the passions of the men engaged in the quarrel, and the three governments concerned came to an agreement in regard to Samoa. For a time the three powers exercised joint control over the island; but this arrangement proved unsatisfactory, and in 1900 the islands were divided between Germany and the United States. We got Tutuila, with the excellent harbor of Pago-Pago, and Germany took the rest. Great Britain gave up all her claims to the country. The Samoan incident, as it is called, occurred between 1886 and 1898.

In 1891 came the Itata incident, which for a few weeks made a war with Chile seem certain. There was a revolution in this Chile and important South American country, and Balmeceda, a Balmeceda usurper, had made himself dictator and was carrying on the government in his own interest. The people rose against him and gradually took the power out of his hands. Our minister in Chile was Patrick Eagan, who showed much partiality for the usurper; and on this account the United States was disliked by the revolutionists. One of their warships was the Itata. She was sent to San Diego to get military supplies for the fleet and army. American officers took possession of the ship while she was in the harbor and detained her. Her captain was very indignant, and believing that he was unlawfully held, overpowered the American officer who had been stationed on his ship, and sailed for Chile.

The American people now became angry. The Chileans had used force against one of our officers doing his official duty, and it was demanded that the Itata should be captured. The Ameri- 
can cruiser Charleston was sent after the Itata with orders to seize her and bring her back to American waters. When the Chilean revolutionists heard of this, they sent a powerful Chasing the Chilean ship to protect the Itata. For several days it Itata looked as if there would be a battle between the two vessels. Both arrived at Acapulco, a Mexican harbor at which it was believed the Itata would stop. They were ready for action, and if the expected ship had appeared, she would undoubtedly have been taken by the Charleston, whereupon the other Chilean ship would have opened fire. Fortunately, the Itata did not stop at Acapulco, but went straight to Chile. A short time was enough to show the revolutionists the folly of having a war with the United States, and when we demanded that the Itata be given up, the demand was granted. An investigation by an American court showed that the vessel should not have been detained and she was handed over to Chile.

By this time there were several American warships on the coast of Chile, and they kept in close touch with all that happened. In August, 1891, the revolutionists prepared a strong Triumph expedition to land on the coast and surprise Santiago, of the Balmeceda's capital, by a quick march overland. The revolution American vessels observed the landing and then went to Valparaiso to cable the news to Washington. In strict fairness they should not have informed Balmeceda of what was going on ; but somehow the news got out and was published in the Santiago newspapers as coming from the United States ships. The revolutionists lost the advantage of giving their opponents a surprise, but they won the victory, overthrew Balmeceda, and took over the government of Chile.

Out of these two events grew a great deal of hostile feeling in Chile for our country. October 16, 1892, the Ameri- The Baltican cruiser Baltimore was at Valparaiso, with Captain more at Schley in command. He allowed some of his crew to Valparaiso go ashore, where they became involved in a riot with the natives. 
Two Americans were killed and nineteen were wounded. It was said by the sailors that the police of the city, instead of protecting the Americans, joined in the attack on them. The Chileans denied the charge and the investigations that were held did not make it clear which statement was correct. News of the affair caused great indignation in America. This feeling grew when it was known that the Chilean government was not disposed to adjust the matter. After about two months' delay they took notice of it by asking for the recall of Eagan. Now Eagan had been a partial minister, and many Americans felt that he was not free from faults. But we were not willing to recall him at the mere dictation of Chile. We accordingly replied that when Chile apologized for the attack on the sailors of the Baltimore and was willing to adjust the matter, we would recall Eagan. This brought the Chileans to look calmly at the matter, and six months later they handed over $\$ 75,000$ to be distributed among the families of the victims of the riot in Valparaiso. Eagan was not recalled, but being a republican appointee he went out of office with the advent of the democrats under Cleveland, 1893.

The Chilean quarrel was hardly over before another Pacific Ocean question was up for decision. It involved the annexation Hawaiian to the United States of the Hawaiian Islands. These Islands islands lie between San Francisco and Hong Kong and are so important as a place of call for steamers that they have become known as "the crossroads of the Pacific." The first American influence there was established by a group of able missionaries about 1820 . The natives accepted the teachings of the mission workers and adopted the ways of civilization very rapidly. There was a line of kings who granted one reform after another at the suggestion of the missionaries. The soil was adapted to the growth of sugar, and foreigners came into the country, some as planters and others as merchants. The most numerous group was the Americans, among whom were many sons and relatives of the missionaries. By 1890 a large part of the wealth and business of 
the islands was in the hands of these foreigners, and the natives were gradually becoming a race of laborers.

This situation aroused the fear of the queen, Liliuokalani, lest her country should fall entirely under the control of the whites. Her method of checking the danger was tyrannical. Hawaiian In 1887 the king had established a constitution in which revolution the whites were allowed to vote and in which an elected parliament was to make laws for the country. In 1893 the queen announced that she would replace the existing constitution with one of her own making. The whites became alarmed and took up arms. The American minister ordered the American ship of war in the harbor of Honolulu to land marines to protect American property. When the natives saw the American force in their streets, they would not come out at the call of the queen; and so she had to yield to superior force. Then the whites proclaimed a republic, and the queen renounced her throne.

The men at the head of the republic were American born, and they took steps to have Hawaii annexed to the United States. This step displeased the British and other foreigners not American Americans, and they made plans to overthrow the new flag raised government. They thought that their interests would be injured if the islands passed under American control. The American minister was now alarmed lest the islands should fall into the hands of some other nation. In his anxiety he raised the American flag in Honolulu and declared that Hawaii was under the protection of the government of the United States. He did not dream that anybody at home would be opposed to receiving this important group of islands. Harrison was then in the last weeks of his presidency. When he knew what was done in the Pacific, he prepared a treaty of annexation with the approval of the Hawaiian agents and sent it to the senate for ratification.

When Cleveland became president, the senators had not voted on the treaty, and he asked them to send it back to him. The request was complied with, and Cleveland began to make an inves- 
tigation of the whole matter. He suspected that the revolution of the islands was due to the aid given by the American marines, Annexation and it did not seem fair in his mind that a great nation deferred should use her power to overawe the Hawaiian people and make their country American territory. He sent an agent to Honolulu who, after talking with many persons, reported that the revolution was accomplished through our aid. Cleveland, therefore, refused to go farther with the task of annexation. He could not restore the deposed queen to her throne, and Hawaii remained a republic for five years. In 1898, after we had obtained a foothold in the Philippines, we felt that the possession of the islands was a necessity, and annexation was carried through congress with but slight opposition. Hawaii is now a territory and may some day become a state.

Another question that has attracted much attention is the attitude of the federal government toward the importation of Chinese Chinese and Japanese laborers. The question aroused much inlaborers terest on our Pacific coast, where these laborers have been most numerous. In the early years of our possession of California there were very few American laborers in the state. Mining was so profitable that most people preferred to follow it as a calling; and the people of the state were glad to get Chinese for the labor of the farms and the towns. They were used in railroad building, in domestic service, and in digging excavations. After a while they were coming in so rapidly that the white laborers began to be alarmed. The Chinaman can live more cheaply than the white man because he is used to doing it in China; and the labor unions complained that he was keeping wages down. The employers were satisfied to keep him as a laborer; but in 1882 congress passed an act to exclude Chinese laborers for ten years. This act was extended another ten years in 1892, and in 1902 it was made permanent.

In 1882 there were few Japanese in America, and nothing was said about them in the law against the immigration of Chinese 
laborers. But their nation was rapidly coming to the front in Asia. In 1895 it finished a war in which the great Chinese empire was defeated; and in 1904 it carried on a remarka- Japanese ble struggle against Russia. At first the success of Ja- laborers pan was observed with much pleasure by the people of the United States. As a people we are apt to be in sympathy with a plucky nation that is rising in power and fighting for her own existence. Soon after the war the number of Japanese in the states increased rapidly, and they became an important part of the laboring population of the Pacific coast. The workmen of California now became alarmed and began to agitate against the admission of these cheap laborers. In 1906 San Francisco ordered that the Japanese children should be taught in an "oriental school." The order gave great offense to Japan, who prided herself on being a civilized nation. She held that she was treated as an inferior state and that we had violated our treaty with Japan. She demanded that the federal government force the Californians to treat Japanese school children as they treated the children of any other foreigners. The government at Washington asked the San Francisco authorities to repeal their order. For a long time the request was refused; but finally an agreement was made by which Japan promised to keep her laborers from coming to America and San Francisco decided to admit to the ordinary schools Japanese children under sixteen years of age.

In 1913 the Japanese question came up again in California. The citizens of Japan were buying land in the fruit-growing section of the state. The farmers became alarmed lest a foreign The Japarace should be planted permanently in their midst, and nese and a law was made to prevent aliens from acquiring land land owning under these conditions. The law brought out a protest from the Japanese government, but it did not result in serious ill feeling between the two nations. At present the matter is still being discussed by the Japanese and American governments.

Another serious matter which will long be remembered in the 
history of our diplomacy was what is known as the Venezuelan The Vene- incident, 1895, a matter which came up during the zuela second term of President Cleveland. Venezuela lies boundary chiefly in the valley of the Orinoco River, and east of it is British Guiana. At that time the boundaries between the two countries had not been determined. Venezuela had several times asked Great Britain to appoint a commission to settle the matter, but the requests had not been granted. The disputed area contained 50,000 square miles. English settlers gradually moved into it, and gold was discovered there about 1875. Great Britain was now less inclined than ever to adjust the controversy and announced that she would be content with nothing less than all the disputed area. Venezuela asked several times that the matter be arbitrated, but Great Britain would not agree to the suggestion.

Venezuela then asked the United States to aid her. We replied favorably and tried to bring the two powers together for a friendly Cleveland's settlement of the dispute. Our advance, though sevdemand eral times renewed, was always rejected by Great Britain, who said there was nothing to arbitrate. Finally President Cleveland became convinced that it was our duty as a nation to take a strong stand in behalf of Venezuela. The Monroe doctrine declared that no European nation should establish colonies at the expense of any of the states south of us or exercise control over those states. If Britain had no right to the territory she claimed, then she was exercising control against the spirit of the Monroe doctrine. This is what Cleveland thought and in $\mathbf{1 8 9 5}$ he made a clear demand on Great Britain that she should submit the Venezuelan boundary claim to arbitration. When this was refused, he asked congress to appoint a commission of fair-minded and competent men who should look into the evidence and decide what was the true boundary. It seems that he meant to force Great Britain to accept the boundary after it was laid down by the commission appointed by congress. Of course, this would have meant war.

For a moment after Cleveland laid his request for a commission 
before congress the British took it as a joke. It had been so long since the Monroe doctrine had been put to any real use that the British ministry could hardly believe that it would again be urged by an American president. But a few days was enough to convince them that Cleveland was grimly in earnest. A few weeks . more showed the British people that they had not acted generously by Venezuela. All that country asked, and all that Cleveland demanded, was that the great British Empire should appoint fairminded men to see what the boundary really ought to be. It was to the great credit of Great Britain that she soon came to see how reasonable was this request. In a little more than two months after the matter came to its exploding point it subsided quietly through the appointment by Great Britain of a committee of arbitration. This was all that we asked. After a full investigation the committee decided the boundary dispute largely in favor of Great Britain.

The Venezuela incident showed that the United States are not willing to give up the Monroe doctrine. In fact, since 1895, they have several times put it into use to regulate the significance affairs of some of the states south of us. In 1895 the of the inBritish people thought that the Venezuelan incident cident was but a bit of Yankee brag. But from that time the attitude of Great Britain towards our government has been more friendly than before. It seems that the vigorous action of Cleveland was appreciated by a nation which has always respected a plain-spoken man.

\section{QUESTIONS}

I. Why was it wise for the United States to refrain from interfering in the affairs of other nations? In what respect did public opinion begin to change about 1885 ? Why have we had to adopt a stronger policy in recent years? In what parts of the world has this policy been applied?

II. Why were the Samoan Islands important? What three nations had interests in them? Why did we refuse to take them? How did the German party seem to be trying to gain control? How did Captain Leary nearly precipitate war? Describe the great storm at Apia. What was 


\section{THE PIAIN STORY OF AMERICAN HISTORY}

the effect on the quarrel? What agreement was now made? How was it afterwards modified?

III. Describe the situation in Chile, 1891. Why did the revolutionary party dislike the United States? How did the Itata affair arise? What was the effect on American opinion? Describe the chase of the Itata. How was the incident settled? Describe the triumph of the revolutionists. How were the American ships charged with giving out information unfairly? Describe the attack on American sailors at Valparaiso. What course did Chile take? What was the American reply? How was the affair adjusted?

IV. Why is the possession of the Hawaiian Islands important to the United States? What was the influence of the missionaries? How did the islands grow in civilization? What was the cause of the revolution of 1893? What part did the American minister take? How did the plan of the foreigners in Hawaii alarm the American minister? What did he do to meet it? What course did President Harrison adopt? Why did President Cleveland hesitate to annex the islands? What was the result of his investigations? How did we finally get possession of Hawaii? What is the present status of Hawaii?

$V$. In what part of the country was most interest felt in the exclusion of Chinese laborers? Why were these laborers considered undesirable? What was the early history of Chinese laborers in California? Why did the labor unions object to them? What act on the subject was passed in 1882 ? Why did the act of 1882 say nothing about the Japanese? How did we come to be suspicious of them? What order was issued in San Francisco? Why did the Japanese object?. What compromise was made? What dispute arose in regard to the ownership of land by the Japanese? What was done about it?

VI. How did the Venezuelan boundary dispute originate? How did the United States come to interfere? How was the Monroe doctrine involved? How did Cleveland announce his position? What was his position? How did the British take it? How did they proceed to settle the matter? To which side was most of the disputed territory allotted? What did the affair signify? How did it affect our relations with Great Britain?

\section{SUGGESTED TOPICS}

Description of Samoa; Balmeceda's Usurpation; Early History of Hawaii ; Present Condition of the Islands ; Our Relations with China in the Boxer War ; The Treaty of Portsmouth; Cleveland's Venezuela Message. 


\section{CHAPTER XXXIV}

\section{THE WARS WITH SPAIN AND THE FILIPINOS}

Our war with Spain was fought to free Cuba. It was not a selfish war. We had stood by many years while a large nation mistreated a small one, we had protested in vain against our service the mistreatment, and at last we removed the large to Cuba nation to such a distance that she could no longer interfere with the small one. When that was done, we put the small nation on her feet and left her to govern herself. We made no other restriction than to warn Cuba that she must not make a bad use of the independence we had given her. Rarely has a nation fought an expensive war with so small a desire to serve its own interests.

The island of Cuba was a valuable Spanish colony from the days of Columbus to 1898. It was devoted to the production of sugar and tobacco, which sold well in all parts of the Two classes world. The wealthy planters and the large merchants in Cuba and bankers were chiefly Spaniards; the laborers and the small landowners as well as many of the poorer men of the towns were native Cubans. Between the two classes there was little sympathy. The Spaniards looked down on the Cubans and did not think them capable of any part in the government. In fact, these poor people had been so long oppressed by the superior classes that they had but little education and were filled with so much hatred for their oppressors that they were not in a state of mind to govern a country wisely and justly. But they were very patriotic and never ceased to dream of the time when there should be a Cuba Libre, a Free Cuba.

In 1868 the Cuban natives began a war against Spain. They were not able to meet in the open field the large army that was 
sent to crush them, but they adopted a kind of warfare that was equally effective. They divided into small, well-drilled bands and The ten took refuge in the hills and swamps. Sallying out, they years'war cut off any weak Spanish force that was sent out of the fortified towns; and when they were pursued, retreated to some new place of defense. When they needed supplies, they raided the plantations of the wealthy planters. They let it be known that they would spare a plantation if the owner would give them a sum of money. It soon came to the pass that no planter could grind his sugar if he did not buy safety from the leaders of the revolution. To the Spaniards in the island this seemed a barbarous kind of warfare. Although they had many times as many soldiers as the revolutionists, they showed no ability to run down the armed bands. In this way the war went on ten years, until both sides were exhausted.

The United States were deeply interested in the war and tried to make peace. In 1877 the president of the revolutionists was Reforms captured, and General Campos, the Spanish governor, promised announced that Cuba would be made a self-governing colony if the revolt was ended. He promised that the island should have representation in the Spanish parliament, that there should be a Cuban lawmaking body for the members of which the Cubans generally should be allowed to vote, and that Cubans should be allowed to hold office in the island. This was not independence, but if it were enforced, it meant that the conditions in Cuba would be a great deal better than ever before. The revolutionists accepted the offer, trusting Campos and Spain to do all that had been promised. The United States were not a party to the agreement, but they approved it and used their influence to get the insurgents to accept it. They were very anxious that it should be carried into effect in good faith.

Year after year now passed without the fulfillment of the Spanish promises. It is true that a decree was issued for elections in Cuba, but the great majority of persons whom it made voters were those 
who favored Spain. The mass of the former revolutionists were not to vote. In February, 1895, Spain ordered the establishment of a lawmaking assembly in Cuba; but it was not the kind that had been promised in 1878. Half of its mem-

Broken faith bers were to be appointed by the king of Spain and the other half were to be elected under the one-sided system in force in Cuba.

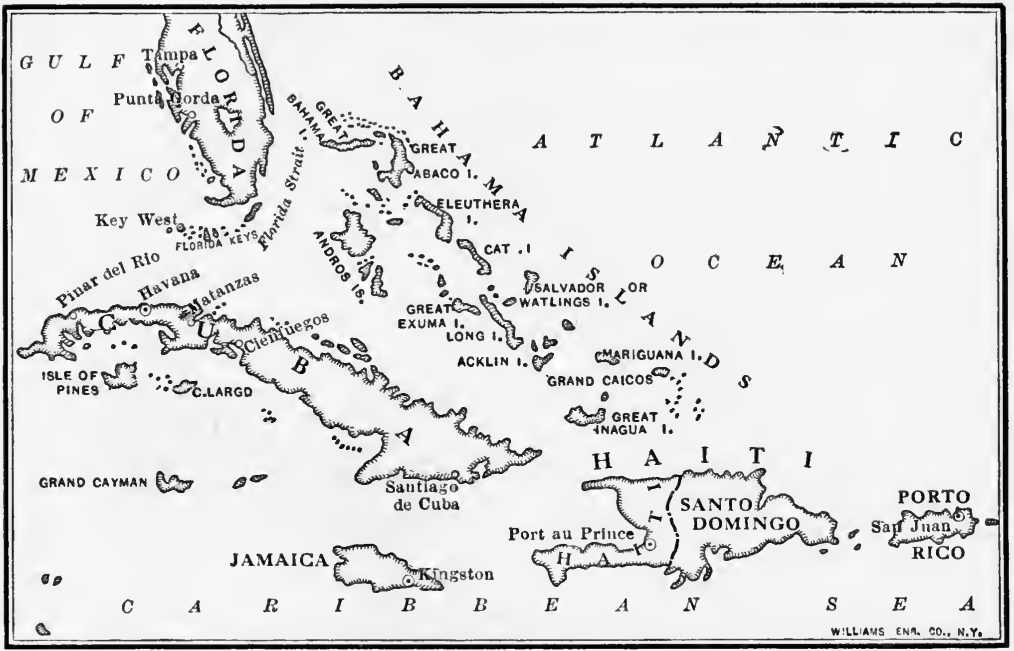

THE WEST INDIES IN 1898

The natives were greatly disappointed at this failure of the promises of Campos and at once reopened the war.

The old methods were now employed. The planters could not grind their cane without permission of the revolutionists, whose bands hovered around the towns waiting for an oppor- Reconcentunity to cut off some straggling body of Spanish troops. tration Although an army of 200,000 men was sent against them, they were not suppressed. At last the Spanish commander in Cuba ordered the country people to leave their farms and come within the fortified towns. By allowing the farms to remain untilled, he thought 
there would be nothing to support the revolutionists, and they must soon be starved into surrender. The result of this policy was a vast amount of suffering by the poor persons who were thus crowded into the towns. It was all useless; for the war went on as before. Gathering the peaceful people into the towns was called "reconcentration."

The Cubans continually called on the United States for help. President Cleveland, who was in office in 1895, when the struggle

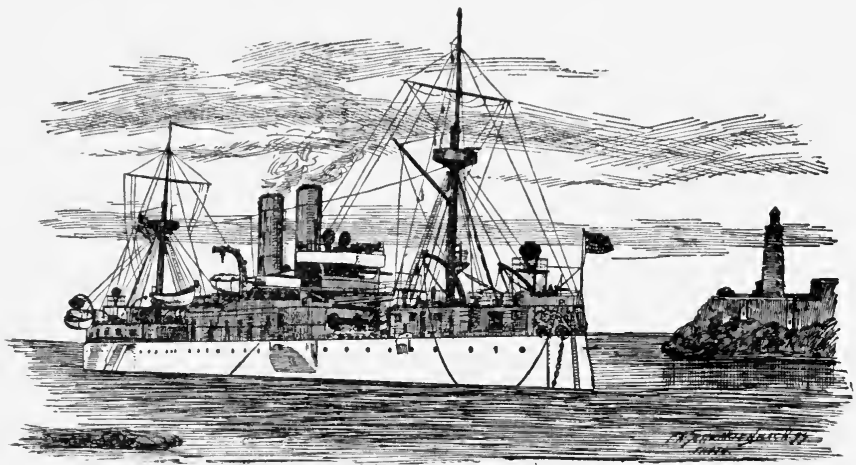

The Maine

began, was opposed to their requests. But the people were very much in sympathy with the sufferers, and Cleveland had trouble to restrain them from extending such assistance to the Cubans that Spain could complain that we were violating neutrality. President McKinley, who was inaugurated in 1897, also wished to avoid taking up Cuba's quarrel, but he was less decided about it than Cleveland. Congress was steadily coming to the point of declaring war to aid the revolutionists. Late in 1897 it was plain that if Spain did not end the war soon, the people of the United States would demand that their government intervene in the struggle.

In Havana there was a strong Spanish party, and they became 
incensed at the friendship felt by our people for the revolution. They showed it so clearly that President McKinley ordered the Maine, one of our best battleships, to go to Havana har- The Maine bor. It was thought that she would cause the inhab- destroyed itants of the city to show more respect to Americans than they had been showing. February 15 she was destroyed by an explosion as she lay at her anchorage in the harbor. There came first a sharp report and then a great uproar while a vast column of smoke and fire rushed upward in the night. The hull of the ship was wrenched open and she sank within twenty minutes. Two of her officers and 258 of her men were killed. It has been thought that a mine went off under the ship, and that this caused her magazines to explode and tear a hole in the hull. Who set off the mine is still an unanswered question.

The destruction of the Maine increased the desire of our people for war. So high ran feeling that when it was announced that Spain had agreed to suspend hostilities and take steps to establish a genuinely liberal government in Cuba, nobody was willing to trust a promise wrung with so much difficulty from a nation who in the past had so often broken her word. The American feeling was so strong that McKinley gave way, and congress declared war on April 19, 1898, the anniversary of the battle of Lexington.

What right had we to interfere in the quarrel between Spain and her colony? We placed our right on two grounds: 1. Humanity. Spain's policy in the island was making Cuba why we a place unfit for habitation. She was driving peo- intervened ple away from their homes and reducing them to the verge of starvation. 2. Our own interests were closely bound up with Cuba's welfare. If her trade was cut off, we suffered, and during any war she might wage against her mother country she was sure to fit out hostile expeditions on our shores. We did not want to suffer injury to our commerce nor to use a large part of our navy to keep Cubans from violating our neutrality. We had urged that Spain end the war or yield what was demanded by Cuba. 
Having failed in our demands, we now proposed to put an end to the war ourselves. In declaring war we announced that we did not fight to acquire territory, and we promised that if we won the war, Cuba should have her independence. The newspapers of Europe and South America treated this declaration with derision; but the time came when they realized that it was made in good faith.

The actual fighting of the war is divided into two sea battles

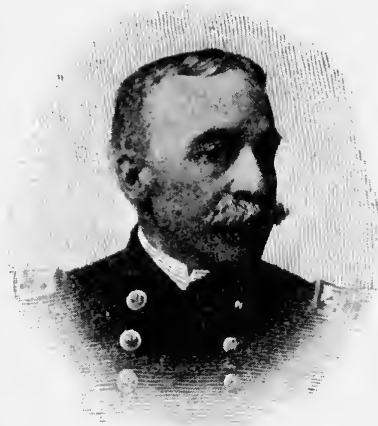

Admiral George Dewey and two land campaigns. The first of the sea battles was at Manila. When war was declared, Commodore Battle at George Dewey was at Manila Hong Kong commanding a squadron composed of four protected cruisers, two gunboats, and a revenue cutter. His flagship was the Olympia, one of the cruisers. $\mathrm{He}$ received "orders to go to Manila and destroy or capture the Spanish squadron known to be there. He lost not a moment in delay. He entered Manila harbor before dawn on May 1, and when day broke, he was ranged before the Spanish ships which, for protection, had drawn up in line under the guns of the shore batteries. Dewey opened a well-aimed fire at once. After an hour the Spanish ships were badly crippled, the American fire was suspended and the sailors were given breakfast. That done, the battle was resumed, and by 12.30 P.M. the enemy ran up a white flag and surrendered their fleet and the fortifications of Cavite. They lost ten warships and a transport, and 381 men were killed, besides a large number wounded. Their fleet was inferior to ours, but the aid of the batteries on shore is supposed to have made up the difference. The Americans lost one man killed and seven wounded, and none of our ships was injured. The marksmanship of the Americans was exceedingly good and that of the Spaniards was bad. Dewey 
remained in front of Manila after the battle awaiting instructions from his government.

Spain was caught unprepared in the Philippines, and her ships there were the poorest she had. - In her navy were a few first-class modern cruisers, and these she wished to use against the Cervera's commerce of the United States. When war was de- squadron clared, a squadron consisting of four armored cruisers and three torpedo-boat destroyers was at the Cape Verde Islands and immediately set out for the West Indies. It was commanded by Admiral Cervera (pronounced Thairvaira). The American navy

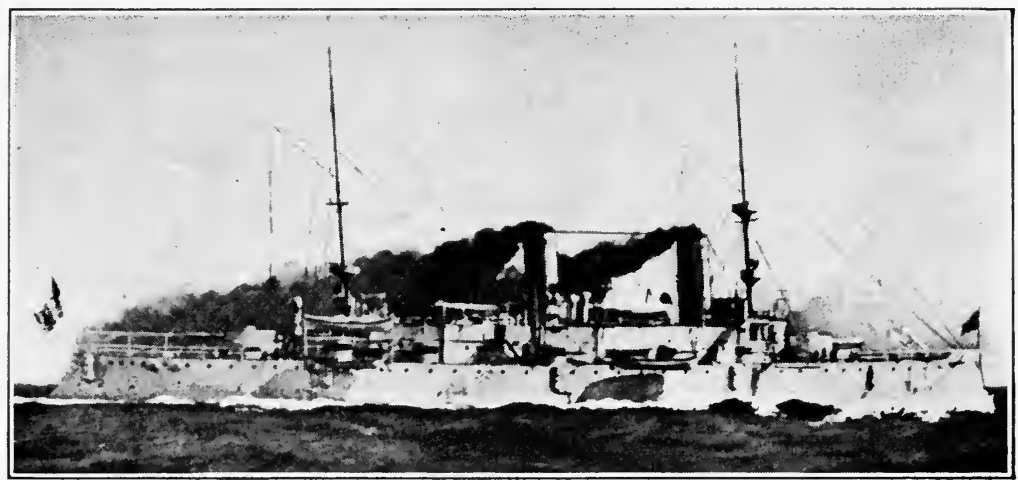

Dewey's Flagship, Olympia

was at once put into motion to find and crush them. It was supposed they would first go to some Cuban port, and taking on coal there, would go north to seize merchant vessels or to bombard the cities of the Atlantic coast. Our best ships were sent to Key West, where they were divided into two squadrons. One, under Commodore Schley, was known as the flying squadron, because it contained fast ships which were able to move rapidly. It was sent around the western end of Cuba to cruise along the southern shore and see if the Spanish ships reached port in that part of the island. The other squadron contained heavier ships and proceeded more 
slowly along the Northern shore. It was under command of Rear Admiral Sampson, who was in superior command to Schley. Admiral Cervera reached the French island of Martinique on May 11, and got valuable information about the location of the Cervera at American squadrons. After some delay he ran for Cuba Santiago and reached Santiago, at the eastern end of the island, on May 19. Wireless telegraphy was not known in 1898, and Schley, who was on the southern coast of Cuba at the time, knew nothing of Cervera's movements. He thought the Spanish fleet was in the concealed harbor of Cienfuegos, and although he had an order from Sampson to go straight to Santiago he delayed for several days until he learned that he was mistaken in supposing that the fleet was at Cienfuegos. He then went to Santiago, where he established the blockade of the Spaniards. The several days of his delay gave Cervera an opportunity to get out to sea, if he had been active enough to use it. Schley was soon joined by Sampson, who came by way of the northern coast, and the Spanish fleet was effectively bottled up.

Sampson found out that only a small body of Spanish troops was in Santiago, and he urged the president to send an army to A land take the place by land. The capture of Santiago would expedition mean that Cervera's fleet would have to go out and be destroyed by the superior American fleet, or that they would be taken with the city. To prevent their escape Sampson sent Lieutenant Hobson with a collier into the narrow portion of the harbor's channel with orders to sink the ship and escape if possible in a launch. Hobson had a picked crew and started on his mission just before dawn. He arrived at the proper spot unperceived, and the vessel was duly sunk in the channel; but she swung with the tide and settled in such a position that passage was not blocked. Hobson's action was none the less brave. He and his men had risked their lives in the coolest manner under the very guns of the castle that guarded the channel. Their launch was cut away and they clung to a raft until daylight when they were made prisoners. 
Admiral Cervera and other Spaniards paid high tribute to their heroism.

The army which was to take Santiago was organized at Tampa, Florida. It was hastily assembled and suffered a great deal from the lack of proper supplies. June 14 it departed for The Santhe front, escorted by the fleet. Most of the 16,887 tiago exmen were regular troops, but there was a regiment of pedition "Rough Riders," unmounted, which attracted much attention. Its lieutenant colonel was Theodore Roosevelt, who had resigned a high position in the navy department to go to the war. The regiment was composed of cowboys, prominent college athletes, and others whose training fitted them for endurance. The expedition was off Santiago on June 20.

The landing was made on the coast ten miles from Santiago at a point from which a road parallel with the shore runs to the town. Along this road the troops were sent as soon as they The dewere landed. A small Spanish force was encountered at fenses of the landing place, but it fell back toward Santiago,

Santiago fighting two skirmishes with the Americans, who pushed on as rapidly as they could. The main defenses of the town were on the crest of San Juan hill, across which the road ran about one mile from the town limits. Here the advance guard halted and joined the larger force which was to defend the town.

July 1 everything was in readiness on the American side, and the troops were ordered forward. .Part of them under General Lawton was sent off to the right to take El Caney, a small town which, Lawton said, could be taken in two hours.

El Caney When it was taken, he was to swing his men around against the right side of San Juan hill, and until he could do this the rest of the army was to lie before San Juan hill, prepared to rise and charge when Lawton arrived. This would give the Americans the advantage of attacking a position from two sides at the same time and with a greatly superior force. But Lawton's plan did not go so smoothly as he expected. He learned that to carry blockhouses $2 \mathrm{H}$ 
defended by magazine rifles which use smokeless powder was a difficult thing. He did not carry El Caney until five o'clock in the afternoon.

Meanwhile, the rest of the army reached a position at the foot of San Juan hill in full view of the enemy. Here they lay for two San Juan or three hours under very little cover while the Mauser hill bullets sang over their heads. They were waiting for the signal that Lawton was at hand, a signal which could not be given for the reason that Lawton was still at El Caney, two miles away. About one o'clock the troops would stand it no longer and

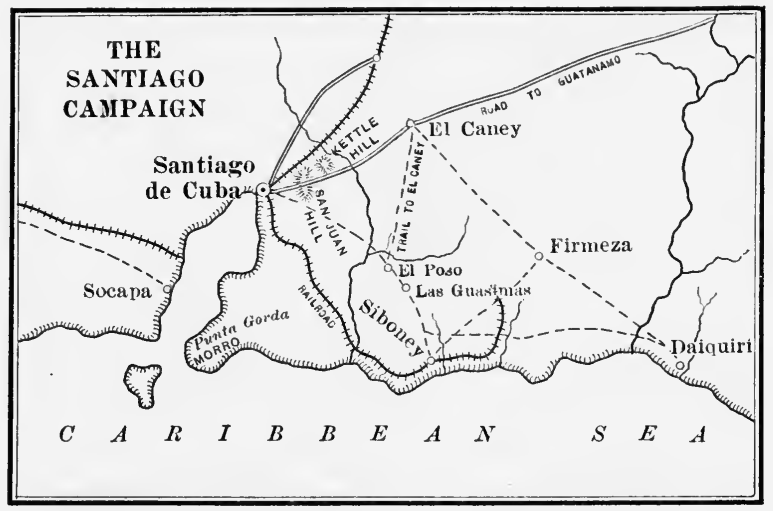

the advance began, without orders from the general. The men rushed forward in small groups, cutting the barbed wire that had been stretched across their way. They carried all before them and did not stop until they drove the Spaniards from their trenches at the top of the slope. The defenders of the hill fell back to a second line of trenches nearer the city. The Americans secured spades and intrenched themselves during the night. They were still over a mile from Santiago, and it seemed a hard task to carry the intrenchments that confronted them. The generals began to despair, when the Spaniards gave them encouragement by an unexpected event. 
When the Spanish fleet arrived at Santiago, it fell under the superior command of the governor of Cuba, who wished to detain Cervera in the island. He thought his army would Cervera rebel if the fleet sailed away, for they would say they ordered out were abandoned by Spain in a distant land. But in July the governor was alarmed lest the warships, the finest in the Spanish navy, should be captured with the town; and he ordered Cervera to make a dash for the open sea. The admiral objected, saying that both the ships and the crews would be destroyed or captured. But the orders were strict, and he obeyed like a good soldier. On Sunday morning, July 3 , he made the attempt. The American ships were waiting vigilantly off the harbor.

When the first Spanish ship appeared coming out, the American ships all made for her. She turned to the west and tried to escape along the shore, with the other ships following. The battle The Americans turned in the same direction and ran off Santiago in a line parallel to that taken by their opponents. The interval between them was close enough for the fire of the guns, and a terrific battle was kept up on both sides. Forty-five minutes from the time she first appeared the leading Spanish ship, the cruiser Theresa, turned her nose to the beach in a sinking condition. She was six and a half miles from the harbor. On her was Admiral Cervera, who was a brave man and took his position on the ship which led the forlorn hope. Five minutes after the Theresa sank the Oquendo turned to the beach and ran into the sand. Two torpedo-boat destroyers were sunk soon after they came out of the harbor. The third destroyer was not in the battle, for she had turned back before the fleet arrived in the West Indies. Two other Spanish ships are to be accounted for. They both passed beyond the first danger zone, but were hotly pursued by the Americans. One, the Vizcaya, reached a point twenty miles from Santiago before she too gave up the attempt to escape. The other, the Colon, a fast ship, held out until she was fifty miles from the harbor. Seeing at last that she could not escape, her officers opened her sea 
valves and allowed her to sink just after she surrendered. In this battle our fleet destroyed six fine ships, killed or wounded 474 of their crews, and took 1782 prisoners. Admiral Cervera was one of the captured. The prisoners were taken to the United States, where they were treated with such humanity that they expressed high esteem for their foes.

The destruction of the fleet encouraged the Americans and depressed the spirits of the Spaniards in Santiago. The besieging Surrender lines were gradually extended around the town, and of Santiago on July 17 the place surrendered. The Americans agreed to send the Spanish troops to Spain, and they received control of most of eastern Cuba. Much dislike was shown by the Spaniards for the United States before the war began; but as soon as Santiago was surrendered the American and Spanish soldiers became very friendly. They shared their food and could often be seen in friendly intercourse in the streets, until at last the transports arrived on which the conquered men were to return to their own country.

It was now evident that Spain could not win the war, and it was good policy for her to make peace before other lives were uselessly Porto Rico sacrificed. This seemed so certain, that the United States hurried off an expedition which was about to be sent to capture Porto Rico. It had no serious opposition, and this rich island became ours by conquest. It was considered desirable to leave Spain no foothold in the West Indies. August 12, less than four months after the war began, the preliminaries of peace were signed and fighting ceased. The exact terms were to be arranged by commissioners who were to meet in Paris October 1.

When the commissioners met in Paris, they readily agreed that Cuba was to have her independence and that Porto Rico was to The treaty pass into the possession of the United States. We were of Paris also to have Guam, an island in the Ladrone group, which is valuable for a coaling station in the Pacific. The question of the Philippines caused more concern. Dewey remained in 
Manila harbor after he won his brilliant victory, and an army was hurried forward to support him. It landed on the shore of the bay, and the day after the preliminary treaty was signed the city of Manila was taken. Should we insist that the islands be ceded? Spain could not well defend them, and we felt that if we gave up our foothold there, they would fall into the hands of some nation who might be hostile to our trade in the Orient. Besides this fact, the scene of Dewey's victory was a spot dear to American hearts, and the more the matter was debated the stronger became the opinion that we should have the islands. When President McKinley saw this, he instructed the commissioners in Paris to secure the Philippines. The treaty when signed provided that we should pay $\$ 20,000,000$ and take the islands.

Taking the Philippines brought us a war with the Filipinos. They had come to our help in the attack on Manila, think- Filipino war ing that we meant to drive out the Spaniards and leave the islands to the natives. They had an able leader named Aguinaldo, and when he saw that we intended to hold the island

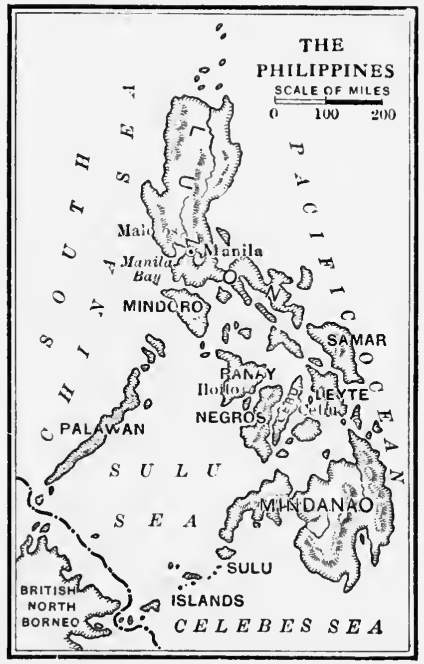

WILLIAYS ENG. COO, N.Y ourselves, he attacked our lines and roused the Filipinos to a general war. A large army was sent to Manila, and it began the slow task of conquering the natives. At the end of a year the islands were held by American soldiers distributed in about four hundred garrisons. But the people were as far from real submission as ever. Shortly afterwards Aguinaldo was captured and after a year of further fighting the islands were pacified.

The war with Spain and the acquisition of the Philippines were 
the two most important things of President McKinley's adminisTwo laws tration. But there were two other matters that should be remembered. One was the passage in 1897 of the Dingley tariff act, an act to revise the Wilson-Gorman tariff of Cleveland's second administration. It was not a low tariff. It was passed by those who favored protection, and the rates were nearly as high as those of the McKinley act of 1890 . Another act was the law of 1900 to adopt the gold standard. It was now provided that 25.8 grains of gold, nine-tenths fine, should be in our standard dollar. The secretary of the treasury was directed to pay it out on demand in exchange for all other forms of the money of the United States, paper or specie. In order that he might do so $\$ 150,000,000$ of gold was set aside as a reserve fund out of which redemption might be made. From that time the question of the free and unlimited coinage of all the silver bullion that may be presented to the treasury for coinage has not been an important thing in our political life. The law of 1900 is still in force.

\section{QUESTIONS}

I. Describe our services to Cuba. What two elasses lived in Cuba? What was the feeling of each for the other? Describe the ten years' war. What method of fighting did the Cubans employ? How did the war come to an end? What reforms were promised? What part had the United States in the compromise? Show how the promises were violated.

II. How did the war begin again? What methods of fighting were employed? What was the result? Describe reconcentration. What was Cleveland's attitude in regard to helping the Cubans? How did McKinley look on the matter? What was the attitude of congress? Why was the Maine sent to Havana? What effect was expected? Describe the destruction of the ship. What reforms were now promised by Spain? Why did they not satisfy the American people? When was war declared?

III. On what grounds did we interfere in Cuba? Describe each. What did we announce as our purpose in the war? Has the promise been kept? How was it regarded in Europe?

IV. Describe the battle of Manila. To what advantage was the 
victory largely due? What did Dewey do after the battle? Describe the departure of Cervera for the West Indies. Where was he expected to strike? What disposition was made of the American navy? Who were its commanders? Describe Cervera's voyage to Cuba. Describe Schley's voyage along the southern coast of Cuba. What other American squadron came up to Santiago? What was now the situation of the Spanish fleet?

V. Why was it thought well to send an army to Santiago? Describe the army which was assembled to take Santiago. When did it arrive before the town? How did it approach? Describe Lawton's attack on El Caney. How did it affect the plan of battle? Describe the attack on San Juan hill. Why did the soldiers now become discouraged?

VI. Why was Cervera ordered to leave Santiago? Why did he object? Describe the naval battle. What was the effect of this battle on the land operations? What were the terms of surrender at Santiago? How did the troops of the two armies feel toward one another? Describe the campaign in Porto Rico.

VII. What was provided in the preliminary peace agreement? What were the terms of the treaty of Paris of 1898 ? What was the situation in the Philippines? Why did we decide to retain them? Why did the Filipinos make war? What was the course of the war?

What two important acts of a civil nature were passed under McKinley? Describe them. What does the law now provide in regard to coinage?

\section{SUGGESTED TOPICS}

The Ten Years' War; The Destruction of the Maine; The Causes of the War with Spain; The Battle of Manila ; The Battle of San Juan Hill ; The Exploit of Hobson; The Health of the Army before Santiago; The Career of Aguinaldo. 


\section{CHAPTER XXXV}

\section{THE POLITICAL LIFE SINCE THE SPANISH WAR}

President McKinley's way of conducting the war with Spain was approved by the people. The success of our army and navy Election of added to the general satisfaction, and he was reëlected 1900 in 1900 by a large vote. His democratic opponent was Bryan, who was still popular with his party. The democrats made a strong stand against the policy of acquiring colonies. They claimed that it would force us to maintain a great army and navy in order to defend the colonies and that it would bring us into conflict with other nations. Mr. Bryan urged all these points in his campaign; but the large majority for McKinley showed that the people approved what had been done.

March 4, 1901, the president was inaugurated for the second time. During the summer he had many reasons to see that he Death of was loved by the entire people. His gentleness of McKinley spirit manifested itself in many ways. The South had sent troops to the recent war as readily as the North, and he showed his appreciation by appointing General Wheeler, an exconfederate general, to a high position in the army. In a public speech he suggested that the nation could afford to pension disabled confederate soldiers. September 6 he was shot by an anarchist while attending the exposition at Buffalo and died on the 14th of the same month. He was succeeded by Theodore Roosevelt, of New York, chosen vice-president in 1900. Roosevelt announced that he would carry out the policies of the dead president.

One of these policies was to decide what should be our future 472 
relation with Cuba. When the war began, congress announced that the United States would withdraw from Cuba when The United Cuban independence was established. This announce- States and ment was received with doubt by Europe generally. Cuba It was said that if we got possession of Cuba, we would not give it up.

Cuba was handed over to the United States at the beginning of 1899. American garrisons were stationed in the important towns, and the Spanish troops left the island for Spain. At once we took up the task of restoring order and establishing a Cuban government. The war had destroyed business, and the farms were becoming unfit for cultivation through neglect. Our officers tried hard to restore both business and agriculture to their former conditions. The schools were reopened and placed on a better basis than ever before in Cuban history. Cuban tariffs were collected, as under Spanish rule, but the money derived from them was spent on the island. In the days of Spanish power

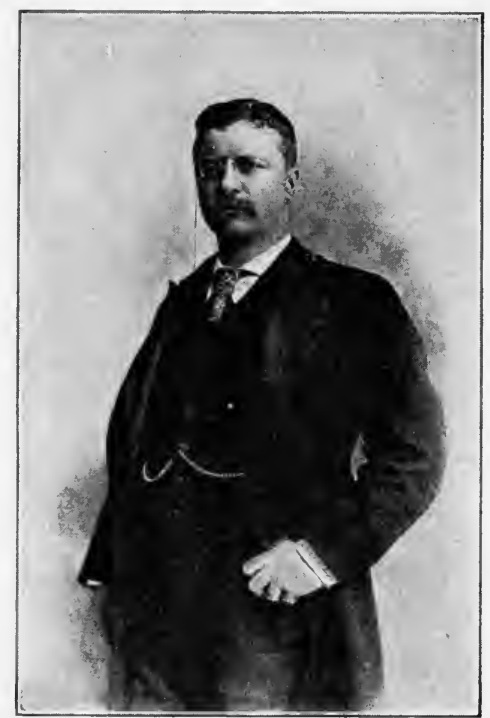

Theodore Roosevelt the revenues amounted to about $\$ 24,000,000$, half of which went to pay the interest on Spain's debt and a fourth to support her army and navy. Only $\$ 1,000,000$ of this total revenue was spent on education and public works in the island. Under American rule the whole revenue was used in Cuba.

One of the discoveries of science during this period proved very important. Dr. Charles Finlay, of Havana, and some American 
army surgeons, proved that yellow fever is transmitted only by Doctor a mosquito. By destroying these pests, and by careFinlay's fully screening persons ill with this disease, it has been discovery possible to stamp out this plague in civilized communities. There was not a city on the shores of the Gulf of Mexico which did not, before 1900, live in deadly terror of this fever.

Our most important work was to help the Cubans set up an orderly government. There was much hatred between the upper Govern- and lower classes in the island, and it seemed certain that ment of the people would begin to quarrel as soon as the governCuba ment was given into their hands. President McKinley was determined to prevent such a state of affairs if possible. $\mathrm{He}$ decided to show the people how an orderly government could be established. The first thing done was to give the right to vote to all who could read and write, who owned as much as $\$ 250$ worth of property, or who had served in the army of the liberators. These voters were allowed to elect the officers of the towns, and after that, September, 1900, they selected delegates to a constitutional convention. When the convention met, it prepared a constitution after the manner of the American states. There was to be in Cuba a president, a congress chosen by the people, and a supreme court. This constitution was to go into force as soon as the American army was withdrawn.

While the convention was in session the American congress passed what was known as the Platt amendment. Its author was The Platt Senator Platt, of Connecticut, and it dealt with Cuba. amendment It authorized the president of the United States to withdraw the troops from the island when the Cuban convention adopted the following principles as parts of the constitution of the island government: 1. That no foreign power should secure a foothold in the island; 2 . Cuba should incur no debt she cannot pay; 3. the United States might send back their army to reëstablish good order and to see that Cuba keeps her promises to other nations; 4. Cuba should keep up the sanitary reforms we had 
begun; and 5 . the Isle of Pines and some naval stations should be ceded to the United States. Cuba hesitated to adopt these principles, saying that to do so would weaken her independence. But we insisted, and when the Cuban convention saw that we were in earnest, it accepted the Platt amendment. Soon afterwards the Cubans elected a president and in 1902 he was inaugurated. Immediately the Americans handed over to him all their authority and left Cuban soil. During the two and a half years of their control of the island they had collected $\$ 57,000,000$ in taxes and spent $\$ 55,000,000$ on the restoration and improvment of the island. The balance was in the Cuban treasury. The United States spent many millions in making Cuba independent, and they did not ask that a dollar of it be restored.

While Cuban affairs were being put into order, it was necessary to prepare a form of government for the Philippines and Porto Rico. As we had never before had a colony, it was Governwell to be careful about what was done. There were ment of several steps toward a settled plan, but the form of Philippines government finally adopted is somewhat like that which was in use in the American colonies before they became independent of Great Britain. There is a governor appointed in Washington. $\mathrm{He}$ is nominated by the president and confirmed by the senate. There is, also, a council which advises the governor, and it has the right to approve or reject the laws passed by the Philippine legislature. There is a lower house of the legislature elected by the people. The legislature consisting of these two houses makes laws bearing on the home affairs of the colony. Matters relating to the colony's duty to the United States are not left to the colonial government. The Philippines are given two delegates in the house of representatives in Washington. They may speak on affairs which affect the interest of their colony but have no vote. In the Philippines men may vote who own property or can read and write or who held office during the Spanish period.

The action of the congress of the United States shows that a 
difference was made between Porto Rico and the Philippines. In each colony it was intended to give the natives as much authority as was thought wise. The Porto Ricans were more advanced in self-government and received a larger share of power. The law provided that at least five members of the council should be natives. The evident purpose of congress was to admit the natives to the government as rapidly as they showed that they had learned how to discharge the duties of government. In the Philippines there has been from time to time an extension of the parts of government given to the Filipinos.

One of the questions that have been discussed frequently since 1898 is: What shall we finally do with the Philippines? Some What shall people hope that they will remain permanent American we do with possessions. Others think that we should train the the Philip- Filipinos to self-government and then turn the islands pines?

over to the natives. This question is not yet determined, but the share of the Filipinos in their government is being steadily extended, and it seems probable that our government will soon have to decide what amount of power it will finally allow them. Americans who have lived in the islands are divided in their opinions on this subject, but they seem to agree that the time has not yet come for the United States to withdraw from the Philippines, as they have withdrawn from Cuba.

Another matter which had to be taken up and settled after the war with Spain was the construction of a canal by which our navy Need of a could get from the Atlantic to the Pacific. Such a canal canal had been talked about for many years before the war, but to dig it was an immense task and we had long hesitated to begin the work. It was now felt that we had such interests on the Pacific Ocean that we could hesitate no longer.

Twenty years before the war began a French company headed by de Lesseps, the constructor of the Suez Canal, got a charter from the government of Colombia to build a canal across the Isthmus of Panama. The company raised $\$ 278,000,000$ in 



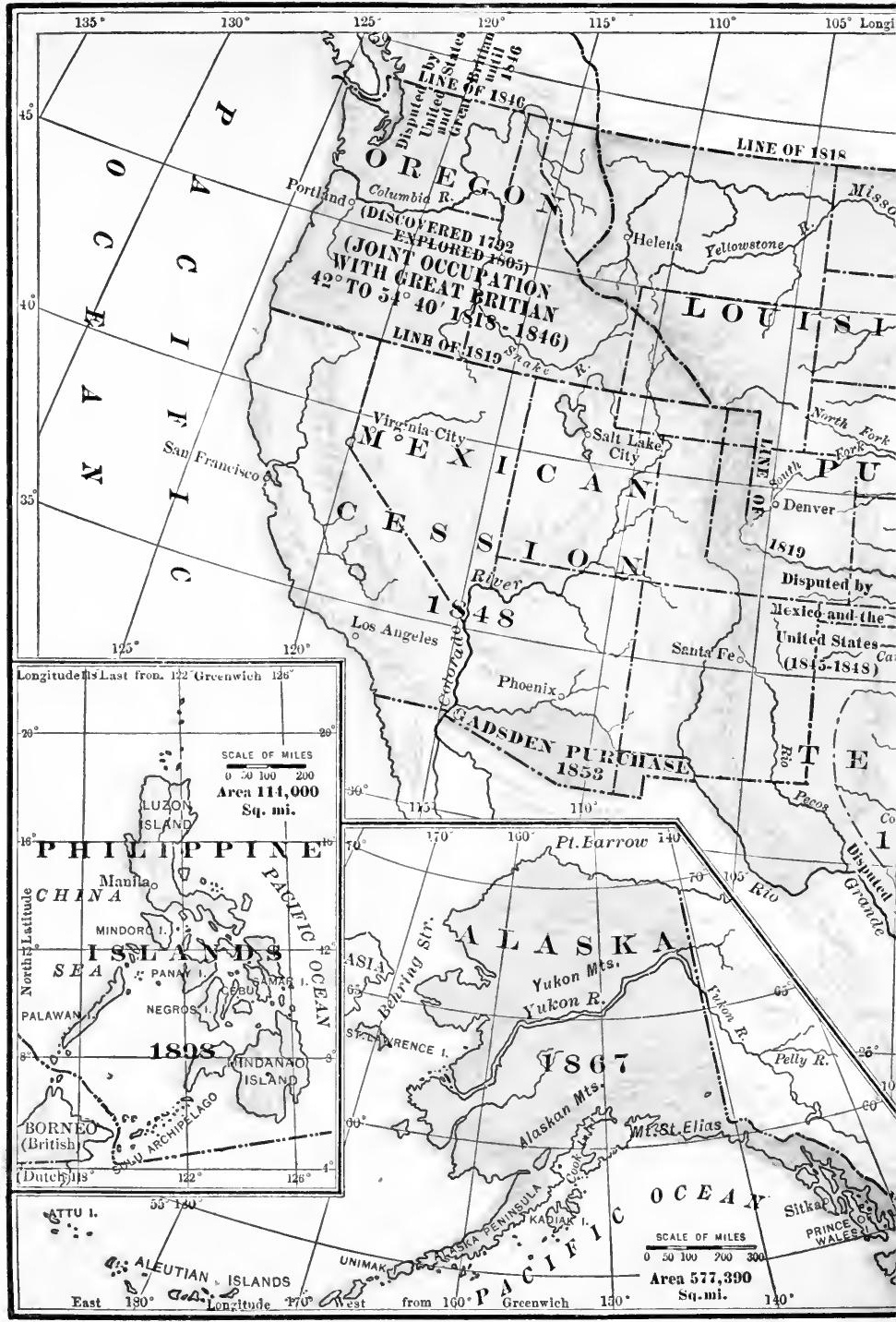

('The different Scales used sh 


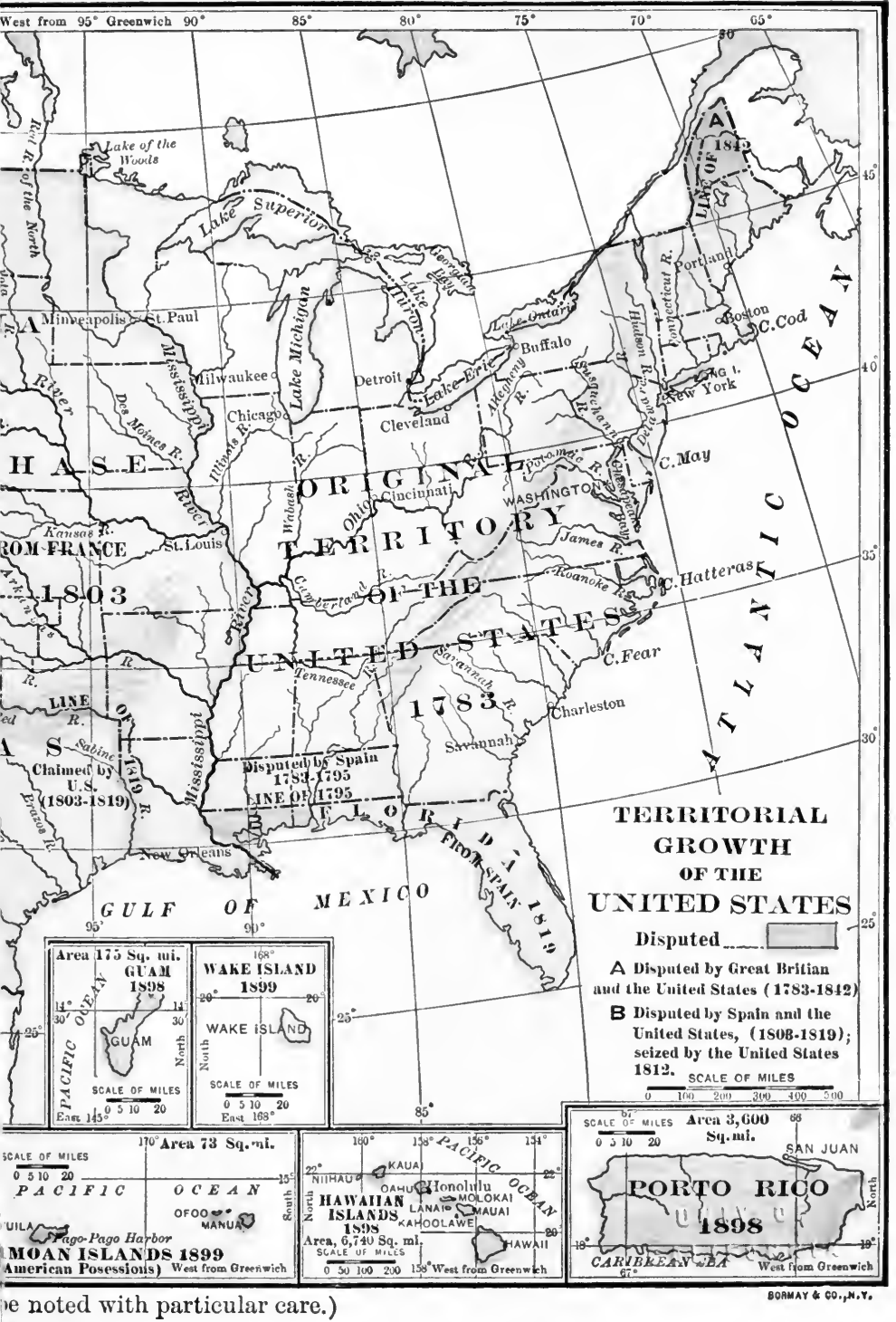




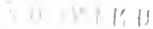
$1185,1,51,110$ 
France by the sale of stock and bonds and began work on the canal. In 1889 the work stopped because the company The French was bankrupt. An investigation showed that much canal comfraud and extravagance had marked the progress of the pany Frenchmen. From that time there was never a probability that the French canal would be completed.

The news that the French were going to construct a canal alarmed the Americans, who felt that if a canal was built, it ought to be owned and controlled by our country. We were The Nicarathe people most interested, and we could not be satisfied gua project to have a foreign power control the means of passage from one ocean to another. So when it seemed that France was going to finish the canal at the isthmus, we made a plan to construct one through Nicaragua. A company was organized and made a start; but it had little money, and as the government of the United States did not come to its aid, the work languished.

When it was known that the United States was at last ready to dig a canal, the friends of the Nicaraguan project began to urge that their site be used. At the same time the French a site company, which was still in existence, although most selected of the stock was owned by a small group of speculators, also urged that we take their site. They offered to sell out for $\$ 100,000,000$. There was much negotiation, and at last it was agreed that the government would purchase the plant of the French company for $\$ 40,000,000$, provided Colombia would make a treaty by which the government of the United States could acquire a legal right to the strip of land through which the canal was to go.

To be fair to Colombia we must remember that a canal across the isthmus was the dream of that country from the days of its settlement by Spain. It was here that the shipping Colombia's of the new world must concentrate, and as a result a dream great trade would grow up at Panama; this commerce would yield rich profits to the government which permitted it to pass through 
its territory. Colombia was so well convinced of the importance of the canal that she concluded that the United States should pay roundly for the privilege of digging it. President Roosevelt, then at the head of our government, induced the Colombian representative in Washington to agree that Colombia should lease to the United States a strip of land six miles wide through which the French canal ran. For it we were to pay $\$ 10,000,000$ in cash and $\$ 250,000$ a year as an annual rental. The government of Colombia was disappointed; for it thought the sum offered too small. Since we were to pay the French company $\$ 40,000,000$ for the incomplete canal and the Panama railroad, the Colombians felt that we should pay more than was proposed to control the site of the canal. The French had done comparatively little and their machinery was nearly useless. The Colombian government refused to approve the agreement made in Washington.

The United States of Colombia is a federated republic, and one of the states was Panama, embracing the isthmus. The people of The state of Panama were dissatisfied with the refusal of Colombia Panama to accept the agreement, for they feared that President Roosevelt would decide to have the canal in Nicaragua. In their alarm they concluded that the only hope of securing the canal at Panama was to revolt from Colombia and set up as an independent state under the protection of the United States. A group of daring men undertook to carry the revolution through. They first enlisted a small band of soldiers. From the agent of the French company they secured the money for arms and other expenses; for if the canal went to Nicaragua, the French company would lose the only opportunity it had to sell the canal. One of the leaders saw President Roosevelt and asked if he would help the proposed republic. The reply was that we could not assist a revolution against Colombia, but that if a new republic was established, it would be recognized as an independent state. This answer satisfied the men who planned the revolt.

Their plans were made for November 4, 1903; but it became 
necessary to act a day earlier. On the $3 \mathrm{~d}$ a body of Colombian soldiers arrived at Colon, at the eastern end of the The revoluPanama railroad. They were sent to arrest the tion on the leaders of the revolt, who were in Panama, at the isthmus western end of the railroad. Before they could cross the isthmus, the revolutionists raised their flag, seized the Colombian officials in Panama, and bribed the commander of the soldiers to take his force away. President Roosevelt gave orders that the American warships in the harbors should not allow any troops to land at either Colon or Panama. He did this because, as he claimed, we were, by a treaty with Colombia, bound to keep the railroad open for the movement of trains and the use of the nations of the world. His action in the matter made it impossible for Colombia to send troops to put down the revolt.

Thus, Panama became an independent state. President Roosevelt recognized it as such, and fifteen days after the revolt was begun a treaty was made by which Panama The treaty ceded to the United States a strip of land ten miles with wide lying along the French canal. For it we paid Panama $\$ 10,000,000$ in cash and promised to pay $\$ 250,000$ a year, beginning in 1913. We also guaranteed to protect the state of Panama from any nation that undertook to seize her territory. The next step, taking over the property of the French company, followed quickly.

The engineers now set to work. The plan adopted was to construct near the eastern coast a great dam against which the water of the Chagres River was to accumulate so as to form a The plan of lake twenty-two miles long. The canal leads from the canal the shore to this dam, where great locks raise the ships to the surface of the lake. From the remote end of the lake there is a deep cut through the highest ground in the isthmus. This is called the Culebra cut and is eight miles long. From its western end the ships are lowered by locks to the western stretch of the canal which runs at sea level to the Pacific Ocean. At its narrowest point, 
in the Culebra cut, the canal is 300 feet wide. It will receive the largest ships, and the lake which has been made will allow several vessels to pass one another. The cost was about $\$ 375,000,000$, and it was opened to the world in 1914. (See the map, p. 499.)

Let us now turn to the political affairs of the past fifteen years. In all our political differences great opposing principles usually Party stand forth. Parties keep them in view, and some principles men believe in one set of principles and others believe in another set. It is our task here to see what have been the principles for which the two great parties have contended since 1900 and to learn how their contests have been fought.

The most marked difference in principles has been in connection with the great monopolies called trusts. These organizations Trusts have usually been formed in connection with manufacturing enterprises. By uniting the majority of the factories which make a certain kind of merchandise into one great firm we have what is called a trust. The first successful trust was that which dealt with the refining of petroleum. It was known as the Standard Oil Company. The head and founder was John D. Rockefeller, of Cleveland, Ohio.

The trusts were defended on the ground that they were more economical than the older form of manufactures. Combine a Arguments large number of factories into one, said the friends of for and this kind of industry, and there is a great saving in the against management and selling of the article produced. Instead of having a large number of presidents there is now only one president. There is only one set of bookkeepers, one set of traveling salesmen, and one set of buyers. The opponents of trusts declared that they were too powerful, that they broke down their business rivals by unfair means, that they would not let new enterprises be established, and that they first drove all their rivals from the market and then fixed the selling price at any figure they chose.

The question of what to do about the trusts came up in con- 
gress, and in 1890 a law was passed to forbid the creation of any combination in restraint of trade. This means that no The law of factories or other business concerns were to combine in $\mathbf{1 8 9 0}$ order to get the whole market or to keep their rivals from sharing it. The law was known as the anti-trust law. A great many people did not know just what would be considered a "combination in restraint of trade"; and as the government did not take immediate steps toward the enforcement of the law, trusts continued to be formed as though there was no law against them.

Bryan, the leader of the democrats, was outspoken in saying that the law of 1890 ought to be enforced; and if he had been elected president, he would perhaps have given orders Roosevelt that some of the trusts be indicted under that law. and the He said so much along this line that in 1901 the coun- trusts try was becoming aroused. The people were coming to ask that the law should be enforced, or a law that could be enforced should be passed. It was at this time that Roosevelt became president. He believed that the law of 1890 should be enforced, and he began quietly to gather evidence to show that some of the trusts had violated the law. It was a slow task, and many things had to be done to get the facts that would be considered as evidence. In many speeches President Roosevelt showed that he wished to restrain trusts. He believed that wealth was too powerful in politics. He favored the restriction of the speculative element in business. All these demands were popular with the masses, and he was successful in 1904 over his democratic opponent, Alton B. Parker, of New York. His principles, however, did not please a large part of his party, and he was soon engaged Election of in a bitter struggle against the more conservative re- 1904 publicans. The more advanced republicans supported him in all he did. They were especially strong in the West.

President Roosevelt's second term of office expired in 1909. Although he had tried hard to get congress to adopt his ideas there had been little success. The most important measures that had 
been passed were: a law to give the railway commission the Roosevelt's right to regulate the rates railroads may charge; a policies law requiring the manufacturers of food products to label their goods correctly, and prohibiting the use of impurities

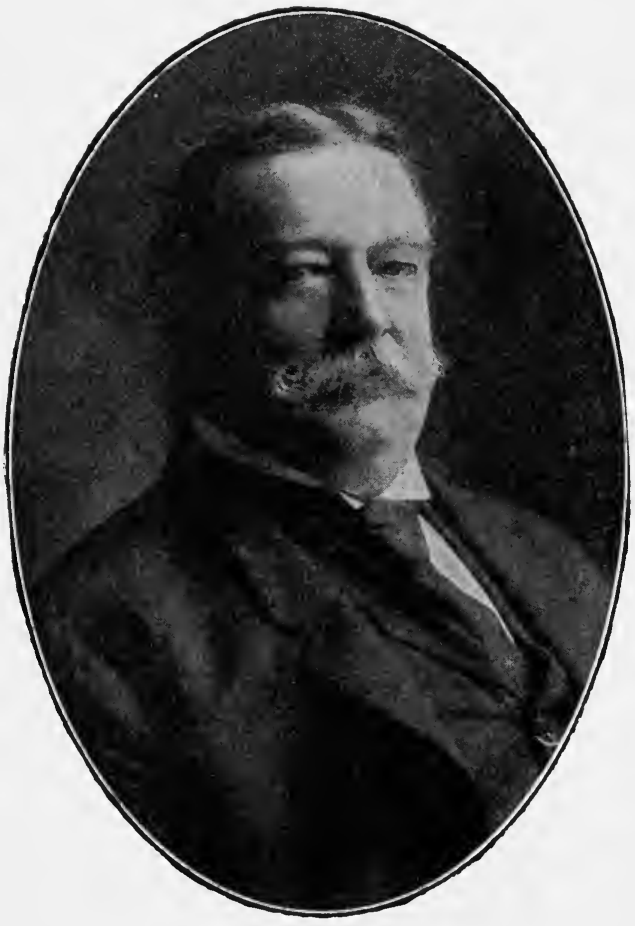

William H. Taft in food; and a law forbidding a corporation to contribute to the campaign funds of a political party. $\mathrm{He}$ himself felt that his work was only begun. He had exerted a powerful influence on the mind of the people, and he believed that in time they would force congress to carry out his policies. But in the interval he wished them to have a leader who believed in the Roosevelt reforms and who would not give up the fight to secure them. As he was president from the autumn of 1901 to the spring of 1909, he refused to become a candidate for another term and threw all his influence in favor of William H. Taft, of Ohio. The democrats gave Election of Bryan a third nomination. They also demanded the 1908 restraint of trusts and the reduction of the power of corporations. In the minds of most people Bryan seemed more likely to deal severely with business than Taft, the republican 
nominee. Many of those who desired reforms preferred to have them come through a moderate policy. This idea was so strong in the East, the Middle West, and the Pacific states that Taft carried all these parts of the country and was elected president. Bryan's strength was in the South and in some of the rural states of the Far West.

In the campaign before the election the republicans promised to revise the tariff. To carry out this promise President Taft called congress in extra session, and the result was the Payne-AlPayne-Aldrich act. The president said it was the drich tariff "best tariff law the republican party has ever made." But all the democrats and a large number of Western republicans declared that it made little or no reduction in rates. When Taft came out in defense of the law, he displeased those republicans who opposed it. They said he was under the influence of the manufacturers. As they were generally warm admirers of Roosevelt, they accused him of giving up the Roosevelt policies. They were soon at open war with the rest of their party and became known as "insurgents." They replied by calling their opponents "standpatters," from the slang expression "stand pat." The two terms soon became the accepted names for the two factions. The division in the party became so wide that the insurgents at last began to act with the democrats in matters which came up in congress. President Taft generally took the side of the standpatters.

In 1910 the democrats elected a majority of the members of the house of representatives, but there was still a republican senate and republican president. Thus, they could not Taft and pass what laws they chose, but they were able to check Roosevelt the lawmaking of their opponents. As the election in ror2 of 1912 approached it began to be seen that the divided republicans might lose also the election of the president. The insurgents made every possible effort to nominate Roosevelt, and the standpatters worked equally hard to nominate Taft for a second term. 
The nominating convention was full of bitter quarrels, and each side charged its opponents with fraud. But the friends of Taft were in the majority, and he was made the regular republican candidate. The friends of Roosevelt believed that they had been

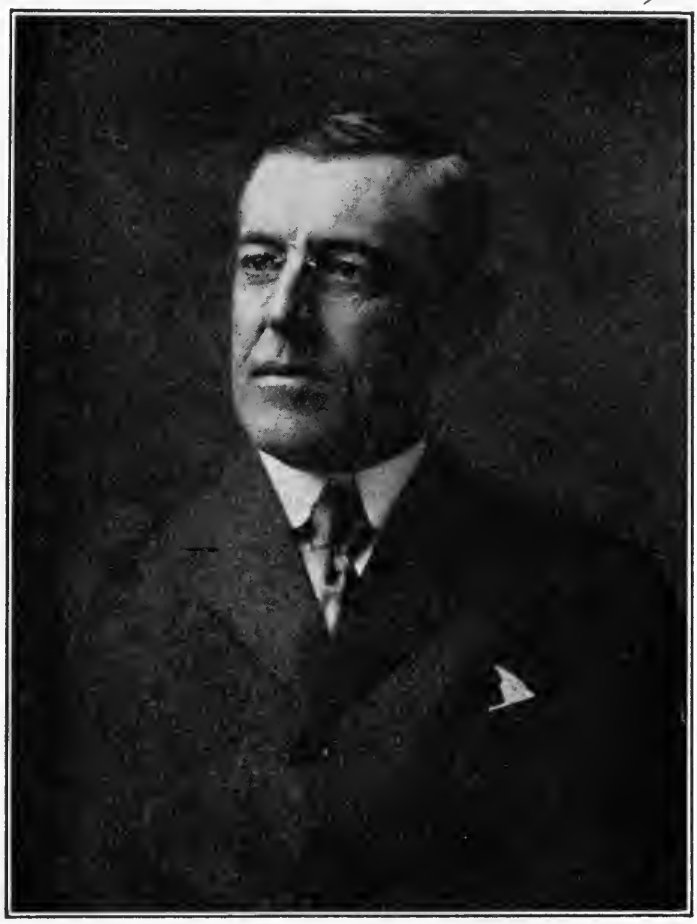

Woodrow Wilson badly treated and withdrew from the convention. They held a separate meeting, and a convention was called to form a new party. It met after a few weeks and organized the progressive party, nominating Roosevelt for the presidency.

The democrats were not so badly divided as the republicans. They

Wilson met in elected convention in Baltimore, where after a stormysession they nominated Woodrow Wilson, of New Jersey. He had been president of Princeton University before 1910, when he became governor of New Jersey. He was known as an able head of the state government, and as an excellent orator. He received a majority of the electoral votes and became president on March 4, 1913.

The first half of his administration has witnessed some very 
important acts of government. First of all he took up the question of the tariff, calling congress in special session for that purpose. A bill was passed which has become known as the Underwood tariff, because Underwood, of Alabama, was the man who had most to do in framing it. It sought to reduce the The Undertariff to a lower basis than has hitherto been in force wood tariff since the civil war. To make up for the loss of revenue that would thus ensue the law provided for a federal tax on incomes.

Another important law passed under Wilson was the currency act of 1913. It provided a means of issuing paper money in times when panics threaten, so that men who need money to The curcarry them through the period of erisis may borrow it rency and without paying unfair rates of interest. It is believed the trusts that such a law will make it impossible to have severe panics. In 1914 President Wilson by persistence got congress to carry through bills to deal with the relation of trusts to the government.

An important matter that President Wilson has had to consider is our relation with Mexico. Just before his inauguration there was a revolution in this republic. The former President Mexican president, Madero, was overthrown by a Wilson and part of the army led by General Huerta. A few days Mexico later Madero was killed, apparently by the order of Huerta. President Wilson refused to recognize Huerta as head of the Mexican government, and when a part of the Mexican people rose in an armed attempt to drive Huerta out of the government, he showed that he sympathized with them. For a long time it seemed that some small act of hostility occurring between the Mexicans and Americans living in Mexico might make it necessary for our government to declare war. American citizens in the country reported that the people were very hostile toward Americans. The president ordered warships sent to the Mexican ports in order to furnish protection if it were needed. Finally, in April, 1914, an officer and a boat's crew from one of the ships were arrested as they landed at Tampico for gasoline. After some 
discourtesies the prisoners were released. The admiral commanding our ships demanded that the Mexicans should salute our flag. Huerta, to whom the demand was referred, decided that no salute should be given.

Then followed a critical moment. A large body of marines was landed at Vera Cruz, and the town was occupied after the At the verge Mexicans had offered resistance. It seemed that war of war had begun. Nobody doubted that the United States could conquer Mexico if they tried; but to wage a war would mean the loss of many lives and the expenditure of a great deal of money. The advantage might be great for Mexico, who sadly needed some strong hand to interfere and force her people to make peace; but it could be only a great task for us. President Wilson and Bryan, his secretary of state, both desired to avoid war. After a few days of waiting a way out was discovered when the governments of Argentina, Brazil, and Chile - popularly called the A. B. C. powers - offered to mediate. Both the United States and Mexico accepted. The mediators then appointed commissioners who met on neutral territory at Niagara Falls, heard the complaints of both sides, and made an adjustment by which Huerta finally agreed to retire from Mexico. Since that time, July, 1914, to July, 1915, two factions have striven for mastery in Mexico, and our government has waited patiently to see which would win and thus secure our recognition.

President Wilson's unwillingness in carrying matters to the point of war caused some people to think he lacked energy. European The presi- newspapers, especially those printed in the most wardent's policy like countries, were very critical. But the issue of the affair seems to justify all he did. We are a nation of peace, we do not desire to extend our territory in the direction of Mexico, and rather than resort to war with its many horrors we are willing to deal patiently with a foreign power that offends us. President Wilson and Secretary Bryan showed much forbearance in handling the Mexican incident of 1914. 


\section{QUESTIONS}

I. On what grounds did the republicans endeavor to win the election of 1900 ? What position did the democrats take? What was the result of the election? Describe the attitude of President McKinley on the relations of North and South. How was his course interrupted?

II. What promises bound us in regard to Cuba? What were some of our tasks in restoring the island to prosperity? What was learned about yellow fever? Deseribe its effects.

III. What condition threatened to seize Cuba as soon as the United States withdrew? How did President McKinley propose to establish regular government in Cuba? Who were allowed to vote? How was the Cuban constitution modeled? What was the Platt amendment? What were the terms? How was it received by the Cubans? What did we do after it was adopted? Summarize the results of our occupation of Cuba.

IV. Why did we come slowly to a permanent form of government for the Philippine Islands? What are the chief features? Who may vote? How does the government of Porto Rico differ from that of the Philippines? Describe the Porto Rican government. What is the result of the discussion in regard to the final disposal of the Philippines?

V. Why was an isthmian canal needed? Why had it not already been begun by the United States? Describe the attempt of the French to construct the canal. Describe the plan for a canal in Nicaragua. Which of these two canal sites was taken over by the United States? What price was agreed upon?

VI. Show how Colombia valued her control of the isthmus. Describe the first agreement in regard to the eanal. How did Colombia treat it? What was the relation of the state of Panama to Colombia? How did the people of Panama feel about the repudiation of the agreement by Colombia? What was their plan of meeting the situation? How did they get money for their project? What did President Roosevelt say to them? Describe the revolution in Panama. How did the orders of Roosevelt affect the success of the revolution? Describe the treaty with Panama. Draw a sketch map of the canal. Describe the Culebra cut. What is the eapacity of the canal? its cost?

VII. What is a trust? Which was the first successful trust? On what grounds are the trusts defended and eriticized? Describe the antitrust law of 1890 . Why was it not enforced for several years after it was passed? What was Bryan's attitude to ward the trusts? How did public 
opinion grow in this respect? What position did Roosevelt take when he became president? Describe the election of 1904. What division began to appear in the republican party? Name the important measures of Roosevelt's second term. What was his idea about his successor? Who was choosen to succeed him?

VIII. What was the Payne-Aldrich tariff? What was Taft's course in regard to it? What was the consequence of his position? Who were the insurgents? the standpatters? To what extent did the insurgents go? On which side did Taft generally take his stand?

IX. What was the result of the congressional elections of 1910 ? How did the result forecast the election of 1912 ? What two republican candidates now appeared? Which was nominated? What new party was formed? Under what circumstances? Whom did the democrats nominate? What was the result of the election?

X. Describe the Underwood tariff law. How was the loss of revenue to be made up? Describe the currency legislation of 1913. What other subjects did Wilson have congress take up? Describe the affairs of Mexico immediately before the inauguration of Wilson. What position did Wilson take in regard to them? What danger for the United States lay in this state of affairs? How did we come to land troops in Mexico? In what manner was the problem of Huerta solved? On what grounds was President Wilson's policy criticized? What can you say in favor of it?

\section{SUGGESTED TOPICS}

The Death of President McKinley; The Early Career of President Roosevelt; American Improvements in Cuba; The Present Government in the Philippines; The Engineering Problems of the Panama Canal; The Panama Revolution. 


\section{CHAPTER XXXVI}

\section{THE PROGRESS OF THE PEOPLE, 1865-1915}

In studying the history of our country we must not think that the history of parties is the only thing worth knowing. Equally important is the story of the progress of our industrial Growth of and intellectual life. This is especially true of the years business since the war between the North and the South. While the men at Washington have been occupied with lawmaking and political contests, the American people have made rapid progress in every form of activity. Since 1860 our population has increased a little less than threefold. But the value of our farm property has increased fivefold, the value of our manufactured products elevenfold, and the value of mineral products still more greatly. Thus wealth has increased more rapidly than population.

During this period the last territory of our possessions between the Atlantic and the Pacific has become a state, and only Alaska and Hawaii now remain in the territorial condition. In 1865 the union consisted of thirty-six states: in

\section{Contrasts} 1915 there are forty-eight. In 1865 there was a great deal of unsettled land in the West which the government was giving away to homeseekers : in 1915 the public land that is suitable for agriculture is nearly taken up. In 1865 we spoke continually of our vast undeveloped regions : in 1915 we are looking to other countries for large undeveloped resources. In 1865 we were shipping abroad immense quantities of food: in 1915 we are coming to see that our population has grown to be such a multitude that we shall soon need all the food we produce. In fact, we are already importing some food products from South America. These contrasts serve to show what has been the progress of fifty years. 


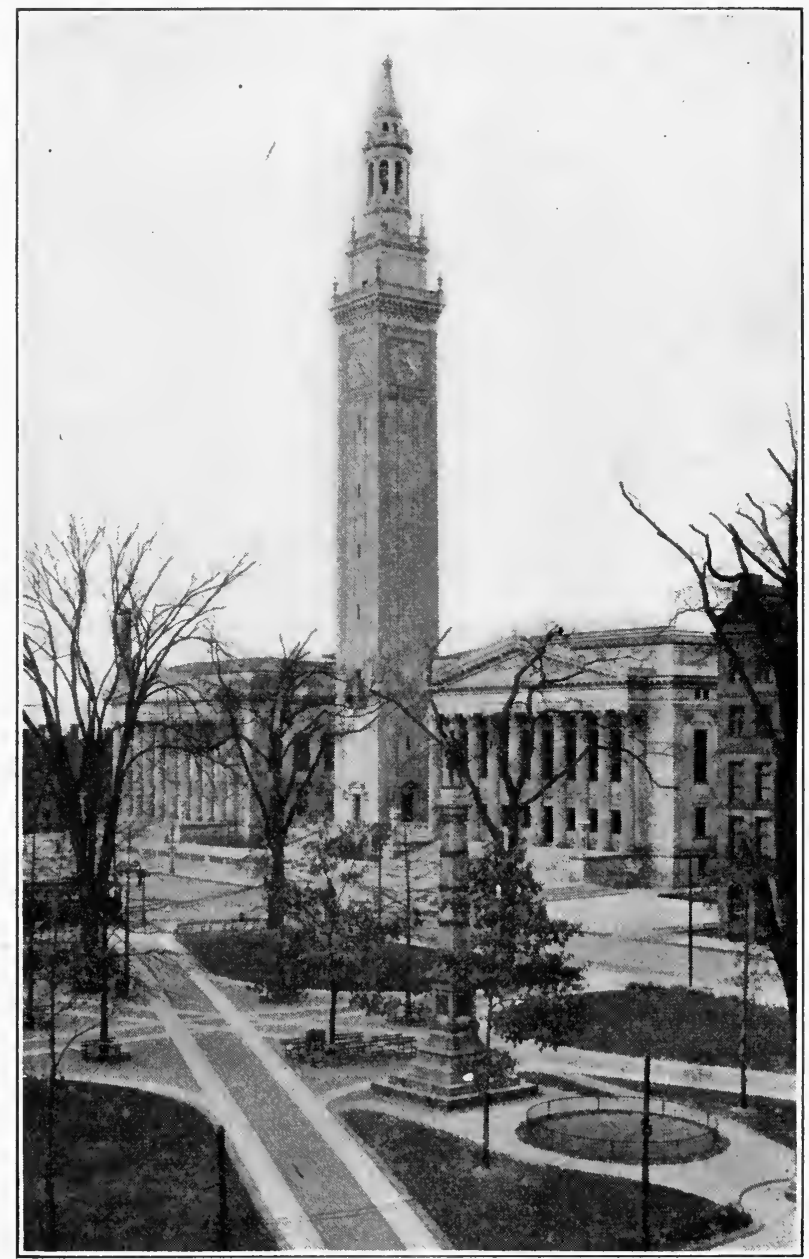

New Municipal Buildings and Campanile, Springfield, Mass. On the left is the Auditorium and on the right is the City Hall. The beautiful campanile is 300 feet high.

This is an illustration of the growing tendency to erect handsome city buildings. 
One of the things we should notice in this place is the gain of the town life over the country life. If we say that a village becomes a town when it has a population of 2500 , we Growth of shall see that there has been a large increase in the town towns population of the United States in the last fifty years. In 1870 the towns of this size had 27 per cent of the total population of the country: in 1910 they had 46 per cent. This means that in 1915 about half of our people are engaged in the callings that townspeople follow and are not concerned with farming.

In 1865 there were few parts of the country in which there were not large supplies of timber. Very little impression had been made on the great areas of white pine in the Disappearnorthern and central parts of the United States, or on ing forests the vast stretches of the long-leaf pine of the South Atlantic states. At the end of fifty years there is quite another story to tell. The forests of pine have melted away before the ax of the lumberman, and the country is threatened with a lumber famine if more careful methods are not adopted to protect and cultivate the portion of the forests that are left to us. One of the greatest perils to the timber is the fires that are started in dry seasons through the careless making of fires. They run over large areas, destroying the young trees which if left to grow would soon replace those which are used for lumber. A forest fire of a day may. destroy the young growth of many years.

The disappearance of the forests set many cautious men to thinking, and the result was a concerted movement by congress and state legislatures about 1900 to do something to preserve not only the forests, but other resources which nature has given us for our support. This policy is known as the conservation policy. It has three main Conservation: $\mathbf{x}$. Forest reserves features: 1 . The preservation of the forests by creating reservations owned by the government. Parts of the great Western forests still unsold have been set aside as permanent reserves, which may never go into the hands of private owners. By care- 
fully cutting the timber and cultivating the young trees the forests may be made a perpetual source of lumber. The reservations have been created in the regions which serve as the headwaters of rivers. Cutting away the forests in such regions allows the waters from the spring rains to rush down in torrents soon after they have fallen. When the slopes are covered with undergrowth and trees, the waters are held back, soak into the soil, and seep out again in springs which feed the streams throughout a longer period of the summer. President Roosevelt gave strong support to the cause of conservation, and by July 1, 1909, orders were given to convert 194,000,000 acres into reserves. Besides the reserves in the West, congress has appropriated money with which large tracts have been purchased in the northern and southern Alleghanies. Such tracts are looked on as the beginning of a vast reservation to be known as the Appalachian Park.

2. Another phase of the conservation policy is irrigation. Large parts of the region west of the Mississippi River are capa-

\section{Irrigation}

ble of irrigation, and when so treated, they prove to be very fertile. The first American citizens to apply irrigation to these lands were the Mormons, who converted the arid shores of the Great Salt Lake into fruitful fields. Before 1900 many other private enterprises were established for the same purpose. Great companies would establish a system of irrigation in some valley, building a storage dam and ditches, and selling to the farmers along the ditches the privilege of taking water. Between the farmers and the companies were many grounds for misunderstanding, and quarrels frequently arose. The result was that opinion began to demand that the government should construct dams and ditches and rent the water rights to the farmers. In 1902 congress appropriated $\$ 20,000,000$ for irrigation purposes and ordered that it should be repaid out of the sales of the lands subject to irrigation. This measure has proved a wise one, and a great many acres have been made available for farming. But we must not forget that there are vast areas in the 
West in which irrigation cannot be established, because they are so situated that water cannot be obtained to irrigate them.

3. A third form of conservation refers to the preservation of our mineral lands. Formerly these lands were distributed to individuals on liberal terms, and they were eventually 3. Mineral sold to large companies, generally at prices out of lands proportion to the wealth that lay beneath them. This was illustrated in the case of the Alaska coal lands, about which a great deal was said while Taft was president. Investigation showed that rich coal fields existed in Alaska, near the shore. Soon afterwards it was discovered that a large number of claims had been filed for this land and that they were about to pass into the hands of a rich syndicate. The law provides that only 160 acres shall pass to one applicant, and that he shall pay ten dollars an acre for the land. It was charged that most of the persons who had filed claims acted for the company which desired to get possession of the lands, and that they would transfer their claims to that company as soon as possible. The syndicate would thus get at a small price land which was thought to be worth $\$ 750$ an acre. A great deal was said in the newspapers about this matter, and the result was that all the claims were held up for a while. Finally it was decided that the Alaska coal lands should remain in the hands of the government and that they would be operated by lease. To enable the coal to be carried to market, the government decided to build a railroad from the mines to the coast. This action meant that the United States was willing to adopt government ownership of some great branch of industry, and it was opposed by those who thought that all forms of business should be left to the direction of the individuals.

One of the important changes of the last fifty years is the great improvement in the means of travel and of carrying freight. Railroads began in the United States in 1828. At Early railfirst they existed in short lines connecting important roads towns or waterways. When a man took a long journey he would 
have to change cars at the end of each short road and purchase a new ticket. Eleven different companies once owned the line which now connects Albany and Buffalo. To the people of the time it seemed a great convenience to have the eleven railroads; for, although it was some trouble to change cars ten times between these two towns, it was less inconvenient than the former journey by canal boat.

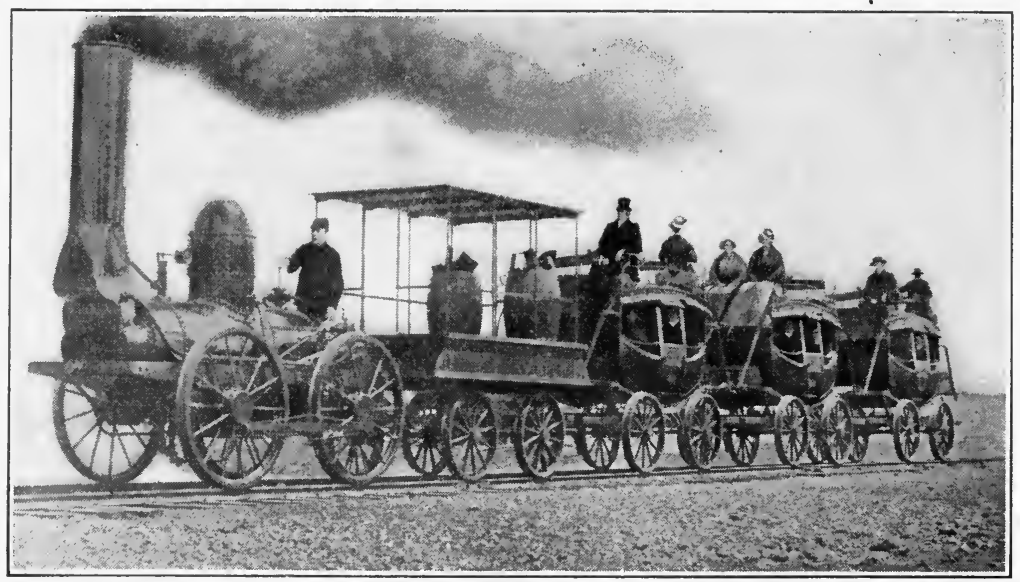

De Witt Clinton, A Railroad Train of 1831

From a photograph of the original train, lent by the New York Central Lines.

About 1865 the short railroads were being combined into longer ones. Thus there grew up trunk lines from one disRailroad tant city to another, and many of these lines bought systems or built branch lines running out on either side. In the course of time railroad building became a thing for large companies, and the short lines were rarely built. In the West and Southwest railroads usually went before the settlement of the country. There are parts of the West in which the railroads ran many miles in unpeopled prairie, and it was many years after they were built before the country through which they passed was densely 
enough settled to create business sufficient to pay the railroad owners for their investment.

Early in the period of which we speak there appeared a great deal of opposition to the railroads on the part of the people. It was said that the roads had unequal rates, and that complaints they gave free passes liberally, which meant that against enough money must be taken from the people who paid railroads to make up for the free rides given to those who had passes. The habit had grown up of giving some shippers of freight what were called rebates. This means that they were charged the same rates that other people paid, but that a certain part of what they paid was handed back to them by the railroad companies. The manufacturers and merchants who did not get rebates could not make as much money as those who got them. Complaints came loudest from the interior states of the union, where the people felt most dependent on the railroads.

Several remedies for these things were suggested. One was that the government should take over the railroads, paying the owners for them. This was a practice largely followed Railroad in Europe, but it was not approved in the United States. commissions Our people have generally thought that the government should not own and run any kind of business that private persons or companies can own and run. After much discussion, it was at last decided to create railroad commissions, which should supervise the railroads and see that they did not do the things that the law said they should not do. Rebates and free passes were forbidden.

The first railroad commissions were created in the states. But it was seen that it was necessary to have a federal railroad commission because so much of the business of the railroads A federal was from one state to another. Only the federal commission government can regulate this kind of business. Thus it happened that in 1887 congress created a federal railroad commission. It was to inquire into the way the interstate railroads conducted 
their business. There was a strong feeling that it should have the power to say whether or not the rates fixed by the roads were just and proper ; but congress did not think it well to give the commission that much authority. In the administration of President Roosevelt this power was added to those already given, and now the great roads of the country must not raise their rates without the consent of the commission.

The development of railroads signifies a greater capacity of communication between different parts of the country. It The tele- has made New Orleans as close to New York as Boston graph and was to Hartford in former days. The same kind of servtelephone ice has been done for men by the invention of the telegraph and the telephone. The former was perfected by S. B. F. Morse in 1844, and was first put into operation in a short line between Baltimore and Washington. One of the first services it did was to send to Washington an account hour by hour of the proceedings of the democratic convention then in session in Baltimore. The telephone was put into use in America about 1877. Several men had a share in the invention, but the finishing touches were added by Professor Alexander G. Bell, of Boston. The newspapers were filled with accounts of a wonderful exhibition he gave in which a gentleman in Boston talked with another in Salem. It seemed astonishing that letters could be read in Boston and heard over the wire in Salem. The papers predicted that the new invention would drive out the telegraph, but in this they were mistaken. In 1896 wireless telegraphy was invented by Marconi, an Italian. It has been of vast service at sea. It has been a means of summoning help to ships in danger. and in doing so it has saved many persons from death.

Another means of utilizing electricity for the comfort of man is the trolley car. In 1865 the towns were served by horse cars. Electric cars Through every busy street gaunt horses tugged at loaded cars of human freight. It was a thing which touched the sympathy of all who loved dumb animals. This 
state of things was greatly improved when in 1885 an electric street car-line was successfully operated in Richmond, Virginia. Other cities quickly followed the example of Richmond, and within a few years the electric cars were being used all over the country towns. They have entirely replaced the horse cars; for they are not only more sightly but larger and faster.

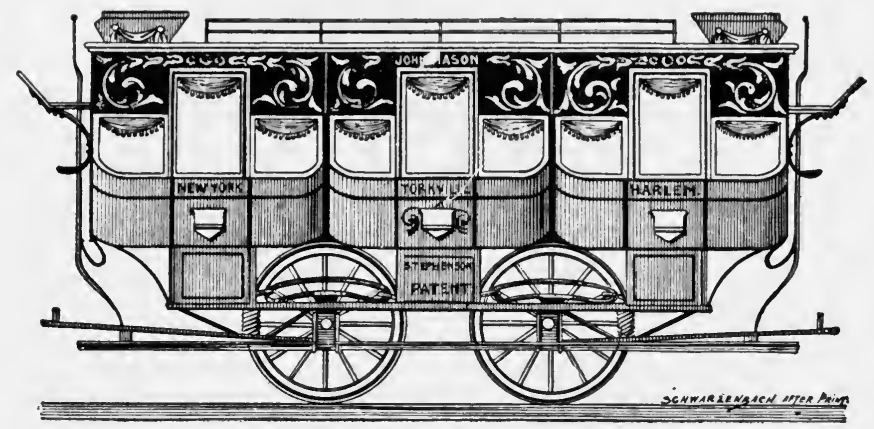

An Early Horse Car

The growth of the large cities made a demand for very rapid systems of transit, and the electric surface cars were found insufficient to carry the people who wished to go from Rapid one place to another. The result was the invention transit of other means of travel. First came the elevated lines, built over the crowded streets and having trains that went much faster than the surface cars. Even these proved insufficient for the heavy traffic, and underground lines were constructed. New York's system of subways, as the underground roads are called in America, is still unfinished; but it will eventually be a wonderful series of tunnels in which express and local trains dart hither and thither with vast numbers of passengers. By having improved rapid transit a large part of our city population has been able to find homes in the suburbs, where life is less crowded and more healthy than in the centers of the cities. 
Recent years have seen the revival of canal building. This form of water communication is not used, as formerly, as an orCanals dinary means of communication. Wherever railroads can be more profitably used there they are still the common means of transit. The most famous of such canals is that which is just finished on the Isthmus of Panama. Next to it is the canal constructed with the aid of congress around the falls on the St. Mary River, connecting Lakes Huron and Superior. This canal is popularly called the "Soo," from Sault Ste. Marie, as the falls are called. Its chief business is to afford a cheap means of bringing the iron ore from the shores of Lake Superior to the many iron furnaces in northern Ohio. Through it passes annually more than three times as many tons of freight as pass through the Suez Canal. In 1914 a canal was completed across the base of the long arm of Cape Cod, making it possible for coastwise shipping to avoid the dangerous passage outside of the cape, where there are many shoals. This canal is part of a larger plan that has been urged by some members of congress for the construction of an inland waterway from Boston to the coast of North Carolina. A canal connects the Delaware and Chesapeake bays, and another connects the Delaware and Raritan rivers passing through New Jersey. Still another connects Chesapeake Bay with Albemarle Sound, and another leads out of the North Carolina sounds into the Atlantic Ocean at Beaufort. It is hoped that this series of canals may be deepened and extended so that ocean-going vessels may be able to pass through it to the seas south of Cape Hatteras.

A marked feature of the history of the past fifty years is the development of organized labor. Unions began to be organized The labor in a small way early in the nineteenth century, but it unions was not until about 1850 that the local unions began to be brought together into great central unions. The purpose is to make laboring men feel that they are one body throughout the country. Among the prominent objects are the passage of laws for the protection of laborers, raising wages, and the shorten- 


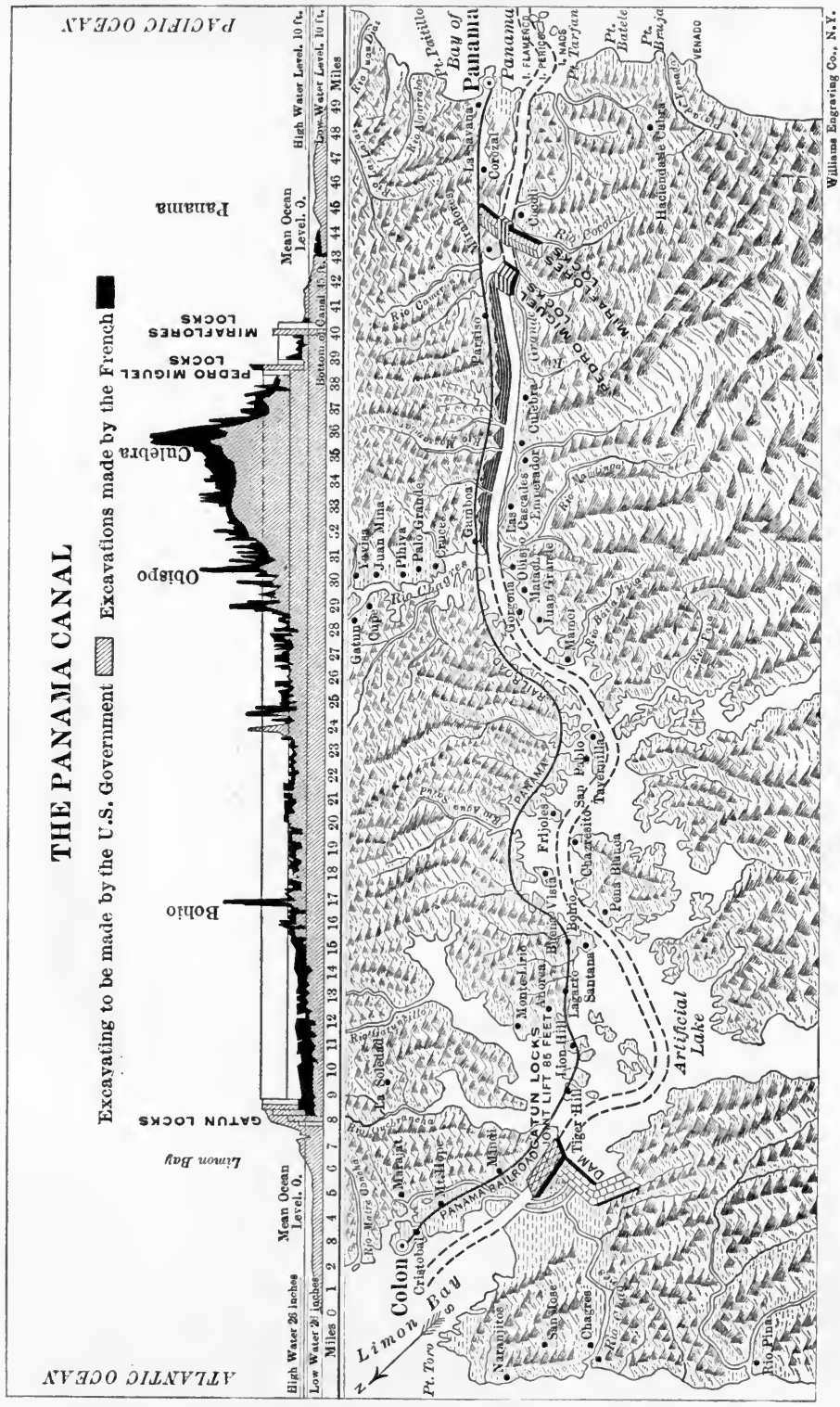


ing of the day in which laborers are required to work. The unions have generally relied on strikes to secure their demands. They have exercised a strong influence in political matters, and many laws for the benefit of labor have been passed because the unions have influenced the action of the lawmakers. Some hard feeling has been raised between the laborers and the employers on account of this struggle ; but it cannot be denied that the living conditions of American laborers are much better to-day than fifty years ago.

Three of the labor organizations have been prominent in our history. The first was the Knights of Labor, founded in 1869.

Three prominent It was built on the idea that all laborers, regardless of organizations their trades, should come together in local unions, and that these locals should be united in a solid army of labor. The organization flourished for a while under the wise leadership of Terrence V. Powderly. It lost favor about 1886 when there were some violent strikes in which the Knights were supposed to have been associated with a group of violent agitators. About this time a second great labor organization was coming into prominence. It was the American Federation of Labor; and it was built upon the idea that men and women of similar trades should form trade-unions and that these unions should be united in a grand federation. In a local of the Knights could be found men of all kinds of trades, men who did not know one another well, and who were not so apt to stand together in a time of trial. The men in a trade-union were accustomed to work together and knew whom to depend upon. The influence of the American Federation is now greater than that of the Knights. A third form of labor organization is the Industrial Workers of the World. They believe in socialism. That is, they demand that all the profits of a business enterprise be divided among the laborers in the enterprise. The Industrial Workers have attracted much attention through their association with several important strikes. 
In educational matters the past fifty years have been a period of remarkable development. When it began, public schools were established in every state, except in some Southern Growth of states, and they were about to be established there. the public The progress of the period has been in making the schools schools more useful and abundant. The American ideal is that every boy and girl shall have opportunity for an education in keeping with the calling he or she wishes to follow. Besides the grammar schools, which have been wonderfully improved in the quality of the teaching, the high school system has been made as efficient as some of the smaller colleges before 1865. At the same time the opportunity has been enlarged by establishing industrial schools, commercial schools, night schools, all designed for special needs. There is no reason why, in most of our American towns, a boy, however poor, should find it impossible to get the training that will fit him for any trade; or lead him to a profession. The result has been to increase in a large way the efficiency of our workmen and business men.

There has been the same kind of improvement in the colleges and universities. The older colleges, as Harvard, Yale, Columbia, and Princeton, have increased their number of students Growth of until there are thousands where there were formerly only the colleges hundreds. They have also enlarged the courses they offer to the students. Formerly, the small number of students took mostly the same studies. Now there are many courses, taught by a large number of instructors; and a student is given opportunity to choose his subjects from a large number of electives. It has made a college education a different thing from what it was in 1865.

While the old colleges of the East have been growing into universities the state universities of the West have been developing in a similar manner. They are founded as the highest State unipart of the state educational system. First, a student versities goes through the primary school, then the grammar school, then 
the high school, then the college department of the university, and last of all the graduate or professional school of the state university. He goes from one school to another on certificate, and everywhere the instruction is free. No better and more economical system of education has been devised in America for all the people. Most of the state universities are co-educational.

During the period under consideration several large universities have been established, among them the Johns Hopkins and the New uni- Chicago Universities, both of which have had a great versities influence on higher education in the United States. The Johns Hopkins University is especially notable because it introduced graduate courses leading to the degree of doctor of philosophy into the United States. The university was founded by a wealthy citizen of Baltimore, who gave it $\$ 3,500,000$, which was then considered a very large endowment. It devoted itself solely to graduate work, after the plan of the German universities. Its work was welcomed by the young American scholars, who were anxious to complete the best courses of instruction in a university in their own land. The influence of Johns Hopkins University was soon seen in the creation of graduate departments at the older universities. Other new universities were also created. One of them was the Chicago University, which has been a great influence in the Middle West. Another was Leland Stanford Jr. University, in California. These institutions were founded by private gifts and proved quite as efficient as the great western state universities or the older universities of the East.

Another step forward in education has been in teaching improved methods of agriculture. In 1862 the government of the United Instruction States decided to give each state land or money to be in agricul- devoted to this purpose. The result is the creation ture of agricultural and mechanical colleges in most of the states, supported by federal and state appropriations. In connection with them agricultural experiment stations have been 
established. Out of the teaching and the experimenting with improved crops have come better methods of farming, a better trained class of farmers, and many new and more productive varieties of plants. By this means the average farm yields more than it yielded fifty years ago, and it seems certain that it will yet give still greater returns to the farmer. As compared with European farms, there is much room for further development.

It is like a democratic country to insist that education shall be given to all. On that principle we have made the greatest efforts to bring into the schools the children of the Democracy humblest as well as the highest classes. The schools of the are open to the boys and girls of immigrant parents, schools and they have been very useful in instilling American principles in these children. Likewise, the federal government has spent large sums on the Indian schools. In the South the states have supported schools for the negroes, paying for them largely out of the funds raised from the white taxpayers. All this happens because it is generally believed that the greatest calamity that can overtake a country is to have the people grow up in ignorance.

A nation is happiest when it has most of sound intelligence, strong and honorable character, a love of humanity as it is taught by the great religious leaders of the world, and sound health under the direction of able physicians. In all these matters we are fortunate. It is the duty of every citizen, man or woman, to strive to make each line of action more successful. Inasmuch as we succeed in this respect we are sure to succeed as a nation, It is in the days of youth that we can most certainly give ourselves to such duties.

\section{QUESTIONS}

I. Explain some of the ways in which we have progressed since 1865. Name some striking points of contrast. Describe the progress of the towns. What effect does it have on food production? What is the history of our forests within this period? What is the cause of the disappearance of the forests? 
II. What is meant by conservation? Name three ways in which it has been attempted. Describe the plans to save the forests. What are the effects of cutting the timber near the rivers? What has been done to establish reservations? In what parts of the country has irrigation been established? Describe irrigation under private control. Why was it better to have public control? What has congress done for irrigation? What has usually been the method of disposing of mineral lands? What was the problem in regard to the Alaska coal lands? How was it finally decided?

III. Describe the early condition of railroads. What changes have been made in them? Why are the long lines more convenient than short lines? How did railroads help develop the country? What complaints were made against the railroads? Describe rebates. What remedies were suggested? Why do we object to state ownership? What is the duty of the railroad commissions? Where were they first established? How did a national railroad commission become established? What could it do? How has its power been extended?

IV. Describe the invention of the telegraph and the telephone. Describe the invention of electric cars. Describe the development of rapid transit. What has been the result in cities? Why have we begun to pay attention to canals? Describe the "Soo" Canal. What system of canals is planned for the Atlantic coast? In what parts has it been finished?

V. Describe the beginning of labor unions in America. Name some of their objects. Why has hard feeling been created?

VI. Describe the growth of the public schools since 1865. In what new lines have the schools developed? What is the American ideal for the public schools? In what respects have the colleges developed? Describe the position of the state university in the state's educational system. For what is the Johns Hopkins University especially notable? Name some other prominent universities recently established. Describe the development of instruction in agriculture. Show how the spirit of democracy is in our schools.

\section{SUGGESTED TOPICS}

A History of the Growth of Your Own Town in Comparison with the Growth of the County in which it is Situated; The Preservation of the Forests ; The Federal Railroad Commission : The Career of Horace Mann ; The Public School Law of Your State ; The Curriculum of a Modern College or University. 


\section{APPENDIX}

\section{THE DECLARATION OF INDEPENDENCE}

(Adopted by the Continental Congress, July 4th, 1776.)

In CONGRESS, July 4, 1776. The unanimous declaration of the thirteen united States of America.

When in the Course of human events, it becomes necessary for one people to dissolve the political bands which have connected them with another, and to assume among the powers of the earth, the separate and equal station to which the Laws of Nature and of Nature's God entitle them, a decent respect to the opinions of mankind requires that they should declare the causes which impel them to the separation.

We hold these truths to be self-evident, that all men are created equal, that they are endowed by their Creator with certain unalienable Rights, that among these are Life, Liberty and the pursuit of Happiness. That to secure these rights, Governments are instituted among Men, deriving their just powers from the consent of the governed, - That whenever any Form of Government becomes destructive of these ends, it is the Right of the People to alter or to abolish it, and to institute new Government, laying its foundation on such principles and organizing its powers in such form, as to them shall seem most likely to effect their Safety and Happiness. Prudence, indeed, will dictate that Governments long established should not be changed for light and transient causes; and accordingly all experience hath shewn, that mankind are more disposed to suffer, while evils are sufferable, than to right themselves by abolishing the forms to which they are accustomed. But when a long train of abuses and usurpa- 
tions, pursuing invariably the same Object evinces a design to reduce them under absolute Despotism, it is their right, it is their duty, to throw off such Government, and to provide new Guards for their future security. Such has been the patient sufferance of these Colonies; and such is now the necessity which constrains them to alter their former Systems of Government. The history of the present King of Great Britain is a history of repeated injuries and usurpations, all having in direct object the establishment of an absolute Tyranny over these States. To prove this, let Facts be submitted to a candid world.

He has refused his Assent to Laws, the most wholesome and necessary for the public good.

He has forbidden his Governors to pass Laws of immediate and pressing importance, unless suspended in their operation till his Assent should be obtained; and when so suspended, he has utterly neglected to attend to them.

He has refused to pass other Laws for the accommodation of large districts of people, unless those people would relinquish the right of Representation in the Legislature, a right inestimable to them and formidable to tyrants only.

He has called together legislative bodies at places unusual, uncomfortable, and distant from the depository of their public Records, for the sole purpose of fatiguing them into compliance with his measures.

He has dissolved Representative Houses repeatedly, for opposing with manly firmness his invasions on the rights of the people.

He has refused for a long time, after such dissolutions, to cause others to be elected; whereby the Legislative powers, incapable of Annihilation, have returned to the People at large for their exercise; the State remaining in the mean time exposed to all the dangers of invasion from without, and convulsions within.

$\mathrm{He}$ has endeavoured to prevent the population of these States; for that purpose obstructing the Laws for Naturalization of Foreigners; refusing to pass others to encourage 
their migration hither, and raising the conditions of new Appropriations of Lands.

He has obstructed the Administration of Justice, by refusing his Assent to Laws for establishing Judiciary powers.

He has made Judges dependent on his Will alone, for the tenure of their offices, and the amount and payment of their salaries.

He has erected a multitude of New Offices, and sent hither swarms of Officers to harass our people, and eat out their substance.

He has kept among us, in times of peace, Standing Armies without the Consent of our legislatures.

He has affected to render the Military independent of and superior to the Civil power.

He has combined with others to subject us to a jurisdiction foreign to our constitution, and unacknowledged by our laws; giving his Assent to their Acts of pretended Legislation:

For quartering large bodies of armed troops among us:

For protecting them, by a mock Trial, from punishment, for any Murders which they should commit on the Inhabitants of these States:

For cutting off our Trade with all parts of the world:

For imposing Taxes on us without our Consent:

For depriving us in many cases, of the benefits of Trial by Jury :

For transporting us beyond Seas to be tried for pretended offences :

For abolishing the free System of English Laws in a neighbouring Province, establishing therein an Arbitrary government, and enlarging its Boundaries so as to render it at once an example and fit instrument for introducing the same absolute rule into these Colonies:

For taking away our Charters, abolishing our most valuable Laws, and altering fundamentally the Forms of our Governments :

For suspending our own Legislatures, and declaring them- 
selves invested with power to legislate for us in all cases whatsoever.

He has abdicated Government here, by declaring us out of his Protection and waging War against us.

He has plundered our seas, ravaged our Coasts, burnt our towns, and destroyed the lives of our people.

$\mathrm{He}$ is at this time transporting large Armies of foreign Mercenaries to compleat the works of death, desolation and tyranny, already begun with circumstances of Cruelty \& perfidy scarcely parallel in the most barbarous ages, and totally unworthy the Head of a civilized nation.

He has constrained our fellow Citizens taken Captive on the high Seas to bear Arms against their Country, to become the executioners of their friends and Brethren, or to fall themselves by their Hands.

He has excited domestic insurrections among us, and has endeavoured to bring on the inhabitants of our frontiers, the merciless Indian Savages, whose known rule of warfare, is an undistinguished destruction of all ages, sexes and conditions.

In every stage of these Oppressions We have Petitioned for Redress in the most humble terms: Our repeated Petitions have been answered only by repeated injury. A Prince whose character is thus marked by every act which may define a Tyrant, is unfit to be the ruler of a free people.

Nor have We been wanting in attentions to our Brittish brethren. We have warned them from time to time of attempts by their legislature to extend an unwarrantable jurisdiction over us. We have reminded them of the circumstances of our emigration and settlement here. We have appealed to their native justice and magnanimity, and we have conjured them by the ties of our common kindred to disavow these usurpations, which would inevitably interrupt our connections and correspondence. They too have been deaf to the voice of justice and of consanguinity. We must, therefore, acquiesce in the necessity, which denounces our Separation, and hold them, as we hold the rest of mankind, Enemies in War, in Peace Friends. 
We, therefore, the Representatives of the United States of America, in General Congress, Assembled, appealing to the Supreme Judge of the world for the rectitude of our intentions, do, in the Name, and by Authority of the good People of these Colonies solemnly PUBLISH and DECLARE, That these United Colonies are, and of Right ought to be free and Independent States; that they are Absolved from all Allegiance to the British Crown, and that all political connection between them and the State of Great Britain, is and ought to be totally dissolved; and that as FreE AND INDependent States, they have full Power to levy War, conclude Peace, contract Alliances, establish Commerce, and to do all other Acts and Things which IndePendent States may of right do. And for the support of this Declaration, with a firm reliance on the protection of divine Providence, we mutually pledge to each other our Lives, our Fortunes, and our sacred Honor.

${ }^{1}$ [New Hampshire.]

Josiah Bartlett,

William Whipple,

Matthew Thornton.

[Massachusetts Bay.]

Samuel Adams,

JoHN ADAMS,

Robert Treat Paine,

Elbridge Gerry.

[Rhode Island.]

Stephen Hopkins,

William Ellerry.

\section{JOHN HANCOCK.}

[Connecticut.]

Roger Sherman, Samuel Huntington, William Williams, Oliver Wolcott.

[New York.]

William Floyd,

Philip Livingston,

Francis Lewis,

Lewis Morris.

[New Jersey.]

Richard Stockton, John Witherspoon, Francis Hopkinson, John HarT, Abraham Clark.

${ }^{1}$ This arrangement of the names is made for convenience. The States are not mentioned in the original. 
[Pennsylvania.]

Robert Morris, Benjamin Rush, Benjamin Franklin, JoHn MORTON, George Clymer, Janes Suith, George Taylor, JAMES WiLSON, George Ross.

\section{[Delaware.]}

Cefsar Rodney, George Read, Thomas M'Kean.

\footnotetext{
[Maryland.]

Samuel Chase, William Paca, Thomas Stone, Charles Carroll of Carrollton.
}

[Virginia.]

George Wythe, Richard Henry Lee, Thomas Jefferson, Benjamin Harrison, Thomas Nelson, Jr., Francis Lightfoot Lee, Carter Braxton.

[North Carolina.] William Hooper, Joseph Hewes, John PENN.

[South Carolina.]

Edward Rutledge, Thomas Heyward, Jr., Thomas Lynch, Jr., Arthur Middleton.

[Georgia.] Button Gwinnett, Lyman HaLl, Geo. Walton.

\section{THE CONSTITUTION OF THE UNITED STATES}

Prenmble. We the people of the United States, in Order to form Objects of the Constitution. a more perfect Union, establish Justice, insure domestic Tranquility, provide for the common defence, promote the general Welfare, and secure the Blessings of Liberty to ourselves and our Posterity, do ordain and establish this - Constitution for the United States of America. 


\section{ARticle I.}

Section 1. All legislative Powers herein granted shall be vested in a Congress of the United States, which shall consist of a Senate and House of Representatives.

Congress.

Two houses.
Section 2. [1] The House of Representatives shall be composed of Members chosen every second Year by the People of the several States, and the Electors in each State shall have the Qualifications requisite for Electors of the most numerous Branch of the State Legislature.

[2] No Person shall be a Representative who shall not have attained to the age of twenty-five Years, and been seven Years a Citizen of the United States, and who shall not, when elected, be an Inhabitant of that State in which he shall be chosen.

[3] [Representatives and direct Taxes shall be apportioned among the several States which may be included within this Union, according to their respective Numbers, which shall be determined by adding to the whole Number of free Persons, including those bound to Service for a Term of Years, and excluding Indians not taxed, three fifths of all other Persons.] The actual Enumeration shall be made within three Years after the first Meeting of the Congress of the United States, and within every subsequent Term of ten Years, in such Manner as they shall by Law direct. The Number of Representatives shall not exceed one for every thirty Thousand, but each State shall have at least one Representative; and until such enumeration shall be made, the State of New Hampshire shall be entitled to chuse three, Massachusetts eight, RhodeIsland and Providence Plantations one, Connecticut five, New York six, New Jersey four, Pennsylvania eight, Delaware one, Maryland six, Virginia ten, North Carolina five, South Carolina five, and Georgia three.

[4] When vacancies happen in the Representation from any State, the Executive Authority thereof shall issue Writs of Election to fill such Vacancies.
House of Representatives. Term and election.

Qualifications age, citizenship, residence.

Method of apportioning representatives. (Part in brackets superseded by Sec. 2 of Amendment

XIV.)

Census.

Temporary apportionment. 


\section{THE PLAIN STORY OF AMERICAN HISTORY}

Officers. [5] The House of Representatives shall chuse their Speaker and other Officers; and shall have the sole Power of Impeachment.

Senate.

Election

and term.

Division of

Senators

into three

classes.

Section 3. [1] The Senate of the United States shall be composed of two Senators from each State, chosen by the Legislature thereof, for six Years; and each Senator shall have one Vote.

[2] Immediately after they shall be assembled in Consequence of the first Election, they shall be divided as equally as may be into three Classes. The Seats of the Senators of the first Class shall be vacated at the Expiration of the second Year, of the second Class at the Expiration of the Vacancies. fourth Year, and of the third Class at the Expiration of the sixth Year, so that one-third may be chosen every second Year; and if Vacancies happen by Resignation, or otherwise, during the Recess of the Legislature of any State, the Executive thereof may make temporary Appointments until the next Meeting of the Legislature, which shall then fill such Vacancies.

Qualifications age, citizenship, residence.

Vice-president.

[3] No Person shall be a Senator who shall not have attained to the Age of thirty Years, and been nine Years a Citizen of the United States, and who shall not, when elected, be an Inhabitant of that State for which he shall be chosen.

[4] The Vice President of the United States shall be President of the Senate, but shall have no Vote, unless they be equally divided.

Officers.

[5] The Senate shall chuse their other Officers, and also a President pro tempore, in the Absence of the Vice President, or when he shall exercise the Office of President of the United States.

Trial of impeach-

[6] The Senate shall have the sole Power to try all Impeachments. ments. When sitting for that Purpose, they shall be on Oath or Affirmation. When the President of the United States is tried, the Chief Justice shall preside: And no Person shall be convicted without the Concurrence of two thirds of the Members present. 
[7] Judgment in Cases of Impeachment shall not extend further than to removal from Office, and disqualification to hold and enjoy any Office of honor, Trust or Profit under the United States: but the Party convicted shall nevertheless be liable and subject to Indictment, Trial, Judgment and Punishment, according to Law.

Section 4. [1] The Times, Places and Manner of holding Elections for Senators and Representatives, shall be prescribed in each State by the Legislature thereof; but the Congress may at any time by Law make or alter such Regulations, except as to the Places of chusing Senators.

[2] The Congress shall assemble at least once in every Year, and such Meeting shall be on the first Monday in December, unless they shall by Law appoint a different Day.

Section 5. [1] Each House shall be the Judge of the Elections, Returns and Qualifications of its own Members, and a Majority of each shall constitute a Quorum to do Business; but a smaller Number may adjourn from day to day, and may be authorized to compel the attendance of absent Members, in such Manner, and under such Penalities as each House may provide.

[2] Each House may determine the Rules of its Proceedings, punish its Members for disorderly Behaviour, and, with the Concurrence of two thirds, expel a Member.

[3] Each House shall keep a Journal of its Proceedings, and from time to time publish the same, excepting such Parts as may in their Judgment require Secrecy; and the Yeas and Nays of the Members of either House on any question shall, at the Desire of one fifth of those Present, be entered on the Journal.

[4] Neither House, during the Session of Congress, shall, without the Consent of the other, adjourn for more than three days, nor to any other Place than that in which the two Houses shall be sitting.
Judgment in cases of impeachment.

Both Houses. Times, places, and method of electing members. Time of meeting.

Membership regulations. Quorum.

Rules of each house. Journals. Special adjournments. 
Members. Section 6. [1] The Senators and Representatives shall Compen- receive a Compensation for their Services, to be ascertained sation and by law, and paid out of the Treasury of the United States.
privileges of members. They shall in all Cases, except Treason, Felony, and Breach of the Peace, be privileged from Arrest during their Attendance at the Session of their respective Houses, and in going to and returning from the same; and for any Speech or Debate in either House, they shall not be questioned in any other Place.

Disabilities of members.

[2] No Senator or Representative shall, during the Time for which he was elected, be appointed to any civil Office under the Authority of the United States, which shall have been created, or the Emoluments whereof shall have been encreased during such time; and no Person holding any Office under the United States, shall be a Member of either House during his Continuance in Office.

Bills and resolutions.

Revenue bills. Veto of President on bills.

Section 7. [1] All Bills for raising Revenue shall originate in the House of Representatives; but the Senate may propose or concur with Amendments as on other Bills.

[2] Every Bill which shall have passed the House of Representatives and the Senate, shall, before it become a Law, be presented to the President of the United States; If he approve he shall sign it, but if not he shall return it, with his Objections to that House in which it shall have originated, who shall enter the Objections at large on their Journal, and proceed to reconsider it. If after such Reconsideration two thirds of that House shall agree to pass the Bill, it shall be sent, together with the Objections, to the other House, by which it shall likewise be reconsidered, and if approved by two thirds of that House, it shall become a Law. But in all such Cases the Votes of both Houses shall be determined by Yeas and Nays, and the Names of the Persons voting for and against the Bill shall be entered on the Journal of each House respectively. If any Bill shall not be returned by the President within ten Days (Sundays excepted) after it shall have been presented to him, the Same shall be a Law, in 
like Manner as if he had signed it, unless the Congress by their Adjournment prevent its Return, in which Case it shall not be a Law.

[3] Every Order, Resolution, or Vote to which the Concurrence of the Senate and House of Representatives may be necessary (except on a question of Adjournment) shall be presented to the President of the United States and before the Same shall take Effect, shall be approved by him, or being disapproved by him, shall be repassed by two thirds of the Senate and House of Representatives, according to the Rules and Limitations prescribed in the Case of a Bill.

Section 8. The Congress shall have Power [1] To lay and collect Taxes, Duties, Imposts and Excises, to pay the Debts and provide for the common Defence and general Welfare of the United States; but all duties, Imposts and Excises shall be uniform throughout the United States;

[2] To borrow Money on the credit of the United States;

[3] To regulate Commerce with foreign Nations, and among the several States, and with the Indian Tribes;

[4] To establish an uniform Rule of Naturalization, and uniform Laws on the subject of Bankruptcies throughout the United States ;

[5] To coin Money, regulate the Value thereof, and of foreign Coin, and fix the Standard of Weights and Measures;

[6] To provide for the Punishment of counterfeiting the Securities and current Coin of the United States;

[7] To establish Post Offices and post Roads ;

[8] To promote the Progress of Science and useful Arts by securing for limited Times to Authors and Inventors the exclusive Right to their respective Writings and Discoveries;

[9] To constitute Tribunals inferior to the supreme Court;

[10] To define and punish Piracies and Felonies committed on the high Seas, and Offences against the Law of Nations;

[11] To declare War, grant Letters of Marque and Reprisal, and make Rules concerning Captures on Land and Water; [12] To raise and support Armies, but no Appropriation of Army.

Powers of Congress. Taxation. Borrowing. Regulating commerce. Naturalization and bankruptcy. Coins, weights, and measures. Counterfeiting.

Post offices. Patents and copyrights. Inferior courts. Piracies. War. 
Money to that Use shall be for a longer Term than two Years ;

Navy.

Land and naval forces. Militia, in service.

Militia, organization.

Seat of government, and stations.

Supplementary legislation.

Limitations on powers of Congress.

Slave trade.

Habeas corpus. Bills of attainder and ex post facto laws.
[13] To provide and maintain a Navy ;

[14] To make Rules for the Government and Regulation of the land and naval Forces;

[15] To provide for calling forth the Militia to execute the Laws of the Union, suppress Insurrections and repel Invasions ;

[16] To provide for organizing, arming, and disciplining, the Militia, and for governing such Part of them as may be employed in the Service of the United States, reserving to the States respectively, the Appointment of the Officers, and the Authority of training the Militia according to the discipline prescribed by Congress.

[17] To exercise exclusive Legislation in all Cases whatsoever, over such District (not exceeding ten Miles square) as may, by Cession of particular States, and the Acceptance of Congress become the Seat of the Government of the United States, and to exercise like Authority over all Places purchased by the Consent of the Legislature of the State in which the Same shall be, for the Erection of Forts, Magazines, Arsenals, dock-Yards, and other needful Buildings;-And [18] To make all Laws which shall be necessary and proper for carrying into Execution the foregoing Powers, and all other Powers vested by this Constitution in the Government of the United States, or in any Department or Office thereof.

Section 9. [1] The Migration or Importation of such Persons as any of the States now existing shall think proper to admit, shall not be prohibited by the Congress prior to the Year one thousand eight hundred and eight, but a Tax or duty may be imposed on such Importation, not exceeding ten dollars for each Person.

[2] The Privilege of the Writ of Habeas Corpus shall not be suspended, unless when in Cases of Rebellion or Invasion the public Safety may require it.

[3] No Bill of Attainder or ex post facto Law shall be passed. 
[4] No Capitation, or other direct, tax shall be laid, unless Direct tax. in Proportion to the Census or Enumeration hereinbefore directed to be taken.

[5] No Tax or Duty shall be laid on Articles exported from any State.

[6] No Preference shall be given by any Regulation of Commerce or Revenue to the Ports of one State over those of another: nor shall Vessels bound to, or from, one State, be obliged to enter, clear, or pay Duties in another.

[7] No money shall be drawn from the Treasury, but in Consequence of Appropriations made by Law ; and a regular Statement and Account of the Receipts and Expenditures of all public Money shall be published from time to time.

[8] No title of Nobility shall be granted by the United States: And no Person holding any Office of Profit or Trust under them, shall, without the Consent of the Congress, accept of any present, Emolument, Office, or Title, of any kind whatever, from any King, Prince, or foreign State.

Section 10. [1] No State shall enter into any Treaty, Alliance, or Confederation; grant Letters of Marque and Reprisal; coin Money; emit Bills of Credit, make any Thing but gold and silver Coin a Tender in Payment of Debts; pass any Bill of Attainder, ex post facto Law, or Law impairing the obligation of Contracts, or grant any Title of Nobility.

[2] No State shall, without the Consent of the Congress, lay any Imposts or Duties on Imports or Exports, except what may be absolutely necessary for executing it's inspection Laws : and the net Produce of all Duties and Imposts, laid by any State on Imports or Exports, shall be for the Use of the Treasury of the United States; and all such Laws shall be subject to the Revision and Controul of the Congress.

[3] No State shall, without the Consent of Congress, lay any Duty of tonnage, keep Troops, or Ships of War in time of Peace, enter into any Agreement or Compact with another State, or with a foreign Power, or engage in War, unless actually invaded, or in such imminent Danger as will not admit of delay.

Titles of nobility and presents.
Limitations on powers of States. Specific prohibitions.

Limitations on imposts.

Prohibitions removable with consent of Congress. 


\section{THE PLAIN STORY OF AMERICAN HISTORY}

\section{Article II.}

PresiDENT.

Term.

Presidential electors and method of choosing President.

(Part in brackets superseded by XII amendment.)
Section 1. [1] The executive Power shall be vested in a President of the United States of America. He shall hold his Office during the Term of four Years, and, together with the Vice President, chosen for the same term, be elected, as follows :

[2] Each State shall appoint, in such Manner as the Legislature thereof may direct, a Number of Electors, equal to the whole Number of Senators and Representatives to which the State may be entitled in the Congress: but no Senator or Representative, or Person holding an Office of Trust or Profit under the United States, shall be appointed an Elector. [The electors shall meet in their respective States, and vote by ballot for two Persons, of whom one at least shall not be an inhabitant of the same State with themselves. And they shall make a List of all the Persons voted for, and of the Number of Votes for each; which List they shall sign and certify, and transmit sealed to the Seat of the Government of the United States, directed to the President of the Senate. The President of the Senate shall, in the Presence of the Senate and House of Representatives, open all the Certificates, and the Votes shall then be counted. The Person having the greatest Number of Votes shall be the President, if such Number be a Majority of the whole Number of Electors appointed; and if there be more than one who have such Majority, and have an equal Number of Votes, then the House of Representatives shall immediately chuse by Ballot one of them for President; and if no Person have a Majority, then from the five highest on the List the said House shall in like Manner chuse the President. But in chusing the President, the Votes shall be taken by States, the Representation from each State having one Vote; A quorum for this Purpose shall consist of a Member or Members from twothirds of the States, and a Majority of all the States shall be necessary to a Choice. In every Case, after the Choice of the President, the Person having the greatest Number of 
Votes of the Electors shall be the Vice President. But if there should remain two or more who have equal Votes, the Senate shall chuse from them by Ballot the Vice President.]

[3] The Congress may determine the Time of chusing the Electors, and the Day on which they shall give their Votes; which Day shall be the same throughout the United States.

[4] No Person except a natural born Citizen, or a citizen of the United States, at the time of the Adoption of this Constitution, shall be eligible to the Office of President; neither shall any Person be eligible to that Office who shall not have attained to the Age of thirty five Years, and been fourteen Years a Resident within the United States.

[5] In Case of the Removal of the President from Office, or of his Death, Resignation, or Inability to discharge the Powers and Duties of the said Office, the same shall devolve on the Vice President, and the Congress may by Law provide for the Case of Removal, Death, Resignation, or Inability, both of the President and Vice President, declaring what Officer shall then act as President, and such Officer shall act accordingly, until the Disability be removed, or a President shall be elected.

[6] The President shall, at stated Times, receive for his Services, a Compensation, which shall neither be encreased nor diminished during the Period for which he shall have been elected, and he shall not receive within that Period any other Emolument from the United States, or any of them.

[7] Before he enter on the Execution of his Office, he shall take the following Oath or Affirmation:- "I do solemnly Oath of office. swear (or affirm) that I will faithfully execute the Office of President of the United States, and will to the best of my Ability, preserve, protect and defend the Constitution of the United States."

Section 2. [1] The President shall be Commander in Chief of the Army and Navy of the United States, and of the Powers of Militia of the several States, when called into the actual President. 
Military, Service of the United States; he may require the Opinion, supervisory, and judicial.

In treaties and in appointments.

Temporary appointments.

Legislative powers. in writing, of the principal Officer in each of the executive Departments, upon any Subject relating to the Duties of their respective Offices, and he shall have Power to grant Reprieves and Pardons for Offences against the United States, except in Cases of Impeachment.

[2] He shall have Power, by and with the Advice and Consent of the Senate, to make Treaties, provided two-thirds of the Senators present concur; and he shall nominate, and by and with the Advice and Consent of the Senate, shall appoint Ambassadors, other public Ministers and Consuls, Judges of the supreme Court, and all other Officers of the United States, whose Appointments are not herein otherwise provided for, and which shall be established by Law: but the Congress may by Law vest the Appointment of such inferior Officers, as they think proper, in the President alone, in the Courts of Law, or in the Heads of Departments.

[3] The President shall have Power to fill up all Vacancies that may happen during the Recess of the Senate, by granting Commissions which shall expire at the End of their next Session.

Section 3. He shall from time to time give to the Congress Information of the State of the Union, and recommend to their Consideration such Measures as he shall judge necessary and expedient; he may, on extraordinary Occasions, convene both Houses, or either of them, and in Case of Disagreement between them, with Respect to the Time of Adjournment, he may adjourn them to such Time as he shall think proper; he shall receive Ambassadors and other public Ministers; he shall take Care that the Laws be faithfully executed, and shall Commission all the Officers of the United States.

Liability to impeachment.
Section 4. The President, Vice President and all civil Officers of the United States, shall be removed from Office on Impeachment for, and Conviction of, Treason, Bribery, or other high Crimes and Misdemeanors. 


\section{Article III.}

Section 1. The judicial Power of the United States, shall JudicIbe vested in one supreme Court, and in such inferior Courts as the Congress may from time to time ordain and establish. The Judges, both of the supreme and inferior Courts, shall hold their Offices during good Behaviour, and shall, at stated Times, receive for their Services, a Compensation, which shall not be diminished during their Continuance in Office.

Section 2. [1] The judicial Power shall extend to all Cases, in Law and Equity, arising under this Constitution, the Laws of the United States, and Treaties made, or which shall be made, under their Authority ; - to all cases affecting Ambassadors, other public Ministers and Consuls ; - to all cases of admiralty and maritime Jurisdiction; - to Controversies to which the United States shall be a party ; - to controversies between two or more States; - between a State and Citizens of another State; - between Citizens of different States between Citizens of the same State claiming Lands under Grants of different States, and between a State, or the Citizens thereof, and foreign States, Citizens or subjects.

[2] In all Cases affecting Ambassadors, other public Ministers and Consuls, and those in which a State shall be Party, the supreme Court shall have original Jurisdiction. In all the other Cases before mentioned, the supreme Court shall have appellate Jurisdiction, both as to Law and Fact, with such Exceptions, and under such Regulations as the Congress shall make.

[3] The Trial of all Crimes, except in Cases of Impeachment, shall be by Jury; and such Trial shall be held in the State where the said Crimes shall have been committed; but when not committed within any State, the Trial shall be at such Place or Places as the Congress may by Law have directed.

Section 3. [1] Treason against the United States, shall consist only in levying War against them, or in adhering to their Treason: definition, Enemies, giving them Aid and Comfort. No Person shall

Original and appellate jurisdiction of Supreme Court.

Jury trial. Place of trial. 
punishment.

be convicted of Treason unless on the Testimony of two Witnesses to the same overt Act, or on Confession in open Court. [2] The Congress shall have Power to declare the Punishment of Treason, but no Attainder of Treason shall work Corruption of Blood, or Forfeiture except during the Life of the Person attainted.

\section{Article IV.}

NATION

AND

States.

Interstate comity.

Interstate citizenship.

Extradition of criminals.

Fugitive slaves.

Admission of new States.

Government of national territory.
Section 1. Full Faith and Credit shall be given in each State to the public Acts, Records, and judicial Proceedings of every other State. And the Congress may by general Laws prescribe the Manner in which such Acts, Records and Proceedings shall be proved, and the Effect thereof.

Section 2. [1] The Citizens of each State shall be entitled to all Privileges and Immunities of Citizens in the several States.

[2] A Person charged in any State with Treason, Felony or other Crime, who shall flee from Justice, and be found in another State, shall on Demand of the executive Authority of the State from which he fled, be delivered up, to be removed to the State having Jurisdiction of the Crime.

[3] No Person held to Service or Labour in one State, under the Laws thereof, escaping into another, shall, in Consequence of any Law or Regulation therein, be discharged from such Service or Labour, but shall be delivered up on Claim of the Party to whom such Service or Labour may be due.

Section 3. [1] New States may be admitted by the Congress into this Union; but no new State shall be formed or erected within the Jurisdiction of any other State; nor any State be formed by the Junction of two or more States, or Parts of States, without the Consent of the Legislatures of the States concerned as well as of the Congress.

[2] The Congress shall have Power to dispose of and make all needful Rules and Regulations respecting the Territory or other Property belonging to the United States ; and nothing 
in this Constitution shall be so construed as to Prejudice any Claims of the United States, or of any particular State.

Section 4. The United States shall guarantee to every State in this Union a Republican Form of Government, and Protection shall protect each of them against Invasion; and on Application of the Legislature, or of the Executive (when the Legislature cannot be convened) against domestic Violence.

\section{Article V.}

The Congress, whenever two thirds of both Houses shall deem it necessary, shall propose Amendments to this Constitution, or, on the Application of the Legislatures of two thirds of the several States, shall call a Convention for proposing Amendments, which, in either Case, shall be valid to all Intents and Purposes as Part of this Constitution, when ratified by the Legislatures of three fourths of the several States, or by Conventions in three fourths thereof, as the one or the other Mode of Ratification may be proposed by the Congress; Provided that no Amendment which may be made prior to the Year One thousand eight hundred and eight shall in any Manner affect the first and fourth Clauses in the Ninth Section of the first Article; and that no State, without its Consent, shall be deprived of its equal Suffrage in the Senate.

\section{ARticle VI.}

[1] All Debts contracted and Engagements entered into, before the Adoption of this Constitution, shall be as valid against the United States under this Constitution, as under the Confederation.

[2] This Constitution, and the Laws of the United States which shall be made in Pursuance thereof; and all Treaties made, or which shall be made, under the Authority of the United States, shall be the supreme Law of the Land; and the Judges in every State shall be bound thereby, any Thing in the Constitution or Laws of any State to the Contrary notwithstanding.

AmendMENT OF ConstituTION.

MiscelLANEOUS. Preëxisting national debt. Supremacy of Constitution, treaties, and national law. 
Oaths of national and state officials.
RATIFICATION.
[3] The Senators and Representatives before mentioned, and the Members of the several State Legislatures, and all executive and judicial Officers, both of the United States and of the several States, shall be bound by Oath or Affirmation, to support this Constitution; but no religious Test shall ever be required as a Qualification to any Office or public Trust under the United States.

\section{Article VII.}

The Ratification of the Conventions of nine States, shall be sufficient for the Establishment of this Constitution between the States so ratifying the Same.

Done in Convention by the Unanimous Consent of the States present the Seventeenth Day of September in the Year of our Lord one thousand seven hundred and Eighty seven and of the Independence of the United States of America the Twelfth In Witsess whereof We have hereunto subscribed our Names,

\section{Go Washington -}

Presidt. and Deputy from Virginia

[and thirty eight members from all the States except Rhode Island.] 
ARTICLES IN ADDITION TO, AND AMENDMENT OF, THE CONSTITUTION OF THE UNITED STATES OF AMERICA, PROPOSED BY CONGRESS, AND RATIFIED BY THE LEGISLATURES OF THE SEVERAL STATES PURSUANT TO THE FIFTH ARTICLE OF THE ORIGINAL CONSTITUTION.

\section{[ARTICLE I ${ }^{1}$ ]}

Congress shall make no law respecting an establishment of religion, or prohibiting the free exercise thereof; or abridging the freedom of speech, or of the press ; or the right of the people peaceably to assemble, and to petition the Government for a redress of grievances.

\section{[ARTICLE II ${ }^{1]}$}

Prohibitions on Congress respecting religion, speech, and the press.

A well regulated Militia, being necessary to the security of a free State, the right of the people to keep and bear Arms, Right to bear arms. shall not be infringed.

\section{[ARTicle III $\left.{ }^{1}\right]$}

No Soldier shall, in time of peace be quartered in any house, without the consent of the Owner, nor in time of war, but in a manner to be prescribed by law.

Quartering of soldiers.

\section{[ARTICLE IV $\left.{ }^{1}\right]$}

The right of the people to be secure in their persons, houses, papers, and effects, against unreasonable searches Right of search. and seizures, shall not be violated, and no Warrants shall issue, but upon probable cause, supported by Oath or affirmation, and particularly describing the place to be searched, and the persons or things to be seized.

${ }^{1}$ First ten amendments proposed by Congress, Sept. 25, 1789. Proclaimed to be in force Dec. 15, 1791. 
Protection of accused in criminal cases.
Rights of accused regarding trial.
Jury trial in lawsuits.

\section{[ARTiCle V ${ }^{1}$ ]}

No person shall be held to answer for a capital, or otherwise infamous crime, unless on a presentment or indictment of a Grand Jury, except in cases arising in the land or naval forces, or in the Militia, when in actual service in time of War or public danger; nor shall any person be subject for the same offence to be twice put in jeopardy of life or limb; nor shall be compelled in any Criminal Case to be a witness against himself, nor be deprived of life, liberty, or property, without due process of law; nor shall private property be taken for public use, without just compensation.

\section{[ARTicLe VI ${ }^{1}$ ]}

In all criminal prosecutions, the accused shall enjoy the right to a speedy and public trial, by an impartial jury of the State and district wherein the crime shall have been committed, which district shall have been previously ascertained by law, and to be informed of the nature and cause of the accusation; to be confronted with the witnesses against him; to have compulsory process for obtaining Witnesses in his favor, and to have the Assistance of Counsel for his defence.

\section{[ARTicle VII ${ }^{1}$ ]}

In suits at common law, where the value in controversy shall exceed twenty dollars, the right of trial by jury shall be preserved, and no fact tried by a jury shall be otherwise reexamined in any Court of the United States, than according to the rules of the common law.

\section{[ARTICLE VIII ${ }^{1]}$}

Bail and punishment.
Excessive bail shall not be required, nor excessive fines imposed, nor cruel and unusual punishments inflicted.

${ }^{1}$ First ten amendments proposed by Congress, Sept. 25, 1789. Proclaimed to be in force Dec. 15, 1791. 


\section{[ARTICLE IX ${ }^{1}$ ]}

The enumeration in the Constitution, of certain rights, shall not be construed to deny or disparage others retained by the people.

\section{[ARticle X ${ }^{1}$ ]}

The powers not delegated to the United States by the Constitution, nor prohibited by it to the States, are reserved to the States respectively, or to the people.

Unenumerated rights.

Undelegated powers.

\section{Article XI ${ }^{2}$}

The Judicial power of the United States shall not be construed to extend to any suit in law or equity, commenced or prosecuted against one of the United States by Citizens of another State, or by Citizens or Subjects of any Foreign State.

\section{Article XII}

The Electors shall meet in their respective states, and vote by ballot for President and Vice-President, one of whom, at least, shall not be an inhabitant of the same state with themselves; they shall name in their ballots the person voted for as President, and in distinct ballots the person voted for as Vice-President, and they shall make distinct lists of all persons voted for as President, and of all persons voted for as Vice-President, and of the number of votes for each, which lists they shall sign and certify, and transmit sealed to the seat of the government of the United States, directed to the President of the Senate; - The President of the Senate shall, in presence of the Senate and House of Representatives, open all the certificates and the votes shall then be counted; - The person having the greatest number of votes for President, shall be the President, if such number be a majority of the whole number of Electors appointed; and if no person

New method of electing President.

(To supersede part of Art. II, Sec. 1 , cl. 2.)

(Proposed Dec. 12, 1803. Declared in force Sept. 25 , 1804.)

${ }^{1}$ First ten amendments proposed by Congress, Sept. 25, 1789. Proclaimed to be in force Dec. 15, 1791.

${ }^{2}$ Proposed September 5, 1794. Declared in force January 8, 1798. 
have such majority, then from the persons having the highest numbers not exceeding three on the list of those voted for as President, the House of Representatives shall choose immediately, by ballot, the President. But in choosing the President, the votes shall be taken by states, the representation from each state having one vote; a quorum for this purpose shall consist of a member or members from two-thirds of the states, and a majority of all the states shall be necessary to a choice. And if the House of Representatives shall not choose a President whenever the right of choice shall devolve upon them, before the fourth day of March next following, then the Vice-President shall act as President, as in the case of the death or other constitutional disability of the President. The person having the greatest number of votes as Vice-President, shall be the Vice-President, if such number be a majority of the whole number of Electors appointed, and if no person have a majority, then from the two highest numbers on the list, the Senate shall choose the Vice-President; a quorum for the purpose shall consist of two-thirds of the whole number of Senators, and a majority of the whole number shall be necessary to a choice. But no person constitutionally ineligible to the office of President shall be eligible to that of Vice-President of the United States.

\section{Article XIII}

Abolition of slavery. (Proposed Feb. 1, 1865 .

Declared in force Dec. 18, 1865.)

Section 1. Neither slavery nor involuntary servitude, except as a punishment for crime whereof the party shall have been duly convicted, shall exist within the United States, or any place subject to their jurisdiction.

Section 2. Congress shall have power to enforce this article by appropriate legislation.

\section{Article XIV}

Citizens of the United States protection

Section 1. All persons born or naturalized in the United States, and subject to the jurisdiction thereof, are citizens of the United States and of the State wherein they reside. No 
State shall make or enforce any law which shall abridge the privileges or immunities of citizens of the United States; nor shall any State deprive any person of life, liberty, or property, without due process of law; nor deny to any person within its jurisdiction the equal protection of the laws.

of. (Proposed June 16,1866 . Declared in force July 28 , 1868.)

Section 2. Representatives shall be apportioned among the several States according to their respective numbers, counting the whole number of persons in each State, excluding Indians not taxed. But when the right to vote at any election for the choice of electors for President and Vice President of the United States, Representatives in Congress, the Executive and Judicial officers of a State, or the members of the Legislature thereof, is denied to any of the male inhabitants of such State, being twenty-one years of age, and citizens of the United States, or in any way abridged, except for participation in rebellion, or other crime, the basis of representation therein shall be reduced in the proportion which the number of such male citizens shall bear to the whole number of male citizens twenty-one years of age in such State.

Section 3. No person shall be a Senator or Representative in Congress, or elector of President and Vice President, or hold any office, civil or military, under the United States, or under any State, who, having previously taken an oath, as a member of Congress, or as an officer of the United States, or as a member of any State legislature, or as an executive or judicial officer of any State, to support the Constitution of the United States, shall have engaged in insurrection or rebellion against the same, or given aid or comfort to the enemies thereof. But Congress may by two-thirds vote of each House, remove such disability.

Section 4. The validity of the public debt of the United States, authorized by law, including debts incurred for payment of pensions and bounties for services in suppressing insurrection or rebellion, shall not be questioned. But neither

Validity of war debt.
Disabilities of officials engaged in rebellion.
New basis of representation in Congress. (Superseding part of Art. I, Sec. 2, cl. 3.) 
the United States nor any State shall assume or pay any debt or obligation incurred in aid of insurrection or rebellion against the United States, or any claim for the loss or emancipation of any slave; but all such debts, obligations and claims shall be held illegal and void.

Section 5. The Congress shall have power to enforce, by appropriate legislation, the provisions of this article.

\section{Article XV ${ }^{1}$}

Voting rights of citizens of the U.S.
Income $\operatorname{tax}$.

Direct election of senators.

Section 1. The right of citizens of the United States to vote shall not be denied or abridged by the United States or by any State on account of race, color or previous condition of servitude.

Section 2. The Congress shall have power to enforce this article by appropriate legislation.

\section{Article XVI ${ }^{2}$}

The Congress shall have power to lay and collect taxes on incomes, from whatever source derived, without apportionment among the several states, and without regard to any census or enumeration.

\section{Article XVII ${ }^{3}$}

The Senate of the United States shall be composed of two Senators from each State, elected by the people thereof, for six years; and each Senator shall have one vote. The electors in each State shall have the qualifications requisite for electors of the most numerous branch of the State legislatures.

Method of election.

Temporary appointments.

When vacancies happen in the representation of any State in the Senate, the executive authority of each State shall issue writs of election to fill such vacancies: Provided that the legislature of any State may empower the executive thereof

${ }^{1}$ Proposed February 27, 1869. Declared in force March 30, 1870.

${ }^{2}$ Proposed July 12, 1909. Declared in force February 25, 1913.

${ }^{3}$ Proposed June 12, 1912. Declared in force May 13, 1913. 
to make temporary appointments until the people fill the vacancies by election as the legislature may direct.

This amendment shall not be so construed as to affect the election or term of any Senator chosen before it becomes valid as part of the Constitution. 



\section{INDEX}

A. B. C. powers, 486 .

Abolitionists, 293-297.

Adams, John, elected president, 212; relations with Hamilton, 243; attitude toward France, 217.

Adams, John Quincy, secretary of state, 265; and the Monroe Doctrine, $269 ;$ and the election of 1824,270 , 271 ; opposition to, 271 ; defeated in $1828,271$.

Adams, Samuel, 144, 145, 146, 147, 148. Agent, colonial, 134.

Agricultural and mechanical colleges, 502.

Aguinaldo, 469.

Alabama, land sales in, 256 ; removal of Indians in, 283, 284.

Alabama, the, career of, 378 ; claims for, 398.

Alamo, the, captured, 303.

Alaska, purchase of, 396 ; coal lands in, 493.

Albany, founded, 85, 253; congress at, 123.

Albemarle Sound, settlements on, 90 .

Alder Gulch, 421.

Algonquins, relations with the French, 114.

Alien laws, the, 218.

Allen, Ethan, 159.

Amendments, 205, 525-528; thirteenth, 528 ; fourteenth, 387,528 ; fifteenth, 389,530 ; sixteenth, 530 ; seventeenth, 530 .

America, the name, 24.

American Colonization Society, 293.

American Federation of Labor, 500.

Amnesty act, 400.

Annapolis Convention, 185.

Antietam, battle of, 363 .

Antislavery petitions, 295.
Apia, threatened conflict at, 447.

Appalachian Park, 492.

Appomattox courthouse, Lee surrenders at, 371 .

Arkansas River, reached by La Salle, 116 .

Army, in the war of $1812,236$.

Arnold, Benedict, 170.

Arthur, Chester A., president, 434.

Articles of Confederation, 159.

Assembly, the colonial, 103, 110, 132134.

Atlanta, Georgia, importance of, 351 ; taken by Sherman, 354 .

Austin, Moses, 301.

Austin, Stephen, F., 301.

Bacon, Nathaniel, rebellion of, 104-105; his influence, 108.

Bad Axe, the battle of, 285.

Balboa, 28.

Balmeceda, 448.

Baltimore, attempt against, 240.

Baltimore, the, 449.

Baltimore, Lord, 45, 46, 47.

Bank, a national, 211.

Bank of the United States, the second, 263 ; destroyed by Jackson, 282, 283.

Beauregard, General, at Bull Run, 338.

Belknap frauds, the, 401.

Bell, Professor Alexander G., 496.

Bennington, battle of, 167 .

Berkeley, Sir William, and Bacon's rebellion, 104-107; his ideas, 108.

Bienville, 117.

Bill, nature of a, 198.

Black Hawk War, the, 285.

Black Hills, gold in, 427.

Bladensburg, battle of, 239.

Blaine, James G., candidate for the presidency, 435. 
Blockade, European, 230 ; southern, 379.

Blockade runners, 380 .

Board of Trade, 134.

Bonds, 375.

Bonhomme Richard, 179.

Bonus bill, the, 265.

Boone, Daniel, 192.

Booth, John Wilkes, 381.

"Border states," 337.

Boston, founded, 57 ; port closed, 148; evacuated by British, 159 .

“Boston massacre," 145.

"Boston tea party," 147, 148.

Braddock, Colonel, 123.

Bradford, William, governor of Plymouth, 53.

Bragg, General, campaign of Perryville, 345 ; at Murf reesboro, 346 ; defends Chattanooga, 347; Chickamauga, 347 ; driven from Chattanooga, $349-351$; removed from command, 353.

Brandywine, battle of, 165 .

Breckenridge, John C., nominated for the presidency, 332 .

Brooke, Lord, 61.

Brooklyn Heights, 161.

Brown, John, his attack on slavery, 330.

Bryan, William J., nominated for the presidency, 442, 472, 482; opposition to trusts, 481 .

Buchanan, James, elected president, 328.

Buell, General, 341, 343, 345; at Perryville, 346 ; removed, 346.

Buffalo, 253.

Bull Run, battle of, 338; second battle of, 361-363.

Bunker Hill, battle of, 152.

Burgoyne, General, campaign of, 165, $167,168$.

Burnside, General, commands at Fredericksburg, 363.

Burr, Aaron, his schemes, 226-229 ; trial of, 228 .

Cabinet, the president's, 202.

Cabot, John, his explorations, 24, 87.

Calaveras skull, the, 4.

Calhoun, a "war hawk," 235; on the bonus bill, 265 ; secretary of war, 265 ; elected vice-president, 270; and nullification, 278 ; on compromise of 1850,318 ; death, 318 .

California, acquired from Mexico, 310; condition in 1846, 310 ; discovery of gold in, 311 ; and slavery, 316 ; admitted to the union, 318, 319 ; growth of agriculture in, 424 .

Calliope, the, 448.

Cambridge agreement, the, 56 .

Camden, battle of, 171 .

Campos, General, 458.

Canada, settled, 114; attack on, 236.

Canal, Panama, 476-480; Nicaraguan, 477.

Canals, the need for them, 252-254; recent construction, 498.

Canning, British minister, 268.

Cape Cod canal, 498.

Captives, in the hands of the Indians, 112.

Carolina, settled, 90.

Carpet-baggers, 393.

Cartier, Jacques, his explorations, 25, 114.

Cass, Lewis, 315.

Catholics, Roman, in Maryland, 45, 47.

Cavite, 462.

Cemetery Ridge, 365, 366.

Central Pacific Railroad, 425.

Cervera (Thair-vair-a), 463, 464, 467, 468.

Champlain in Canada, 114.

Champlain, Lake, battle of, 238.

Chancellorsville, battle of, 364 .

Charleston, founded, 90; attacked by British, 160 ; captured, 171 ; abolition literature in, 295.

Charleston, the, 449.

Charlestown, Mass., founded, 57.

Chattanooga, importance of, 345 ; campaign against, $347-351$.

Cherokees, removal of, 283, 284.

Chesapeake, the, 238.

Cheyennes, war with, 427.

Chicago University, 502.

Chickasaws, the, 283, 284.

Chile, our controversy with, 448-451.

Chinese immigration, 452.

Choctaws, 283, 284.

Cibola, 31.

Cincinnati, 249, 255. 
Civil rights act of 1866,387 .

Civil service reform, origin of, 402 ; Hayes's attitude toward, 432 ; the law of 1883,433 ; its enforcement by Cleveland, 437 .

Clark, George Rogers, 178.

Clay, Henry, a "war hawk," 235 ; opposes Monroe, 265; the election of 1824,270 ; secretary of state, 270 ; compromise tariff of, 281 ; candidate in 1832, 282; and the bank, 282 ; and the Missouri compromise, 292 ; candidate in 1844,306 , 307 ; part in compromise of 1850 , 317,318 ; death, 320 .

Clermont, the, 251.

Cleveland, Grover, governor of New York, 436; president, 436; defeated, 438; reëlected, 440; attitude toward free coinage, 441 ; disliked by his own party, 442; opposed to Hawaiian annexation, 451 ; on the Venezuelan boundary, 453455; Cuban policy, 460.

Clinton, De Witt, 253.

Cod, value as a fish, 77 .

Colleges, colonial, 81 ; recent development, 501.

Colombia, United States of, and the Panama Canal, 477-479.

Colon, the, 467.

Colonial policy, England's, 100-103.

Colonies, kinds of, 97 ; attitude toward England, 100.

Colorado, early history, 420 .

Columbia River, discovered, 225.

Columbus, Christopher, and Leif Ericsson, 14 ; his plan, 17 ; his voyage of discovery, 17 ; other voyages, 19-21.

Compromise, Missouri, see Missouri Compromise ; of 1850, 317-319.

Concord, battle at, 151 .

Confederate states of America, organized, 333 ; new states admitted, 337 ; government, 333 ; flag of, 378 ; foreign relations, 378 ; navy of, 378 ; ports blockaded, 379 .

Congress, in constitutional convention, 186,187 ; powers, etc., 186-188, $198,199$.
Connecticut, colony founded, 60, 61 ; charter granted, 61; governor's salary in, 104.

Conservation policy, 491.

Constellation, the, 217.

Constitution, the federal, adopted, 189 ; text of, 510-531.

Constitution, the, 237.

Constitutional convention, federal, 186189.

Continental Congress, first, 149.

Continental money, 183.

"Copperheads," 397.

Corinth, Miss., occupied by Johnston, 343 ; by Grant, 344 .

Corn, Indian, advantages of, 69.

Cornwallis, campaign in New Jersey, 162-164; campaign in the South, 171-175; surrender of, 175 .

Coronado, 31.

Corte-Real, his explorations, 25.

Cortez, in Mexico, 30.

Cotton, the cultivation of, 246.

"Cotton is King," 377.

Council, the colonial, 132, 133.

County, in Virginia, 136; in the Middle colonies, 137.

Courts, colonial, 137 ; later, 203.

Cowpens, battle of, 173 .

Crawford, W. H., secretary of the treasury, 265 ; and the election of $1824,270$.

Creek, Indians, war with, 241 ; in Seminole war, 267 ; removal of, 283, 284.

Cuba, discovery of, 19 ; colonization of, 27 ; insurrection in, 399 ; the war to liberate, $457-469$; two classes of people in, 457; the ten years' war, 457 ; outbreak of a new war, 459 ; reconcentration, 459 ; destruction of the Maine, 461; intervention, 461 ; independent, 468 ; in American hands, 473; restoration of, 473; government of, 474; the Platt amendment, 474.

Curtis, George William, 403.

Custer, General, attacks the Cheyennes, 427 ; in the Black Hills, 427; at Little Big Horn, 428.

Dale, Governor, in Virginia, 41, 42.

Dalton, Georgia, 351. 
Dare, Eleanor, 37.

Davis, Jefferson, president of the Confederacy, 333.

Debts, due to British subjects, 177 ; owed by Congress, 182 ; state, 210 ; national, $375,413$.

Declaratory act, 144.

Declaration of Independence, 156 ; text of, 505-510.

Deerfield, attack on, 119.

Delaware, earliest history, 89 .

De Lesseps, Ferdinand, 476.

Democratic party, 273; recovering from the war, 397,403 ; triumph under Cleveland, 436; and the tariff question, 437 ; and the silver question, 441,442 .

Dewey, Admiral, at battle of Manila, 462.

Diaz, Bartholomew, 15.

District of Columbia, slave trade in, 316, 318.

"Dixie," 313.

Dorchester founded, 57.

"Dough-face," 326.

Douglas, Stephen A., and the KansasNebraska Act, 324; debates with Lincoln, 329; nominated for presidency, 332.

Drummond, William, 106.

Durham, North Carolina, 371.

Dustin, Hannah, 119.

Dutch, see Holland.

Eagan, Patrick, 448, 450.

El Caney, battle of, 465 .

Electoral commission, 405.

Electric cars, 496.

Emancipation proclamation, the, 376 .

Embargo, Jefferson's, 231.

Endicott, John, 55.

England, attitude towards the Southern Confederacy, 377; and the Venezuelan boundary, 453-455.

"Era of good feeling," 266.

Eric the Red, 14.

Erie Canal, the, 253.

Erie, Lake, battle of, 238.

Eskimos, 2.

Excise tax, a, 211.

Executive, 199, 200.
Far West, settlement of, 419-430.

Federalist party, the, 208; party defeated, 213, 218, 220; opposed to war of $1812,261$.

Ferdinand, and Isabella, 17.

Ferguson, Major, 171.

Finlay, Dr. Charles, 473.

Fish, Hamilton, 399, 400.

Fishing, 77.

Flag, 240; union, 374; confederate, 378. Florida, discovery of, 28; De Soto in, 29 ; acquired, 266-268, 301 ; removal of Indians in, 284.

Forbes, General, 124.

Forests, disappearing, 491 ; reserves, 491.

Fork of the Ohio, 121.

Fort Donelson, 341.

Fort Duquesne, 122, 123, 124.

Fort Henry, 341.

Fort Lee, 162.

Fort Moultrie, 160.

Fort Necessity, 122.

Fort Pitt, 124.

Fort Sumter, attack on, 335 .

Fort Washington, 162.

France, explorations, 25 ; colonial efforts, 113-117; wars with British, 118126 ; aid for the American revolution, 169; at Yorktown, 175; at the treaty-making, 176 ; quarrel with, 213-218; Genêt, 214; sea fights, 217; a new treaty, 217; friendly toward the confederacy, 377. See French.

Franklin, Benjamin, at Albany congress, 122 ; colonial agent, 134.

"Franklin, the State of," 193.

Fredericksburg, battle of, 363 .

Freedmen's bureau, 386 .

Frémont, John C., 328.

French, join Indians in war against English, 113 ; attempted settlement of, in Florida, 113; trading on the St. Lawrence, 114; settle Canada, 114; relations with Iroquois, 114 ; colonial growth, 116, 117.

Frontenac, governor of Canada, 118.

Fugitive slave laws of 1793 and 1850 , 318, 319-321.

Fulton, Robert, 251.

Fur trade, 76. 
"Gag rule," the, 296.

Gage, General, 145, 150, 151, 159.

Gallatin, Albert, secretary of the treasury, 223.

Gama, Vasco da, 24.

Garfield, James A., elected president, 434 ; assassinated, 434, 435.

Garrison, William Lloyd, his plan, 293; use of the mails, 295; against a political party, 327 .

Gates, General, campaign in South Carolina, 171.

General court, the, 58 .

Genêt (Zhen-nay), in the United States, 214.

George III, and the colonies, 144, 145, $148,149,156,169$.

Georgia, settled, 95 ; early history, $95-$ 97 ; overrun by the British, 170 , 174 ; removal of Indians, 283, 284; Sherman in, 354 .

Germans, in Pennsylvania, 74, 92.

Germantown, battle of, 166 .

Germany and the Samoan Islands, 447.

Gerry, Elbridge, 216.

Gettysburg, the campaign of, 364-368.

Ghent, treaty of, 243.

Gin, the cotton, invented, 246.

Gold, in Hayti, 20; in Mexico and Peru, 31 ; sought in Virginia, 69 ; in California, 311; discovered at Mount Davidson, 420; at Idaho Springs, 420 ; at Alder Gulch, 421 ; in the Black Hills, 427 ; the standard for coinage, $441,442,470$.

Goldsboro, North Carolina, 355 .

Gorges, Fernando, 64 .

Government, self-, in Virginia, 44; colonial, 128-138; actual, 196-206.

Governor, salary dispute, 103 ; the colonial, $128,129,130,131$; of a state, 199.

Grant, General U.S., his campaign in West Tennessee, 341 ; at the battle of Shiloh, 344; campaign against Vicksburg, 364; in the battle of Chattanooga, 349-351 ; in command in the East, 353, 357 ; the Wilderness campaign, 368 ; at the battle of Spotsylvania, 369 ; at Cold Harbor, 369 ; the siege of Petersburg, 370 ; forces Lee to surrender, 370 ; elected president, 397 ; attitude toward reforms, 397; reëlected, 398 ; and the Virginius affair, 400; political scandals and, 400-402; and civil service reform, 402 .

Great Britain, see England.

Great Northern Railroad, 426.

Greeley, Horace, candidate for presidency, 398.

Greenbacks, 375 ; depreciation oî, 415 , 416.

Greene, Nathanael, command in the South, 171-174.

Greenland, colonized, 14.

Grenville, his laws, 141.

Guam, 468.

Guanahani, 19.

Guerrière, the, 237.

Guilford Courthouse, battle of, 174 .

"Hair Buyer, the," 178.

Hakluyt (Hack-lit), 38.

Hale, Nathan, execution of, 162.

Half breeds, 433.

Hamilton, Alexander, his plans for the debt, 209-211; for a bank, 211 ; for manufactures, 211; for an excise $\operatorname{tax}, 211$.

Hancock, John, 146.

Harlem, battle of, 162 .

Harper's Ferry, seized by John Brown, 330 .

Harper's Weekly, 404.

Harrison, Benjamin, elected president, 438; defeated, 440.

Harrison, W. H., 286 ; elected in 1840 , 287 ; as president, 306.

Hartford, founded, 60; Dutch at, 85 ; convention, 261.

Harvard College, founded, 81.

Haverhill, Mass., attacked, 119.

Hawaiian Islands, revolution in, 450452 ; annexed, 452.

Hayes, Rutherford B., nominated for the presidency, 405; disputed election, 405; becomes president, 432 ; his civil service policy, 432 ; his southern policy, 433.

Hayne, Robert Y., debate with, Webster, $279,280$.

Hayti, discovery of, 19 ; colonized, 27. 
Helena, Montana, 421.

Henry, Patrick, 142.

Henry the Navigator, 15.

Hispaniola, see Hayti.

Hobson, Lieutenant, 464.

Holland, and the English separatists, 50, 51; her American colony, 85.

Homestead act, the, 257, 408.

Hood, General, defeated at Atlanta, 354 ; at Nashville, 354 .

Hooker, General, at Lookout Mountain, 349,350 ; at Chancellorsville, 364 ; removed from command, 365 .

Horseshoe Bend, battle of, 241.

Houston, Samuel, 304.

Howe, General, New York campaign, 161, 162; Philadelphia campaign, $165,166$.

Hudson, Henry, 85.

Huerta, 485.

Hull, Captain Isaac, 237.

Hutchinson, Mrs. Anne, expelled from Massachusetts, 59 ; founds Rhode Island, 60.

Iberville, 117.

Iceland, colonized, 13.

Idaho Springs, 420.

Immigration, 409.

Impeachment, 203; of President Johnson, 389.

Impressment, 229.

Indented servants, 73 .

Indians, origin of, 1 ; their manner of living, 2 ; age of the race, 4 ; linguistic families, 5 ; confederacies, 6 ; clans, 7 ; government, 7 ; marriage, 8 ; making war, 8,9 ; houses, 10 ; and slavery, 27, 32; relations with the Spaniards, 32; missionaries to, 32 ; Las Casas and, 33; massacre whites in Virginia, 43 ; defeated by Bacon, 105; why hostile, 110; treatment of captives, 112 ; driven back before the whites, 258; in Georgia and Alabama, 283; resist railroad building in the Far West, 426; wars with, 427; civilizing them, 428 ; citizenship of, 430 .

Indian Territory, set off, 284 ; abolished, 430.
Indies, the council of, 34 .

Industrial Workers of the World, 500 .

"Insurgents," 483.

"Interlopers," 77.

Internal improvements, 264, 276.

Internal revenue taxes, 374 .

Intervention, Cuban, 461.

Iroquois, confederacy of, 7 ; oppose the

French, 114-116; subjects of England, 120.

Irrigation, 492.

Isabella, Queen, 17.

Itata, the, 448.

Jackson, Andrew, subdues the Creeks, 241, 259; defends New Orleans, 241-243; against the Seminoles, 267 ; and the election of 1824,270 ; elected president, 271 ; presidency of, 276-286; and the spoils system, 276 ; against internal improvement, 276 ; attitude towards nullification, 279 ; his nullification proclamation, 281; destroys the Bank of the United States, 282, 283 ; his Indian policy, 283 ; and Texas, 305.

Jackson, Michigan, 327.

Jackson, "Stonewall," in the seven days' fight, 360 ; against Pope, 361-363 ; killed at Chancellorsville, 364 .

Jamestown, settlement of, 38 ; early history, 38-43; destroyed by Bacon, 106.

Japan, immigration from, 452; land ownership in California, 453.

Jay Cooke and Company, 413.

Jay treaty, 215.

Jefferson, Thomas, defies the king, 156; writes Declaration of Independence, 156 ; secretary of state, 212 ; as republican president, 222; elected president in 1804, 226; his policy of peace, 229 ; favors the embargo, 230 ; refused a third term, 232.

Jesuits, in Canada, 116.

Johns Hopkins University, 502.

Johnson, Andrew, becomes president, 385 ; his plan of reconstruction, 385 ; his vetoes, 386,387 ; impeached, 389.

Johnston, General Albert Sidney, 343. 
Johnston, General Joseph E., defends Atlanta, 353; at battle of Kennesaw Mountain, 353 ; removed from command, 354; defends Richmond, 359 ; surrender of, 371 .

Jones, John Paul, 178.

Kansas, territory created, 324 ; settled, 325 ; civil war in, 325.

Kansas-Nebraska act, 324 .

Kennesaw Mountain, battle of, 353 .

Kentucky, early history, 192; riflemen at New Orleans, 242; and secession, 337.

Kentucky and Virginia resolutions, 219.

Key, Francis Scott, 240.

Kidnapping, 73.

King's Mountain, battle of, 171 .

Knights of Labor, 500.

Ku Klux Klan, 390-393.

Labor, early system in Virginia, 38, 41 ; in Plymouth, 51, 54.

Labor unions, growth of, 498.

Laborers, in early Virginia, 69, 73.

Lafayette, General, at Yorktown, 174, 175.

Land, ceded in the West, 190 ; sales of, 255-257; mineral, 493.

Lansing skulls, the, 4 .

La Salle, explorations of, 116.

Las Casas, 33.

Laud, Archbishop, 56.

Law, nature of a, 198.

Lawmaking, 129, 198.

Lawrence, Captain James, 238.

Lawton, General, 465.

Leary, Captain, at Apia, 447.

Lee, General Charles, 169.

Lee, General Robert E., placed in command, 360 ; in the seven days' fight, 360 ; his campaign against Pope, 361-363; at Fredericksburg, 363; at Chancellorsville, 364 ; his Gettysburg campaign, 364-368; in the Wilderness campaign, 368 ; at Spotsylvania, 369 ; at Cold Harbor, 369 ; retreat from Petersburg, 370 ; surrender of, 371 .

Leif Ericsson, 14.

Leland Stanford Jr. University, 502.
Leon, Ponce de, 27.

Lewis and Clarke, expedition of, 225.

Lexington, battle of, 151.

Liberal republicans, 397.

Liberator, the, established, 293.

Liberia, established, 293.

Liliuokalani, 451.

Lincoln, Abraham, debate with Douglas, 329,330 ; nominated for the presidency, 331 ; elected, 332 ; and the southern forts, 335 ; raises an army, 335 ; his emancipation proclamation, 376 ; preserver of union, 380 ; reëlected president, 381 ; assassinated, 381 ; his recorsstruction plan, 385.

L'Insurgent, the, 217.

Little Round Top, 367.

Livingston, minister to France, 224.

London Company, the, created, 38 ; destroyed, 44 ; and the Pilgrims, 51.

Long Island, settled, 87 ; favors the English, 89.

Lookout Mountain, battle on, 349.

"Loose construction," 272.

"Lost Colony of Roanoke, The," 37.

Louisburg, capture of, 120.

Louisiana, settled, 117 ; purchased, 224 ; transferred to Spain, 299; to France, 299 ; life in, 299 ; boundaries, 301 ; disputed election in, 405.

Louisville, 249.

Lumber, 79.

Lundy, Benjamin, 292.

Madero, 485.

Madison, James, .president, 222, 223 ; and the "war hawks," 235 ; veto of bonus bill, 265.

Magellan, his discoveries, 21.

Mails, used by abolitionists, 295 .

Maine, beginning of, 64 ; a state, 292.

Maine, the, destruction of, 461.

Manila, the battle of, 462 .

Manufactures, in early Virginia, 76; in early New England, 79; colonial restrictions on, 103; protection of, 211 ; and the War of 1812,243 ; growth after 1865, 408.

Marco Polo, 17, 20.

Marquette, Father, 116. 
Marshall, John, commissioner to France, 216.

Maryland, founded, 45; early history, 45-47; religious toleration in, 45, 47 ; government, 46 ; boundary dispute, 93; and secession, 337; General Lee in, 363.

Mason, Captain John, 62.

Mason and Dixon's line, 93, 313.

Massachusetts, growth of, 58; early government of, 58 ; relations with New Hampshire and Maine, 64 ; and the New England Confederation, 65 ; agriculture in, 76 ; manufactures in, 79 ; religion in, 79-81; education in, 81 ; loss of charter, 94 ; proposed dominion, 95 ; new charter, 95 ; governor's salary, 104 ; expedition against Quebec, 119 ; and the revolution, 145, 148.

Massachusetts Bay Colony, receives a charter, 55 ; moves to New England, 56.

Massasoit, 53, 110.

Mayflower, the, 52.

Mayflower Compact, the, 55.

Maysville road, 277.

McClellan, General Geo. B., training the army, 357 ; the peninsula campaign, $357-361$; removed, 361 ; in command at Antietam, 363.

McDonough, Captain, 239.

McDowell, General, at Bull Run, 338.

McKinley, William, Jr., his tariff bill, 439 ; elected president, 443 ; Cuban policy of, 460, 461; and the Philippines, 469 ; reëlected, 472 ; death of, 472 ; on the government of Cuba, 474.

Meade, General, commands in Gettysburg campaign, 365-368.

Merrimac, the, 378 .

Mexico, inhabitants of, 2 ; conquest of, 30 ; independence declared, 301; early relations with Texas, 302 ; struggle against, 303-305; our war with, 309 ; treaty with, 310 ; recent relations with, 485,486 .

Middle states, migration from, 247.

Militia, 129, 136.

Mineral lands, 493.
Mining, methods, $422,423$.

Ministers, influence of, 58,180 ; on the f rontier, 258.

Missionary Ridge, battle of, 350 .

Missions, Spanish, 32.

Mississippi, land sales in, 256; laws for negroes, 386.

Mississippi River, discovered by De Soto, 29 ; by Father Marquette, 116.

Missouri, admitted to the union, 292 ; and secession, 337 ; liberal repub': cans in, 397.

Missouri compromise, 268, 291, 313 ; reversed by Kansas-Nebraska act, 324 ; by the Dred Scott decision, 329 .

Mobile, seized, 241.

Mohawks, and the Pequots, 63.

Mohegans, 62, 63.

Molasses act, 101, 141.

Monhegan, 53.

Monitor, the, 378.

Monmouth, battle of, 169 .

Monroe doctrine, 268-270; later phases, $446,454$.

Monroe, James, 222 ; and the purchase of Louisiana, 224; elected president, 262 ; and Clay, 265; and "era of good feeling," 265; and the Monroe doctrine, 268.

Montana, early history of, 421 .

Montcalm, General, 124, 125.

Montgomery, Ala., first capital of the confederacy, 333.

Montreal, reached by Cartier, 25 .

Moore's Creek, battle of, 159.

Morgan, General, 173.

Mormons, early hardships, 424 ; introduce irrigation, 492 ; and the admission of Utah, 423.

Morse, S. B. F., 496.

Mound builders, the, 5 .

Mount Davidson, 420.

Mount Hope, battle at, 112.

Murfreesboro, battle of, 346 .

Mystic River, fort on, 62.

Narragansetts, 53; in Pequot war, 62, 63 ; conquered, 111.

Nar-vā-ez (-ath), de, 29. 
Nashville, battle of, 354 .

Naval stores, 79 .

Navigation, medieval, 15.

Navigation acts, 101.

Navy, John Paul Jones and, 178; in the war of 1812, 237; enlarged under Harrison, 438.

Nebraska, territory created, 324 .

Negro, what to do with him in 1865,384 ; allowed to vote, 388 ; misuse of the privilege, 390 ; overthrow of negro voters, 393, 394.

Nevada, settlement of, 419 .

New Amsterdam, 86.

New England, beginning of, 49 ; life in, $76-82$; migration from, 247.

New England Confederation, the, 65.

Newfoundland, acquired by England, 120.

New France, 114.

New Hampshire, beginning of, 64 .

New Haven, founded, 61.

New Jersey, settled, 89.

New Mexico, and slavery, 316, 318.

New Netherland, 86-88.

New Orleans, attacked by the British, 241-243; trade of, 250-252 ; taken by the North, 345 .

New York, fort on Manhattan Island, 85 ; colonial government of, 87 ; taken by the English, 88 ; occupied by the British, 161; growth of, 254.

Nicaragua Canal, 477.

Non-intercourse act, the, 232.

Norsemen, as explorers, 13.

North Carolina, settled, 90 ; life in, 91 ; Cornwallis in, 171, 173, 174; and the federal constitution, 190.

Northern Pacific and the panic of 1873, 413 ; extension, 425.

Northwest, taken by Clark, 178 ; growth of, 409.

Northwest Ordinance, 191, 192, 313.

Nova Scotia, acquired by England, 120 .

Nullification, doctrine of, 278; and Hayne-Webster debate, 279, 280; Jackson against it, 278, 281.

Oglethorpe, General, 95.

Oklahoma, made a state, 430 .

Oquendo, the, 467.
Oregon, discovered by Lewis and Clarke, 225 ; boundary settled, 305 ; a territory, 316; disputed electoral vote, 405 ; agriculture and lumbering in, 424 .

Oriskany, battle of, 168 .

Osceola, 284.

Otis, James, 142.

Pacific Ocean, discovered, 28.

Panama, 476, 477, 478, 479.

Panama Canal, 476, 479.

Panama congress, 271.

Panama, Isthmus of, 28.

Panic, of 1837,286 ; of $1873,413$.

Parker, Alton B., 481.

Patroons, 86.

Pemberton, General, 347.

Peninsula campaign, the, 357-361.

Penn, William, buys Delaware, 89; founds Pennsylvania, 91; his connection with, 92-94.

Pennsylvania, early history, 91-94; government of, 92,94 ; boundary dispute, 93; tax eontroversy, 94; local government in, 137; Lee's campaign in, 364-368.

Pensions, for service, 439.

Pequots, war on the whites, 62 ; defeated, 63.

Perry, Captain Oliver H., 238.

Perryville, battle of, 346 .

Peru, conquest of, 31 .

Petersburg, siege of, 370 .

Philadelphia, 92, 254.

Philip, King, war of, 110-113.

Philippines, Dewey's victory in, 463 ; acquired from Spain, 469 ; war against the natives, 469 ; government in, 475 .

"Pickett's charge," 367.

Pierce, Franklin, president, 322-325 ; favors the South, 326 .

Pilgrims, 52.

Pinckney, C. C., 216, 226.

Pinzon, his discoveries, 21.

Pioneer, the, 257.

Pitt, William, 123.

Pittsburgh, 121, 124, 247, 249, 252, 255 ; importance of the site of, 121 .

Pittsburg Landing, battle of, 344 .

Pizarro, 31. 
Plains of Abraham, the, 125.

Plantations, established in Virginia, 70 ; character of, 72.

Platt amendment, 474.

Plymouth, settlement at, 52-55; common property, 54 ; expansion of, 54 ; absorbed by Massachusetts, 94 .

Plymouth Company, the, 38; and the Pilgrims, 55.

Pocahontas, 42.

Polk, James K., elected president, 306, 307 ; and the Oregon question, 308 ; and the Mexican War, 309; and the acquisition of California, 310 .

Pope, General, in command, 361; his campaign of second Bull Run, 361363 ; removed, 363.

Pope's bull, the, 23.

Popular sovereignty, 324.

Port Hudson, Miss., importance of, 345 ; taken by the federals, 347 .

Portland, Maine, 118.

Porto Rico, occupied by the United States army, 468; the treaty of Paris, 468; government of, 476 .

Portuguese, explorations of, 15 ; secures Brazil, 23.

Powderly, Terrence V., 500.

Powhatan, power of, 7, 42 .

Preachers, pioneer, influence of, 258.

President, powers, etc., 199-203.

Princeton, battle of, 163.

Progressive party, founded, 484.

Providence, R. I., founded, 59.

Pulaski, Tennessee, 391, 392.

Puritans, origin of, 49,55 ; settlement in New England, 55; persecuted, 60.

Quakers, in Pennsylvania, 91, 92.

Quebec, founded, 114; attack planned, 119 ; captured by Wolfe, 124 .

Quebec act, 148.

Railroads, extension after 1865, 412; to the Pacific coast, 425 ; early history, 493 ; great systems, 494 ; complaints against, 495; commissions, 495.

Raleigh, Sir Walter, 36, 37.

Rapid transit, 497.

Rebates, 495.
Reconcentration, 459.

Reconstruction, 384-394; two steps in, 384 ; the first attempt, 385 ; Stevens's policy, 386-388; the acts of 1867 , 388 ; southern states readmitted, 388; how it affected the South, 390394.

Redemptioners, 74 .

Religion, condition of in the colonies, $79-81$; on the frontier, 258.

Republican party, first, in power, 222.

Republican party of 1854 , founded, 327.

Resumption of specie payment, 416 .

Revere, Paul, 151.

Revolution, causes of, 140-153.

Rhode Island, founded, 60 ; excluded from the confederation, 65 ; and governor's salary, 104 ; rejects the constitution, 190.

Richmond, Virginia, electric cars first used in, 497.

Right of search, see Impressment.

River towns of Connecticut, 60.

Roads, in early Virginia, 75.

Roanoke Island, 36.

Robinson, Rev. John, 50, 52.

Rochambeau, at Yorktown, 175.

Rock Island, 285.

Rockefeller, John D., 480.

Rolfe, John, raises tobacco, 41.

Roosevelt, President Theodore, in Spanish War, 465; becomes president, 472; attitude toward trusts, 481; elected president, 481; his policies, 482 ; in the campaign of 1912, 483; conservation policy, 492.

Rosecrans, General, 346 ; at Mursfreesboro, 346 ; at Chickamauga, 347 ; removed, 349 .

“Rough Riders," 465.

Sachem, 7.

Sacs, the, 285.

St. Clair, 259.

St. Leger, campaign of, 165, 168.

St. Louis, 250.

St. Mary's, Maryland, 46.

Salmon Falls, 118.

Samoan Islands, dispute over, 446-448.

Samoset, 53. 
Sampson, Rear Admiral, 464.

Sandys, Sir Edwin, 44.

San Jacinto, battle of, 304 .

San Juan, battle of, 465,466 .

Santa Anna, General, 303; his treaty, 305.

Santa Fé system, of railroads, 426 .

Santiago, Cuba, reached by Cervera, 463 ; blockaded, 464; land expedition against, 464-466; naval battle off, 467 ; surrendered, 468.

Saratoga, battle of, 168 .

Sassacus, 63.

Savannah, founded, 95 ; taken by British, 171 ; Sherman's army at, 354 .

Saybrook, Conn., founded, 61 ; attacked by Pequots, 62.

Saye and Sele, Lord, 61.

Scalawags, 393.

Schenectady, attacked, 118.

Schley, Rear Admiral, 463, 464.

Schools, public, growth of, 501 .

Schurz, Carl, a reformer, 432, 433.

Scotch-Irish, the, in America, 92.

Scott, Dred, decision, 328, 329.

Scott, General Winfield, in Mexico, 309.

Scrooby, 50.

Secession, 332, 337.

Sedition law, the, 218.

Seminoles, at war in 1817,267 ; resist removal, 284 .

Senate, the federal, 186, 199.

Separatists, origin of, 49.

Seven Pines, the battle of, 359 .

Sevier, John, 193.

Seward, William H., purchases Alaska, 396.

Seymour, Governor, 397.

Shannon, the, 237.

Sheridan, his Indian policy, 427 ; operations against the Sioux, 427.

Sheriff, 136.

Sherman, General, W. T., at the battle of Chattanooga, 349, 351; Atlanta campaign, 353; marching through Georgia, 354; at Goldsboro, 354; receives surrender of Johnston, 371.

Shirley, Governor, of Massachusetts, 120.

Silk, early attempt to produce, 70 .

Silver, free coinage of, 441 .
Sioux, war with, 427.

Sitting Bull, 427.

Slavery, of Indians, 27 ; of negroes, 27 ; introduced into Virginia, 74 ; in the constitutional convention, 187 ; the slave trade, 189; abolished in the North, 290; prices of slaves, 291 ; the foreign slave-trade prohibited, 291 ; opposed by abolitionists, 293 297 ; conditions of, 296 ; its relation to the war, 297 ; in Texas, 303 ; in the territories, $314,315,316,317$ 319 ; the demands of the South on, 316,317 ; Lincoln's view of, 375 ; the emancipation proclamation, 376 ; abolished by the thirteenth amendment, 376, 528 .

Smith, Captain John, 40, 43, 52 .

Smuggling, 102; on the Potomac, 185.

Sons of liberty, 142.

"Soo," the, 498.

Soto, de, 29.

South, the, migration from, 245 ; and the tariff, 277 ; on slavery in the territories, 316, 317 ; development after the war, 409 ; labor system of, 411 ; cropping, 411 ; towns built up, 412 ; railroads in, 495 .

South America, discovered by Columbus, 20.

South Carolina, settled, 90 ; life in, 91 ; taken by the British, 170-173; recovered by Greene, 174; opposition to tariff, 277; and nullification, $278,279,281$; leads in secession, 332 ; disputed electoral vote of, 405 .

Southern Pacific Railroad, 426.

Southwest, early history of, 299-311.

Spain, aids Columbus, 17, 19; her explorers, 21-24 ; colonial policy, 2734 ; transfers Florida, 266-268; the Virginius affair, 399; her Cuban policy, 457 ; ten years' war 457 ; promises to Cubans, 458; the war with the Cubans, $459-469$; treaty of peace, 468 .

Speaker, colonial, 133.

Spoils system, 276; Hayes on, 432.

Spotsylvania, battle of, 369 .

Squanto, 53. 
Squatter, the, 257.

"'Squatter sovereignty," 324 .

Stalwarts, 433.

Stamp Act, passed, 141 ; resisted, 142 ; repealed, 144.

Stamp Act Congress, 141, 142, 148.

Standish, Miles, 53.

"Stand-patters," 483.

Stark, Colonel John, 167.

"'Stars and Bars," 378.

"Star-Spangled Banner, the," 240.

State rights, 273.

States, created, 156 ; rivalry between small and large, 186; duties of, 196 ; government of, 197.

Steamboats, invention of, 251.

Stevens, Thaddeus, 387.

Stone River, or Murfreesboro, battle of, 346.

Stowe, Mrs. Harriet Beecher, 330.

"'Strict construction," 272.

Stuyvesant, Peter, 88.

Sugar, raised, 20, 27; in Louisiana, 299

Swansea, attacked by the Indians, 111.

Sweden, colony of, 89 .

Taft, William H., elected president, 482 ; supports tariff law, 483 ; in the campaign of $1912,483$.

Tampa, 28, 29.

Tampico, 485.

Tariff, first protective, 263 ; later acts, 273, 277 ; Clay's compromise, 281; war tariff, 374 ; other acts, 414, 415 ; tariff of 1883,435 ; under Cleveland, 437 ; the McKinley law, 439; the Wilson-Gorman law, 441; Dingley act, 470; Payne-Aldrich act, 483; Underwood act, 485 .

Tarleton, Colonel, 173.

Taxation under the Confederation, 183, 184.

Taylor, General Zachary, fighting in Mexico, 309 ; elected president, 316. Tea, tax on, 144, 147 ; “tea party," 147.

Telegraph, 496.

Telephone, invention of, 496.

Tennessee, early history, 193 ; riflemen of, at New Orleans, 242.

Territorial government, 192 .
Texas, early boundaries, 301; Austin's colony, 301 ; restrictions by Mexico, 302 ; war of independence, 303305 ; annexation, 305, 306, 307 ; payment for land of, 318 .

Theresa, the, 467 .

Thomas, General, at Chickamauga, 347 ; at Chattanooga, 351.

Tilden, Samuel J., governor of New York, 404 ; exposes the Tweed ring, 405; candidate for the presidency, 405 .

Times, the New York, 404.

Tobacco, discovered by Columbus, 19 ; cultivated in Virginia, 41, 70; used as money ; 72 ; a staple crop, 75.

Tonti, 117.

Tories, harsh laws against, 177.

Town, New England, 58, 136; in Virginia, 70; in Middle colonies, 137 ; in the West, 249 ; trading, 97 ; development of, 491 .

Townshend duties, 144, 146, 148.

Township system, the, 192.

Trade, in colonial times, 76, 77; Indian, 105 ; fur in Canada, 114.

Travel, means of, 248 .

Travis, William B., 303.

Treaty of Paris, 1763, 126; with Great Britain, 1783, 175; of Ghent, 243; with Mexico, 310 ; with Spain, in $1898,469$.

Trenton, battle of, 163 .

Trial, how conducted, 205.

Trusts, 480; law against, 481 ; Roosevelt and, 481 .

Tweed frauds, 404.

Tyler, John, elected vice president, 287 ; as president, 307.

“'Uncle Tom's Cabin,” 330.

Underground railway, the, 294, 316.

Union, the question of, 158.

Union Pacific Railroad, 425.

Universities, 501, 502 .

Utah, and slavery, 318 ; early history of, 423.

Utrecht, treaty of, 120 .

Vaca, Cabeça de (Vah-kah, Ca-bā-za de), 29,31 .

Valley Forge, 166. 
Van Bureu, Martin, 276, elected president, 285; defeated in 1840, 287.

Venezuelan boundary dispute, 451-453.

Vera Cruz, troops landed at, 486.

Verrazano, his explorations, 25.

Vespucci, Amerigo, 24.

Vicksburg, Miss., importance of, 344 ; taken by Grant, 346 .

Vinland, 14.

Virginia, the name, 36 ; first attempt to settle, 37 ; early history of, 38-45; suffering of the colonists, 39 ; tobacco, 41 ; services of Pocahontas, 42 ; massacre of 1621,43 ; Indian war of 1644,43 ; self-government in, 44 ; a royal province, 45 ; "Mother of States," 45 ; life in, 69-76; religion, 81 ; education, 81 ; the county in, 136; and the revolution, 145, 149 ; calls continental congress, 149 ; Cornwallis in, 174, 175; against emancipation, 290.

Virginia and Kentucky resolutions, 219. Virginia, the, 378.

Virginia City, 420.

Virginius, the, 399.

Vizcaya, the, 467.

Voting in $1789,198$.

Wampanoags, friendly to the whites, 53. "War hawks," the, 234, 235, 261.

War of $1812,232,234-243$; causes of, 234-236 ; its declaration, 236.

Wars, Indian, against the Virginia Indians, 43 ; with Pequots, $62-64$; King Philip's, 110-113; King William's, 113, 118 ; Queen Anne's, 113, 119 ; King George's, 113, 120; the Seven Years' War, 113 ; in Ohio, 259; with the Creeks, 271; with Seminoles, 267 ; Black Hawk, 285 ; with Western Indians, 426-428.

Washington, agriculture and lumbering in, 424 ; created a state, 425 .

Washington City, burned, 240.

Washington, George, sent to the Ohio, 121 ; at Fort Neressity, 122; with Braddock, 123 ; revolutionary commander in chief, 153; at Boston, 159 ; campaign around New York,
161 ; in New Jersey, 162-164 ; canpaign in Pennsylvania, 165, 166; at Valley Forge, 167 ; at battle of Monmouth, 169 ; at Yorktown, 175 ; president, 209-216.

“'Watauga Association, the," 193.

Watertown, founded, 57.

Watling's Island, 19.

Webster, Daniel, 272; debate with Hayne, 280; candidate for the presidency, 285 ; on the compromise of 1850,318 ; death, 321 .

West, the settlement of, 245-259, 419430 ; desires free silver, 441 ; railroads in, 495.

"Western Reserve, the," 248.

Wethersfield, Conn., founded, 60.

Whaling, 78.

Wheeler, General Joseph, 472.

Whig party, 273, 327.

Whisky insurrection, 212.

Whisky ring, the, 401.

White, H. L., 286.

White Plains, battle of, 162.

Whitney, Eli, 246.

Wilderness, battle of the, 368 .

William and Mary College, 82.

Williams, John, 119, 120.

Williams, Roger, 111 ; expulsion of, 59 ; founds Providence, 59 ; and the Narragansetts, 62 ; dislike of Massachusetts for, 65 .

Williamsburg, 131.

Wilmot proviso, the, 314 .

Wilson, Woodrow, elected president, 484 ; his Mexican policy, 485.

Wilson-Gorman tariff, the, 440 .

Windsor, Conn., founded, 60.

Winthrop, John, a founder of Massachusetts, 56.

Wireless telegraphy, 496.

Wolfe, General, 124, 125.

Wyoming, settlement of, 423 .

X Y Z papers, 217.

Yale College, founded, 82.

Yellow fever, prevented, 473.

York, the Duke of, 88 .

Yorktown taken, 175. 
THE following pages contain advertisements of a few of the Macmillan books on kindred subjects. 



\title{
The Dawn of American History in Europe
}

By WILLIAM L. NIDA, Superintendent of Schools, River Forest, Illinois, Author of "City, State, and Nation"

Cloth, I2mo, ill. . . . . . . . . . . 80 cents

The Dawn of American History in Europe is a simple account or story of Old World conditions, and of the important series of events that led to the discovery and colonization of America. It follows the suggestions and meets the requirements laid down by the Committee of Eight in its report to the American Historical Association for sixth grade history.

The book is conveniently divided for study into chapters, each of which is synoptically outlined, the paragraph topics indicated and covered by definite formal stimulating reviews.

\section{City, State, and Nation}

\author{
By WILLIAM L. NIDA
}

Author of "The Dawn of American History in Europe"

Cloth, ill., I2mo . . . . . . . . . . . . . 75 cents

City, State, and Nation provides a definite, logical, and graded course of instruction in citizenship for children in the elementary schools. It approaches the subject matter from a social standpoint and emphasizes the practice of civic virtue in community life. Community health, public education, public utility, public recreaticn, and the many ways in which society is putting forth effort to protect itself and provide security and comfort, are topics of study. The economic features of the treatment so appeal to the student as to make him a faithful and loyal servant of the city, state, and nation.

\section{THE MACMILLAN COMPANY}

\section{4-66 Fifth Avenue, New York}




\section{PIONEER HISTORY SERIES}

\section{By CHARLES A. McMURRY}

Designed as a complete series of early history stories of the Eastern, Middle, and Western States, suitable as an introduction for children to American History. Illustrated and equipped with maps.

Cloth I $2 \mathrm{mo} \quad 40$ cents each

\section{Pioneers on Land and Sea}

The first of the three volumes deals with the chief ocean explorers, Columbus and Magellan, and with the pioneers of the Eastern States, Canada, and Mexico, such as Charnplain, Smith, Hudson, De Leon, Cortes. These stories furnish the gateway through which the children of our Atlantic States should enter the fields of History. The attempt is to render these complete and interesting stories, making the experiences of pioneer life as graphic and real as possible.

\section{Pioneers of the Mississippi Valley}

Such men as La Salle, Boone, Robertson, George Rogers Clark, Lincoln, and Sevier supply a group of simple biographical stories which give the children a remarkably good introduction to History. Teachers are beginning to believe that children should begin with tales of their own home and of neighboring states, and then move outward from this center. For eastern children these stories form a very suitable continuation to "Pioneers on Land and Sea," and vice versa.

\section{Pioneers of the Rocky Mountains and the West}

In some respects these western stories are more interesting and striking than those of the States farther east, because of their physical surroundings. Children of the Western or Mountain States should enjoy these stories first. The various exploring expeditions which opened up the routes across the plains and mountains are full of interesting and instructive incidents and of heroic enterprise. The chief figures in these stories are men of the most striking and admirable qualities, and the difficulties and dangers which they overcame place them among the heroes who will always attract and instruct American children. Incidentally, these narratives give the best of all introductions to western geography. They are largely made up from source materials fur nished by the explorers themselves.

\section{THE MACMILLAN COMPANY}

\section{4-66 FIFTH AVENUE, NEW YORK}




\section{Source Readers in American History}

Selected and annotated by ALBERT BUSHNELL HART, Assisted by BLANCHE E. PACKARD, of the Rhode Island Normal School, MABEL HILL, of the Lowell Normal School, ANNIE BLISS CHAPMAN, of the Worcester Normal School, and ELIZABETH STEVENS

I. Colonial Children. Cloth, I2mo. Ill. xviii +234 pages . . . . . . . . . . . . . . . . $\$ 40$

2. Camps and Firesides of the Revolution. Cloth, I2mo. Ill. $\mathrm{xv}+3$ ro pages . . . . . . . . . . ${ }^{50}$

3. How Our Grandfathers Lived. Cloth, I2mo. Ill. xiv +372 pages . . . . . . . . . . . . 60

4. The Romance of the Civil War. Cloth, r2mo. Ill. xiv +4 I8 pages . . . . . . . . . . . . 60

5. This volume is in preparation.

This series of readers contains sources adapted for use in elementary schools, and does easily, by these selections, what much study of the ordinary history textbook would fail to do.

These books are made up of sources but not sources in the garb of three centuries ago, unfamiliar to the modern child. The form has been freely changed, but the thought has been preserved. If children are interested in these books, it is because the writers are interesting and not because a modern mind has invented the story for them.

In one sense these books are the basal texts for the teaching of history. They present the history with the emphasis upon its social side. They get away from the old-fashioned history of troubles, battles, and wars.

\section{THE MACMILLAN COMPANY}

64-66 Fifth Avenue, New York 


\title{
The Teaching of History
}

\section{By HENRY JOHNSON, Professor of History, Teachers College, Columbia University}

Cloth, r2mo, xxix +497 pages . . . . . . . . \$r.40

The distinguishing features of Professor Johnson's The Teaching of History are: Sketches of history teaching from the seventeenth century to the present, a general description and approval of present theory and practice in the principal countries of Europe and in the United States; a full discussion of the problem of grading history, with specific suggestions for a solution of the problem, a new approach to the question of aims and values; a specific treatment of topics usually disposed of in a few generalities and the application of principles. In this last connection the book aims to tell the teachers specifically what to do with different types of material.

Because of the author's qualifications, The Teaching of History is more than a theory. It is the outgrowth of twenty-five years of study, observation, and experiment. The book is a product of direct experience in the classroom.

\section{How to Teach American History}

\author{
By JOHN W. WAYLAND, Pн.D., Professor of History \\ and Social Science, State Normal School, \\ Harrisonburg, Virginia
}

Cloth, I2mo, viii +324 pages . . . . . . . . . \$1.10

The purpose of this book is to instruct teachers in the art of presenting American history so that the subject may interest the child, so that its study will take rank among his studies as a source of adventure and contrast, so that it will seem a thing close to his life from which he is to take knowledge and inspiration for the solving of his problems and the problems that must be solved with others of his age.

The treatment covers the theory and practice of history teaching. It is a simple, concise, and complete treatment of the study.

\section{THE MACMILLAN COMPANY}

\section{4-66 Fifth Avenue, New York}





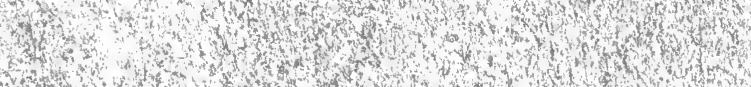

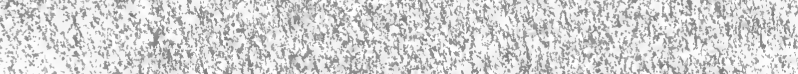

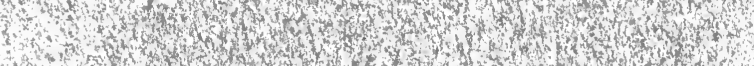

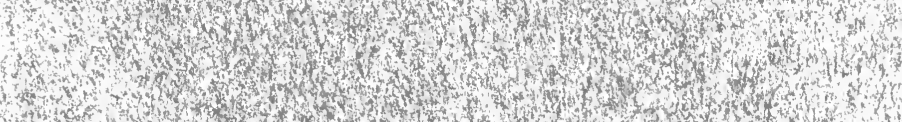

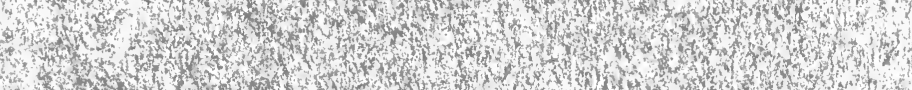

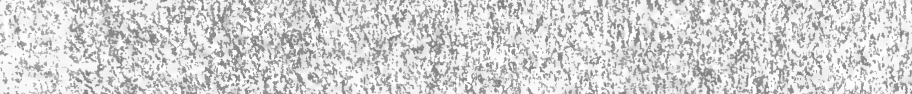

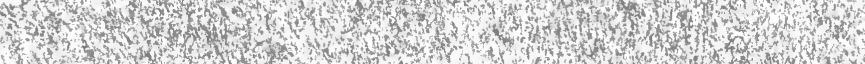

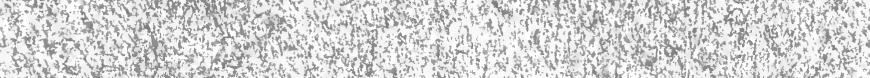

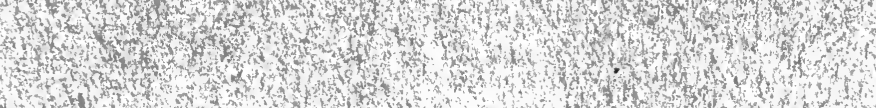




\section{DAY USE \\ RETURN TO DESK FROM WHICH BORROWED EDUCATION-PSYCHOLOGY LIBRARY}

This book is due on the last date stamped below, or on the date to which renewed. Renewed books are subject to immediate recall.

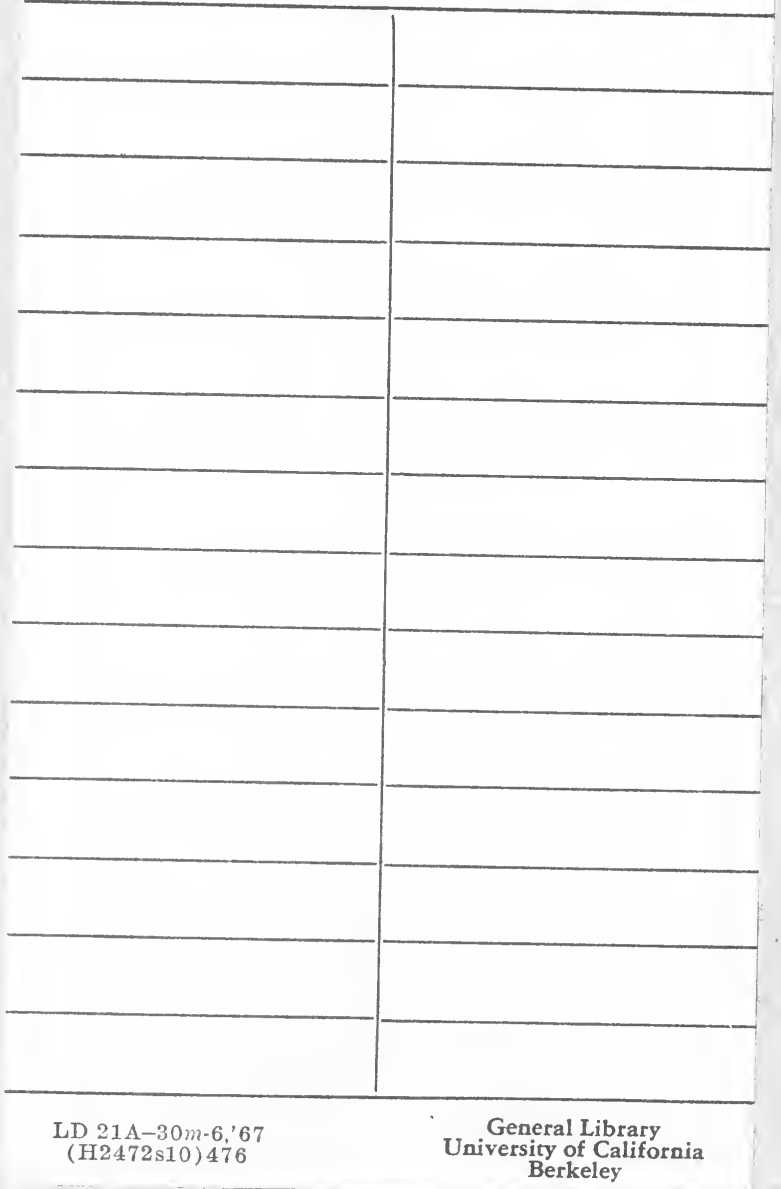




\section{।}

\section{$\bar{M} 69882$ E17}

THE UNIVERSITY OF CALIFORNIA LIBRARY 
